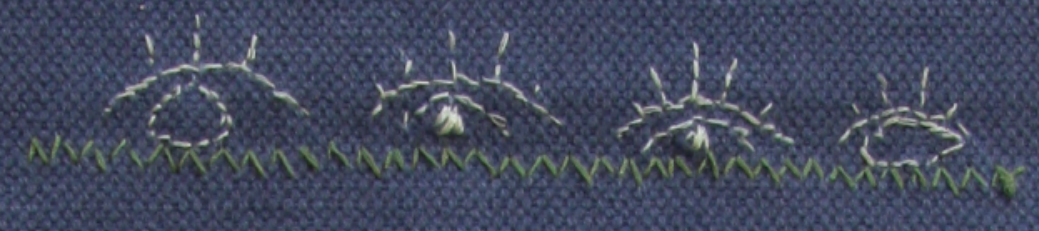

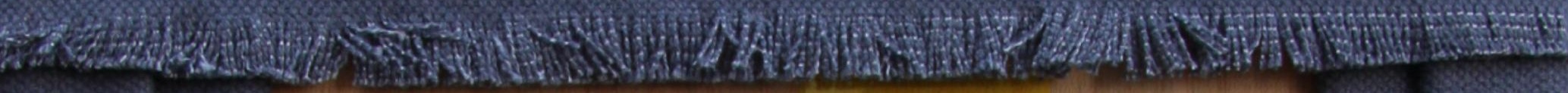

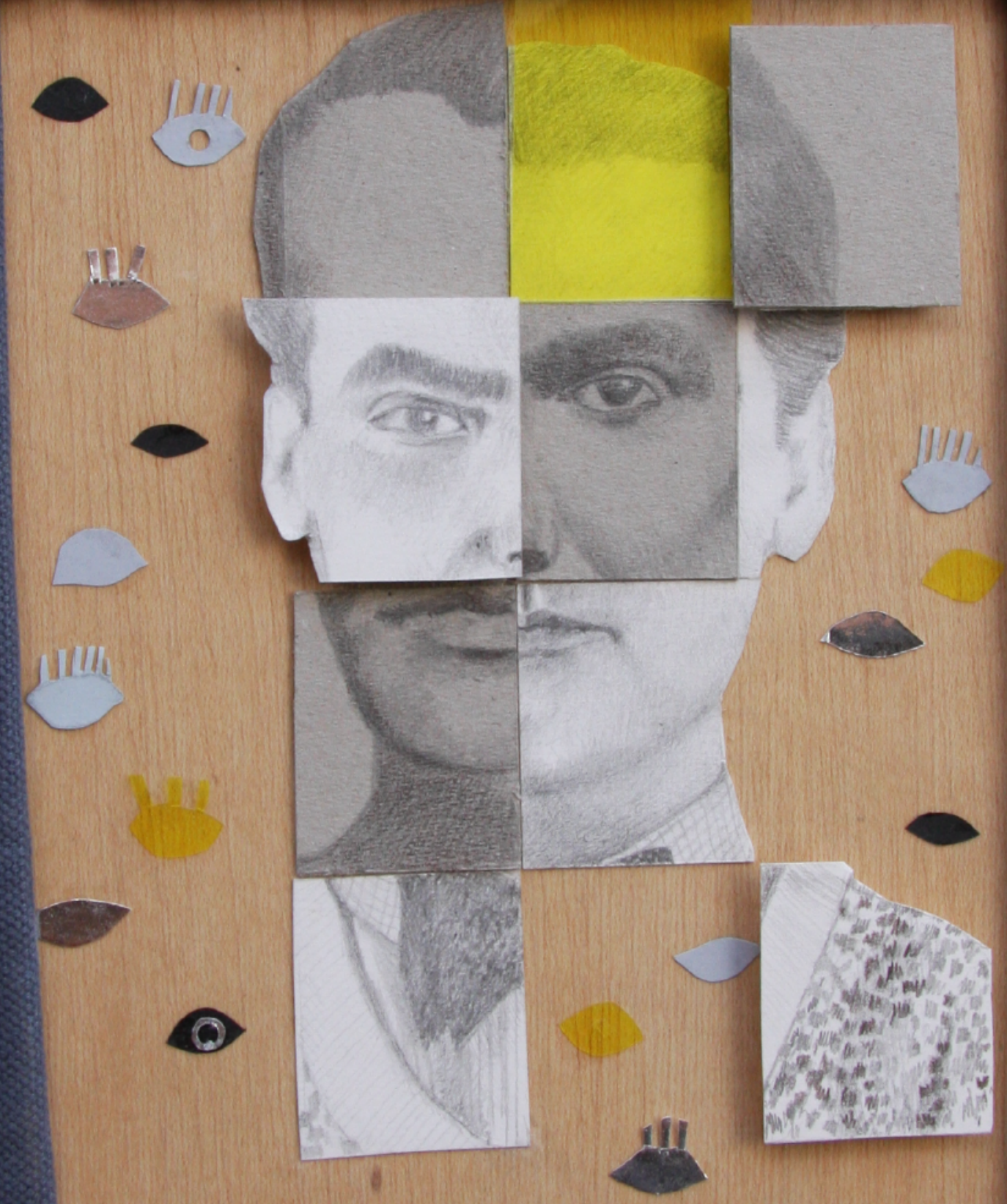

El surrealismo en el teatro de vanguardia de Federico García Lorca: El público y Comedia sin título.

Autora: Dña. Rosa Anna Ferrando Mateu Director: Dr. Santiago Fortuño Llorens Octubre 2020 



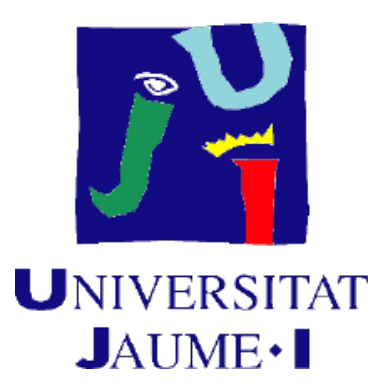

Programa de Doctorado en Lenguas Aplicadas, Literatura y Traducción

Escuela de Doctorado de la Universitat Jaume I

\title{
El surrealismo en el teatro de vanguardia de Federico García Lorca: El público y Comedia sin título.
}

\begin{abstract}
Memoria presentada por Rosa Anna Ferrando Mateu para optar al grado de doctora por la Universitat Jaume I
\end{abstract}

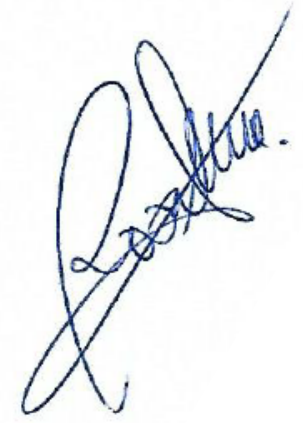

Castelló de la Plana, octubre 2020 
Agradecimientos:

Al Dr. Santiago Fortuño Llorens, director de esta tesis que sin su ayuda, interés, conocimientos y paciencia la realización de este estudio no habría sido posible.

A Sonia M. Paredero, autora de la portada, quien ha sabido plasmar la idea de esta tesis en una imagen: una visión surrealista del rostro de Federico García Lorca, rodeado por esos ojos del público que contempla la representación sobre un escenario.

A aquellos que, en algún momento de esta investigación, me han acompañado: Mónica y Cèlia de la Librería Noviembre de Benicàssim, Eva, David, Juan Carlos, Paloma, Patri...

A Esteban y Julia.

A Roge por el apoyo recibido desde la distancia. 


\section{Índice}

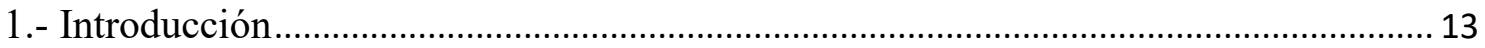

1.1.- Biobibliografía de Federico García Lorca ....................................................... 13

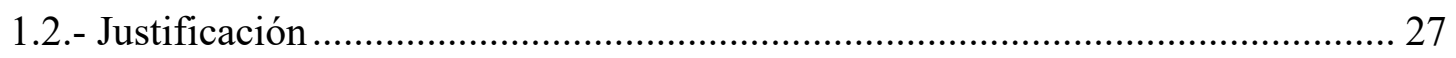

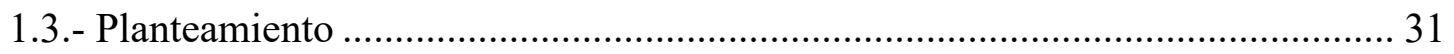

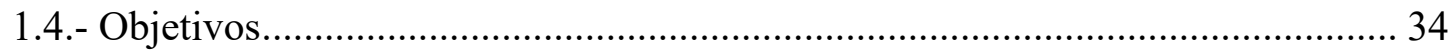

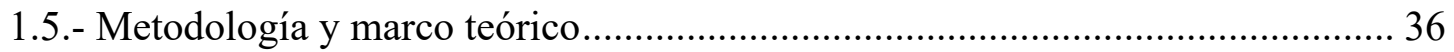

I. EL TEATRO DE PRINCIPIOS DE SIGLO XX EN ESPAÑA ………………….... 43

2.- El teatro de éxito comercial......................................................................................... 45

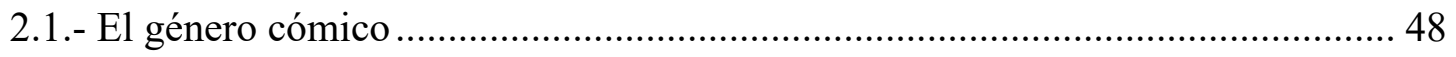

2.1.1.- La comedia de costumbres: los hermanos Álvarez Quintero......................... 48

2.1.2.- El sainete: Carlos Arniches y Pilar Millán Astray ........................................ 50

2.1.3.- La comedia de tesis. La alta comedia: Jacinto Benavente ............................ 54

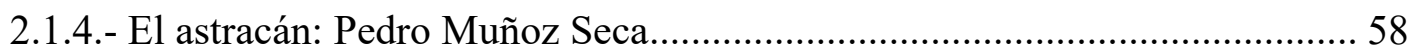

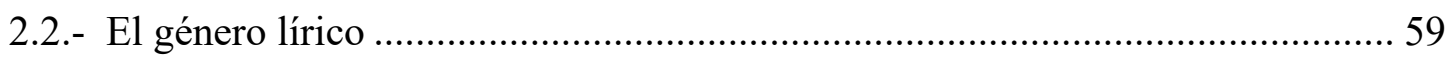

2.2.1.- Autores destacados del teatro poético: Eduardo Marquina, Francisco Villaespesa, los hermanos Manuel y Antonio Machado y Dolores Ramos de la

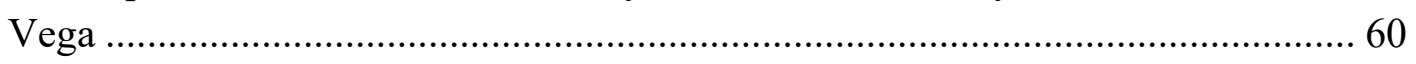

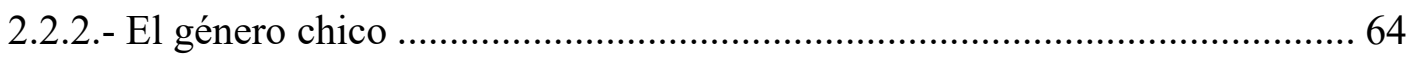

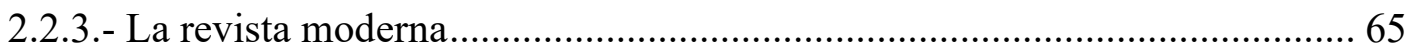

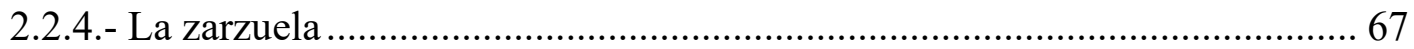

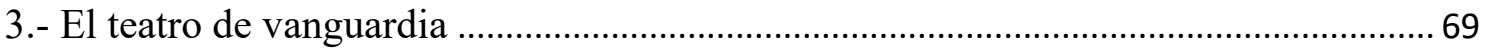

3.1.- La crítica teatral ante la situación del teatro ...................................................... 70

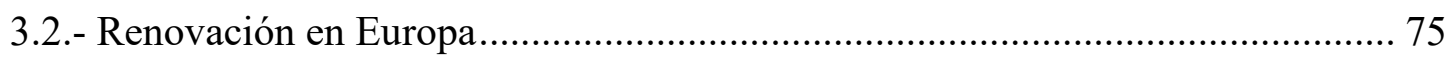

3.2.1.- El teatro naturalista: Henrik Ibsen, August Strindberg, André Antoine, Anton Chéjov y George Bernand Shaw ........................................................... 76

3.2.2.- El teatro de vanguardia: Alfred Jarry, Luigi Pirandello, Antonin Artaud, Roger Vitrac y Bertolt Brecht ............................................................................ 79

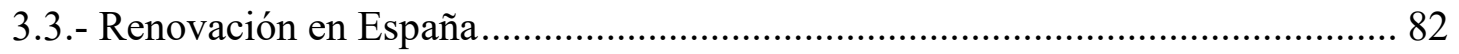


3.3.1.- Autores renovadores. El teatro de la generación del 98 y de la generación del 14: Miguel de Unamuno, Ramón María del Valle-Inclán, José Martínez Ruiz (Azorín), Ramón Gómez de la Serna y Jacinto Grau 84

3.3.2.- Autores renovadores. Teatro de la generación del 27: Pedro Salinas, Rafael Alberti, María Teresa León, Max Aub y Miguel Hernández. 93

3.3.3.- La renovación en la comedia: Enrique Jardiel Poncela y Miguel Mihura... 96

3.3.4.- Las mujeres de la Generación del 27: Las Sinsombrero y María Francisca Clar Margarit (Halma Angélico, Ana Ryus) 98

3.4.- El Teatro de Arte: Teatre Íntim de Adrià Gual, El Mirlo Blanco, Cántaro Roto, El Teatro Íntimo Fantasio, El Caracol, Club Teatral Anfistora y Gregorio Martínez Sierra y María de la O Lejárraga 103

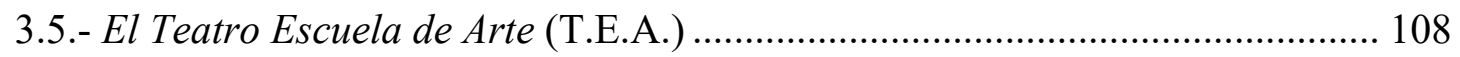

3.6.- El Teatro Nacional .......................................................................................... 110

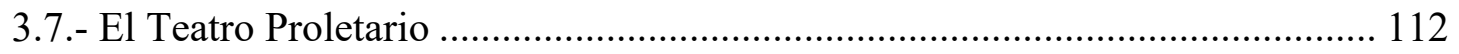

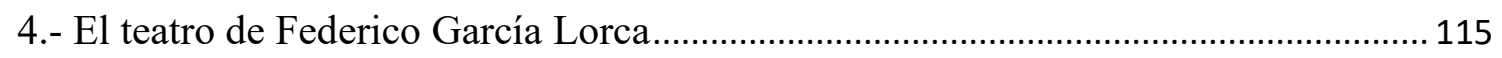

4.1.- Lorca, dramaturgo: El maleficio de las mariposas (1920), Los títeres de la cachiporra Tragicomedia de don Cristobal y la señá Rosita (1922), María Pineda (1925), Amor de don Perlimplín con Belisa en su jardín. Aleluya erótica en cuatro cuadros y un prólogo (1926), La zapatera prodigiosa (1930), El público (1930), Así que pasen cinco años. Leyenda del tiempo (1930), Bodas de sangre (1932), Retablillo de don Cristobal (1934), Yerma (1934), Doña Rosita la soltera o el lenguaje de la flores (1935) y La casa de Bernarda Alba (1936) ................................................... 115

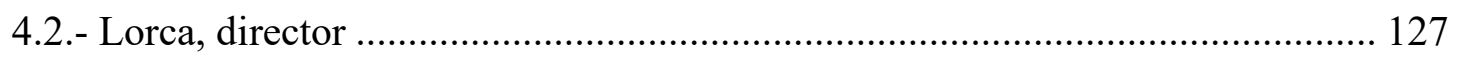

4.3.- El Teatro del Pueblo de las Misiones Pedagógicas......................................... 128

4.3.1.- Las Misiones Pedagógicas ....................................................................... 130

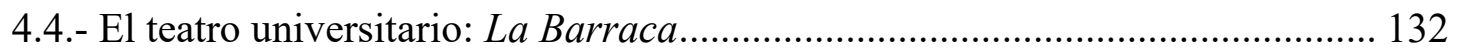

4.4.1.- La Residencia de Estudiantes.............................................................. 141

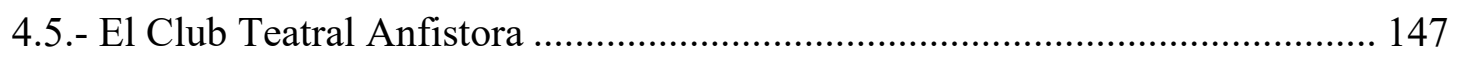

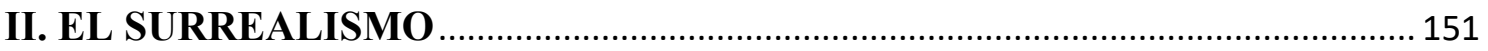

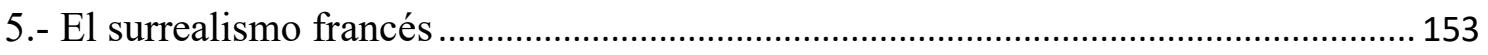

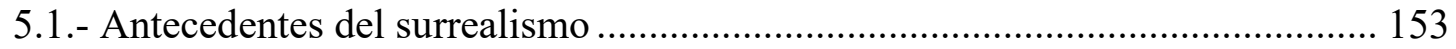

5.2.- Año 1924: El nacimiento del surrealismo. Los manifiestos ............................. 158

5.2.1.- Una ola de sueños de Louis Aragon....................................................... 159 


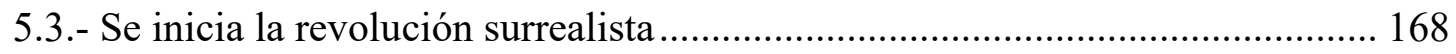

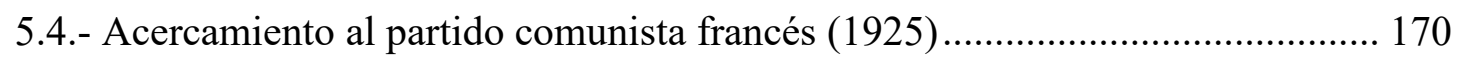

5.5.- El surrealismo al servicio de la revolución (1929): El segundo manifiesto ..... 175

5.6.- La crisis del surrealismo (1930): El caso Aragon ........................................... 179

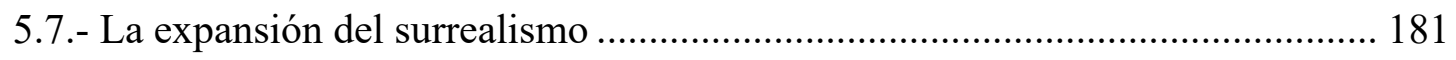

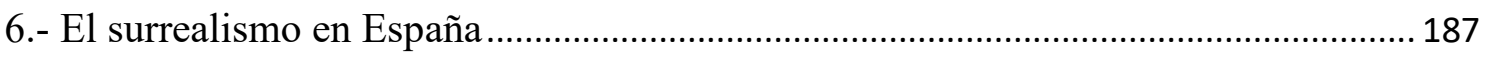

6.1.- El término surrealismo y sus autores: Luis Cernuda, José María Hinojosa y

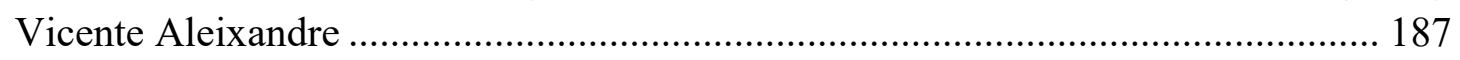

6.2.- La Vanguardia y el surgimiento del surrealismo en España ........................... 195

6.3.- La entrada del surrealismo en España: aparición de nuevas revistas literarias 199

6.4.- La aparición de nuevos estudios y la revisión del surrealismo español ........... 212

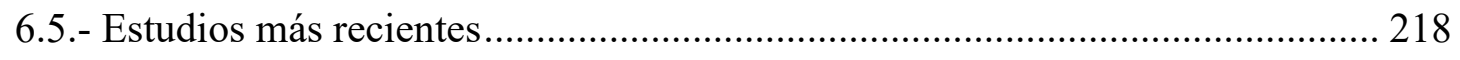

7.- El Surrealismo en Federico García Lorca..................................................................... 221

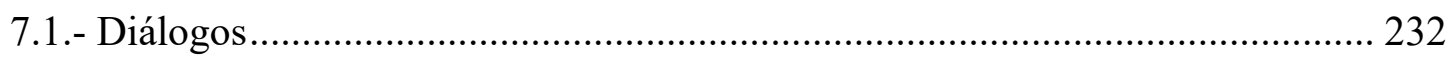

7.1.1.- Diálogos publicados en vida: «El paseo de Buster Keaton», «La doncella, el marinero y el estudiante», «Escena del teniente coronel de la Guardia Civil» y «Diálogo del Amargo» (1925) ...................................................................... 232

7.1.2.- Diálogos publicados póstumamente: «Quimera» (1940), «Diálogo mudo de los cartujos», «Diálogo de los dos caracoles (1985) y «La sabiduría. El loco y la

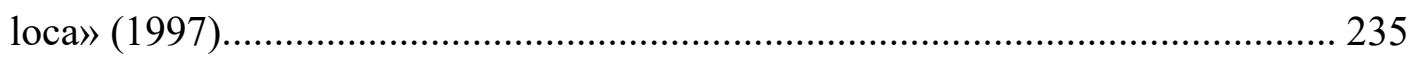

7.1.3.- Diálogos inconclusos: «Diálogo con Luis Buñuel», «Diálogo de la Residencia de Estudiantes», «Diálogo de don Fabricio y la señora» y «Diálogo del dios Pan»

7.1.4.- Diálogos desaparecidos: «Diálogo de la danza» y «Diálogo fotografiado» 238

7.2.- Poemas en prosa: «Santa Lucía y San Lázaro», «Nadadora sumergida. Pequeño homenaje a un cronista de salones», «Suicidio en Alejandría», «Amantes asesinados por una perdiz», «Degollación de los inocentes», «Degollación del Bautista», «La gallina. Cuento para niños tontos» y «Meditaciones a la muerte de la madre de

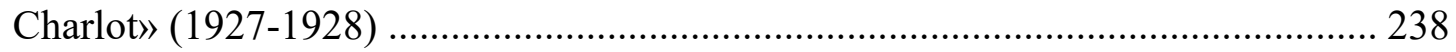

7.3.- Poemario: Poeta en Nueva York (1929-1930) ................................................ 242

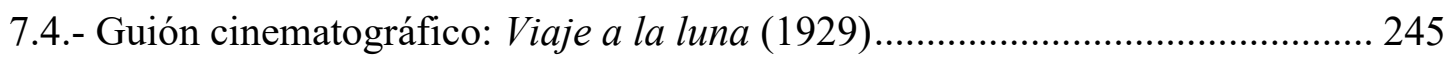

7.5.- Comedias imposibles: El público (1929) y Así que pasen cinco años (1931) . 250 
8.- El origen de El público. 259

8.1.- Antecedentes a su viaje a América 259

8.2.- El viaje a Nueva York 264

8.2.1- La influencia americana en El público: Nueva York 272

8.3.- El viaje a La Habana. .275

8.3.1.- Las conferencias. 278

8.3.2.- Los días cubanos: amistades y viajes por la isla 281

8.3.3.- La influencia americana en El público: La Habana. 290

8.4- La historia del manuscrito 292

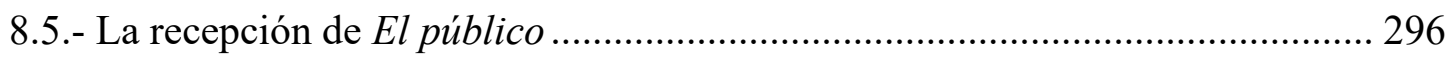

8.6.- La publicación y posteriores ediciones.......................................................... 300

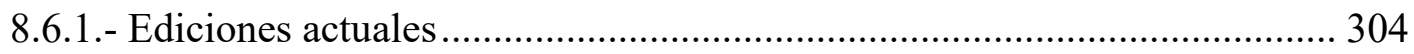

9.- Análisis semiótico teatral: Nivel sintáctico ................................................................ 309

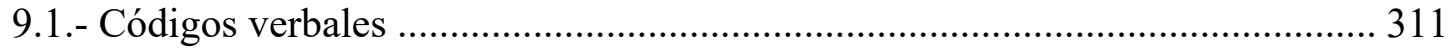

9.1.1.- Estudio de la acción y de las acotaciones ............................................... 311

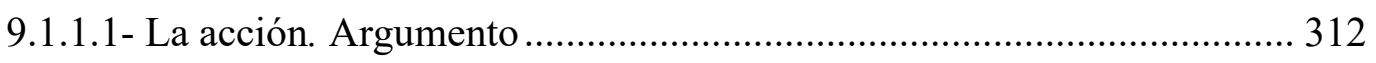

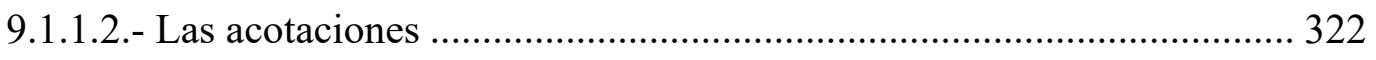

9.1.2.- Estudio y caracterización funcional de los personajes............................... 323

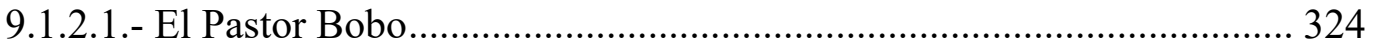

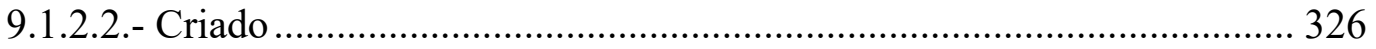

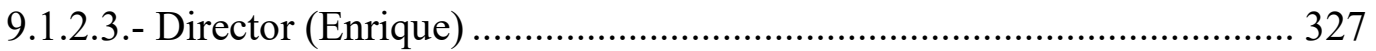

9.1.2.4.- Los cuatro caballos: Caballo Blanco 1, Caballo Blanco 2, Caballo Blanco 3 y Caballo Blanco 4 .......................................................................... 329

9.1.2.5.- Los tres hombres: Hombre 1, Hombre 2 y Hombre 3 ….................... 329

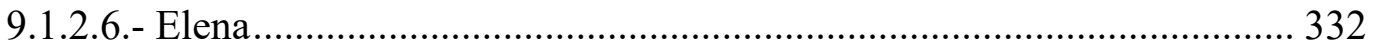

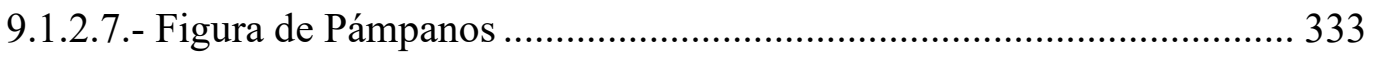

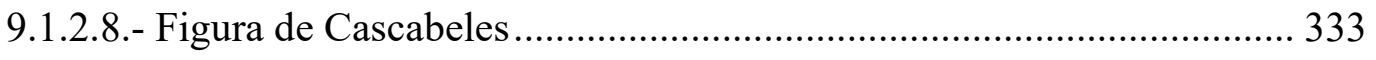

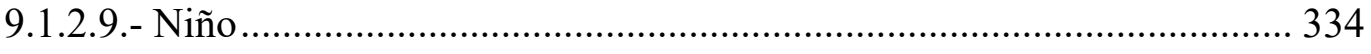


9.1.2.10.- El Emperador y el Centurión 337

9.1.2.11.- Julieta 337

9.1.2.12.- Caballo Negro .............................................................................. 338

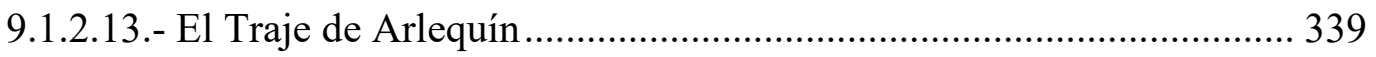

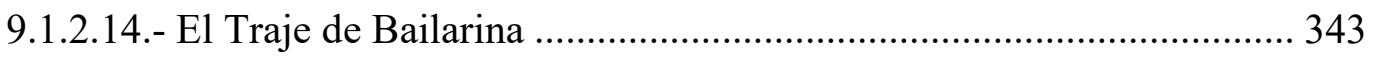

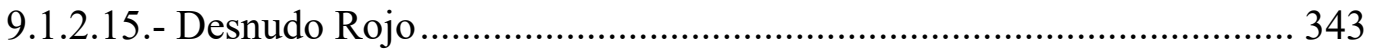

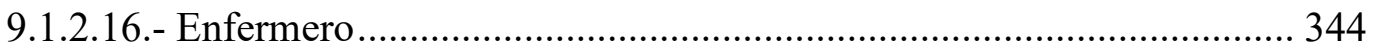

9.1.2.17.- Los estudiantes: Estudiante 1, 2, 3 y 4 _............................................ 345

9.1.2.18.- El Muchacho 1 y las damas: Dama 1, 2, 3 y 4 ................................ 346

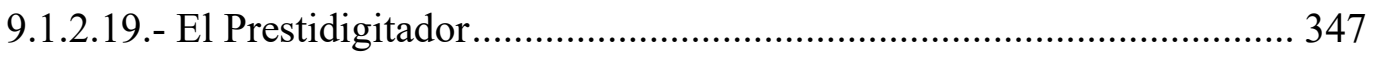

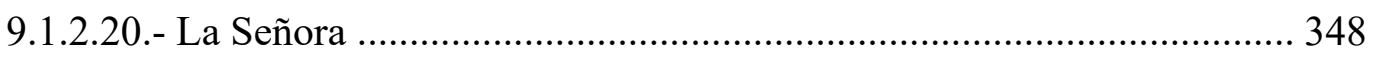

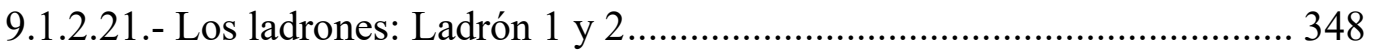

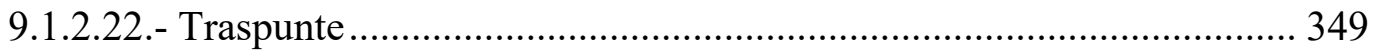

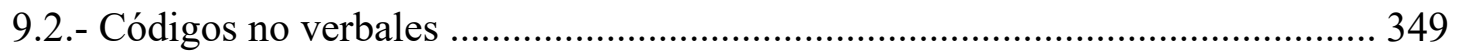

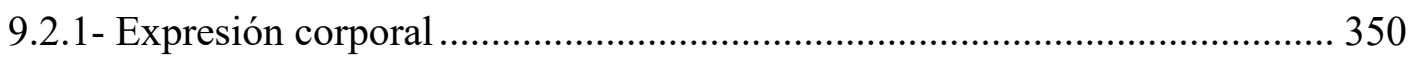

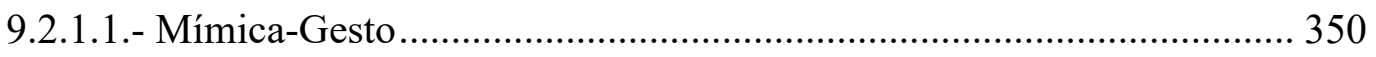

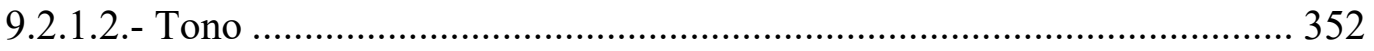

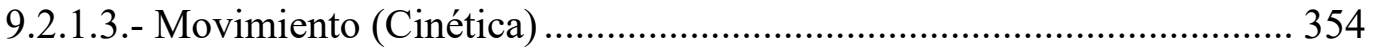

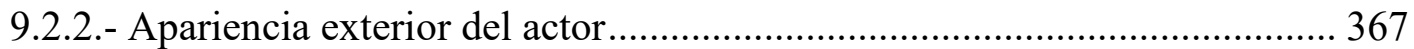

9.2.2.1.- Maquillaje-Peinado ............................................................................ 367

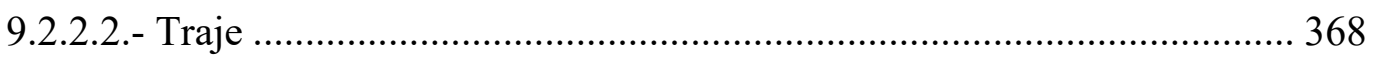

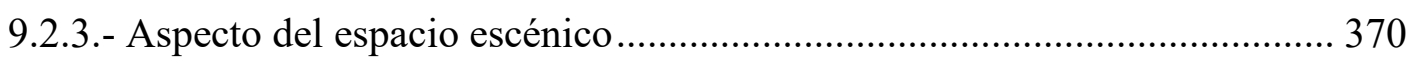

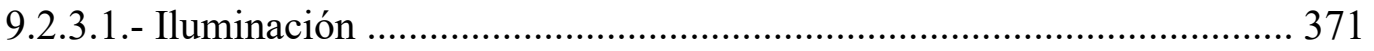

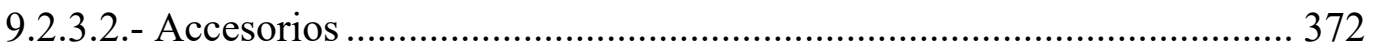

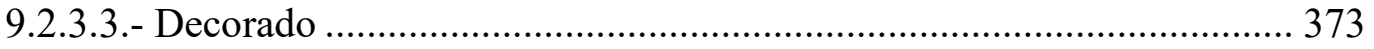

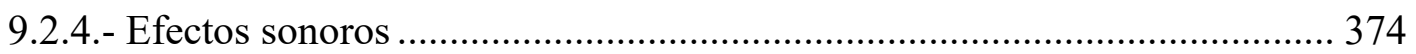

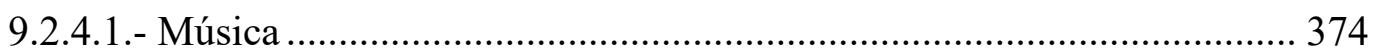

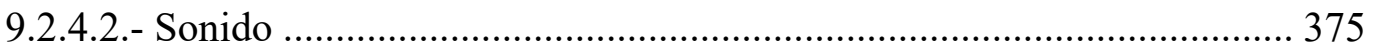

10.- Análisis semiótico teatral: Nivel semántico ……....................................................... 377

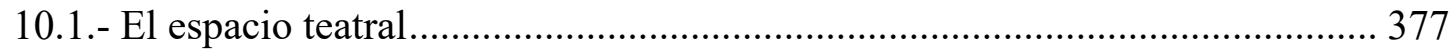

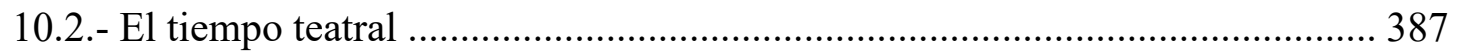

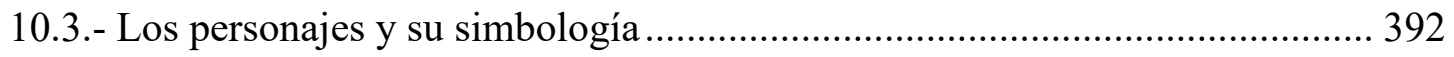


10.3.1.- El Pastor Bobo 392

10.3.2.- El Director. 393

10.3.3.- Los Caballos: los cuatro caballos blancos y el caballo negro 394

10.3.4.- Los tres hombres: Hombre 1, Hombre 2 y Hombre 3. 397

10.3.5.- Elena 399

10.3.6.- La Figura de Cascabeles y la Figura de Pámpanos 399

10.3.7.- El Emperador, Centurión y Niño 402

10.3.8.- Julieta 403

10.3.9.- Los trajes 405

10.3.9.1.- El traje de Arlequín 408

10.3.10.- Desnudo Rojo, Enfermero y Ladrones.. 408

10.3.11.- Los Estudiantes, Las Damas y el Muchacho 413

10.3.12.- El Prestidigitador 415

10.3.13.- La Señora 419

11.- Análisis semiótico teatral: Nivel pragmático. 421

11.1.- Las primeras representaciones. 421

11.2.- Lluís Pasqual: estreno mundial. Visión crítica 425

11.3.- El público después de Lluís Pasqual. La ópera. Siguientes críticas 432

11.4.- Llegamos a Àlex Rigola 437

11.5.- Análisis de la obra El público a través de Lluís Pasqual y Àlex Rigola........ 440

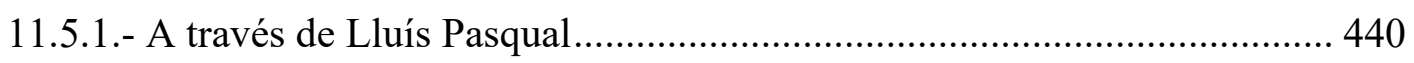

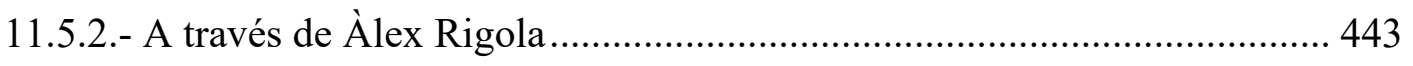

11.6.- La última puesta en escena: Ksec Act ........................................................ 445

IV. ANÁLISIS SEMIÓTICO TEATRAL DE COMEDIA SIN TÍTULO 447

12.- El origen de Comedia sin título 449

12.1.- Las ideas anteriores de Comedia sin título ................................................... 450

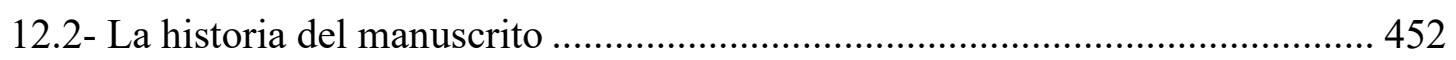

12.3.- Los primeros testimonios de Comedia sin título ........................................... 454

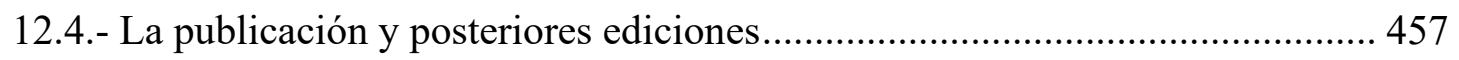

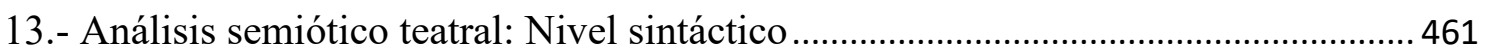


13.1.1.- Estudio de la acción (argumento) y de las acotaciones........................... 462

13.1.2.- Coincidencias con El público............................................................... 464

13.1.2.- Estudio y caracterización funcional de los personajes............................ 467

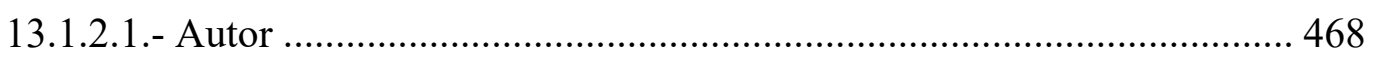

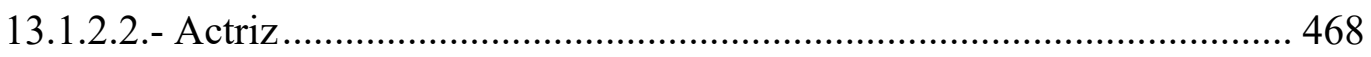

13.1.2.3.- Los espectadores de la Sala: Espectador $1^{\circ}$, Espectadora $1^{\circ}$, Espectador

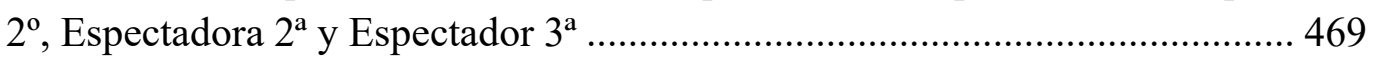

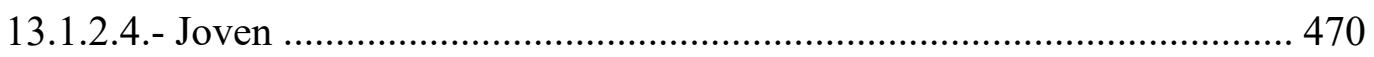

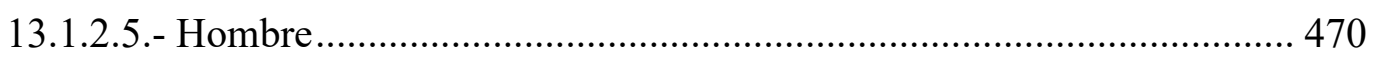

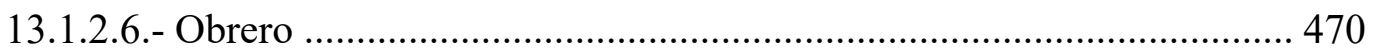

13.1.2.7.- Leñador y el resto de personajes de la obra de Shakespeare............. 470

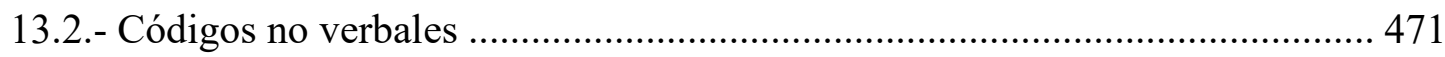

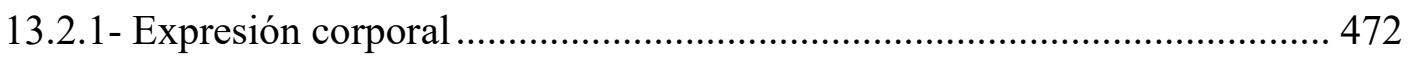

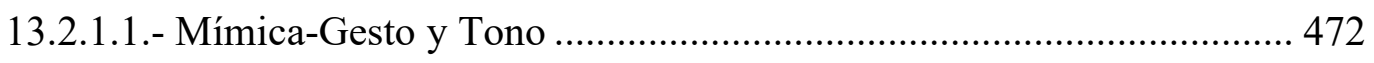

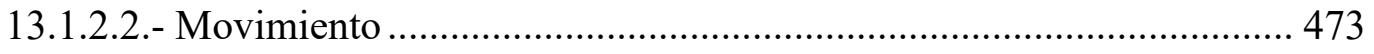

13.2.2.- Apariencia exterior del actor: Maquillaje-Peinado y Traje...................... 476

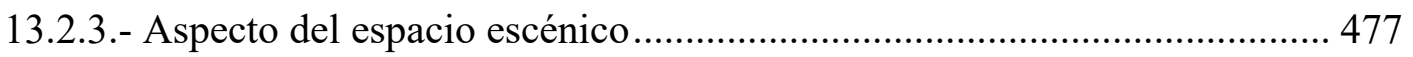

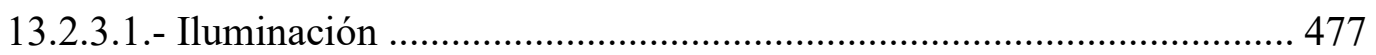

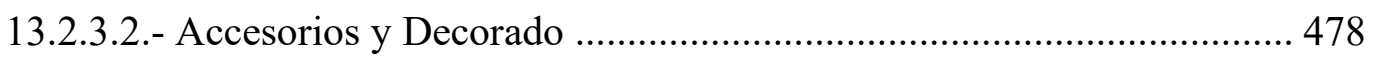

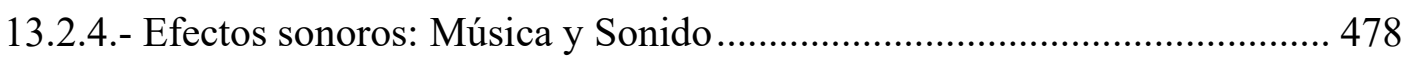

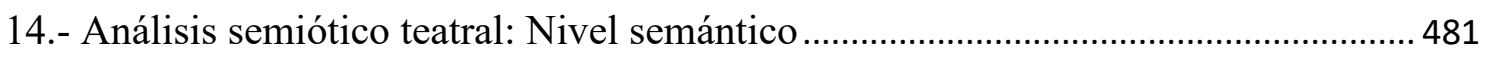

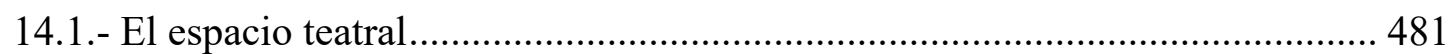

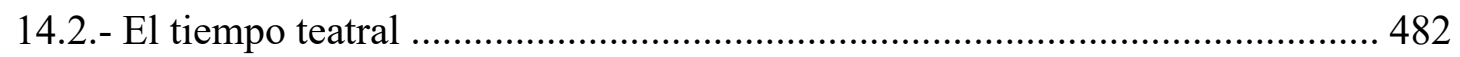

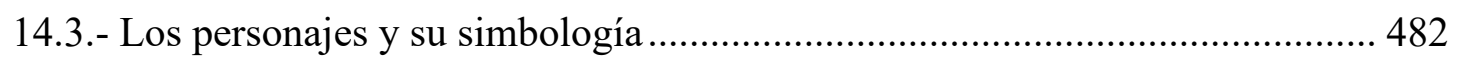

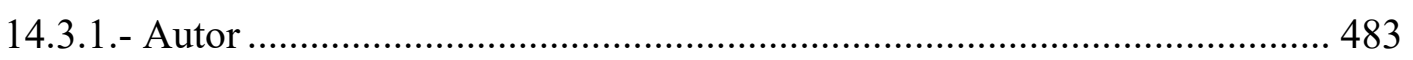

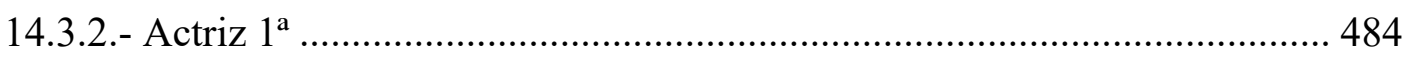

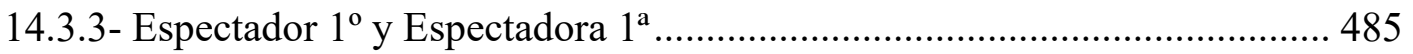

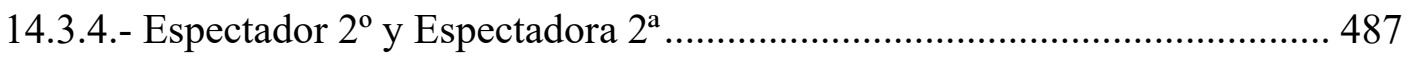

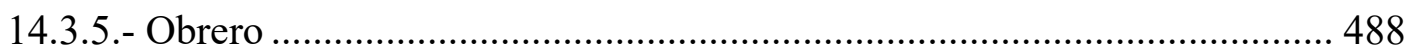

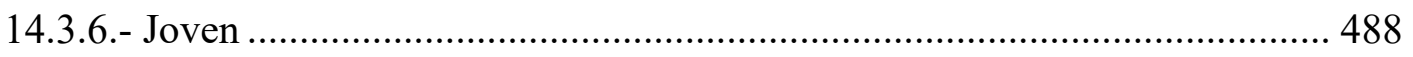

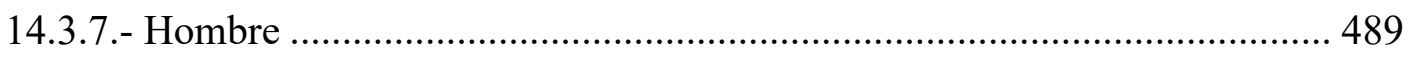


15.- Análisis semiótico teatral: Nivel pragmático

15.1.- La propuesta de Alberto Conejero: El sueño de la vida ................................. 496

15.1.2.- La nueva puesta en escena de Lluís Pasqual......................................... 500

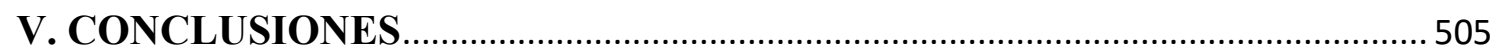

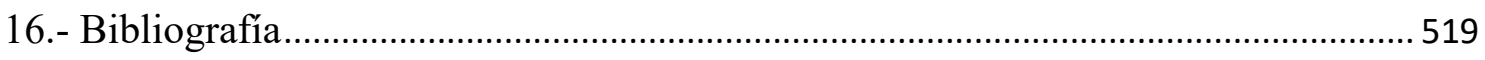

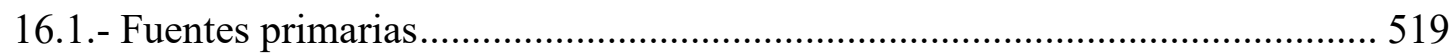

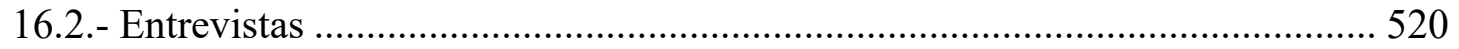

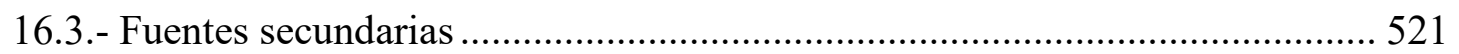

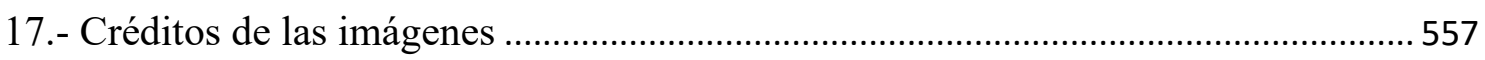




\section{1.- Introducción}

Nuestra investigación se centra en el análisis de las obras teatrales El público (1929) y Comedia sin título (1935-36) de Federico García Lorca, en situarlas dentro de su producción dramática y contextualizarlas en el marco teatral español y europeo de la década de los años veinte y treinta del siglo XX, con el surgimiento de las vanguardias rupturistas y, en especial énfasis, con el movimiento surrealista y su influencia en los jóvenes autores españoles. Pero antes de adentrarnos en el tema, que nos proponemos investigar, realizaremos una breve presentación cronológica de la vida de Federico García Lorca y su obra.

\section{1.- Biobibliografía de Federico García Lorca}

Se ha escrito mucho sobre la vida y obra de Federico García Lorca (1898-1936). Entre las numerosas biografías ${ }^{1}$ que existen hasta el momento, podemos encontrar la de su hermano, Francisco García Lorca, Federico y su mundo ${ }^{2}$ (escrito, entre 1959 y 1965, y publicado en 1981); la del hispanista Ian Gibson, Vida, Pasión y Muerte de Federico García Lorca (escrito entre 1989 y 1997), en la que existen elementos no exactos y desde la perspectiva de un autor pesimista y frustrado en la vida y el amor (en su obra el tema principal es el deseo, más que la frustración amorosa); el extraordinario libro de José Luis Cano, García Lorca (1962), pero con carencias por la época en la que se publicó; el estudio sobra la relación que mantuvieron los tres artistas, Buñuel, Lorca, Dalí: el enigma sin fin (1988) de Agustín Sánchez Vidal y, en el ámbito de ensayo creativo, hemos de destacar el de Francisco Umbral, Lorca, poeta maldito (1968).

Para comparar y verificar los elementos de las diferentes biografías, hay que recurrir a estudios más especializados como son las introducciones a libros o artículos ensayísticos que proceden de revistas y periódicos diversos, en los que relacionan

\footnotetext{
${ }^{1}$ Es aconsejable consultar el exhaustivo capítulo «García Lorca, Federico» de Rafael Alarcón Sierra que aparece en el libro Temas Literarios Hispánicos (II) editado por Leonardo Romero Tobar, en el 2013, por la Universidad de Zaragoza, en el que muestra todas las publicaciones bibliográficas hasta el momento y diversos textos literarios, composiciones musicales y piezas cinematográficas (películas, series y documentales) en los que Lorca es protagonista o motivo de inspiración.

${ }^{2}$ Una ausencia en esta biografía es la obra teatral El público, ya que su tardía publicación, en 1976, debió de dificultar el acceso a Francisco García Lorca al texto y poder realizar una crítica adecuada.
} 
sendas obras con cada momento de la vida del poeta. Un ejemplo de estos estudios es el que hallamos en la serie Biblioteca García Lorca de Alianza editorial y editados por Mario Hernández. En la bibliografía nos ocupamos de todo esto.

Finalmente, es importante recalcar que aunque Lorca no escribió su biografía ${ }^{3}$, sí existe un gran número de referencias autobiográficas en su epistolario, en las que mezcla datos vividos y literatura, ya que, según a quien iban dirigidas las cartas, la información no era la misma, incluso en algunas su escritura es muy poética. Muchas de ellas han sido recopiladas en su Epistolario completo (1997), por Christopher Maurer y Andrew A. Anderson, y, años más tarde, los mismos autores las documentaron en Federico García Lorca en Nueva York y La Habana. Cartas y recuerdos (2013).

Federico García Lorca nació en el pueblo de Fuente Vaqueros (Granada), el 5 de junio de 1898. En 1906, la familia se trasladó al vecino pueblo de Asquerosa (posteriormente llamado Valderrubio) ya que los negocios de su padre exigían la presencia en el cortijo y la finca de Daimuz Bajo 4 .

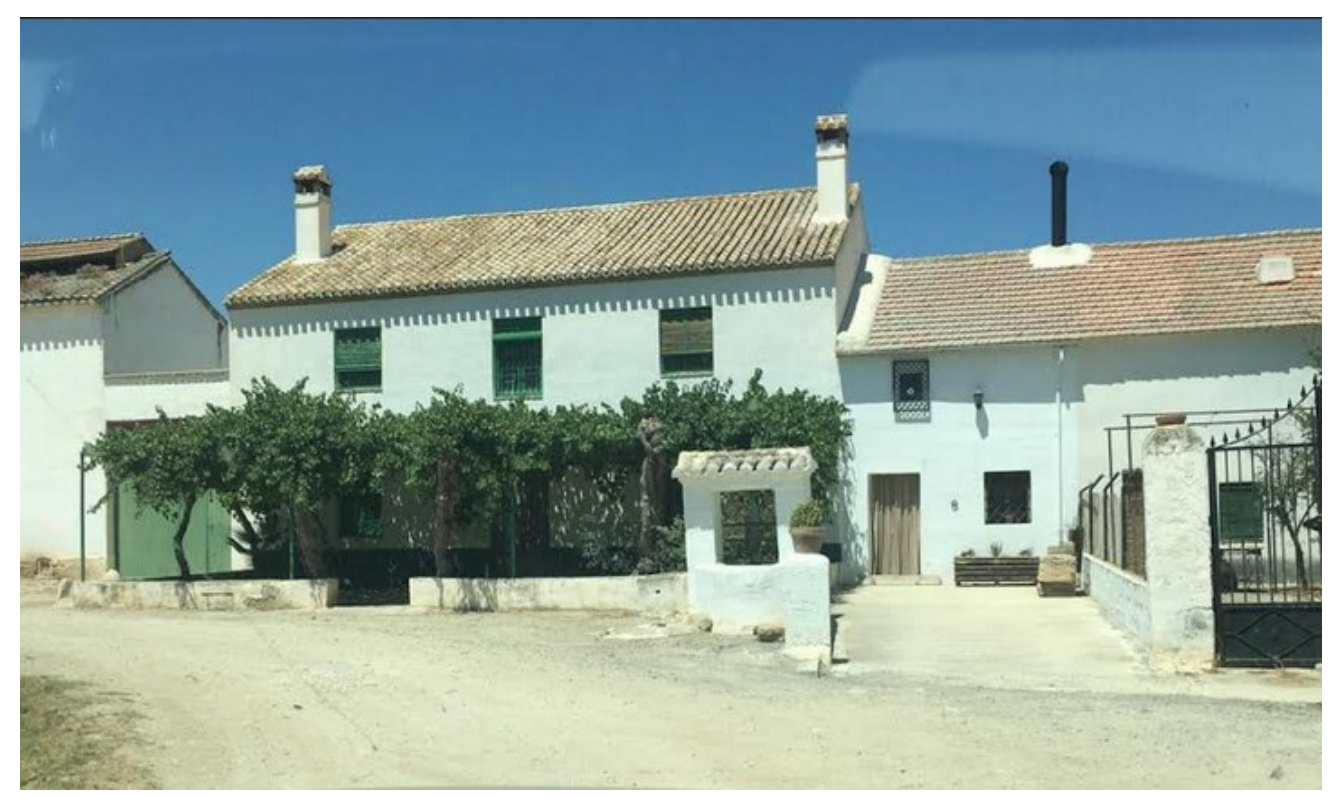

Fig. 1: Cortijo Daimuz en la actualidad.

\footnotetext{
${ }^{3}$ En marzo de 2019, se presenta la plataforma virtual «Universo Lorca», impulsada por la Diputación de Granada junto a otras instituciones que reúne por primera vez en una sola página de Internet la vida y obra de Federico García Lorca, junto a una amplia selección de lugares, rutas y personajes relacionados con su vida y producción artística. https:/www.universolorca.com.

${ }^{4}$ En la vega del Valderrubio, pero perteneciente al municipio de Pinos Puente, donde el padre de Lorca amasó su fortuna.
} 
En 1909, cuando tenía once años, la familia decide trasladarse a la ciudad de Granada. $\mathrm{Su}$ nueva vida en la ciudad hizo que experimentara una ruptura con el campo. Su primera vocación artística fue la música, desde muy joven empezó a tocar la guitarra y estudió el piano, compuso canciones con fuertes raíces flamencas, pero no recibió el apoyo de su familia, y debió olvidar este tipo de estudios. En otoño de 1914, se matriculó en un curso de acceso a las carreras de Filosofía y Letras y de Derecho ${ }^{5}$ de la Universidad de Granada.

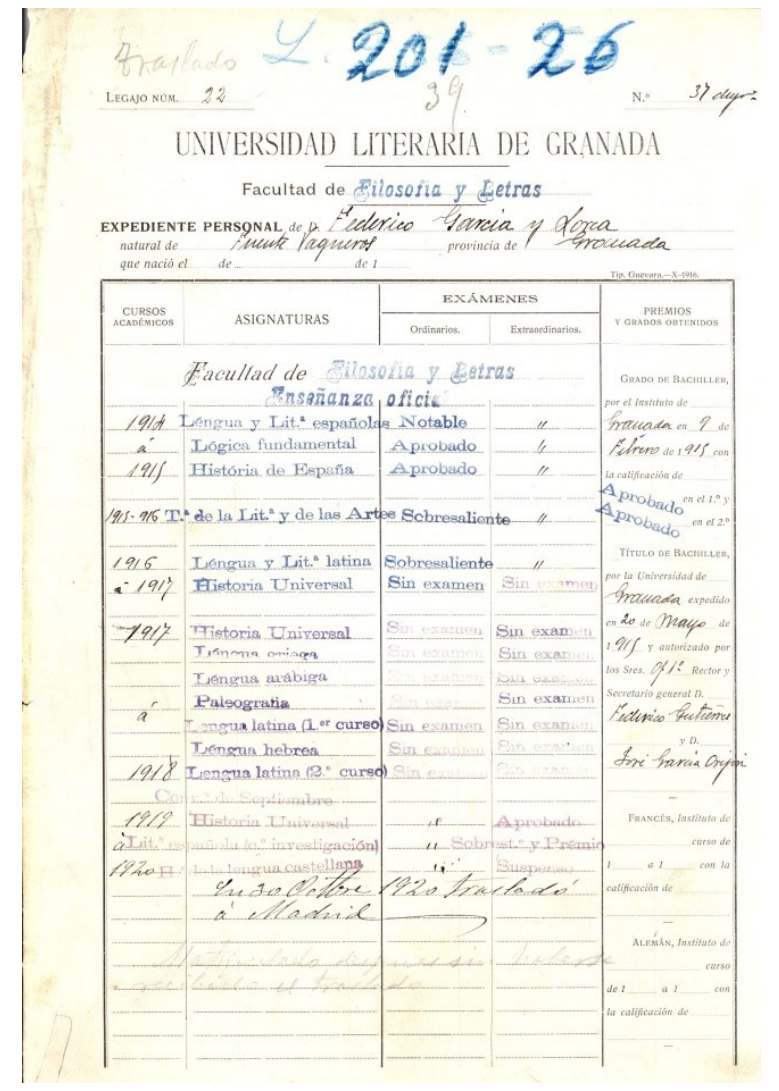

Fig. 2: Expediente ${ }^{6}$ universitario de Federico García Lorca en la Facultad de Filosofía y Letras de la Universidad Literaria de Granada.

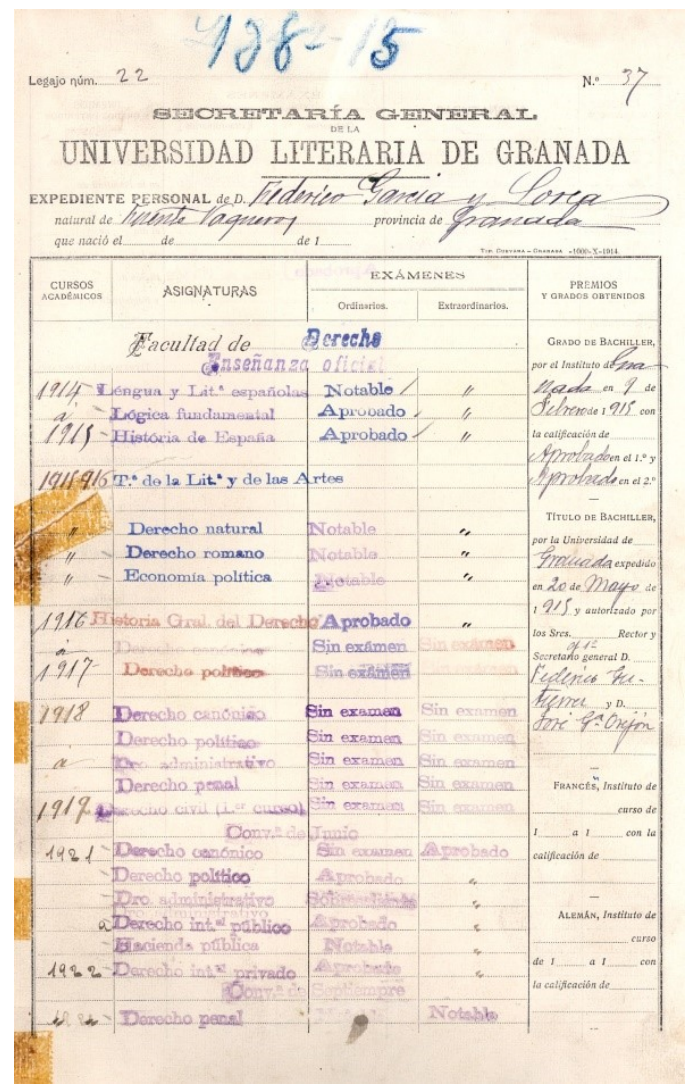

Fig. 3: Expediente universitario de Federico García Lorca en la Facultad de Derecho de la Universidad Literaria de Granada.

Forma parte de los intelectuales y artistas de Granada. En febrero de 1917, el Boletín del Centro Artístico y literario de Granada publica sus primeros trabajos literarios

\footnotetext{
5 En la página electrónica del Archivo Universitario de la Universidad de Granada de encuentra digitalizados, en acceso abierto, el expediente de Bachiller (1914-1915), el expediente académico de Derecho (1915-1922) y el expediente académico en Filosofía y Letras (1914-1921).

https://archivo.ugr.es/pages/trabajosdocumentos/personajes-ilustres-escritores-academicos-y-humoristas

${ }^{6}$ Se puede observar en el expediente de Letras la fecha de cierre escrita a tinta negra, «En 30 octubre 1920 trasladó a Madrid» y en lápiz, «Matriculado después sin haberse recibido el traslado».
} 
«Divagación. Las reglas de la música» y «Fantasía simbólica», con motivo del centenario de Zorrilla (Ory [1967] 2019, 173; Soria Olmedo 2007, 17). La segunda semana de abril de 1918, Federico García Lorca publicó su primer libro Impresiones y paisajes, fruto de una serie de viajes ${ }^{7}$ por otras regiones de España, sobre todo por tierras de Castilla la Vieja, que realizó con sus compañeros de estudios y el profesor de Historia del Arte don Martín Domínguez Berrueta, profesor de Teoría de las Artes y de la Literatura en la Facultad de Letras e influido por el espíritu de la Institución Libre de Enseñanza, que tenía la costumbre organizar excursiones en relación con temas de arte y culturales en Granada con sus alumnos. En el libro únicamente nombra el paisaje, los jardines y los monumentos, sin mencionar el viaje académico, con su profesor y compañeros, lo que disgustó a Berrueta, llegando a romper totalmente su amistad (García Lorca, Francisco 1981, 93; Soria Olmedo 2007, 17-18). El libro está escrito en prosa, con un tono ensayístico, única obra de estas características entre su producción. Con la publicación de este libro, impreso con el dinero de su padre, no se esperaba que tuviera un reconocimiento nacional.

Ante la dificultad en algunas asignaturas, su carrera universitaria se encontraba estancada (en los cursos 1917-1918 y 1918-1919 no se había presentado a ningún examen). A finales de 1918, sus padres, persuadidos por Fernando de los Ríos, consideran conveniente trasladar los estudios a Madrid. En la primavera de 1919, se desplazó a Madrid con una carta de presentación de Fernando de los Ríos para el director de la Residencia de Estudiantes, uno de los centros de intercambios culturales más importante en España en la época. En un principio vivió en una pensión familiar, con Mora Guarnido, hasta instalarse en la Residencia de Estudiantes. La estancia en la Residencia se prolongará hasta 1928, sin dejar de estar vinculado a ella por siempre. Allí conoció a Pepín Bello, Luis Buñuel, Salvador Dalí, Emilio Prados, José Moreno Villa y otros miembros del 27. Frecuentaba tertulias literarias y el Ateneo de Madrid. Ese mismo año escribió su primera obra dramática El maleficio de la mariposa, obra que estrenó el 22 de marzo de 1920 en el teatro Eslava de Madrid, con un fugaz estreno después de un rotundo fracaso de público y prensa.

\footnotetext{
${ }^{7}$ Su primer viaje de estudios, en junio de 1916, a Baeza, Úbeda, Córdoba y Ronda. El segundo viaje que realizó, en octubre de 1916, por Madrid, El Escorial, Ávila, Medina del Campo, Salamanca, Zamora, Santiago de Compostela, La Coruña, Lugo, León, Burgos y Segovia. De nuevo, en la primavera de 1917, a Baeza. Y por último, en el verano y otoño de 1917, a Burgos.
} 
Lorca para contentar a sus padres decidió retomar sus estudios universitarios ${ }^{8}$, pero esta vez por libre. En el artículo de Andrés Soria Olmo, «El estudiante Federico García Lorca» de 2007 (año que vieron la luz sus expedientes en acceso abierto), se realiza un exhaustivo recorrido por sus estudios universitarios, los años de estudios, las asignaturas matriculadas, las notas y los diferentes profesores.

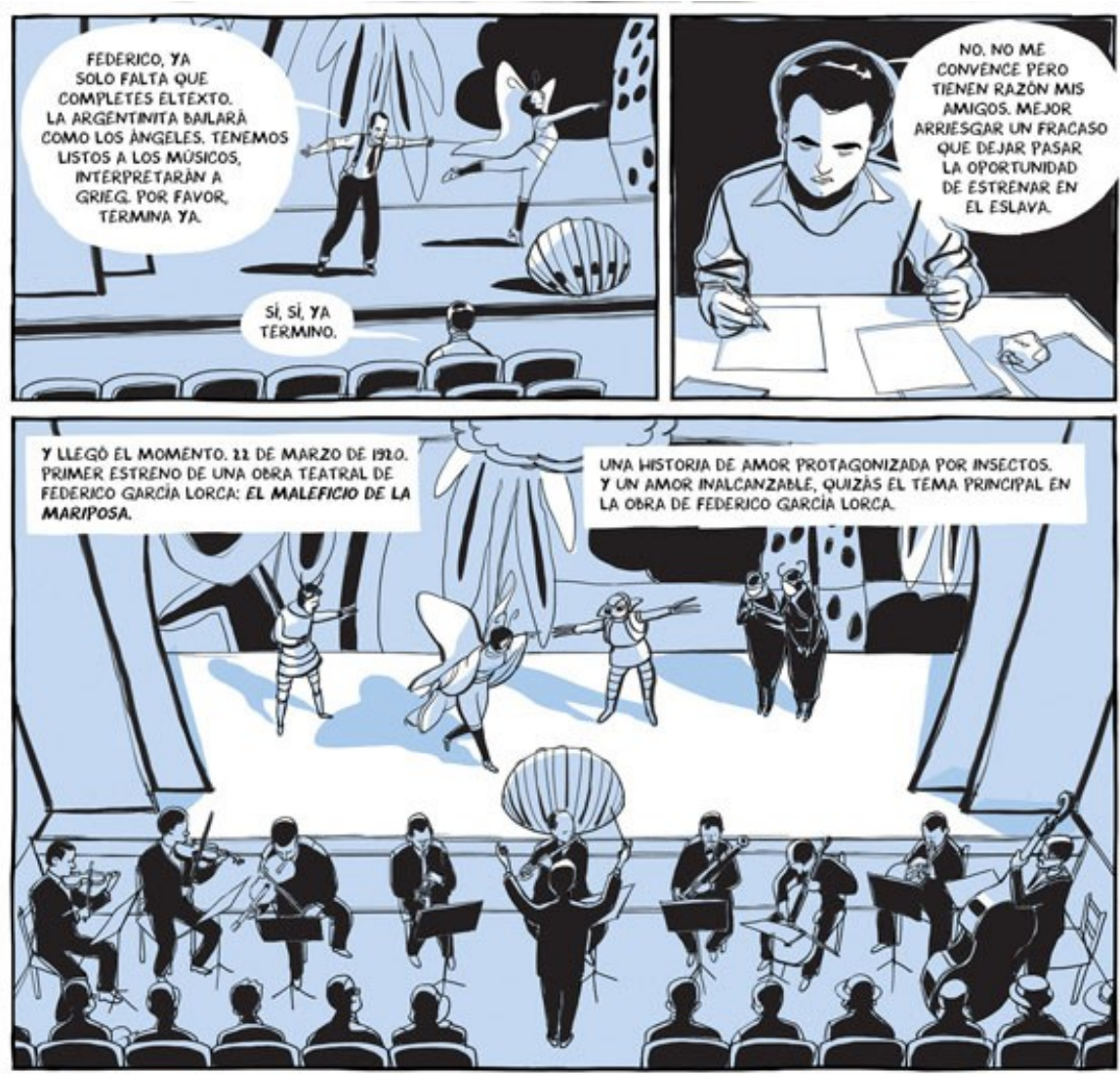

Fig. 4: Viñeta correspondiente al momento del estreno de El maleficio de la mariposa, perteneciente a la novela gráfica Vida y muerte de Federico García Lorca ${ }^{9}$.

En octubre de 1921, regresó a la Residencia de Estudiantes y publicó su primer libro de poesía, Libro de poemas $^{10}$, publicado en Índice, dedicado a su hermano Francisco, formado por una serie de versos seleccionados de su producción poética juvenil, en los que es evidente la falta de madurez. La edición se agotó pronto (Babín 1976, 39). Ese

\footnotetext{
${ }^{8}$ Con la ayuda de su profesor de economía don Agustín Viñuales, consigue licenciarse, en 1923, en Derecho por la Universidad de Granada, — no llegó por el contrario a licenciarse nunca en Filosofía y Letras-. En Conversaciones con José «Pepín» Bello, su amigo Pepín Bello cuenta la anécdota de cómo consigue licenciarse (Castillo y Sardá 2007, 40-41).

${ }^{9}$ El ilustrador Quique Palomo y el hispanista británico Ian Gibson nos presentan un recorrido por la vida de Federico García Lorca, desde el nacimiento hasta su muerte, en esta novela gráfica.

${ }^{10}$ Su primera poesía está fechada el 29 de junio de 1917 y la más tardía en diciembre de 1920.
} 
mismo año, conoció a Juan Ramón Jiménez que le invitó a colaborar en la revista Índice. Publica en los números 2 y 3 de dicha revista, con los poemas «El jardín de las moreras» y «Suite de espejo» (Ory [1967] 2019, 174). En 1922, junto a Manuel de Falla e Ignacio Zuloaga ${ }^{11}$, formó parte en la preparación del Primer Concurso de Cante Jondo en Granada cuyo objetivo era marcar la diferencia entre el cante jondo y el cante flamenco. Inicia la composición de una serie de versos que formarán parte del Poema del cante jondo (escritos en 1921 pero corregidos y publicados en 1931) (Mainer 2013, 495). Meses antes del concurso pronunció una conferencia «Importancia histórica y artística del primitivo canto andaluz llamado cante jondo», que posteriormente la impartiría en diferentes ciudades.

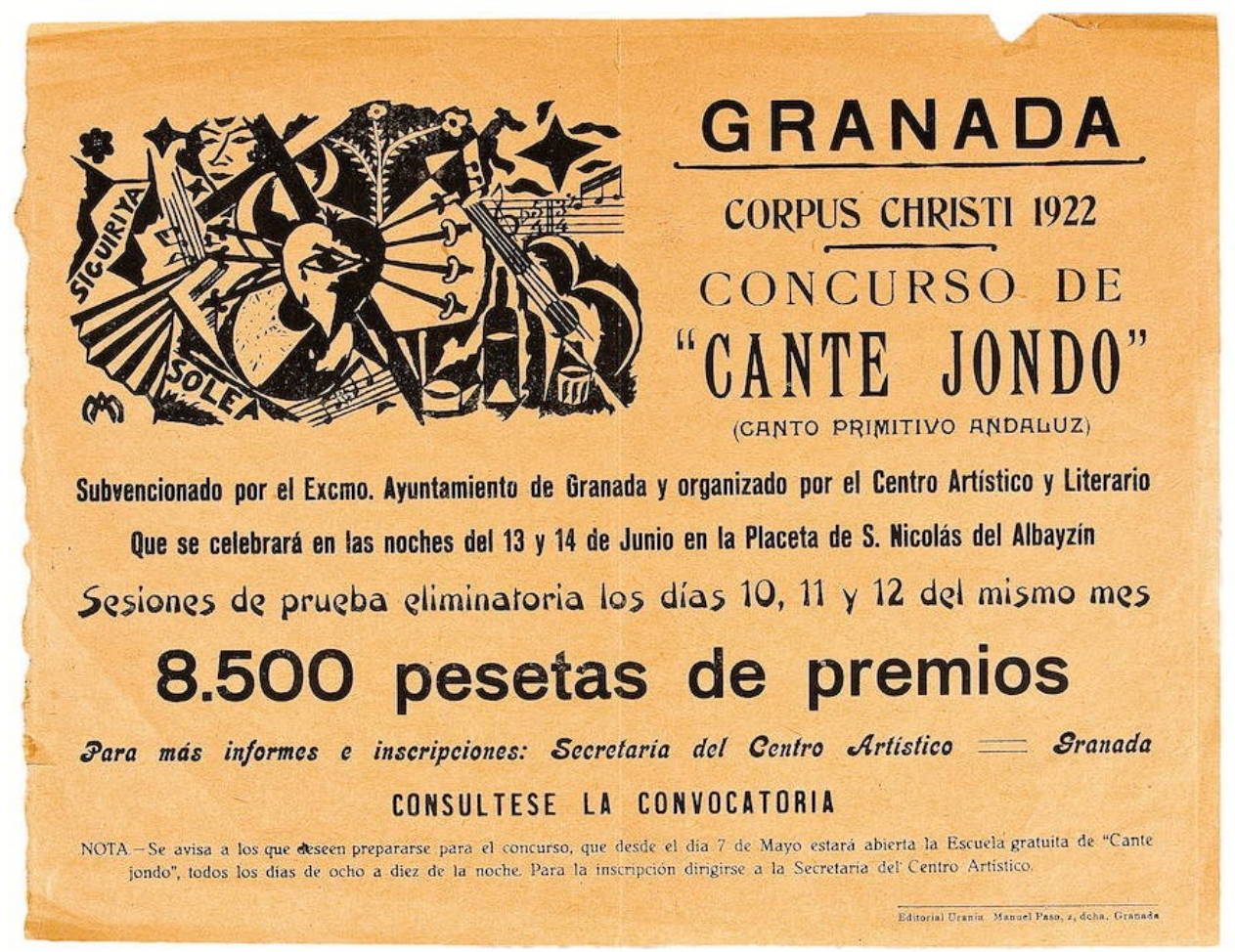

Fig. 5: Cartel del Concurso de Cante Jondo elaborado conjuntamente por Manuel Ángeles Ortiz y Hermenegildo Lanz. En él figura la sede prevista inicialmente, la Plaza de San Nicolás, en el Albaicín, aunque al final se trasladó la celebración a la plaza de los Aljibes.

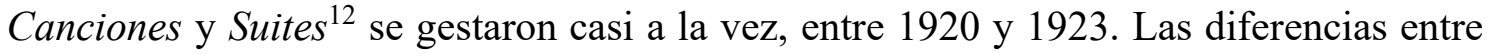
ambos libros son pocas, aunque Canciones es un libro más acabado pensado por el autor para gustar al público. En 1924, concluyó su libro Canciones (publicado en 1927 en un

\footnotetext{
${ }^{11}$ El pintor colaboró económicamente en el Primer Concurso de Cante Jondo en Granada.

12 Publicadas en 1982 por André Bellamich (Mainer 2013, 495).
} 
suplemento de la revista Litoral), terminó una nueva pieza dramática Mariana Pineda y empezó a escribir el Romancero gitano. El 8 de enero de 1925, finaliza la tercera versión de Mariana Pineda, en Granada (Ory [1967] 2019, 175). Salvador Dalí, a quien había conocido en la Residencia de Estudiantes en 1922, le invitó a pasar, en la primavera de 1925, la Semana Santa en Cadaqués. Fue su primer viaje a Cataluña, donde se hace amigo de la hermana de Dalí, Ana María, y leyó a la familia su pieza teatral Mariana Pineda. Mientras, continúa escribiendo el Romancero gitano. En 1926, acabó la primera versión de La zapatera prodigiosa, al menos escribió dos versiones de la misma (Fernández Cifuentes 1986, 97).

El 13 de febrero de 1926, pronuncia la conferencia «La imagen poética de don Luis de Góngora» en el Ateneo científico, artístico y literario de Granada, publicada en el periódico El Defensor de Granada, en la que no oculta su admiración por el poeta, en el que busca inspiración no influencia (Cano [1962] 1974, 52).

En febrero de 1927, junto a su hermano Francisco García Lorca y sus amigos de "El Rinconcillo" de Granada, desarrolló el proyecto de la revista gallo y publicó su segundo libro de poesía Canciones (1927). En mayo y por segunda vez, viaja a Cadaqués, donde pasó una larga temporada en casa de Salvador Dalí, preparando el estreno de Mariana Pineda, que tuvo lugar el 24 de junio en el teatro Goya de Barcelona, a cargo de la compañía de Margarita Xirgu ${ }^{13}$, de cuya escenografía se encargó el propio Dalí. En octubre, la estrenaría en Madrid en el teatro Fontalba.

Son numerosos los poemas y los diálogos en prosa que publica a lo largo de este año en diferentes revistas, entre ellos «Viñetas flamencas», «El paseo de Buster Keaton», «Quimera», «Romance de la luna de gitanos» etc., que luego los recogerá y publicará para formar parte de libros posteriores.

Dalí consiguió que Lorca expusiera veinticuatro dibujos ${ }^{14}$ en las Galerías Dalmau de Barcelona, donde conoce a Sebastià Gasch, empezando una amistad entrañable entre

\footnotetext{
${ }^{13}$ Es recomendable la película La Xirgu (2015) dirigida para la televisión por Silvia Quer y protagonizada por la actriz Laia Marull, en el papel de Margarita Xirgu, en la que nos cuenta las dificultades que tuvo la actriz para estrenar la obra Mariana Pineda en Barcelona, por la temática que narra la pieza y el momento histórico.

${ }^{14}$ 1. Claro de luna, 2. Sueño del marino, 3. Vaso de cristal, 4. Vaso de cristal, 5. Dama en el balcón, 6. Payaso, 7. Gota de agua, 8. Ojo de pez, 9. Escándalo, 10. Sta. Teresita del Santísimo Sacramento, 11. Claro de circo, 12. Naturaleza muerta, 13. Payaso japonés, 14. Leyenda de Jerez, 15. Teorema del jarro,
} 
ellos. La exposición no fue popular, la exposición permaneció abierta durante una semana, pero interesó a una minoría ilustrada, junto a la aparición de varias críticas ${ }^{15}$ de la exposición en las revistas especializadas como La Nova Revista con Salvador Dalí, Ciutat con José María de Sucre y Rafael Benet y L'amic de les Arts con Sebastià Gasch (Areán 1986, 108). La exposición barcelonesa no fue la única en la que Lorca exhibió sus dibujos. El 26 de junio de 1932, en el Ateneo Popular de Huelva, se inauguró una muestra colectiva en la que se expusieron ocho de sus dibujos ${ }^{16}$ en los salones del Ateneo. Fue tal el escándalo entre el público que la exposición fue clausurada al día siguiente (Rodrigo 1975, 125: Millán 1986b, 61: Plaza Chillón 2019, 265).

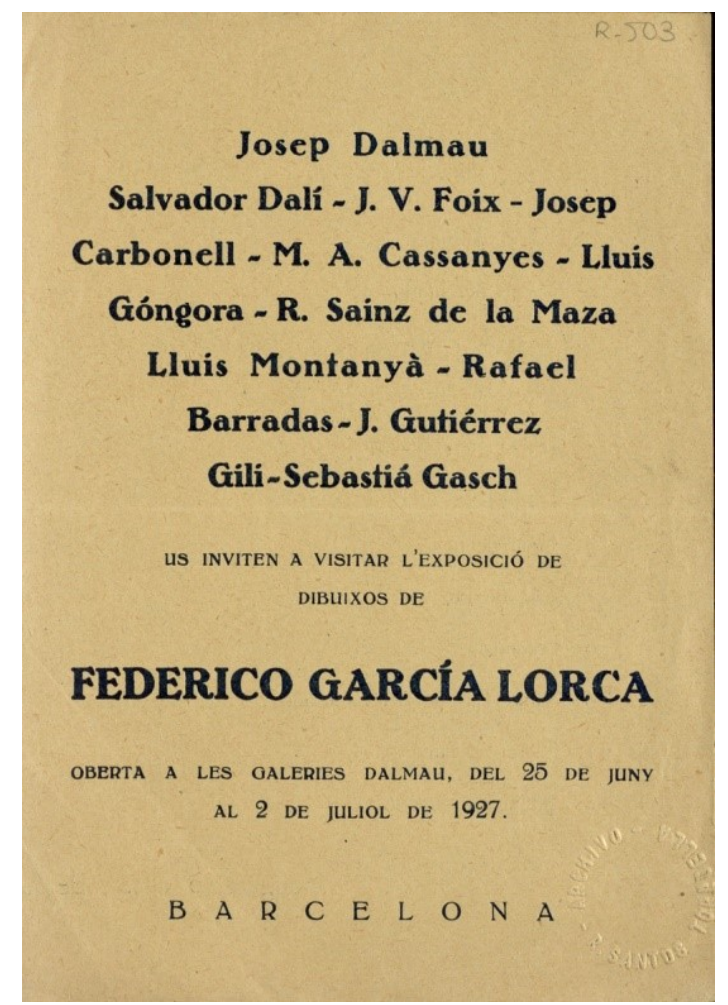

Fig. 6: Invitación y catálogo de la Exposición de dibujos de Federico García Lorca en las Galerías Dalmau de la calle Portaferrisa, Barcelona, 1927.

16. La mantilla, 17. La musa de Berlín, 18. El viento Este, 19. Teorema de la copa y la mandolina, 20. Merienda, 21. Pecera, 22. Beso en el espejo, 23. Naturaleza muerta, y 24. Retrato del pintor Salvador Dalí. Muchos de ellos hoy en día están perdidos (Millán 1986b, 60).

${ }^{15}$ Las podemos encontrar transcritas por Antonina Rodrigo en García Lorca en Cataluña (114-121).

16 1. La luna de los seminaristas, 2. Asesinato, 3. Bailarina española, 4. Deseos de las ciudades muertas, 5. San Cristóbal, 6. Orfeo, 7. Muerte de santa Rodegunda y 8. Parque, algunos de estas obras hoy en día están perdidas. (Millán 1986b, 61). 
En diciembre de 1927, tuvo lugar la celebración del tricentenario de Luis Góngora y Argote (1561-1627) en el Ateneo sevillano que sirvió para reunir a una serie de poetas, la denominada Generación o Grupo Poético del 27: Federico García Lorca, Dámaso Alonso, Gerardo Diego, Rafael Alberti, Mauricio Bacarisse, Jorge Guillén, José Bergamín y Juan Chabás, quienes pronunciaron conferencias o recitaron poemas durante dos veladas literarias y un banquete ${ }^{17}$ en la venta de Antequera.

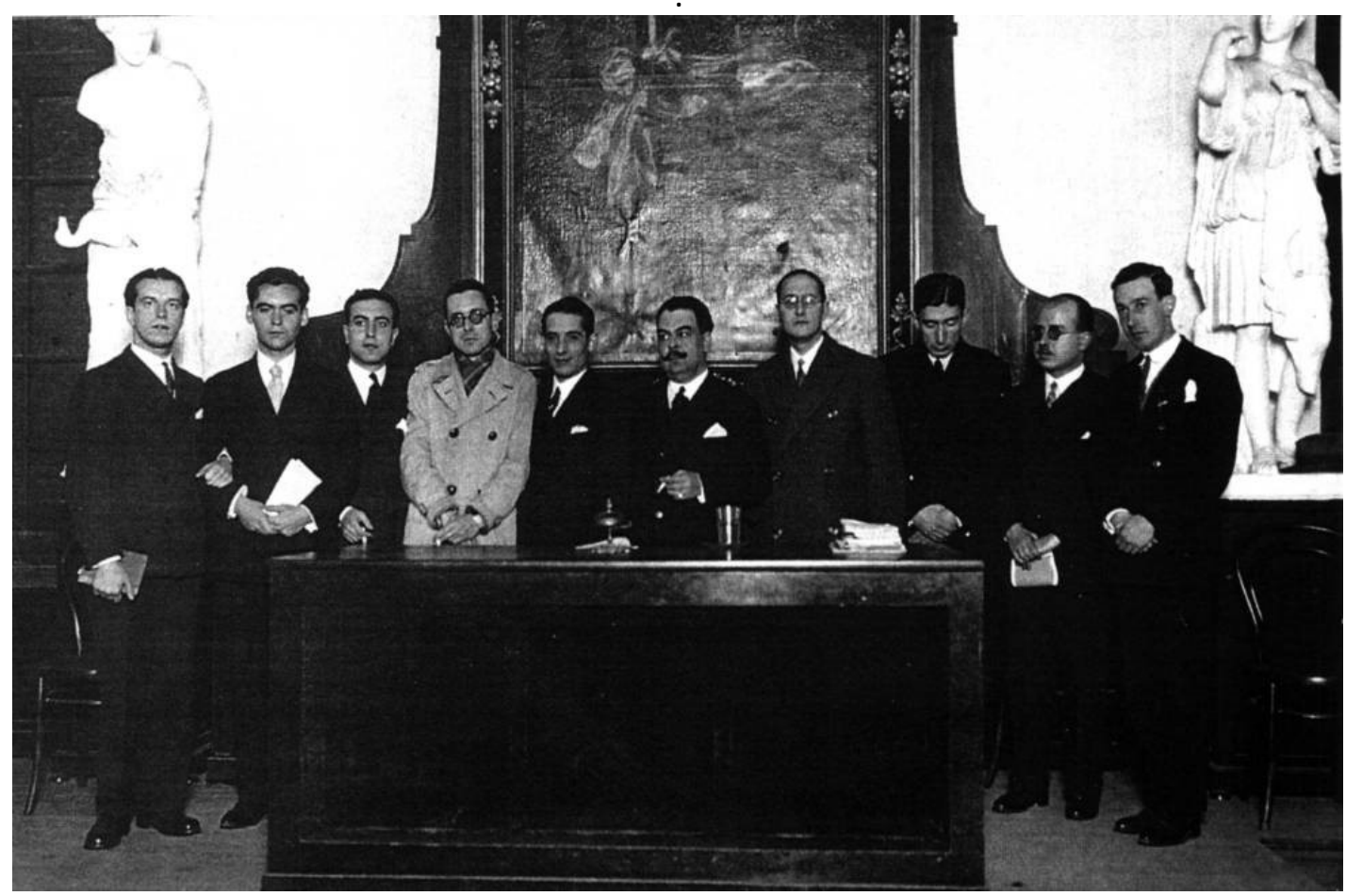

Fig. 7: Fotografía ${ }^{18}$ del grupo poético del 27 en su visita a Sevilla, en diciembre de 1927, por la celebración de tricentenario de Góngora.

En julio de 1928, se publica Primer romancero gitano ${ }^{19}$ en la Revista de Occidente, dirigida por Ortega y Gasset, cuya popularidad fue inmediata. En la misma revista, aparece en abril de ese mismo año su «Oda al Santísimo Sacramento del Altar». Ese mismo año, también publica su obra teatral Mariana Pineda y pronuncia, el 13 de

\footnotetext{
${ }^{17}$ Ignacio Sánchez Mejías corrió con parte de los gastos, ya que la estancia y celebración se alargó un par de días.

${ }^{18}$ De izquierda a derecha: Rafael Alberti, Federico García Lorca, Juan Chabás, Mauricio Bacarisse, José María Romero Martínez (presidente de la sección de literatura del Ateneo), Manuel Blasco Garzón (presidente del Ateneo de Sevilla), Jorge Guillén, José Bergamín, Dámaso Alonso y Gerardo Diego.

${ }^{19}$ El ordinal «Primer» en la edición argentina de 1933 desapareció, y también en las siguientes (Mainer 2013, 496).
} 
diciembre, la conferencia «Las nanas infantiles» ${ }^{20}$ en la Residencia de Estudiantes (Sociedad de Cursos y Conferencias), siendo varias las conferencias que dicta durante 1928. Un año más tarde prepara la segunda edición de Canciones para la Revista de Occidente.

En la primavera de 1929, al sentirse abrumado por el éxito del Romancero, sufrir el rechazo entre sus amigos Luis Buñuel y Salvador Dalí y la separación con su amigo Emilio Aladrén, decidió viajar a Nueva York junto a su profesor Fernando de los Ríos y se instaló en la Columbia University. Durante el verano viajó por Vermont y otros lugares. En otoño, mantuvo un encuentro con Dámaso Alonso, León Felipe y Rubio Sacristán y, en noviembre, con Ignacio Sánchez Mejías ${ }^{21}$ y Antonia Mercé, la Argentinita, a la que se rindió un homenaje en diciembre en el Instituto de las Españas de Nueva York. Durante estos meses, realizó diversas conferencias en Columbia University y en Vassar College. Escribió una versión más completa de su pieza teatral La zapatera prodigiosa. El poemario Poeta en Nueva York fue escrito entre 1929 y 1930, aunque no fue publicado en vida (publicado y prologado en 1940 por José Bergamín) (Mainer 2013, 497).

En la primavera de 1930, viajó a Cuba, invitado por la Institución Hispano-Cubana de Cultura donde impartió conferencias. Empezó a escribir Así que pasen cinco años y El público. En junio regresó a España y el 24 de diciembre estrenó en el teatro Español su obra La zapatera prodigiosa, con la compañía El Caracol, dirigida por Cipriano Rivas Cherif, y con Margarita Xirgu en el papel de protagonista.

En 1931, publicó Poema del cante jondo en Ediciones Ulises, escrito una década antes como hemos apuntado. En octubre leyó en casa de Carlos Mora la obra Así que pasen cinco años y emprende la redacción de El retablillo de don Cristóbal.

Con la proclamación de la Segunda República en abril de 1931, aunque hacía años que ya participaba activamente en la vida literaria española, empezó a colaborar en varios

\footnotetext{
${ }^{20}$ En la última edición publicada, José Javier León afirma que Lorca «volvió a dictarla dos veces más, ambas en el segundo trimestre de su curso americano: en Vassar College (Poughkeepsie, estado de Nueva York), el 21 d enero de 1930 y, en la Habana, el 16 de marzo de ese mismo año» (2020, 29).

${ }^{21}$ Para ampliar conocimientos sobre la vida de Ignacio Sánchez Mejías, consultar la tesis Ignacio Sánchez Mejías: Torero y Escritor. Su relación con la Vanguardia y con la Generación del 27 de Susana María Teruel Martínez defendida en 2014 en la Universidad de Murcia. Acceso abierto en la página https://digitum.um.es/xmlui/handle/10201/39846
} 
proyectos culturales, que pretendían el intercambio entre la ciudad y los pueblos. En noviembre concibe y proyecta el teatro universitario La Barraca dirigido por el propio Lorca y el dramaturgo Eduardo Ugarte. El 6 de julio de 1932, tuvieron lugar los primeros ensayos en la Residencia de Señoritas, y el mismo mes se registró la primera actuación en la plaza de Burgo de Osma (Soria). Entre noviembre y diciembre, continuaron las representaciones por Granada, Alicante y Barcelona. Sin embargo, La Barraca no le impedía seguir trabajando en sus nuevos proyectos.

Entre marzo y mayo de 1932, ofreció distintas conferencias por diferentes ciudades españolas: Valladolid, Sevilla, Salamanca, Galicia y San Sebastián. El 16 de marzo presentó, por primera vez, en la Residencia de Señoritas, su obra Poeta en Nueva York. En septiembre lee en casa de Carlos Morla, Bodas de sangre. Se atreve a escribir unos poemas en una lengua que no es la suya, Seis poemas galegos, escritos entre 1932 y 1934, y publicados en 1935.

El 8 de marzo de 1933, estrenó en el Teatro Infanta Beatriz de Madrid la obra Bodas de sangre por la compañía de Josefina Díaz de Artigas, que se mantuvo varios meses en el cartel. En la primavera de 1933, colaboró con Pura Ucelay en la creación de los Clubs Teatrales de Cultura (Club de Teatro Anfistora). El 5 de abril, estrenó en el teatro Español la obra Amor de don Perlimplín con Belisa en su jardín bajo su dirección.

En 1933, recibió una invitación ${ }^{22}$ de la Sociedad de Amigos del Arte de Buenos Aires para recitar una serie de conferencias y asistir al éxito de Bodas de sangre ${ }^{23}$, que se estaba representando allí por la compañía de Lola Membrives. Viaja con su amigo Manuel Fontanals. El 1 de diciembre, estrena La zapatera prodigiosa con la interpretación de Lola Membrives y, cada noche, Federico García Lorca recitaba el prólogo de la obra. También estrena, con la misma compañía, Mariana Pineda. A finales de mes de diciembre, acepta una invitación desde Montevideo para leer una serie de conferencias y colaborar en el homenaje al pintor Barradas con el que mantuvo una gran amistad en vida del pintor (Cano [1962] 1974, 102). Durante su estancia en

\footnotetext{
${ }^{22}$ Se alojó en el hotel bonaerense Castelar (del 13 de octubre de 1933 a marzo de 1934) en la habitación 704.

${ }^{23}$ El 21 de noviembre la obra alcanza las cien representaciones.
} 
Montevideo, fue a visitar el cementerio en el que se encontraba enterrado, y según narra José Mora Guarnido:

Un grupo de amigos [...] acompañamos a Federico al cementerio del Buceo, [...] el poeta, en silencio, fue arrojando un puñado de humildes florecillas. Ninguna solemnidad, ni el menor aparato, sino un sencillo y callado acto de recordación y de meditación (citado en García Lorca, Francisco 1981, 213).

A comienzos del verano de 1934, escribió Yerma, y retomó la dirección de La Barraca llevándola hasta Santander y en Santiago de Compostela. El 11 de agosto muere el torero Ignacio Sánchez Mejías a quien en septiembre dedicará su elegía «Llanto por Ignacio Sánchez Mejías». El 29 de diciembre estrena la obra Yerma en el Teatro Español de Madrid, a cargo de la compañía de Margarita Xirgu; la obra se mantuvo en cartel varios meses. Cabe destacar que suscitó una reacción violenta en la prensa conservadora, aunque el tema de la obra no lo justificase, pero debemos señalar que entre marzo de 1933 y diciembre de 1934 existieron grandes tensiones políticas entre la derecha y la izquierda, y puede ser que ese fuera el motivo del rechazo por parte de una prensa más conservadora. Al cumplirse las cien representaciones, la compañía dedica un homenaje al poeta, en el que lee «Llanto por Ignacio Sánchez Mejías». Publica en el número 3 de Los Cuatro Vientos, dos de los cuadros que formarán parte del El público: «Ruina romana» y el Cuadro Quinto.

A mediados de febrero de 1935, de regreso a Buenos Aires, estrena, con la compañía de Eva Franco, la adaptación de la obra original La dama boba de Lope de Vega con variantes modernas, en la que cambió levemente el título por La niña boba y añadió canciones propias, música y bailes.

El 25 de marzo, antes de su partida, ofreció un homenaje en el teatro Avenida con una representación que consistió en un espectáculo de títeres ${ }^{24}$, con la colaboración del pintor Ernesto Arancibia, el escenógrafo y el acuarelista Jorge Larco que modelaron los títeres y los decorados, y Manuel Fontanals, quien estuvo a cargo de los trajes, los

\footnotetext{
${ }^{24}$ Después de la presencia de Lorca se produce un gran movimiento en Buenos Aires del arte de los títeres. Hasta entonces el teatro de títeres del estilo de Lorca (conocidos como títeres de guante) no era muy conocido en Argentina ni en el resto de América Latina.

Luego de la partida de Lorca, Ernesto Arancibia crea su propia compañía de Títeres de Cachiporra «Los Fantoches de Maese Perico» (Medina 2017).
} 
decorados y la portada del retablo, según las sugerencias de Lorca (Medina 2017). Las tres obras representadas fueron Dos habladores de Cervantes, Euménides de Esquilo, y el Retablillo de don Cristóbal y doña Rosita del propio Lorca, escrita expresamente para esta función, con la colaboración de la actriz valenciana Helena Cortesina y otros actores de la compañía de Membrives. Dos días más tarde, el 27 de marzo, embarca junto a Fontanals, en el transatlántico italiano Conte Biancamano, de regreso a España (Cano [1962] 1974, 103).
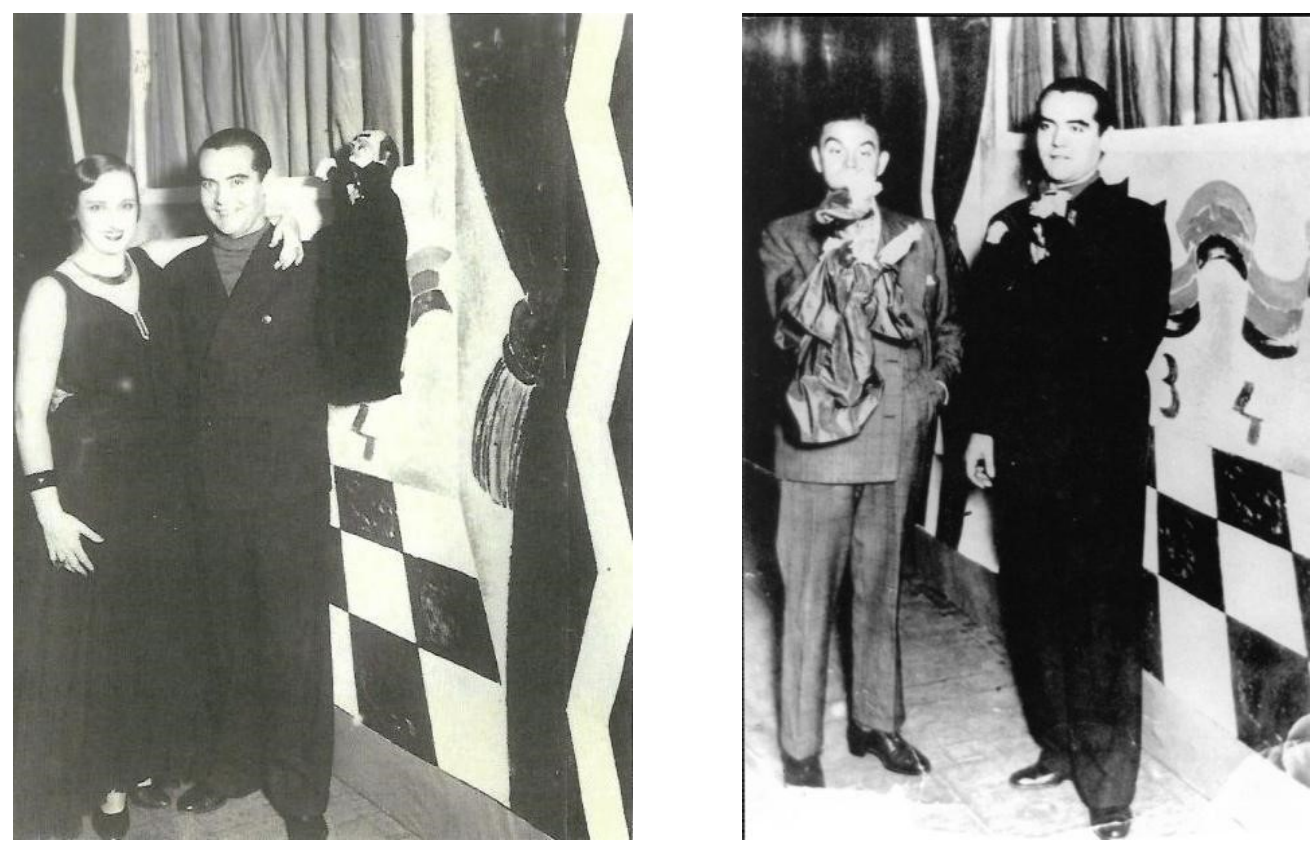

Fig. 8 y 9: Lorca con don Cristóbal a la derecha, junto a la actriz Helena Cortesina, en la representación del Retablillo, Argentina, 1934.

Colección: Fundación Federico García Lorca.

Ese mismo año, pronunció la conferencia, «Charla sobre teatro» en el teatro Español. Estrenó en el teatro Coliseum de Madrid La zapatera prodigiosa, por la compañía de Lola Membrives y bajo su dirección. Termina, en junio, la obra Doña Rosita la soltera. Viaja a Barcelona para asistir al estreno, el 17 de septiembre, de Yerma por la compañía de Margarita Xirgu. Asimismo a Granada donde recitó poemas inéditos de El Diván del Tamarit.

En enero de 1936, publicó Bodas de Sangre, en la edición de Cruz y Raya, y Primeras canciones, en la colección «Héroe» que dirigía su amigo Manuel Altolaguirre. En febrero participó en un homenaje a Rafael Alberti y, pocos días después, en otro homenaje que se ofrecía a Ramón del Valle-Inclán en el Teatro de la Zarzuela. Viajó a 
San Sebastián para dar algunas conferencias donde se encontró con Gabriel Celaya. Planeaba otro viaje a América, esta vez a México, donde esperaba reunirse con Margarita Xirgu. El 19 de abril participó en el homenaje ofrecido a Luis Cernuda por la publicación de su libro La realidad y el deseo. En junio concluía la obra La casa de Bernarda Alba, que leyó en el domicilio de los condes de Yebes el 24 de junio. Ese mismo mes, ensayó su pieza surrealista Así que pasen cinco años con el Club Teatral Anfistora, aunque no llegó a estrenarse.

La situación política española se volvía cada vez más convulsa. El 13 de julio de 1936 decidió marcharse a Granada, asustado por los acontecimientos que se estaban viviendo en Madrid, preludio de la guerra civil, para reunirse con su familia y celebrar la festividad de San Federico en la Huerta de San Vicente. Antes de su despedida hizo entrega a su amigo Rafael Martínez Nadal, entre otros documentos, del manuscrito de El público.
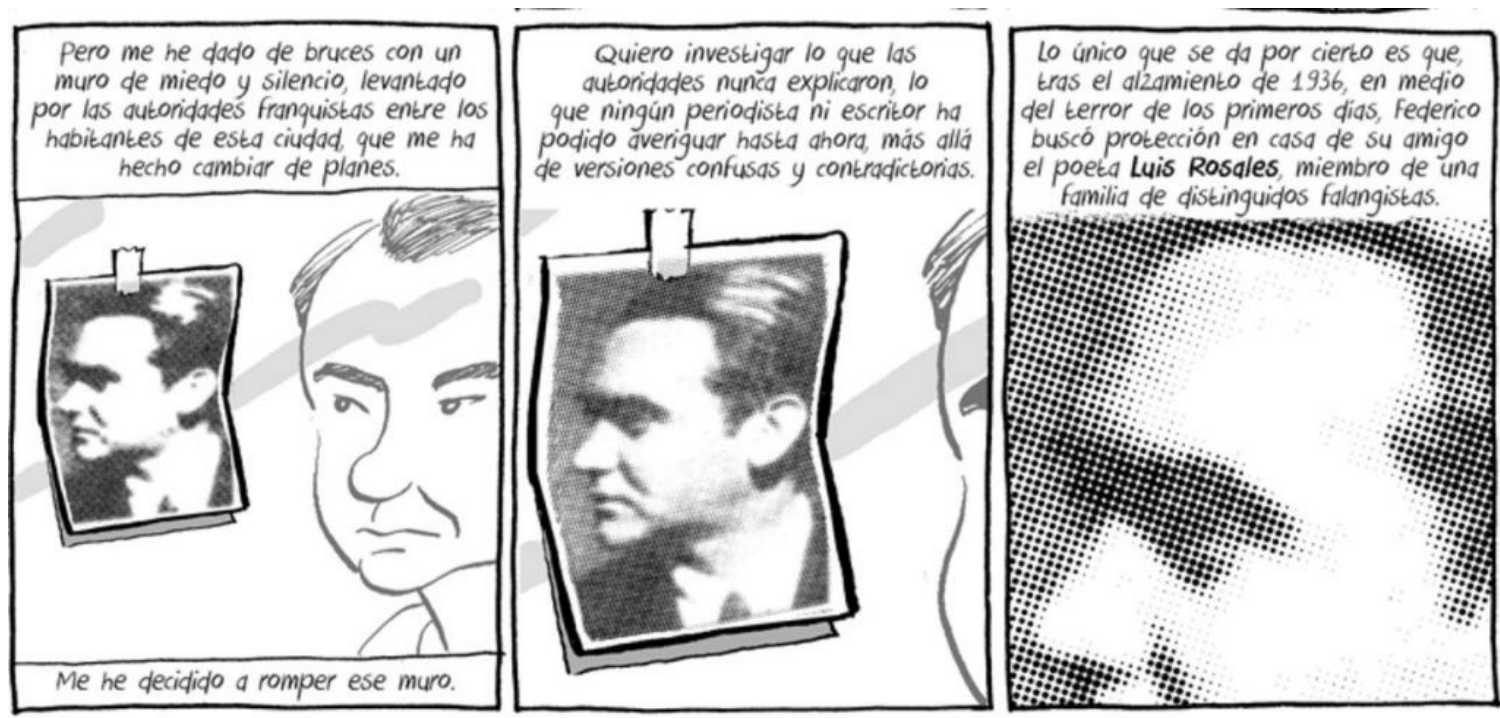

Fig. 10: La novela gráfica La araña del olvido ${ }^{25}$ de Enrique Bonet. En esta se centra en las investigaciones realizadas por Agustín Penón ${ }^{26}$ sobre la muerte de Federico García Lorca. En la viñeta refleja el momento en el que Lorca busca ayuda en la casa de los Rosales.

${ }^{25}$ La araña del olvido está basada en la peripecia real de Agustín Penón y su estancia de casi dos años en Granada. Enrique Bonet nos presenta una historia detectivesca y nos ofrece un retrato de la ciudad de Granada de los años cincuenta y nos muestra una serie de personajes necesarios para entender los últimos días de vida de Lorca.

El título es un verso del poema de Federico García Lorca «Sueño II» del Libro de Poemas (1919)

Mi corazón reposa junto a la fuente fría

(Llénala con tus hilos,

araña del olvido.)

Versos que son citados en la obra en la página 116. 
El 20 de julio la sublevación triunfó en Granada capital y comenzó una feroz represión. Durante la estancia de Lorca en la Huerta de San Vicente se produjeron dos registros (el 6 de agosto y el 9 de agosto). La noche del 9 de agosto pensó que la casa de la familia de su amigo el poeta Luis Rosales, pues sus hermanos eran dirigentes de Falange, sería un lugar más seguro. Sin embargo, la tarde del 16 de agosto, fue detenido y trasladado al Gobierno Civil. Entre el 17 y el 19 de agosto salió camino de Víznar, donde fue fusilado en un lugar no aclarado en las afueras de Granada (entre uno o dos kilómetros de distancia).

\section{2.- Justificación}

Uno de los motivos por los que iniciamos la realización de este trabajo de investigación fue el de profundizar en el conocimiento sobre algo tan relacionado con la existencia humana como es el sueño. En estudios anteriores ya habíamos realizado algunas primeras incursiones en este ámbito del sueño en el arte como nuestro Trabajo Final del Grado $^{27}$, expuesto en julio de 2014, «El sueño en el arte. La vertiente onírica del surrealismo» y nuestro Trabajo Final de Máster $^{28}$, defendido, un año más tarde, en julio del 2015, «Sueños animados. Un análisis comparativo entre Alicia en el país de la maravillas (1865) de Lewis Carroll y Alice de Švankmajer».

El sueño se ha convertido en fuente de inspiración para numerosos autores y artistas de todas las disciplinas a lo largo de la historia y, no en vano, el pasado siglo fue prolífíco en la interpretación del sueño: siempre auspiciado por el marco teórico de los estudios de Sigmund Freud (1856-1939) que supondrían una inabarcable fuente de inspiración

\footnotetext{
${ }^{26}$ En 1955, diecinueve años después de terminada la guerra civil, Agustín Penón (Barcelona, 1920-San José [Costa Rica], 1976) llegó a Granada para realizar una investigación sobre Federico García Lorca y las circunstancias que rodearon su muerte. Encontró una sociedad reacia a hablar, aun así, descubrió que Lorca no murió inmediatamente después de ser detenido, lo que le hizo alargar su viaje hasta año y medio. Entre todos sus descubrimientos, encontró la partida de defunción, y manuscritos inéditos del autor. Nunca fue capaz de ordenar y publicar su investigación. Años más tarde, su amiga Marta Osorio, con toda esa documentación, elaboró un libro como homenaje póstumo (Martínez Reverte 2011).

Ian Gibson, en los años ochenta, utilizó parte de los trabajos de Penón para realizar la biografía de Lorca.

${ }^{27}$ Grado Universitario en Historia y Patrimonio en la Universitat Jaume I de Castelló.

${ }^{28}$ Máster Universitario en Humanidades: Arte, Literatura y Cultura en la Universitat Oberta de Catalunya.
} 
para muchos análisis. Precisamente, en ese momento surge el movimiento surrealista y sus diferentes manifiestos.

Nuestro primer trabajo de investigación, «El sueño en el arte. La vertiente onírica del surrealismo», lo centramos en el análisis de dos textos fundamentales del surgimiento del surrealismo por sendos pilares del movimiento, Une vague des rêves de Louis Aragon y Le Manifeste du surréalisme de André Breton, ambos de 1924, año de fundación y aparición. En nuestro estudio, «Sueños animados. Un análisis comparativo entre Alicia en el país de la maravillas de Lewis Carroll y Alice de Švankmajer», nos adentramos en la importancia del cine en el surrealismo, centrando la investigación en el caso concreto del cineasta de animación checo Jan Švankmajer (Praga, 1934) y en el análisis comparativo de su largometraje Alice (Něco z Alenky, 1988) y la obra literaria Alicia en el país de las maravillas (1865) de Lewis Carroll.

El mundo de la infancia y el de los sueños son clave en la obra de Carroll, considerándose un precedente del surrealismo ya que de algún modo se anticipa a la «escritura automática» de los autores surrealistas. Estando presente por su manera de escribir y de contarnos historias en las que parece que se ha perdido el sentido - $-\mathrm{y}$ el absurdo reina entre las palabras - mezcla el sueño y la realidad y toma elementos domésticos de la vida cotidiana para otorgarles el don de la magia.

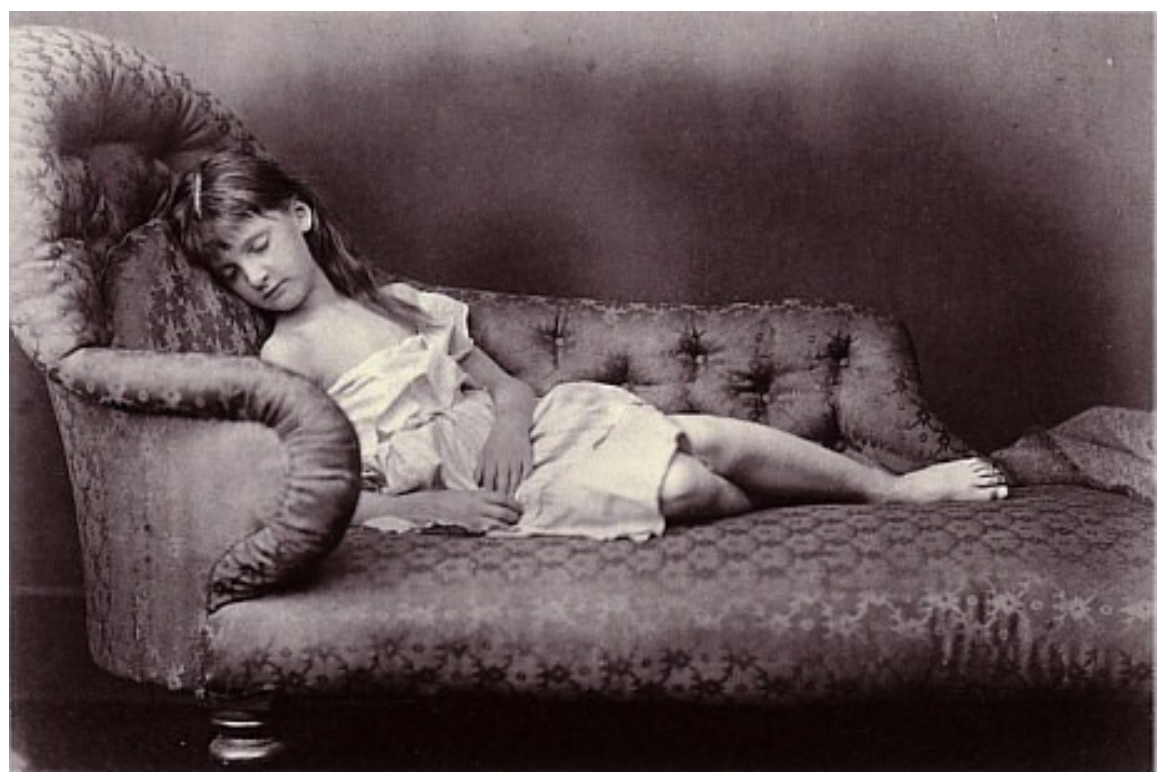

Fig. 11: Xic durmiendo (1874) de Lewis Carroll. Copia a la albúmina, 10,2 x 14,3 $\mathrm{cm}$. The Israel Museum. Jerusalén, The Vera and Arturo Schwarz Collection of Dada and Surrealist Art in The Israel Museum. 
Jan Švankmajer, como Lewis Carroll, consideran que es en la infancia donde más libertad tiene la imaginación. El imaginario de Švankmajer surge en el punto donde coincide la imaginación infantil y la magia, motivo por el cual se siente atraído por el cuento de Carroll y las aventuras de Alicia, donde la realidad y el sueño se encuentran comunicados:

Si tuviera que comparar el sueño con algo, lo haría con la infancia. Los sueños son una extensión de la infancia. Para mí son, en verdad, un mensaje, quizá un augurio, algunas veces un puzle, e incluso un objeto de análisis. Depende el tipo de sueño, y sobre todo, de qué modo me estimula su contenido "misterioso" durante la vigilia, puesto que no todos los sueños tienen la misma carga emotiva. Něco z Alenky (Alicia), tal y como la rodé y, por supuesto, tal y como la concibió Lewis Carroll en su escrito, es un sueño infantil. [...] El sueño se fusiona con la realidad según el principio de los "vasos comunicantes" (Švankmajer [2012] 2014, 71).

Esa lucha que mantiene la lógica y la razón con el mundo de la imaginación y los sueños es la que predominará con el surrealismo: la imaginación de la infancia que hemos perdido, de forma que, de acuerdo con Breton, «la complacencia hacia el absurdo vuelve a abrir al hombre el reino misterioso que habitan los niños» (1991, 117). Es tal la importancia de la infancia, que en el inicio de su Manifiesto del surrealismo ya deja plasmado que es, gracias a ella, cómo conseguiremos volver a darle a la imaginación el lugar que le corresponde, ya que los seres humanos vivimos bajo el imperio de la lógica y del racionalismo:

Si le queda un poco de lucidez, no tiene más remedio que dirigir la vista hacia atrás, hacia su infancia que siempre le parecerá maravillosa, por mucho que los cuidados de sus educadores la hayan destrozado. En la infancia, la ausencia de toda norma conocida ofrece al hombre la perspectiva de múltiples vidas vividas al mismo tiempo; el hombre hace suya esta ilusión; sólo le interesa la facilidad momentánea, extremada, que todas las cosas ofrecen. Todas las mañanas, los niños inician su camino sin inquietudes. Todo está al alcance de la mano, las peores circunstancias materiales parecen excelentes. Luzca el sol o esté negro el cielo, siempre seguiremos adelante, jamás dormiremos (Breton 2009, 15-16).

No sólo en el surrealismo tiene un gran valor el periodo de la infancia en la vida de un ser humano. Para Federico García Lorca es un tema que si no es el principal, la figura 
del niño sí que aparece en numerosos textos, como parte central de la trama, o incluso como un simple papel secundario. El mundo de la infancia no sólo está presente en su obra dramática sino también en su obra poética, incluso llegó a dedicarle una conferencia a las canciones de cuna, canciones que aparecerán en diferentes obras teatrales importantes, como Bodas de sangre y La casa de Bernarda Alba.

La importancia del carácter visual del sueño hace que el cine desempeñe un papel importante entre todas las artes. Al tratarse de imagen en movimiento, los surrealistas consideraron el cine con más capacidad que las otras artes para reproducir el fenómeno onírico. André Breton y sus amigos iban al cine sin saber previamente qué iban a ver y se sentían fascinados por las películas. En la propia sala del cine existían unas condiciones similares a las que se dan cuando vamos a dormir:

En la sala oscura se producía el encuentro con lo insólito, con lo maravilloso, sin que hubiera ninguna predeterminación previa, ni consciente. Era, propiamente, el ámbito del sueño con los ojos abiertos, mirando la gran pantalla (Jiménez 2013, 5).

Así, el cine se convirtió pronto en uno de los ámbitos preferidos por los surrealistas. Cambiaban de salas de forma compulsiva, recreando luego, con su recuerdo y su imaginación, la película a la que habían asistido. Animaban al público a que asistiera a las funciones sin saber qué iban a encontrar dentro de ese espacio en penumbra, con una actitud rebelde, fuera del ritual típico burgués del momento de acudir al cine.

Louis Aragon llamaba a las salas de cine el «burdel de los sueños», pensaba que el mecanismo del proyector cinematográfico opera en las salas oscuras de un modo similar al de los sueños, creando un trance hipnótico que desencadena lo más profundo del psiquismo humano (Sánchez Vidal 2013, 94). Cabe recordar que el cine, en este periodo todavía iniciático, carecía de los medios a los que actualmente estamos acostumbrados gracias a una industria cinematográfica inmersa en una espiral de avances tecnológicos.

Rafael Alberti, en sus memorias, expondrá sus impresiones respecto a la llegada del cine y sus expreriencias como espectadores:

Era la época de las novedades de vanguardia, llegadas a Madrid con algún retraso [...]. El gabinete del doctor Caligari había sido la primera sorpresa de lo mágico en medio de un silencio de locura, crueldades y crímenes. [...] Los nuevos nombres de René Clair, 
Germain Dullac, Cavalcanti y Epstein se desplegaban ante nuestros ojos en un desfile de imágenes sorprendentes, montajes de imprevistas y absurdas metáforas muy en consonancia con la poesía y la plástica europeas del momento (Tzara, Aragon, Éluard, Desnos, Péret, Max Ernst, Tanguy, Masson, etc.) ([1959] 1975, 278-279).

Ese tipo de cine inicial, mudo, carecía de uno de los elementos más importante de la comunicación: el lenguaje verbal. Este hecho hacía que el mensaje transmitido quedara únicamente representado por la acción plástica, ya que el texto escrito dialogado era prácticamente inexistente. Frente a esta situación, el teatro emerge como la alternativa más completa, porque en él el lenguaje asume un protagonismo suficiente capaz de transmitir a través de las palabras una realidad ya pensada.

Federico García Lorca también se sintió atraído por el cine. Durante su estancia en Nueva York, escribió su único guión cinematográfico Viaje a la luna (1929-1930). Sin embargo, es en el teatro donde se siente más realizado. Es por ello que elegimos las obras teatrales El público (1929) y Comedia sin título (1935-1936) para centrar, primordialmente, toda nuestra investigación. Ambas obras tiene como punto común la revolución, una revolución teatral porque al crear el autor una atmósfera de sueño quiere que el público transforme la realidad en la que en el amor y en la vida todo es posible.

El teatro no sólo es texto escrito, para su realización completa necesita de un director para su puesta en escena, de un espacio físico, de unos actores y actrices para su representación y de la complicidad de un público que es quien ha de unir todos esos elementos y unificarlos en un sentimiento personal. Es entonces cuando el círculo se cierra. Por eso, para Federico García Lorca, el público constituyó uno de los elementos teatrales indispensables y más importantes para el éxito de una obra. En ambas obras, el público forma parte de la obra, incluso en Comedia sin título, Lorca cuenta con él, antes del inicio de la obra, ya que hay personajes que cumplen el papel de Espectador y así crea un ambiente ambiguo entre la real y lo ficticio

\section{3.- Planteamiento}

Para llevar a cabo el trabajo, hemos estructurado nuestra investigación en cuatro partes claramente diferenciadas: el teatro de principios de siglo XX en España, el surrealismo 
como movimiento vanguardista con gran influencia en los jóvenes autores españoles, el análisis de la obra teatral El público y, por último, el análisis del único acto de la obra teatral Comedia sin título. Estas a su vez, los hemos dividido en tres apartados.

En la primera parte, «El teatro de principios de siglo XX en España», contextualizamos la situación teatral de la década de los años veinte y treinta del siglo XX en España. En estas décadas se producen cambios en las propuestas teatrales, se busca una nueva producción dramática en los textos, innovaciones en la puesta en escena, profesionalización de los actores y actrices para conseguir unas actuaciones de calidad adquiendo gran importancia la figura del director de escena. En este epígrafe, distinguiremos tres puntos: el teatro de éxito comercial, donde el teatro es tratado como simple mercancía comercial, y cuyo mayor público se encuentra en la clase burguesa acomodada que busca en las representaciones diversión y alienación; el teatro de vanguardia, $\mathrm{y}$, tanto la crítica como ciertos autores renovadores quieren experimentar y proponer nuevos valores mirando hacia el teatro europeo $\mathrm{y}$, por último, el punto dedicado a las propuestas teatrales que propuso Federico García Loca, con el teatro universitario La Barraca o el Club Teatral Anfistora junto a Pura Ucelay.

La segunda parte de nuestra investigación se centrará en la aparición del movimiento surrealista en Francia, su expansión e influencia en otros países, primordialmente en el caso de España y la polémica sobre la posible existencia de un surrealismo español o no, según los autores quienes se dejan influenciar por el movimiento, y lo concluiremos con la influencia surrealista en la obra de Federico García Lorca.

Para finalizar, en la tercera y cuarta parte, analizaremos las obras El público y Comedia sin título, mediante un análisis semiótico del texto formado por un análisis del argumento, los personajes, el tiempo en que transcurre la acción y el espacio teatral. Antes de analizar minuciosamente el texto de El público, presentaremos el origen de la obra, cómo a partir de su viaje a Nueva York y La Habana cambia su estética en sus nuevos textos, las diferentes lecturas entre sus amigos y familiares de la obra, la historia del manuscrito y sus posteriores ediciones hasta el día de hoy. Cerraremos el análisis de las dos obras, mostrando las diversas representaciones teatrales y más relevantes, llevadas a la escena por diferentes compañías. Y destacaremos la propuesta que 
presentó Alberto Conejero en 2018, para un hipotético final con un segundo y tercer acto, de Comedia sin título, en El sueño de la vida.

Una vez desarrolladas todas las partes y expuestos todos los puntos, con los datos extraídos, analizados y contrastados, finalizaremos nuestra investigación con la exposición de las conclusiones a las que hemos llegado. De este modo, situamos la renovación que supuso el teatro lorquiano.

En cuanto a la bibliografía, el número de publicaciones sobre Federico García Lorca es, como puede suponerse, vastísima. Por nuestra parte, hemos realizado varias visitas a la Biblioteca Nacional de España, en la que se encuentra depositado el manuscrito de $E l$ público. Asimismo, al Centro Dramático Nacional, en el que se halla un amplio catálogo de libros de teatro, artículos, fotografías, folletos teatrales, etc., en donde se incluye la posibilidad de tener acceso a la videoteca de gran número de producciones teatrales, algunas de ellas en opción de consulta a distancia por la plataforma teatroteca $^{29}$. También hemos visitado la biblioteca de la Fundación Juan March de Madrid tras varios años cerrada por restructuración y abierta al público a finales del año 2017. Entre su catálogo se encuentra la biblioteca personal de Rafael Martínez Nadal ${ }^{30}$. Más cercana, la biblioteca de la Universitat Jaume I de Castelló de la Plana también dispone de un buen número de ejemplares de temas teatrales y nos ofrece la posibilidad de solicitar textos a otras bibliotecas mediante acuerdos interbibliotecarios. La facilidad de las diferentes hemerotecas ${ }^{31}$ en las que existen gran cantidad de prensa de la época digitalizada nos ha facilitado el poder consultar periódicos, revistas culturales y suplementos de crítica teatral de las primeras décadas del siglo XX.

\footnotetext{
${ }^{29}$ A partir de febrero del 2019, puede tener acceso a todo el catálogo cualquier persona que se registre. Hasta ahora sólo podían consultarlo profesionales o investigadores. http://teatroteca.teatro.es/opac/

${ }^{30}$ Fue uno de sus más íntimos amigos. A él le confió unos documentos antes de partir hacia Granada, en 1936, entre los que se encontraba el manuscrito de El público que hoy día conocemos.

31 Entre las diferentes hemerotecas consultadas encontramos: la del periódico $A B C$ http://hemeroteca.abc.es/; la del periódico La Vanguardia http://www.lavanguardia.com/hemeroteca; la Biblioteca Nacional de España tiene la opción de consultar la mayoría de sus fondos a distancia en el portal digital, Biblioteca Digital Hispánica con un gran número de textos digitalizados de acceso abierto, http://www.bne.es/es/Catalogos/BibliotecaDigitalHispanica/Inicio/; la hemeroteca municipal de Madrid, Biblioteca Digital Memoria de Madrid; http://www.memoriademadrid.es/; la Biblioteca Virtual de Prensa Histórica que ofrece un extenso repertorio de prensa histórica y revistas culturales, http://prensahistorica.mcu.es; la Biblioteca Virtual de Andalucía que ofrece documentos relacionados con la cultura andaluza, http://www.bibliotecavirtualdeandalucia.es, y también bibliotecas digitales autonómicas y repositorios de diferentes universidades.
} 
Durante el año 2019 tuvo lugar la celebración en Madrid del centenario de la llegada de Lorca a la capital desde su Granada natal. Entre las diferentes actividades que tuvieron lugar en ese año, cabe destarcar el Congreso Internacional, entre el 18 al 23 de febrero, «Federico García Lorca: 100 años en Madrid (1919-2019)» bajo la dirección de Emilio Peral Vega, que tuvo lugar en varias sedes (el Museo Nacional Reina Sofía, el Paraninfo Histórico de la Universidad Complutense de Madrid, la Residencia de Estudiantes, la Real Casa de Correos, el Teatro Español de Madrid y la Sala Verde de los Teatros del Canal) todas vinculadas con la vida de Lorca durante los años vividos en Madrid. En el congreso se reunieron los principales estudiosos de las diferentes facetas del poeta, al que tuvimos el privilegio de asistir como público.

También, a finales de 2019 principios del 2020, en el Centro Federico García Lorca de Granada, tuvo lugar la exposición Jardín deshecho. Lorca y el amor comisariada por Christopher Maurer en el que se reunió la obra relacionada con el amor, el deseo y la sexualidad, mediante cartas, dibujos y poemas. En la que se expusó entre otros el manuscrito de El público y el del guión Viaje a la luna. El magnífico catálogo, que acompañaba a la exposición, estaba formado por las diferentes obras expuestas y acompañado de cinco ensayos relacionados con la exposición.

En la elaboración de este trabajo, la bibliografía consultada y utilizada la dividimos en fuentes primarias y secundarias. En las fuentes primarias, vienen referenciadas todas las obras escritas por Federico García Lorca que hemos consultado. En las fuentes secundarias, hemos incluido los libros, capítulos, revistas, artículos, prensa, conferencias, etc. sobre la figura y obra del autor.

Todas las imágenes utilizadas en este trabajo vienen referenciadas al final de la bibliografía en nuevo apartado con el título «Créditos de las imágenes» en el que indicamos el lugar de procedencia de las mismas.

\section{4.- Objetivos}

Esta investigación tiene como finalidad analizar el texto de las obras teatrales El público y Comedia sin título de Federico García Lorca, contextualizarlas dentro de su periodo surrealista y señalarlas parte indispensable dentro de su producción teatral. Cómo el 
tema del sueño y el subconsciente (temas fundamentales en el surrealismo) están presentes en el texto de El público, e intentaremos llegar a la conclusión de que es posible que toda la obra teatral surja del pensamiento del personaje del Director, o sea, de su sueño.

Y el autor, tanto en El público como en Comedia sin título - los personajes del Director y del Autor son un alter ego del propio Federico García Lorca-, busca una revolución total teatral para encontrar una solución a la crisis teatral vigente, en los años veinte y treinta en España, de ahí que en la primera parte de la investigación realizamos una exhaustiva contextualización del panorama teatral de principios de siglo XX y de sus autores.

Es imposible analizar los textos sin haber estudiado el resto de la obra de Lorca. Y ésta situarla en su contexto teatral. Intentaremos demostrar cómo sus propuestas de un teatro rupturista e irrepresentable, denominación designada por el propio autor, se verán reflejadas en posteriores obras dramáticas del autor con temáticas más cercanas al gusto del público. Con este análisis conseguiremos encontrar cómo Lorca inserta en su obra dramática motivos cotidianos, siempre desde un prisma surrealista que no abandonará en el resto de su producción.

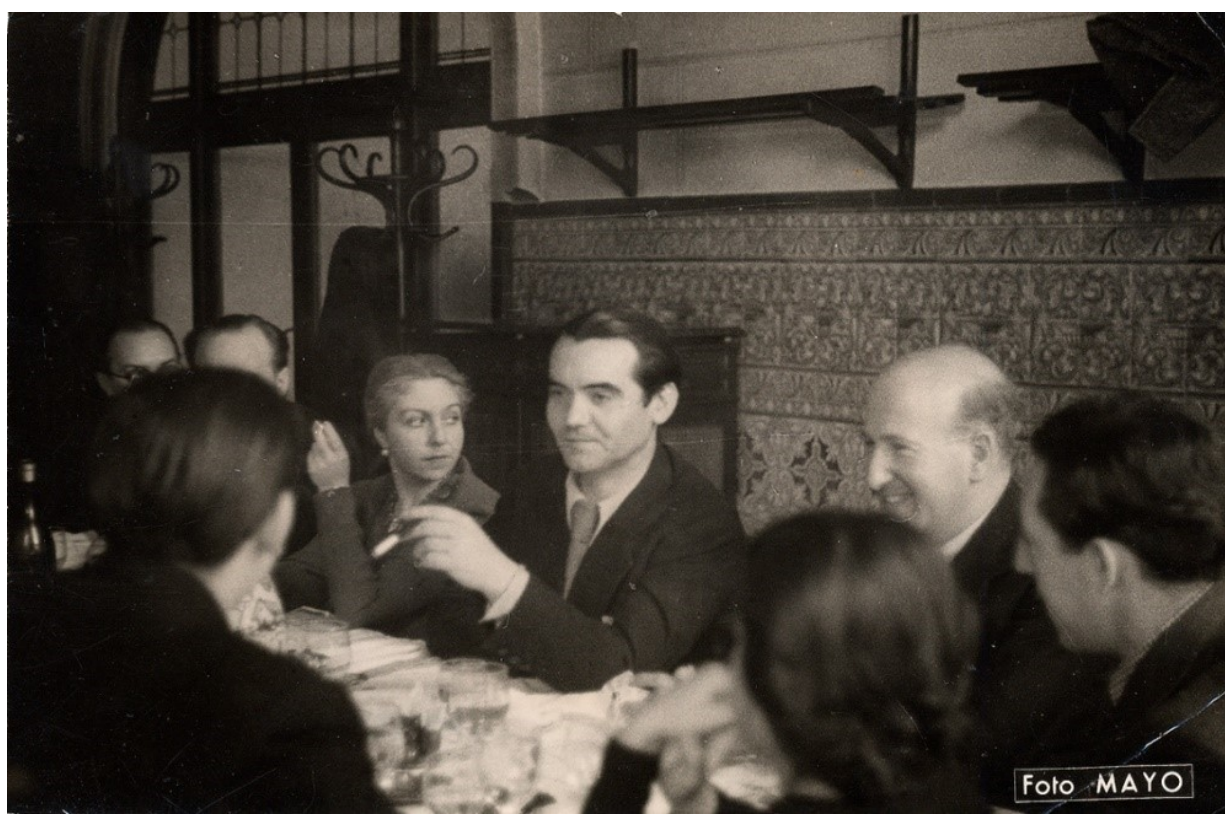

Fig. 12: Una de las últimas fotografías de Federico García Lorca, en 1936, junto a María Teresa León y Vicente Aleixandre durante una comida en honor de los periodistas argentinos, Madrid, febrero de 1936. Colección: Fundación Federico García Lorca. 
De este modo, el objetivo fundamental de este trabajo es demostrar ese cambio de estética en la obra de Lorca, con la influencia de las vanguardias, en concreto con las ideas surrealistas, que se alcanzan con el sueño y el subconsciente, y su nueva visión del mundo después de su primer viaje a América y del contacto con la gran metrópolis neoyorquina, y con el aspecto humano que consigue reencontrar en La Habana, al que alude en su epistolario.

Para alcanzar nuestro propósito, debemos contextualizar la oferta teatral de los años veinte y treinta en España, y el surgimiento del surrealismo en Francia y su llegada a España, y así entender mejor cuáles fueron los antecedentes e influencias que tuvo Federico García Lorca y cómo los refleja en su obra teatral.

\section{5.- Metodología y marco teórico}

Para la elaboración de este trabajo y conseguir los objetivos planteados, se ha realizado una fase destinada a la búsqueda de documentación, ya anteriormente descrita, consultando los manuscritos originales que aporten información a nuestro tema de investigación. Tras ello se ha procedido a la fase hermenéutica ${ }^{32}$ con la lectura del material conseguido que nos servirá para contextualizarlo.

Los criterios metodológicos establecidos han sido los siguientes: en primer lugar, hemos ido a las fuentes primarias, esto es, a las obras escritas por Federico García Lorca pertenecientes a su período al que podemos denominar surrealista: Diálogos (19251927), Poemas en prosa (1927-1928), Poeta en Nueva York (1929-1930), Viaje a la luna (1929), El público (1929), Así que pasen cinco años (1931) y, la inconclusa, Comedia sin título (1935-1936), sin olvidar su producción teatral, que expondremos en el punto de «Lorca, dramaturgo». Este conjunto de obras formará uno de los apartados del trabajo y que hemos desarrollado bajo el título «El surrealismo en Lorca». También las diferentes entrevistas realizadas por el poeta y la correspondencia mantenida con

\footnotetext{
${ }^{32} \mathrm{El}$ término proviene del griego $\dot{\rho} \rho \mu \eta \varepsilon u ́ \omega$ cuyo significado primero era la expresión de un pensamiento, dando lugar a su explicación, pero sobre todo a la interpretación del mismo. Según Ferrater Mora este sentido es el que hoy en día más se aproxima a su significado, pudiendo ser: «(1) interpretación literal o averiguación del sentido de las expresiones empleadas por medio de un análisis de las significaciones lingüísticas o (2) interpretación doctrinal, en la cual lo importante no es la expresión verbal, sino el pensamiento» (1991, 1493-1494).
} 
amigos y familiares nos ha sido muy útil para comprender opiniones, sus ideas poéticas y situaciones personales.

En segundo lugar, hemos contado con las fuentes secundarias para ampliar pluralmente las diferentes partes que dividen la investigación. En primer lugar, los estudios coetáneos, junto a las publicaciones de prensa del momento y, los estudios realizados $a$ posteriori, para situar este período en la obra de Federico Lorca, y, a su vez, contextualizar su producción dramática en las obras representadas en España en la segunda y tercera décadas del siglo XX. Para ello, hemos analizado la crítica teatral en los diferentes periódicos del primer tercio del siglo XX y así poder averiguar cuál era la situación teatral en España y descubrir esos elementos renovadores que aparecen en Europa y que influyen en los nuevos textos teatrales de los autores españoles. De este modo, destacamos a Federico García Lorca en su aspecto innovador.

Otro punto importante, antes de adentrarnos en la influencia surrealista en la obra de Federico García Lorca, fue situar el origen del propio movimiento. A partir de dos de los textos clave del movimiento: Una ola de sueños de Louis Aragon y Manifiesto del surrealismo de André Breton, fundadores del movimiento en Francia. Una serie de estudios contribuyeron a mejorar la percepción crítica de la influencia surrealista en los autores españoles, a favor y en contra de la posibilidad de la existencia de un surrealismo español, debido a la especificidad del surrealismo en España. Igualmente hemos consultado numerosas publicaciones más recientes en revistas de divulgación e investigación científica, en las que su posición es más clara e indubitable en reconocer que, a principios del siglo XX, existió una influencia surrealista en la literatura y en las artes plásticas en España.

Una vez finalizada dicha tarea, se ha procedido al análisis del texto El público y Comedia sin título. Pero antes, era imprescindible comprender que el texto literario teatral, el poético y el novelístico tienen en común diversos aspectos, como son: una narración, unos personajes, un tiempo, un espacio y la utilización de unos signos lingüísticos verbales y no verbales. Pero así como la poesía y la novela están escritas para ser leídas de una manera individual, el teatro es un género literario que necesita ser representado ante un público y en un espacio adecuado para su representación. Como afirma Rubia Barcia, «el teatro, como es sabido no constituye un arte exclusivamente, ni 
primordialmente, individual y literario, sino más bien colectivo y espacial, realizable o cosificable ante un presente auditorio en masa que ve, oye y reacciona en comunidad de sentimientos» $(1986,388)$.

Los primeros estudios semióticos teatrales aparecen hacia la década de los años treinta del siglo XX, en países centroeuropeos en torno al Círculo Lingüístico de Praga, en un periodo de entreguerras. En un principio, los elementos son un objeto (el teatro), un tiempo y un espacio determinado. En 1946, Charles Morris ${ }^{33}$ propone un esquema, en el que divide el funcionamiento de los signos en tres los niveles: sintáctico, semántico y pragmático. El nivel sintáctico analiza las relaciones de los signos entre sí, el semántico, en el que se estudia el significado del lenguaje literario y el pragmático es la relación del autor con la obra y la obra con el espectador (Tordera Sáez 1978, 178).

Tadeusz Kowzan ${ }^{34}$ fue el primer teórico que logró integrar los distintos códigos teatrales no verbales desde una perspectiva más completa. En su libro El signo y el teatro ${ }^{35}$ (1997), trata de definir el teatro y establece el tipo de relaciones que existen entre el texto y la representación. En el nivel sintáctico hay una subdivisión entre signos lingüísticos y no lingüísticos. Entre los signos no lingüísticos o paraverbales encontramos el tono, la mímica, el gesto, el movimiento, el maquillaje, el peinado, el vestuario, los accesorios, el decorado, la iluminación, la música y los efectos sonoros, elementos que nos propone Kowzan, y que nosotros utilizaremos dentro del nivel sintáctico ya que la consideramos la más clara en su comprensión, en el punto de los códigos no verbales. Entre los varios estudios de análisis del texto teatral hemos optado por este por su claridad y exposición, entre otras características.

En 1978, ediciones Cátedra nos presenta una compilación de diferentes estudios sobre teoría general y semiótica literaria y del espectáculo en Elementos para una semiótica del texto artístico. Diferentes autores nos proponen a partir, del recorrido histórico de los diferentes estudios teatrales, varios métodos de análisis textual de la obra de teatro. Sería de destacar el resumen propuesto por Jenaro Talens en el que divide el análisis del

\footnotetext{
${ }^{33}$ Charles William Morris (Denver [Estados Unidos], 1901-1979 Gainesville [Estados Unidos]) filósofo y semiótico influenciado por la lógica y la semiótica de Charles Sanders Peirce.

${ }^{34}$ Tadeusz Kowzan (Vilda [Lituania],1922-2010) historiador y lingüista.

35 Este libro parte de la obra escrita en francés Sémiologie du théâtre (1992), revisado, actualizado y ampliado en su totalidad. Su traducción al español estuvo a cargo de Carmen Bobes Naves.
} 
texto artístico, en «el nivel sintáctico analiza las relaciones entre los signos. El nivel semántico, las cuestiones referentes al significado de los signos. El nivel pragmático, las relaciones que se establecen entre los signos y los usuarios» $(1978,47)$. También, José Romera Castillo utiliza una clasificación similar, aunque cambiando la terminología: plano morfosintáctico, semántico y retórico.

De nuevo, Manuel Sito Alba en su obra Análisis de la Semiótica Teatral (1987) nos señala seis componentes para realizar el análisis de la obra teatral: el autor y director, el texto literario y códigos complementarios, el actor y los personajes, el espacio, el tiempo y el público. El elemento del texto y el de los códigos complementarios lo podemos relacionar con el del análisis semántico con sus códigos verbales y paraverbales. Y el componente del público, con el del análisis pragmático y el conjunto de códigos utilizados en la representación que van dirigidos al espectador como receptores del mensaje (Sito Alba 1987, 105).

Anne Ubersfeld ${ }^{36}$ en su obra Semiótica teatral (1993) divide el análisis en personajes, espacio, objeto (útil, referencial o simbólico), tiempo y discurso. Sitúa al mismo nivel el autor del texto con el director teatral, creando un problema ya que el texto teatral es anterior a la representación, y el lector del texto bien podría ser, en un primer momento, el director de escena y no tendría por qué asumir en principio las funciones del autor, sin olvidar el papel de los actores y los espectadores, que puede variar según la representación. Ubertsfed con este análisis busca superar el subjetivismo del teatro. De este método, consideramos apropiado su planteamiento del análisis del espacio, el tiempo y sus secuencias.

Así como Tadeusz Kowzan plantea cuatro categorías de análisis de aquellos elementos no lingüísticos y los agrupa en expresión corporal, apariencia exterior del actor, el aspecto del espacio escénico y los efectos sonoros no articulados, Erika FischerLichte $^{37}$, por su parte, señala catorce códigos, al añadir al que denomina cuadro espacial a los trece que propone el primero. No en todos los textos dramáticos se utilizan todos los elementos, el dramaturgo da mayor importancia a unos sobre otros, incluso puede

\footnotetext{
${ }^{36}$ Anne Ubersfeld (Besanzón [Francia], 1918-2001 París [Francia]) historiadora francesa de teatro. A partir de métodos lingüísticos, semiológicos o psicoanalíticos teorizó sobre el teatro.

${ }^{37}$ Erika Fischer-Lichte (Hamburgo, 1943-) profesora en el Instituto de Estudios Teatrales de la Freien Universität de Berlín. Sus líneas de investigación se centran en la estética performativa.
} 
llegar a no utilizar algunos en el teatro de vanguardia. Sin embargo, son varios los investigadores que consideran no importantes estos códigos, ni correcta su clasificación. Nosotros utilizaremos la propuesta de Kowzan porque consideramos que es la más sencilla en su comprensión y división y no exenta de rigor. Aunque como afirma Anne Ubersfeld, no es necesario el desarrollo de todos para entender la representación dramática, cada texto solicitará el más adecuado.

La división que nos propone, por su parte, Carmen Bobes Naves en Semiología de la obra dramática (1997) coincide con las ya expuestas, en las que el análisis semiológico está formado por los niveles: sintáctico, semántico y pragmático. En la segunda edición corregida y ampliada, la obra es muy exhaustiva y explicativa. Junto a la propuesta presentada por Antonio Tordera Sáez en «Teoría y técnica del análisis teatral», en Elementos para una semiótica del texto artístico (1978), creemos que es la que mejor resume los diferentes estudios que hemos encontrado y expuesto anteriormente. La consideramos, además, la más clarificadora a la hora de analizar el texto teatral y su representación escénica.

Cabe destacar, asimismo, el artículo de Fabián Gutiérrez Flórez, «Aspectos del análisis semiótico teatral» publicado en 1989, en la revista Estudios de literatura, en el que expone teóricamente los estudios de semiótica teatral incluidos en la semiótica literaria y ésta circunscrita en la semiótica general. Su propuesta de modelo de análisis es la que más se asemeja a la que nosotros proponemos, en el que el hecho teatral está formado por su conjunto de categorías, signos y sistemas codificados; dividido en dos fases: el texto y la representación, con las sugerencias que añade el autor para una representación ideal $(1989,79)$.

De este modo, para nuestro análisis textual utilizaremos el modelo semiótico del análisis del signo, dividido en tres niveles según la relación que mantiene: el nivel sintáctico, la relación que mantienen los signos entre sí y en sus relaciones internas con la obra dentro de la división de los elementos paraverbales en este nivel el propuesto por Kowzan, como hemos dicho-; el nivel semántico, la relación de los signos con el conjunto de sistemas culturales que les dan sentido y el nivel pragmático del texto que es la relación de los signos con los emisores y receptores, los usuarios, predominantemente en las representaciones llevadas a cabo. 
En todo momento, tanto para el estudio y análisis del tema como de las técnicas dramaturgias, hemos acudido a la bibliografía clásica y actualizada. 


\section{EL TEATRO DE PRINCIPIOS DE SIGLO XX EN ESPAÑA}




\section{2.- El teatro de éxito comercial}

A finales del siglo XIX, junto a los avances tecnológicos y científicos del momento, se origina una nueva visión del mundo. Esta nueva visión origina una nueva teatralidad en Europa. Ya no sólo es importante el texto teatral sino que su puesta en escena adquiere gran importancia. A la hora de representar estos textos, la figura del director de escena toma un papel más relevante, ya que se busca en la representación el punto de vista del propio director.

Entre los diferentes géneros literarios encontramos el teatro, un género que necesita ser representado, y que precisa de un espacio para ser llevado a escena por unos actores ante un público. Por ello, dos factores son trascendentes para el éxito de una obra: un espacio apropiado para su representación y un público. Federico García Lorca, en una entrevista realizada por Felipe Morales y publicada en $L a$ Voz de Madrid, el 7 de abril de 1936, define el teatro como:

la poesía que se levanta del libro y se hace humana. Y al hacerse, habla y grita, llora y se desespera. El teatro necesita que los personajes que aparezcan en la escena lleven un traje de poesía y al mismo tiempo que se les vean los huesos, la sangre. Han de ser tan humanos, tan horrorosamente trágicos y ligados a la vida y al día con una fuerza tal, que muestren sus traiciones, que se aprecien sus olores y que salga a los labios toda la valentía de sus palabras llenas de amor o de ascos (citado en Sánchez 1999, 449; Inglada 2017, 458).

En la década de los años veinte y treinta del siglo XX, mientras que en la escena europea empezaba a aparecer nuevas propuestas dramáticas, fuera de todo realismo, en España seguía triunfando el teatro conservador burgués, centrado en un teatro naturalista. Gran parte de los teatros españoles era de propiedad privada, cuyo dueño era un empresario con visión de negocio en busca de beneficios. Diez Canedo, en su artículo «Panorama del Teatro Español desde 1914 hasta 1936» publicado en Hora de España ${ }^{38}$, en abril de 1938, describe claramente la figura del empresario como alguien que no tiene

\footnotetext{
${ }^{38}$ Publicado por primera vez en The Theatre in a Changing Europe, Nueva York, 1937. Reproducido un año más tarde en Hora de España.
} 
más conocimientos que los prácticos del hombre que vive junto a la escena, ni más anhelo que el de una taquilla próspera, y, por supuesto, sin curiosidad ninguna por las nuevas tendencias: aventuras peligrosas frente a las cuales blasona de una seguridad, sólo posible para él en los senderos conocidos. Las novedades extranjeras le atraen poco; las verdaderas novedades (citado en Bilbatúa 1976, 12).

No debemos olvidar que el mayor número de público era burgués y acomodado, por tanto, el teatro representado buscaba el éxito comercial sin ninguna otra preocupación estética. Ese fue uno de los motivos por los que las innovaciones técnicas introducidas fueran escasas.

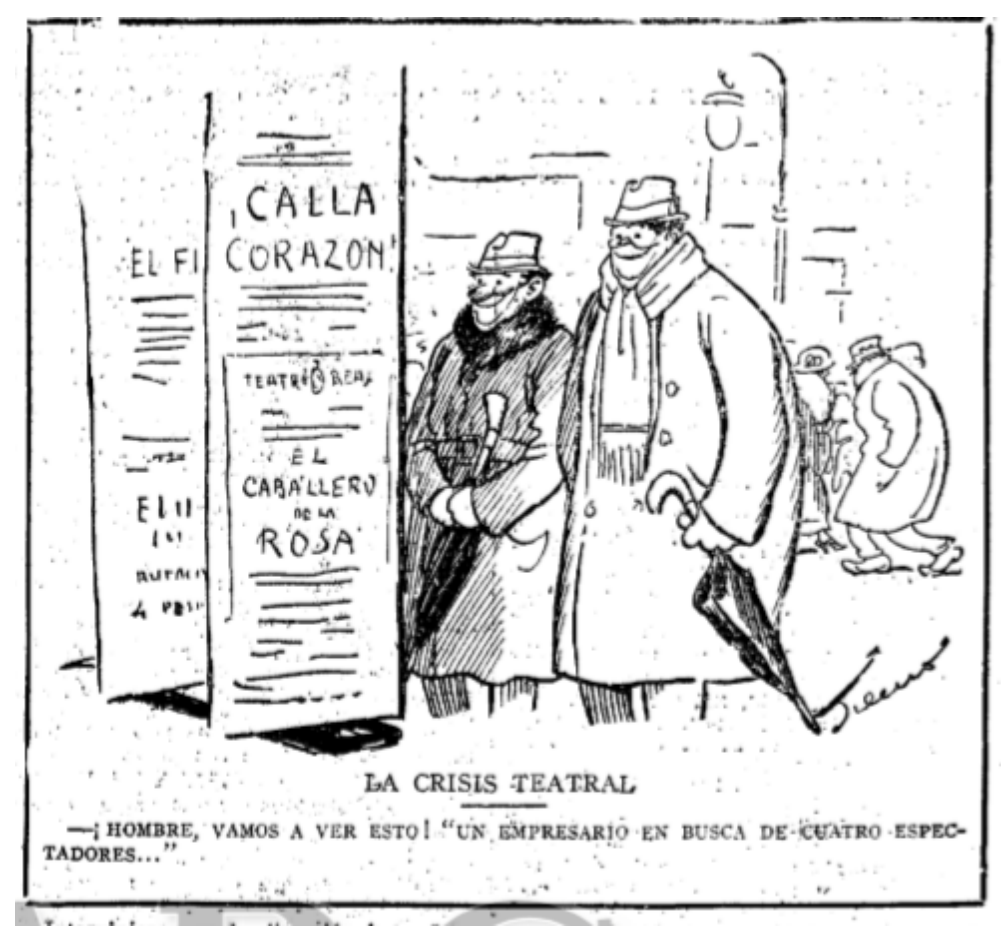

Fig. 13: Viñeta cómica en la que se refleja la crisis teatral que se empieza a vivir en los años veinte y treinta.

En la segunda mitad del siglo XIX, la consolidación de la burguesía como clase dirigente conlleva un cambio de mentalidad. Entre las diversiones urbanas, el teatro era la que más importancia y presencia social tenía. La mayoría de los espectadores pertenecían a la burguesía que ejercía gran presión sobre las producciones artísticas y sus gustos preferentes en materia teatral eran:

la alta comedia de Benavente y sus seguidores y el teatro cómico, ya sea el astracán de Muñoz Seca, ya el sainete de costumbres andaluzas (Álvarez Quintero) o madrileñas 
(Arniches). Por último, el prestigio del teatro en verso, dentro de lo que es la función social del teatro, hace que éste sea el tercer tipo más representado (Marquina) (Fuente [1992] 1999, 510).

El común denominador de la mayoría de estos autores fue hacer del teatro un negocio lucrativo (Jerez-Farrán [1991] 1999, 522). Desde el punto de vista estilístico, los autores teatrales no experimentaban sino que seguían el mismo estilo teatral de épocas anteriores: lenguaje asequible, ambientes conocidos, personajes de la misma clase social que el público, etc. En $1893^{39}$, Benito Pérez Galdós afirmaba que «el éxito es la preocupación constante, ineludible, del autor. El triunfo instantáneo, ganado como por sorpresa, es la obsesión que le persigue mientras elabora su drama o comedia» ([1893]1998, 89). Frente al teatro artificioso, propio de las exigencias del público de la época, Galdós propone un teatro vivo, cuyos temas reflejen las preocupaciones reales del público, que debata cuestiones morales reales de la sociedad. El teatro de Galdós supuso un intento de nuevo realismo, rompiendo con el melodrama neorromántico de Echegaray, aunque no llegó a ser aceptado como dramaturgo por la sociedad (Bilbatúa $1976,16)$.

El sistema teatral estaba estructurado casi exclusivamente de forma comercial. Era un teatro de evasión sin finalidad crítica o moral, destinado a entretener a un público burgués acomodado que sólo buscaba la diversión y el entretenimiento en las representaciones a las que asistía (Jerez-Farrán [1991] 1999, 522). Muy pocos empresarios se arriesgaron a introducir innovaciones ya que llevar a escena una representación implicaba unos gastos, y como afirma Ricardo de la Fuente:

El teatro es un negocio, es una industria en la que el empresario arriesga su dinero y como es legítimo intenta no sólo recuperarlo sino ganar lo más posible. [...] en estos años la cartelera había que cambiarla constantemente [...] y la ayuda estatal, a pesar de las peticiones realizadas por la crítica, era impensable. El miedo al fracaso hace que los empresarios pidan obras nuevas siempre a los mismos autores, cerrando el paso a los dramaturgos noveles ([1992] 1999, 508).

\footnotetext{
${ }^{39}$ De su artículo «Viejos y nuevos moldes» publicado en La Prensa de Buenos Aires, el 28 de agosto de 1893.
} 
Aunque todo el teatro comercial buscaba una misma meta, los beneficios económicos, dentro de este tipo de teatro existían diferentes clases de propuestas teatrales como era el género cómico con la comedia de costumbres y el sainete, o el género lírico con el género chico, la revista moderna y la zarzuela, entre otros que a continuación desarrollaremos.

\section{1.- El género cómico}

El teatro cómico conoce durante este período una etapa de extraordinaria popularidad entre el público, no así entre la crítica, «que lo consideraba un teatro de muy escasa calidad y corruptor del buen gusto» (Pérez-Rasilla 1997, 15). Este estilo es el conocido como realismo burgués o realismo de la apariencia, que engloba los distintos géneros teatrales como son la comedia de costumbres, el sainete, la alta comedia, el astracán y la tragicomedia grotesca. Son géneros de la misma dramaturgia que utilizan técnicas semejantes de construcción teatral.

\subsection{1.- La comedia de costumbres: los hermanos Álvarez Quintero}

Los propósitos de la comedia de costumbres y del sainete son idénticos, reflejar con "naturalidad" la vida, entendida como un conjunto orgánico de costumbres, guiños, vicios y defectos de la sociedad contemporánea. Pero esa naturalidad no es la de la realidad sino de la visión de la realidad. En el sainete o en la comedia de costumbres esa visión es de carácter sentimental no racional de la vida humana. En ese teatro, la realidad humana era la institucionalización y objetivación de la visión burguesa (Ruiz Ramón, 1977). El costumbrismo, según expone José Escobar, es un fenómeno literario

nacido de la transformación revolucionaria de la estética dieciochesca. El ansia de identificarlo, en el siglo siguiente, con «esencias autóctonas» es un resultado de la reacción del Romanticismo conservador contra la revolución cultural burguesa propugnada por la Ilustración, de la cual la mímesis moderna es una manifestación [...], la naturaleza humana modificada por las costumbres locales, por la sociedad, en un momento histórico determinado $(2000,7)$. 
Aunque la palabra costumbrismo fuera usada a finales del siglo XIX, el Diccionario de la Academia Española no la recoge hasta su edición en 1956. Pero la palabra costumbrista aparece en el año 1925 y, en su definición, se entiende que lo costumbrista es una forma, una manera de imitar la naturaleza. Y como afirma Álvarez Barrientos «lo costumbrista sería una invención literaria, y sólo literaria» $(2000,4)$.

La comedia de costumbres nacía del interés del público y de los autores por la realidad cotidiana. Estaba ambientada en espacios urbanos, ciudades como Madrid o Sevilla. «Sus plazas, calles, bares y cortijos eran plasmados en estas creaciones con todo lujo de detalles [...]. En estas comedias de costumbres, los autores buscaban crear unos personajes que representaran a los tipos más populares que habitaban estos medios» (Vilches y Dougherty 1997, 71-72) y su posición era una defensa de valores frente a la sociedad moderna. En sus representaciones aparecían distintos personajes y situaciones caricaturizadas, en los que el ciudadano de la época se veía reflejado, y de este modo causaba diversión y agrado al espectador.

Los hermanos Álvarez Quintero: Serafín (Utrera [Sevilla], 1871-Madrid, 1938) y Joaquín (Utrera [Sevilla], 1873-Madrid 1944) lograron una gran popularidad, con una producción de más de doscientas piezas dramáticas, entre ellas sainetes (piezas cortas) y comedias, que estrenaron a lo largo de medio siglo de actividades conjuntas (siempre trabajaron en colaboración, jamás firmaron una obra por separado). En sus obras utilizan un lenguaje cuidado y refinado, donde el enredo es ingenuo, casi infantil.

Su primer éxito comercial lo obtuvieron en 1900, con la comedia Los Galeotes, inspirada en un episodio cervantino de Don Quijote. Casi todas sus piezas son de ambiente andaluz, como El patio (1900), Las de Caín (1908) y El genio alegre (1906). Los hermanos Quintero también trabajaron con el músico José Serrano, llegando a realizar diferentes obras de gran éxito, como son los sainetes andaluces, El mal de amores (1905), La mala sombra (1906) y, sobre todo, La reina mora (1903) (Muñoz $1946,315)$.

En sus comedias de costumbres pretendían mostrar los ambientes populares y las costumbres de la clase media, donde la acción de la obra se centraba en un personaje central, y las acciones secundarias transcurrían a su alrededor. A través de una visión 
plácida, sonriente y amable del mundo, mostraban unos personajes y situaciones susceptibles de ser admiradas, donde la crítica social o política es mínima, y como mucho aparecía en forma irónica.

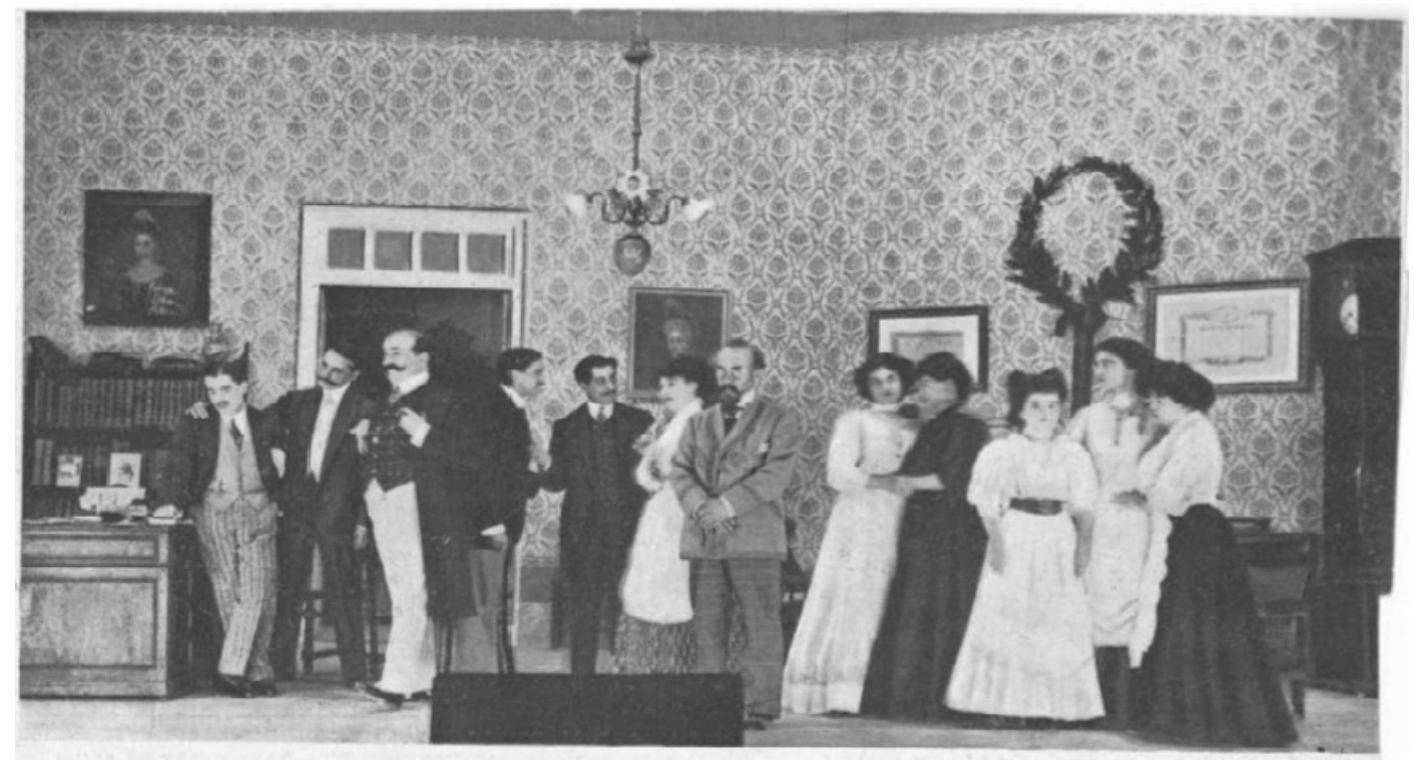

Fig. 14: Una escena de la comedia Las de Cain de los hermanos Quintero.

Fotografía de Fols R. Cifuente.

\subsection{2.- El sainete: Carlos Arniches y Pilar Millán Astray}

Las diferencias genéricas entre el sainete y la comedia de costumbres son mínimas. La diferencia principal reside en la extensión: de dos o tres actos en la comedia de costumbres frente a uno en el sainete. Se caracterizan por un fuerte realismo y su carácter urbano, centrado en la clase social más baja.

Sus antecedentes los encontramos en el género del entremés, género teatral característico del siglo de Oro que estaba pensado para su representación en la pausa o el intermedio entre actos mayores de un drama de larga duración.

Nacido durante los años de la Restauración con todas sus limitaciones estructurales de tiempo, propias del teatro por horas, el sainete del último tercio del siglo XIX estaba impregnado por el conocido costumbrismo, asociado a un colectivo concreto en el tiempo y en la geografía (costumbrismo madrileño, costumbrismo andaluz, 
costumbrismo rural, etc.). Es un género teatral breve, con una duración de unos cincuenta minutos aproximadamente por representación y de argumento liviano.

Después de años de representaciones de temas fantásticos, históricos y ambientaciones remotas, «el público encontró gran placer en verse reflejado a sí mismo en el escenario» (Temes 2014, 55-56), de ahí el gran éxito que obtuvo entre el público. El sainete mostraba escenas de carácter popular de las clases media y baja, con ambientes pintorescos. Sus características son la brevedad y la ligereza en el argumento, sin reivindicación social, política o religiosa. Aunque no todos los sainetes son cómicos, el sentido del humor siempre está presente.

En la conferencia «Las dramaturgias mayores: las tres primeras décadas», impartida en la Fundación Juan March de Madrid en el ciclo sobre Teatro español del siglo XX, Francisco Ruiz Ramón afirmaba que este género

supuso una especie de cura del lenguaje dramático y una desintoxicación del drama neorromántico de Echegaray. [...] Lo que a finales del siglo XIX era un modo terapéutico al lenguaje dramático neorromántico, a comienzos del XX ese lenguaje ocultaba la verdadera condición humana del pueblo que protagonizaba esos sainetes (1977).

En el sainete finisecular la acción dramática es mínima o nula. En cambio, en el sainete de Arniches encontramos mayor dramatización de la acción, cuyo núcleo es un triángulo de fuerzas con tres personajes: el antihéroe, el héroe y la heroína. Carlos Arniches (Alicante, 1866-Madrid, 1943) inicia su producción dramática con La casa editorial, estrenada el 9 de febrero de 1888 en el teatro Eslava de Madrid, en plena restauración de la monarquía (la Restauración borbónica tuvo lugar entre finales de 1874 y el 14 de abril de 1931 con la proclamación de la Segunda República). Su posición política es monárquica y liberal. Favorecido por el creciente liberalismo, se inicia en el llamado "género chico" (Monleón 1975, 146-148) que lo relaciona con la tradición pero no dejó de buscar una renovación en el lenguaje teatral sin dejar de satisfacer las expectativas del público (Ríos Carratalá 1992, 103).

Sus obras pertenecen a un teatro de costumbres, «de inspiración directa de la realidad ambiente, de transcripción fácil y elemental de sus datos» que muestra unos «modos de 
vivir y de hablar, tipos, inclinaciones de las gentes, usos y amaneramientos sociales» (Salinas 1933, 128). Los elementos característicos de su obra convencional, con final feliz, son la comicidad, el costumbrismo madrileño (madrileñismo), la crítica moderada y un espíritu comprensivo. Según afirma Temes,

Giros de lenguaje, expresiones, pequeños chascarrillos y situaciones inverosímiles que llamaban su atención, y que después reflejaba con toda naturalidad en sus obras teatrales. Ello, unido a su facilidad para las situaciones cómicas y de enredo, le convierten en un dramaturgo de éxito seguro; siempre y cuando, naturalmente, no pretendamos buscar en sus trabajos ni profundidad de caracteres ni complejidades dramatúrgicas, sino un humor limpio, ingenuo y hasta casi infantil $(2014,290)$.

Prefirió escribir sus sainetes en colaboración con otros autores. Entre sus sainetes de ambiente madrileño, con una gran comicidad verbal, encontramos El santo de la Isidra (1898), en colaboración con el compositor Tomás López Torregrosa; La alegría del batallón (1909), en colaboración con Félix Quintana y música de José Serrano; El amigo Melquíades (1914), con música de José Serrano y Joaquín “Quinito” Valverde y Los milagros del jornal (1924) (Ruiz Ramón 1986, 40).

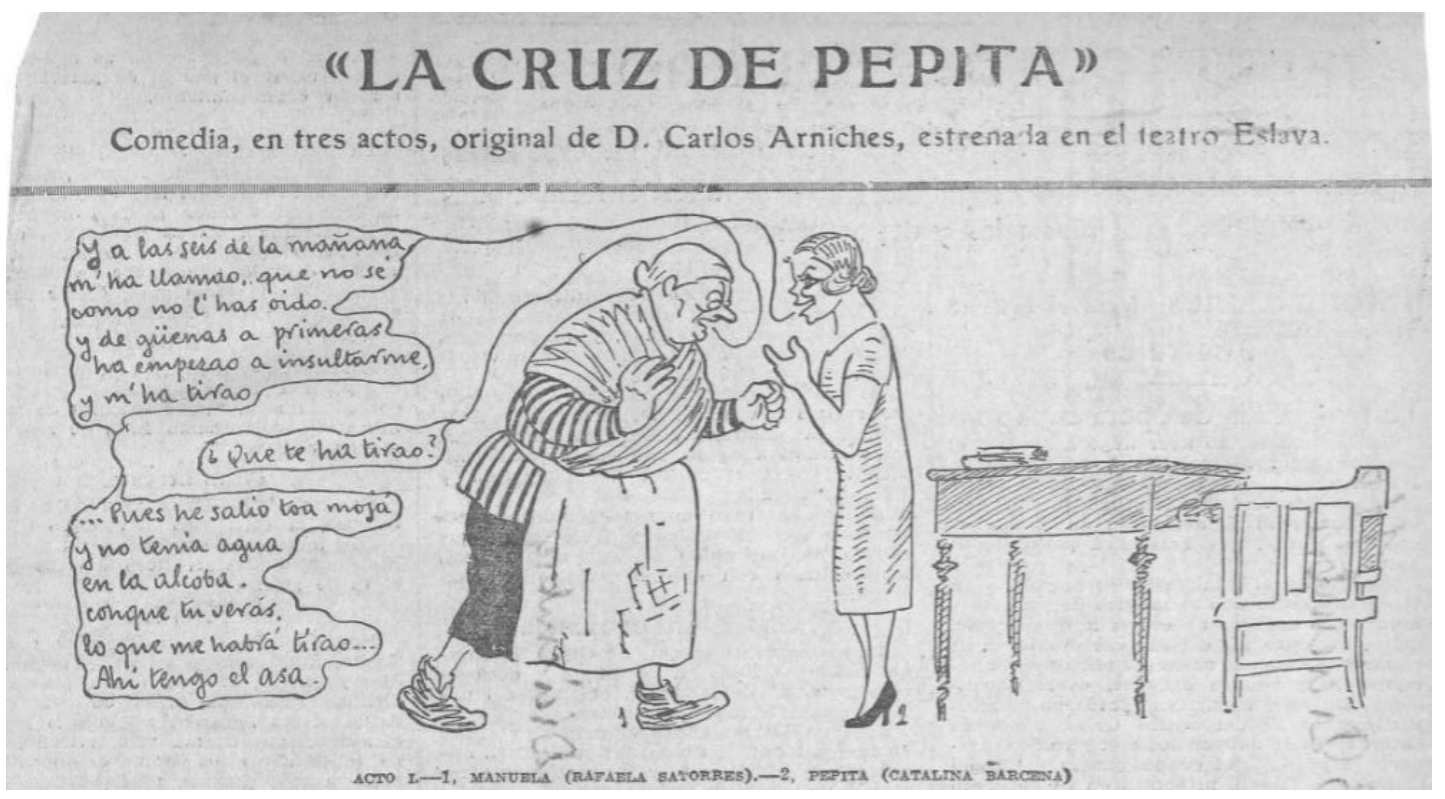

Fig. 15: Viñeta del Acto I de la comedia La Cruz de Pepita de Carlos Arniches, estrenada en la temporada 1925-26. 
Carlos Arniches evolucionó «desde los sainetes y juguetes cómicos que le consagraron popularmente hasta las comedias y tragedias grotescas que le proporcionaron un prestigio» (Ríos Carratalá 2003, 2393). El propio Lorca, en una entrevista realizada por Nicolás González-Deleito, en mayo 1935, alabará el teatro de Arniches ante el resto de la producción teatral en verso, predominante, en esos años:

La gente está acostumbrada al teatro poético en verso. Si el autor es un versificador, no hay un poeta, el público guarda cierto respeto. Tiene respeto al verso en teatro. El verso no quiere decir poesía en el teatro. Don Carlos Arniches es más poeta que casi todos los que escriben teatro en verso actualmente.

No puede haber teatro sin ambiente poético, sin invención... Fantasía hay en el sainete más pequeño de don Carlos Arniches... La obra de éxito perdurable ha sido la de un poeta, y hay mil obras escritas en versos muy bien escritos que están amortajados en sus fosas (citado en Sánchez 1999, 449: en Inglada 2017, 369).

En su última etapa, escribe piezas más extensas y de mayor alcance crítico, donde mezcla lo trágico y lo cómico, las denominadas "tragedias grotescas". La tragedia grotesca es la consolidación de la dramaturgia de la apariencia aunque aparentemente saca la negación de ese sistema de valores. «Lo grotesco es un simple exageración de los elementos expresivos, a través de la cual se alcanza una dudosa mezcla de comicidad y melodramatismő» (Monleón 1975, 155). Como dice García Templado, «gracias a lo grotesco, a la caricatura, Arniches alude el melodrama» $(1980,71)$, mediante una situación hilarante esconde en realidad un tragedia. Aunque la comedia grotesca no es el esperpento de Valle-Inclán, se puede hablar de una línea estética que se empieza en Arniches y se consolida con Valle-Inclán. Su obra maestra, la tragedia grotesca, La señorita Trevélez ${ }^{40}$ (1916), es el drama de una solterona de pueblo, burlada por unos jóvenes. Es una crítica a la juventud burguesa ociosa de Madrid y, según José Monleón, «quizá el autor sólo quiera echar en cara a los personajes su traición política a la sociedad liberal que quiere levantarse» $(1975,147)$.

\footnotetext{
${ }^{40}$ En 1956, el director de cine y guionista Juan Antonio Bardem realizó una adaptación libre de la obra de Arniches, la magnífica Calle Mayor, dando más importancia a la parte dramática del texto, ya que el dramaturgo supo ocultar detrás del chiste y las risas un trasfondo de soledad, crueldad y provincianismo (Ríos Carratalá 1992, 105).
} 
Entre las diferentes dramaturgas de los años veinte, la autora que mayor éxito tuvo fue Pilar Millán Astray ${ }^{41}$ (La Coruña, 1879-Madrid, 1949). Cultivó, sobre todo, dos géneros, la comedia costumbrista sentimental y el sainete madrileño. Estrenó veinte títulos diferentes de carácter conservador y temas del gusto del público de la época, ligadas en muchos aspectos al sainetero Carlos Arniches.

Inició su carrera teatral con Al rugir del león (1923). Entre los veinte títulos que forman su repertorio, sobresalen dos sainetes que superaron las cien representaciones: su segundo estreno, el sainete de ambiente madrileño El juramento de la Primorosa (1924), cuyo tema era la épica de la maternidad que la consagró como autora de éxito comercial y La tonta del bote $e^{42}(1925)$ en la que reproducía el popular mito de la Cenicienta convertida en princesa, en la que alcanzó las 140 representaciones en el teatro Lara de Madrid.

También obtuvieron importante éxito de público comedias y sainetes como Mademoiselle Naná (1928), El millonario y la bailarina (1930) y Los amores de la Nati (1931), entre otras. A pesar de la buena acogida de sus obras entre el público, la crítica no siempre se mostró favorable a la autora (Nieva de la Paz 1992, 131; Hormigón 1997, 829).

\subsection{3.- La comedia de tesis. La alta comedia: Jacinto Benavente}

Este tipo de comedia es una crónica dramática de los defectos y las virtudes de la burguesía. Se caracteriza por su tono irónico y por presentar personajes arquetípicos que mantienen largas conversaciones y monólogos con un lenguaje elegante e ingenioso.

Este modelo estaba constituido por los dramas sociales satírico-críticos y las piezas de salón derivadas de la tradición de la alta comedia surgida a mediados del siglo XIX. Este

\footnotetext{
${ }^{41}$ Su hermano menor fue el militar José Millán Astray fundador de la Legión Española. El 12 de octubre de 1936 tuvo lugar en el paraninfo de la Universidad de Salamanca el altercado que mantuvo con Miguel de Unamuno. En el que Unamuno respondió «Venceréis porque tenéis sobrada fuerza bruta. Pero no convenceréis. Para convencer hay que persuadir, y para persuadir necesitaréis algo que os falta: razón y derecho e la lucha». Véase también la película de Alejandro Amenábar, Mientras dure la guerra (2019) en la que reconstruye el momento histórico y el enfrentamiento entre ambos.

${ }^{42}$ Esta obra fue su mayor éxito sobre el escenario. Aparte de las numerosas reposiciones (incluso después de la guerra civil), hay que añadir varias versiones cinematográficas posteriores.
} 
teatro burgués permaneció encadenado a la estética de ilusión e identificación propia de la tradición burguesa. Como exponen Vilches y Dougherty, la comedia de tesis

ambientada casi siempre en medios urbanos, ofrecía tipos extraídos de las clases medias, cuyas costumbres y problemas eran llevados a escena, a veces desde una perspectiva satírica, con el objetivo de exponer socialmente un problema y plantear los medios adecuados para su resolución $(1997,82)$.

La función moralizante era la clave de su éxito, puesto que la burguesía asistía al teatro para ver reflejados sus problemas sobre el escenario y buscaba que en la contemplación de estos se solucionaran. Las tensiones socioeconómicas de la sociedad de entreguerras se concentraban en dos temas relacionados con la ruptura de la jerarquía de clases: el matrimonio (emancipación de la mujer) y la aparición de una nueva burguesía enriquecida.

Su máximo representante, Jacinto Benavente (Madrid, 1866-Madrid, 1954) intentó la renovación del teatro español desmarcándose del teatro de su época. Influenciado por el teatro europeo y por los autores clásicos españoles consigue, mediante esta fusión, que su obra fuera clásica y renovadora a la vez. (Fortuño 2008, 95). Teatro fantástico, (1892) es la primera tentativa dramática de Benavente, cuyas piezas contienen propuestas con la intención de crear un "teatro libre" (Rubio Jiménez 1998, 37), pero

no obtuvo el éxito esperado [...] tras advertir que estas obras primeras de Benavente no estaban destinadas a la representación. [...]. En Teatro fantástico Benavente fusionó la fantasía y la commedia dell'arte, el juego y el sueño [...]. Por medio de sus figuras consiguió la deshumanización de sus personajes y de sus sentimientos (Fortuño 2008, 97-99).

En su Cuento de primavera, pieza que forma parte del Teatro fantástico se puede observar la influencia del «teatro de ensueño» de Maeterlinck. La idea viene ligada a la expresión del estado de ánimo debido a la soledad y la muerte. Otros autores a partir de principios del siglo XX introdujeron el término en el título de sus obras (Hurtado Hernández 2019, 48).

Sus siguientes obras fueron El nido ajeno (1894) y Gente conocida (1896). El estreno de El nido ajeno no tuvo éxito ante el público, acostumbrado a los dramas de 
Echegaray, sin embargo inaugura un nuevo modo de entender el texto dramático que se impondrá durante mucho tiempo en la escena española. Tan sólo hay que esperar unos años para ver cómo su éxito ante el público se afirma con obras como Sacrificios (1901), La Noche de Sábado (1903), el Dragón de fuego (1903) y Los malhechores del bien (1905). Benavente aportó al teatro español un tono europeo, emancipado del Romanticismo y conocedor de los grandes autores contemporáneos. Se propuso crear un teatro que mostrara las contradicciones de la sociedad burguesa (teoría/praxis, sistema/individuo, etc.) pero sin poner al descubierto las raíces ideológicas, sociales, políticas y religiosas de una sociedad burguesa. Le ofrecía al público la mala conciencia, pero el autor y el público consiguieron entenderse, creando la identificación de una forma teatral.

El teatro modernista surgió como un intento de hacer desaparecer el teatro naturalista. José de Echegaray (1832-1916), heredero, a su vez, de Manuel Tamayo y Baus, dominaba la escena española en esta época. [...] El destinatario del teatro de Echegaray y Benavente fue la burguesía de la Restauración, clase social a la que ambos pertenecían. En un primer momento, éste pretende, y lo consigue, alejarse de la dramaturgia del teatro neorromántico (Fortuño 2008, 89-90).

Es un teatro de intriga bien construida y diálogos elegantes e ingeniosos, que plantea conflictos amoroso, familiares o económicos con una suave crítica social y finales casi siempre satisfactorios. La alta comedia benaventina se caracteriza

por su ubicación preferente en lugares acomodados, por la elección de personajes pertenecientes a la aristocracia o a la alta burguesía, por el predominio de los modales refinados y las formas de vida brillantes, y, sobre todo, por el uso de un exquisito diálogo basado en el ingenio e impregnado de un suave humor, más inclinado a buscar la sonrisa que a provocar la carcajada (Pérez-Rasilla 1997, 23).

$\mathrm{Su}$ teatro intentaba divertir y distraer, era un teatro de la apariencia, alejado de la realidad, cuyo espacio escénico se había «impuesto sustituyendo a los tres decorados de Serlio, desde el último tercio del siglo XX» (Bobes Naves 1988, 158) formado por un único decorado interior, una sala más o menos lujosa, siempre igual y con las mínimas variaciones. 
Con Los intereses creados (1907) alcanza el punto álgido de su primera época, en la que alcanza uno de su mayor y más duradero éxito. La obra es una farsa que, utilizando personajes y ambientes de comedia del arte italiana y de la tradición picaresca, muestra una cínica visión de los ideales burgueses. En ella, se hace una crítica del positivismo imperante en la época que defiende, entre otras, las ideas del determinismo. «La tesis que se defiende en esta obra [...] no es otra que los hombres se mueven por intereses económicos» (Fuente [1992] 1999, 511).Años más tarde, en un artículo «Estreno en Lara de "Los interese creados"», con fecha de 9 de diciembre de 1909, Benavente opinaba sobre su obra: «Hoy la escribiría de otra manera; más en tono de farsa. Ya no es pecado escribir farsas; pero enemigo como soy de corregir mis obras aunque tuviera la seguridad de mejorarlas, así durará... lo que el público quiera» (citado en CDAEM 2017, Vol. 1907-1909, 73).

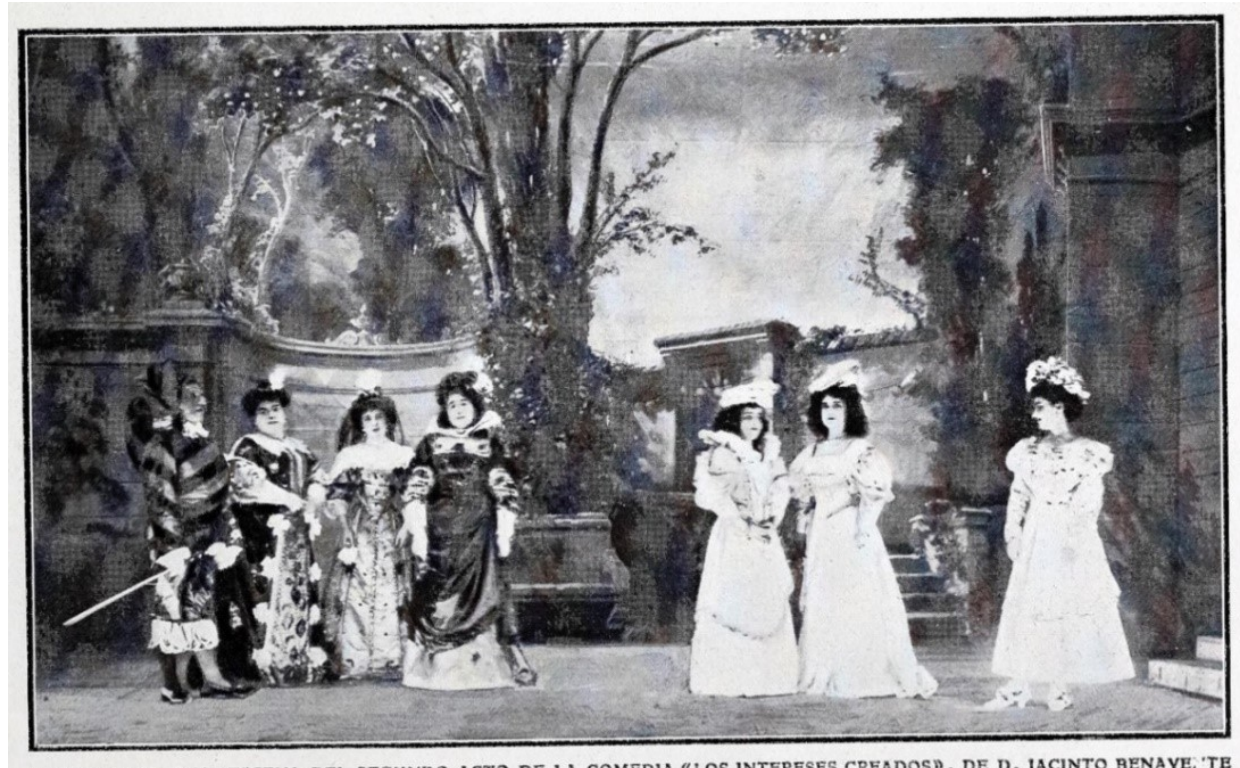

TEATRO LARA. UNA ESCENA DEL SEGUNDO ACTO DE LA COMEDIA (LOS INTERESES CREADOS》, DE D. JACINTO BENAVE. 'TE

Fig. 16: Fotografía (1907) de una escena de Los Intereses creados de Jacinto Benavente.

Desde 1908 Benavente parece abrir una nueva época en que predominan las comedias sombrías Por las nubes (1908) y La losa de los sueños (1908). Los dramas rurales Señora Ama (1913) y La Malquerida (1913) son las obras más notables de esta época de plenitud. No se pueden considerar dos periodos contradictorios, ya que también sigue estrenando comedias (Díez Canedo 1938, 18). 
Realizó varias incursiones en el género chico, Teatro feminista, con música de un compositor aficionado, Pablo Barbero. Las siguientes las llevó a cabo, ya con compositores conocidos, como son Ruperto Chapí en La sobresalienta (1905); Amadeo Vives en Viaje de instrucción (1900) y con Vicente Lleó La copa encantada y Todos somos unos (ambas en 1907) (Temes 2014, 284-285).

\subsection{4.- El astracán: Pedro Muñoz Seca}

El astracán es un subgénero cómico considerado como algo más burdo, pero exitoso en su época y «deudor de la comedia de tesis en el planteamiento de una moraleja y de la comedia de costumbres en la presentación de una acción que pretendía reflejar la vida cotidiana» (Vilches y Dougherty 1997, 88) que se extiende de 1900 a 1930. Son repertorios ocasionales que se representaban por Pascua en el Teatro de la Comedia, durante el descanso de la temporada de teatro nacional o importado del extranjero.

Con el chiste fácil, basado en el retruécano, donde personajes y situaciones son desarticulados y vueltos a articular, junto a las semejanzas fonéticas, buscaba la carcajada del público en todo momento (García Templado 1980, 73). Como afirma Eduardo Pérez-Rasilla, el astracán era

\footnotetext{
un tipo de teatro generalmente banal, escrito con la única pretensión de hacer reír, y apoyado en recursos como la situación disparatada y la comicidad lingüística basada en el retruécano y en otras formas de juegos de palabras. Por lo demás, suelen ser piezas plagadas de chistes y sometidas a unos patrones que permite la facilidad de su construcción $[\ldots](1997,20)$.
}

Algunos de los componentes del astracán son la falsilla sentimental, los despropósitos de situación de carácter y de lenguaje, la ramplonería de forma, los nombres de personajes combinados que dan pie al chiste y la tipificación regionalista. Estos rasgos ya estaban en el juguete cómico, pero lo propio del astracán es la radicalización y conversión de dichos elementos en absolutos de la comicidad (Ruiz Ramón, 1977).

Pedro Muñoz Seca (El Puerto de Santa María [Cádiz], 1881-Paracuellos [Madrid], 1936) es el mejor representante de este género, cuyo objetivo era hacer reír al 
espectador, «no solo con la trama en sí misma, sino con un uso muy imaginativo y culto del lenguaje y sus recursos» (Temes 2014, 299). Una de sus obras maestras fue La venganza de don Mendo (1918) parodia del teatro clásico-romántico, «en la que a los recursos propios del astracán añade el tratamiento ridiculizador de los motivos dominantes en el teatro romántico, neorromántico y modernista» (Pérez-Rasilla 1997, 21). Su teatro inaugura el género del astracán o astracanada. El astracán es, además, una consecuencia del sainete, surgida a comienzos del siglo $\mathrm{XX}$, en la que se deforma deliberadamente la realidad en sus aspectos más disparatados por lo que resulta antecedente del teatro del absurdo (Temes 2014, 442).

Muñoz Seca situó entre los grandes éxitos comerciales del período «unas obras híbridas entre el juguete cómico, el melodrama, el sainete, la comedia y la farsa» (Vilches y Dougherty 1997, 88). Sus textos más representativos son Los extremeños se tocan (1927), ¡Pégame, Luciano! (1929) y El alfiler (1929), entre otros.

También realizó teatro musical con importantes compositores de la época, como Arturo Saco del Valle en El naranjal o Ruperto Chapí en El triunfo de venus (1906). De sus varias colaboraciones literarias con Pedro Pérez Fernández (conocidos como "los Pericos") encontramos Trianerías (1909) con música de Amadeo Vives; El rey nuevo (1923) con música de Jacinto Guerrero o La mujer de nieve (1924) con música de Federico Moreno Torroba y Ernesto Pérez Rosillo (Temes 2014, 299).

\section{2.- El género lírico}

El género más representado y de más aceptación por el público de principios de siglo, fue el teatro en verso o teatro poético. Más concretamente, entre 1907 y 1914, se produce un verdadero fervor social por el teatro poético en verso, «orientado con frecuencia hacia una visión idealizada y nostálgica de la historia de España, imaginada como un conjunto de hechos heroicos y esplendorosos» (Pérez-Rasilla 1997, 28).

En sus obras se combinaba la huella posromántica y barroca con los rasgos de estilo modernista: la sonoridad de los versos, los perfiles heroicos o grandiosos de los personajes, la importancia de los aspectos extratextuales en la iluminación, el decorado, 
el vestuario, etc. De ideología tradicionalista, exaltaba los ideales nobiliarios y los grandes hechos del pasado español, para superar la desmoralización colectiva que siguió a la pérdida de las colonias.

\subsection{1.- Autores destacados del teatro poético: Eduardo Marquina, Francisco} Villaespesa, los hermanos Manuel y Antonio Machado y Dolores Ramos de la Vega

Autores destacados fueron Eduardo Marquina, Francisco Villaespesa y con una ambientación más moderna, los hermanos Machado.

Eduardo Marquina (Barcelona, 1879-Nueva York, 1946) fue poeta, novelista, articulista y dramaturgo. Su obra se construye sobre los valores formales y tradicionales del teatro histórico español. Su obra dramática se puede agrupar en tres géneros: drama histórico en verso, comedia realista en prosa y drama rural en verso. Se convirtió en el dramaturgo de mayor éxito de esta modalidad de teatro poético. Su primera pieza en verso fue El pastor (1902). El drama histórico en verso es el género que más cultivó, ejemplo de ello son En Flandes se ha puesto el sol (1910), Por los pecados del rey (1913) y El gran Capitán (1916) (Ruiz Ramón 1986, 65). Uno de sus triunfos dramáticos fue el drama rural El pobrecito carpintero (1924), estrenado el 29 de marzo en el teatro de la Princesa de Madrid. También de gran éxito fue su obra, La ermita, la fuente y el río (1927) con Margarita Xirgu en el papel protagonista, con quien años más tarde, también estrenará sus dramas en verso Fuente escondida (1931) y Los julianes (1932) como actriz principal.

Además colaboró con varios compositores, en obras como: Emporium (1906) con música de Enric Morera; La morisca (1918) con Jaime Pahissa y El collar de Afrodita (1925) en colaboración con José Juan Cadenas y música de Jacinto Guerrero (Temes 2014, 298). No debemos dejar de nombrar la relación que mantuvo con Federico García Lorca, a quien le presentó personas influyentes del mundo teatral. Y compartió dirección en el estreno de Bodas de sangre (1933). 


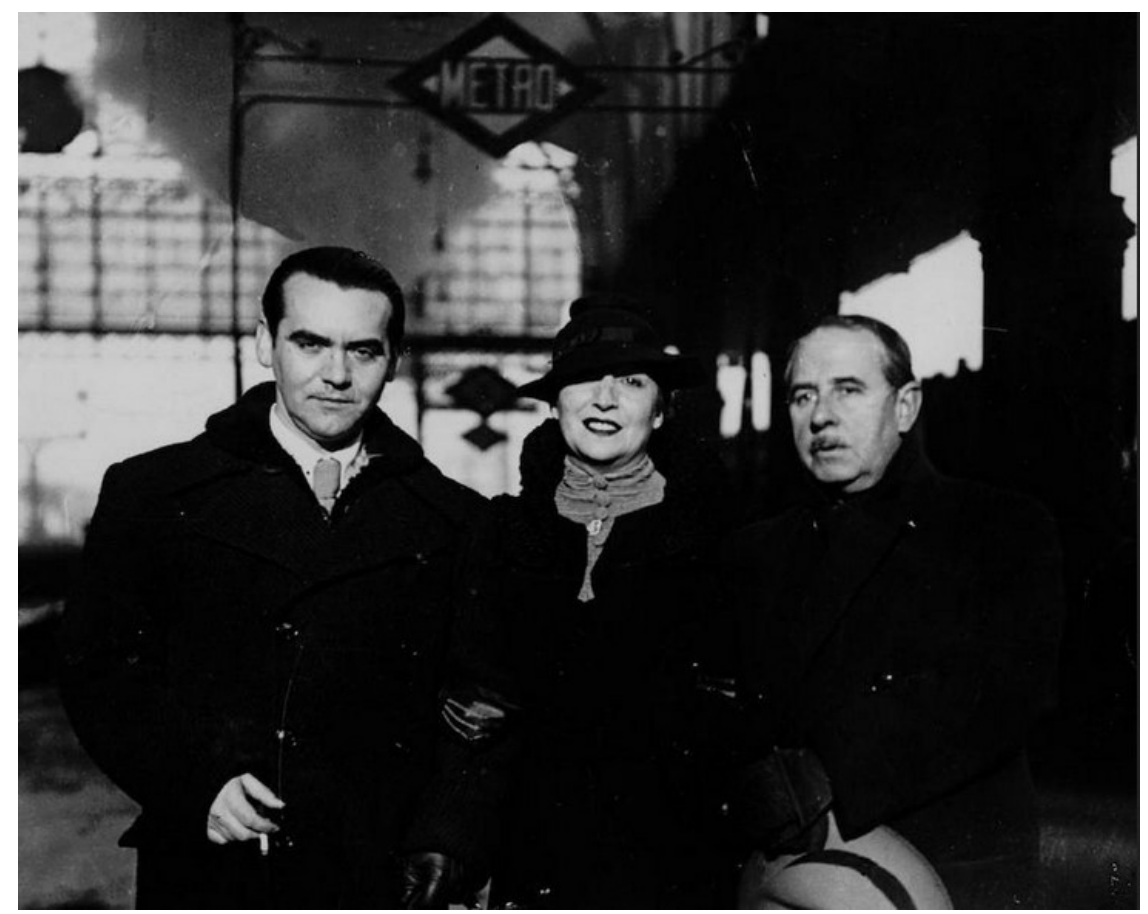

Fig. 17: Fotografía de Federico García Lorca, junto a la actriz Lola Membrives y el dramaturgo Eduardo Marquina. Madrid, 1934.

Marquina también publicó artículos donde expuso «sus ideas sobre el nuevo teatro pretendido y su carácter proselitista de una visión tradicionalista» (Rubio Jiménez 1998, 29). Ideas que compartía con Fernando Díaz de Mendoza y María Guerrero, miembros de la misma compañía sobre el ideal colectivo y patriótico políticos. En una conversación, mantenida con Pablo Suero, opinaba sobre el estado del teatro:

Te hablaré únicamente del teatro en España únicamente. Si el teatro está en crisis se debe ello a que, en una época en que todo se organiza, el teatro o se organiza como industria de arte, con capital responsable. Por otra parte, en lo que respecta a nosotros, carecemos de actores. No tenemos sino actrices, lo que dificulta en extremo la labor del autor, pues se ve privado de escribir para protagonistas hombres [...]. El teatro se ha reformado más en procedimientos que en ideas (1937 [2015], 368-369).

La obra de Francisco Villaespesa (Laujar de Andarax [Almería], 1877-Madrid, 1936) se caracteriza por la disociación y la absoluta falta de integración de los elementos líricos y los elementos dramáticos, con una estructura dramática casi inexistente. Entre sus obras citaremos su primer éxito, El alcázar de las perlas (1911) con unos decorados y una ambientación más modernos, y Doña María de Padilla (1913). Su teatro histórico en verso contó con el apoyo de María Guerrero. 
También cultivaron el teatro poético en verso los hermanos Manuel (Sevilla, 1874Madrid, 1947) y Antonio Machado (Sevilla, 1875-Collioure, 1939). Su colaboración teatral comenzó cuando firmaron, con Francisco Villaespesa, la adaptación en verso de Hernani de Víctor Hugo, estrenada en 1925. Su teatro popular va de la comedia costumbrista al teatro lírico. La obra dramática, escrita en colaboración por Antonio y Manuel entre 1926 y 1932, comprende siete piezas: su primera obra original y tributo al teatro modernista, Desdichas de la fortuna o Julianillo Valcárcel (1926), tragicomedia cuyo personaje principal es el Conde Duque de Olivares; Juan de Mañara (1927) que muestra la renovación de la leyenda del burlador penitente, Maraña, conocido pecador y luego convertido santo en el siglo XVII; de ambientación contemporánea fue Las Adelfas (1928) en la que se utilizan las lecciones del psicoanálisis; con La Lola se va a los puertos (1929), basada en una copla popular, alcanzaron uno de sus mayores éxitos populares; con La prima Fernanda (1931), sátira de la vida política, buscan reflejar el momento vital de los espectadores; La duquesa de Benameji (1932) en verso y prosa, comedia de bandidos y El hombre que murió en la guerra $\left(\right.$ s.f. $\left.^{43}\right)$ en la que se reflexiona acerca de la guerra, la muerte y la identidad. Manuel Machado, compartiendo opinión con Eduardo Marquina, se quejaba de la dificultad en la que se encontraban para poder estrenar la obra: «Tenemos una obra titulada Un hombre murió en la guerra. Es obra de aliento y de actualidad, pero no tenemos dónde colocarla. Aquí no hay más que compañías de actriz. Y nuestra obra requiere un actor galán» (citado en Suero [1937] $2015,283)$.

La colaboración entre los dos hermanos había comenzado anteriormente con adaptaciones del teatro español clásico (Díez Canedo 1938; Ruiz Ramón 1986; Mainer 2013, 337). También teorizaron sobre el teatro español de la época, Manuel Machado en su Teatro Poético y Antonio Machado en El gran climatérico (1935) que representa una disertación de su apócrifo Juan de Mairena (1936) (Monleón 1976, 1069). En el texto de Juan de Mairena se puede observar con mayor claridad la síntesis del pensamiento de Antonio Machado frente al teatro español:

\footnotetext{
${ }^{43}$ Se desconoce la fecha de la escritura pero su estreno fue el 18 de abril de 1941 en el Teatro Español de Madrid. Se publicó en la colección Austral de Buenos Aires, en 1947. En su prólogo, Manuel Machado afirmaba que la obra se estrenaba trece años después de ser escrita, siendo 1928 la posible fecha de escritura (Baltanás, 2008).
} 
Nuestro deseo de renovar el teatro no es un afán novelero $—$ o novedoso, como dicen nuestro parientes de América-, sino que es, en parte y por de pronto, el propósito de restaurar, mutatis mutandis, mucho de lo olvidado o injustamente preterido.

Es la dramática un arte literario. Su medio de expresión es la palabra. De ningún modo debemos mermar en él los oficios de la palabra. Con palabras se charla y se diserta; con palabras se piensa y se siente y se desea; [...]. Los grandes poetas de la escena supieron esto mejor que nosotros; ellos nunca limitaron la palabra a la expresión de cuantas naderías cambiamos en pláticas superfluas, mientras pensamos en otra cosa, sino que dicen también esa otra cosa, que suele ser lo más interesante.

Lo dramático [...] es acción [...]. Acción humana, acompañada de conciencia y, por ello, siempre de palabra. A toda merma en las funciones de la palabra corresponde un igual empobrecimiento de la acción (Machado [1935] 2001, 89-90).

El teatro de los hermanos Machado se mantiene dentro de los límites del teatro tradicional, sin llegar a realizar sus ideas dramáticas en sus obras teatrales. En 1933, en respuesta a Miguel Pérez Ferrero sobre la situación del teatro, los hermanos Machado expusieron:

En el teatro, arte de tradición, hay mucho que hacer, mucho que continuar. [...]. La acción en verdad, ha sido casi expulsada de la escena [...]. El diálogo [...] divorciado de la acción, pierde su valor poético, aunque conserve alguna vez su valor didáctico [...]. El teatro volverá a ser acción y diálogo; pero acción y diálogo que respondan, en suma, al conocimiento de lo humano, que ha sido posible hasta ahora (citado en Monleón 1976, 1073-1074).

El texto, firmado por los dos hermanos, es similar al que encontramos dos años más tarde, en boca de su apócrifo Juan de Mairena (Monleón 1976, 1074).

También debemos destacar la producción teatral de Dolores Ramos de la Vega (Málaga, último tercio siglo XIX, primera mitad siglo XX), actriz y escritora teatral. Actuó en todas las ciudades importantes de España, y fue autora de numerosas obras estrenadas durante las dos primeras décadas del siglo XX, entre las que predominó el género lírico de folklore andaluz, con temática costumbrista y con cierto maniqueísmo. Utilizó el pseudónimo de Elías Alolsomar. Fue una de las pocas autoras, junto a Pilar Millán Astray, que publicó sus obras en ediciones populares y que consiguió grandes éxitos con sus representaciones (Quiles Faz 2018). Como afirma Juan Antonio 
Hormigón, «dos son las notas características de su teatro: el tipismo de sainete, generalmente andalucista, y el melodramatismo populista» $(1997,1040)$.

Entre su obra a destacar encontramos: ¡La estocá de la tarde! (1905), zarzuela en prosa en un acto y cinco cuadros, en prosa y verso, con música de Julián Vivas; el libreto de la zarzuela en un acto y tres cuadros, en prosa y verso, El niño de Brenes (1908) con música de Pedro Córdoba, y el drama popular Málaga tiene la fama (1929 publicada en 1931), basado en una antigua copla andaluza, en un prólogo y tres actos, que es su única obra escrita en colaboración con Manrique Gil (Nieva de la Paz 1993, 169; Hormigón $1997,141-142)$.

\subsection{2.- El género chico}

El género chico surge como fórmula literaria de comedia breve (con una duración de una hora de espectáculo y casi siempre de un solo acto) que, a veces, incluye acompañamiento de música y baile, «surgido como reacción a la llamada zarzuela grande o de larga duración y de trama más compleja» (Temes 2014, 448). Inicialmente el género chico nació sin música, pero más tarde aparece la posibilidad de añadir ilustraciones musicales, por ello este género se puede desarrollar con música o sin ella.

La existencia del género chico está ligada al concepto de teatro por horas, «varias piezas breves con entrada independiente para cada una de ellas» (Pérez-Rasilla 1997, 17), «su brevedad lo hace conciso, unidireccional, con unos códigos de excelencia muy diferentes a cualquier otra especialidad»(Temes 2014, 448). Carlos Fortuny, en su artículo «Vida, esplendor y muerte del llamado género chico», publicado en 1930 en el Heraldo de Madrid, exponía:

Hay gente que supone que el género chico son las zarzuelas en un acto, exclusivamente. Sin embargo conviene proclamar que en la denominación de género chico entran «todas aquellas piezas teatrales en un acto, generalmente con música, o sin ella, que empezaron representándose en secciones por horas» $(1930,8)$ 
El último tercio del siglo XIX y los primeros años del siglo XX, son los años de mayor auge que vive este género literario. Como afirma Alberto Romero Ferrer, respecto a la aparición del género chico en España,

no es una apuesta aislada en el contexto europeo. También coincide cronológicamente con el redescubrimiento en Francia de la Commedia dell'Arte por Maurice Sand, las consignas del Théâtre en liberté, de Víctor Hugo, el Théâtre de poche, de Théophile Gautier y la revalorización de la obra dramática de Carlo Goldoni $(2003,2033)$.

En la primera década del siglo XX, este resurgimiento del género chico supone el aumento del número de autores, compañías, compositores y escenógrafos. En este breve periodo de tiempo se llegó a estrenar más de 1500 obras, con semejanza a un modelo de producción casi industrial. El género chico se inspiraba en las clases trabajadoras y la pequeña burguesía urbana, personajes de baja condición social o rural, desde una perspectiva realista. Los elementos más frecuentes en sus textos son el chiste lingüístico, el habla popular, la exageración deformante y el recurso a la parodia (PérezRasilla 1997, 17).

La revista moderna, el circo y la proliferación de las salas cinematográficas, que desviaban parte del público habitual del género chico, causan que entrara en decadencia ya que representan una gran competencia, junto a la llegada de la vanguardia y la modernidad. La crítica teatral de la época exponía que:

el género chico ha fallecido asfixiado, pues llegó a faltarle aire que respirar y savia para nutrirse. Había nacido en un Madrid pintoresco, lleno de color y de vida, con personalidad propia, y al pretender trasplantarse a un Madrid modernizado y artificioso se murió de asquito (Fortuny 1930,9).

\subsection{3.- La revista moderna}

La revista es un género novedoso, sin antecedentes previos a 1870, compuesto por pequeños números teatrales y musicales aislados, solo levemente conectados unos a otros. Ya en el siglo XX, aparece un personaje central femenino, la vedette, provocadora y seductora, en torno a ella giraba todo el espectáculo musical frívolo, con cierto atrevimiento en torno a la insinuación erótica femenina, con vistosos decorados, 
iluminaciones coloristas, coreografías seductoras y atrevidos vestuarios de fantasía de las vedettes y las coristas. Con el tiempo «fue tan importante la vedette en una revista como el coro femenino, las llamadas "chicas de revista" o "coristas"» (Temes 2014, 454). Se sitúa también en los felices años 20.

La revista moderna, de carácter parisino, halló bastante resistencia en el público madrileño, acostumbrado a un género estructurado en torno a un argumento y unos tipos sainetescos. Las revistas de Guillermo Perrín y Miguel de Palacios le dieron un sabor marcadamente nacional y aprovecharon para ello temas genuinamente nacionales. Con un éxito rotundo, encontramos Cuadros disolventes (1896); El trueno gordo (1904) y Cinematógrafo nacional (1907), entre otras muchas (Muñoz 1946, 325). Se trataba de adaptar «los números vistosos de la revista francesa al ambiente madrileño, sirviéndose de personajes venidos del sainete y de la zarzuela» (Vilches y Dougherty 1997, 28). La revista moderna estaba formada por

representaciones lujosas de trajes y decorados coloristas, numerosas coreografías y musicales pegadizos, lenguaje picaresco rayando en ocasiones en lo procaz, argumentos disparatados y numerosas bellezas casi desnudas, confluían en un género que acaparó el interés del público y, en ocasiones, el beneplácito de la crítica, llegando muchas de sus creaciones a convertirse en grandes éxitos comerciales (Vilches y Dougherty 1997, $135)$.

Ejemplos de revista moderna con éxito los encontramos en Noche loca (1927), revista moderna en dos actos, de Joaquín Vela y José Luis Campúa, con música de Francisco Alonso; Todo el año es carnaval o Momo es un carcamal (1927) fantasía lírica en un acto de Joaquín Vela y Ramón María Moreno, con música de Ernesto Rosillo, que marca el momento de transición desde la revista española a la europea y Las bellezas del mundo (1930), revista europea de Antonio Paso Cano y Tomás Borrás con música de Reveriano Soutullo y Juan Vert. 


\subsection{4.- La zarzuela}

La zarzuela, que surgió a mediados del siglo XIX, consiguió su difusión y desarrollo hasta mediados del siglo XX. Conocida como zarzuela romántica ${ }^{44}$ o zarzuela restaurada, según define José Luis Temes, la zarzuela romántica es

una forma de espectáculo mixta de teatro y música. Su punto de partida es un texto teatral (creado ex professo para esa zarzuela, o preexistente como obra escénica), para el que un compositor elabora una serie de ilustraciones musicales con orquesta: unas para ser cantadas por los personajes de la dramaturgia o el coro y otras para ser interpretadas por la orquesta sola $(2014,16)$.

La zarzuela surgió a partir de un grupo de autores, como vía alternativa a la ópera española donde todo el texto era cantado. A diferencia del género chico, de un solo acto, la zarzuela grande, formada por dos o tres actos, era de larga duración y su trama era más complicada.

Tal vez fue la zarzuela el género que más acusó la crisis sufrida en el teatro de principios de siglo, ya que el público prefería otro tipo de espectáculos, como el cine, o la propia revista, y se llegó a pensar que si no era su formato "grande" terminaría por desaparecer. Pero a partir de la segunda década del siglo XX, se incorporan nuevas obras en el listado de zarzuela grande con argumentos basados en temas históricos, dando muestras de revitalización.

Se estrenan obras que sustentan el concepto de zarzuela grande. En la temporada 19221923 se pueden ver en cartelera obras como son La montería de Ramos Martín, con música de Jacinto Guerrero y Doña Francisquita ${ }^{45}$ de Federico Romero y Guillermo Fernández-Shaw Iturralde y música de Amadeo Vives. En 1924, La Bejarana, de Luis Fernández Ardavín, con música de Emilio Serrano y Francisco Alonso. En 1925, La

\footnotetext{
${ }^{44}$ La expresión zarzuela romántica se acuñó para diferenciarla de su precedente, la zarzuela barroca, y que se gestó en el Romanticismo.

${ }^{45}$ En mayo y junio de 2019, Doña Francisquita ha vuelto a subir a las tablas del teatro de la Zarzuela. Y el encargado de modernizar este clásico ha sido Lluís Pasqual; los tres actos originales se suceden en tres momentos de la historia, 1934, 1964 y en la actualidad. Esta nueva puesta en escena no ha podido evitar la irritación de los espectadores tradicionales de la zarzuela que esperaban una representación fiel (Perales 2019; Fernández Guerra 2019).
} 
calasera de Martínez Román y González del Castillo, con música de Francisco Alonso. Hasta el año 1936 se estrenaron veinte zarzuelas más (Huélamo Kosma 2003, 2546).

La zarzuela grande fue ampliamente cultivada durante el primer tercio del siglo XX, reponiéndose las obras consideradas ya clásicas de este repertorio y efectuándose estrenos que lograron atraerse con el éxito del público y el de la crítica (Vilches y Dougherty 1997, 147). 


\section{3.- El teatro de vanguardia}

El repertorio teatral español de comienzos del siglo $\mathrm{XX}$ no se diferenciaba esencialmente del de las demás urbes europeas. La diferencia principal la encontramos en el teatro comercial y conservador, con éxito en los escenarios españoles, que era absolutamente dominante. Federico García Lorca se posicionará en contra del teatro burgués, pero a su vez a favor de parte de este teatro ligero. En su «Charla sobre teatro ${ }^{46} \gg$ expondrá:

El delicioso teatro ligero de revista, vodevil y comedia bufa, géneros de los que soy aficionado espectador, podría defenderse y aún salvarse; pero el teatro en verso, el género histórico, la llamada alta comedia y la espléndida zarzuela hispánica sufrirán cada día más reveses, porque son géneros que exigen mucho y donde caben las innovaciones verdaderas, y no hay autoridad ni espíritu de sacrificio para imponerlos al público al que hay que domar con altura y contradecirlo y atacarlo en muchas ocasiones ([1935] 1989, 5-7).

El público español no estaba dispuesto a aceptar experimentos estéticos ni a verse confrontado en el teatro con los grandes problemas sociales o existenciales de su época (Floeck 1996, 30). Sin embargo, Lorca consideraba que el teatro no podía estar dominado por la actitud del público ante las nuevas propuestas teatrales y que se debía reaccionar ante esa postura, «el teatro debe imponerse al público y no el público al teatro. Para eso, autores y actores deben revestirse, a costa de sangre, de gran autoridad» (García Lorca [1935] 1989, 7). En diferentes entrevistas también se puede observar la opinión de Lorca de la situación teatral respecto a su público. En la realizada por Alardo Prats, para el periódico El Sol, el 15 de diciembre de 1934, expone:

lo grave es que las gentes que van al teatro no quieren que se les haga pensar sobre ningún tema moral. Además, van al teatro como a disgusto. Llegan tarde, se van antes que termine la obra, entran y salen sin respeto alguno. El teatro tiene que ganar, porque la ha perdido, autoridad. [...] Hoy solo algunos autores viejos tienen esta autoridad $(1934,8)$.

\footnotetext{
${ }^{46}$ Entregada por Federico García Lorca a Miguel Pérez Ferrero para ser publicada en el Heraldo de Madrid, el 2 de febrero de 1935.
} 
Aun así, también encontramos un teatro innovador más atrevido y creativo pero con menos popularidad. La difusión de este tipo de teatro, mal visto por los empresarios y el público burgués, estuvo a cargo de pequeños grupos independientes formado por aficionados. Fue, a partir de la Primera Guerra Mundial, cuando hallamos los primeros intentos de superar la función teatral dominante de consumo, entretenimiento y evasión. Supuso un periodo de exploración escénica tan activo en España como en cualquier otro país europeo (Jerez-Farrán [1991] 1999, 521).

Una serie de autores, de finales del siglo XIX y principios del XX, intentó llevar a cabo una renovación del teatro, frente al espectáculo comercial y conservador preferido por el público (Floeck 1996, 29) y se ponen en escena textos dramáticos con ideas innovadoras, pero dichos estrenos tuvieron poco éxito y muchos no llegaron a ser representados.

Estas obras se engloban dentro de las dramaturgias de la ruptura y, según Ruiz Ramón, las situamos entre 1896 y 1932. El año 1896 es la fecha de la publicación del ensayo La negación del teatro español de Miguel de Unamuno y, en el verano de 1932, Federico García Lorca crea La Barraca con sus primeras representaciones (1977).

\section{1.- La crítica teatral ante la situación del teatro}

Los escritores, intelectuales y críticos pertenecían tradicionalmente a la clase media de Madrid o de provincias, como lo eran sus lectores o espectadores. La prensa, formada por una gran variedad en periódicos y revistas, fue el impulso de la vida intelectual, no sólo porque la prensa periódica daba trabajo a un número de escritores, sino que proporcionaba una proyección pública a la profesión.

Durante los años veinte se observa entre la clase intelectual una preocupación por el fenómeno de la decadencia teatral. En este periodo se suceden una serie de declaraciones y posiciones frente al teatro dominante del momento, poniéndose en cuestión el concepto de lo teatral. No obstante, si retrocedemos a finales del siglo 
anterior $^{47}$, ya encontramos las palabras de Benito Pérez Galdós en su artículo «Viejos y nuevos moldes» publicado en La Prensa de Buenos Aires, el 28 de agosto de 1893, donde afirmaba que «el público se cansa de las viejas formas dramáticas, se las sabe de memoria, conoce los resortes tan bien como los autores más hábiles, y apenas halla atractivo en las obras que años atrás eran su encanto» $(1998,84)$ que se podrían trasladar a ese principio de siglo XX.

Durante estos años aumenta el número de libros y publicaciones periódicas dedicados al análisis de la escena, revistas y semanarios en los que se comentaba y difundía la cartelera. También se da la coincidencia que la mayoría de periódicos ${ }^{48}$ publicaban suplementos semanales dedicados al análisis de la cartelera $\mathrm{Y}$ periódicos como $A B C, E l$ Sol o El Heraldo de Madrid, inauguran una serie de secciones fijas dedicadas exclusivamente al estudio de la escena extranjera y al ensayo teórico en torno al teatro como doctrina social» (Romero Ferrer 2004, 188).

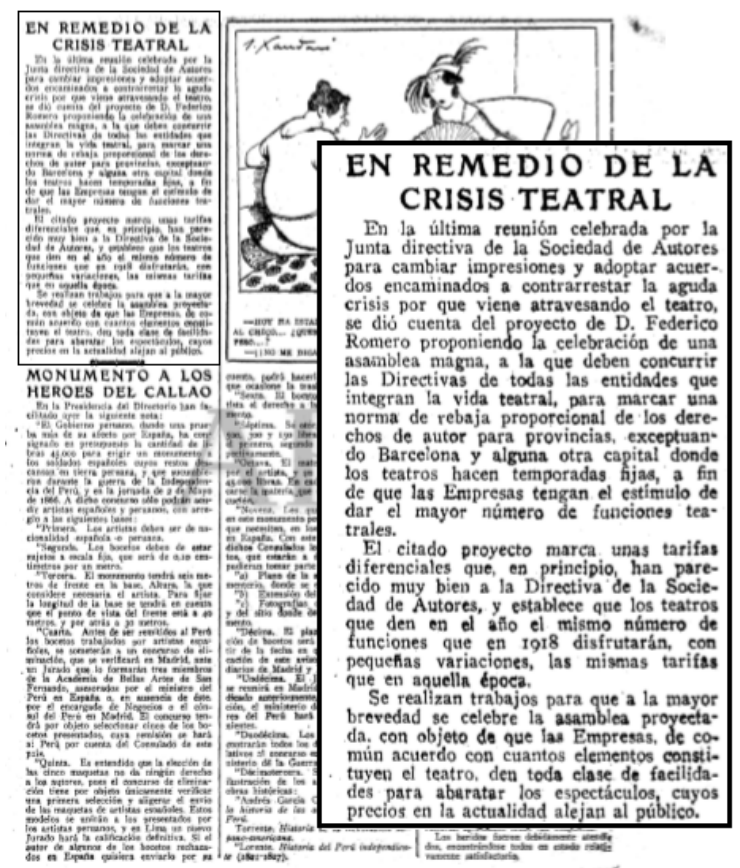

Fig. 18: Recorte de prensa, aparecido en el $A B C$ de Madrid, el 22 de julio de 1924, en el que se ve reflejada la crisis teatral de los años veinte.

\footnotetext{
${ }^{47}$ Entre 1880 y 1914 aparecen numerosos ensayos sobre la renovación del teatro español (Rubio Jiménez 1998, 21).

${ }^{48}$ Entre ellos encontramos a ABC, Ahora, El Debate, El Heraldo de Madrid, El Imparcial, El Liberal, La Libertad, La Nación, La prensa, El Sol, La Voz.
} 
En la década de los años veinte numerosas encuestas, entrevistas y ensayos tratan de esclarecer el motivo de esta crisis teatral que se estaba viviendo. Críticos teatrales como Enrique Díez Canedo, Luis Araquistáin, Ricardo Baeza, o autores como Gerardo Diego y el propio José Ortega y Gasset, entre otros, se sienten preocupados por la crisis teatral y sus consecuencias para España.

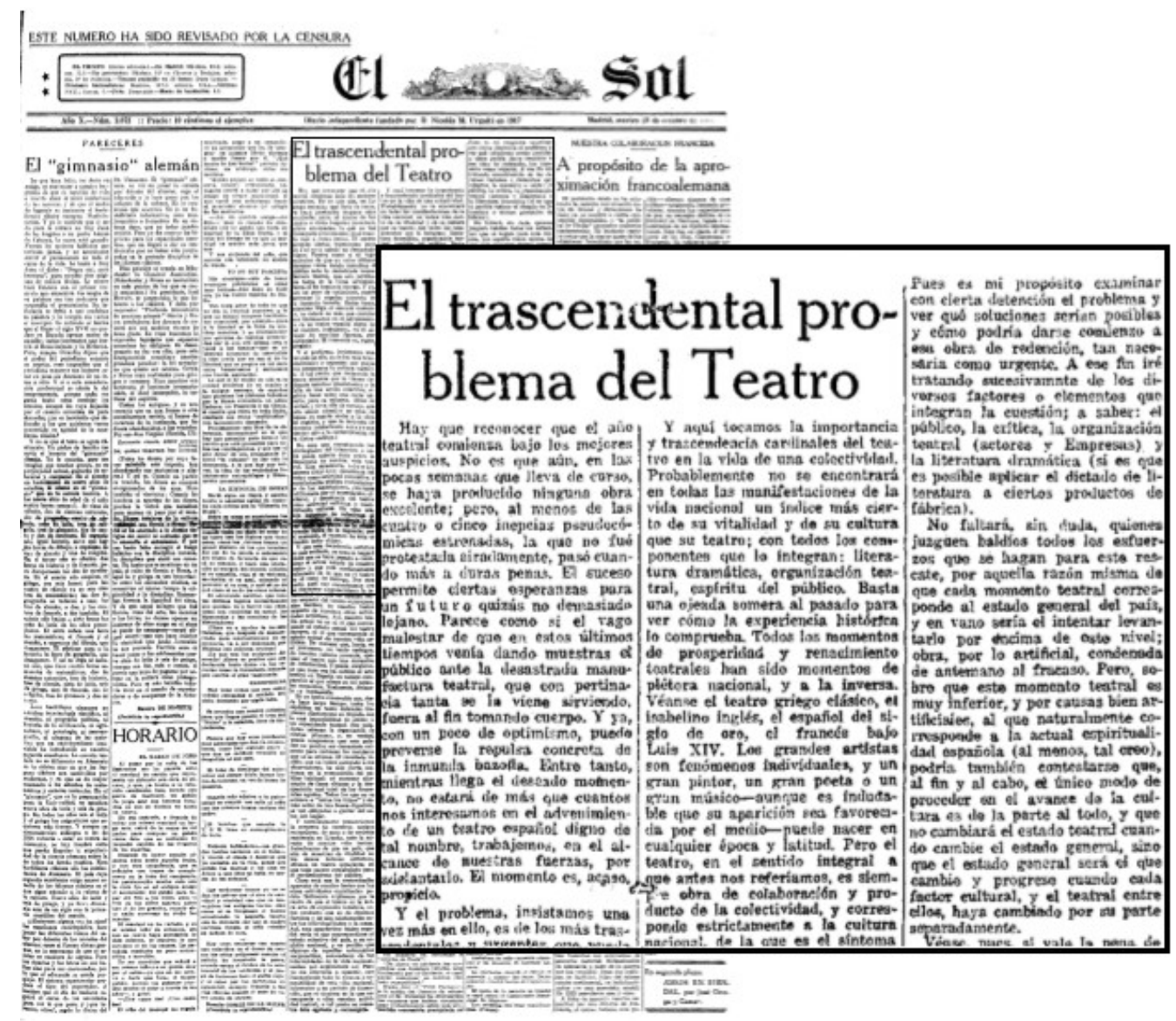

Fig. 19: Recorte de prensa aparecido en primera plana, el 19 de octubre de 1926, en el periódico El Sol, en el que Ricardo Baeza trata la crisis teatral de los años veinte.

El periodista Ricardo Baeza, uno de los autores «más comprometidos y radicales dentro de la polémica teatral» (Romero Ferrer 2004, 183), publicó en El Sol, entre los años 1926 y 1927, varios artículos dedicados a la problemática teatral, entre ellos citaremos su artículo «El trascendental problema del Teatro», publicado el 19 de octubre de 1926, en el periódico El Sol, en el que acusaba a los intelectuales del país de la falta de una acción colectiva para una reforma. Y - añadía - que la situación del teatro nacional se alejaba mucho del teatro europeo, por la falta de apoyo del Estado. Y concluía que momentos de prosperidad y renacimiento teatral vienen acompañados de un auge 
nacional y por eso «la extraordinaria importancia de la actividad teatral en la vida de una nación y la atención preferente que a ella debieran dedicar los gobernantes» (1926, 1). En su artículo, Ricardo Baeza reflexionaba, pues, sobre el papel que desempeña el teatro en la educación del pueblo.

Por su parte, Luis Araquistáin, miembro del PSOE y diputado durante la República, retomaba el pensamiento de Galdós y planteaba la necesidad de una transformación teatral, tanto en las estructuras internas del teatro, como en la búsqueda de un público fuera de la burguesía y el proletariado (Bilbatúa 1976, 19). Fue un impulsor de dicho teatro experimental, y en su libro La batalla teatral (1930) reunía una serie de artículos escritos desde 1924 hasta 1930. En sus ensayos teoriza sobre la renovación teatral ligada a la de la sociedad española. Así, en su artículo «Muchedumbres y minorías», publicado el 10 de octubre de 1928, en el periódico El Sol, ante esa crisis teatral escribe:

La crisis del teatro de muchedumbres arranca de la ley misma de su constitución. Obligado a mantenerse de la media docena de autores en boga — porque su organización económica no permite experimentar con autores y obras de éxito problemático [...]. El mal [...] no es exclusivo de España. En todas partes hay teatro de muchedumbres, sujetos incluso a mayores necesidades económicas que en nuestro país. Pero junto a esos teatros organizados en forma de gran industria coexisten los teatros de minorías, de poco costo y de público reducido, aunque suficiente para sostenerlos el tiempo necesario a su función renovadora. La particularidad de esos teatros minoristas generalmente llamados teatros de Arte $(1928,8)$.

También Felipe Sassone, en un artículo publicado en el periódico $A B C$ el 26 de abril de 1928, opinaba sobre la situación crítica teatral del momento y la necesidad de buscar un nuevo teatro para no perder al público:

El teatro se achataba, se empequeñecía, perdía sentido poético, y el espectáculo vulgar de la vida corriente empezaba a aburrir a los espíritus selectos. La misma realidad sujeta a fórmulas, dejaba de serlo; se hizo una realidad de teatro, una realidad convencional, sólo apariencia, reducida y falsa, de la vida verdadera $(1928,10-11)$.

Además, Federico Navas realizó para el Heraldo de Madrid diferentes entrevistas a autores, actores, directores y empresarios sobre la crisis del teatro, que posteriormente 
recopiló en forma de libro bajo el nombre de Las esfinges de Talía o encuesta sobre la crisis del teatro (1928) (Aguilera Sastre 1992, 175).

No sólo encontramos opiniones sobre la crisis teatral entre los críticos y periodistas, también los autores de la época declaraban su posición ante la situación. El propio Paulino Masip ${ }^{49}$ exponía:

El teatro está en crisis es verdad. Pero es que se le exige mucho al teatro. Son muchas compañías y muchos teatros. Para surtir la cartelera y la avidez de espectáculos del público, por fuerza se llega a estandarizar la producción. El año pasado se estrenaron 150 obras. ¿Qué queda de eso? Nada, o casi nada. Ya no hay producción clásica (citado en Suero 1937 [2015], 344).

El propio Lorca en una entrevista, realizada por Pablo Suero el 15 de octubre de 1933 y publicada en Noticias Gráficas de Buenas Aires, expondrá:

Es necesario comprender por qué el teatro está en decadencia... El teatro, para volver a adquirir su fuerza, debe volver al pueblo, del que se ha apartado... El teatro es además cosa de poetas... Sin sentido trágico no hay teatro... Y del teatro de hoy está ausente el sentido trágico.... [...] La clase media y la burguesía han matado el teatro y ni siquiera se van de él, después de haberlo pervertido... (citado en Soria Olmedo 2017, 73-74)

Y un año más tarde, también afirmaría: «Yo espero para el teatro la llegada de la luz de arriba siempre, del paraíso. En cuanto los de arriba bajen al patio de butacas, todo estará resuelto. Lo de la decadencia del teatro a mí me parece una estupidez. Los de arriba son los que no han visto [...] teatro» (García Lorca 1934, 8). Su postura ${ }^{50}$ es crítica hacia el público burgués, y cómo hay que buscar una nueva mirada:

Yo arrancaría de los teatros las plateas y los palcos y traería abajo el gallinero. En el teatro hay que dar entrada al público de alpargatas [...]. Si lo burgués está acabando con lo dramático del teatro español, que es esencial en el teatro español. Está echando abajo

\footnotetext{
49 (Granadella, [Lleida], 1899 -Cholula, Puebla, [México], 1963) autor dramático y guionista cinematográfico perteneciente a la generación del 27.

${ }^{50}$ Publicada en Crítica, en Buenos Aires, el 15 de octubre de 1933.
} 
uno de los dos grandes bloques que hay en la literatura dramática de todos los pueblos: el teatro español el otro bloque es el teatro chino ${ }^{51}$ (citado en Inglada 2017, 176-177).

En diferentes ocasiones, Federico García Lorca expresó su postura en contra de la figura del empresario que domina la escena teatral:

Digan lo que digan [...] el teatro no decae. Lo absurdo y lo decadente es su organización. Eso que un señor, por el mero hecho de disponer de unos millones se erija en censor de obras y definidor del teatro, es intolerable y vergonzoso. Es una tiranía que, como todas, solo conduce al desastre $(1934,8)$.

\section{2.- Renovación en Europa}

Antes de introducirnos en la renovación teatral en España, haremos una breve contextualización de cuándo y por qué tuvo lugar esta renovación y reforma en el ámbito europeo. El teatro moderno nace con el Realismo y el Naturalismo. En pleno apogeo romántico, se adoptó la necesidad de una representación más coherente con la realidad. Los textos existentes en la segunda mitad del siglo XIX no conectaban con la vida cotidiana ni con la realidad del espectador. En esta época romántica los autores dirigen su vista hacia la comedia de costumbres, un teatro realista con ambientación contemporánea mediante piezas moralizantes que reflejaba un mundo burgués convencional sin profundizar en los verdaderos problemas de la vida real. Aunque no tardaron en aparecer las primeras reacciones en contra de este realismo, ya que no todos los dramaturgos durante el realismo adoptaron esta estética. Podemos afirmar que Alfred Jarry con su obra Ubú rey (1890), en la que se busca la destrucción de la norma imperante, fue el precursor del teatro de vanguardia.

Los cambios y las nuevas ideas teatrales no sólo se producen en los autores. Durante el primer cuarto de siglo XX, en Europa y en Estados Unidos, las nuevas propuestas vanguardistas predominaron en el decorado y en la puesta de escena. Entre los grandes renovadores del teatro encontramos al actor, productor, director de escena y escenógrafo

\footnotetext{
${ }^{51}$ Refiriéndose al teatro chino al que pudo asistir como espectador en su viaje a Nueva York. Referencia extraída de la charla publicada en la revista Crítica de Buenos Aires, el 15 de octubre de 1933.
} 
Edward Gordon Craig (Hertfordshire [Reino Unido], 1872-Vence [Francia], 1966), quien, entre otras novedades, introduce la invención de pequeños y móviles biombos para sustituir la función del escenario; al escenógrafo y decorador Adolphe Appia (Ginebra [Suiza], 1862-Nyon [Suiza], 1928) quien enfatizó el uso de las luces, gracias a las nuevas posibilidades eléctricas y sustituyó los decorados fijos por telas corpóreas; al director teatral Vsévolod Emílievich Meyerhold (Penza [Rusia], 1874-Moscú [Rusia], 1940) impulsor de la biomecánica teatral en la que cada actor debía conocer y perfeccionar su cuerpo a partir de entrenamiento $\mathrm{y}$ al actor $\mathrm{y}$ director escénico Konstantín Stanislawski (Moscú [Rusia], 1863-Moscú [Rusia], 1938) creador del método interpretativo homónimo. Según su método psicológico-realista, el actor debía reflejar los sentimientos e intentar imitar del mejor modo posible la acción, llegando a identificarse con ella (Lunatxarski [1921-24] 1972, 90).

La regeneración teatral se inicia con el llamado teatro naturalista en contraposición con el teatro realista, imperante en el momento, y continúa hasta llegar a un teatro vanguardista más rupturista e innovador.

\subsection{1.- El teatro naturalista: Henrik Ibsen, August Strindberg, André Antoine, Anton Chéjov y George Bernand Shaw}

A diferencia del teatro realista, el teatro naturalista trata de reproducir la realidad introduciendo el comportamiento humano, a través del retrato de los personajes en su intimidad. Según afirma Rubio Jiménez, «el drama naturalista [...] se sujeta a la realidad social contemporánea, concediendo la primacía a la verdad humana de los caracteres, sometiéndolos al encadenamiento de los hechos» $(1982,13)$.

A mitad del siglo XIX, en la escena de la dramaturgia escandinava, se crean dos grandes teatros: la Escena nacional de Bergen y el Teatro de Christiana, luego Teatro Nacional de Oslo, hecho que influye notablemente en el ascenso del teatro nórdico en las novedades. El dramaturgo noruego Henrik Ibsen (Skien [Noruega], 1828-Oslo [Noruega], 1906) recorrió toda Europa y es considerado el gran renovador del teatro moderno (Oliva y Torres Monreal 1994, 317). Los temas tratados en sus piezas dramáticas son: los conflictos morales, los prejuicios, la verdad y la hipocresía, la 
sinceridad, el choque entre la libertad del individuo y los convencionalismos sociales burgueses, las dificultades económicas y la responsabilidad en las relaciones humanas. Tiene tres etapas: la primera con dramas poéticos nacionales, como Brand (1866); la segunda etapa es su época realista con la obra más conocida Casa de muñecas (1879) y Un enemigo del pueblo (1882); y finalmente, la etapa simbolista con La dama del mar (1888) y Hedda Gabler (1890). Las ideas que presenta en sus dramas son una sociedad más libre y en la que los más avanzados han de iluminar el camino (Rubio Jiménez $1982,56)$

Otra figura relevante en el teatro nórdico es el sueco August Strindberg (Estocolmo [Suecia], 1849-Estocolmo [Suecia], 1912). Es el introductor del naturalismo en su país con su novela El cuarto rojo (1897). Seguidor del teatro de Ibsen, es uno de los precursores del teatro del absurdo. Entre sus piezas dramáticas señalamos El padre (1888), La más fuerte (1891) y La señorita Julia (1888). Con su obra teatral El sueño ${ }^{52}$ (1902), podemos considerar a Strindberg como el precursor del surrealismo, «pues el inconsciente liberado se adueña de la escena, imponiendo sus esquemas incoherentes» (Oliva y Torres Monreal 1994, 320). En 1902, fundó en Estocolmo, el Intima Teatern. El término íntimo puede aplicarse tanto a las dimensiones del local, como a la temática de las obras, o a su modo de representación. Mediante la simplificación de elementos decorativos, se creaba un clima psicológico gracias a la ayuda de los juegos de iluminación que formaban sombras de los actores (Oliva y Torres Monreal 1994, 320).

A finales de siglo, autores defensores del naturalismo teatral introducen innovaciones en las técnicas teatrales, como André Antoine (Limoges [Francia], 1858-Le Pouliguen [Francia], 1943). El 30 de marzo de 1887, inauguró su Théâtre Libre (Teatro Libre) de París (1887-1894), en la pequeña sala del Elíseo de Montmartre con capacidad para unas trescientas cincuenta personas (Oliva y Torres Monreal 1994, 321). Según el director de escena Gaston Baty,

Antoine puso al desnudo todos los artificios de las fórmulas antiguas, arrojó fuera las complicaciones, los trucos, los golpes efectistas, la ampulosidad, los largos parlamentos

\footnotetext{
${ }^{52}$ Se puede encontrar el paralelismo con la obra española Tic-tac de Claudio de la Torre, estrenada el 3 de octubre en el Teatro Infanta Beatriz de Madrid (Aznar Soler 1993, 32).
} 
[...]. Creó el gusto por lo simple, rápida, concisa y visual, tanto en los gestos como en las actitudes y en las palabras (citado en Oliva y Torres Monreal 1994, 321).

La aportación más interesante en sus montajes fue la llamada cuarta pared, que consiste en que los actores actúen como si la boca del escenario fuera la cuarta pared cerrada del lugar en el que se desarrolla la acción, ignorando la presencia del público. Concentró la luz en el escenario, dejando a los espectadores en la oscuridad.

En el Teatro de Arte de Moscú (1898-1917), fundado por Konstantin Stanislavski y Vladimir Nemirovich-Danchenko, se estrenó la mayoría de las obras del dramaturgo ruso Anton Chéjov (Taganrog [Rusia], 1860-Badenweiler [Alemania], 1904). El tema predominante del teatro de Chejov es la frustración, derivada de la imposibilidad del ser humano para ver cumplidos sus sueños y deseos, el pesimismo y la angustia de vivir. Con la representación de La gaviota (1896), se inauguró el Teatro de Arte de Moscú, que contaba con actores, directores y técnicos. Fue el teatro más influyente gracias a las teorías interpretativas de su director Stanislavski. Tras el éxito que obtuvo se estrenaron tres nuevas obras de Chéjov, escritas por petición de Dantchenko y Stanislavski, Tío Vania (1899), Las tres hermanas (1901) y El Jardín de los cerezos (1904) (Lunatxarski [1921-24] 1972, 35-36).

El intento de trasladar a Inglaterra la experiencia del Teatro Libre de Antoine dio lugar a la creación del Teatro Independiente de Londres en 1891. Entre sus dramaturgos se encontraba el irlandés George Bernard Shaw (Portobello Dublín [Irlanda], 1856-Ayot St. Lawrence [Reino Unido], 1950), que destacaba por su sentido del humor con comedias de ingenioso humor, como La profesión de la Señora Warren (1898) y Pigmalión (1914). Con él aparece el teatro de la inteligencia. Como afirma Paul-Louis Mignon «ella es la que dirige la acción y denuncia apasionadamente, hasta en el humor, los defectos de la humanidad» ([1969] 1973, 30). 


\subsection{2.- El teatro de vanguardia: Alfred Jarry, Luigi Pirandello, Antonin Artaud, Roger Vitrac y Bertolt Brecht}

El cambio de estilo en la escena europea en el siglo XX viene causado por los progresos industriales y técnicos (escenarios móviles y mayor control en la iluminación) ${ }^{53}$; la popularización del cinematógrafo; la importancia de la figura del director de escena (separándose de la figura del actor y del empresario) y la difusión de todos avances y teorías de una manera más rápida (Oliva y Torres Monreal 1994, 363-364).

La primera ruptura con la norma imperante en el texto dramático la encontramos con el joven Alfred Jarry (Laval [Francia], 1873-París [Francia], 1907), quien con tan sólo dieciséis años escribió una primera versión de la obra Ubú, rey, inicialmente llamada Los Polacos; la obra se convirtió en precursora del teatro de vanguardia y del teatro del absurdo de comienzos del siglo XX. A partir de Ubú Rey se elabora «un estética fundamentada en la sorpresa y el escándalo, la explotación de todos los espejismos escénicos» (Béhar 1987, 355). Se podría decir que con esta obra se inicia el teatro surrealista y el teatro del absurdo.

El tema principal de las obras de Luigi Pirandello (Agrigento [Italia], 1867-Roma [Italia], 1936) es la relatividad de toda realidad humana. Por eso se sirve del teatro en sí mismo. Explora generalmente el fenómeno de ilusión que padece el actor respecto al espectador desde que queda poseído por el personaje, para denunciar la imposibilidad en que tengamos que saber, con certeza, la verdad sobre la personalidad de otro y sobre la nuestra propia. Pasea a sus criaturas hasta el límite de lo real y de lo imaginario con un arte de rara sutileza; juega con la máscara y el rostro con un virtuosismo tan natural, que la verdad, apenas fijada, se disipa y no cesa de desvanecerse (Mignon [1969] 1973, $30)$.

En 1917, en su obra Así es (sí así os parece), había declarado la imposibilidad de dar con una sola verdad cierta. Pero fue en la obra Seis personajes en busca de autor (1921), donde el tema de la relatividad de la existencia se mostrará mejor mediante el recurso del metateatro o el teatro dentro del teatro. Donde el ser y el parecer, la imagen

\footnotetext{
${ }^{53}$ Se pueden iluminar de forma independiente el escenario y la sala. En el escenario también se pueden iluminar de manera distinta las diferentes partes del espacio, ofreciendo primeros planos entre los personajes o zonas. Adquiere gran importancia este nuevo lenguaje no verbal.
} 
y la máscara están presentes en el desarrollo de la obra, en el que el espectador es testigo del ensayo de la obra El juego de los papeles.

El dramaturgo Antonin Artaud (Marsella [Francia], 1896-Ivry-sur-Seine [Francia], 1948) no pretendió destruir el teatro. Tenía una visión totalmente diferente al teatro tradicional y para ello debía acabar con el teatro anterior que era fácil de entender y disfrutar. La dramaturgia de Artaud se caracteriza «por la discontinuidad de la fábula, organizada en secuencias parciales, yuxtapuestas, según la lógica contradictoria del sueño. El personajes estalla en distintos planos psicológicos exhibiendo a la vez lo manifiesto y lo latente, lo consciente y lo inconsciente» (Béhar 1987, 357). El teatro de Artaud queda claramente definido con palabras de Eugène Ionesco:

El teatro (porque burgués o popular o ideológico), en lugar de ser la expresión de una toma de conciencia aguda - y amplia, también— de la condición del hombre, de la realidad; en lugar de ser revelador, de una manera ásperamente cómica o trágica, como lo son, a veces, los sueños, las pesadillas, no ha contribuido, él también, más que a poner entre nosotros y el mundo pantallas protectoras y disimuladoras. Es falso (político y tendencioso), incompleto (no encarando más que aspectos superficiales que no comprometen al ser total), blando (comedia ligera de salón, optimismo de beneficencia), dramático para problemas secundarios, es decir mediocremente dramático. Nos ha instalado en el confort o un dormir sin sueño significativo. [...]

Es ése, me parece, el reproche mayor que Antonin Artaud hacía al teatro, al arte de su tiempo. [...] La falsa cultura nos separa de todo y de nosotros mismos, nos esconde la realidad, es "inauténtica", es una autodefensa torpe como un arma que se volviera contra quien la utiliza $(1975,33-34)$.

Artaud fue un apasionado del grupo surrealista, hasta su expulsión en 1925 por André Breton, ya que los planteamientos del surrealismo no dejaban mucha opción al teatro. En 1926, excluido del surrealismo, funda con Robert Aron y Roger Vitrac el Teatro Alfred Jarry; el teatro que propone es inquietante, destructor y revolucionario (Oliva y Torres Monreal 1994, 387). Según afirma Béhar, el director de escena Artaud puso los cimientos a lo que

sería más tarde el Teatro de la Crueldad y que desde entonces lo alejará de las perspectivas surrealistas: se trataba de construir un mundo tangente a lo real, único en tanto que rechaza la repetición, que implica una participación total del espectador que se 
ofrece a una operación verdadera donde su espíritu y su carne estaban en juego, con la ambición de cada uno encuentre su unidad original $(1987,355)$.

Para Artaud el teatro es un lenguaje, pero no se refiere al lenguaje convencional, ya que el actor debe crear su propio lenguaje teatral. Por tanto, el lenguaje teatral es más una creación que una enunciación. Entre sus célebres ensayos encontramos «La puesta en escena y la metafísica» (1932) y «Primer manifiesto sobre el teatro de la crueldad» (1932), reunidos posteriormente en su libro El teatro y su doble (1938). Artaud teorizó sobre la situación del texto teatral de su época y afirmó que este «vivía bajo la dictadura exclusiva de la palabra» $(2015,50)$ y por eso, se debía buscar un lenguaje teatral puro, que no necesitara de la palabra: un lenguaje de signos, gestos y actitudes. «Ese lenguaje [...], nos ayuda a entender lo que podría ser para el teatro una poesía en el espacio independiente del lenguaje hablado» (Artaud 2015, 50).

Pocos son los dramaturgos franceses que presentan obras surrealistas. Junto a Antonin Artaun encontramos a Roger Vitrac (Pinsac, Lot [Francia], 1899-París [Francia], 1952) quien con su obra maestra Víctor o Los niños al poder (1928) realiza

una isocronía perfecta del tiempo de la representación, de la ficción teatral y de la narración, el espacio-tiempo se encuentra dilatado o por el contrario sintetizado al extremo, sin indicaciones cronológicas ni locativas, reducido de hecho al jugar y al espacio de la representación que la imaginación del espectador puede amueblar a su antojo, ayudándose de elementos dados por el texto que le sirven de trampolín. Se procede a la destrucción de lo real, por la burla, al tener el escenario, para concluir, la débil consistencia del sueño (Béhar 1987, 357).

En España no se llegó a experimentar con las obras surrealista, si bien «tenía poetas, dramaturgos, pintores, pero no tenía los directores adecuados para la novedad» (Salaün 1999, 69). Aunque no se representó, dejó su huella en obras posteriores.

Antes de finalizar este breve recorrido por algunos autores vanguardistas, que propusieron diversas reformas teatrales que tuvieron lugar en la Europa de finales de siglo XIX y principios del XX, no debemos dejar de nombrar al dramaturgo que transformó el drama europeo: Bertolt Brecht (Augsburgo [Alemania], 1898-Berlín Este [Alemania], 1956). Su trayectoria autoral fue muy variada, ya que fue asimilando todos 
los movimientos artísticos y literarios europeos. Inició su carrera adaptando textos de otros autores y, en 1928, crea su primer gran texto La ópera de perra gorda. Para Brecht «el teatro debía ser consecuente con el momento histórico en el que uno vive. Y su realidad exigía una escena racional, científica, precisa y objetiva» (Oliva y Torres Monreal 1994, 381).

\section{3.- Renovación en España}

Históricamente la década de los años veinte coincide con otro cambio radical, el momento de transición entre la dictadura de Primo de Rivera (1923-1930) y los primeros pasos de la Segunda República (1931). Según Rebollo Calzada, «en estos años resultaba difícil separar lo que trascendía ser crisis social o estética, problemas económicos o espirituales, cuestiones políticas o asuntos dramatúrgicos» $(2004,57)$. Un teatro fijado en los últimos años del siglo pasado ya no servía a una sociedad conmovida por los cambios cada vez más acelerados, y como afirma Dougherty

era necesario reconocer que la nueva vida europea, profundamente alterada por la primera guerra mundial, pedía nuevos procedimientos escénicos. [...]. Pero esta evolución escénica en España se hacía cada vez más larga. La dramaturgia caduca se mantenía en las tablas, y a medida que se aplazaba la llegada de un renovador, capaz de suplantar a Benavente como éste había superado a Echegaray, la conciencia de crisis se agudizaba, llegando su apogeo en el lustro 1925 a 1930 (1984, 92-93).

A excepción de algunos autores como fueron Miguel de Unamuno o Ramón María del Valle Inclán, entre otros, el teatro que se enfrenta al teatro comercial se queda a mitad camino entre la revolución y la tradición. La revolución se producirá sobre papel sin casi transcendencia en la acción y de este modo el teatro español se quedará desfasado de la revolución teatral europea. Según afirma Urszula Aszyk, «los esfuerzos de los artistas partidarios de la Reforma Teatral no cambiaban en realidad mucho en el paisaje teatral de los años veinte y treinta» ([1983] 1986, 176). Los artistas que más se aproximaron a la Reforma europea fueron: Gregorio Martínez Sierra, Cipriano Rivas Cherif y Margarita Xirgu. 


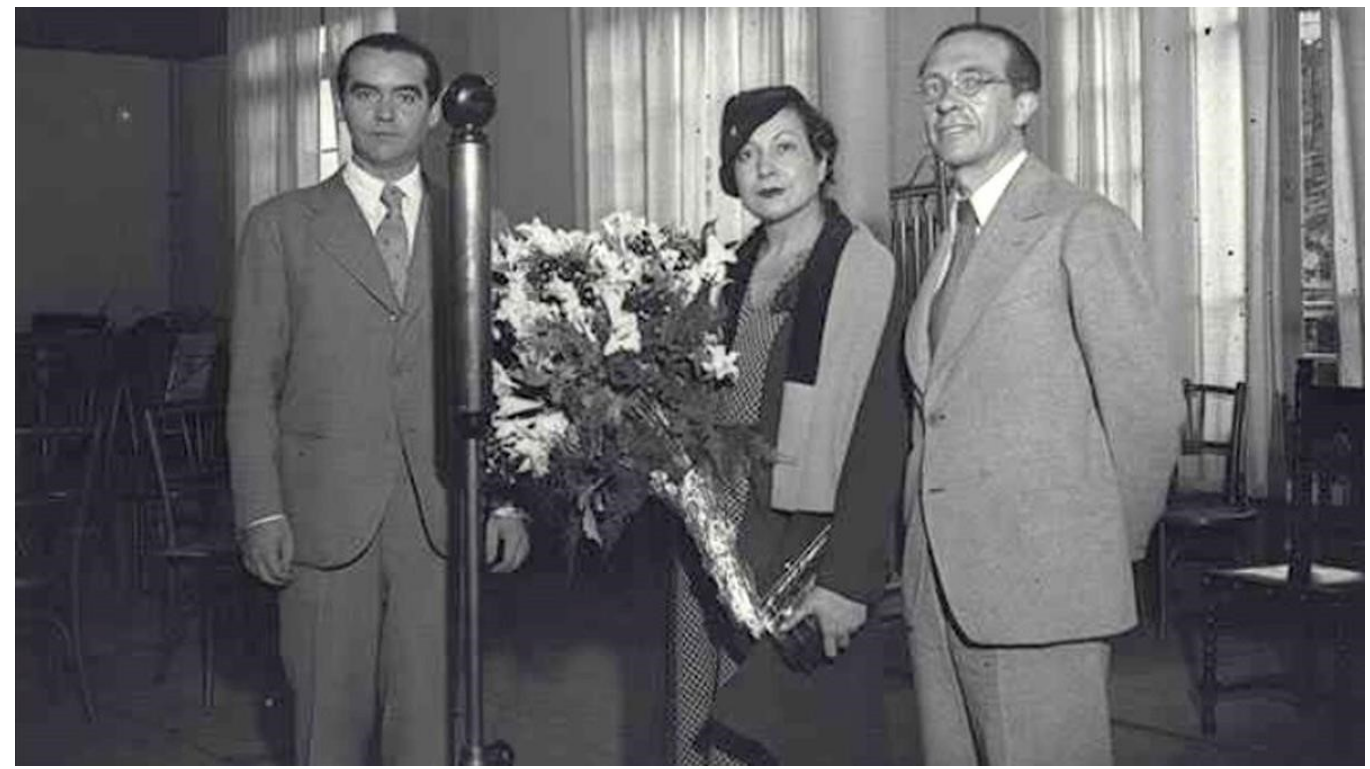

Fig. 20: Fotografía de Federico García Lorca, Margarita Xirgu y Cipriano Rivas Cheriff, en Barcelona, en $1935^{54}$.

Fotógrafo: Josep Branguli

Colección: Arxiu Nacional de Catalunya.

Las obras teatrales de Unamuno y Valle-Inclán en el momento que fueron escritas no tuvieron éxito, aunque en sus escasas representaciones el público sí acudió, más por el favor del público a los autores que por el interés del empresario teatral. Como afirmaba Díez Canedo:

Unamuno, Valle-Inclán, no pactan, tampoco y quieren elevar a sí un público, sin concederle nada. El uno, con formas escuetas, diálogos bruscos, vueltas de pensamiento inesperadas; el otro con una opulenta retórica en que van complicadas una sensualidad refinada y una rebeldía popular $(1938,35)$.

Hubo intentos de superar la función teatral dominante de consumo, entretenimiento y evasión. A partir, principalmente, de la creación de algunos grupos teatrales, teatros experimentales que apenas encontraron resonancia e incluso algunas obras no llegaron a ser estrenadas. Faltaron profesionales capaces de desarrollar por sí mismos los nuevos

\footnotetext{
${ }^{54}$ En 2018, el fotoeditor e investigador Joaquín D. Gasca descubrió que la fotografía de Josep Brangulí, estaba mal catalogada en el Arxiu Nacional de Catalunya. Fechada en 1931, año en el que ni Lorca ni Rivas Cherif visitaron Barcelona. En 1935, Lorca visitó la ciudad durante cuatro meses y participó en la vida cultural barcelonesa.

Esta fotografía sólo existe copia en papel, y perteneció a los archivos Brangulí, que pasaron en 1992 a ser depositados en el Arxiu Nacional, tras ser comprados por la Generalitat (Hevia 2018).
} 
principios teóricos o dramáticos y las nuevas ideas de dirección escénica para aplicarlas a la práctica, algo muy complicado en el sistema teatral español.

\subsection{1.- Autores renovadores. El teatro de la generación del 98 y de la generación del 14: Miguel de Unamuno, Ramón María del Valle-Inclán, José Martínez Ruiz (Azorín), Ramón Gómez de la Serna y Jacinto Grau}

A principios de siglo, las vanguardias literarias con su carga de ruptura, de renovación y de originalidad llegan al teatro, pero las obras resultan tan dificultosas y fuera de las normas teatrales clásicas que a veces no llegan a representarse porque su puesta en escena es prácticamente imposible.

El teatro de Miguel de Unamuno, Ramón María de Valle-Inclán, Azorín, Ramón Gómez de la Serna, Jacinto Grau, se quedó en teatro para leer o teatro en soledad. Sus estrenos fueron fracasos por incompatibilidad entre su realización y el texto. No obstante, los autores experimentan, conscientes de que con este género no gozarán de la aprobación del gran público.

El teatro de Miguel de Unamuno y Jugo (Bilbao, 1864-Salamanca, 1936), posteriormente al apogeo de su fama de escritor y filósofo, en su mayoría no fue representado ni impreso. Su obra dramática consta de nueve dramas y dos piezas menores. El rector de Salamanca buscaba en el teatro un medio de expresar sus inquietudes existenciales. Su obra dramática es conocida como el teatro de la desnudez, la reducción y la concentración en contra del teatro de la apariencia. En su teatro elimina todo lo que es accesorio del escenario, quedando desnudo y caracterizado por la economía de la palabra, la disminución de los personajes y de las pasiones (Ruiz Ramón 1977). Estos conceptos son un anticipo a las tendencias vanguardistas del drama existencialista y del teatro del absurdo (Aszyk [1983] 1986, 177).

Se manifestó en contra del teatro comercial de su tiempo, incluso escribió varios artículos en los que atacaba la situación teatral, como en su artículo «La regeneración del teatro español ${ }^{55}$ » en el que afirmaba que «dramaturgos y público y críticos están

\footnotetext{
${ }^{55}$ Publicado en julio de 1896 en La España Moderna.
} 
teatralizados; no respiran aire libre. Ni el dramaturgo es poeta, verdadero poeta en rigor íntimo en su sentido, ni el público es apenas pueblo» $(1988,159)$. Con motivo del estreno de Fedra (1910) en el Ateneo de Madrid en 1918, escribió un «Exordio» (publicado, más tarde, en el semanario España) en el que explicaba su situación ante la situación teatral de la época:

[...] ni formo parte del cotarro de lo que se llama por antonomasia los autores, ni hago nada para entrar en él mediante los procedimientos ya clásicos, y que tampoco me puedo ni debo reducir a perder el tiempo en saloncillos y otros lugares análogos solicitando, $[\ldots]$, un turno para que den al público a conocer mis obras dramáticas. $[\ldots]$

Hay un perenne conflicto entre el arte dramático y el arte teatral, entre la literatura y la escénica, y de ese conflicto resulta que unas veces se impone al público dramas literariamente detestables, estragando su gusto, y otras veces se ahoga excelentes dramas.

$[\ldots]$

Y hay que educar al público para que guste del desnudo trágico (citado en Cuadernos Pedagógicos 1999, 20-21).

Unamuno considera el teatro como un método de conocimiento. Mediante la casi total carencia escénica y una concentración sobre el diálogo dramático (la ausencia de un auténtico diálogo, parece que sea un monólogo), nos expone ideas sin conseguir materializar la acción dramática (Floeck 1996, 30). Él mismo afirmaba que

Llamo desnudo en la tragedia o desnudez trágica al efecto que se obtiene presentando la tragedia en toda su augusta y solemne majestad.

[...] la mayor desnudez posible, suprimiendo todo episodio de pura diversión, todo personaje de mero adorno, toda escena de mera transición o de divertimento. Los personajes están reducidos, [...] el desarrollo de la acción [...] va por la línea más corta posible. El diálogo mismo tiende a ser lo menos oratorio posible.

$[\ldots]$

El teatro poético será el que cree caracteres, ponga en pie almas agitadas por las pasiones enteras y nos las meta al alma, purificándonosla, sin necesidad de ayuda, sino la precisa, de las artes auxiliares (citado en Cuadernos Pedagógicos 1999, 21-22). 
Miguel de Unamuno dejó de fijarse en el mundo exterior para mostrar su inquietud ante el misterio de la finitud humana y adentrarse en sí mismo (Fortuño 2008, 86). Lo importante para Unamuno de su teatro existencialista, según García Templado, «era plasmar de alguna manera los problemas que lo atormentaban sin que una técnica dramática previa desvirtuase su importancia» $(1980,28)$. Es suyo el término «druma ${ }^{56} »$ : tipo de teatro esquemático y austero, en el que sólo tienen cabida los conflictos internos de los personajes. Entre sus obras encontramos temas como,

la maternidad frustrada de La Raquel encadenada (1922), la muerte de Fedra (1910) entendida como un desdoblamiento de identidad de El Otro (1926), intuida como un desdoblamiento de personalidad, son explicaciones que siempre exigen la referencia a una problemática e ideología de Unamuno. Es decir, que sus personajes acaban por ser un reflejo de Don Miguel (García Templado 1980, 29).

De este período son los dramas Sombras de sueño (1926) obra estrenada en Salamanca, en 1930, en la que se confrontan los sueños de Elvira enamorada de un héroe revolucionario a través de los libros que ha leído y la realidad. De ese mismo año, es la obra $E_{\text {otro }}{ }^{57}$ (1926 y estrenada en 1932) en la que nos presenta la historia de Caín y Abel, en las figuras de dos hermanos gemelos Cosme y Damián, en la que uno de los hermanos mató al otro y, desde ese momento, se hace llamar «el otro» ya que piensa que es ambos hermanos y ninguno al mismo tiempo. A partir de este momento, Laura y Damiana han de disputar entre ellas y reconocer cuál de los dos es el verdadero otro ya que ambas piensan que el superviviente es el hermano de su marido.

Federico García Lorca hablaba con admiración de la obra teatral Don Juan y El otro de Miguel de Unamuno y afirmaba: «Yo no quiero admirar al artista en sí. Eso no tiene importancia... Es el hombre como realización lo que vale... La humanidad del individuo, su capacidad de humanidad...» (citado en Suero [1937] 2015, 396).

\footnotetext{
${ }^{56}$ El termino druma o drama desnudo tiene su equivalente en la novela, nivola, es el neologismo creado por Miguel de Unamuno para distanciarse de la novela realista imperante en el siglo XIX y expresar su rechazo. Aparece por primera vez como subtítulo de la obra Niebla (1907).

${ }^{57}$ La obra de Unamuno comparte una psicología idéntica a la obra Así es (si así os parece) (1917) de Luigi Pirandello ya que existen los mismos trastornos mentales.
} 


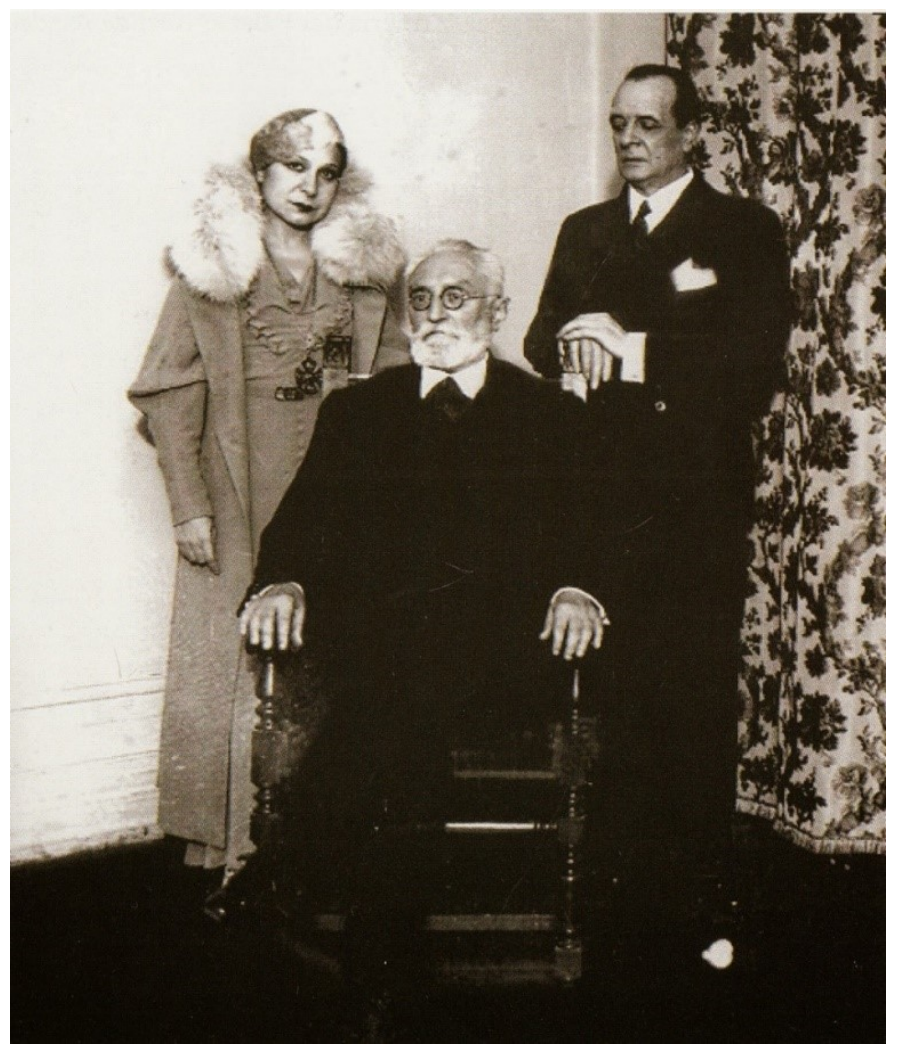

Fig. 21: Fotografía de Miguel de Unamuno con Margarita Xirgu y Enrique Borrás, perteneciente al día del estreno de El Otro por la compañía de Xirgu y Borrás, en el Teatro Español de Madrid. Colección: Casa Museo Unamuno Universidad de Salamanca, el 14 de diciembre de 1932.

También en la comedia El hermano Juan o el mundo es teatro (1929), estrenada en 1936 con un extraño humor, se entremezclan las continuas alusiones a la vida como sueño y como ficción dramática (Mainer 2013, 398). Los personajes están llenos de vida interior, «seres que sufren, aman y mueren, figuras vistas por dentro, en la viva realidad de su íntimo ser, con un naturalismo verdadero y hondo, que no se pierde en la fácil copia de lo externo, sino que revuelve en la entraña» (Díez Canedo 1938, 35).

Ramón María de Valle-Inclán (Villanueva de Arosa [Pontevedra], 1866-Santiago de Compostela [La Coruña], 1936) fue uno de los autores que más contribuyó a la revitalización escénica del momento. Gran innovador, al que se le debe un nuevo concepto del espacio escénico que rompía con la rigidez del momento y se aproximaba al teatro de la vanguardia posterior. Representaba su mundo dramático sobre un escenario abierto, huyendo del teatro a la italiana e identificaba el espacio escénico con el espacio dramático. «Ofrecía más que teatro, espectáculo, una amplia concepción del 
espacio por el que los personajes pudieran desenvolverse sin limitaciones» (Urrutia 1989, 80). Los nuevos personajes creados por Valle-Inclán volvían a encarnar los impulsos elementales del ser humano en uno mismo «con la ambigüedad de la moral sus personajes son movidos por las más oscuras pulsiones de la carne y del espíritu» (Ruiz Ramón 1977).

Valle-Inclán rompe con la tradición humanística y con la tradición aristotélica del teatro europeo y distancia al espectador de la acción dramática, al actor de su papel y, también, al personaje de su estatus. Hace que el espectador tome conciencia del carácter absurdo de su propia realidad, pero ni el público ni los propietarios teatrales estaban preparados para su teatro. La escasa representación de sus obras se debe a que algunas de sus obras, como Águila de blasón (1907) o Divinas palabras (1920), para hacerlas compatibles con las concepciones teatrales del momento, tuvieron que ser adaptadas. Otras ni siquiera fueron representadas por considerar que sus textos no eran teatrales, como en caso de Luces de bohemia (1924), Romance de lobos (1908) o Los cuernos de don Friolera (1925). Como afirma Juan Antonio Hormigón,

A medida que Valle-Inclán comprendió la distancia que mediaba entre su literatura dramática y las concepciones dominantes de lo que se entendía como teatro, escribió de manera más libre pero también fue consciente de que sus obras no subirían a los escenarios entonces, o muy difícilmente y no en las condiciones deseables (1985b, 88).

Su estilo se caracteriza por un lenguaje rico y expresivo, unas acotaciones detallistas y extensas y el uso de contrastes violentos (lo trágico y lo cómico, situaciones serias y burlescas...). Además, incluye un gran número de personajes en sus obras y lleva a cabo continuos cambios de espacio y de tiempo entre las escenas. Como afirma Jerez-Farrán, «se sirve de la caricaturas, lo grotesco, la animalización, la gesticulación, el grito, el color, el movimiento, la plástica, la mímica y el cine para reproducir una realidad que nos la devuelve distorsionada» ([1991] 1999, 528). El lenguaje cinematográfico se encuentra presente en toda su obra. Entre sus primeras obras encontramos Cenizas $^{58}$ (1899) pero su mayor actividad en la escena viene años más tarde. Su amplia obra teatral suele dividirse en tres bloques: el ciclo mítico, que presenta una Galicia ancestral

\footnotetext{
${ }^{58}$ Jacinto Benavente propone al Teatro Artístico la escenificación de la obra, a beneficio del autor, para que pueda adquirir un brazo ortopédico. Después de varias fechas pospuestas, su estreno tuvo lugar el 12 de diciembre de 1902 (Hormigón 1985a, 20).
} 
y primitiva, a veces sórdida, las conocidas comedias bárbaras, donde muestra la descomposición del mundo rural. Entre ellas Águila blasón, Romance de lobos, Divinas palabras y Cara de plata (1923); las farsas líricas o satíricas, escritas generalmente en verso nos presentan un mundo fantástico y estilizado como en La cabeza del dragón (1914), Farsa de la enamorada del rey (1920), Farsa y licencia de la Reina Castiza (1922) entre otras y las farsas en prosa, denominadas por el propio Valle-Inclán como esperpentos donde nos ofrece una visión ridícula y deformada de la realidad, con Luces de bohemia, Los cuernos de don Friolera y con la trilogía Martes de Carnaval (1930) (Díez Canedo 1938, 37).

El esperpento empieza con Luces de bohemia. Es un intento de mostrar la realidad española, pero no mediante una visión natural y real, sino una visión exagerada y burlesca, una realidad deformada, como afirma Zamora Vicente, «el esperpento supone una quiebra al sistema lógico y de las convenciones sociales. [...] El prodigio del esperpento es la deformación idiomática. Los personajes hablan desde ángulos que no son los acostumbrados en la lengua pulcra del arte modernista» (2010, 23-24). Es un cambio radical en su forma de escribir, ligado a la grave situación sociopolítica de España (Caudet 2017, 42).

Aunque el dominio en el panorama teatral español lo poseía el teatro realista y burgués, no debemos dejar pasar que el concepto del esperpento nace casi al mismo tiempo que la idea del teatro de la crueldad de Artaud en Francia y la del teatro puro de Witkiewicz $^{59}$ en Polonia (Aszyk [1983] 1986, 178). En el esperpento, Valle-Inclán utiliza los registros lingüísticos más extremos, con unos personajes deshumanizados, convertidos en fantoches, que traslucen una amarga visión de España. Son obras difícilmente representables, en las que introduce la estética deformante y caricaturesca. Valle-Inclán crea un teatro dialéctico incorporando su obra dentro de un marco histórico; una de las características del esperpento es que utiliza hechos históricos «cuya naturaleza intrínseca es absurda, farsesca, extraña, pero siempre imbuida de consecuencias serias, aun trágicas» (Cardona y Zahares 1989, 127). El esperpento es la única forma dramática que puede presentar simultáneamente lo trágico y lo grotesco.

${ }^{59}$ Stanislaw Ignacy Witkiewicx (Varsovia [Polonia], 1885-Jeziory [Polonia], 1939) revolucionó la escena europea con su teatro puro mientras que en España seguía dominada por el Realismo y el Naturalismo. 
Los otros autores pertenecientes a la generación del 98 tampoco corrieron mejor suerte, es el caso de José Martínez Ruiz (Azorín) (Monóvar [Alicante], 1873-Madrid, 1967) cuya aproximación al teatro es más una experimentación que una profesión. Coincide con Valle-Inclán en su tendencia hacia la unidad de texto dramático, pero reduciendo ese texto al puro diálogo. Sus intentos renovadores no se concretan en la forma dialógica, sino también en cambiar la estructura escénica, dando libertad tanto a los actores y al director. Quiso incluir en su teatro la representación de la realidad psíquica de acuerdo a «los nuevos conceptos de la personalidad del ser que estaban realizando los adelantos científicos de Freud»(Jerez-Farrán [1991] 1999, 532). Defendía al superrealismo como simple evasión de lo literal y cotidiano en la vida. Azorín lleva esa técnica a la práctica en varias de sus obras como, por ejemplo, el sainete sentimental Brandy, mucho brandy (1927). Encontraba en el cine «una de las modalidades que el teatro moderno debía adaptar para desafiar victoriosamente la amenaza que para algunos representaban los nuevos adelantos cinematográficos» (Jerez-Ferrán 1999, 529), hacia los que expresó sus reticencias.

Sus piezas teatrales se concentran entre 1925 y 1936. Entre sus mejores obras encontramos Lo invisible (1928), trilogía integrada por La arañita en el espejo, El segador y Doctor Death de 3 a 5, cuyo denominador común es la muerte. En su obra Angelita, (1930) trata el tema del tiempo, siendo su estructura dramática la más conseguida. Su primera comedia fue Old Spain! (1926) «que pone frente a frente dos conceptos distintos de la vida: el que la estima como acción y extravagancia, [...] y el que la ama como contemplación y profundidad» (Díaz Canedo 1398, 40) y que abrirá su serie teatral; con Farsa docente (1942) la cerrará.

Ramón Gómez de la Serna (Madrid, 1888-Buenos Aires [Argentina], 1963), fue el impulsor de las vanguardias en España, perteneciente a la generación de 1914, rompe con la generación del 98. En abril de 1909, un mes después de su publicación en París, el 20 de febrero, en la revista Le Figaro y en Italia, en la revista la Gazzetta dell'Emilia, se publicó en España en su revista Prometeo $^{60}$ (en el número 6), el Manifiesto futurista

\footnotetext{
${ }^{60}$ Revista con un carácter político, social, cultural y literario, fundada en 1908 por el padre de Ramón, Javier Gómez de la Serna, pero un contratiempo político (fue elegido diputado por el Partido Liberal de Canalejas en varias ocasiones) le obliga a ceder la dirección a su hijo, en otoño de 1909 (Anderson 2018, 213).
} 
de Marinetti (Morelli 2007, 62), bajo el título «Fundación y manifiesto del Futurismo», y así se tiene por inaugurado el vanguardismo español.

En las primeras décadas del siglo XX, estaban en auge las tertulias literarias. Entre las más famosas estuvo las tertulias del Café Pombo de la calle de Carretas, número 4, en Madrid, fundada por el propio Gómez de la Serna, en 1914 (Sánchez Vidal 1999, 343; Fuente [1992] 1999, 517; Morelli 2007, 62). Al lado de la Puerta el Sol, Pablo Suero afirmaba:

punto neurálgico de España donde se oye el grito siempre que a España le duele algo. Pombo es toda una institución. Fue el café de Larra y de Espronceda. Frente a los cafés modernos [...], estos viejos cafés de Madrid de antaño se vengan con una atmósfera de hogar de que aquellos carecen (1937 [2015], 275).

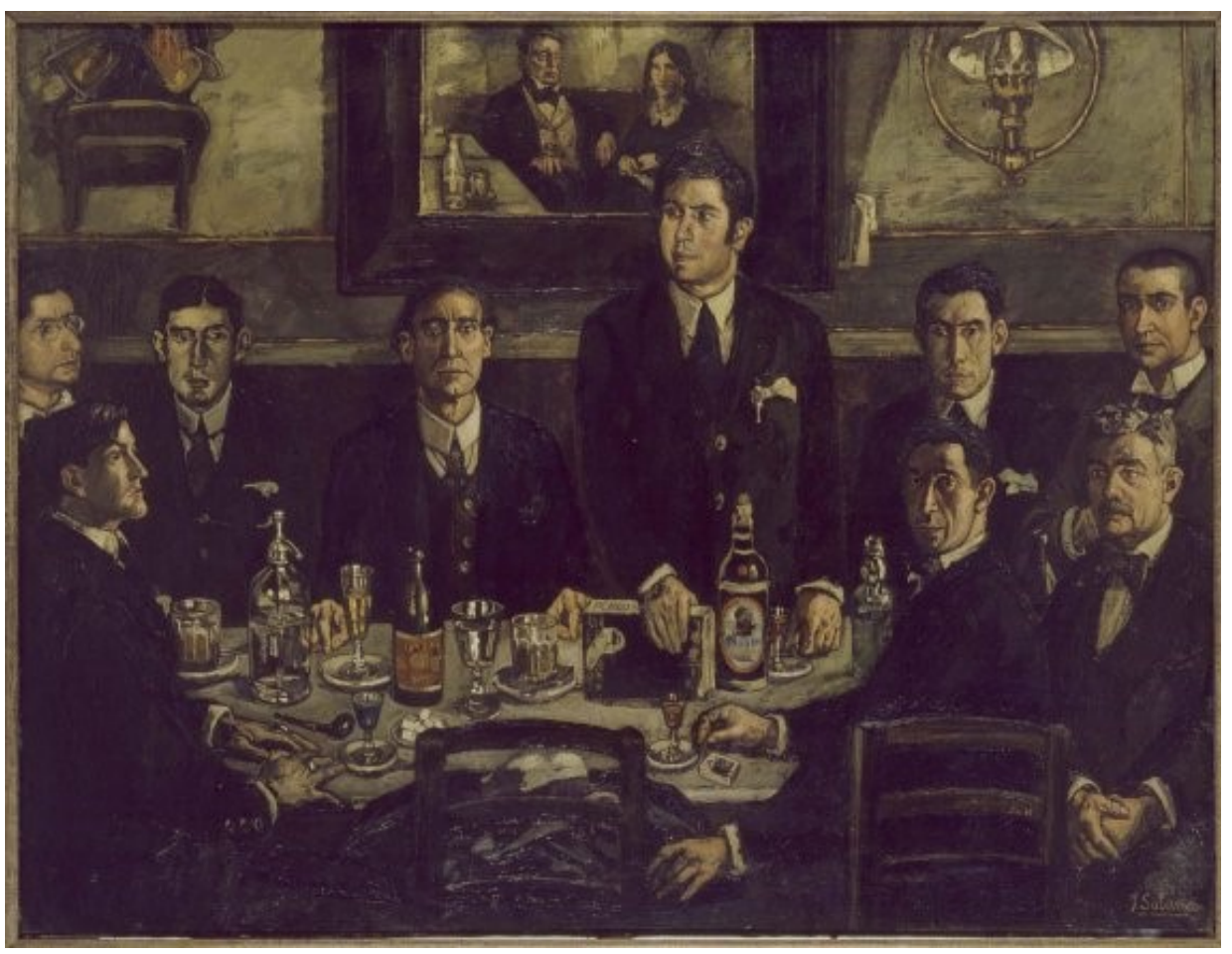

Fig. 22: La tertulia del Café de Pombo ${ }^{61}$ (1920) de José Solana (José Gutiérrez Solana). Óleo sobre lienzo, 161,5 x $211,5 \mathrm{~cm}$.

\footnotetext{
${ }^{61}$ Los protagonistas de la pintura son algunos intelectuales de la época que formaban parte de estas tertulias. De izquierda a derecha: Manuel Abril, Tomás Borrás, José Bergamín, José Cabrera, Ramón Gómez de la Serna, Mauricio Bacarisse, el propio pintor José Gutiérrez Solana, Pedro Emilio Coll y Salvador Bartolozzi.

El lienzo fue donado al Estado español por Ramón Gómez de la Serna en 1947. En la actualidad, se encuentra expuesto en el Museo de Arte Contemporáneo Reina Sofía de Madrid.
} 
Don Ramón practicaba un teatro muy innovador y concibió la dramaturgia como una necesidad expresiva, aunque no tuvo buena acogida por parte del público ni de la crítica. Sus primeros textos teatrales están inspirados en los modelos del teatro europeo de la época (Ibsen, Maeterlinck, Strindberg, Wilde, Shaw,...). Los temas que dominan su creación teatral giran en torno al erotismo y a la problemática social, incluyendo los del socialismo utópico, la moral sexual y el feminismo (Soldevila-Durante 1992, 69), que aparecen en títulos como La Utopía (1909) dedicado al escultor Julio Antonio, El drama del palacio deshabitado (1909) sobre el final de una aristocracia fantasmal, Los sonámbulos (1911) o El lunático (1912), todas obras de juventud. Su teatro pertenece casi por entero a su época juvenil, escrito entre 1909 y 1912, con un total de diecisiete piezas dramáticas, la mayor parte de un acto. La obra que mayor trascendencia tuvo, y llegó a ser representada, fue Los medios seres (1929), publicada primero en Revista de Occidente (Ruiz Ramón 1986, 155); aun así su estreno fue un fracaso (SoldevilaDurante 1992, 70).

Utilizó todos los géneros literarios, creó una nueva manera de verlos y muestra de ello son, a partir de 1912, sus famosas greguerías, «una especie de cabriola verbal que pone en contacto realidades inesperadas y pertenecientes a campos semánticos distintos» (Morelli 2007, 58) que definen su obra y su persona. Su tratamiento de la metáfora mediantes las greguerías, textos breves con humor, que según el propio Gómez de la Serna formulaba que era «humorismo + metáfora = greguería» (citado en Videla 1971, 21) ejerció gran influencia en los diversos autores de la generación del 27 (Morelli 2007, 61).

Aunque contemporáneo de la Generación del 98, no se encuentra exactamente dentro de ella, Jacinto Grau (Barcelona, 1877-Buenos Aires [Argentina], 1958) quien recoge rasgos característicos de las corrientes más avanzadas del teatro europeo de esos años, como el realismo simbólico de Ibsen o de Chéjov, pero que aún poseyera una mayor abstracción. Inicia su carrera dramática en 1902 y abarca la primera mitad del siglo XX. En teatro se dio a conocer con una zarzuela, Las bodas de Camacho (1907), estrenada en Barcelona (Mainer 2013, 338). Escribió unas treinta de obras y sólo llegó a estrenar la mitad (Kronik 1992, 79-81). Como afirma Ruiz Ramón, Grau inició su teatro «con una clara voluntad de superar la escena naturalista, apegada a lo inmediato y a lo 
cotidiano, mediante la restauración de la tragedia»(1986, 142), como Entre llamas (1907), El conde Alarcos (1907) o El hijo pródigo (1917).

Sus tragedias fueron rechazadas por el público y la crítica, pero fuera de España su teatro tuvo mayor interés; respecto a ello, Enrique Díez Canedo exponía que el teatro de Jacinto Grau «de escaso éxito en España, donde sus obras, animadas por un afán de arte grande, no han encontrado público, y de cierta resonancia en el extranjero, después de las representaciones de "El señor de Pigmalión" en Praga y en París» $(1938,26)$. Su mejor obra fue El señor de Pigmalión (1921), farsa tragicómica, en la que unos muñecos se rebelan contra su creador y buscan vida propia. Pablo Suero afirmaba que la gran parte de su teatro había sido estrenado fuera de España, en «los teatros de París, de Praga, de Ámsterdam, de Bruselas, se han honrado con la primicia de su producción. Su obra se ha traducido ya al checo, al francés, al húngaro y se está traduciendo al alemán» (1937 [2015], 236-237).

La originalidad de la obra de Grau, según García Templado, «estriba en la tipología popular que representan los muñecos, extraídos de nuestro acervo folklórico, de manera que cada personaje asume unos rasgos peculiares, distribuidos por el pueblo, como representativos de su compleja manera de ser» $(1980,35)$. Jacinto Grau hizo de «los decorados, de la luminotecnia y del vestuario uno de los valores interpretativos más importantes de su teatro, como también hizo de los movimientos antinaturalistas de sus personajes marionetiles un tributo» (Jerez-Farrán [1991] 1999, 529).

\subsection{2.- Autores renovadores. Teatro de la generación del 27: Pedro Salinas, Rafael Alberti, María Teresa León, Max Aub y Miguel Hernández}

La generación del 27 es conocida primordialmente por su faceta poética, de ahí que sea conocida también el denominado Grupo poético del 27. Pero sus autores no se dedicaron exclusivamente a un género, también tuvieron propuestas nuevas en otros géneros, entre ellos el teatro. Se propusieron tres objetivos: incorporar elementos vanguardistas que rompieran con la representación realista, acercar el teatro al pueblo (que no fuera un género exclusivo de las clases altas) e incorporar la poesía al teatro, no sólo con el uso del verso sino con gran carga poética en sus contenidos. El propio 
Rafael Alberti en sus memorias recoge sus impresiones del momento y la importancia de los miembros del grupo:

La nueva y verdadera vanguardia íbamos a ser nosotros, los poetas que estábamos a punto de aparecer, todos aún inéditos — salvo Dámaso, Lorca y Gerardo Diego - pero ya dados a conocer algunos en Índice, la revista que Juan Ramón Jiménez, junto con la editorial del mismo nombre, había empezado a publicar. Aquella otra vanguardia primera, la ultraísta, estaba en retirada (Alberti [1959] 1976, 164).

El teatro de la generación del 27 buscaba una ruptura con el teatro comercial, una renovación teatral en la puesta en escena y una originalidad en los nuevos textos propuestos. La temática de la mayoría de los textos escénicos de esta generación se caracterizaba por la aspiración amorosa y la frustración.

Aunque la faceta más conocida de Pedro Salinas (Madrid, 1891-Boston, 1951) es la de poeta y ensayista, también se adentró en el género literario teatral. La primera pieza teatral de Salinas es El Director (1936), drama en tres actos en la que expresa el desasosiego humano ante el problema de la felicidad. Debido al inicio de la Guerra Civil y del exilio no pudo llegar a estrenarse. En esta primera obra optó un teatro clásico adaptado a la época contemporánea (Benítez Vega 2013). El periodo, en el que desarrolla su vertiente de dramaturgo, comprende entre 1936 y 1947 cuando fusiona rasgos entre la tradición y la novedad.

Rafael Alberti Merello (El Puerto de Santa María [Cádiz], 1902-El Puerto de Santa María [Cádiz], 1999) inicia su trayectoria escénica con su primera obra dramática, El hombre deshabitado (auto sacramental sin sacramento) (1930) con un marcado giro político, escrita como tal subgénero, y estrenada el 26 de febrero de 1931, con la actriz mexicana María Teresa Montoya (Soria Olmedo 1992, 133). Y también significativo fue el documental escénico, Fermín Galán (1931), estrenado el 1 de febrero de 1931 en el Teatro Español. La obra fue un encargo de Margarita Xirgu que se reservó el papel de madre del héroe (Mainer 2013, 591). Una obra políticamente comprometida en la que Alberti buscaba «la síntesis del mensaje político y las formas artísticas populares» (Fuentes 2006, 200). A partir de 1934, con las dos farsas políticas Bazar de la Providencia y Auto de los Reyes su teatro se politiza. Rafael Alberti comentaba que, junto a María Teresa León, presentan «pequeños actos de guiñol para obreros y 
campesinos... Porque no sé si sabrás que tenemos un guiñol para el que trabajan todos los escritores jóvenes de izquierda... Damos funciones al pueblo... [...] representándose mi pieza Bazar de la providencia» (citado en Suero 1937 [2015], 318).

María Teresa León (Logroño, 1903-Madrid, 1989) estudió en la Institución Libre de Enseñanza y más tarde cursó licenciatura de Filosofía y Letras. En 1931, Rafael Alberti y María Teresa León, pensionados por la Junta de la Ampliación de Estudios, viajaron a Alemania para conocer el teatro político-social de Edwin Piscator, cuyo teatro se tradujo en España ese mismo año (Benítez Vega 2013). En 1932, junto a Rafael Alberti, inicia un viaje por Europa: Berlín, la Unión Soviética, Dinamarca, Noruega, Bélgica y Noruega para estudiar los movimientos teatrales europeos de vanguardia y conocer de primera mano las tendencias teatrales europeas. Entre ellas el gran teatro soviético de Meyerhold y Tairov. A su vuelta a España, publica diversos artículos en el Heraldo de Madrid sobre el teatro internacional. El compromiso político impregna su obra, entre las que encontramos Huelga en el puerto (1933), una obra muy breve, ambientada en el mundo proletario para ser representada en su teatro de guiñol, y Cuentos de la España actual (1935) donde denunciaba la situación del país (Hormigón 1997, 704-705).

Con gran conciencia cívica, fue la impulsora del teatro madrileño durante la guerra. En 1937, se encargó de la dirección del Teatro de Arte y Propaganda recién creado, siendo responsable de destacados estrenos teatrales. Las funciones programadas por una temporada tuvieron lugar en el teatro de la Zarzuela, sede de dicho teatro. María Teresa León no sólo consiguió programar un teatro gran calidad (con un claro valor propagandístico) sino que consiguió llenar la platea del teatro de trabajadores. Debido a la Guerra Civil, el teatro de la Zarzuela debió cerrar, y crea la compañía ambulante Guerrillas de Teatro, con el mismo espíritu de La Barraca y de las Misiones Pedagógicas. Iniciada en 1938, llegó a las ciento diecinueve representaciones en el frente (Balló 2016, 203-204; Bilbatúa 1976, 52).

Otro autor, que llegó a participar en la guerra civil, fue Max Aub (París, 1903-Ciudad de México, 1972), pero ya, antes del inicio de la guerra, era considerado como un autor de teatro imaginativo y renovador. La familia de Aub era de origen judío, de padre alemán y madre francesa, huyendo de la Guerra Mundial se estableció en Valencia, en 1914, sin conocimientos del idioma. Max Aub, a los 20 años, adquiere la nacionalidad 
española y, aun conociendo el alemán y el francés, eligió el español como lengua para escribir su obra, en la que abarcó todos los géneros literarios. En la década de los años treinta, contaba con una amplia obra: Crimen (1923), un intenso drama en un acto; El desconfiado prodigioso (1924) publicado en la revista Alfar en 1926, es una farsa deshumanizada en la que en la acotación inicial indica que «los personajes casi son marionetas. No tengo la seguridad de si llevan máscaras» con la dificultad de la comunicación humana, presente en su teatro; Una botella (1924); El celoso y su enamorada (Farsa de adolescentes) (1925); Narciso (1927) y La Jácara del avaro (1935), entre otras (Oliva y Torres Monreal 1994, 359; Carreira 2003; Mainer 2013, 577). Es uno de los pocos dramaturgos comprometido que utilizó cambios en el plano de la construcción escénica.

Miguel Hernández (Orihuela, 1910-Alicante, 1942), aunque muy cercano a la generación del 27, su obra se ha incluido en la generación del 36, considerado por Dámaso Alonso, «genial epígono de la Generación del 27». En su obra dramática, encontramos el auto sacramental Quién te ha visto y quién te ve y sombra de lo que eras (1933) publicado por Cruz y Raya en 1934, y El refugiado (1937). En 1935, Miguel Hernández, militante, se pasa a la prosa con la obra Los hijos de la piedra. Drama del monte y sus jornaleros (publicada en 1960) donde reflejaba el clima insurreccional de mineros y campesinos (Mainer 2013, 592-593).

\subsection{3.- La renovación en la comedia: Enrique Jardiel Poncela y Miguel Mihura}

La gran renovación en la comedia teatral y en el lenguaje del humor la encontramos con Miguel Mihura y Enrique Jardiel Poncela. Aunque su teatro, conocido como el "teatro de lo inverosímil", posteriormente llamado teatro del absurdo, alcanzó su mayor esplendor en un período posterior a la Guerra Civil.

En el teatro de Enrique Jardiel Poncela (Madrid, 1901-Madrid, 1952) se muestra una nueva manera de hacer comedia, aunque sus inicios teatrales como dramaturgo fueron con un teatro no humorístico. Tuvo que esperar hasta 1927 para dar comienzo su carrera teatral cómica con el estreno de la comedia Una noche de primavera sin sueño (1927) con diálogos ingeniosos y chispeantes. Sus ideas de la comedia contemporánea se 
apartaban de los esquemas tradicionales y se encontraban en la antítesis de las comedias de los hermanos Álvarez Quintero, alejándose del teatro realista. La publicación de textos teóricos, durante la primera década del siglo XX en España, define una nueva corriente antirrealista entre los autores vanguardistas que «defiende una concepción humorística de la escena, no meramente cómica y chabacana» (Conde Guerri 1998, 86).

Entre sus comedias comedías destacan: Usted tiene ojos de mujer fatal (1933), Las cinco advertencias de Satanás (1935), cuya madurez escénica se hace más visible, y Cuatro corazones con freno y marcha atrás (1936). Después de la guerra civil, Eloísa está debajo de un almendro (1940), Los ladrones somos gente honrada (1941) y Los tigres escondidos en la alcoba (1949). Como afirma Antonio Carreño, «sus formas dramáticas se mueven entre la farsa fantástica, la sátira ingeniosa y burlesca, el teatro de costumbres con tendencia al "vaudeville", el sainete, y el teatro llamado de "evasión"» (1998, 14). En ocasiones, sus comedias se han calificado, equivocadamente, como obras con exponentes surrealistas, pero están más de acuerdo con un teatro del absurdo. Las innovaciones que planteaba Jardiel en sus comedias eran mal recibidas por el público (en sus estrenos el público pateaba), aunque la crítica sí valoraba su teatro (Conde Guerri 1998, 86-89).

Las comedias de Miguel Mihura (Madrid, 1905- Madrid, 1977), escritas antes de 1936, rompen con «las formas dramáticas en vigor, anulando los viejos temas convencionales» (Carreño 1998, 20). El objeto del humor en el teatro de Mihura es la propia existencia del individuo mismo, las relaciones entre hombre y mujer, y la relación del propio individuo con la sociedad. Con la obra Tres sombreros de copa ${ }^{62}$ (1932) establece «un teatro de situaciones donde el contraste y la parodia son claves. Impera la lógica de lo incongruente» (Carreño 1998, 24). En sus obras se pueden ver reflejados los problemas básicos de las vivencias humanas: las confrontaciones con la mujer, los convencionalismos sociales, etc. (Miguel Martínez 1998, 122, 140). Muchas de sus obras son muy posteriores a la guerra civil, donde su teatro empezó a ser representado. Entre ellas, encontramos las comedias de corte policíaco El caso de la

\footnotetext{
${ }^{62}$ Aunque escrita en 1932, tardaría veinte años en ser llevada a escena por un grupo de teatro universitario en 1952 (Miguel Martínez 1998, 121), lo que hace que pierda su autor el ser considerado el primero en construir una obra del teatro del absurdo.
} 
mujer asesinadita (1946). Maribel y la extraña familia (1959) y Ninette y un señor de Murcia $^{63}$ (1964).

\subsection{4.- Las mujeres de la Generación del 27: Las Sinsombrero y María Francisca Clar Margarit (Halma Angélico, Ana Ryus)}

Durante la segunda mitad del siglo XIX, en Europa, con la aparición de los primeros movimientos feministas y sufragistas, procedentes de Inglaterra y Estados Unidos, y la nueva independencia económica de la mujer debido a su incorporación en el mundo laboral tras la revolución industrial, permitió que la mujer tuviera acceso a la educación y la vida pública. Era una mujer cosmopolita e independiente.

A partir de la segunda República, estos cambios también empiezan a reflejarse en España, con el surgimiento de numerosos clubs femeninos y asociaciones cuyos miembros eran únicamente mujeres. Entre ellos, el Lyceum Club Femenino, y como afirmaba Pablo Suero era

Una institución intelectual de mujeres, de las que abundan en Madrid, desde la República, lo que demuestra el afán de la mujer española por liberarse. [...] Es un ambiente muy agradable. Hay en él una biblioteca, una sala de conferencias, un salón de té y otras habitaciones de recibo. Las socias pueden invitar a sus amigos del sexo enemigo a tomar el té en la casa, pero estos no pueden ir por iniciativa propia. En el sótano hay una sala de ensayos ([1937] 2015, 234).

El Lyceum Club Femenino, inaugurado en 1926, fue la primera asociación feminista de España, destinado a reunir a todas aquellas mujeres que querían desarrollar su talento intelectual y artístico. Su primera presidenta fue María de Maeztu - también directora de la Residencia de Señoritas y hermana de Ramiro de Maeztu-, y las primeras reuniones fundacionales se realizaron en el salón de actos de la Residencia de Señoritas. Posteriormente, el Club se traslada a la Casa de las Siete Chimeneas, 31. Según Tània Balló,

\footnotetext{
${ }^{63}$ Aparte de las diferentes adaptaciones teatrales y televisivas, el texto ha sido llevado al cine en dos ocasiones: en 1965, por el actor y director Fernando Fernán Gómez, y más recientemente, en 2005, dirigida por José Luis Garci bajo en nombre de Ninette.
} 
Al inicio se crearon seis secciones, cada una de ellas dedicadas a un tema de interés y presidida por una de sus socias: «Social», «Musical», «Artes Plásticas e Industriales», al frente de las cuales estaba Carmen Baroja, «Literatura», «Ciencias», «Internacional», y una séptima especial, creada posteriormente, llamada «Hispanoamericana». Cada una de ellas obraba de forma independiente impulsando cursillos, exposiciones, debates, recitales o conciertos, acordes con su temática $(2016,28)$.

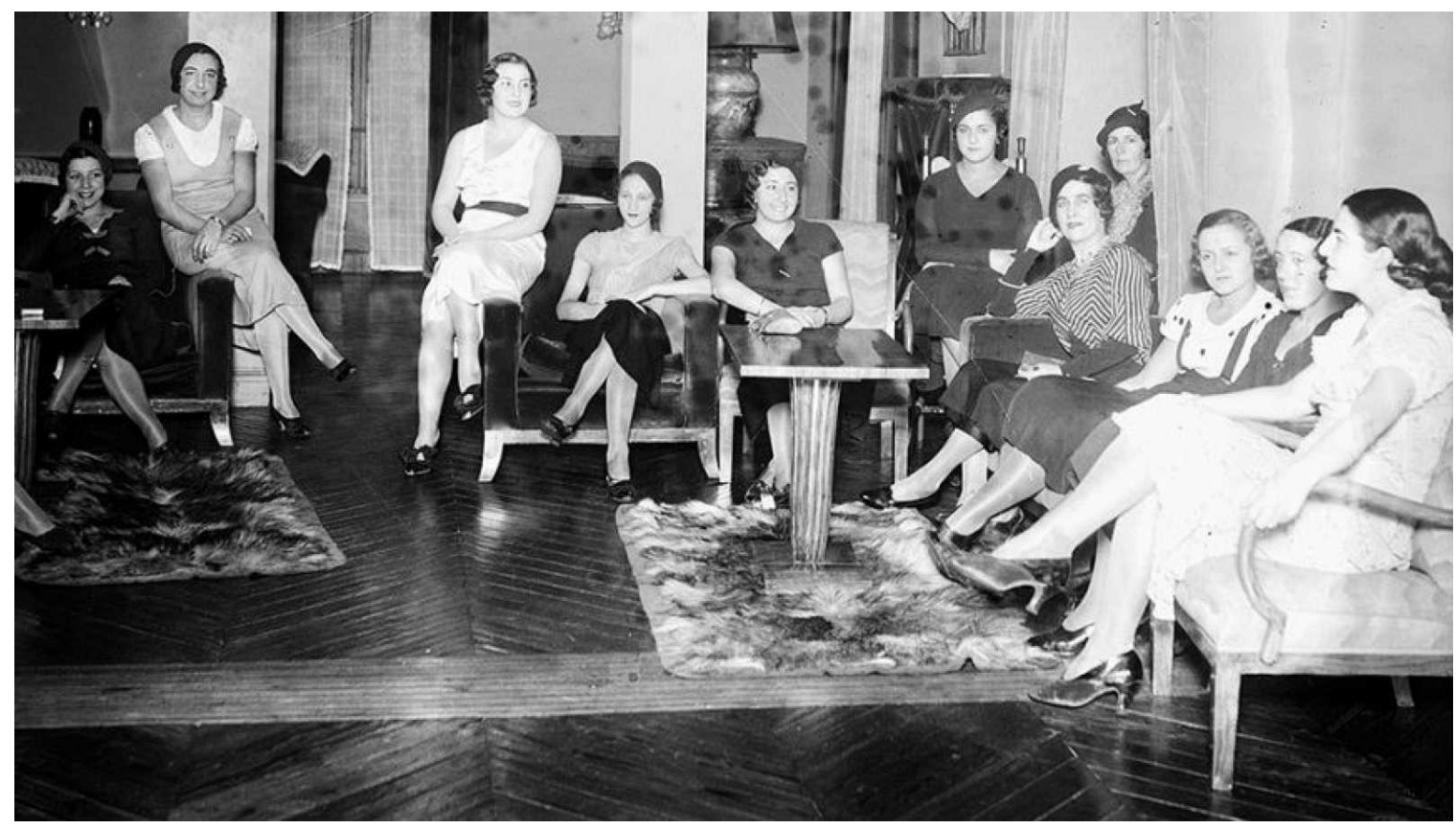

Fig. 23: Fotografía de un grupo de mujeres pertenecientes al Lyceum Club Femenino

El Lyceum Club fue clausurado en 1939, y sus instalaciones fueron ocupadas por la Falange, para que la Sección Femenina lo convirtiera en el Club Medina (Balló 2016, 31).

Junto al Lyceum Club, a "La Cívica”, escisión del Lyceum (que desarrollaremos en el capítulo siguiente con el surgimiento del Club Anfistora), apareció otra plataforma feminista, el Ateneo Femenino Magerit que fue inaugurado en marzo de 1932. Era un club solo para mujeres, aunque existía la posibilidad de asistir en compañía de hombres, únicamente en el primer piso, ya que la planta baja era exclusiva para aquellas. Se encontraba situado en la avenida Conde Peñalver número 24 de Madrid (la actual Gran Vía, número 1) (Eureka 2019). 
También aparecieron otros grupos como la Agrupación Femenina Republicana o el Consejo Supremo Feminista de España, formado por cinco asociaciones: La Mujer del Porvenir, la Progresiva Femenina de Barcelona, la Liga para el Progreso de la Mujer, la Liga Concepción Arenal de Valencia, y la ANME. Durante este periodo también surgieron movimientos femeninos falangistas y ultraconservadores como fueron la Junta de Damas de la Unión Iberoamericanas, las "Margaritas", o la Asociación Femenina de Acción Nacional. Estos grupos incluso crearon periódicos como Ellas (Eureka 2019).

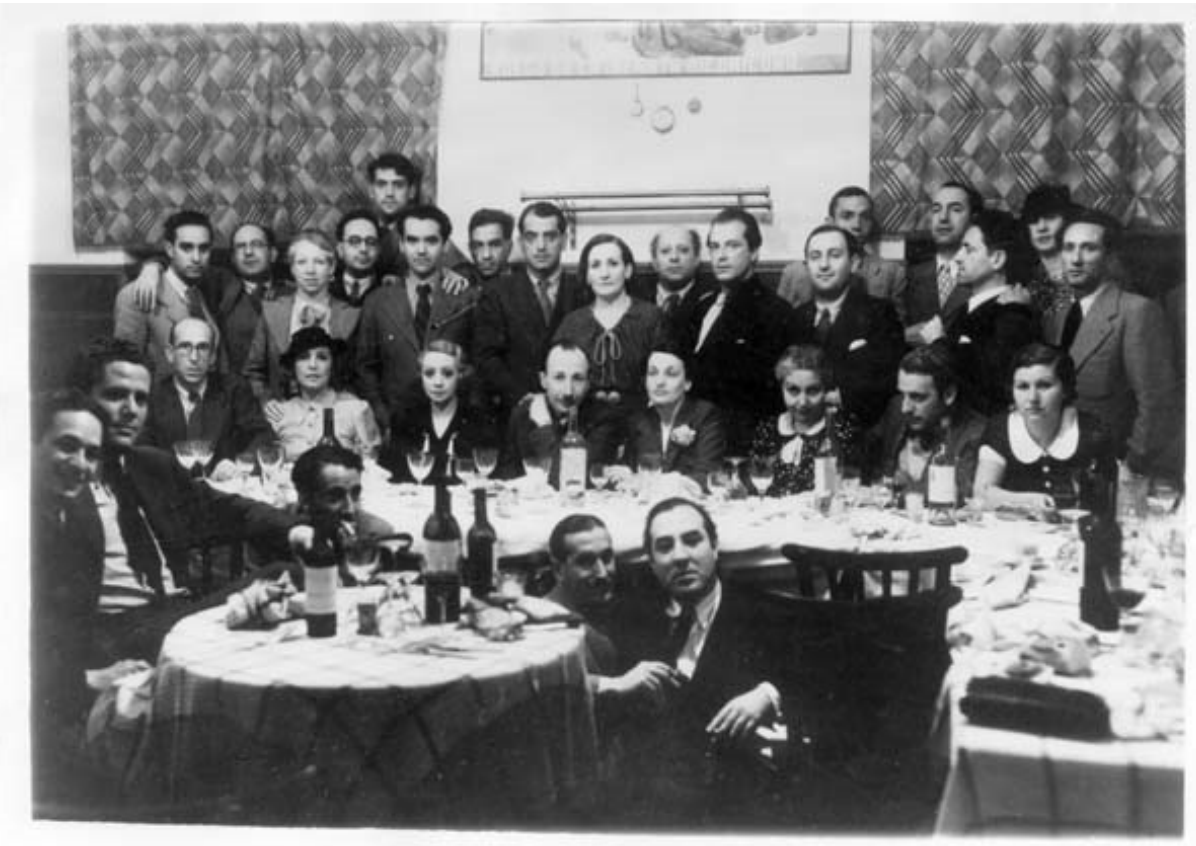

Fig. 24: Fotografía tomada en la hostería Cervantes de Madrid, el 13 de mayo de 1936 con motivo de un homenaje al pintor Hernando Viñes ${ }^{64}$.

Archivo: Juan Vicens y María Luisa González. Archivo: Residencia de Estudiantes.

\footnotetext{
${ }^{64}$ De pie, de izquierda a derecha: José Caballero, Eduardo Ugarte, Eva Thais, Adolfo Salazar, Alfonso Buñuel, Federico García Lorca, Juan Vicens, Luis Buñuel, Lupe Condoy, Acacio Cotapos, Rafael Alberti, Guillermo de Torre, Miguel Hernández, Pablo Neruda, Rafael Sánchez Ventura, Maria A. Agenaar Volgelzanz, Honorio Condoy. Sentados: Alberto Sánchez, Delia del Carril, Pilar Bayona, Hernando Viñes, Lulú Jourdan, María Teresa León, Gustavo Durán, Sra. de Dorronsoro. En primera fila: Domingo Pruna, Hortelano, Pepín Bello y Santiago Ontañón.

Esta misma fotografía, también aparece en el libro Federico y su mundo (1981) de Francisco García Lorca. Según dibujo explicativo de Francisco García Lorca por orden de izquierda a derecha y de arriba abajo. En la línea superior: 1. José Caballero, 2. Rafael Ugarte, 3. Ernestina (?), 4. Adolfo Salazar, 5. Alfonso Buñuel, 6. Federico, 7. Juan Vicens, 8. Luis Buñuel, 9. Sra. Condoy, 10. Cotapos, 11. Alberti, 12. G. de Torre, 13. Miguel Hérnandez, 14. Pablo Neruda, 15. Rafael S. Ventura, 16. , 17. Honorio Condoy; en la línea central: 18. Lazaro (?), 19. Delia del Carril, 20. , 21. Hernando Viñes, 22. , 23. Ma Teresa Leon, 24. Gustavo Durán, 25. , 26. , y en primera línea: 27. Rapún (?), 28. Hortelano, 29. Pepín Bello y 30. S. Ontañón.

Se puede observar como las mujeres del grupo no son identificadas por el hermano del Federico García Lorca. Tampoco lo es, correctamente, Rafael Rodríguez Rapún, inspirador de los Sonetos de amor oscuro.
} 
Aunque en un primer momento, en el acto de creación del grupo, no hubo mujeres, entre la generación del 27 también coincidieron gran número de ellas, incluso en la Antología de Poesía Española Contemporánea ${ }^{65}$ de Gerardo Diego de 1932 destacaba a Josefina de la Torre, Ernestina de Champorucín, María Zambrano y Concha Méndez.

En Madrid, en la década de los años veinte, aparece el grupo de las Sinsombrero ${ }^{66}$. Entre 1923 y 1925, Maruja Mallo, Salvador Dalí y Margarita Manso coinciden como estudiantes en la escuela de Bellas Artes de San Fernando y, junto a Federico García Lorca, crean una fuerte amistad. La anécdota de la creación del término sinsombrerista se debe a que iban los cuatro amigos por la Puerta del Sol de Madrid cuando se quitaron el sombrero en medio de la calle con intención de romper la norma, creando tendencia. La historia de quitarse el sombrero y liberar las ideas la cuenta posteriormente la propia Maruja Mallo (Balló 2016, 33). Aunque el vocablo no existía en la prensa de la época, se atribuye a Ramón Gómez de la Serna, quien en un artículo publicado, el 24 de agosto de 1930, en El Sol «En, por, sin, sobre el sin sombrerismo» exponía:

El fenómeno del sinsombrerismo es más amplio y significativo de lo que parece. Es el final de una época, como lo fue el lanzar por la borda las pelucas. Quiere decir presteza en comprender y en decidirse, afinidad con los horizontes que se atalayan, ansia de nuevas leyes y nuevos permisos, entrada en la nueva cinemática de la vida, no dejar nunca en el perchero la cabeza, no apagar luces del aceptar, ir con rumbo bravo por los caminos de la vida, desenmascararse, ser un poco surrealista $(1930,1)$.

Formaron parte del grupo de las Sinsombrero mujeres como las poetas Ernestina de Champourcín y Josefina de la Torre; las pintoras Maruja Mallo, Margarita Manso, Delhy Tejero, Marga Gil Roësset y Ángeles Santos; las escritoras Rosa Chacel y María Teresa León; la editora Concha Méndez y la filósofa María Zambrano, entre otras.

Entre las dramaturgas destacamos a María Francisca Clar Margarit (Palma de Mallorca [Islas Baleares], 1888-Madrid, 1952), conocida, incluso familiarmente, por el

\footnotetext{
${ }^{65}$ Aunque no aparecen en la obra de Gerardo Diego debemos nombrar tambien a Rosa Chacel y Carmen Conde.

${ }^{66}$ El 9 de octubre de 2015, el programa Imprescindibles de RTVE lo dedicó a las Sinsombrero, con acceso abierto en el siguiente enlace: http://www.rtve.es/alacarta/videos/imprescindibles/imprescindiblessin-sombrero/3318136/

En marzo del 2019, se emitió la segunda parte, Las Sinsombrero. Ocultas e impecables, por el momento no disponible en línea.
} 
pseudónimo Halma ${ }^{67}$ Angélico, cultivó con éxito la novela, el cuento, el artículo periodístico y el género teatral. En todas sus facetas manifestó su preocupación por la situación de la mujer en la vida social y familiar. Tuvo vinculación activa con organizaciones feministas de preguerra como el Lyceum Club Femenino, la Asociación Nacional de Mujeres Españolas, la Unión de Mujeres de España y España Femenina (Nieva de la Paz 2018; Hormigón 1997, 357).

Con el pseudónimo Ana Ryus, publicó dos obras dramáticas Los caminos de la vida (1920) y Berta (1922) que serían las primeras versiones de dos obras posteriores que ya firmaría como Halma Angélico. La primera se convertiría en la obra Entre la cruz y el diablo (1932) y la segunda La nieta de Fedra (1929) en la que actualiza el personaje mítico de Fedra. Fue publicada con el subtítulo de «Teatro irrepresentable» por la dificultad temática y técnica, según la autora, para su puesta en escena (Cataslán García 2008, 167). Su obra más representativa, Al margen de la ciudad (1934), comedia en tres tiempos, aborda cuestiones sociales y educativas que condicionaban a la mujer para ocultar su atracción sexual (Nieva de la Paz 1993, 166). Aunque fue publicada en el volumen colectivo de Teatro de mujeres, editado por Aguilar en 1934, no llegó a ser estrenada.

Al iniciarse la Guerra Civil, se afilió a la CNT, siendo la única mujer que durante la guerra estrenó en el Teatro Español, con la obra Ak y la humanidad ${ }^{68}$ (1938).

\footnotetext{
${ }^{67}$ En marzo de 2019, el Centro Dramático Nacional recupera su figura con la obra Halma [En letra grande], escrita y dirigida por Yolanda García Serrano y protagonizada por Ana Villa y Enrique Asenjo. La función teatral imagina, con datos reales, el encuentro de Halma Angélico y el director y actor de $A k y$ la Humanidad, Manuel González, en medio de la campaña de acoso que sufrió la autora durante el estreno de la obra en el Teatro Español de Madrid y retirada por orden gubernamental a los nueves días de su estreno, el 26 de agosto de 1938. García, Rocío. 2019. «Halma Angélico, la anarquista repudiada por la República». En El Pais, 19 de febrero.

${ }^{68}$ Pero, acusada de ver un mensaje contrarrevolucionario y de provocar el desaliento en el frente por sus propios compañeros de la Confederación Nacional del Trabajo, dos semanas después de su exitoso estreno fue prohibida su representación. Dolida por las duras críticas recibidas contra su obra y su persona, por parte de la prensa, abandona el sindicato, dejando claro su posición antifascista y recordando que tenía un hijo en el frente. Al finalizar la guerra, permaneció encarcelada durante tres meses. No volvió a escribir más, quedando su obra y figura en el olvido. Murió arruinada catorce años más tarde (Cataslán García 2008, 187).
} 


\section{4.- El Teatro de Arte: Teatre Íntim de Adrià Gual, El Mirlo Blanco, Cántaro Roto, El Teatro Íntimo Fantasio, El Caracol, Club Teatral Anfistora y Gregorio Martínez Sierra y María de la O Lejárraga}

Una de las diferencias principales entre el modelo teatral de España y el del resto de Europa es que en el modelo español los movimientos renovadores quedaron reducidos a círculos de una limitada minoría de personas dedicadas de manera directa a la profesión teatral, sin lograr influir sobre la actividad teatral pública. Críticos, autores y hasta actores pedían una acción oficial, alegando que en todos los países existía un teatro subvencionado, menos en España. Países como Rusia, Francia, Alemania y, sobre todo, Italia recibieron ayudas directas de sus gobiernos. Ricardo Baeza en su artículo «En torno al problema del teatro. Necesidad de una acción pública», publicado el 22 de enero de 1927, en el periódico El Sol, exponía:

La organización de la escena y la existencia de una buena crítica y de un público refinado no bastan para que surjan grandes autores dramáticos [...]. Pero, en primer lugar, no se trata de trocar súbitamente, como por arte de ensalmo, nuestra mediocre producción actual en magnífica, sino de lograr, de una parte, que ciertas formas chabacanas y soeces que hoy son el principal nutrimiento de nuestro público, con la progresiva educación de éste acaben por desaparecer, y de otra parte, [...] para tener una literatura dramática gloriosa, será el preparar desde hoy un teatro capaz de acogerla y hacerla vivir.

Sin una fuerte acción exterior, requiérase imprescindiblemente una intervención oficial. [...] Es necesario que nuestros Gobiernos se percaten de la trascendencia del teatro en la vida cultural y social del país. [...] todos los Gobiernos españoles jamás se han preocupado de lo que atañe al teatro, y la necesidad de que sea remediada cuanto antes [...]. $(1927,1)$.

Existen posturas que defienden que un arte subvencionado se presta a defender la causa política del momento pero, como defendía André Breton, el arte debe ponerse al servicio de una idea política:

durante el período en que se transforme en acto, y en que ese acto, para llegar a su cumplimiento total, necesite ser exaltado de todas las formas posibles. Pasado ese tiempo, es indispensable que recobre su independencia, si el artista quiere escapar a 
contradicciones graves, objetivamente perjudiciales para la misma idea a la que quiere servir (Breton 1935).

Según afirmaba este, el arte debe independizarse de la política nada más se alcance los propósitos primeros y, por eso, aunque es necesario que el Estado ayude y promueva ideas nuevas, sin embargo, esto no implica una dependencia de estas a las posiciones políticas del gobierno vigente. De este modo, tanto dramaturgos como compañías teatrales arriesgarán en nuevas propuestas sin la necesidad de implicarse en defender posiciones políticas o en pensar en los beneficios económicos, porque las ayudas que reciban, para llevar a escena sus propuestas arriesgadas y novedosas, serán independientes.

Aun así, según Dru Dougherty, «las tentativas en pro de un Teatro Nacional estaban llamadas a fracasar. De ahí que muchos volvieron los ojos a modelos no estatales que pudieran aportar una alternativa a la organización capitalista vigente» $(1984,109)$. De estas alternativas, la que más interés despertaba era el modelo del Teatro de Arte, ya que la mayoría de los comentaristas habían recibido una formación burguesa.

El Teatre Íntim ${ }^{69}$ fue fundado en Barcelona, a finales del siglo XIX y resucitado en 1926 por Adrià Gual (Barcelona, 1872-Barcelona, 1942), que se dispuso a reanudar las actividades del Teatre Íntim después de impartir la conferencia Hacia un teatro nuevo en el Ateneo de Madrid. Cipriano Rivas Cherif quedó tan impresionado con la posibilidad de un cambio que le propuso organizar el proyecto de un Teatro Íntimo en Madrid. Adrià Gual es quien «aporta en España la teoría y la práctica más elaborada de toda la época al servicio del teatro» (Salaün 1999, 37). Junto a su trabajo en la dirección escénica, también impartió conferencias y publicó ensayos en los que mostraba sus reflexiones teóricas casi únicas en España aquellos años (Rubio Jiménez 1998, 52).

El Teatre Íntim de Adrià Gual en Cataluña fue conocido como uno de los primeros teatros de Arte español, «se creó bajo la concepción del arte por el arte. Un teatro elitista, para unos pocos iniciados, en sintonía con el simbolismo maeterlinckiano ${ }^{70}$, en

\footnotetext{
${ }^{69} \mathrm{El}$ nombre de Teatre Íntim se debe a que fueron obras leídas y montadas en círculos reducidos.

${ }^{70}$ El teatro simbolista del belga Maurice Maeterlinck (Gante [Bélgica], 1862-Niza [Francia], 1949) no estaba destinado a la representación sino al libro impreso, puesto que «su escenario era más la imaginación del lector que un escenario material» (Rubio Jiménez 1982, 43). Pero el estreno con éxito de
} 
el que la psicología de los personajes primaba sobre las situaciones dramáticas y su individualidad se eleva a abstracción» (Fortuño 2008, 93). En junio de 1924, en la Sala Myria, el Teatre Intim organizó tres sesiones, representando teatro clásico, obras del propio Gual y piezas contemporáneas e inéditas. La reanudación del Teatre Intim alcanzó un éxito (Gallén 1992, 165). Adrià Gual también propuso la creación de la Escuela Catalana de Arte Dramático en 1913 (Fuente [1992], 1999, 514).

Madrid gozaba de algunas tentativas dentro de la línea de los teatros de arte, en escenarios de cámara se representaban obras alternativas por grupos teatrales como $E l$ Mirlo Blanco, de Carmen Monné; el grupo El Caracol, de Cipriano Rivas Cherif; el Cántaro Roto, de Valle-Inclán: o El Teatro Íntimo Fantasio, de la poeta y dramaturga Pilar Valderrama Alday ${ }^{71}$, y en Las Palmas de Gran Canaria, El Teatro Mínimo de la poeta Josefina de la Torre (Díez Canedo 1932, 1942). Pero la transcendencia de dichos grupos, su puesto impacto en el «teatro de muchedumbres», se puso en duda por falta de público.

Algunas de sus manifestaciones se llevaron a cabo, el 8 de febrero de 1926, con la apertura del grupo teatral experimental El Mirlo Blanco, que estaba instalado en el domicilio de los Baroja: Pío, Ricardo y Carmen, el marido de ésta, Caro Raggio; la madre, Carmen Nessi, y la propia Carmen Monné (Peláez Martín 2003, 2221). El escenario ocupaba un rincón del comedor de la casa de los Baroja. Como afirma Juan Antonio Hormigón, «reunió a un grupo de hombres de letras, músicos y pintores en improvisada compañía que interpretó para un público de élite los textos más arriesgados de la literatura dramática nacional y extranjera» (1972, 349). Constituía una combinación entre el Teatre Íntim de Adrià Gual en Barcelona y el teatro experimental. Este teatro doméstico funcionó entre 1926 y 1927, cuando se estrenaron obras de los escritores de la familia: Marinos vascos, El maleficio y El torneo de Ricardo Baroja; Adiós a la bohemia y Arlequín, mancebo de botica de Pío Baroja; El gato de la Mère

La intrusa (1891) acabó convirtiéndolo en el autor más representativo del teatro simbolista. Entre sus otras obras se encuentran Pelleas y Melisande, ballet con música del compositor Claude Debussy, en esta edición.

${ }^{71}$ Mantuvo una relación con Antonio Machado entre 1928 y 1936. En 1950, Concha Espina, en su libro De Antonio Machado a su grande y secreto amor, dio a conocer el idilio que mantuvieron pero protegiendo la identidad. En 1981, con la publicación de la biografía de Pilar de Valderrama junto a las correspondencia que intercambiaron, se descubrió quién se ocultaba en los versos de Antonio Machado dedicados a Guiomar. 
Michel de Carmen Baroja; y se estrenaron obras de Cipriano Rivas Cheriff, Claudio de la Torre, Edgar Neville, Eduardo Villaseñor y Valle-Inclán (Mainer 2013, 208).

Valle-Inclán, incomprendido por los empresarios teatrales, decide fundar su propio grupo de teatral experimental, el Cántaro Roto, dirigido por él mismo en el Círculo de Bellas Artes aunque en un principio se inicia en 1926, bajo la dirección de Rivas Cherif. El grupo conservaba los mismos ideales que defendía El Mirlo Blanco. La primera función contaba con dos títulos La comedia nueva o El café de Moratín, y Ligazón de Valle-Inclán. A comienzos de 1927, suspende sus representaciones, por falta de medios (Peláez Martín 2003, 2221).

El grupo El Caracol fue fundado en 1928 por Cipriano Rivas Cherif, cuyas actuaciones se celebraban en el angosto escenario de la Sala Rex y que en 1930 reaparece $^{72}$ en el Teatro Español con nuevas sesiones experimentales. Se añadió al proyecto la actriz Margarita Xirgu y su compañía. El propio Rivas Cherif, en una entrevista realizada por César González-Ruano, afirmará el motivo de esta nueva aparición:

Cuando fui a América con Irene López Heredia pude convencerme de que El Caracol tenía una popularidad que, francamente, no creí. A la vuelta hablé con más personas, y todas me animaron en mi idea de que El Caracol saliera de la órbita de las minorías para ser una conquista, una expansión de contacto y relación con el gran público.

$[\ldots]$

Una misión experimental. El teatro debe ser para todos, no para las minorías; pero hemos de ver muchas de ellas antes en sesión de Caracol para que pasen á las representaciones ordinarias, si tienen popularidad ciertamente (Rivas Cherif 1931, 5).

Entre otros grupos de teatros experimentales encontramos El Teatro Íntimo Fantasio, en 1929, teatro de cámara regentado por la dramaturga Pilar Valderrama Alday y su marido el escenógrafo Rafael Martínez de Romarate, con el que participó en la renovación teatral de aquel periodo, no sólo con una interesante selección de textos para

\footnotetext{
${ }^{72} \mathrm{El} 24$ de diciembre, a las seis y media, fue la primera sesión experimental en su nueva aparición. Con la representación de la fábula china medieval El Príncipe, la Princesa y su destino, y el estreno de la farsa de Lorca La zapatera prodigiosa, en la única función que el propio autor recitó el prólogo de la obra. Según apareció anunciado en prensa: «Primera sesión del "Caracol". "La zapatera prodigiosa", farsa violenta de Federico García Lorca». En Ahora: diario gráfico, el 25 de diciembre de 1930, Madrid: 28; «Gacetillas. "Caracol" en el Español». En Ahora: diario gráfico, el 24 de diciembre de 1930, Madrid: 24, y «El "Caracol" aparece de nuevo». En Ahora: diario gráfico, el 19 de diciembre de 1930: 24, entre otros.
} 
su representación sino que también destacó con su escenografía e iluminación; y el Club Teatral Anfistora en 1933 que ampliaremos en el siguiente capítulo (Hormigón 1972, 351; Gesù, 2006, 57). Ajenos al mercantilismo teatral, estos grupos tuvieron libertad para experimentar con nuevos textos y renovar la escenografía y la iluminación. Todas estas diversas compañías tienen en común el dirigirse a un público minoritario, conocedor y deseoso de ver y sorprenderse ante las nuevas técnicas (Hormigón 1972, $353)$.

Otro intento teatral fue el de Gregorio Martínez Sierra (Madrid, 1881-Madrid, 1947) y su Teatro de Arte en 1916, que se mantuvo hasta 1926 en el teatro Eslava de Madrid. Representó su proyecto más ambicioso sin renunciar a compatibilizarlo con el éxito en taquilla (Checa Puerta 1992, 121), dando oportunidad a autores noveles como Lorca, Borrás, Luca de Tena y Sassone. Es la primera empresa teatral española comercial con una propuesta moderna, cuyo teatro se caracterizó, sobre todo, por sus aportaciones escenográficas (Fuente [1992] 1999, 514). Según afirma Serge Salaün, Martínez Sierra «apostó por el teatro burgués, el único en la época que favorece garantías de beneficios económicos» $(1999,12)$. Junto a su mujer María de la O Lejárraga participan en la vida cultural de principios de siglo.

La gran cantidad de obras literarias escritas, los proyectos editoriales, como Helios o Renacimiento, las propuestas teatrales las llevó a cabo con la colaboración de su esposa, María de la O Lejárraga ${ }^{73}$ (San Millán de la Cogolla [La Rioja], 1874-Buenos Aires [Argentina], 1974) maestra, escritora y diputada ${ }^{74}$ socialista en las Cortes de la Segunda República. En 1905, consiguió una beca que le permitió viajar por Bélgica y otros países europeos para conocer sus sistemas pedagógicos que le influyeron en sus ideas políticas. Escribe artículos y ensayos que reivindican la posición de la mujer en la sociedad española, pero incluso estos trabajos de carácter feminista los firmó su marido (Caballero 2019). Autora de la mayor parte de las obras que publicó con el nombre de

\footnotetext{
${ }^{73}$ El Centro Dramático Nacional encargó a Vanessa Montfort que realizara una obra para recuperar la figura de María de la O Lejárraga García. Del 23 de abril al 5 de mayo de 2019, en el Teatro Valle Inclán (Sala El Mirlo Blanco) de Madrid, se pudo ver representada la obra Firmando Lejárraga dirigida por Miguel Ángel Lamata. Es la primera vez que su figura sube al escenario. Bravo, Julio. 2019. «Firmado Lejárraga. La autora oculta». En ABC, 19 de abril, 55

${ }^{74}$ En 1931, ingresa en el PSOE. Dos años más tarde, se presenta en la elecciones por la circunscripción de Granada, llegando a ser diputada en el Congreso, cuyas intervenciones fueron duras e incisivas (Caballero 2019).
} 
Martínez Sierra, ya que no se aprecia nunca la parte que corresponde a cada cual. Ya en 1938, se reconocía la importancia de María de la O Lejárraga en el teatro de Martínez Sierra. Según afirmaba Díez Canedo, su producción se caracterizaba por tratarse de

obras rebosantes de ternura y optimismo que han evolucionado más tarde en un sentido de apostolado social. Su mayor éxito Canción de cuna (1911) fábula de la niña abandonada en el torno de un convento, que viene a ser hija de la comunidad que la ampara $(1938,22)$.

El exitoso estreno de Canción de cuna (1911) —en un principio figuraba su marido como el autor, pero posteriormente se reconoció su autoría - fue el primer éxito en la carrera teatral. Son innumerables las obras de teatro escritas por el matrimonio. En las tres últimas obras teatrales, firmadas por Gregorio Martínez Sierra y escritas, una vez más, por María de la O Lejárraga, en $1930^{75}$, La Hora del diablo, Triángulo y Sortilegio, ya se observa un cambio en el estilo, con una visión más oscura, en la que la mujer toma un papel de la vida moderna con plena igualdad de condiciones con los hombres (O’Connor 2000, 209).

El Teatro de Arte en España, en los años veinte, requería una independencia de la taquilla y, al mismo tiempo, una suma considerable de fondos disponibles a fin de aprovechar los adelantos técnicos para la escenificación experimental. De estos teatros de minorías salen los directores, autores y comediantes que han de renovar la escena teatral cuando el público, cansado de la monotonía de ese teatro que durante un tiempo le entretuvo, busca nuevas propuestas (Dougherty 1984, 111).

\section{5.- El Teatro Escuela de Arte (T.E.A.)}

A este grupo de teatros privados hay que añadir uno de los fenómenos culturales más importantes: La Escuela Nueva y la compañía que se creó con su ayuda, el Teatro de la Escuela Nueva del partido socialista. Un organismo subvencionado por el gobierno, con

\footnotetext{
${ }^{75}$ Fue en ese mismo año, cuando Martínez Sierra firma un documento legal en el que reconoce a María Lejárraga había sido su colaboradora $y$, a partir de entonces, pide que aparezca su nombre junto a él como autora (O'Connor 2000, 209).
} 
todos los elementos necesarios para realizar un teatro moderno. La Escuela Nueva fue creada por Manuel Núñez de Arenas en 1911. De 1919 a 1921 se incorpora Cipriano Rivas Cherif para llevar las actividades teatrales y renovar el concepto de teatro popular, situándolo al nivel dominante en los teatros socialistas europeos. En 1920, se inicia el Teatro Escuela de Arte, T.E.A. (Hormigón 1972, 351).

La sociedad del Teatro Escuela de Arte fue fundada a partir de los alumnos del Conservatorio (Chabás 1933, 6) y pudo contar con el escenario del Teatro María Guerrero para sus representaciones. Su primera función de abono en el teatro María Guerrero tuvo lugar en enero de 1935 y se representó La fiera de Benito Pérez Galdós, con el teatro lleno. En uno de los entreactos, Cipriano Rivas Cherif «leyó unas bellísimas cuartillas sobre propósitos y orientación de la Tea [sic]» (La Libertad 1935, 4).

A sus actores se les exigía una disciplina perfecta, donde se cuidaba mucho el conjunto de la agrupación. En los decorados se ensayaban los distintos procedimientos de la escena moderna, donde predominaban los más sencillos (Díez Canedo 1938, 44).

La Escuela Nueva era una obra social y educativa que reunía de forma cultural al obrero y al intelectual. Su actividad era dirigida a un público de masas y «debía reunir los principios estéticos de los teatros de élite, pero manipulados para un público de masas. [...] por primera vez aparecía un teatro dirigido al proletariado» (Hormigón 1972, 352).

La labor de Rivas Cherif como director teatral sólo tiene como antecedentes en España, la de Gregorio Martínez Sierra en el Teatro Eslava o la de Adrià Gual en Cataluña. Antonio Espina afirmará que Rivas Cherif tenía razón

en lo que dijo de anecdótico sobre la necesidad de que el teatro nacional continúe la tradición de nuestra dramaturgia clásica $-\mathrm{y}$ romántica - en cuanto a ideas y sentimientos civiles.

Continuar con la tradición significa verdaderamente que al autocratismo, al catolicismo, a la emoción monarquista de ayer, se sigan en espiral de progreso evolutivo los ideales dramáticos y dramatizables —nacionales - de hoy: democracia, librepensamiento y emoción republicanista (1934a, 9). 
Entre los grupos subvencionados por el gobierno republicano, también encontramos $L a$ Barraca — que trataremos en el capítulo siguiente-y el grupo teatral El Búho, con tendencia antifascista, creado a finales de 1935 y formado por estudiantes universitarios de la Federación Universitaria $\operatorname{Escolar}^{76}$ (F.U.E.) de la Universidad de Valencia, En los primeros meses de la guerra civil fue dirigido por Max Aub.

El propio Max Aub en su discurso, en el X Congreso Internacional de Teatro, celebrado en París entre el 5 y el 10 de junio de 1937, expuso que en el teatro universitario El Búho fueron representados autores como Cervantes, Torres Villarroel, Alberti, el propio Aub y que explicó cómo

íbamos a todos los pueblos, actuábamos en todos los sindicatos, en los hospitales, en la plaza de la Universidad de Valencia, levantando nuestro tablado en los lugares en que no encontrábamos ninguna sala para representar. El pueblo se nos unía y nos aplaudía calurosamente (citado en Aznar Soler 1993, 178).

\section{6.- EI Teatro Nacional}

La problemática de un Teatro Nacional de iniciativa pública era una cuestión que se arrastraba desde el siglo XIX. En 1909, fue aprobada la creación de un Teatro Nacional (aunque esta ley nunca llegó a pasar del papel). Ya en 1908, Alejandro Miquis en diversos artículos publicado en el Diario Universal, exigía un Teatro Nacional: «Nos está haciendo muchísima falta, casi la misma, aunque no tan urgente, como escuelas de primera enseñanza [...], como escuelas técnicas sin verbalismo» $(1998,228)$. El Estado debía proteger la Cultura y el Arte y, aunque no tenía tradición teatral en el ámbito municipal, sí que existía esa tradición de actores profesionales.

Se buscaba un sistema de producción teatral alternativo a la empresa privada comercial $\mathrm{y}$, aunque aparecieron los partidarios de este tipo de teatro, también estaban los que se oponían (Rubio Jiménez 1998, 40). A mediados de los años veinte, entre los críticos teatrales se presentan dos tendencias: la de José Casado con la creación del Teatro

\footnotetext{
${ }^{76}$ La F.U.E. fue una asociación de estudiantes que nació en 1927 contra la legislación académica de la Dictadura de Primo de Rivera, con el tiempo fue el elemento de cohesión en la universidad republicana.
} 
Nacional de España y en oposición la de Luis Araquistáin, que propugna un sistema independiente y sin la intervención del Estado (Aguilera Sastre 1992,176). Pero tuvo que esperar hasta finales de los años veinte, cuando se favoreció mediante una subvención por parte del Estado, la creación de una compañía teatral, la del Teatro Lírico Nacional, durante la temporada 1926-1927.

Con la llegada de la Segunda República, de nuevo se intenta crear un teatro independiente que se aleje del concepto de teatro como mercancía, con intención de devolverle unos valores artísticos que sean retransmitidos a la sociedad, con un repertorio y equipo formado en dramaturgia y con conciencia de colectividad. Como afirma Hormigón, con este teatro se «descubre e impone la puesta en escena, no como mera organización, sino como creación productiva y autónoma capaz de señalizar unas líneas bien definidas en la marcha del espectáculo» $(1972,353)$.

Ante la necesidad de que el Estado se involucre en el futuro del teatro, el 12 de mayo de 1936 Max Aub presenta un proyecto de estructura para un Teatro Nacional y Escuela Nacional de Baile, dirigido al presidente de la Segunda República, Manuel Azaña Díaz. Consciente de la necesidad de una renovación en el teatro, el escritor franco-alemán considera que el problema está en la formación de actores y directores y plantea que aquellos sean considerados como funcionarios, proponiendo diversos posibles directores de escena: Federico García Lorca, Cipriano de Rivas Cherif, Alejandro Casona y Gregorio Martínez Sierra (Aznar Soler 1993, 130-132; Bilbatúa 1976, 37-38). Y, junto al Teatro Nacional, ha de crearse una Escuela Nacional de Baile, ya que para Max Aub «el baile español no ha demostrado que no es exclusivamente un arte individualista; el gran "ballet" español está por crear; no dudo su formidable éxito, de su enorme resonancia en el mundo entero» (citado en Aznar Soler 1993, 144). Con el inicio de la guerra civil, el proyecto nunca pudo realizarse ni llegó a dirigir el Teatro Nacional, aunque sí fue secretario del Consejo Central de Teatro desde el 27 de agosto de 1937 hasta su salida de España dos años más tarde (Aguilera Sastre 1992, 182; Pérez Bazo 1993, 29). En su discurso El teatro español sacado a luz de las tinieblas de nuestro tiempo $^{77}$ mostraba un recorrido por el teatro español y su situación desde una

${ }^{77}$ El 13 de diciembre de 1956, Max Aub escribe un discurso apócrifo, que nunca llegó a leer, para su entrada en la Real Academia Española. En el discurso entrelaza historia y ficción, partiendo de que la Guerra Civil nunca ocurrió y, por tanto, no tuvo que exiliarse y pudo dirigir el Teatro Nacional. 
perspectiva de fantástico ficticia, con las facilidades por parte del Estado para llegar a darse esta revolución teatral:

El estado actual del teatro en España abre las esperanzas a los jóvenes y les da las facilidades que nosotros quisimos (y no encontramos tan a pie llano) gracias a la liberalidad de un Estado acogedor y tolerante con las expresiones artísticas, sean las que fueren, sabiendo que no hay mejor política para el hombre y la realidad de España (1956 [1993], 14-15).

\section{7.- El Teatro Proletario}

También denominado indistintamente como teatro de política o social, teatro revolucionario, teatro comprometido, teatro popular, teatro de masas, teatro de propaganda. Durante la segunda República, tienen lugar en España grandes transformaciones sociales y políticas que se ven reflejadas en las nuevas propuestas y cambios del espectáculo teatral. Este intento de transformar las estructuras del espectáculo teatral para llevar este a un nuevo público, provoca la creación de un repertorio adecuado al mismo y a sus intereses (Bilbatúa 1976, 9).

En 1931, Ramón J. Sender publica un libro teórico, Teatro de masas, en el que se aleja de buscar una renovación dentro del teatro burgués y emprende un camino hacia un teatro proletario, con una postura totalmente opuesta a Araquistáin (él no buscaba un nuevo teatro dirigido a las masas ni creía que fuera el proletariado ese nuevo público para renovar la escena teatral). Sender ataca al espectador burgués y busca un nuevo público que lo encuentra en una nueva clase social ascendente: el proletariado (Bilbatúa 1976, 23).

Surgen autores y grupos dedicados a este tipo de teatro con bastante difusión. El denominado de agitación y propaganda política, según exponía Antonio Espina

hemos de entender por teatro de masas — no es ocasión de vigorizar el concepto- el moderno teatro proletario, el que alienta —o pretende alentar - con el espíritu del pueblo, el que se dirige a la sensibilidad de las colectividades obreras, trata asuntos de tipo social y económico y lleva hasta el escenario, al mismo tiempo que la técnica 
moderna de ingeniería espectacular, verdaderas multitudes, en su real presencia cuantitativa, o personajes representativos de estas multitudes (1934b, 10).

De entre estos grupos, destacan el grupo teatral Nosotros, el Teatro Proletario, la Compañía Española de Teatro Revolucionario y también las actividades de las Casas del Pueblo, en cuyos locales se representaba este tipo de teatro como son las representaciones de juguetes cómicos, sainetes, zarzuelas (especialmente de género chico) y también obras escritas por personas ligadas a organizaciones obreras. (Bilbatúa 1976, 48), cuyo público era el proletariado de las ciudades, a diferencia de las Misiones Pedagógicas o los grupos universitarios La Barraca o El Búho cuyas representaciones iban dirigidas al campesinado.

El grupo teatral Nosotros fue fundado por Irene Falcón ${ }^{78}$ (Madrid, 1908-El Espinar [Segovia], 1999). De creación colectiva, pretendía crear sus propias técnicas y formar a sus actores ${ }^{79}$ y autores. El repertorio teatral era muy variado pero se caracterizaba por que los trabajadores se identificaban entre los personajes de las obras representadas (Vicente Hernando 2009, 34). Junto a su marido, el peruano César Falcón, «formaron la Central del Teatro Proletario, en Madrid, con su propia escuela de teatro, y realizaron giras por varios lugares de España» (Fuentes 2006, 198). El matrimonio se inspiró en el teatro social visto en Rusia, Alemania e Inglaterra. En Rusia, ya se tenía una experiencia de más de quince años antes de llegar a España. Aún así, según Espina, «ni en Rusia, ni en Alemania, ni, en tono menor, en Francia y en Norteamérica, se ha conseguido plenamente el gran arte proletario, específico, que preconizaban y preconizan sus apologistas» (1934b, 10). Ya que, aunque la dramaturgia rusa empezó con un gran empuje intelectual y material con el favor del Estado Soviético, se convirtió con los años en instrumento de mera propaganda con una «mezcla literaria de pequeños valores estéticos, con grandes dosis de fraseología de mitin, de polémica y de catecismo bolchevique» (Espina 1934b, 10).

Otro grupo de teatro independiente y de creación colectiva fue el de la Compañia Española de Teatro Revolucionario, ligado a la sección española de la A.E.A.R.

\footnotetext{
${ }^{78}$ Irene Lewy Rodríguez, su nombre, secretaría personal de Dolores Ibárruri, la Pasionaria.

${ }^{79}$ Gran número de actores viajan a América, en especial a Buenos Aires, y por ello se recurre a actores y actrices no profesionales.
} 
(Asociación de Escritores y Artistas Revolucionarios), a la revista Octubre y a Rafael Alberti y María Teresa León. En este proyecto nacieron las dos farsas revolucionarias de Rafael Alberti, Bazar de la providencia y La farsa de los Reyes Magos, publicadas en 1933 en la revista Octubre. 


\section{4.- El teatro de Federico García Lorca}

En este punto desarrollaremos las dos vertientes de Federico García Lorca. Por una parte, el Lorca dramaturgo, que buscaba en el texto propuestas nuevas por las que apostar, y por otra, el Lorca director de escena, con la creación del teatro ambulante $L a$ Barraca en la que quería llegar al máximo número de público de toda clase social (proyecto paralelo al teatro ambulante de la Misiones Pedagógicas), y con la participación en la formación del Club Teatral Anfistora, según afirmó ${ }^{80}$ que «yo fundé para luchar contra las sociedades filodramáticas, empeñadas en representar obras caducas y sin ningún interés» (citado en Inglada 2017, 203). Lorca buscaba en los textos del teatro clásico del Siglo de Oro proyectos para reponer sobre los escenarios.

A su llegada a Madrid, se encuentra una ciudad cosmopolita y con un ambiente social y cultural del que Lorca se propone formar parte y aprovechar al máximo. Sus años en la Residencia de Estudiantes, proyecto surgido de la Institución Libre de Enseñanza, le ayudarán a desarrollar su faceta dramaturga, hasta el momento eclipsada por su obra poética.

4.1.- Lorca, dramaturgo: El maleficio de las mariposas (1920), Los títeres de la cachiporra Tragicomedia de don Cristóbal y la señá Rosita (1922), María Pineda (1925), Amor de don Perlimplín con Belisa en su jardín. Aleluya erótica en cuatro cuadros y un prólogo (1926), La zapatera prodigiosa (1930), El público (1930), Así que pasen cinco años. Leyenda del tiempo (1930), Bodas de sangre (1932), Retablillo de don Cristóbal (1934), Yerma (1934), Doña Rosita la soltera o el lenguaje de la flores (1935) y La casa de Bernarda Alba (1936)

Federico García Lorca, en los primeros años como estudiante en la Residencia de Estudiante, es un joven que quiere abrirse camino en el mundo teatral cuando conoce a Eduardo Marquina, uno de los dramaturgos más consagrados del momento y se convierte en su embajador intelectual. Marquina le presenta a Martínez Sierra, director del teatro de Arte Eslava de Madrid, de quien surge la puesta en escena de su primera

${ }^{80}$ Palabras extraídas de la entrevista de autor anónimo «F. García Lorca habla de "La zapatera prodigiosa". "Es una farsa muy española con ritmo de ballet", dice el joven poeta», La Razón, Buenos Aires, 28 de noviembre de 1933, p. 8. 
obra teatral El maleficio de la mariposa ${ }^{81}$ (1920), una comedia protagonizada por insectos. Estrenada el 22 de marzo de 1920 por la Compañía Cómico-Dramática “Gregorio Martínez Sierra” en el Teatro Eslava (Rodrigo 1980, 151). Una comedia en verso, de dos actos precedidos de un Prólogo en el que hay un alegato a la Naturaleza y el amor. Con ilustraciones de Grieg, e instrumentadas por José Luis Lloret (Rodrigo 1975, 50). El tema de la obra gira en torna al sentimiento de frustración sentimental. Solamente tuvo cuatro representaciones y fue un rotundo fracaso de público y prensa.

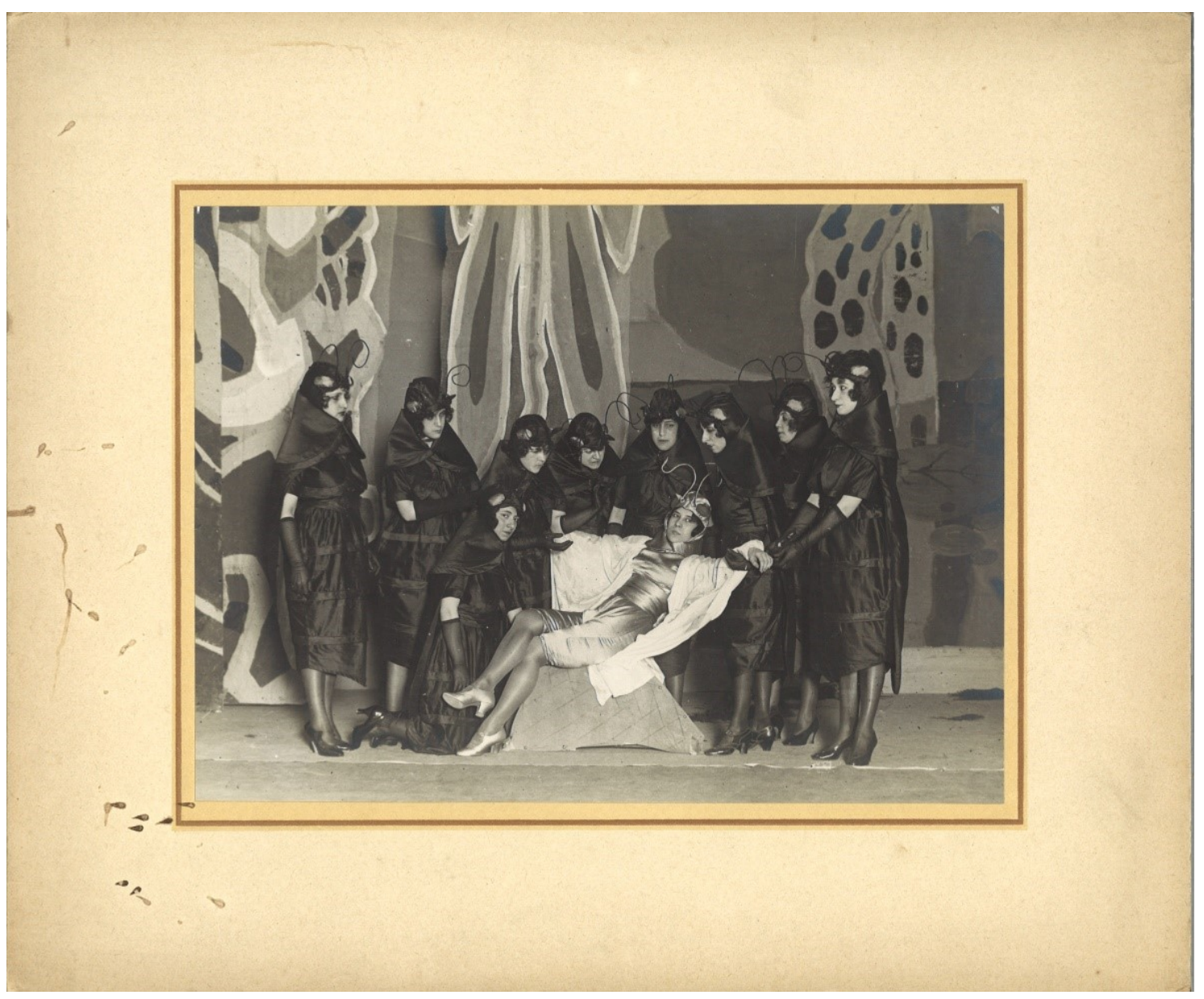

Fig. 25: Posado de escena para el estreno de El maleficio de la mariposa ${ }^{82}$.

\footnotetext{
${ }^{81}$ Se publicó por primera vez en 1954, en las Obras completas, cuya edición estuvo a cargo de Arturo del Hoyo.

${ }^{82}$ En el año 2016, la Biblioteca Nacional de España recibió la donación por parte de Ángel Martínez Roger, de una colección de diez fotografías de representaciones teatrales de los años 20 del siglo pasado, estrenadas en el Teatro Eslava de Madrid y en el Teatro Goya de Barcelona. Entre ellas, cabe destacar ésta, en la que se puede observar, entre las actrices fotografiadas, a Catalina Bárcena en el papel de Curianito el nene y de Encarnación López, la Argentinita, en el papel de la mariposa herida. Con decorados de Mignoni y vestuario de Barradas.
} 
Que los actores y las actrices fueran vestidos de insectos provocó un gran desconcierto e indignación (Soria Olmedo, 2016; Vilches de Frutos y Dougherty 1992, 13). Fracaso que marcó al joven autor que aún no había cumplido los 22 años. En diferentes entrevistas ${ }^{83}$ se refirió a la reacción del público ante la obra:

El primer estreno fue un hermoso pateo, «El maleficio de la mariposa», que puso Martínez Sierra en escena. La obra tenía un valor plástico, acrecentado por las decoraciones de Barradas; [...] artista uruguayo [...]. Era un decorado cubista (citado en Inglada 2017, 57).

Cuando yo estrené mi primera obra, «El maleficio de la mariposa», con ilustraciones musicales de Debussy y decoraciones de Barradas, me dieron un pateo enorme, ¡enorme!... (García Lorca 1935, 3).

Los títeres de la cachiporra Tragicomedia de don Cristóbal y la señá Rosita ${ }^{84}$, farsa guiñolesca en seis cuadros y una advertencia que fue escrita en 1922 pero no llegó a estrenarse en vida de Federico García Lorca. Esta obra sería estrenada, el 10 de septiembre de 1937, por la compañía de Teatro de Arte y Propaganda, dirigida por María Teresa León y Felipe Lluch Garín, en el teatro de la Zarzuela de Madrid. Fue el debut de esta compañía y, aunque el espectáculo se tituló Los títeres de la Cachiporra, se trataba de la obra conocida como Tragicomedia de don Cristóbal y la señá Rosita.

En 1923, con la colaboración de Manuel de Falla y el pintor Hermenegildo Lanz como escenógrafo, funda el grupo de aficionados Teatro Cachiporra Andaluz con un carácter familiar. En la noche de Reyes de 1923, organiza en la casa granadina de la familia Lorca, el estreno del grupo con Los dos habladores, entremés atribuido a Cervantes y refundido por D. Manuel De Foronda en 1881, el auto medieval Misterio de los Reyes Magos, anónimo del siglo XIII y La niña que riega la albahaca y el príncipe preguntón (1923), la segunda obra de Lorca basada en una adaptación de un cuento tradicional para niños. La cita y el comentario del espectáculo salieron publicados, días después, en

\footnotetext{
${ }^{83}$ El primer extracto pertenece a la entrevista realizada por Alfarache, Juan de, 1931. «Federico García Lorca, o la simpatía. Un hermoso pateo. -El autor es el que "ve" la obra. -Margarita Xirgu es maravillosa. - Conferencia de pago. - Cuba y Granada. - Toros y Fútbol». En Miradero, nº 1, Madrid, febrero: $74-78$.

${ }^{84}$ Fue publicada en 1948 por Juan Guerrero Zamora en Raíz. Cuadernos literarios de la Facultad de Letras de Madrid. El texto procede de una copia de uno de los actores del estreno de 1937, José Franco.
} 
diferentes periódicos (Vilches de Frutos y Dougherty 1992, 33; Hernández 1992, 27; Hurtado Hernández 2019, 157-158).

El teatro de muñecos no era una mera distracción sino que era su modelo de teatro futuro; estuvo muy interesado por el teatro de títeres ${ }^{85}$ sobre el que investigó en sus primeros años de creación, siendo un género teatral que nunca abandonó (Hurtado Hernández 2019, 144). Compagina la vanguardia y lo popular, y su gran aportación fue incorporar personajes de carne y hueso con las características de los personajes de títeres. Escribió cuatro farsas: dos para guiñol, Tragicomedia de Don Cristóbal y la señá Rosita (1922) y Retablillo de don Cristóbal (1934), y dos para personas, La zapatera prodigiosa (1930) y Amor de Don Perlimplín con Belisa en su jardín (1929).

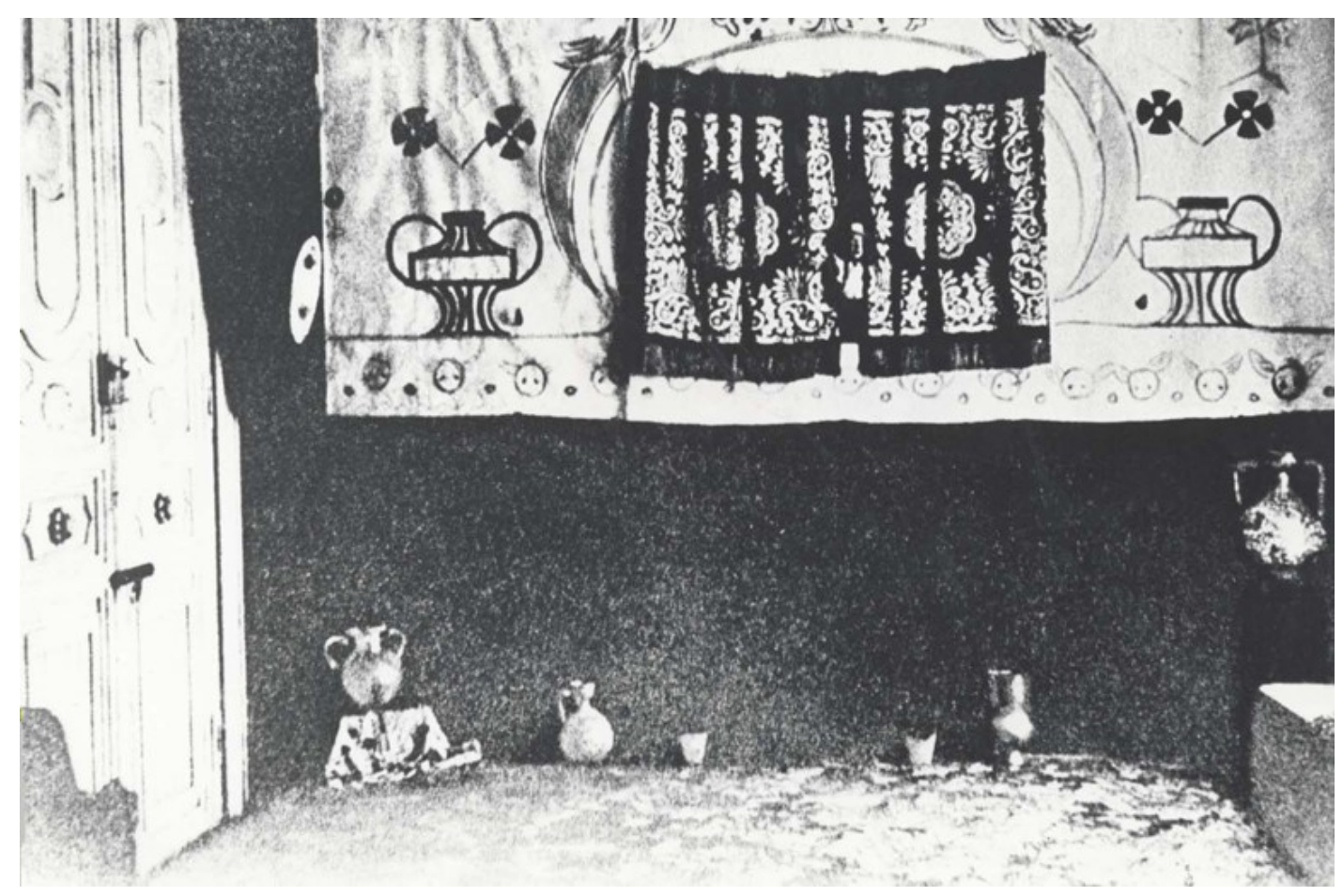

Fig. 26: Fotografía de la embocadura exterior y teloncillo del guiñol casero del teatrillo de muñecos en la casa de la familia García Lorca. Construido por Federico García Lorca para celebrar el Día de Reyes de 1923 (6 de enero). Uno de los muñecos asoma entre las cortinas.

Tuvo que esperar siete años, desde el fracaso de El maleficio de la mariposa, para presentar una nueva obra ante el público y los críticos: Mariana Pineda (1925),

\footnotetext{
${ }^{85}$ El 13 de enero de 2017, en la Universitat de Barcelona, se leyó la tesis Federico García Lorca: la obra de juventud, el teatro para títeres y los proyectos inconclusos de Mónica Hurtado Hernández dirigida por Marisa Sotelo Vázquez. Es uno de los últimos estudios exhaustivos en el que se analiza este tipo de teatro y la importancia que tuvo en la obra de Lorca. Se encuentra en acceso abierto en el Depósito Digital de la misma universidad http://diposit.ub.edu/dspace/handle/2445/107836
} 
romance popular en tres estampas, símbolo de la libertad - la heroína romántica fue ejecutada en Granada por orden de Fernando VII- Federico García Lorca renuncia a una innovación radical pero su texto tiene cierta apertura a las costumbres teatrales del momento. De nuevo, acude a la ayuda de Eduardo Marquina, a quien a principios de 1926 le encargó que le entregara la pieza a Margarita Xirgu, aunque es la propia Xirgu quien solicitó a Lorca que fuera a su domicilio a entregárselo. Aún así, Lorca tardó unos meses en recibir respuesta de Xirgu de la aceptación de poner a escena la obra (Rodrigo 1975, 77-78). El estreno tuvo lugar, el 24 de junio de 1927, en el Teatro Goya de Barcelona, estando a cargo de la Compañía Dramática Española Margarita Xirgu. En Madrid, se estrenó en el Teatro Fontalba, en octubre de 1927. El decorado y el diseño de los trajes fueron preparados por Salvador Dalí, a partir de unos bocetos dibujados por García Lorca, en los que mostraba la idea de distintas escenas (Babín 1976, 33; García de Capri 1986 33). La obra se publicó, en 1928, en la colección La Farsa con dibujos del propio autor. Con esta obra tanteó el teatro histórico, una línea dramática que no continuaría. Pero el éxito de público aún tendría que esperar unos años.

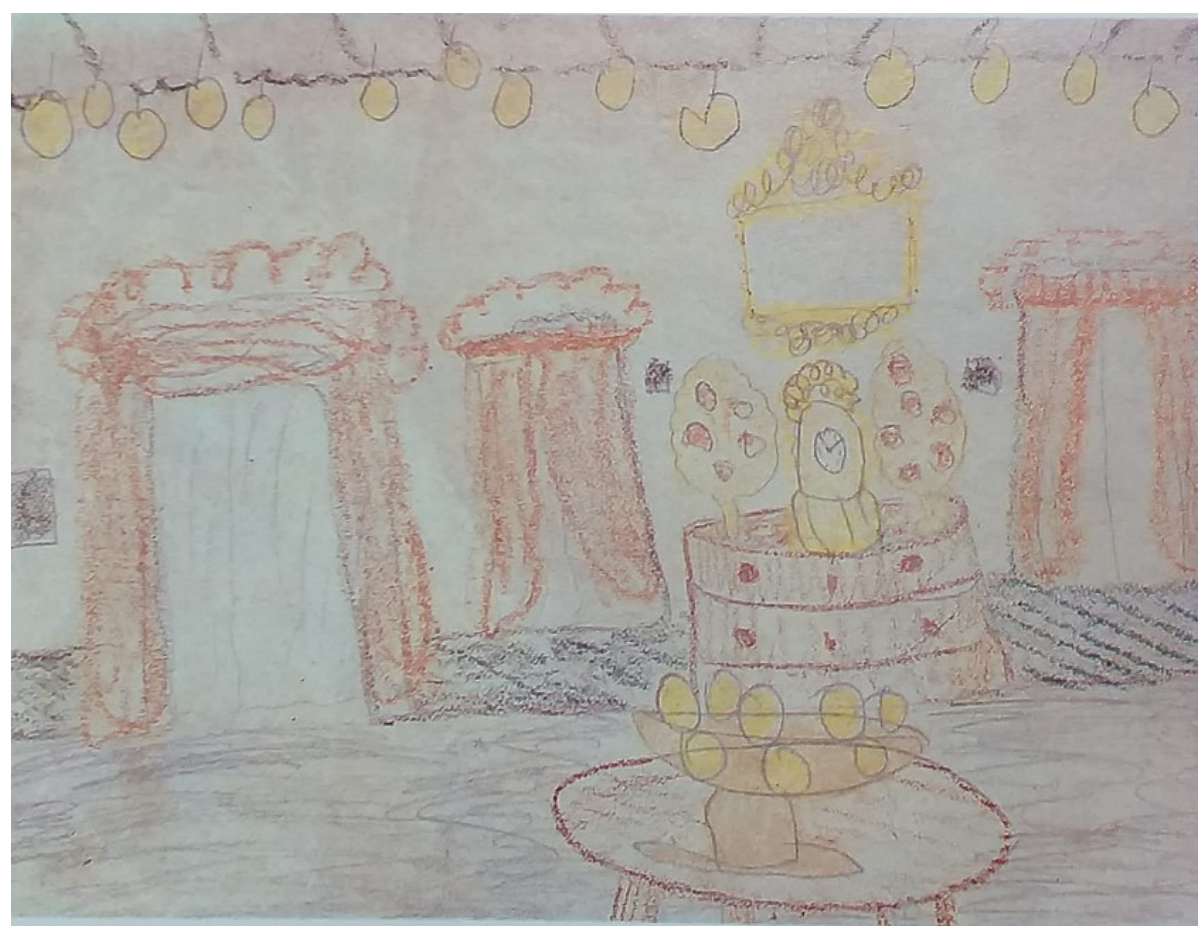

Fig. 27: Estampa primera: Casa de Mariana Pineda (1927). Paredes blancas. Sobre una mesa, un frutero de cristal lleno de membrillos. Todo el techo estará lleno de la misma fruta, colgada. Encima de la cómoda, grandes ramos de rosas de seda.

Lápiz y lápices de colores sobre papel, 31 x $24 \mathrm{~cm}$.

Colección particular, Barcelona. 
En 1929, la censura prohíbe el estreno de Amor de don Perlimplín con Belisa en su jardín. Aleluya erótica en cuatro cuadros y un prólogo (1926) por el grupo experimental El Caracol. Debe esperar al 5 de abril de 1933 para ver su estreno en el Teatro Español de Madrid que obtuvo un fracaso entre la crítica, debido a ser una obra escrita hacía años, con personajes extravagantes y deformados. Fue la primera actuación con la que inauguró el proyecto del Club Teatral Anfistora. En esta obra confluyen tradición y vanguardia, en la que contrasta constantemente lo grotesco con lo lírico.

De vuelta a España, después de su estancia en Estados Unidos y Cuba, estrena La zapatera prodigiosa $^{86}(1930)$ el 24 de diciembre de 1930, en el teatro Español de Madrid, por el grupo teatral El Caracol, dirigido por Cipriano Rivas Cherif y la compañía Dramática Española Margarita Xirgu. El propio Lorca recita el prólogo de la obra $^{87}$. Existen tres estrenos de la obra, en 1930, en 1933 y en 1935, que repite el de 1933 en Buenos Aires, al existir al menos dos versiones de la obra (Fernández Cifuentes 1986, 97).

El 24 de diciembre de 1930, en el periódico La Libertad, en la entrevista ${ }^{88}$ «La vida escénica. Ecos, noticias y comentarios del día. Antes del estreno. Hablando con Federico García Lorca», el poeta opinaba sobre la obra:

Es la lucha perpetua, con su fondo dramático expuesto tranquilamente, sencillamente (yo creo que por esto más íntimo) entre la fuerza de la ilusión sentida hacia lo que huyó de nuestra mirada y la fuerza de la realidad, la pobreza de la realidad, cuando vemos llegar a lo que perdimos y por perdido encendió tanta ilusión... La maravilla de lo que creímos que era y la vulgaridad de lo que es $(1930,9)$.

La zapatera prodigiosa es una farsa violenta en dos actos que fue concebida casi como un ballet. La obra está compuesta de dos actos precedidos de un prólogo del autor. Lorca recurre a un tema utilizado en la literatura, el de una joven mujer casadera y un

\footnotetext{
${ }^{86}$ Empezó la redacción de esta obra en el verano de 1923 hasta diciembre de 1933.

${ }^{87}$ La crítica teatral vino reflejada en la prensa, ejemplo de ellos fue: «Primera sesión del "Caracol”. "La zapatera prodigiosa”, farsa violenta de Federico García Lorca». En Ahora: diario gráfico, el 25 de diciembre de 1930, Madrid: 28.

${ }^{88}$ La entrevista está firmada por las iniciales J. L.
} 
hombre mayor. El romance entre el viejo zapatero y la joven y alegre zapatera. Los personajes secundarios son estereotipos.

En este tercer estreno, la crítica también se dividió. Pero el 1 de diciembre 1933, en Buenos Aires, en el Teatro Avenida estrena una versión más completa en la que incorpora música y canciones que se encarga él de supervisar.

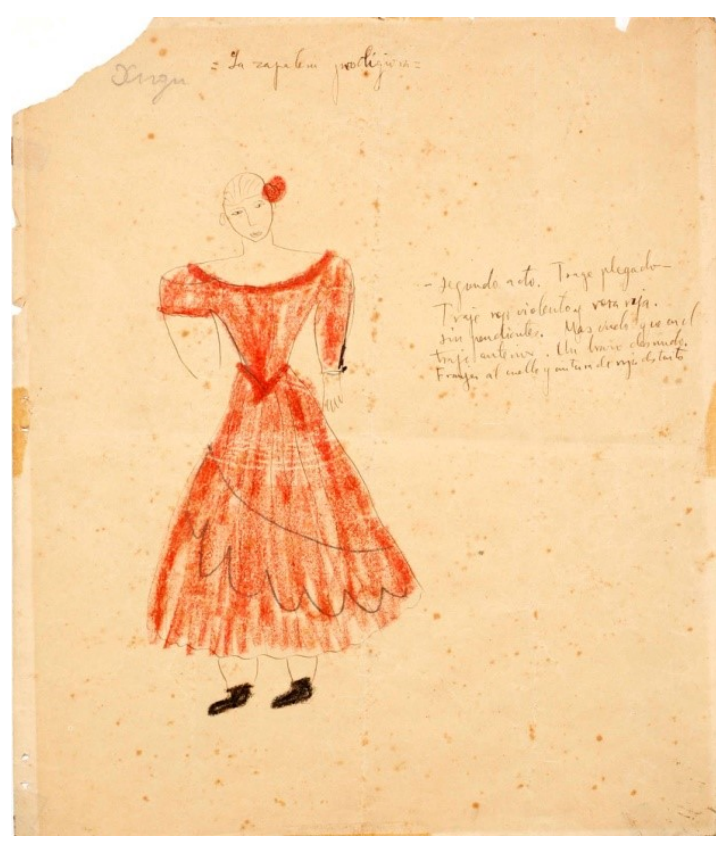

Fig. 28: Traje de la Zapatera. Segundo Acto (1930).

Figurines ${ }^{89}$ dibujados por Federico García Lorca para La Zapatera Prodigiosa.

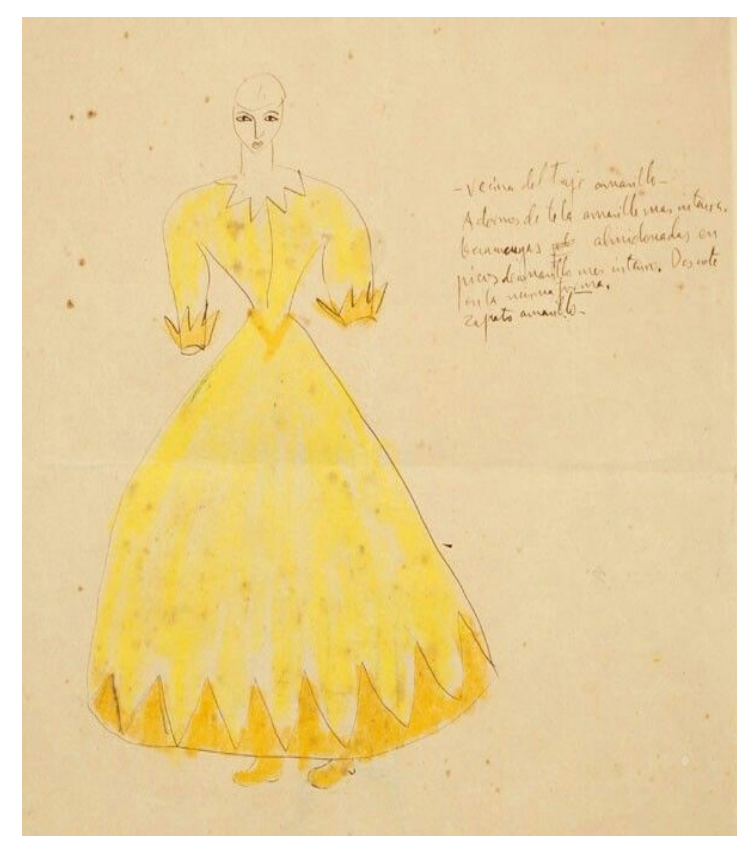

Fig. 29: Vecina del Traje amarillo (1930).

Entre su "teatro imposible", encontramos la obra teatral sobre la que gira nuestra investigación, El público (1930). Como afirma Francisco Abad Nebot,

quiso manifestar con la obra ciertamente su derecho de autor escénico a seguir una estética propia y no impuesta por los gustos del público, y su derecho de persona a un amor homofílico; pero a pesar de este discurrir racional, lo que de veras le importaba era el amor $(1996,118)$.

En Así pasen cinco años. Leyenda del tiempo (1930) introduce un subtema en el problema del amor humano «el del error del aplazamiento o espera en el logro sentimental» (Abad Nebot 1996, 120). No se puede esperar en el amor porque nos

${ }^{89}$ Composición de diez figurines para La zapatera prodigiosa realizados con lápices de color sobre papel de $23 \times 17,5 \mathrm{~cm}$. Colección desconocida 
llevará a la destrucción o la frustración. En junio y julio de 1936, Pura Ucelay, al frente del Club Teatral Anfistora, empieza sus ensayos para ser llevada a escena. Debido al inicio de la guerra no llegó a estrenarse.

Pero Lorca seguía ambicionando el éxito teatral, y sin renunciar a sus propósitos renovadores, presenta Bodas de Sangre ${ }^{90}$ (1932), tragedia en tres actos y siete cuadros, escrito en prosa y verso. Fue estrenada el 8 de marzo de 1933 en el teatro Beatriz de Madrid por la compañía de Josefina Díaz de Artigas y Manuel Collado, dirigida por Eduardo Marquina y el propio Lorca. Pero su primer triunfo comercial debería esperar aún unos meses, con su estreno de Bodas de Sangre en Buenos Aires, a finales de ese mismo año, lo que le proporcionó el primer éxito como dramaturgo dentro y fuera de España (Vilches de Frutos y Dougherty 1992, 73; Babín 1976, 39).

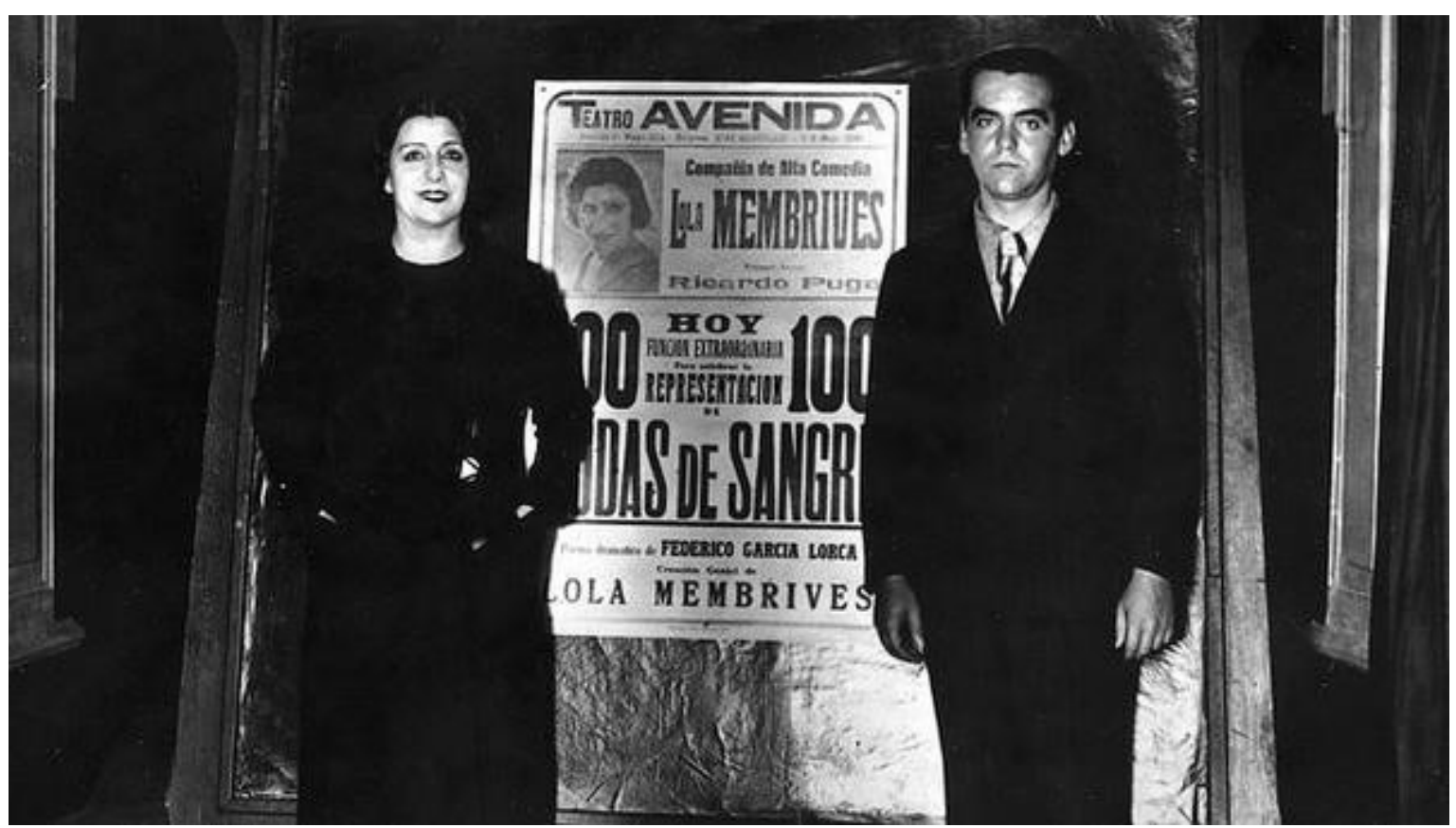

Fig. 30: Fotografía de Lola Membrives y Federico García Lorca ante el cartel de las cien representaciones de Bodas de sangre en el Teatro Avenida de Buenos Aires (1934).

Colección: Fundación García Lorca.

A pesar del éxito en la crítica, todavía no existe unanimidad. En este drama, clasificado por el propio Lorca como tragedia, como en otras ocasiones, lleva a escena un caso real

\footnotetext{
${ }^{90}$ Se publicó en vida del autor en Ediciones Árbol, de la revista Cruz y Raya dirigida por José Bergamín. En el texto no se recogen las rectificaciones posteriores de la versión barcelonesa de 1936 y contiene errores de copia.
} 
de rivalidades heredadas, ocurrido en Níjar (Almería), en 1928. En el texto alterna prosa y verso, distribuyendo las partes poéticas por la obra cumpliendo la función de los antiguos coros trágicos (Soria Olmedo, 2016).

El primer manuscrito autógrafo del Retabillo de don Cristóbal también titulado Retablillo de don Cristóbal y doña Rosita ${ }^{91}$ (1934) está fechado en marzo de 1934 en Buenas Aires. Aleluya popular basada en el viejo y desvergonzado guiñol andaluz. Esta obra fue escrita expresamente para «una función realizada en el vestíbulo del teatro Avenida, de Buenos Aires, el domingo 25 de marzo de 1934» (Vilches de Frutos y Dougherty 1992, 88). A su vuelta de Argentina, fue representada por La Barraca en un hotel.

Con Yerma ${ }^{92}$ (1934), poema trágico en tres actos, divididos en seis cuadros, en verso y prosa combinados, Lorca consigue el éxito de público en España, que buscaba desde su primer fracaso teatral. El 29 de diciembre de 1934, Cipriano Rivas Cherif, al frente de la Compañía de Margarita Xirgu y Enrique Borrás, estrenaba Yerma en el teatro Español, de Madrid, alcanzando las ciento treinta y siete representaciones, consagrándolo definitivamente como un gran autor dramático. El éxito continuó en los diferentes lugares que fue representada, entre ellos Barcelona y Buenos Aires. Yerma es un drama sociológico en el que se plantea otro tipo de frustración, la del deseo de la fecundidad. Como afirma Vilches de Frutos y Dougherty, «Lorca resolvió la dureza del diálogo y del argumento —el drama de la mujer estéril en el campo español— introduciendo elementos musicales y coreográficos inspirados en el folklore andaluz» $(1992,101)$. Para el estreno en Barcelona, en una entrevista ${ }^{93}$ realizada el 17 de septiembre de 1935 , Lorca declaraba que

Yerma no tiene argumento. Yerma es una figura que se va desarrollando en el transcurso de los seis cuadros de los que consta la obra. Tal como conviene en una tragedia, le he introducido a Yerma unos coros que comentan los hechos, o el tema de la

\footnotetext{
${ }^{91}$ La obra Tragicomedia de don Cristóbal y la señá Rosita (1922), aunque comparta personajes con la obra Retablillo de don Cristóbal y doña Rosita, son dos creaciones diferentes entre las que pasan varios años. El único manuscrito que se conserva completo está fechado el 5 de agosto de 1922.

${ }^{92}$ La primera edición apareció en 1927, en Buenos Aires, en la Editorial Anaconda.

93 Tomás, Joan. 1935. «El teatre. L'estrena d'avui al Barcelona. Federico García Lorca parla de "Yerma"». En La Publicitat, Barcelona, 17 de septiembre, 6.
} 
tragedia, que es constantemente el mismo. Fíjese lo que digo: tema. Repito que Yerma no tiene argumento. En muchos momentos al público le parecerá que lo tiene, pero es un pequeño engaño... (citado en Inglada 2017, 393).

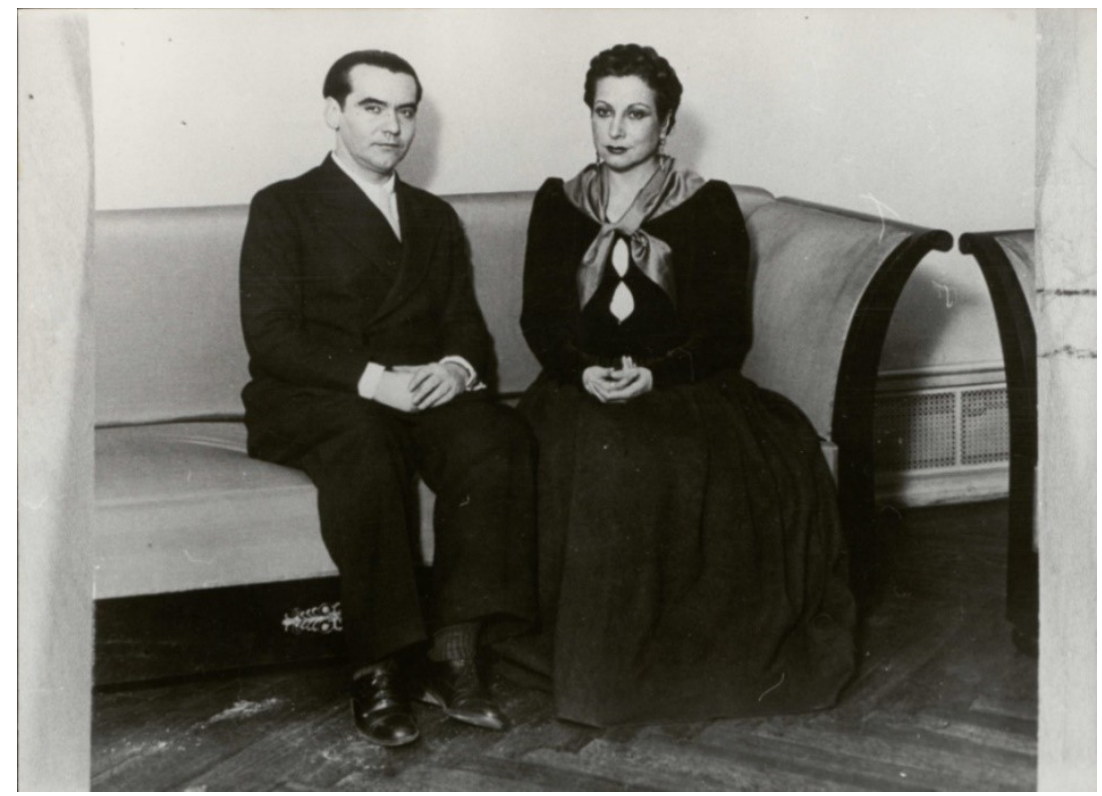

Fig. 31: Fotografía de Federico García Lorca y Margarita Xirgu caracterizada para la tragedia Yerma.

Doña Rosita la soltera o el lenguaje de las flores (1935) poema granadino del novecientos, dividido en varios jardines, con escenas de canto y baile estructurada en tres actos que se sitúan en 1890, 1900 y 1910, fue la última obra estrenada en España antes de la muerte de Federico García Lorca. Se representó con éxito en el teatro Principal Palace de Barcelona, el 12 de diciembre de 1935, por la Compañía Dramática Margarita Xirgu, pero ya no sería puesta en escena en Madrid (Babín 1976, 130), a pesar de que la prensa de Barcelona ya anunciaba el privilegio de que fuera estrenada en esta ciudad antes que en Madrid. Durante la semana después del estreno, aparecen más de veintisiete reseñas y reportajes publicados en la prensa, creando así un ambiente de éxito (Fernández Cifuentes 1986, 213).

Como ya había hecho en otras obras, Bodas de Sangre y La casa de Bernarda Alba, Lorca se inspira en casos, personajes o situaciones surgidos de la realidad, como reconocía, en la entrevista ${ }^{94}$ con Felipe Morales, sobre cuál fue el origen de la comedia:

\footnotetext{
94 Morales, Felipe. 1936. «Conversaciones Literarias: Al habla con Federico García Lorca». En La Voz, Madrid, 7 de abril: 2 .
} 
Mi última comedia, «Doña Rosita, o El lenguaje de las flores», la concebí en el años 1924. Mi amigo Moreno Villa ${ }^{95}$ me dijo una día: «Te voy a contar la historia bonita de la vida de una flor» — “La rosa mutábile”, de un libro de rosas del siglo XVIII-. «Venga.» «Había una vez una rosa...» Y cuando acabó el cuento maravilloso de la rosa, yo tenía hecha mi comedia. Y, sin embargo, no la he escrito hasta 1936 [sic]. Han sido los años los que han bordado las escenas y han puesto versos a la historia de la flor (citado en Inglada 2017, 459).

La rosa mutabilis es una rosa singular que al abrirse es roja, intensifica su color en plena eclosión y va palideciendo según va marchitándose, hasta llegar a ser blanca. Como afirma Antonina Rodrigo:

El argumento lorquiano surgió de la imagen de los tres tiempos de la vida efímera de la rosa. El poeta vio en la historia de la rosa mutabile, como él la llamó, el oscuro drama de la soltería de las muchachas españolas sacrificadas por el medio social que condicionaba el futuro de sus vidas $(1985,34)$.

En Doña Rosita la soltera o el lenguaje de las flores ${ }^{96}$, Lorca nos presenta la situación, en España de finales del siglo XIX, de la mujer de clase media que llega a la madurez sin haber contraído matrimonio. La obra se divide en tres actos y entre cada acto hay un salto de tiempo de diez años, en los que Doña Rosita ve pasar el tiempo esperando a su prometido y un matrimonio que nunca llegará. Lorca recalca la importancia del paso del tiempo y la espera. Vuelve a llevar un pensamiento análogo al de La zapatera prodigiosa:

nuestra individualidad y ansia de soledad libre se ven amenazadas incluso por la presencia de quien nos ama, [...] y en general, por cualquier otra presencia de los demás. Los demás nos hacen ridículos grotescos porque no entienden nuestros sueños ni nuestra identidad personal (Abad Nebot 1996, 123).

En vida, Federico García Lorca sólo había publicado dos de todas las obras teatrales llevadas a escena, Mariana Pineda y Bodas de Sangre. Su fama de autor y director

\footnotetext{
${ }^{95}$ José Moreno Villa era bibliotecario del Palacio Real, miembro de la Generación del 27.

${ }^{96}$ El dramaturgo Pablo Remón aceptó la propuesta de los Teatros del Canal de Madrid de llevar a escena una versión de la obra, para la celebración del Año Lorca (el centenario de la llegada del poeta a la ciudad). Remón reescribe la obra: recorta el texto de Lorca, propone texto nuevo, y la sitúa en la actualidad. La titula Doña Rosita: anotada (Vidales 2019; Ordóñez 2019).
} 
teatral era llevada a los escenarios. Pero sólo hay que observar la mayoría de manuscritos para ver cómo estos eran modificados ${ }^{97}$, corregidos y tachados según iban avanzando los ensayos. Pero obras como La casa de Bernarda Alba ${ }^{98}(1936)$, Así que pasen cinco años (1930), El público (1930), la inacaba Comedia sin título, se estrenaron ya después de la muerte del autor.

\begin{tabular}{|c|c|}
\hline \multicolumn{2}{|c|}{ Clasificación en cuatro grandes grupos } \\
\hline \multirow{3}{*}{ Teatro afín al modernismo } & El maleficio de las mariposa (1920) \\
\hline & Mariana Pineda (1927) \\
\hline & Doña Rosita o el lenguaje de las flores (1935) \\
\hline \multirow{4}{*}{ Teatro de farsa o teatro de títeres } & La tragicomedia de don Cristóbal y la señá Rosita (1922) \\
\hline & El retabillo de don Cristóbal (1928) \\
\hline & La zapatera prodigiosa $(1930)$ \\
\hline & Amor de Don Perlimplín con Elisa en su jardín (1933) \\
\hline \multirow{3}{*}{ La tragedia y el drama rural } & Bodas de sangre (1933) \\
\hline & Yerma (1935) \\
\hline & La casa de Bernarda (1936) \\
\hline \multirow{2}{*}{ Teatro surrealista } & El público (1930) \\
\hline & Así que pasen cinco años (1930) \\
\hline
\end{tabular}

Dentro de la línea vanguardista de Lorca podemos incluir las obras teatrales surrealistas de El público, Así que pasen cinco años, la inconclusa Comedia sin título y las piezas cortas como El paseo de Buster Keaton, La doncella, el marinero y el estudiante y Quimera.

\footnotetext{
${ }^{97}$ José Manuel Blecua, en su discurso «Sobre el rigor poético en España» leído en la recepción de la Real Academia de Buenas Letras de Barcelona, el 14 de diciembre de 1969, afirmará, «los poetas españoles $[\ldots]$ han retocado muchas veces su obra poética con un rigor tan grande como en el resto de Europa, y a veces mucho más $(1977,15)$. Juan Ramón Jiménez, un maestro entre los miembros de la Generación del 27, es conocido por ser un gran perfeccionista y sus numerosas correcciones en su texto. «Su pasión y su fervor por la obra bien hecha es muy perceptible por todos ellos» (Blecua 1977, 38), estas lecciones por el perfeccionismo en la literatura la continuaron los poetas del 27 en los que se observa cómo son numerosas las diferentes ediciones o versiones de una misma obra.

${ }^{98}$ Se representó por primera vez en 1945, por Margarita Xirgu, ya en el exilio, en el Teatro Avenida.
} 


\section{2.- Lorca, director}

Entre las aficiones que tuvo Lorca, no debemos olvidar que, desde niño, se sintió muy atraído por el teatro del guiñol, asistiendo a las pequeñas representaciones que se realizaban en las plazas de su pueblo como, posteriormente, al representarlo en casa como un juego.

Fue un director de escena que debió formarse según iba trabajando, podemos afirmar que fue autodidacta. Según la entrevista realizada por Juan Chabás, en 1934 en el periódico $L u z$, a la pregunta sobre su opinión del trabajo de director respondía:

Es, como todo trabajo que se hace por devoción, alegre. Fatiga, pero con gozo, Y además, a la vuelta de ensayos y experiencia, yo siento que me voy formando como director de escena, formación difícil y lenta. Estoy animado a aprovechar esa experiencia para hacer muchas cosas (García Lorca 1934, 7).

El 14 de abril de 1931, con la proclamación de la Segunda República, la nueva política cultural republicana concebía la educación como una de las vías más importantes para el desarrollo del país. Las tasas de analfabetismo en España eran elevadas (37\% de hombres y $48 \%$ de mujeres) y el nuevo gobierno sintió la obligación de realizar un cambio en las políticas educativas. El teatro se convirtió en uno de los sectores culturales más subvencionados por el Estado. Aunque la situación administrativa del teatro cambió, las renovaciones técnicas y temáticas permanecieron inscritas en los espacios privados y experimentales de las compañías teatrales.

Los rectores de la política cultural en los primeros gobiernos de la República, Marcelino Domingo y Fernando de los Ríos, impulsaron dos grandes proyectos de divulgación teatral: el Teatro del Pueblo, vinculado a las Misiones Pedagógicas (1931), y La Barraca (1932), protagonizado por jóvenes universitarios que tuvieron en Federico García Lorca a su líder de excepción.

Los dos proyectos escénicos tienen un mismo origen, los ideales pedagógicos que había alentado Francisco Giner de los Ríos desde la Institución Libre de Enseñanza, creada en 1876, por un grupo de profesores expulsados de la universidad por defender la libertad de cátedra, entre ellos, Francisco Giner de los Ríos, Gumersindo de Azcárate y Nicolás Salmerón. Su pedagogía impulsaba el estudio de las ciencias y las humanidades y su 
interdisciplinariedad. La Institución Libre de Enseñanza «defendió la igualdad social y de sexos, los derechos de la mujer, la búsqueda de la paz y de la cooperación entre los pueblos o la protección del medio ambiente» (Residencia de Estudiantes 2010a, 43).

En este periodo de los años treinta coinciden dos teatros ambulantes en los escenarios de España, que, aunque tengan un origen común, poseen una pequeña diferencia: el Teatro del Pueblo de la Misiones Pedagógicas tiene una finalidad más pedagógica, mientras que La Barraca es más artística (Díez Taboada 1992, 115).

\section{3.- El Teatro del Pueblo de las Misiones Pedagógicas}

El teatro de las Misiones Pedagógicas estaba dirigido ${ }^{99}$ por Alejandro Casona ${ }^{100}$. El repertorio que se eligió para representar estaba formado por obras cortas del teatro clásico de Juan de la Encina, Lope de Rueda, Cervantes o Calderón de la Barca. Este debía ser sencillo y al alcance del entendimiento de los campesinos. El propio Casona afirmó:

Íbamos a llevar el teatro a los campesinos analfabetos que no sabían lo que el teatro era y que, por tanto, lo veían por primera vez. Por esa razón nuestro repertorio tenía que ser forzosamente más simple, piezas cortas con música y pequeñas danzas. Lo difícil era crear este repertorio que no existía (citado en Díez Taboada 1992, 115).

Alejandro Casona dirigía a un grupo de unos cincuenta jóvenes, estudiantes universitarios. Algunos de estos actores fueron renovándose, porque los estudiantes acababan sus estudios, pero el núcleo inicial se mantuvo estable (Rey Faraldos 1992, 155). El repertorio inicial estaba formado por «una Égloga, de Juan del Encina; La Carátula, El convidado y Las aceitunas, de Lope de Rueda; Los alcaldes de Daganzo y El juez de los divorcios, de Cervantes, y El dragoncillo de Calderón de la Barca»

99 Las Misiones Pedagógicas empezaron a funcionar seis meses después de que Cossío las anunciara (el 13 de agosto de 1931). Antonio Machado sugirió para dirigirla a Rafael Marquina, que estuvo poco tiempo a su frente; quien se hizo cargo definitivamente fue Alejandro Casona.

100 Alejandro Casona (Besullo - Cangas del Narcea [Asturias] 1903, Madrid, 1965) dramaturgo de la Generación del 27, emparentado con el teatro poético. Entre sus obras más reconocidas encontramos $L a$ sirena varada (1934) pieza antinaturalista, estrenada el 17 de marzo de 1934 en el Teatro Español por la compañía de Enrique Borrás y Margarita Xirgu. 
(Bilbatúa 1976, 31). Junto con el teatro también actuaba un coro, dirigido por Eduardo Martínez Torner, que llevaba un repertorio musical integrado de canciones populares y romances que se alternaban entre las representaciones. Y, de este modo, se intercambiaban los recitales de coro con las obras de teatro (Otero Urtaza 2008, 217).

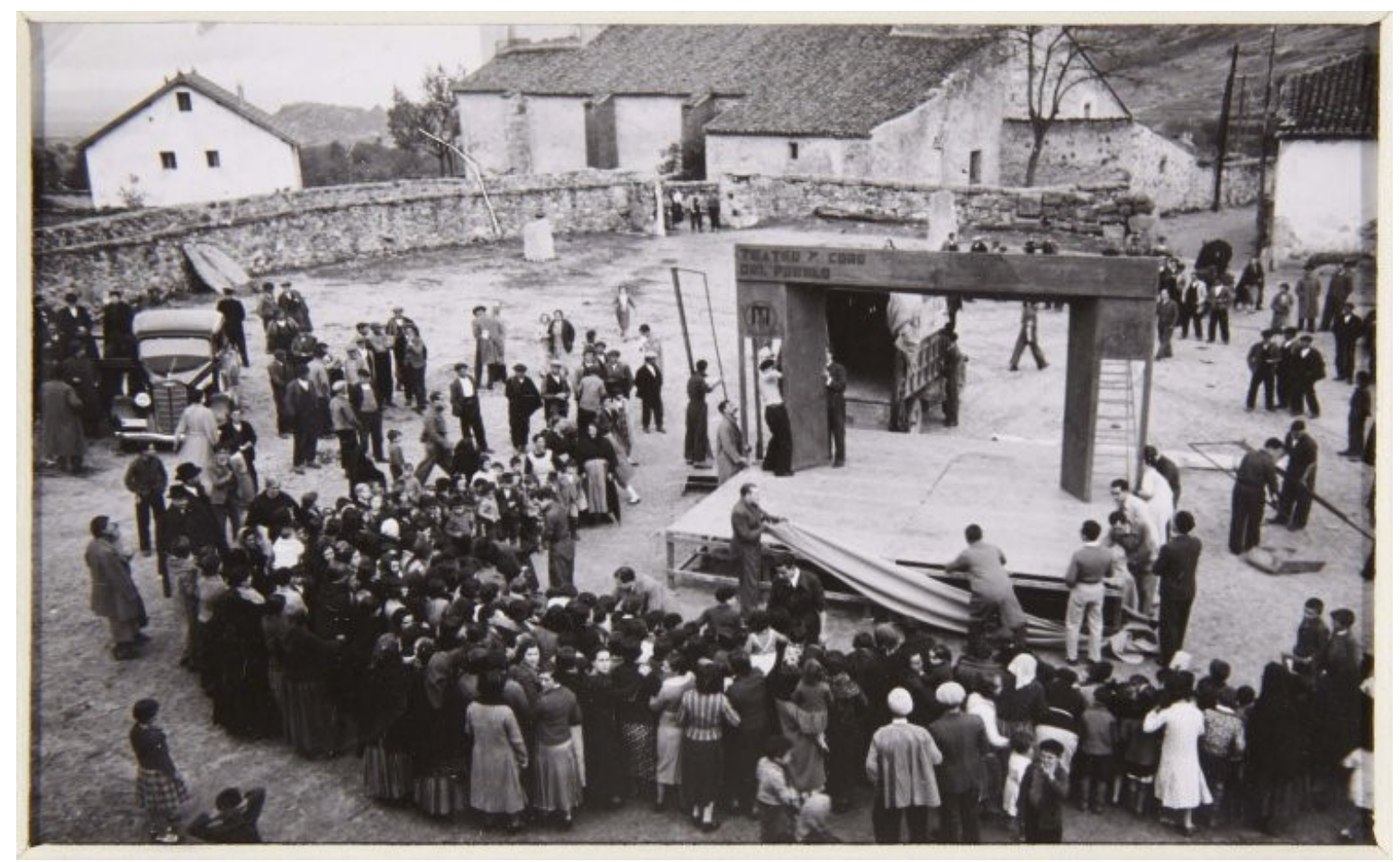

Fig. 32: Fotografía ${ }^{101}$ del montaje de escenario. Misiones Pedagógicas, 1934 (ca.) Impresión fotomecánica sobre papel fotográfico, 9 x 13,6 cm.

En la prensa del momento se pudo apreciar críticas del buen trabajo de estas misiones, según afirmaba Gonzalo Rodríguez Lafora en su artículo «Misiones Pedagógicas. Los titiriteros de Esquivias»:

Una compañía de jóvenes estudiantas y estudiantes entonan antiguas canciones y representan entremeses de Lope de Rueda y de Cervantes. Son las Misiones Pedagógicas organizadas por el ministerio de Instrucción Pública para llevar a los rincones sórdidos de la nación la esperanza, la alegría del provenir y el arte de nuestros antepasados.

El pueblo está encantado de que alguien, allá en la capital, se acuerde de ellos. [...] Dan [...] cultura gratuita en forma artística y agradable $(1932,3)$.

\footnotetext{
${ }^{101}$ La copia se encuentra en el Museo Nacional Centro de Arte Reina Sofía, en depósito temporal cedido por el Museo Nacional del Teatro de Almagro desde 2012.
} 
Los útiles del teatro se trasladaban en un camión, y en ocasiones llegaban a actuar, dos veces en el mismo día, en pueblos diferentes. El radio de acción era limitado ya que no siempre se podía llegar a todos los lugares, porque muchas de las aldeas carecían de acceso por carretera. Los actores al ser estudiantes no siempre estaban disponibles, ello limitaba las actuaciones a fines de semana o periodos vacacionales.

El Patronato pensó organizar «un teatro de guiñol que tuviera un cometido semejante. Y aquí apareció en escena Rafael Dieste, que lo estrenó en Malpica (A Coruña) y luego en A Fonsagrada (Lugo)» (Otero Urtaza 2008, 219). Rafael Dieste se convirtió en el director de la compañía del Teatro de Guiñol. El 20 y 21 de octubre de 1933, en el curso de una Misión realizada en Galicia, tuvo lugar la primera actuación de este teatro. Esta alternativa era menos costosa económicamente y podían acceder a cualquier lugar ya que era de fácil transporte (Rey Faraldos 1992, 159). El guiñol tenía una cualidad extra, ya que los campesinos no desconfiaban y de inmediato surgía una simpatía que no se conseguía con los misioneros ya que estos, al ser estudiantes universitarios y venir de la ciudad, suscitaban suspicacias entre el campesinado.

El cine era lo que más impresionaba a los campesinos, de los treinta y seis aparatos de proyección sólo dos de ellos eran sonoros. Otro servicio que resultó una novedad extraordinaria fue el Museo circulante de pintura, en el que se exhibían unas magníficas copias de cuadros del Museo del Prado realizadas, entre otros, por Ramón Gaya, Eduardo Vicente y Juan Bonafé (Otero Urtaza 2008, 220).

\subsection{1.- Las Misiones Pedagógicas}

Las Misiones Pedagógicas fue un proyecto pedagógico patrocinado por el gobierno de la Segunda República y por la Institución Libre de Enseñanza. El primer intento por parte de Francisco Giner de los Ríos y Manuel Bartolomé Cossío de crear las Misiones Pedagógicas acaeció en 1881. Ambos tenían claro que para transformar a España se debía eliminar el abismo que existía entre las ciudades y el mundo rural.

El Patronato de Misiones Pedagógicas fue creado por el primer gobierno de la República, según decreto de 29 de mayo de 1931 y publicado en la Gaceta el día 30 del 
mismo mes, dependiente del Ministerio del Instrucción Pública y Bellas Artes. Tenía un triple objetivo: el fomento de la cultura general, la orientación pedagógica de las escuelas rurales y la educación ciudadana (Otero Urtaza 2008, 213-214; Díez Canedo $1938,47)$.

Manuel Bartolomé Cossío fue nombrado Presidente de las Misiones Pedagógicas, quien, desde la muerte de Giner en 1915, se encargó de dirigir la Institución Libre de Enseñanza. Para organizar las actividades se rodeó de un grupo de intelectuales, entre ellos Antonio Machado, Pedro Salinas, Luis Bello, Rodolfo Llopis, Oscar Esplá que formaron parte de la Comisión Central del Patronato (Otero Urtaza 2008, 214; Rey Faraldos 1992, 154).

Las Misiones, más que una escuela ambulante, eran un encuentro para divertirse: maestros, profesores, artistas e intelectuales participaron en las Misiones Pedagógicas. Como afirma Otero Urtaza,

Los misioneros no iban a instruir, ni a realizar campañas de alfabetización o higienismo, tampoco eran enviados para sustituir o complementar la labor que hacía la escuela, sino que su objetivo era, como el propio Cossío afirmaba, todo lo demás, aquello que no se atiene a ninguna receta académica o docente, todo saber «sin preocupación de profesionalidad» $(2008,216)$.

Era la primera vez en España que la base de la enseñanza de una escuela de primaria se basaba en la ciencia y el conocimiento racional, en vez de en los dogmas religiosos. Inician su actividad inmediatamente. La primera Misión tuvo lugar en el pueblo segoviano de Ayllón del 16 al 23 de diciembre de 1931. Hasta el 15 de marzo de 1934 se llegan a realizar setenta misiones y se visitaron 298 pueblos (Díez Canedo 1938, 47), en su mayoría en comarcas castellanas y leonesas, pero el Patronato quería llegar a todos los pueblos y comunidades de España. 


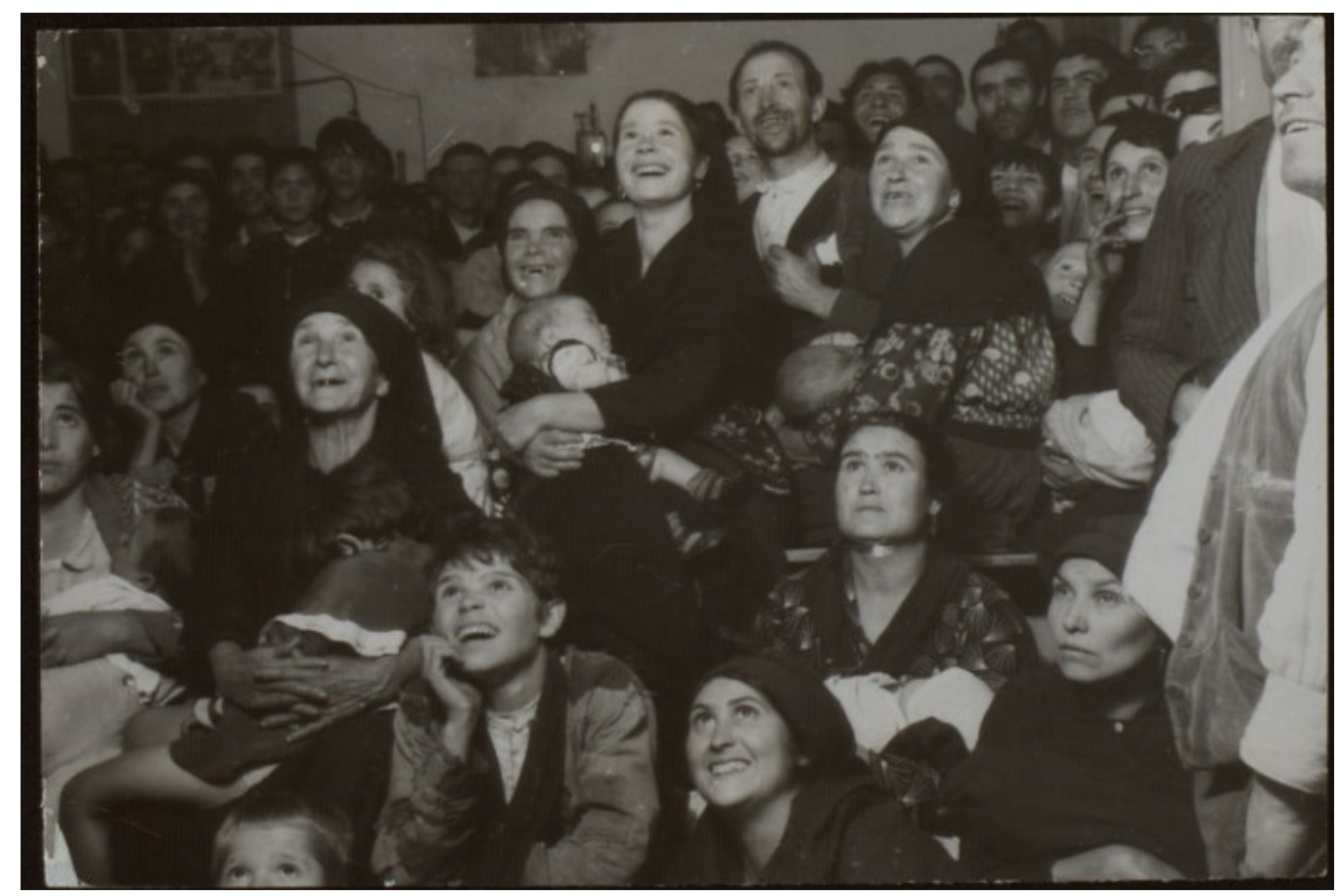

Fig. 33: Fotografía tomada en el transcurso de las Misiones Pedagógicas por José Val del Omar (entre 1932 y 1936). Papel gelatina, 10,2 x 15, $3 \mathrm{~cm}$.

En sus cinco años de existencia, se crearon 5.522 bibliotecas, por las diferentes aldeas, ubicadas generalmente en escuelas o en locales a propósito como fueron asociaciones obreras y culturales, regimiento militares y prisiones, entre otros (Otero Urtaza 2008, 215-218). El aprendizaje en las Misiones Pedagógicas fue recíproco, supuso la irrupción de la modernidad en el mundo rural $\mathrm{y}$, a la vez, los propios misioneros descubrieron unos valores que había que acoplar a la cultura de las ciudades.

\section{4.- El teatro universitario: La Barraca}

En abril de 1931, con el cambio de régimen político ${ }^{102}$, en un grupo de estudiantes de la Universidad de Madrid surgió la idea de crear un teatro universitario dedicado a divulgar por los rincones más perdidos de Castilla las obras del teatro del Siglo de Oro: Cervantes, Lope de Vega, Tirso de Molina, Calderón de la Barca...

${ }^{102}$ El 14 de abril de 1931 se proclama la segunda República, que representó un momento de esplendor cultural e intelectual en España, hasta el 18 de julio de 1936. 
El 15 de diciembre de 1931, fue nombrado ministro de Instrucción Pública y Bellas Artes Fernando de los Ríos ${ }^{103}$ quien prestó un firme y decidido apoyo al proyecto: la creación de un teatro transportable con capacidad para cuatrocientos espectadores que se representara por las ciudades y los pueblos de España. Formado por una compañía ambulante, integrada por jóvenes aficionados universitarios. Como afirmaba Rafael Rodríguez Rapún, miembro de La Barraca:

En las reuniones habidas para confeccionar el proyecto que habría de elevarse al gobierno, solicitando su ayuda económica, se pensó en instalar en Madrid una barraca desmontable que funcionara durante el invierno. Se darían representaciones de pago y gratuitas. Estas para los obreros y aquellas para personas previamente abonadas y que constituirían los que podríamos llamar amigos de "La Barraca". Con los fondos recaudados y la ayuda material del Estado esta barraca recorrería durante el verano pueblos y ciudades de España dando representaciones $(1935,275)$.

Pero este proyecto requería personas que se dedicaran en exclusiva, siendo incompatible alternar esta labor con las tareas académicas. También la instalación ${ }^{104}$ de una barraca en Madrid para representar teatro por unos actores no profesionales implicaba un problema de intromisión en el campo profesional. Por su parte, la Universidad se despreocupó del problema.

Se desechó este proyecto con arreglo a los medios disponibles y, en noviembre de 1931, en el II Congreso Ordinario de la Unión Federal de Estudiantes Hispanos (UFEH) ${ }^{105}$, se nombró una comisión de Teatro Universitario, donde Federico García Lorca defendió su nuevo proyecto (Huerta Calvo 2011, 24). La UFEH pediría al gobierno una subvención

${ }^{103}$ En el discurso pronunciado el 23 de marzo de 1932, en la sesión de Cortes por el presupuesto de Instrucción Pública, se puede observar cómo muestra un claro apoyo al proyecto de La Barraca:

va a ir por las aldeas, y construirá su barraca, y divertirá noblemente al pueblo. ¿Es que a eso hay quien pueda ponerle ni siquiera el reparo de la oportunidad? Pero ¿es que nosotros no queremos dar la sensación de un despertar de colaboración de clases, de fraternidad entre hombres? ¿Es que cuando el otro día han ido los estudiantes de la Universidad de Madrid, constituyendo una orquesta, por pueblos y aldeas de Levante, no han hecho una obra enormemente educativa al presentarse allí precisamente para divertir a los hombres del pueblo noblemente? (Ríos 1932, $11)$.

${ }^{104}$ Lorca, en una entrevista realizada por Enrique Moreno Báez, dirá: «Al principio pensamos abrir en Madrid una barraca, para dar en ella representaciones, y después, «La Barraca» se ha seguido llamando, hasta que nos encariñamos con el nombre» (citado en Soria Olmedo 2017, 59).

${ }^{105}$ Fundada en la etapa final de la dictadura de Primo de Rivera, la Unión Federal de Estudiantes Hispanos defendía las libertades y los derechos de los universitarios. 
para crear un teatro integrado exclusivamente por estudiantes que darían representaciones por pueblos y ciudades aprovechando las vacaciones. El gobierno accedió a la solicitud y concedió una subvención anual de 100.000 pesetas ${ }^{106}$ (Rodríguez Rapún 1935, 276).

El 2 de diciembre de 1931, Federico García Lorca concede una entrevista a V. S. (posiblemente se trate del escritor y periodista Víctor de la Serna) en el periódico El Sol en la que afirmaba que estaba perfilando los últimos retoques de un nuevo proyecto formado por

el teatro de la F.U.E. de la Universidad de Madrid. Los estudiantes van a lanzarse por todos los caminos de España a educar al pueblo. Sí, a educar al pueblo con el instrumento hecho para el pueblo, que es el teatro y que se le ha hurtado vergonzosamente. Los estudiantes de Arquitectura harán «La Barraca» y los de Filosofía colaborarán con el grupo de poetas ${ }^{107}$ del Comité directivo en la dirección literaria del teatro $(1931,1)$.

En 1932, el Teatro Universitario La Barraca fue fundado por Federico García Lorca con criterios de renovación tanto en los textos para representar como en la concepción escénica, según afirma Peláez Martín:

La Barraca tenía un sentido de vanguardia, de ideario didáctico y de imagen cultura basada en la universalidad de valores que hasta entonces podían ser considerados de localistas. Sin duda la atmósfera de libertad y apertura generada dentro de este fenómeno incidió notablemente en la concepción de la escenografía quitando cualquier obstáculo a su ambición $(2000,103)$.

\footnotetext{
${ }^{106}$ En un principio, la subvención fue de 100.000 pesetas, que más tarde se redujo a 50.000 pesetas pero con el cambio de gobierno, el 19 de noviembre de 1933, está subvención se suprimiría al año siguiente. El propio Lorca lo explicaba en una entrevista realizada por Silvio d'Amico en septiembre de 1935: «En un principio, de una subvención del gobierno de cien mil pesetas al año, para treinta personas más los decorados, los atrezos, los trajes y la gasolina para los viajes. Un buen día la subvención se redujo a cincuenta mil pesetas. Ahora, el nuevo gobierno nos la ha suprimido» (citado en Soria Olmedo 2017, 132).

${ }^{107}$ En la misma entrevista, Lorca enumera los diferentes poetas que formaban el proyecto, entre los que se encontraban el propio Federico García Lorca, Vicente Aleixandre, Manolo Altolaguirre y Luis Cernuda.
} 


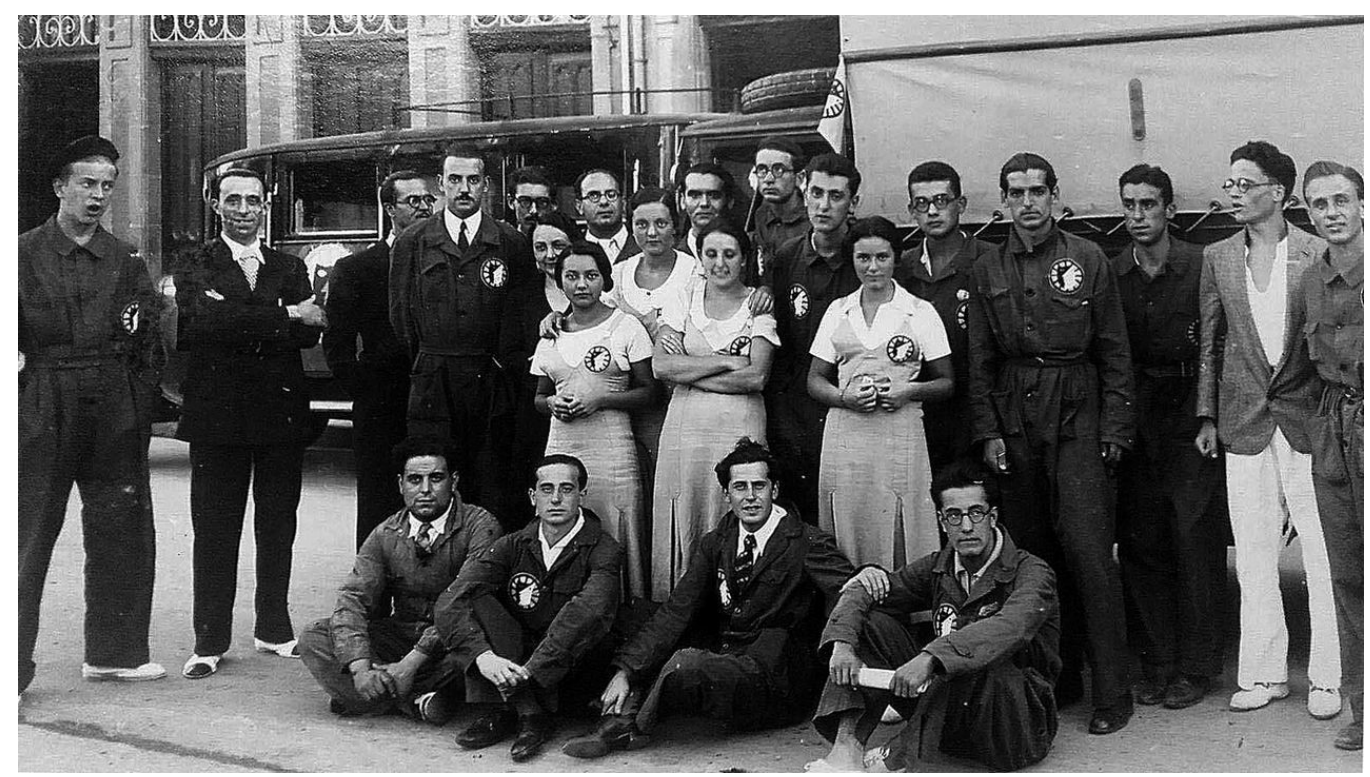

Fig. 34: Federico García Lorca con La Barraca durante su segundo itinerario (A Coruña, agosto de 1932).

Fotografía de Cancelo. Colección particular (A Coruña).

El 6 de junio de 1932, dieron comienzo los ensayos de La Barraca en el Auditorium de la Residencia de Estudiantes. Fueron numerosos los estudiantes de la Universidad Central de Madrid que se presentaron a la convocatoria para actores. En la selección de estos se encontraban Eduardo Ugarte y Federico García Lorca, con el consejo de los catedráticos Pedro Salinas y Américo Castro (Huerta Calvo 2011, 39).

Los estudiantes ${ }^{108}$ debían aprender sus papeles y procurar ser buenos actores, pero como expone Antonio Campoamor González,

las disponibilidades económicas del grupo, pese a la subvención recibida, eran tan escasas que su labor no podía limitarse a eso sólo, y ellos mismos, además de maquillarse, caracterizarse y representar, debían desempeñar todos los cometidos: cargar y descargar cestos y atrezzos de los camiones, montar y desmontar los caballetes y el tablado, levantar el tinglado del escenario, colocar las cortinas y los telones de fondo, instalar los focos y las luces, hacer de tramoyistas, conducir los camiones y las furgonetas, cuidar el equipaje y trabajar como administrativos (1986, 785-786).

\footnotetext{
${ }^{108}$ Los estudiantes, conocidos como los barracos, eran reclutados mayoritariamente en las aulas de la Universidad Central de Madrid. Los actores de La Barraca compaginaron sus estudios con la dedicación al teatro.
} 
Los objetivos de La Barraca eran llegar a los lugares más recónditos de España y mostrar las obras más populares del teatro clásico español en las plazas de las ciudades y de los pueblos. Como afirma Carlos García, se trataba de «un teatro estudiantil universitario, ambulante y misionero, encargado de llevar las grandes obras dramáticas castellanas a los auditorios más rústico y abandonados de campos y aldeas» $(2009,398)$.

El 7 de diciembre de 1933, Federico García Lorca publicó en el Heraldo de Madrid las bases del reglamento del teatro universitario La Barraca. Para llevar a cabo el proyecto se contó con un camión y dos furgonetas que transportarían los decorados, el atrezo, los focos y el vestuario. Y un autobús para los actores:

Se construyó un tablado de madera de 8 por 6 y $1,30 \mathrm{~m}$. de altura y los elementos necesarios para montar un escenario en plazas de los pueblos. Se adquirió una camioneta $^{109}$ para trasladar el material y el día 10 de julio de 1932 se efectuó la primera salida para recorrer unos pueblos de la provincia de Soria con el siguiente repertorio: Auto sacramental de "La Vida es Sueño", Calderón. Figurines y decorado: Benjamín Palencia. "La Guardia Cuidadosa", "La Cueva de Salamanca” y "Los Dos Habladores", entremés de Cervantes, con decorados y trajes por Ponce de León, Ontañón y Gaya, respectivamente (Rodríguez Rapún 1935, 276).

Benjamín Palencia se encargó de dibujar el boceto que representaría el emblema del grupo La Barraca: la máscara y la rueda. Se escogió el uniforme que llevarían los miembros del grupo: «para ellos, el mono azul de mecánico, y para ellas, falda del mismo color y blusa blanca, sobre los que destacaría el emblema diseñado por Palencia» (Campoamor González 1986, 786). El mono azul de los miembros del grupo contribuía a resaltar el carácter de trabajadores de la cultura.

La colaboración en la realización plástica estuvo a cargo de José Caballero, Manuel Ángeles Ortiz, Santiago Ontañón, Norah Borges, Alberto Sánchez, Ramón Gaya y Alfonso Ponce de León, quienes crearon los decorados y los figurines y resolvieron los posibles problemas en la puesta en escena (Rodríguez Rapún 1935, 277). Gonzalo Menéndez-Pidal era el encargado de la instalación eléctrica y de las luces escénicas y también de recoger con su cámara de cine las imágenes de La Barraca en movimiento.

\footnotetext{
${ }^{109}$ La camioneta, a la que Federico García Lorca bautizó con el nombre de «La Bella Aurelia», pues el chófer que la conducía se llamaba Aurelio Romero.
} 


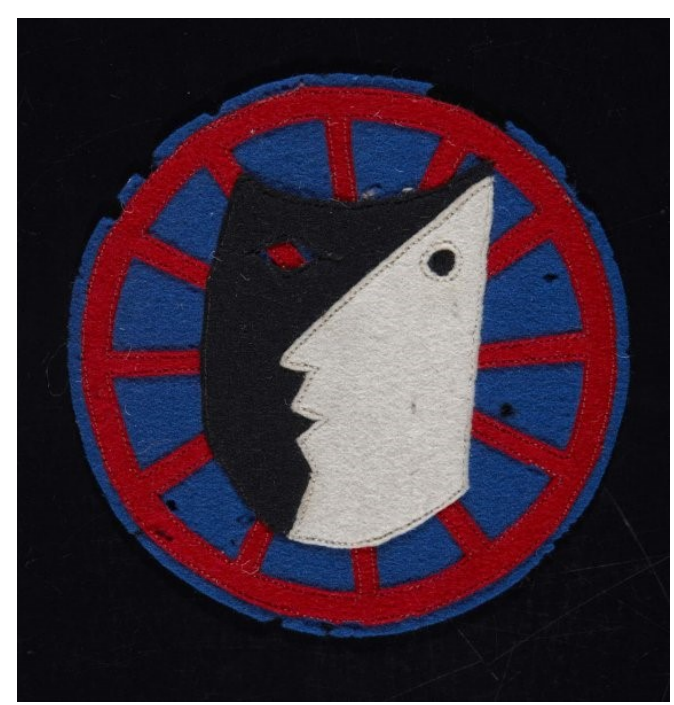

Fig. 35: Insignia ${ }^{110}$ de La Barraca 1931 (ca.) Filtro, diámetro: $11,5 \mathrm{~cm}$.

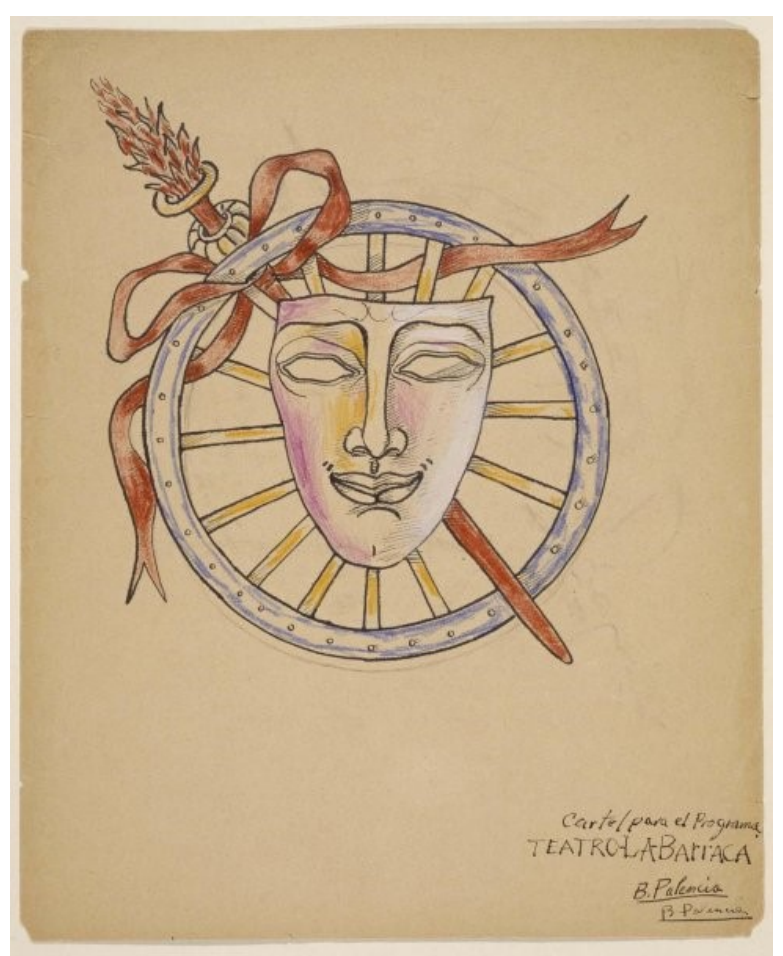

Fig. 36: Máscara ${ }^{111}$. Cartel de La Barraca (1932)

Tinta, cera y grafito sobre papel, $30 \times 24,3 \mathrm{~cm}$.

La Universidad Central de Madrid fue la cantera de la que salieron los actores de $L a$ Barraca, y era lógico que su presentación en sociedad tuviera lugar ante sus profesores y estudiantes. Fue el 30 de octubre de 1932, después de visitar varias localidades ${ }^{112}$, cuando La Barraca representó el auto sacramental La vida es sueño de Pedro Calderón de la Barca en el viejo Paraninfo de San Bernardo y en presencia del rector don Claudio Sánchez Albornoz (Huerta Calvo 2011, 60-63). La puesta en escena del auto sacramental fue ilustrada con la partitura de Julián Bautista, que interpretó la Orquesta universitaria bajo la dirección del maestro Rafael Benedito Vives.

El 8 de noviembre de 1933, apareció en la página internacional del periódico cultural Comoedia, una entrevista realizada por Georges Lorant-Brienë, en la que Federico García Lorca se sorprendió al comprobar que el entrevistador no conociera ni el uniforme (el mono azul) de La Barraca ni su teatro ambulante, y realizó la oportuna explicación:

\footnotetext{
${ }^{110}$ La copia se encuentra en el Museo Nacional Centro de Arte Reina Sofía, en depósito temporal cedido por la Fundación Federico García Lorca, desde 2015.

${ }^{111}$ La copia se encuentra, en depósito, en el Museo Nacional Centro de Arte Reina Sofía desde 1993.

${ }^{112}$ La primera función de La Barraca tuvo lugar, el 10 de julio de 1932, en la plaza del pueblo de Burgo de Osma. El grupo universitario siguió viaje a San Leonardo, Vinuesa, Soria, Ágreda y Almazán.
} 
El emblema que llevamos en el traje, compuesto por una rueda y una máscara. Es la insignia de «La Barraca». Es una institución creada y subvencionada por el Ministerio de Instrucción Pública, para hacer posible mostrar al pueblo los clásicos españoles, en particular Cervantes, Calderón y Lope de Vega.

Los estudiantes dan las representaciones. [...] Es por tanto un teatro de universitarios y ellos no tienen pretensiones artísticas [...].

El espectáculo va destinado a todos, tanto a los adultos como a los niños, por más en particular a los trabajadores, lo que no han tenido nunca tiempo de dejar sus ocupaciones para ir a instruirse o a divertirse, a quienes no han ido nunca a la escuela $[\ldots]$.

No se trata de pedirles asimilación [...]. Queremos mostrarles cosas bellas para darles el gusto por lo bello (citado en Soria Olmedo 2017, 169-170).

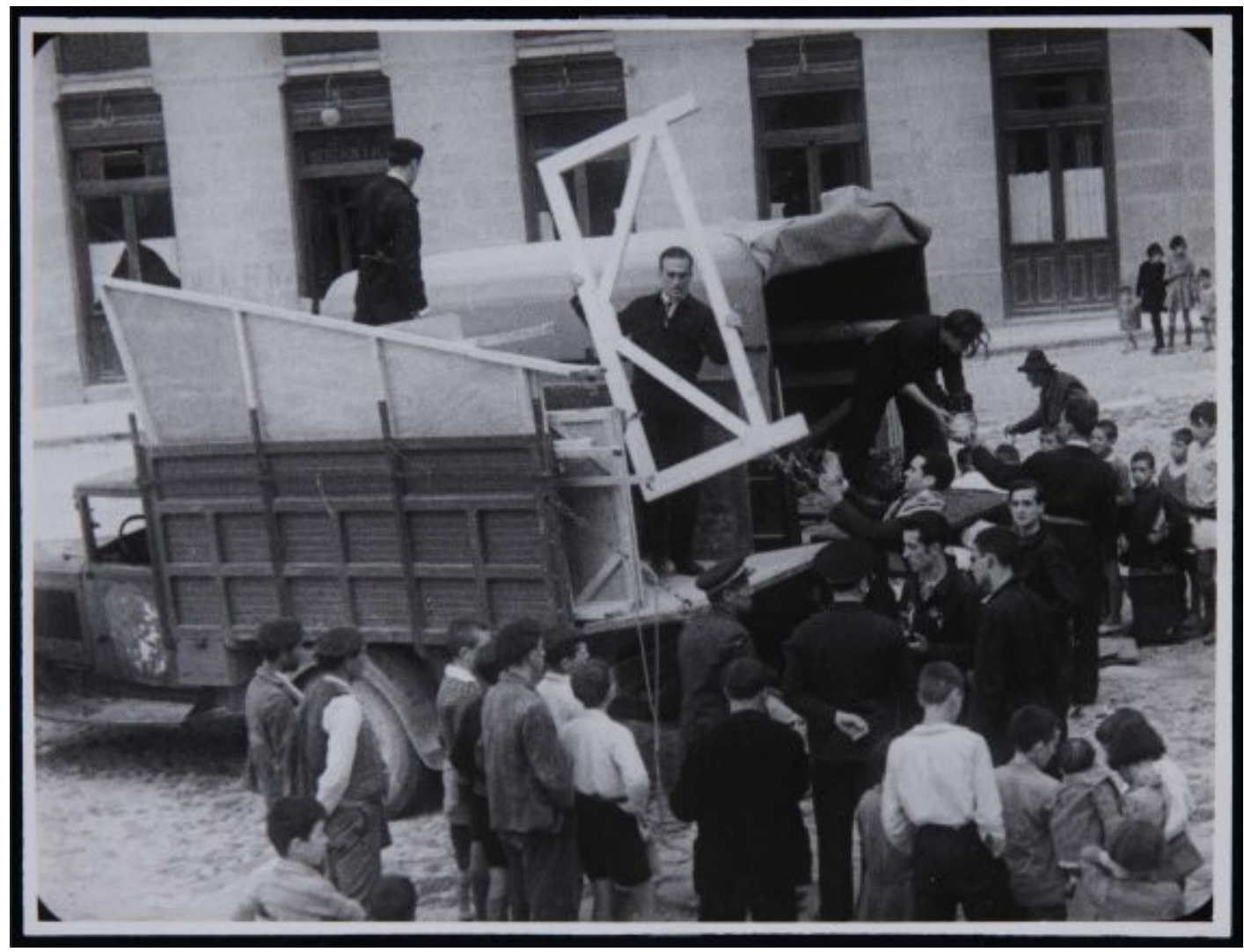

Fig. 37: Fotografía ${ }^{113}$ del montaje del escenario por los componentes de La Barraca para la representación de La guarda cuidadosa de Miguel de Cervantes, en Almazán, Soria. 1932 (julio) / Copia posterior. Gelatinobromuro de plata sobre papel, 12,4 x 16,4 cm. Anónimo.

${ }^{113}$ La copia se encuentra en el Museo Nacional Centro de Arte Reina Sofía en depósito temporal, cedido por la Fundación Federico García Lorca desde 2012. 
El 28 de enero de 1934, en una entrevista publicada en La Nación de Buenos Aires y realizada por Octavio Ramírez, Lorca expondrá su opinión sobre el proyecto de este Teatro para el Pueblo:

La Barraca para mí es toda mi obra, la obra que me interesa, que me ilusiona más todavía que mi obra literaria, como que por ella muchas veces he dejado de escribir un verso o de concluir una pieza, entre ellas Yerma, que la tendría ya terminada si no me hubiera interrumpido para lanzarme por tierras de España, en una de esas estupendas excursiones de «mi teatro». Digo mío, aunque no lo dirijo solo. Compartimos dirección con Eduardo Ugarte [...]. Pero la verdad es que el que dirige soy yo, y Ugarte es mi control. Yo hago todo; él lo observa todo y me va diciendo si está bien o mal, y yo siempre hago caso a su consejo, porque sé que siempre es acertado. Es el crítico que necesita todo artista lleva consigo (citado en Sánchez 1999, 446).

Lorca tenía la idea de internacionalizar su proyecto. En los meses de marzo y abril de 1934, La Barraca emprendió rumbo por varias ciudades del norte de África: Ceuta, Melilla, Tetuán y Tánger con la que se representarían los Entremeses y Fuenteovejuna (Huerta Calvo 2011, 89; Sánchez García 2012, 207). En la entrevista concedida, en septiembre de ese mismo, a Juan Chabás, para el periódico Luz de Madrid, Lorca expone las posibilidades de continuar el proyecto fuera de las fronteras de España:

Jean Prévost dice que no ha visto por Europa ningún teatro universitario mejor. Ha causado tanto entusiasmo, que este invierno iremos a París. Allí inauguraremos el Colegio Español y daremos varias representaciones. También Ezio Levi, profesor de la Universidad de Nápoles, quiere que vayamos a Italia $(1934 b, 6)$.

El 13 de agosto de 1934, un día duro emocionalmente ya que fue el mismo día en que muere el torero Ignacio Sánchez Mejías ${ }^{114}$ en Madrid, tras haber sido herido por el toro "Granadino" el día 11. La Barraca pone en escena Égloga de Plácida y Vitoriano de Juan del Encina, en el marco de la Universidad Internacional de Santander con motivo de los cursos de verano (García 2009, 347-348). El diseño del vestuario estuvo a cargo de Norah Borges, según afirma Plaza Chillón:

\footnotetext{
114 En el documental, García Lorca: toreando las estrellas, se puede ver la relación del poeta con la tauromaquia y la generación del 27. Y la creación del poema «Llanto por Ignacio Sánchez Mejías» por la muerte de su amigo. El documental fue emitido por televisión, el 23 de diciembre del 2018, en la 2. Se encuentra disponible a la carta en la página de rtve http://www.rtve.es/alacarta/videos/otrosdocumentales/otros-documentales-garcia-lorca-toreando-estrellas/4907888/
} 
todos los figurines, cuando se convirtieron en vestidos fueron realizados a base de brocados y rasos, lo que suponía una gran riqueza estética y visual. Los trajes de Norah Borges, cosidos por la sastra de "La Barraca", fueron muy elogiados por la crítica, en muchas referencias sobre sus actuaciones, pero especialmente cuando el grupo acudió en agosto de 1934 a Santander (citado en García 2009, 349).

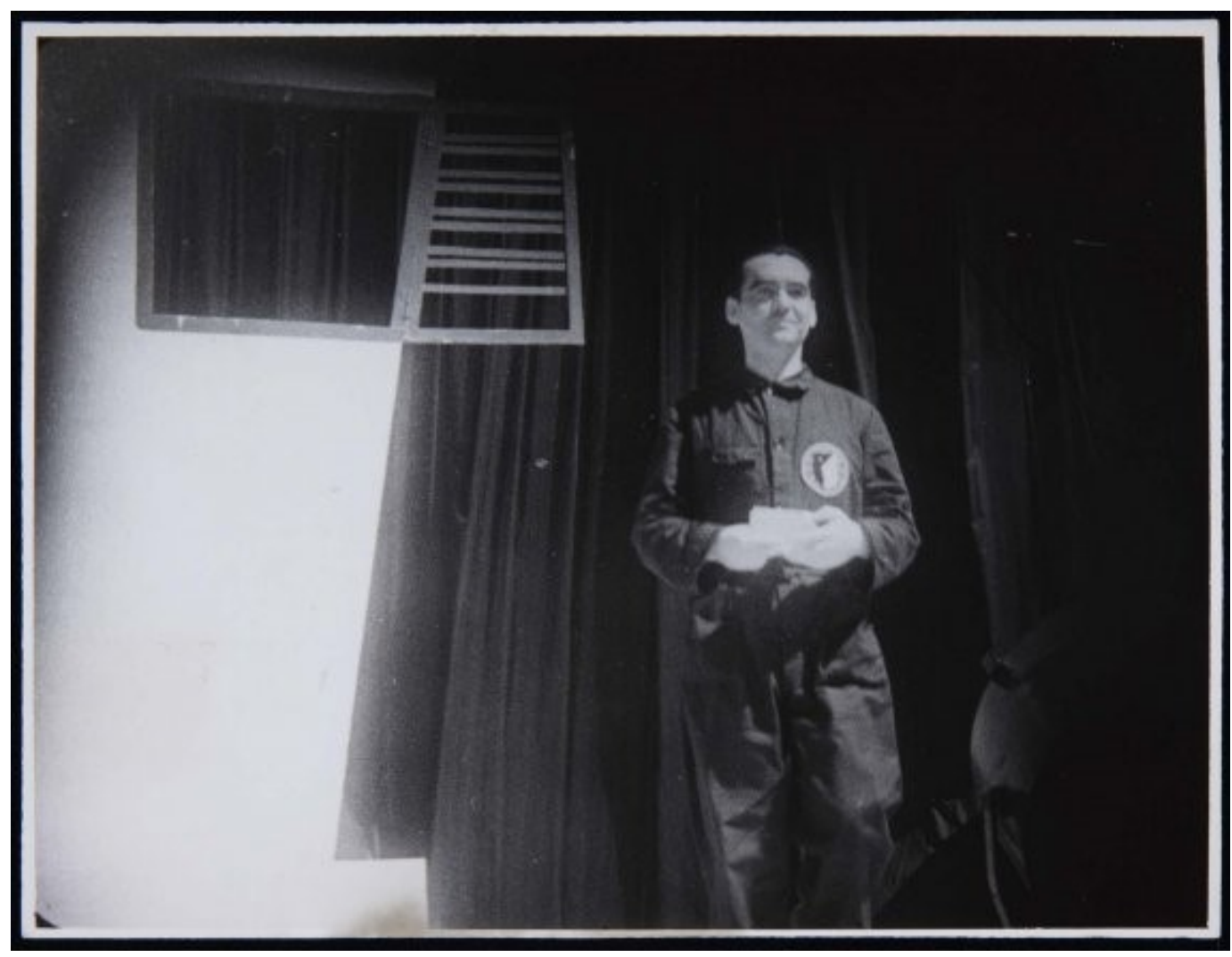

Fig. 38: Fotografía ${ }^{115}$ de Federico García Lorca leyendo un texto antes de la representación por $L a$ Barraca de La guarda cuidadosa de Miguel de Cervantes, Almazán, Soria.1932 (julio). Copia de época.

Gelatinobromuro de plata sobre papel, 12,5x 16,2 cm. Anónimo.

Tras casi cuatro años de intensa actividad, Lorca va soltando amarras de su tan querida Barraca. Una serie de causas diversas - consagración como dramaturgo, los cada vez más numerosos compromisos, la incomprensión de los políticos de turno- lo van distanciando del proyecto. En agosto de 1935, Margarita Xirgu le encarga el arreglo de La dama boba, y Lorca va delegando responsabilidades en su fiel Ugarte y en el cada vez más activo Luis Sáenz de la Calzada. A pesar de todo, Lorca nunca se quitaría del todo el mono azul de La Barraca (Huerta Calvo 2011, 100).

\footnotetext{
${ }^{115}$ La copia se encuentra en el Museo Nacional Centro de Arte Reina Sofía, en depósito temporal, cedida por la Fundación Federico García Lorca desde 2012.
} 
Lorca había encontrado en La Barraca la posibilidad de dar un giro en los planteamientos teatrales que habían dominado en la escena española hasta entonces. Mediante la compañía ambulante, quería devolver el teatro al pueblo y veía con esta democratización del teatro una vía alternativa a la escena estable imperante. Fueron sesenta y cuatro los pueblos y ciudades por los que pasó La Barraca, y en la gran mayoría de sus representaciones obtuvo un éxito de crítica y público (Sánchez García 2012, 211).

\title{
4.4.1.- La Residencia de Estudiantes
}

El 6 de mayo de 1910 por Real Decreto se funda la Residencia de Estudiantes ${ }^{116}$, en el que el Ministro de Instrucción Pública y Bellas Artes, Álvaro Figueroa, justificaba la necesidad de crearla:

\begin{abstract}
En los órdenes superiores de la enseñanza de España, nos preocupamos casi exclusivamente de la parte instructiva de los escolares, pero nada o muy poco de la parte que pudiéramos llamar educativa propiamente tal, es decir, de la que afecta a la formación de carácter, a las costumbres, a la cortesía en el trato social, a la tolerancia y respeto mutuos (citado en Abella 2010, 7).
\end{abstract}

El 1 de octubre abre sus puertas en Madrid, creada por la Junta para Ampliación de Estudios e Investigaciones Científicas (JAE), dirigida por Alberto Jiménez Fraud, e inspirada por la Institución Libre de Enseñanza (ILE) (Residencia de Estudiantes 2010a). Fue uno de los núcleos principales de modernización científica, educativa y social entre 1910 y 1936 y formaba parte del proyecto impulsado por la Institución Libre de Enseñanza. Como afirma Sánchez Vidal, «constituía un meditado programa educativo que había aflorado desde los márgenes del sistema político de la Restauración hasta su mismo núcleo, con el objetivo de dotar a España de un lugar de encuentro interdisciplinar similar a los colleges ingleses» $(188,36)$. No sólo se proponía facilitar

\footnotetext{
${ }^{116}$ María Maeztu era la directora de la Residencia de Señoritas, creada en 1915 e instalada en los números 28 y 30 de la calle Fortuny. La Residencia fue pionera en fomentar el acceso a las mujeres a los estudios superiores. Así como la Residencia de Estudiantes tenía inspiración de las universidades inglesas, la de Señoritas estaba más influenciada por el modelo norteamericano. Entre sus residentes se encontraban Victoria Kent, Matilde Huici o Josefina Carabias.
} 
alojamiento a los estudiantes acomodados, sino formar a una vanguardia intelectual educada en la cultura, la libertad y el conocimiento.

En un principio (1910), inició su andadura en un pequeño edificio situado en la calle Fortuny, 14 de Madrid, en su inauguración tenía quince habitaciones. Entre los primeros residentes se encontraban Jorge Guillén, Miguel Prados y Pere Bosch Gimpera. En 1912, la Residencia amplía su espacio, ocupando el chalet número 10 de la misma calle, y ya contaba con cincuenta alumnos. Al año siguiente, ocupan cuatro hoteles contiguos (del número 8 al 14 de la calle Fortuny). El 11 de agosto de 1913, por real decreto, se autoriza la construcción de los nuevos edificios de la Residencia en los Altos del Hipódromo (Abella 2010, 8-9).

En 1915, la Residencia definitiva —correspondiente al período entre 1915 y 1936 - se traslada y se ubicó en la calle Pinar, 7 (en la actualidad el número 21), casi en pleno campo. Fue Juan Ramón Jiménez quien bautizó el lugar con el nombre de Colina de los Chopos debido a los que bordeaban sus jardines. Tanto la primera sede residencial como la segunda y definitiva se situaban en el norte de Madrid, en áreas no céntricas (Pérez-Villanueva Tovar 1990, 81). En la anterior sede de la calle Fortuny se instala la Residencia de Señoritas, muestra del cambio en la situación social de la mujer en España.

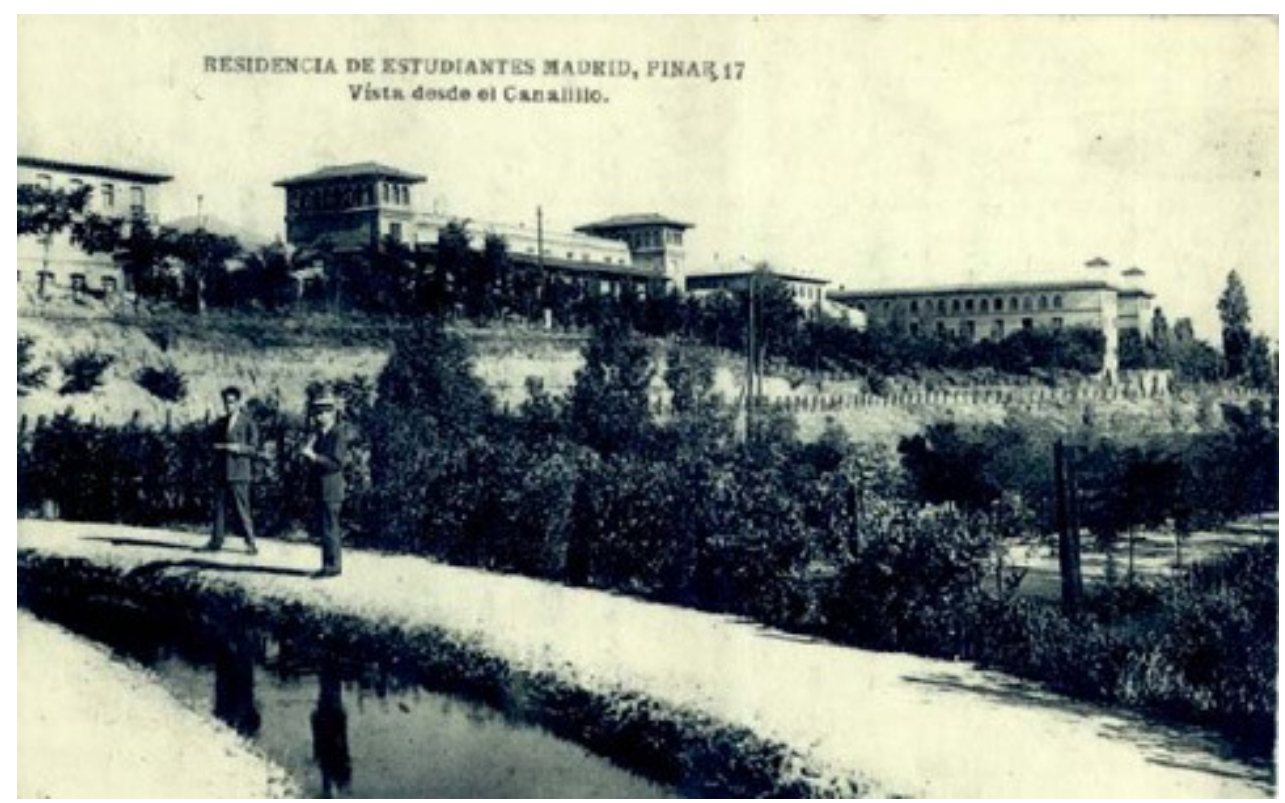

Fig. 39: Tarjeta postal de la Residencia de Estudiantes vista desde el canalillo, años veinte. Colección: Residencia de Estudiantes. 
La Residencia de Estudiantes estaba formada por cinco pabellones que podía albergar unos ciento cincuenta residentes, "la mayoría estudiantes de medicina y de ingeniería industrial» (Abella 2010, 10). En cada habitación solían residir dos estudiantes. Los dos primeros pabellones de la Residencias estaban formados por veinticuatro dormitorios cada uno, y el tercer pabellón (de Laboratorios o también llamado Transatlántico) tenía treinta y seis habitaciones. (Abella 2010, 8-9).

La Residencia ofrecía innumerables actividades culturales: conciertos, conferencias (invitados tanto de ámbito nacional como extranjeros), proyecciones cinematográficas (existía un club de cine) proporcionando un acceso a las novedades intelectuales, artísticas y científicas procedentes de fuera de España (Residencia de Estudiantes 2010a, 6). Fomentaba una educación integral y activa, basada en el diálogo entre los estudiantes, los tutores, los intelectuales y artistas que la frecuentaban, con el contacto con la naturaleza y el aprendizaje de los idiomas (Residencia 2010a, 15). Se enmarcaba dentro de los límites del liberalismo con amplios límites que permitía a sus estudiantes que tomaran diferentes direcciones estéticas, políticas y vitales pero, como afirma Sánchez Vidal «algo que caracterizaba a la Residencia era el equilibrio como norma, lo que la convertía en una encrucijada privilegiada. Allí podían coincidir gentes de todas partes de España» $(1988,45)$.

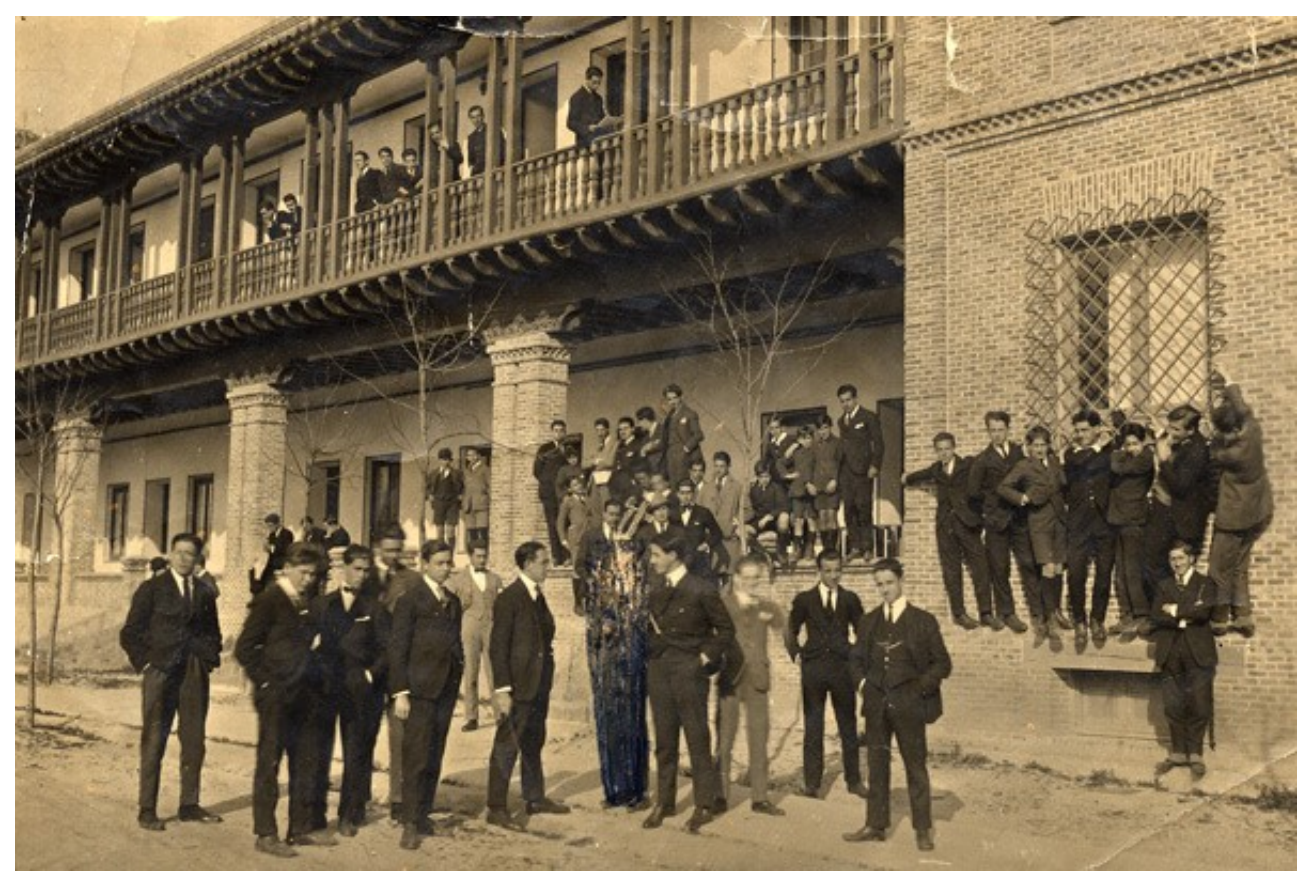

Fig. 40: Residentes ante el pabellón Transatlántico de la Residencia de Estudiante, en 1919. Colección: Fundación Federico García Lorca. 
El planteamiento y la finalidad de la Residencia de Estudiantes era buscar una armonía y una equivalencia entre pensamiento y acción, fondo y forma, teoría y práctica. Junto a las ciencias y al pensamiento, la música, las artes escénicas, la arquitectura, las artes plásticas, la poesía, etc. estaban presentes en las actividades educativas y en la programación cultural. Se podía observar cómo se mantenía ese equilibrio entre los estudios de las letras y las ciencias, como afirma Isabel Pérez-Villanueva Tovar:

frente a la tendencia a la especialización y a la fragmentación de materias, la Residencia aborda, con pretensión armónica y sintética, una "educación humanista" que quiere aunar artes, letras, ciencias, técnica, y relacionar así los diversos campos del conocimiento y las más variadas perspectivas culturales $(1990,79)$.

La Residencia, con un aire de casa campestre tanto el aspecto interno como el externo, presentaba la misma sobriedad, con recintos regulares, ordenados, nítidos y pulcros (Pérez- Villanueva Tovar 1990, 85).

En una carta de Juan Ramón Jiménez a su madre, fechada en 1913, explicará cómo es el proyecto $^{117}$ de la Residencia de Estudiantes:

Aquello será ya la perfección. Todos los cuartos aislados, con baño y calefacción, jardines esplendidos, laboratorios modernos, bibliotecas, juegos, salas de tertulia y conciertos, todo a propósito y con arreglo a los adelantos más recientes (citado en Residencia de Estudiantes 2010b).

En abril de 1919, se produce el primer viaje a Madrid ${ }^{118}$ de Federico García Lorca, para entrevistarse con el director de la Residencia para ingresar y confirmar una plaza para el curso 1919-1920; llevaba una carta de presentación de Fernando de los Ríos para Juan Ramón Jiménez. El 23 o 24 de noviembre se instaló en la Residencia, en seguida se apuntó al Ateneo y usó su biblioteca (Soria Olmedo 2018, 18-19; Hernández 1981, XIII).

\footnotetext{
${ }^{117}$ El propio Rafael Alberti en su libro Imagen primera y sucesiva de Federico García Lorca, publicada por primera vez en 1945 en la Editorial Losada de Buenos Aires, afirma: «Las sobrias alcobas y los árboles de la Residencia han ayudado al crecimiento del nuevo espíritu liberal español, a la creación de sus mejores obras [...].Hija de la Institución Libre de Enseñanza, [...] la Residencia de Estudiantes vino siendo la casa de las más grandes inteligencias españolas» $(1984,108)$.

${ }^{118}$ Este año, 2019, se celebra centenario de su llegada a Madrid. Para la ocasión se celebrarán diferentes actos, entre ellos representaciones teatrales de sus obras y el Congreso Internacional titulado «100 años Lorca».
} 


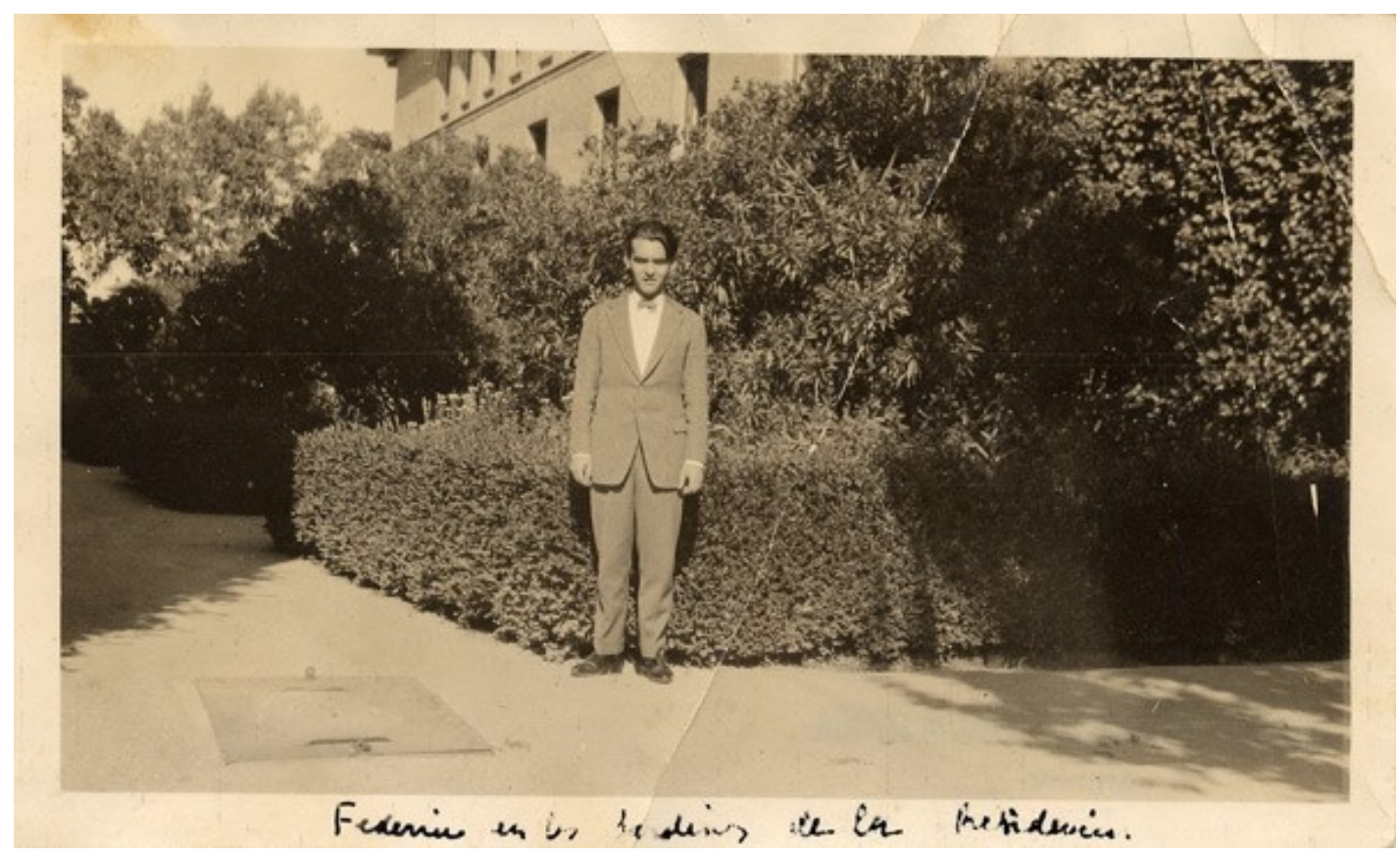

Fig. 41: Federico García Lorca en el jardín de las adelfas de la Residencia de Estudiantes, 1919. Colección: Fundación Federico García Lorca.

En 1922, Federico García Lorca termina su carrera de Derecho, pero sigue viviendo en la Residencia de Estudiantes; su estancia duró hasta 1928, con algunas temporadas de ausencia. Vivió seis años como residente permanente y allí conoció a Salvador Dalí, Luis Buñuel y Pepín Bello con los que vivió estrechamente unido durante esos años compartiendo ideas. Como afirma Alicia Gómez-Navarro, Lorca

fue animador constante $[\ldots]$ con sus cautivadoras conversaciones, recitando sus poemas, cantando o interpretando al piano sus arreglos y composiciones, y también a través de sus provocadoras ocurrencias juveniles, como los «putrefactos»o los «anáglifos ${ }^{119}$ », y de sus conferencias, lecturas poéticas o debates con sus interlocutores más «serios» $(2018, \mathrm{~s} / \mathrm{p})$.

\footnotetext{
${ }^{119}$ Los anáglifos son imágenes en dos dimensiones que con la ayuda de unas gafas (con un cristal rojo y otro azul) pueden provocar un efecto tridimensional. Al grupo de la Residencia les impresionó tanto que utilizaron la palabra para crear un juego literario que consistía en poner siempre una palabra entre tres sustantivos. Como afirmaba Pepín Bello, «la palabra había de ser siempre "la gallina". Llegó un momento en que aquel juego nos obsesionó. Fue como una verdadera epidemia. Los hacíamos a todas horas, obsesivamente» (citado en Castillo y Sardá, 2007, 64-65).
} 


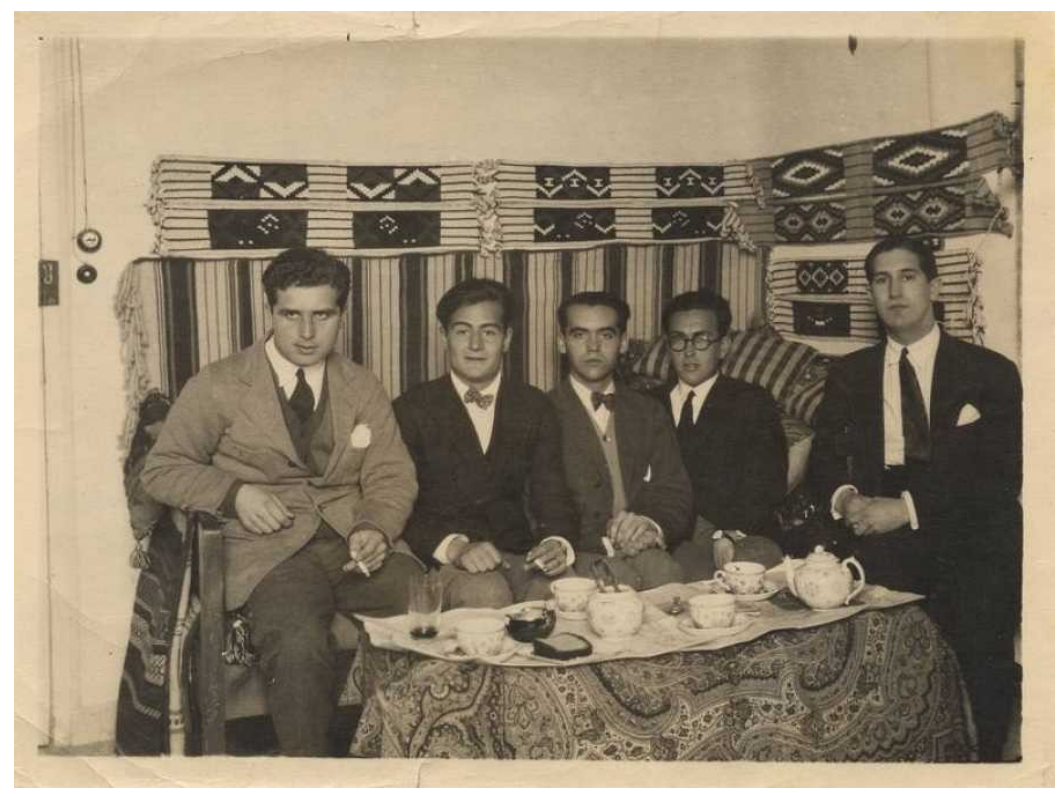

Fig. 42: Federico García Lorca rodeado de sus amigos. De izquierda a derecha: Louis Eaton-Daniel, Juan Centeno, Federico García Lorca, Emilio Prados y Juan Vicens, en una habitación de la Residencia, Madrid, 1924.

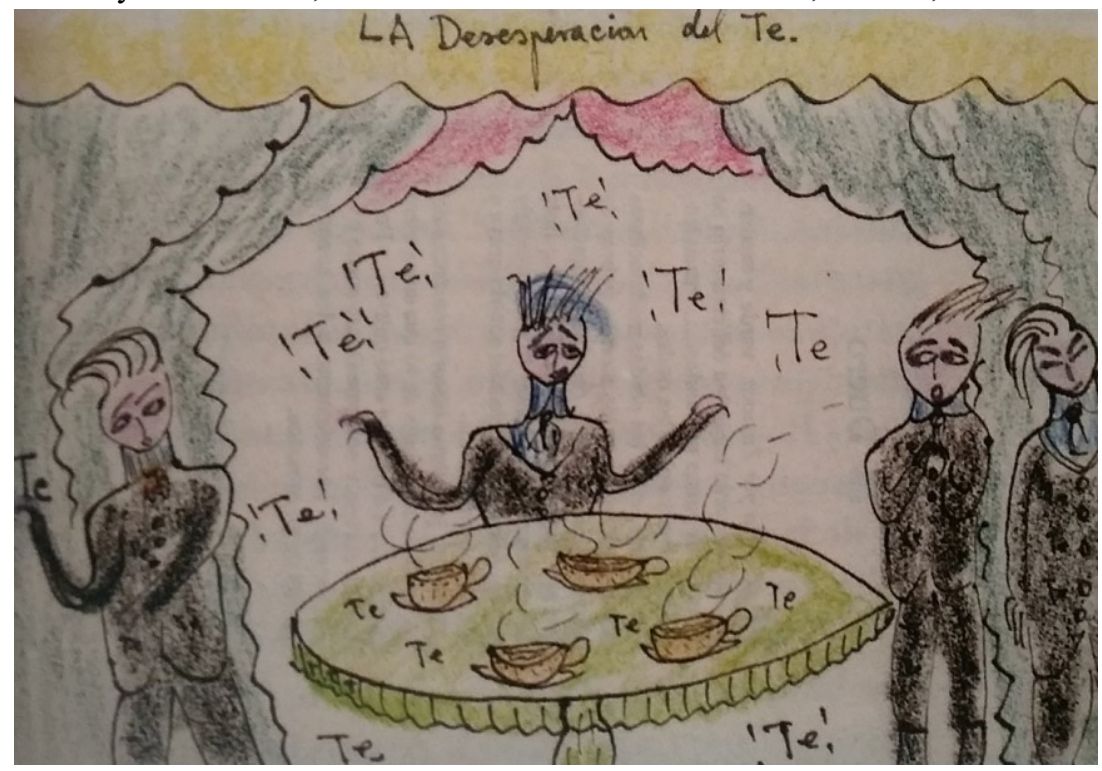

Fig. 43: La desesperación del té ${ }^{120}(1924)$ de Federico García Lorca. Dibujo a tinta y lápices de color en el interior de un libro Impresiones y Paisajes, 1918. Ejemplar dedicado a Juan Vicens ${ }^{121}$, conservado en la Residencia de Estudiantes.

\footnotetext{
${ }^{120}$ Después de la comida, entre el grupo de la Residencia no se hacía la siesta, se subía a las habitaciones a tomar té. Como afirma Sánchez Vidal, «lo solían tomar en la habitación de Juan Vicens, que tenía 28 años, era huérfano y heredero [...]. La desesperación del té solía terminar allá a las cinco, hora a la que cada cual reanudaba sus afanes estudiantiles» $(1988,54)$.

${ }^{121}$ En la exposición Una habitación propia. Federico García Lorca en al Residencia de Estudianes, 1919-1936 que tuvo lugar, del 14 de junio al 27 de julio de 2017, en la Residencia de Estudiantes de Madrid, se expuso el libro dibujado y dedicado de Lorca a Juan Vicens.

https://www.lavanguardia.com/cultura/20170613/423374673284/exposicion-lorca-madrid-residenciaestudiantes.html
} 
Después de su viaje a Nueva York y Cuba, ya no regresó a la Residencia sino en calidad de veterano. Sin embargo, en verano de 1932 volvió a pasar algunas noches mientras dirigía los ensayos de La Barraca ${ }^{122}$, cuyos componentes sí estaban ligados estrechamente a la Residencia (Soria Olmedo 2018, 23). En La arboleda perdida, Rafael Alberti recuerda que después de ese viaje transatlántico, «Federico la dejaría a su regreso, domiciliado ya con su familia en la casa de la calle de Alcalá. Aquella década ejemplar; de amor, de unión, de juventud y de entusiasmo, tocaba a su fin...» ([1959] 1976, 293).

La Residencia de Estudiantes fue unos de los proyectos, junto a muchos otros, que fueron truncados por la Guerra Civil y el inicio de la dictadura franquista. En 1937, la Residencia se convirtió en Hospital de Carabineros. Al final de la guerra, se decretó la disolución de la Junta para Ampliación de Estudios e Investigaciones Científicas (JAE) y sus centros. Durante los años posteriores, las instalaciones se transformaron completamente. El pabellón Central de la Residencia pasó a ser el lugar de los investigadores del Consejo Superior de Investigadores Científicas (CSIC) acabado de crear, y el Auditorio se convirtió en la Iglesia del Espíritu Santo (Residencia de Estudiantes 2010a, 33). Se tuvo que esperar al 12 de junio de 1986 para que el nombre de la Residencia de Estudiantes fuera restituido.

\section{5.- El Club Teatral Anfistora}

En la compañía universitaria La Barraca Federico García Lorca pudo desarrollar su faceta de director de escena, pero no debemos olvidar su colaboración con el Club Teatral Anfistora. Con este grupo llevó a escena cinco obras: Liliom de Ferenc Molnár, Peribañez el comendador de Ocaña de Lope de Vega, y El trovador de García Gutiérrez y sus propias obras, La zapatera prodigiosa y Amor de don Perlimplín con Belisa en su jardín, con las que inauguró el nuevo proyecto teatral.

${ }^{122}$ En julio de 1931 se presenta en los jardines de la Residencia el grupo teatral La Barraca (Abella 2010, $19)$. 


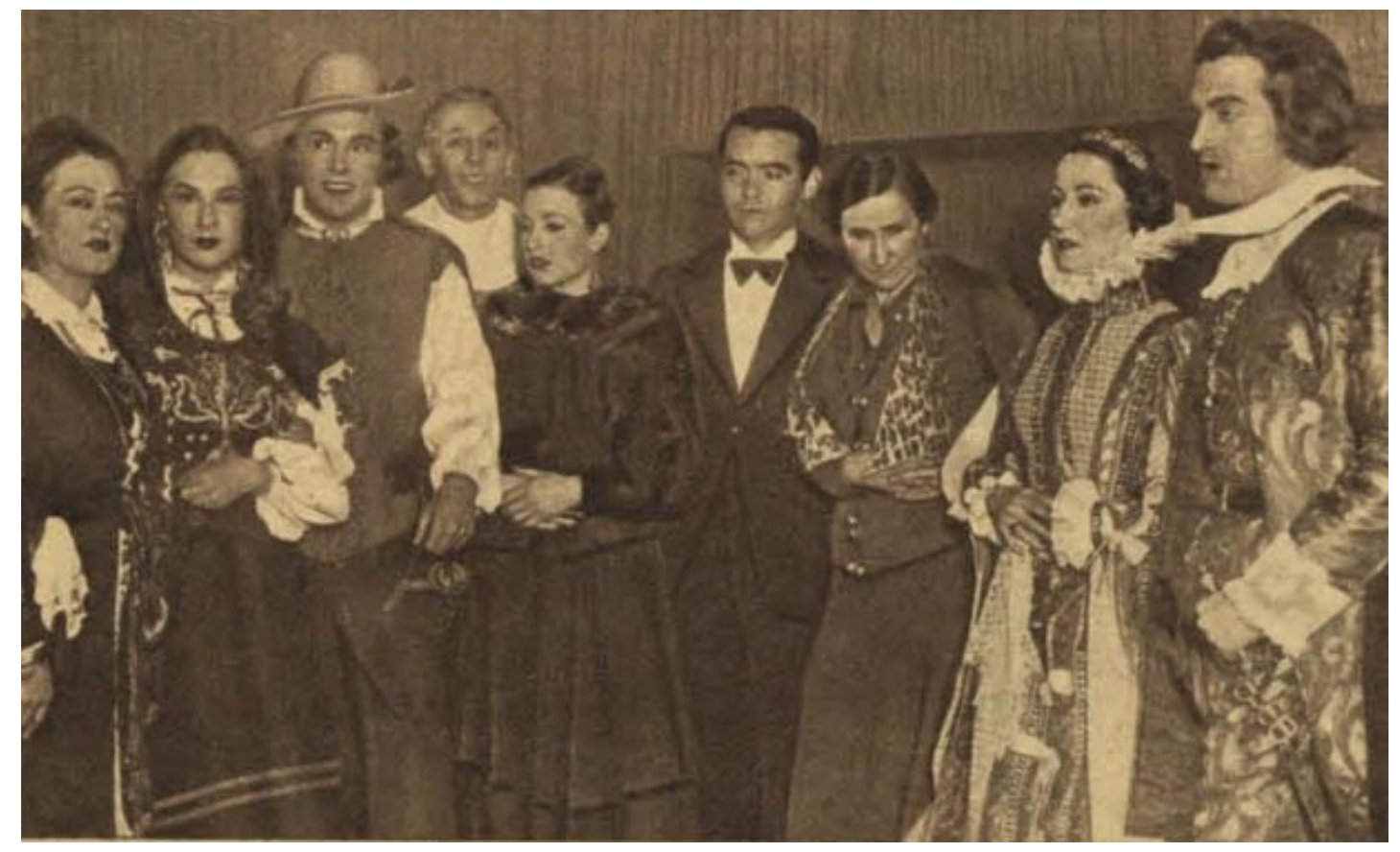

Fig. 44: Fotografía de Pura Moártua de Ucelay y Federico García Lorca con algunos intérpretes de Peribañez el comendador de Ocaña de Lope de Vega representada en el Teatro Capitol.

El Club Teatral Anfistora tuvo una existencia de tres años. Su creación surgió de un encuentro entre Pura Moártua de Ucelay con Federico García Lorca en Madrid durante los años treinta. Pura Moártua de Ucelay acababa de abandonar el Lyceum Club Femenino para unirse a María Martínez Sierra en una nueva empresa, la fundación de otro club femenino: la nueva Asociación Feminista de Cultura Cívica, fundada el 11 de marzo de 1932, cuya sede estaba en la Plaza de las Cortes, número 8. La Cívica llegó a tener 1500 afiliadas.

Pura Moártua de Ucelay, al ser nombrada responsable de la sección teatral de la asociación, se puso en contacto con Lorca para llevar adelante el nuevo proyecto (Ucelay 1992, 453). El nacimiento oficial del Club Teatral de Cultural tuvo lugar cuando Lorca anunció que sería codirector, pero aún no tenía un nombre propio. Durante los ensayos el nombre sufrió diferentes alteraciones: Asociación Femenina de Cultura Cívica, Club Cívico Culto de la Mujer Educada Femenina, Club Educado Femenino de la Mujer Cívica Culta, etc. En el programa de su estreno apareció con el nombre de Club Teatral de Cultura y, según afirma Margarita Ucelay, fue Santiago 
Ontañón quien recurrió al absurdo lorquiano para denominarlo Anfistora ${ }^{123}$ (1992, 456).

El club funcionó desde otoño de 1933 hasta comienzos del 1934 en el mismo salón de música donde habían tenido lugar los ensayos del Club Femenino de Cultura Cívica. En febrero de 1934, se mudaron al último piso del torreón del recién construido edificio Capitol en la Gran Vía y plaza del Callao, hasta julio de 1936.

El 5 de abril de 1933, el grupo teatral Anfistora estrenó La Zapatera prodigiosa, obra ya conocida pues había sido estrenada por Margarita Xirgu, con la compañía El Caracol el 24 de diciembre de 1930, en el teatro Español, y Amor de don Perlimplín con Belisa en su jardín, obra inédita (Ucelay 1992, 455).

Su costumbre fue hacer de sus representaciones noches de gala, es decir, ir de etiqueta, ya que su intención era doble, hacer un teatro artístico de calidad y a la vez tener repercusión en la alta sociedad (Ucelay 1992, 459). Las fiestas teatrales que ofrecía el Club Anfistora, según crítica de Juan Chabás, se podía ver en ellas que «la desastrada y chabacana dirección artística de las Empresas teatrales ha alejado del teatro a un público inteligente escogido, mucho más numeroso de lo que se supone» (1934a, 6).

En la entrevista, realizada por el periódico El Sol en 1933 «Una interesante iniciativa. El poeta Federico García Lorca habla de los Clubs Teatrales», este explicará con detalles cuál era la misión del Club Teatral:

Hacer arte. Pero arte al alcance de todo el mundo. Vamos principalmente contra esas Sociedades meramente recreativas, donde el baile o la cachupinada teatral son la principal razón de existencia. Tanto daño como el teatro en general, este teatro de ahora, ñoño y cursi por un lado, y por el otro grosero y zafio; tanto como este teatro, repito, originan daño esas agrupaciones que vienen a ser su propia continuación (citado en Soria Olmedo 2017, 44).

Se utilizaron diferentes términos para estas agrupaciones: grupo experimental, teatro de arte, teatro nuevo, teatro escuela y teatro de la nueva escuela. Pero lo importante de

${ }^{123}$ Anfistora no tenía ningún significado pero las interpretaciones que circularon por Madrid fueron muchas. Entre ellas se encontraba la que Lorca contaba que "se le había ocurrido utilizarla como ampulosa alabanza a una asistenta de casa de sus padres y repetía con grandes risas el corte que había recibido de ésta» (Ucelay 1992, 456). Era una de las tantas palabras que a Lorca le gustaba utilizar que aunque no significara nada, tenía un gran valor eufónico (jitanjáforas). 
estos clubs teatrales era que empezaran a actuar y a representar las obras que no admitían las empresas. Y Lorca defendía está actitud ya que

de otra manera, a la guisa de las sociedades actuales de aficionados, resulta que el público que acude a ellas vive varios años de retraso respecto de los espectáculos públicos. Solo representan obras ya caducas, fáciles sin interés alguno. Así ni pueden surgir buenos intérpretes ni menos autores (citado en Soria Olmedo 2017, 46).

El crítico Juan Chabás tenía una postura optimista respecto del nuevo teatro que estaba llegando a la escena española y, en el periódico madrileño $L u z$, publicó:

Sólo falta ahora — ante la buena obra que realiza este Club y la admirable tarea del T.E.A. y de La Barraca y el Teatro de Misiones - que los autores jóvenes, de espíritu o de edad, acudan a esos nuevos centros de renovación y dignificación del teatro con sus obras y sus iniciativas $(1934 a, 6)$.

De este modo, los nuevos escritores e intelectuales, cansados de la decadencia en que había caído el teatro comercial, vieron la oportunidad de ver sus obras estrenadas en estos grupos teatrales, puesto que la sociedad aún no las aceptaba por ser un teatro demasiado innovador y atrevido.

Los montajes del Club Teatral Anfistora seguían la pauta de otros grupos de aficionados, como el caso del grupo El Caracol, dirigido por Cipriano Rivas Cherif y el Teatre Íntim de Adrià Gual, cuya intención era representar un espectáculo de arte, dirigido a un público reducido y culto (Vilches de Frutos y Dougherty 1992, 247).

Aun siendo un grupo no profesional, sus representaciones eran de una gran calidad tanto por las actuaciones, tan bien cuidadas, como por los decorados y el vestuario. Compitiendo de manera directa con el teatro comercial, en 1935 se llegó a pensar en la posibilidad de que el Club Teatral Anfistora participara en el concurso de premios, por el centenario de Lope de Vega, a la mejor representación de Peribáñez y el Comendador de Ocaña. Ante la preocupación por parte de las compañías teatrales profesionales de que pudieran conseguirlo, el alcalde Salazar Alonso decidió subvencionar todos los gastos de una nueva representación (Ucelay 1992, 462).

El Club Teatral Anfistora se disolvió después de la muerte de Federico García Lorca (1936). 


\section{EL SURREALISMO}




\section{5.- El surrealismo francés}

\section{1.- Antecedentes del surrealismo}

En 1919, previa a la formación del grupo surrealista, Philippe Soupault, André Breton y Louis Aragon publican por primera vez la revista Littérature (de marzo de 1919 a agosto de 1921). Una revista mensual con cubierta amarilla, de dimensiones reducidas y discreta tipografía en el panorama editorial parisino con un total de veinte números. Durante los doce primeros, el equipo directivo quiso marcar en la revista un matiz antológico, con un tono subversivo y experimental (Rabourdin 2005, 318).

El acontecimiento de mayor importancia en Littérature es la publicación de los tres primeros capítulos ${ }^{124}$ de Les champs magnétiques. Como afirma Eulalia Adelantado Mateu, «se trata de un texto escrito en total libertad, sin plan preconcebido. Un texto donde no hay lugar para las tachaduras, un texto ajeno a toda preocupación literaria» $(1990,28)$.

Les champs magnétiques (1919) surgió cuando Breton le propuso a Soupault escribir un libro sin premeditación, sin un tema propuesto y sin una posterior corrección. En un principio, Breton quiso denominar esta forma de escribir «escritura mecánica»o «escritura del pensamiento», pero al final decidió llamarla «surrealista» en homenaje a Guillaume Apollinaire ${ }^{125}$, quien utilizó por primera vez el término en su obra de teatro Las tetas de Tiresias. Drama surrealista en dos actos y un prólogo (1903), denominada drama por el autor para diferenciarlo del resto de obras de comedias del momento. Apollinaire creó este adjetivo surrealista, para expresar una vuelta a la naturaleza pero sin imitarla. La obra fue escrita en 1903, catorce años antes de su representación.

\footnotetext{
${ }^{124}$ Aparecen en los números 8 (octubre de 1919), 9 (noviembre de 1919) y 10 (diciembre de 1919) de la revista Littérature.

${ }^{125}$ Guillaume Apollinarie en una carta dirigida a Paul Dermée en marzo de 1917 describirá el término indicando que «bien meditado, creo en efecto que vale más adoptar surrealismo que supernaturalismo, denominación que primeramente había empleado. Surrealismo no existe aún en los diccionarios, y será más cómodo de manejar que supernaturalismo, ya empleado por los señores filósofos» (citado en Cirlot 1953, 126).
} 
Años más tarde, Aragón recordaría el día en el que Breton le leyó por primera vez los textos que había escrito junto a Soupault, ante el temor de que pudiera diferenciar las partes escritas por cada uno de ellos. Pero la unidad era evidente:

Les champs magnétiques se convirtieron en la obra de un solo autor con dos cabezas y la mirada doble por sí sola les permitió a Philippe Soupault y André Breton avanzar por esa vía en la que nada los había precedido por estas tinieblas en las que ellos hablaban en voz alta (Aragon 1968, 5).

El libro, aunque no habla de los sueños propiamente dichos, al referirse al mundo de los trances y el automatismo, entra en el espacio del inconsciente, de ahí su importancia dentro de los inicios del movimiento. Porque la escritura automática o el automatismo psíquico será lo que defina y caracterice en esencia al movimiento.

Con el número 13, las páginas de Littérature se ponen al servicio de Dadá, incluso en su aspecto externo se pueden observar los cambios. Se advierte cómo los grandes seguidores del simbolismo y los amigos de Apollinarie desaparecen casi por completo de sus páginas y son reemplazados por nuevos colaboradores. El contenido muestra características del Dadá, como son la insolencia, el absurdo y el humor corrosivo.

Pero el surgimiento del movimiento Dadá lo encontramos en plena Primera Guerra Mundial, en un país neutral, Suiza y, en una ciudad, Zúrich. El matrimonio Emmy Hennings y Hugo Ball fundaron el Cabaret Voltaire, el 5 de febrero de 1916, en la taberna Holländische Meierei (Bozal 1978, 205; Anderson 2018 350). Un cabaret de vanguardia donde se realizan espectáculos, conciertos, recitales de canciones y poemas. En medio del desorden social de la época, el Cabaret Voltaire funcionó como catalizador e inspirador de inquietudes culturales y artísticas (Torre 1967, 12).

El movimiento Dadá nunca adoptó posiciones políticas, fue esencialmente individual, sus miembros «intentaron atacar al sistema social en su totalidad, por considerarlo íntimamente ligado a la estupidez humana, que había culminado en una guerra absurda y monstruosa» (Martínez Sarrión 2008, 32). Dadá no sólo fue el resultado de un estado de ánimo, sino que fue un estado de disconformidad y desengaño absoluto en lo que al mundo de la cultura y el arte se refiere (Torre 1965, 326). 
La primera publicación del movimiento lleva el título del establecimiento donde tenía su sede: Cabaret Voltaire, donde se publica el primer manifiesto del grupo, con un gran número de colaboraciones de pintores y escritores (Torre 1965, 327). Primer y único número de esta revista, publicado a mediados de junio de 1916 (Anderson 2018, 350). Más tarde, en julio de 1917, aparece el primer número de Dadá, revista dirigida por Tristan Tzara, concebida como continuación de Cabaret Voltaire. En el número 3, ya colabora Francis Picabia ${ }^{126}$, este número lo recibe André Breton, en París, y queda fuertemente impresionado. En abril de 1919, aparece el número 4-5 con el nombre de Anthologie Dada, es la despedida del movimiento de Zurich que con el final de la guerra se traslada a París, capital del arte en ese momento (Santos Torroella 1948, 8). Entre otras publicaciones del grupo dadaístas encontramos las revistas Cabaret Voltaire, Dadá I, II y III, Camera Work, 291, 391, The Blind man, Wrongwrong y Der Ventilator (Cirlot 1953, 100).

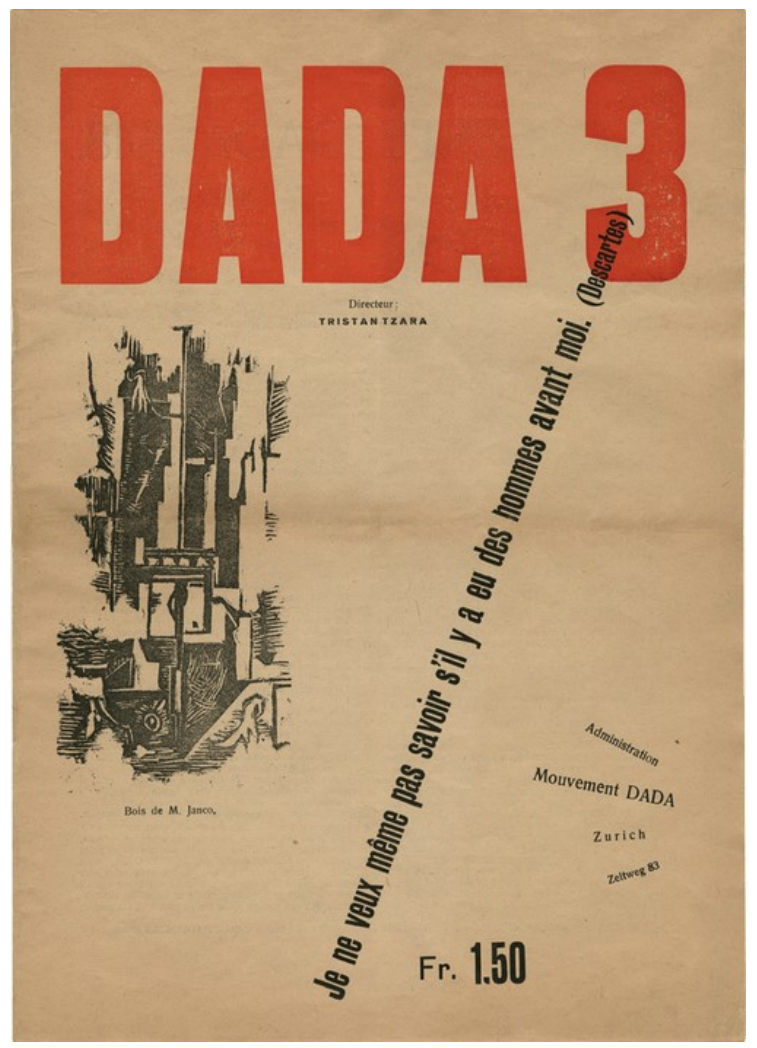

Fig. 45: Portada del número 3 de la revista Dada dirigida por Tristan Tzara

\footnotetext{
${ }^{126}$ En enero de 1917, Picabia había fundado en Barcelona su revista 391, publicando los cuatro primeros números, de enero a marzo. Los numeros 5, 6 y 7 los publica en Nueva York, periodo en el que se encuentra viviendo en esa ciudad. (Anderson 2018, 352).
} 
En la primera mitad de 1920, con la llegada de Tristan Tzara a París, los impresos, las exposiciones y las manifestaciones dadaístas se suceden sin cesar. Este auge duró apenas dos años (Martínez Sarrión 2008, 32). La provocación Dadá no funcionó como era de esperar en la revista Littérature. Según afirma Adelantado Mateu,

cada vez fueron más frecuentes las discrepancias entre Dada y el grupo Littérature. Sin embargo dos motivos parecen haber contribuido de una forma determinante. Por una parte la decepción que, al parecer, produjo Dada en los jóvenes parisinos. Y por otra la fuerte rivalidad que entre Tristan Tzara y André Breton parecía existir (1990, 49).

El origen de la defunción del Dadá se encuentra cuando sus provocaciones eran asumidas por la burguesía a que debían provocar, la agresividad de sus acciones desaparecía porque los agredidos parecían dispuestos a tolerar y aceptar cualquier cosa (Bozal 1978, 208).

El proceso ${ }^{127}$ Barrès celebrado el 13 de mayo de 1921 en la Salle des Sociétes Savantes contribuyó a hacer aún más notables las divergencias. La revista Littérature lo anunció previamente como Acusación y juicio al señor Maurice Barrés. En este juicio, se escogió a un famoso escritor como representativo de la tendencia conformista y tradicionalista (Cirlot 1953, 108) en el que se le acusaba de "crimen contra la seguridad del espíritu". Los abogados defensores fueron Louis Aragon y Philippe Soupault y, como explica Santos Torroella,

en el banquillo de los acusados se colocó un maniquí de madera que hacía las veces de encausado; jueces, abogados y fiscales vestían blusas y delantales blancos, tocándose con birretes del mismo color; Benjamín Peret, a un extremo de la sala, manteníase en posición de firmes, representaba al soldado desaparecido alemán $(1948,9)$.

Ya no se trataba de una mera provocación, como en otras manifestaciones dadaístas, como afirma Juan Eduardo Cirlot

En el transcurso de ese simulacro de proceso se produjeron discusiones entre Tzara y Breton, que mostraron la divergencia de actitudes. Consideraba este último que había terminado el interludio festivo del humor puro y que se trataba, cada vez con mayor

\footnotetext{
${ }^{127}$ En el siguiente enlace encontramos la transcripción en francés de todo el proceso: http://moicani.over-blog.com/article-28739405.html
} 
urgencia, de establecer los fundamentos de una nueva concepción del hombre y del mundo $(1953,109)$.

Y por ello, a partir de este momento, la rivalidad entre Tristan Tzara y André Breton irá aumentando progresivamente. La ruptura tendrá lugar de una forma definitiva en 1922, cuando André Breton y sus amigos Aragon, Eluard y Peret deciden separarse del grupo. El último número de Littérature, el número 20, se publica en agosto de 1921 bajo la dirección en solitario de Philippe Soupault, y recoge todas las incidencias habidas en el Procès a Barrès, bajo el título «L'affaire Barrès». El número 21 que contenía el resto de actas de proceso se quedó sin publicar (Torre 1965, 348; Mañero Rodicio 2012, 195).

La segunda etapa de Littérature o Littérature 'nouvelle série' consta de un total de trece números (marzo de 1922 a junio de 1924), repartidos en siete número en 1922, cuatro (uno de ellos doble) en 1923 y un número en 1924. Con cubiertas rosas y azules, con Man Ray, y después blancas con Francis Picabia, los tres primeros números están codirígidos por André Breton y Philippe Soupault. A partir del número 4, Breton dirige en solitario la revista (Rabourdin 2005, 318). La pérdida de Tzara como colaborador, desde el caso Barrès, es compensada por la activa incorporación de Picabia (Mañero Rodicio 2012, 196).

Dos grandes preocupaciones parecen acaparar el contenido de Littérature 'nouvelle série': terminar con los posibles rastros de Dadá, mediante ataques al movimiento y a Tristan Tzara, y orientar y sistematizar las prácticas experimentales en el terreno del sueño hipnótico y las asociaciones de ideas incontroladas mediante la escritura automática.

El último número de Littérature 'nouvelle série' aparece en junio de 1924 y, el primer número de La Révolution Surréaliste, el órgano oficial del movimiento surrealista francés, ve la luz en diciembre de ese mismo año. Tan sólo unos meses separan ambas publicaciones, y entonces André Breton escribe el Manifieste du Surrealisme, Louis Aragon escribe Une vague des rêves y, en la rue Grenelle de París, se inaugura Le Bureau de Recherches Surrealistes (Adelantado Mateu 1990, 69). 


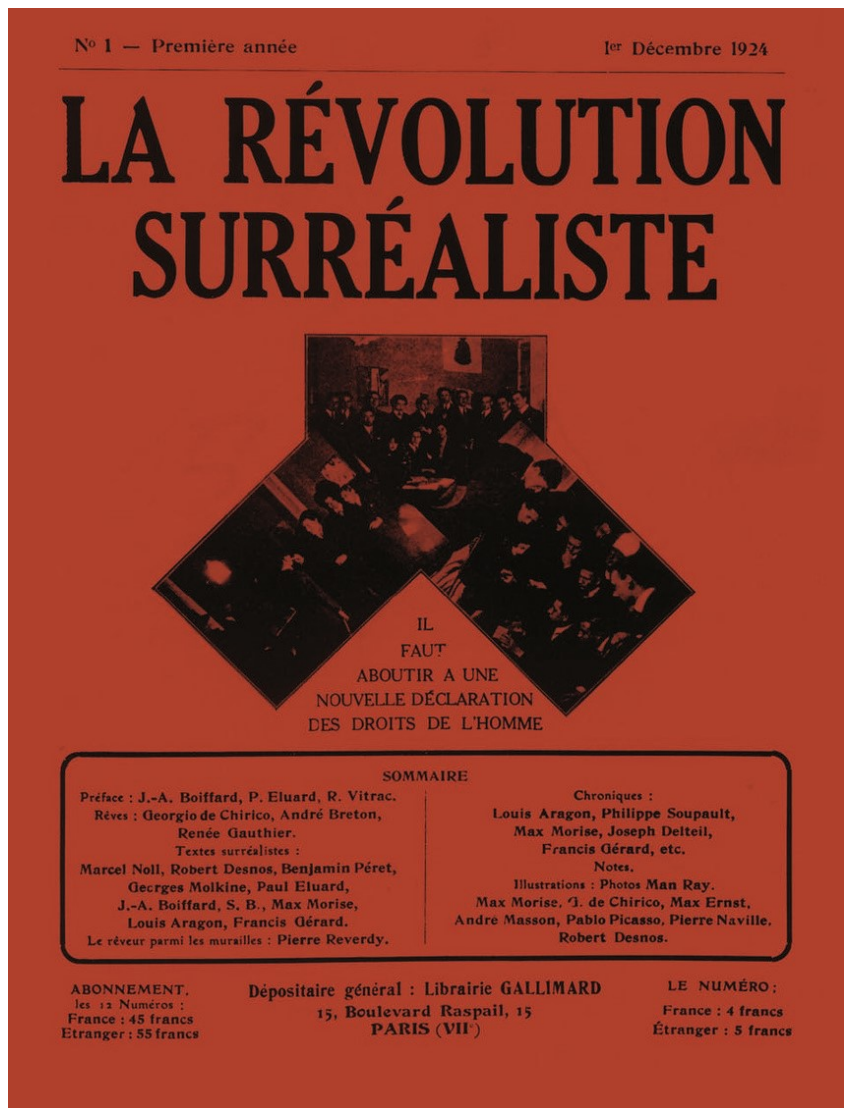

Fig. 46: Cubierta del número 1 de La Révolution surréaliste.

Colección particular.

\section{2.- Año 1924: El nacimiento del surrealismo. Los manifiestos}

Muy pronto los sueños ocuparon un primer plano en las preocupaciones surrealistas. En agosto de 1924 aparece Une vague des rêves de Louis Aragon y en octubre de ese mismo año Le Manifeste du surréalisme de André Breton. Una ola de sueños, su traducción, es uno de los escritos fundamentales sobre la formación del surrealismo y sobre ese primer periodo de sueños hipnóticos o trances que tuvo lugar durante el invierno de 1922 y 1923.

Al romper con el movimiento surrealista en 1932 y comprometerse con el Partido Comunista Francés, gran parte de los escritos de Aragon fueron cayendo en el olvido. Así, Una ola de sueños, aun escribiéndose y publicándose meses antes que el Manifiesto del surrealismo de Breton, quedó marginado del canon surrealista, convirtiéndose en una especie de manifiesto alternativo poco conocido. No fue hasta bastante después de 
la muerte de Aragon, en 1989, cuando vuelve a ver la luz de nuevo, formando en un principio parte de su Euvre poétique. Al año siguiente sería publicado de forma separada e independiente.

Ambos textos (el de Aragon y el de Breton) son crónicas de un momento, de unas vivencias en cuyo centro están los sueños, pero entre ellos existe unas diferencias a la hora de explicar su naturaleza. Breton se centra sobre todo en los propios sueños (los que se manifiestan en el acto de dormir); en cambio, para Aragon la experiencia mental va más allá de ese tipo de sueño, incluyendo por semejanza a esas ensoñaciones, las alucinaciones, los trances hipnóticos o las visiones inducidas por narcóticos y estupefacientes. Por otra parte, conocidas son sus diferencias en torno al padre del psicoanálisis, Sigmund Freud. Así Breton, en su primer manifiesto, refleja su atracción hacia los descubrimientos de Freud y reconoce la gran importancia que tiene La interpretación de los sueños [Die Traumdeutung] (1900) en la era moderna; en cambio Aragon es conocido por su fuerte oposición a Freud y al psicoanálisis. Según Dawn Ades, Aragon «eligió para su gran crónica de este periodo el título Una ola de sueños como desafío al autor de La interpretación de los sueños.» $(2014,37)$. En otro orden de cosas, y para Ricardo Ibarlucia, el surrealismo de Aragon confiere un «rasgo de espontaneidad creativa que se aleja de la pasividad con la que podría asociarse la escritura automática de Breton como dictado del pensamiento» $(2013,45)$.

\subsection{1.- Una ola de sueños de Louis Aragon}

En Una ola de sueños, Aragon nos cuenta cómo «André Breton en 1919, al aplicarse a captar el mecanismo del sueño, encuentra en el umbral del sueño el umbral y la naturaleza de la inspiración» $(2004,56)$, refiriéndose al descubrimiento por parte de Breton y Soupault de esos momentos de trance en los que encuentran el origen de la inspiración. No solo ellos dos se adentran en ese mundo, también los jóvenes y amigos intentaban llegar a ese estado de hipnosis mediante el alcohol o las drogas.

A finales de 1922, René Crevel había aprendido con la ayuda de un médium a inducir un trance hipnótico, «le enseñó a dormir un sueño hipnótico particular, semejante más bien al estado de sonambulismo» (Aragon 2004, 60). A estas experiencias le siguieron 
sesiones de espiritismo simuladas que sobrecogieron a quienes las experimentaron. Se trataba de una búsqueda de la «surrealidad» (término propuesto por Aragon) a través de los sueños inducidos y las experiencias con las drogas. Soñando con los ojos abiertos, los surrealistas deambulaban por las calles de París, pero

Los trances se vuelven cada vez más peligrosos; no sólo provocan toda clase de trastornos sensoriales a quienes se entregan a estas prácticas, sino que terminan por desarrollar, en algunos surrealistas, los impulsos más temibles. [...] La idea de acabar con estas experiencias se apodera de algunos miembros del grupo (Ibarlucia 2004, 31$32)$.

Cada vez más, se empieza a sentir un cierto temor ante las consecuencias de estos estados. Así, en la misma obra Una ola de sueños podemos leer cómo el propio Aragon muestra su prevención ante las posibles consecuencias de esas experiencias:

Sus sueños son cada vez más prolongados. Ya no quieren que se los despierte. Se adormecen viendo dormir a otro, y dialogan entonces como habitantes de un mundo ciego y lejano, se increpan y a veces hay que arrancarles los cuchillos de las manos $(2004,61)$.

En cualquier caso y a pesar de los posibles problemas que pudiera conllevar su exploración, el mundo del sueño atrapa a todos los autores surrealistas. André Breton anota sus sueños, conservando su carácter de relato; Robert Desnos aprende a soñar sin dormir, logrando a voluntad intervenir en los sueños; Louis Aragon verá en ellos el punto de partida del surrealismo... su contagio llegará a todas las personas que se vincularon a este nuevo y fantástico mundo:

Sueños, sueños, sueños, el dominio de los sueños se extiende cada vez más. Sueños, sueños, sueños, el sol azul de los sueños hace por fin retroceder a las bestias de ojos de acero hacia sus guaridas. Sueños, sueños, sueños sobre los labios del amor, sobre las cifras de la felicidad, sobre los sollozos de la atención, sobre las señales de la esperanza, en las canteras donde se resigna un pueblo junto a los picos. Sueños, sueños, sueños, todo no es más que sueño donde el viento vaga, y los perros salen aullando a los caminos. ¡Oh gran Sueño, en la mañana pálida de los edifícios ya no abandones, atraído por los primeros sofismas de la aurora, esas cornisas de tiza donde acodándote mezclas 
tus trazos puros y lábiles con la inmovilidad milagrosa de las Estatuas! (Aragon 2004, $63)$.

También es interesante Una ola de sueños porque aquí asistimos a una narración acerca del nacimiento del surrealismo que complementa la expresada por Breton en el Manifiesto del Surrealismo. En ambos casos se señala el año 1924, como el inicio de una nueva era surrealista,

1924: bajo este número que sostiene una draga y arrastra tras de sí una siembra de peces-lunas, bajo este número ornado de desastres, extrañadas estrellas en sus cabellos, el contagio del sueño se expande por los barrios y las campiñas (Aragon 2004, 63).

A continuación, nos enumera los que él considera los nombres referenciales para la nueva vanguardia artística de ese díscolo siglo XX. Nombres con los que quizá no está de acuerdo en algunos puntos (acabamos de mencionar el caso de Freud) pero de los que reconoce su papel como precursores:

Saint-Pol Roux, Raymond Roussel, Philippe Daudet, Germaine Berton, Saint-John Perse, Pablo Picasso, Giorgio De Chirico, Pierre Reverdy, Jacques Vaché, Léon-Paul Fargue, Sigmund Freud, los retratos de ustedes están clavados en las paredes de la habitación del sueño, ustedes son los presidentes de la República del sueño $(2004,63)$.

Tras ellos, pasa a presentarnos a «los soñadores» que son los miembros del naciente grupo surrealista: Georges Limbour, André Masson, Max Morise, Paul Éluard, Joseph Delteil, Man Ray, Suzanne (Suzanne, entre las que nombra, es la única mujer que no se ha podido identificar entre las que participaron activamente dentro del grupo surrealista), Antonin Artaud, Mathias Lübeck, Jacques Baron, André Breton, Philippe Soupault, Denise Kahn, Jacques-André Boiffard, Roger Vitrac, Jean Carrive, Pierre Picon, Francis Gérard, Simone Kahn, Robert Desnos, Max Ernst, René Crevel, Pierre Naville, Marcel Noll, Charles François Baron, Benjamin Péret, Geroges Malkine, Maxime Alexandre, Renée Gauthier, Alberto Savinio y George Bessière. 


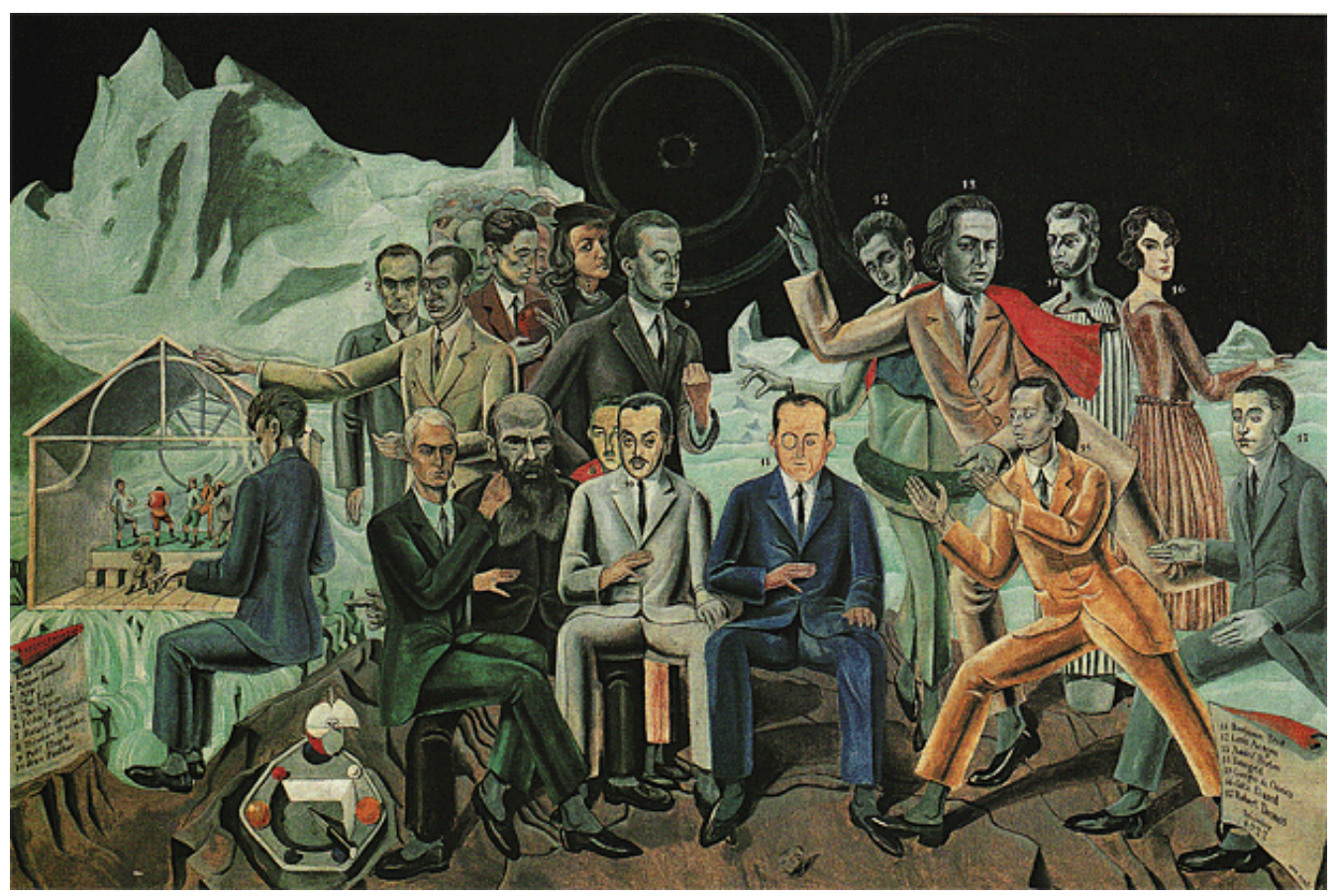

Fig. 47: La reunión de amigos ${ }^{128}$ (1922) de Max Ernst

Óleo sobre lienzo, 130 x $195 \mathrm{~cm}$

Museo Ludwig ${ }^{129}$ de Colonia

Tras sus alusiones a los sueños y estados de trance propios del surrealismo, de mostrarnos los artistas que son su referente y de presentarnos, uno a uno, quiénes son los que forman parte de este nuevo movimiento, Aragon finaliza Una ola de sueños invitando, no solo a los que han formado y forman parte del grupo en un momento inicial, sino a todos aquellos que estén dispuestos a seguir dentro del grupo en un futuro del movimiento surrealista, proponiéndonos que, mediante los sueños, alcancemos la plena libertad, hasta encontrar el infinito:

Libre, libre: es la hora en que la cadena de los anillos claros del viento echa a volar por los moarés del cielo, es la hora en que el hierro se torna esclavo de los tobillos, donde

\footnotetext{
${ }^{128}$ En la obra se puede observar cómo el grupo se encuentra en un paisaje lunar. En él aparecen André Breton, Louis Aragon, el propio Max Ernst sobre las rodillas de Andréi Dostoievski, el busto de George de Chirico sobre una columna, y a los lados de la columna se encuentra Gala Éluard y René Crevel. Theodore Fraenkel, Jean Paulhan, Benjamin Peret, Johannes T. Baargeld, Philippe Soupault, Jean Arp, Max Morise, Raphael (no porque sea un modelo para él, sino más bien por la comparación e importancia en su momento histórico de los miembros que forman Una reunión de amigos y los de La Escuela de Atenas) y Paul Eluard, pero el protagonista de la obra es Robert Desnos (quien había aprendido a soñar sin dormir) y que entra apresurado bureau en la escena. En esta pintura vemos cómo el pasado y el presente, lo real y lo irreal, la realidad y los sueños, los vivos y los muertos se mezclan en este espacio misterioso e inquietante.
}

${ }^{129}$ Adquirido, en 1976, con el apoyo del Estado Federal de Renania del Norte-Westfalia. 
las esposas son alhajas. Ocurre que entre los muros del calabozo el recluso talla una inscripción que hace sobre la piedra un ruido de alas. Ocurre que esculpe encima del remache el símbolo emplumado de los amores de la tierra. Es que él sueña y yo sueño, transportado, sueño. Sueño un largo sueño donde cada uno sueña. No sé lo que va a resultar de esta nueva empresa de sueños. Sueño al borde del mundo y de la noche. [...] ¿Quién está ahí? Ah muy bien: hagan pasar al infinito $(2004,69)$.

\subsection{2.- El Manifiesto del surrealismo de André Breton}

Una vez reseñado el fundamental texto de Aragon, pasemos ahora a analizar la obra de André Breton, el Manifiesto del surrealismo. Como hemos dicho antes, entre los dos escritos hay una diferencia de tan sólo unos meses. Breton, hombre de gran personalidad que está seguro de que su grupo de amigos le respaldaría en sus ideas, escribió el Manifiesto del surrealismo para tratar de explicar en qué consistía el nuevo movimiento surrealista. En su texto podemos ver cómo la imaginación y la libertad son dos de los valores más importantes, más allá de las restricciones de la moral y de las convenciones sociales del gusto. Merced al surrealismo, la imaginación de los adultos volvería a rebrotar: «Quizá haya llegado el momento en que la imaginación esté próxima a volver a ejercer los derechos que le corresponden» (Breton 2009, 22-23). Según se envejece, observa, se pierde la imaginación libre y sin normas de la infancia, y a ella debemos volver.

En el Manifiesto, Breton nos hacía partícipes de la idea de que vivimos en el imperio de la lógica y del racionalismo absoluto y, por tanto, nuestra propia experiencia se ve sometida a ciertas limitaciones «La experiencia está confinada en una jaula, en cuyo interior da vueltas y vueltas sobre sí misma, y de la que cada vez es más difícil hacerla salir» $(2009,22)$ y son esas barreras del orden de la lógica, de la moral y del gusto, lo que el surrealismo deberá superar.

Pero, además, Breton cuestiona el valor que se le atribuye a la vida despierta, no siendo este más importante que el del estado de sueño, y que los periodos en el que el ser humano sueña son superiores a la suma de momentos de realidad, aun así: «El sueño queda relegado al interior de un paréntesis, igual que la noche. Y, en general, el sueño, 
al igual que la noche, se considera irrelevante» (Breton 2009, 24). En el sueño todo es posible, y en la síntesis entre el sueño y la realidad es donde se encuentra el surrealismo.

Una de las cosas más significativas de los sueños es su posible continuidad, elemento muy importante para poder comprenderlos en su totalidad. Al fin y al cabo, esta continuidad definirá una disposición interna determinada:

Dentro de los límites en que se produce el sueño es, según todas la apariencias, continuo y con trazas de tener una organización o estructura. Únicamente la memoria se irroga el derecho de imponerle lagunas (Breton 2009, 24).

Es la memoria la única que nos ofrece una serie de sueños discontinuos dentro del propio sueño, y es ésta la que nos aleja de ese sueño lineal y continuo. No poder recordar los sueños es lo que nos da la sensación de que son discontinuos y no lineales. Breton propone incluso que es el estado del sueño, y no el de la vigilia, la verdadera verdad de nuestras vidas (Breton 2009 24-25).

Siguiendo en la línea precedente, los surrealistas reivindican la continuidad entre el estado del sueño y el estado de vigilia, ya que el sueño no puede reducirse a la noche. Breton cree encontrar una armonización entre el estado del sueño y la vigilia, aparentemente contradictorios, y será en «una realidad absoluta, en una sobrerrealidad o surrealidad» $(2009,27)$. Así, define al surrealismo como «automatismo ${ }^{130}$ psíquico puro por cuyo medio se intenta expresar, verbalmente, por escrito o de cualquier otro modo,

\footnotetext{
${ }^{130}$ Ante la avalancha de escritos automáticos que siguieron al Primer Manifiesto, tuvo que aclarar su significado y en su libro Point du jour (1933) incluye el ensayo «Le Message automatique» en el que señala

"L'historie de l'éscriture automatique dans le surréalism serait, je ne crains pas de le dire, celle d'une infortune", estipulando que es difícil reconocer los textos auténticamente surrealistas debido a "l'absence objective de tout critérium d'origine". Y redefine sus principios de la "escritura automática". Los falsos surrealistas o "médiums" al tratar de ejecutarla, "ils ignorent absolument ce qu'ils écrivent ou dessinent et leur main, anesthésiée, est comme conduite par autre main". Acto seguido, admite que la verdadera "escritura automática" es un ideal - "la limite à laquelle le poète surréaliste doit tendre". Mas en la práctica, es menester considerar estados intermedios:

D'autre part, il nous a paru d'emblée for difficile et, à considérer ce qu'il pouvait y avoir d'extra-psychologique dans le but que nous poursuivions, presque superflude nous embarrasser d'une división de l'ecriture dite couramment "inspirée", que nous voulions opposer a la littérature de calcul, en écriture "mécanique", "semi-mécanique" ou "intuitive", ces trois qualificatifs ne visant à rendre compte que de différences de degrés (citado en Cao 1984, 59-60).
} 
el funcionamiento real del pensamiento. Es un dictado del pensamiento, sin la intervención reguladora de la razón, ajeno a toda preocupación» $(2009,39)$.

Se opinó mucho en torno a los sueños en 1924, año que vio nacer el Surrealismo. Tras la creación oficial del movimiento en el mes de octubre, se aceleran los acontecimientos y, en diciembre de ese mismo año, la revista Littérature pasa a llamarse La Révolution Surréaliste, dando comienzo una nueva acción colectiva, en la que los sueños y elementos paralelos continuarán teniendo una gran importancia. Según Walter Benjamin el surrealismo, en sus inicios

[...] irrumpió sobre sus fundadores como una ola cargada de sueños, se anunció como el más cabal, concluyente y absoluto de los movimientos. Hacía suyo cuanto tocaba. Parecía que la vida sólo merecía la pena si el umbral entre vigilia y sueño quedaba anulado por un ingente flujo de imágenes; el lenguaje parecía serlo sólo si sonido e imagen, imagen y sonido se interpretaban con la automática y feliz exactitud que no dejaban resquicio alguno por donde insertar la ficha del "sentido". Imagen y lenguaje se imponían $(2013,33)$.

Otra obra necesaria ineludible para entender la conexión que existe entre el mundo de la vigilia y el mundo de los sueños, es el libro que redacta André Breton entre 1931 y 1932, Les vases communicants, centrado ampliamente también en el tema del sueño y, como el título indica, muestra la conexión entre el mundo de los sueños y el de la vigilia y cómo éstos actúan como dos vasos comunicantes entre los cuales no existe barrera alguna. El libro se encuentra entre las obras fundamentales de los textos surrealistas y es un intento de conciliar las ideas surrealistas con el materialismo dialéctico marxista (Sebbag 2013, 32).

Como ya dijera en el Manifiesto del surrealismo, Breton da la misma importancia al mundo del sueño como al mundo de la realidad, ya que los dos se necesitan y están en contacto, «el mundo del sueño y el mundo real no hacen más que uno, o dicho de otra manera que el segundo, para constituirse, no hace más que extraer del "torrente de lo dado"» $(2005,51)$ y el hilo conductor entre el mundo de la vigilia y el de los sueños para Breton será el surrealismo, el cual 
no deberá ser considerado como existente más que en la no especialización a priori de su esfuerzo. Deseo que sea considerado por no haber intentado nada mejor que tender un hilo conductor entre los mundos excesivamente disociados de la vigilia y del sueño, de la realidad exterior e interior, de la razón y de la locura, de la calma del conocimiento y del amor, de la vida por la vida y de la revolución, etc. Por lo menos, se habrá buscado, mal buscado, quizá, pero buscado, no dejar ninguna pregunta sin respuesta $(2005,76)$.

En uno de los pasajes de Los vasos comunicantes, Breton nos describe la época en la que paseaba por la rue de Faubourg-Saint-Honorée, y cómo durante esos paseos perdía la conciencia, llegando a vagar sin rumbo fijo por París; afirma que en donde la única diferencia que encontraba entre ese estado y el del sueño era que en este último estaba tumbado y durmiendo, mientras que en el primero, deambulando por las calles de París, vivía un estado de soñar despierto:

En estos dos planos oponibles, el mismo favor y el mismo desfavor me persiguen. Las puertas de la movilidad, al abrirse ante mí, no me permiten introducirme con certeza en un mundo más consistente que aquel sobre el cual, un poco antes, un poco después, esas puertas pueden cerrarse $(2005,91)$.

Estos paseos y este tipo de estado de soñar despierto nos los describe también en uno de los pasajes de su novela Nadja publicada en 1928. Y será de esta forma fortuita y por azar cómo conocerá a la misteriosa mujer que da nombre al libro.

En Los vasos comunicantes, también podemos comprobar en sus páginas a una especie de repaso por los principales teóricos del sueño, a los que agrupa según su orientación: los partidarios del materialismo primitivo, los positivistas (el sueño es un estado de degradación del estado de vigilia) y los idealistas (el sueño es una liberación del estado de vigilia).

Breton escribe Los vasos comunicantes tras haber estudiado en profundidad La interpretación de los sueños de Freud, manifestándose las diferencias que existían entre ellos. Freud afirma que los deseos son algo que se nos escapa, quedando ocultos en nuestros sueños, en nuestro inconsciente. A través de la interpretación de dichos sueños se nos desvelará el verdadero sentido de éstos, que se encuentran allí cifrados. En una posición contraria, Hervey de Sainte-Denys -a quien Breton nombra en las primeras 
líneas de Los vasos comunicantes-(Breton 2005, 11-13), considera que el sueño es la realización de un deseo y que la incoherencia de sueños es sólo aparente. Los surrealistas irán incluso más allá, y dirán que los sueños pueden ser contados, y que será la vida real la que necesita ser descifrada (Sebbag 2013, 32-33).

En cualquier caso es en esta obra donde podemos ver las claras diferencias que Breton mantenía con Freud:

Freud se equivoca también con toda seguridad al llegar a la conclusión de la no existencia del sueño profético -quiero referirme al sueño que empeña el porvenir inmediato-, pues considerar exclusivamente el sueño como revelador del pasado es negar el valor del movimiento $(2005,20)$.

Aun así, Breton considera que la obra de Freud es original como método de interpretación de los sueños, aunque como tal método tenga dos obstáculos: el primero, la barrera definida bajo el nombre de «muro de la vida privada» y el segundo, las preocupaciones sexuales. Freud consideraba estos sueños de personas enfermas o histéricas, fácilmente sugestionables y susceptibles (2005, 26-27).

Pero había más desacuerdos que acuerdos entre Breton y Freud, quizá debido a que el escritor no tuvo un venturoso encuentro con el psicoanalista, a quien visitó en Viena en octubre de 1921, sin obtener el reconocimiento esperado. De hecho, se negaba a hablar de la experiencia con sus compañeros de café. En 1922 escribió un texto sobre el encuentro que fue publicado en el primer número de la revista Littérature. Breton permaneció varios años sin perdonar este desengaño. Y es que había muchas diferencias o distancias entre Freud y Breton: entre ellas la edad, la formación y sus objetivos. Freud (1856-1939) tenía una edad avanzada cuando se conocieron, era un científico y todos sus estudios iban dedicados a una solución terapéutica para los enfermos, en cambio Breton (1896-1966) era un joven escritor de vanguardia. El choque parecía inevitable.

En la edición española del 2005 de Los vasos comunicantes, se adjuntan, en un apéndice, tres cartas de Sigmund Freud a André Breton y una réplica. En las cartas se puede observar el poco interés de Freud al recibir el «librito» de Breton. La carta, fechada el 26 de diciembre de 1932, Freud la finaliza con «yo mismo no soy capaz de 
aclararme qué es y qué quiere el surrealismo. Quizá no estoy hecho para comprender, yo que estoy tan alejado del arte» (2005: 137).

\section{3.- Se inicia la revolución surrealista}

Como hemos dicho, 1924 es el año oficial de la fundación del grupo surrealista y será el 11 de octubre de ese mismo año cuando se inaugure su sede en el despacho denominado Le Bureau de Recherches Surréalistes, situado en el número 15 de la rue de Grenelle de París, en un local facilitado por un familiar de Pierre Naville (Adelantado Mateu 1990, 85). Breton afirmaba:

Una "Oficina de investigaciones surrealistas" fue abierta [...] y su objetivo inicial era recoger todas las comunicaciones posibles, referentes a las formas que podía adquirir la actividad inconsciente del espíritu. Esta oficina, ante el número de curiosos y de importunos que le asediaban, tuvo que cerrarse rápidamente al público. Artaud, que asumió su dirección sucediendo a Francis Gérard, se esforzó por convertirla en un centro de "readaptación" a la vida $(1972,112)$.

Le Bureau de recherches surréalistes se convirtió en «un centro de reunión activo y lleno de gentes extrañas, que figuraban constantemente en informes de prensa, en una extraordinaria publicidad y en escándalos literarios» (Roger 1956, 47).

Su revista, La Révolution surréaliste, no era una revista literaria corriente, tenía un aspecto casi de revista científica. El formato y la presentación de la revista indican una alta preocupación por el contenido, pero no por la apariencia externa, con una edición de formato neutro y distribución del texto como si se tratara de una revista científica (Mañero Rodicio 2012, 201). De tapa naranja (del mismo color que el Manifiesto del surrealismo) para los seis primeros números, y los restantes, blancos (Rabourdin 2005, $318)$.

El primer número de la revista surrealista se imprimió en Alençon, una imprenta especializada en ediciones católicas, sin que hubiera intención maliciosa en ello (Roger 1956, 47). El depositario hasta el número 11 (15 de marzo de 1928) será la Librairie Gallimard, y el número 12 (15 Diciembre 1929) será José Corti. Se imprime con la 
aportación económica de los surrealistas y de algunos mecenas. En palabras de propio Breton,

Al principio, la revista hizo hincapié en el surrealismo puro —el surrealismo, digamos, en su estado nativo- y es lo que hizo que se confiara la dirección a Pierre Naville y Benjamin Péret, que en aquellos momentos podían ser considerados como los más plenamente animados por el nuevo espíritu y los más rebeldes a toda concesión. Debe señalarse que los primeros números de La Révolution surréaliste no incluyen poemas, pero en cambio abundan en ellos los textos automáticos y las narraciones de sueños $(1972,110)$.

Inicialmente Pierre Naville y Benjamin Péret son encargados de la dirección de la revista. A partir del número 4 (15 Julio 1925), André Breton toma las riendas de la misma sin por ello excluir formalmente a sus antiguos responsables (Calvo Serraller $1983,39)$.

En el primer número de la revista surrealista ya se puede observar cómo la experimentación y la búsqueda en el dominio de la exploración mental es parte primordial del contenido de la revista. Aunque este era bastante variable, todos los números están marcados por un amplio despliegue de la actividad experimental en forma de textos automáticos, poemas y narraciones de sueños. Adelantado afirma que

junto al entusiasmo por las palabras, los poemas, el lenguaje y la exploración en el ámbito de la actividad psíquica a través de textos automáticos y narraciones de sueños, La Révolution Surreáliste recoge, al mismo tiempo, todo un abanico de preocupaciones que a modo de constantes acompañarán siempre al surrealismo. En este sentido, el contenido de la revista se estructura en torno a los grandes universos temáticos: suicidio, muerte, locura y amor $(1990,128)$.

La revista surrealista enseguida se dedicó a hacer estudios sobre pintura. Entonces «Breton comienza una historia de la pintura moderna en la que quiere señalar sus relaciones con el movimiento surrealista. Este estudio se publicará en muchos números de la revista bajo el título de Le surréalisme et la peinture» (Roger 1956, 50), uno de los textos más difundidos.

En los doce números que forman la totalidad de la revista, los surrealistas expresan su carácter revolucionario y vinculan las ideas de revolución y de libertad «para que la 
emancipación del espíritu se lleve a cabo, es necesario que se produzca a la vez una profunda revolución en las relaciones sociales» (Adelantado Mateu 1990, 95).

La vinculación del movimiento surrealista hacia posiciones políticas y sociales provoca la adscripción de algunos de sus miembros al partido comunista francés, lo que genera discusiones importantes en el seno del grupo que se reflejan, asimismo, en La Révolution Surréaliste.

\section{4.- Acercamiento al partido comunista francés (1925)}

En este momento, Breton ejercía una gran influencia sobre sus amigos y hacia el verano de 1925 surge un acercamiento al Partido Comunista Francés (PCF) por parte de los miembros del grupo. Será la tendencia política revolucionaria la que enseguida dividirá el movimiento (Martínez Sarrión 2008, 121).

Con este acercamiento del grupo surrealista a posiciones políticas y sociales, se producen las relaciones entre la revista Clarté y La Révolution Surréaliste. El acuerdo entre los surrealistas de La Révolution Surréaliste, el grupo Clarté, la revista Philosophies y el periódico belga Correspondance se concierta en forma de manifiesto titulado La Révolution d'abord et toujours, publicado en 1925 (Roger 1956, 54). El pensamiento de este texto oscilaba entre el surrealismo y el comunismo. Como afirma Roger:

el texto del manifiesto fue sometido al estudio de la Asamblea plenaria y aceptado por la misma. Los surrealistas y todos aquellos que hasta entonces habían estado bien alejados del comunismo, rivalizaron en su ardor revolucionario, incluso aquellos que Breton tuvo tantas dificultades de convencerlos se convirtieron repentinamente en marxistas acérrimos $(1956,55)$.

Tres meses después de la publicación del manifiesto, «la actividad puramente surrealista parece sufrir una disminución: se renuncia a la escritura automática y en la revista se publican menos relatos de sueños» (Roger 1956, 57).

En el número 5 (15 octubre de 1925) de La Révolution Surréaliste se publica por primera vez en la revista el primer manifiesto explícitamente político. Como afirma 
Adelantado «una profunda modificación en los planteamientos del movimiento surrealista, al incorporar un nuevo objetivo: no es posible la revolución del espíritu sin que se produzca primero una profunda revolución en las relaciones sociales» (1990, 116).

Se pensó en la creación de una revista en común entre los dos grupos, debiendo desaparecer Clarté y La Révolution Surréaliste. Se discutió el título que se debía escoger entre La Bataille, Commune, La lutte de clase, l'Emeute, etc., y, al final, se escogió el de La Guerre civile.

En el número de diciembre de Clarté se anunció en la portada: «Clarté desaparece. Le sucede La Guerre civile» (Roger 1956, 58). Los surrealistas, por su parte, hacen el mismo anuncio en La Révolution Surréaliste del 1 de marzo de 1926, aunque sin afirmar que su propia revista debiera desaparecer en provecho del esfuerzo común (Nadeau 1972, 121).

La adhesión al proyecto no es total. La Guerre Civile no llegó a publicarse nunca ya que el surrealismo no quiso sacrificar sus ideas (Roger 1956, 60). Según Roger,

los surrealistas comienzan a darse cuenta que Clarté no es el Partido comunista y que la alianza concertada con este grupo no ha resuelto todas las dificultades, ya que no les abre las puertas del Partido. Clarté se presenta cada vez más como un grupo de oposición $(1956,57)$.

Cuanto más intentaban aproximarse los dos grupos, mayores eran las diferencias, mientras los comunistas exigía el cumplimiento de sus principios y métodos, los surrealistas negaban abandonar los suyos (Torre 1965, 390). Aunque las relaciones no prosperan, queda una estrecha colaboración entre los miembros de ambas revistas.

La polémica que mantuvieron André Breton y Pierre Naville se debió a que en un artículo, publicado en el número 3 de La Révolution surréaliste, Naville declaraba que no había pintura surrealista y por ello Breton decide tomar la dirección de la revista. Después de cinco números sin aparecer en la revista y de haber realizado el servicio militar lejos de París, Naville regresa y ya «había liquidado todo su pasado surrealista y estaba resuelto a dedicar su acción exclusivamente a la política» (Breton 172, 129). 
En 1926, Pierre Naville publica el folleto La Révolution et les Intellectuels (Que peuvent faire les surréalistes?) para el que, aunque «los intelectuales han podido desempeñar en Francia un papel más decisivo que en otros países, no son en absoluto una ayuda directa para el proletariado revolucionario, la única fuerza capaz de realizar la revolución que desean los surrealistas» (Nadeau 1972, 127) y planteaba la cuestión:

Esta revolución tan deseada, ¿es la del espíritu a priori o la del mundo de los hechos? ¿Está unida al marxismo o a las teorías contemplativas [...]. Se pregunta qué puede hacer el individuo reducido a sus propias fuerzas, y responde que nada, sino pronosticar en sus escritos. Los surrealistas han proclamado la vanidad de la actividad literaria y reconocido también lo eficaz de la actividad colectiva para la existencia de su grupo. Esta actividad colectiva no resuelve nada si se limita a predicar los valores individuales (Roger 1956, 61-62).

Breton explicaba que «la discusión entre Naville y los surrealistas se inició con su folleto La Révolution et les intellectuales, al que respondí en Légitime défense» (1972, 129). Légitime défense fue un folleto publicado en septiembre de 1926 donde Breton reitera su apoyo al programa comunista. «Niega rotundamente lo inconciliable del mundo espiritual a priori y el mundo de los hechos» (Roger 1956, 61). Estos dos textos proporcionan un testimonio del desconcierto de los espíritus en este momento crucial.

Naville replicó a la respuesta de Bretón con el texto titulado "Mieux et moins bien". «La polémica finalizó con la carta dirigida a él, que figura en Au grand jour» (Breton 1927, 130).

En este, Breton levanta acta de la crisis producida por el grupo surrealista y su deseo de ponerle fin. Los cinco, Aragon, Breton, Éluard, Péret y Unik, anuncian públicamente que «comprometen la simpatía del movimiento surrealista entero hacia la organización comunista [...]. El anarquismo puro se ha convertido según ellos en algo estéril por resultar ineficaz» (Nadeau 1972, 138).

El surrealismo acababa de tomar posiciones en el mundo de la política. Naville, quien había intentado arrastrar al grupo hacia el partido comunista, dejó a sus amigos de golpe y pasó a codirector de Clarté, donde siguió publicando los escritos de estos (Roger 1956, 64). 
Gradualmente, una parte del grupo asume posiciones próximas al compromiso político. En 1927, tras muchas dudas, Louis Aragon, André Breton, Paul Eluard, Benjamin Péret y Unik se adhieren al partido comunista francés (Martínez Sarrión 2008, 121). Pero los surrealistas no quisieron convertirse en políticos militantes, con lo que su afiliación al Partido Comunista francés es únicamente formal y tiene sólo un valor simbólico (Nadeau 1972, 137).

Desde un principio, los comunistas franceses no estuvieron de acuerdo en la adscripción del grupo surrealista al partido. Las hostilidades y los mecanismos de control que los comunistas desarrollaron hacia los surrealistas, mediante continuas comisiones de control en las actividades surrealistas, fueron incompatibles con la manera de actuar del grupo (Adelantado Mateu 1990, 119). Los surrealistas seguían defendiendo que «frente al totalitarismo comunista, Breton y sus amigos afirman la libertad del individuo» (Roger 1956, 63-64). Lejos de ceder los obstáculos crecieron con el tiempo y la distancia entre ambas formas de entender la revolución social y la acción política fue en aumento y con ello estaban condenadas a no reconciliarse.

A la altura de 1929, el surrealismo languidecía entre falsas tomas de posición ideológica y política y un puro desgaste del programa de 1924, aunque por aquellos años seguían apareciendo grandes obras que son clásicas:

La época comprendida entre 1926 y 1929 aportó un florecimiento de obras surrealistas que se ha considerado muy a menudo como el más resplandeciente. Aragon publicó Le Paysan de Paris y Traité du style, Artaud Le Pèsenerfs, Crevel L'Esprit contre la raison, Desnos Deuil pour deuil y La Liberté ou l'amour, Éluard Capitale de la douleur y L'Amour la Poésie, Ernst La Femme 100 têtes, Péret Le Grand jeu, yo mismo Nadja y Le Surréalisme et la peinture (Breton 1972, 138).

El último número de La Révolution Surréaliste, 12 de la serie, aparece el 15 de diciembre de 1929. En este número se recogen dos textos de especial importancia: Second Manifieste du Surréalisme de André Breton, que se incluye como editorial y Introduction a 1930 de Louis Aragon. El texto de Aragon realiza un balance de los cinco años transcurridos desde 1924 con la aparición del primer número de la revista surrealista. Menciona la crisis, los distanciamientos y las irregularidades en algunos de los números de la revista y declara cómo «la unidad del surrealismo como movimiento, 
estaba seriamente dañada» (Adelantado Mateu 1990, 179). Esta crisis surgió por la vinculación al compromiso social y político y la adscripción de determinados surrealistas al partido comunista francés.

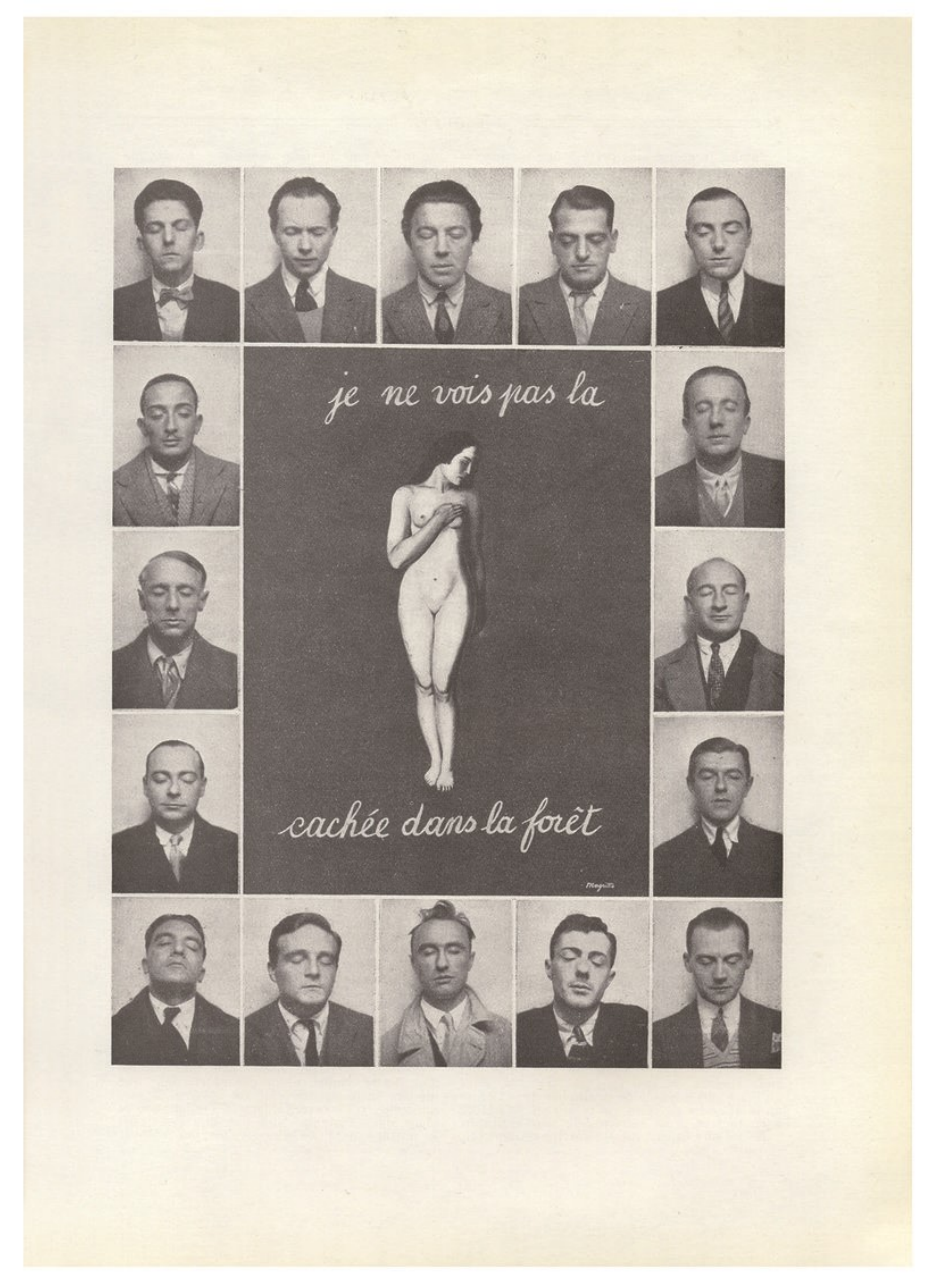

Fig. 48: Fotomontaje ${ }^{131}$ publicado en el último número de $L a$ Révolution surréaliste, $\mathrm{n}^{\circ} 12$, del 15 de diciembre 1929, pág. 73 .

La crisis dentro del surrealismo cada vez estaba más cerca y la ruptura en el movimiento se ve reflejada en la redacción del Segundo manifiesto de Breton, en el final de la revista La Révolution Surréaliste y su sustitución por Le Surréalisme au service de la

\footnotetext{
${ }^{131}$ Reproduce una serie de fotografías tamaño carnet tomadas Man Ray. En el sentido de lectura: Maxime Alexandre, Louis Aragon, André Breton, Luis Buñuel, Jean Caupenne, Salvador Dalí, Paul Éluard, Max Ernst, Marcel Fourrier, Camille Goemans, René Magritte, Paul Nougé, Georges Sadoul, Yves Tanguy, André Thirion, Albert Valentin. Que rodean una pintura de René Magritte: La Mujer escondida (1929). En la que se incorpora una frase «No veo la $[\ldots]$ oculta en el bosque» y la pintura sustituye la palabra «mujer».
} 
Révolution, donde muestra un apoyo incondicional a la Unión Soviética en caso de que fuera atacada. (Martínez Sarrión 2008, 123).

\section{5.- El surrealismo al servicio de la revolución (1929): El segundo manifiesto}

Artaud, Soupault y Vitrac son excluidos del grupo, Desnos se aleja del movimiento, Naville se integra en el movimiento comunista y los miembros de Clarté rechazan cualquier colaboración con los surrealistas, se avecina una crisis dentro del surrealismo que se produce en el año 1929 (Roger 1956, 69).

En este año aparece el último número de la revista oficial del surrealismo La Révolution Surréaliste. El Second Manifieste du Surréalisme cierra como editorial el último número de la revista surrealista y también una etapa de cinco años que se inicia con la publicación del Manifieste du Surréalisme, la apertura del Bureau de Recherches Surrealiste y el lanzamiento de la revista La Révolution surréaliste.

El texto Le Second Manifeste du Surréalisme confirma la importancia del dogma surrealista y refleja en sus páginas el momento conflictivo por el que atraviesa el movimiento. Breton expone que todos los antiguos colaboradores que proclaman haberse apartado del surrealismo por propia voluntad, en realidad «han sido, sin una sola excepción, expulsados por nosotros» (Breton 2009, 163). En el manifiesto, Breton ataca a todos aquellos que se han distanciado del movimiento surrealista:

No estoy autorizado a dejar en paz a los granujas, los impostores, los arribistas, los falsos testigos y los delatores. [...]. Yo creo que realizar una tajante discriminación es la única actitud perfectamente digna que perseguimos, y creo que supondría cierta ceguera mística al infraestimar el disolvente alcance de la permanencia de estos traidores entre nosotros, del mismo modo que sería indicio de la más lamentable confusión de carácter positivista el suponer que estos traidores, que tan sólo lo son a sus primeras intentonas, puedan permanecer indiferentes ante dicha sanción $(2009,149)$. 
En el Second Manifieste du Surréalisme insiste en los temas que han ido surgiendo dentro del movimiento surrealista desde sus inicios, como ha sido el carácter revolucionario del surrealismo y, según Adelantado,

vincula las ideas de revolución y libertad a presupuestos sociales, intentando establecer un puente de unión entre el individuo y la totalidad del mundo exterior, pues considera que, para que la emancipación del espíritu se lleve a cabo, es necesario que se produzca una profunda revolución en las relaciones sociales $(1990,182)$.

El surrealismo reconoce que existe una cuestión social y rechaza un régimen basado en la explotación de la mayoría, colocándose al lado de los revolucionarios que pretenden echar abajo este régimen. Breton afirma que el surrealismo en sus comienzos se proyectó en un ámbito poético pero ahora «toma partido en la lucha social [...]. No podemos evitar plantearnos con toda crudeza la cuestión del régimen social bajo el que vivimos, quiero decir con esto la cuestión de la aceptación o la no aceptación de este régimen» (Breton 2009, 152-153).

Breton dedica las páginas siguientes del Segundo manifiesto a comentar los pormenores de su adhesión al comunismo francés y menciona los incidentes surgidos:

Reconozco que si en el partido comunista me tomaron por un intelectual del tipo más indeseable que quepa imaginar, ello se debía únicamente a un error de interpretación. Mis simpatías están con la masa formada por aquellos que realizarán la revolución social (Breton 2009, 157).

Del mismo modo que mostró en El Manifiesto de 1924, Breton da gran importancia al automatismo psíquico y a los relatos de sueños que ya se recogían en dos diferentes números de La Révolution Surréaliste:

Estos productos de la actividad psíquica, lo más apartados que sea posible de la voluntad de expresar un significado, lo más ajenos posible a las ideas de responsabilidad siempre propicias a actuar como un freno, tan independientes como quepa de cuanto no sea la vida pasiva de la inteligencia, estos productos que son la escritura automática y los relatos de sueños ofrecen, a un mismo tiempo, la ventaja de ser la únicos que proporcionan elementos de apreciación de alto valor a una crítica que, en el campo de lo artístico, se encuentra extrañamente desarbolada, permitiéndole efectuar una nueva 
clasificación general de los valores líricos, y ofreciéndole una llave que puede abrir para siempre esta caja de mil fondos llamada hombre, y le disuade de emprender la huida, por razones de simple conservación, cuando, sumida en las tinieblas, se topa con las puertas externamente cerradas del "más allá", de la realidad, de la razón, del genio, y del amor (Breton 2009, 177-178).

Breton recuerda que el objetivo del surrealismo ha sido la recuperación total de la fuerza psíquica del hombre, «la ideología del surrealismo tiende simplemente a la total recuperación de nuestra fuerza psíquica por un medio que consiste en el vertiginoso descenso al interior de nosotros mismos» (Breton 2009, 151) y lo que pretende es desarrollar todo aquello que «pueda contribuir a liberar la imaginación y el inconsciente humano, haciendo accesible la otra realidad» (Adelantado Mateu 1990, 184).

La respuesta a los ataques realizados por André Breton en el Second Manifieste du Surréalisme se encuentra agrupada en un texto de extrema violencia, con ataques personales, que insulta de todas formas a Breton y Masson, titulado Un Cadavre (1930) «parodiando con ello el publicado seis años antes con motivo de la muerte de Anatole France» (Adelantado Mateu 1990, 181), cuyos participantes fueron muy diversos.

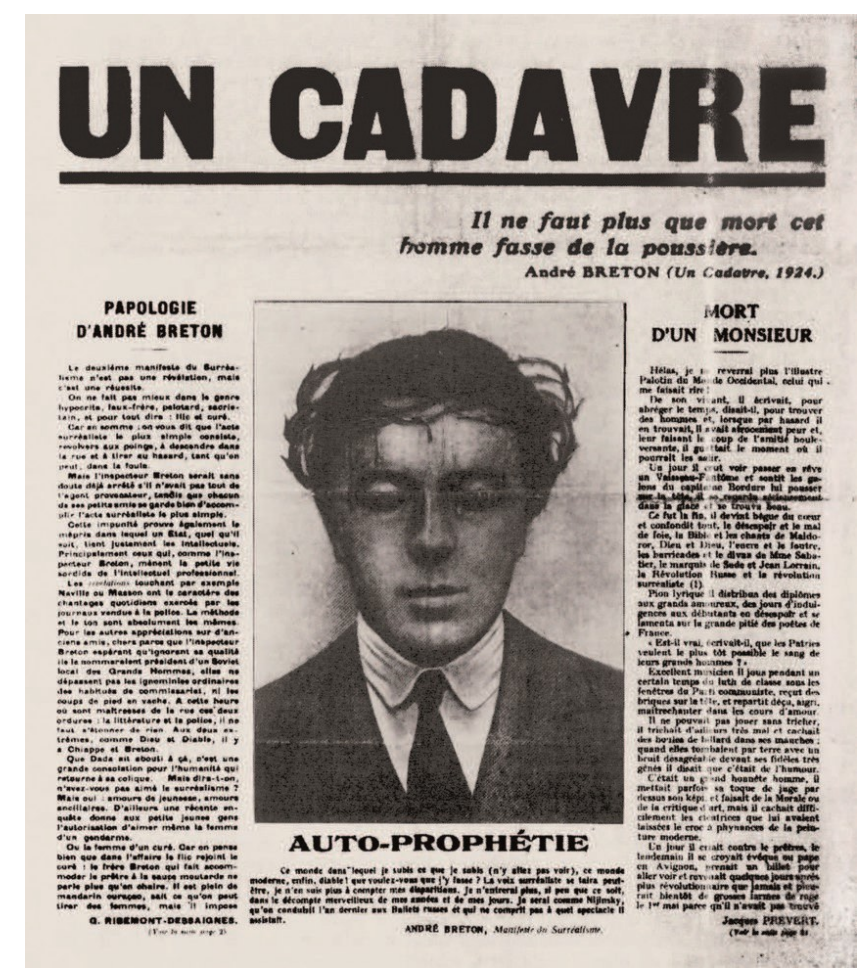

Fig. 49: Primera página del panfleto anti bretoniano "Un cadáver", enero 1930. 
La réplica al panfleto por parte de Breton no se hizo esperar y se encuentra en una edición, en forma de libro, Deuxième Manifeste du Surréalisme. El movimiento surrealista no se vio muy afectado por esta crisis (Nadeau 1972, 181). Como afirmaba Breton,

Si la publicación de Un Cadavre, de 1930, consagró su ruptura con numerosos surrealistas de la primera y segunda hora, esto no supuso, desde el punto de vista de la colectividad, ningún desperdicio de energía. Se levantó mucho fango en contra mía, pero como contrapartida tuve el apoyo de mis antiguos compañeros: Aragon, Crevel, Éluard, Ernst, Péret, Tanguy, que se pusieron de acuerdo para declarar públicamente que "el Second Manifeste da todas las seguridades para apreciar lo que está muerto y lo que está más vivo que nunca en el surrealismo" y que en ese libro se ha hecho "la suma de los derechos y los deberes del espíritu" $(1972,156)$.

Breton se reconcilia cada vez más con el movimiento revolucionario y dirigirá la nueva revista del movimiento que se titula Le Surréalisme au service de la Révolution, «demostrando con ello, que menos que nunca se trataba de "revolución surrealista" [...]. Breton pone de nuevo a su grupo al servicio del partido soviético, pero tratando, no obstante de salvaguardar su libertad» (Roger 1956, 79).

Seis meses después de la desaparición, a pesar de su éxito, La Révolution surréaliste, en julio 1930, en plena efervescencia política, Breton la sustituye por una nueva revista $L e$ Surréalisme au service de la Révolution (S.A.S.D.L.R.) (Santos Torroella 1948, 12), que durante los tres años y seis números, será el nuevo órgano oficial del surrealismo francés, de carácter radical y sobriedad gráfica. Su cubierta es blanca y en tinta verde sólo lleva impreso el nombre de la revista, un extraño emblema y el número del fascículo (Mañero Rodicio 2013, 213). Con el número 1 de Le surréalisme au service de la révolution, se abre con una declaración de fidelidad a la III $^{\mathrm{a}}$ Internacional y al partido comunista francés, que sin embargo, el partido «no está dispuesto a acoger incondicionalmente a esos partidarios un poco demasiado molestos, y decididos a continuar libremente [...] sus experiencias poéticas» (Rabourdin 2005, 318).

Con el cambio de nombre, como dice Ángela Merino, «surge el problema de la servidumbre que la ideología marxista pueda imponer al arte, que debe abdicar de su propio ser para servir al Partido a cuenta de la revolución» (1978, 94). Los tres años de 
existencia de la revista fueron años de luchas en «un clima de desconfianza, de protestas, de compromiso erróneo, de traiciones y de crisis, la más importante de la cuales comportará la ruptura definitiva con Aragon» (Rabourdin 2005, 318).

Años más tarde, Breton en una entrevista opinará de la revista:

De entre todas las publicaciones surrealistas, Le Surréalisme au service de la Révolution, cuyos seis números se escalonaron entre 1930 y 1933 fue sin duda la más rica, en el sentido en que nosotros lo entendíamos, la más equilibrada, la mejor constituida y también la más viva (con una vida exaltante y peligrosa). En ella el surrealismo dio la medida de su llama: durante un tiempo, tanto unos como otros no vieron más que esa llama y no temieron consumirse en ella $(1972,157)$.

\section{6.- La crisis del surrealismo (1930): El caso Aragon}

En 1930 se inicia lo que sería conocido posteriormente como el "caso Aragon". Mientras Breton guarda celosamente su autonomía, otros miembros del grupo han avanzado hacia el comunismo, entre ellos Aragon y Sadoul.

Louis Aragon, en compañía de Georges Sadoul, aceptan la invitación para participar en el II $^{\mathrm{o}}$ Congreso Internacional de Escritos Revolucionarios, que se celebró en Jarkov (Ucrania actual) del 6 al 15 de noviembre de 1930 (Roger 1956, 80). En palabras de André Breton, Aragon

se relacionó con los círculos literarios de Moscú y Leningrado, expuso nuestro común punto de vista, creyó haber logrado disipar ciertas aprensiones referentes al concepto surrealista de la poesía y el arte, etc. [...] Fue invitado a participar, a título consultivo, en la Segunda Conferencia internacional de escritores revolucionarios que se celebró en el mes de noviembre de 1930 en Jarkov (Breton 1972, 168)

Tras el congreso de Jarkov, Sadoul y Aragon se retractan del Segundo manifiesto y reniegan públicamente de Trotsky y de Freud, y «aceptan someter su actividad literaria a la disciplina y el control del Partido, cosa a la que se habían negado rotundamente hasta entonces, e incluso se comprometen a combatir el freudismo y el trotskismo»» (Goutier 2005, 314). Según Breton, «una hora o dos antes de su salida, se les había 
presentado, para que firmaran, una declaración que implicaba el abandono, por no decir la negación, de casi todas las posiciones que habíamos mantenido hasta entonces» (1972, 169).

Aragon, para dar una prueba de su adhesión al partido comunista, compone el poema Front rouge que, en julio de 1930, publica en la revista soviética La Littérature de la Révolution mondiale, órgano de la Unión Internacional de Escritores Revolucionarios (U.I.E.R.). Un poema revolucionario en el que «no sólo hace un llamamiento al asesinato de los dirigentes del régimen, sino también al de los "osos amaestrados de la socialdemocracia”»(Nadeau 1972, 193). A su regreso a París, vuelve absolutamente convertido al comunismo, aunque siga siendo surrealista (Roger 1956, 81). El grupo surrealista de París reaccionó negativamente, y Aragon fue acusado por su poema Front rouge de «"incitación a la desobediencia de los militares" y de "provocación al asesinato como objetivo de la propaganda anarquista"» (Breton 1972, 171). Breton salió en su defensa en un opúsculo titulado Misère de la poésie ${ }^{132}$. Según Breton «era precioso, a cualquier precio, sustraer a Aragon de las persecuciones, y, para ello, era preciso provocar un movimiento de la opinión en su favor. Es a lo que me dediqué, con su pleno consentimiento, emprendiendo la redacción de Misère de la poésie» (1972, 171). Paradójicamente la ruptura entre Breton y Aragon fue consumada en el instante que Breton publicó el folleto cuya objeto era defenderlo (Breton 1972, 172).

El 10 de marzo de 1932, Aragon sumido en las contradicciones, publica una nota en l'Humanité en la que declara «dejar de solidarizarse con las ideas de Breton en razón de los ataques contra el partido comunista. La antigua disputa vuelve a renacer: o servidumbre o libertad» (Roger 1956, 82).

El asunto Aragon condujo a la ruptura de este con el grupo. Aragon fue uno de los fundadores del surrealismo, estuvo desde los primeros años y fue uno de los defensores más reconocidos, pero Aragon debe elegir entre los surrealistas y el partido, y «reniega del surrealismo para convertirse en comunista» (Nadeau 1972, 197). Breton y sus amigos consideran que «este gesto es una traición y se lo reprocharán siempre de aquí

\footnotetext{
${ }^{132}$ Miseria de la poesía, en castellano, como guiño al célebre escrito Miseria de la filosofía (1847) de Karl Marx en contra Pierre-Joseph Proudhom, en el que critica los argumentos expuestos en el libro Filosofía de la miseria (1846) de este.
} 
en adelante» (Roger 1956, 83). Compartimos las palabras de Nadeau, «la salida de Aragon fue una importante pérdida para el grupo entero. El surrealismo perdía con él no sólo a uno de sus fundadores, sino a un poeta de dotes poco corrientes» $(1972,198)$.

En los dos años siguientes, a pesar de la diferencias cada vez más patentes con el Partido, se observa cómo un buen número de surrealistas se esfuerza en mantenerse en la Asociación de Escritores y Artistas Revolucionaros (A.E.A.R.). El 4 de julio de 1933, Breton es expulsado de la Asociación de Escritores y Artistas Revolucionarios por su actitud contrarrevolucionaria (Goutier 2005, 314; Rojas 2012, 75). Breton explicará:

La primera exclusión que pronunció la A.E.A.R. fue la mía: el motivo de esta exclusión fue que el n. 5 del Surréalisme au service de la Révolution incluía una carta que me había remitido Ferdinand Alquié —carta de espíritu libertario, y también conmovedora - en la que se atacaban violentamente las concepciones cívico-morales que habían presidido en el film ruso El camino de la vida. [...] La intensidad de la vida y de rebelión que contenía esa carta me indujeron a su publicación $(1972,173)$.

Aunque se queda sin voz en el Congreso de Escritores para la Defensa de la Cultura, gracias al apoyo de René Crevel, consigue que su comunicado sea leído. Lo leerá Paul Éluard en condiciones lamentables. Breton comentará acerca del hecho que «se acordó que mi discurso sería leído por Paul Éluard, pero cuando le fue concedida la palabra ya pasaba de la medianoche, la sala estaba medio vacía y se empezaban a apagar las luces» $(1972,180)$. Este discurso, junto a todas las conclusiones colectivas que provocó este congreso, se publican en el panfleto Du temps que les surréalistes avaint raison, tras una reunión el 2 de julio de 1933 entre Breton y el grupo surrealista. Desde entonces, Breton y los amigos se mantienen fieles a sus posturas políticas, denuncian la postura de Stalin y dejan de colaborar con las organizaciones manipuladas por el Partido Comunista (Goutier 2005, 314; Rojas 2012, 81).

\section{7.- La expansión del surrealismo}

Aun teniendo sus orígenes en Francia, el movimiento surrealista pronto se extendió por todo Occidente. A principios de la década de los años treinta, se forman grupos en diferentes países y se celebran exposiciones internacionales del surrealismo en 
Copenhague y Tenerife (1935), Londres (1936), París (1938) etc. Estas exposiciones surgen como resultado de la intención decidida de internacionalizar el movimiento. Junto a estas exposiciones también son impartidas conferencias por diversas capitales del mundo a cargo de Breton, Eluard, Peret y otros miembros del grupo. En países como

en Bélgica, bajo el impulso de Paul Nougué, Messens y René Magritte, se constituyó tempranamente un núcleo surrealista; asimismo en Yugoslavia, por obra de Ristitch, y en Checoslovaquia, por la de Toyen y Vitezlav Nezval. Sin embargo, la verdadera expansión internacional del surrealismo se ha verificado más bien por su influjo sobre artistas, escritores e intelectuales aislados, como Duprey, Heisler, Legrand, Luca Mitrani, Schuster, Trost, Zimbacca, etc. (Cirlot 1953,192).

Según expone Cirlot, no sólo es una expansión del grupo por países sino que es una influencia del movimiento en autores aislados. En marzo de 1935, André Breton, Jacqueline Lamba y Paul Éluard viajan a Praga a la inauguración de una exposición, acompañada de conferencias y la publicación del Boletín. André Breton pronuncia, en la Asociación de Pintores y Artistas Plásticos Mánes de Praga, un discurso antes unas 800 personas (Rojas 2012, 80).
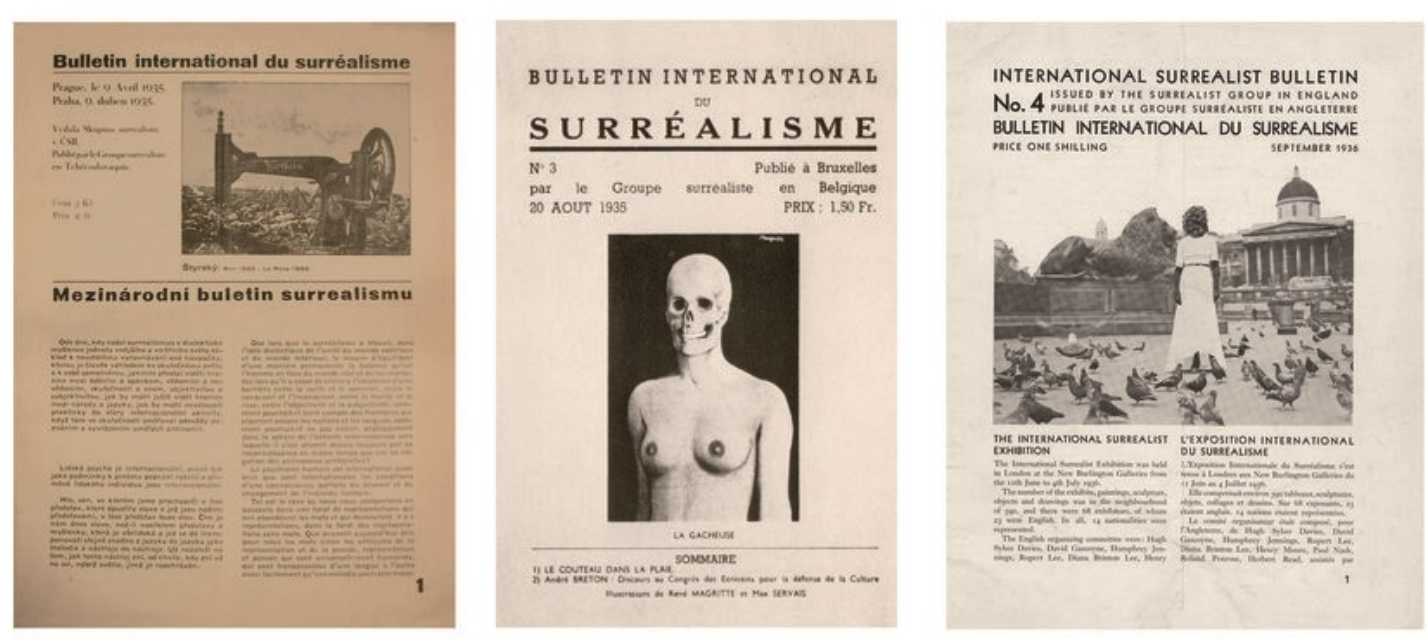

Fig. 50: Portada del número 1 (Praga, abril de 1935), del número 3 (Bruselas, agosto de 1935) y del número 4 (Londres, septiembre de 1936) del Bulletin international du surréalisme.

Con la idea de dar forma de carácter internacional al movimiento, surge el Bulletin international du surréalisme. Desde Praga, Tenerife, Bruselas y Londres se editan sucesivamente, en la lengua propia y en francés, los cuatro números que componen esta 
publicación (Mañero Rodicio 2013, 240). El primer número se publica en Praga en francés y checo, el segundo en Tenerife en español y francés, el tercero lo publica el grupo surrealista de Bélgica en Bruselas, y en septiembre de 1936, el grupo surrealista de Inglaterra publica el cuarto en la Gran Bretaña (Morris 1983, 11-12).

En España el surrealismo consigue formar un grupo en Tenerife con actividades alrededor de gaceta de arte, revista dirigida por Eduardo Westerdhal (Torre 1965, 382) y con su implicación en el número 2 del Bulletin international du surréalisme, al firmar su adhesión al surrealismo con su Déclaration, que aparece en las páginas interiores (Mañero 2013, 240). Por otra parte, cabe considerar, de acuerdo con Cristina Díaz Valera, que «el surrealismo supera la categoría de escuela artística para convertirse en una filosofía de vida, en una nueva forma radical de ver el mundo, pues propone fórmulas para alcanzar una existencia plena mediante la liberación de todo aquello que constriñe el espíritu humano» $(2004,80)$.

No hay que confundir la cronología del surrealismo, que representaría la ortodoxia de la escuela francesa, con la diferente repercusión y acogida en otras zonas. En este sentido, cabe distinguir la recepción que tuvo en Francia o Bélgica, y la que comprobamos en Italia o España, que es en la que se centra nuestra investigación. Las inquietudes de las vanguardias literarias y artísticas españolas concuerdan con las europeas. Los autores vanguardistas buscan ideas y conceptos nuevos.

A la llegada del surrealismo a España, encontramos dos movimientos propios de España y por extensión en Hispanoamérica: el creacionismo ${ }^{133}$ y el ultraísmo ${ }^{134}$ pertenecientes a la primera vanguardia española. Mientras que el primero es novedoso y original y opera sobre supuestos cubistas, el ultraísmo tiene una base futurista. Como afirma Sánchez Vidal, «el ultraísmo es más retórico, externo y limitado, con su obsesión por las

\footnotetext{
${ }^{133}$ Movimiento fundado en Buenos Aires, en 1916, por el poeta chileno Vicente Huidobro. En 1918 llegó a España y marcó influencia entre algunos poetas españoles, entre ellos Gerardo Diego y Juan Larrea que tuvieron una fase creacionista.

${ }^{134}$ Ultraísmo viene de la palabra ultra allá; más allá de los ismos. El principal promotor del ultraísmo fue Guillermo de Torre, ferviente admirador y poeta influenciado por el futurismo (Anderson 2018, 249). El ultraísmo tuvo una vida breve, nacido en 1918 de las tertulias en el café Colonial lideradas por Rafael Cansinos-Assens y desaparece en 1922 cuando deja de publicarse la revista Ultra. Según afirma Gloria Vida, «el ultraísmo español no es una escuela. [...] Fue, simplemente, un movimiento de superación de la lírica vigente, una reacción contra el modernismo, una voluntad de renovación, un ir "más allá", como indica su nombre» $(1971,91)$.
} 
máquinas y el esdrújulo técnico-científico [...], el creacionismo se basa en una materia prima más moldeable y rica, la de las imágenes» $(1999,45)$. En la práctica el ultraísmo tomó préstamos del creacionismo de Pierre Reverdy y Vicente Huidobro, y también de otras fuentes como el expresionismo, el dadá y, como ya hemos afirmado, del futurismo. (Anderson 2018, 246).

El ultraísmo buscaba «la emancipación del ritmo, de la rima y de la puntuación ("verso blanco y libre" es el dogma de base)» (Salaün 1998, 43), en cambio, el creacionismo aspiraba a una teoría estética general. Vicente Huidobro en la breve introducción a su obra Horizon carré (1917), de estética cubista y escrito en francés, definía así su nuevo estilo y estética:

Créer un poème en empruntant à la vie ses motifs et en les transformant pour leur donner une vie nouvelle et indépendante.

Rien d'anecdotique ni de descriptif. L'émotion doit naître de la seule vertu créatrice.

Faire un POÊME comme la nature fait un arbre (Huidobro [1917] 2002, 9) ${ }^{135}$.

Aun así, el creacionismo y el ultraísmo, predicaban una ruptura radical con el lenguaje poético tradicional (el lenguaje modernista), sin embargo, perdura una continuidad en el discurso poético. Como afirma Serge Salaün, «creacionismo y ultraísmo se complementan más que se excluyen» $(1998,44)$. Fue con la llegada del surrealismo y la generación del 27 cuando se presenta la crisis del lenguaje poético postsimbolista. Como afirma Anthony Leo Geist, el lenguaje del surrealismo

es revolucionario de una forma que supera la lingüística, a la estilística y a la temática. La historia del surrealismo ha sido una historia de subversión. La irrupción del inconsciente en medio del discurso poético, al cuestionar su base cartesiana, subvierte ese mismo discurso. Pero el lenguaje literario es simplemente la expresión en un horizonte cultural de un discurso más amplio de poder. Al hacer la irracionalidad el centro del discurso, se subvierte el discurso hegemónico. El surrealismo cuestiona radicalmente "el poder de las palabras sobre las cosas", cimiento de la ideología burguesa. Al hacerlo, cuestiona también a los que manejan ese poder $(1993,62)$.

135 «Crear un poema tomando a la vida sus motivos y transformándolos para darles una vida nueva e independiente. Nada anecdótico ni descriptivo. La emoción ha de nacer de la única virtud creadora. Hacer un poema como la naturaleza hace un árbol» (Huidobro [1917] 2002, 9). 
Pero con la aparición de un gran número de simpatizantes, entre los jóvenes autores, con las ideas surrealistas, Vicente Huidobro se posiciona en contra del surrealismo. En su libro Manifiestos (1925), recopilación de ensayos y escritos sobre los movimientos de vanguardia, refleja su actitud antisurrealista y su opinión sobre la ineficacia de la escritura automática:

Supongamos, incluso, que pudierais producir este automatismo psíquico puro, que pudierais disociar la conciencia a voluntad ¿quién podría probaros que vuestras obras son superiores? [...].

¿Acaso creéis que un hombre dormido es más hombre —o menos interesante— que uno despierto?

[...] La poesía ha de ser creada por el poeta, con toda la fuerza de sus sentidos más despiertos que nunca. El poeta tiene un papel activo y no pasivo en la composición y el engranaje de su poeta (citado en Morelli 2007, 215). 


\section{6.- El surrealismo en España}

Durante las primeras décadas del siglo XX, emergen tendencias y grupos en casi todos los países europeos que influyen a escritores, dramaturgos, compositores, pintores, escenógrafos, etc. Todos estos cambios y nuevas propuestas son conocidas como la Vanguardia. España, en un principio, se queda un poco apartada y poco receptiva a esas nuevas iniciativas vanguardistas. Aunque se puede observar que, con el cambio de siglo (del XIX al XX), en la literatura sí surgen cambios, se queda atrás el Realismo y el Naturalismo y cede el paso al Modernismo.

La vanguardia llega bastante tarde a España, fue durante la segunda década del siglo XX cuando empieza a surgir una difusión de estos grupos y movimientos artísticos tan variados que ya circulaban por Europa. Con la difusión de la obra de Guillaume Apollinaire, la llegada del creacionismo de Vicente Huidobro, la presencia del expresionismo alemán a través de un joven Jorge Luis Borges, entre otros y, ya a mediados del siglo XX, llegará el surrealismo a España.

\section{1.- El término surrealismo y sus autores: Luis Cernuda, José María Hinojosa y Vicente Aleixandre}

El problema de la existencia o no de un movimiento surrealista en España ha sido cuestionado por la crítica, y existen numerosos estudios y artículos que aportan sus opiniones sobre el tema. La problemática llega incluso a la hora de denominar el movimiento, ya que se creyó que era un movimiento autóctono respecto al surrealismo francés. A lo largo de la historia del surrealismo, la misma palabra que le da nombre se ha entendido con una múltiple variedad de significados. Como dice Bodini:

la oscilación semántica superrealismo, surrealismo, infrarrealismo, y después también hiperrealismo, términos que no tienen significados distintos y representan si acaso la resistencia a definir el movimiento o la poética con un único término inequívoco y, en todo caso, a identificar o a distinguir semánticamente el surrealismo francés del español $(1971,9)$. 
Debido a esta ambigüedad han surgido malentendidos dentro del propio movimiento. El término francés surréalisme ha tenido varias traducciones en español: Fernando Vela empleó el término sobrerrealismo o suprarrealismo, José Bergamín supra-realismo, Guillermo de Torre y Carlos Bousoño superrealismo (Solà Solé 2014, 47), pero casi todos rechazaron con vigor el galicismo surrealismo (Personneaux 1986, 447). El prefijo francés sur, también sobre, expresa la noción de un "más allá": como expone Fernández «cuando hablamos de surrealidad (surrealité) estamos refiriéndonos a una realidad en la que lo extraordinario [...] tiene en cuenta no sólo los aspectos racionales de la existencia [...] sino también aquellos que escapan al control de nuestra lógica» (1999, 361). Y en el punto — conocido como el punto supremo (point suprême)donde se unen las realidades objetivas y subjetivas es donde los surrealistas quieren llegar. Sin embargo, en muchos casos llegan a darle tanta importancia a una de las realidades que llegan a olvidar la otra.

La polémica surgió entre los que se sintieron ajenos al movimiento vanguardista, rechazando cualquier posible influencia y entre los que afirmaron un contacto claro entre el surrealismo francés y el español (Morelli 2007, 224). De los diferentes artículos que aparecen a mediados de los años veinte, en los que se intenta definir y dar nombre, cabe destacar el de Fernando Vela «El suprarrealismo» publicado en octubre de 1924 de la Revista de Occidente en el supone que el surrealismo es

otro intento de evadirse de la realidad, pero no a través de la imaginación y la fantasía —donde la parte consciente del poeta puede ejercer influjo-, sino a través del sueño, con lo que el poeta no tiene la más mínima posibilidad de controlar su obra, ésta se le escapa por ese "túnel subterráneo del sueño" (citado en García Gallego 1984, 31).

El suprarrealismo trata de aplicar al mundo del sueño el mismo examen metódico que a la vigilia: así descubriremos su integridad, su realidad, y que esos efectos llamados subjetivos obedecen a propiedades y leyes tan objetivas como las del mundo de la vigilia (citado en Morelli 2007 225-226)

En 1928, Felipe Sassone en su artículo «Superrealismo y ultraísmo: opiniones sin fundamento» ${ }^{136}$ publicado en $A B C$ definía el surrealismo como

\footnotetext{
${ }^{136}$ Días más tardes, el 10 de mayo de 1928, en el mismo $A B C$, José López Rubio escribe una columna en la que se posiciona en contra de las ideas de Sassone, donde afirma que «Los surrealistas inventaron el
} 
Superrealismo es... la superación de la realidad. [...] Hay dos maneras de huir de la realidad, que es el disgusto de los poetas: una, que pudiera llamarse mejor ultrarrealismo, más allá de lo real, y otra, superrealismo, más adentro en lo real. El ultrarrealismo vuela; el superrealismo ahonda. El primero que tiende a mezclar lo sobrenatural y lo fantástico con la humanidad del poema $(1928,10-11)$.

El crítico literario Guillermo Díaz-Plaja, en 1931, definiría y expondría el concepto del superrealismo como que

sólo consiste en explorar los más profundos pozos del espíritu humano. Del subconsciente. Del sueño. Cualquier hombre que describa de una manera auténtica y veraz las imágenes surgidas en su interior durante el sueño; habrá escrito un texto superrealista. Precisa, solamente, que este hombre sepa eliminar todas sus veleidades estéticas, formalísticas y lógicas. Que escriba de una manera automática, pura. Las obras realizadas dicen claramente cómo esta desencadenada fantasía, sin amarras con la realidad, produce obras profundamente poéticas. Bellas. Y, sobre todo, de un sinceridad extraordinaria ([1931] 1975, 69).

Los poetas españoles de la época estaban atentos a los nuevos rumbos de la poesía y por ello no se les debió escapar la revolución que traía el surrealismo y sus posibilidades para librarse del estancamiento. Aunque no pueda considerarse que en España se diera como una escuela organizada, pero sí fue un movimiento generalizado que se adoptó de una manera singular y personal en cada poeta (Onís 1974, 80; Villena 1997, 153).

En los años veinte, algunos de los miembros de la Generación del 27 se ven afectados de una crisis cultural y, como afirma Anthony Leo Geist, «en este momento crítico abandonan su estilo poético anterior y, unos más, otros menos, llevan a su arte técnicas e imágenes surrealistas» (1987, 231). Entre 1927 y 1932, en España, un buen número de poetas practicaron el surrealismo, aunque no quizás en su forma más ortodoxa. Según Luis Antonio de Villena, «la novedad técnica de la imagen surrealista — metáfora en

surrealismo para ellos. El nombre les pertenece, y no puede llamarse surrealismo lo que no esté dentro de esta definición que André Breton da» (1928, 10). El 17 de mayo, $A B C$ publica «En torno al superrealismo: por última vez» en el que Sassone replicaba a Rubio

Sr. López Rubio [...] de que el superrealismo es una invención francesa de Aragón, Delteil Scupault, Breton, Vildrac, Crevel, Boiffard, etc., etcétera [...] acaba prohibiéndome denominar superrealismo a todo lo que no tenga las características marcadas por sus inventores. [...] ¿De veras no hay más superrealismo que el firmado por cualquiera de los ochos sabios y sus etcéteras?

demostrando las posturas tan opuestas entre los diferentes autores, críticos y poetas. 
que habla lo subconsciente - es utilizada por los principales poetas no como un mero experimento lingüístico o literario, sino como cauce para la expresión de una rebelión o un estado de conciencia íntimo y turbio» $(1997,153)$.

El poema en prosa es uno de los géneros literarios más desarrollados durante el período de vanguardias. Aunque muchas de estas composiciones eran concebidas y reunidas como poemarios, incluso, algunas obras contienen textos en verso. Entre los autores y las obras que se pueden considerar surrealistas encontramos: Oscuro dominio (1926), compuesto por poemas en prosa y textos en verso, y Versión celeste (1927) de Juan Larrea $^{137}$; Sobre los ángeles ${ }^{138}(1927-28$, publicado en 1929) y Yo era un tonto y lo que he visto me ha hecho dos tontos ${ }^{139}$ (1929) de Rafael Alberti; Pasión de la tierra (19281929) poemario compuesto por poemas en prosa, Espadas como labios (1932) y La destrucción o el amor (1933) de Vicente Aleixandre; Un río, un amor (1929-30, publicado en 1936) y Los placeres prohibidos ${ }^{140}$ (1931) de Luis Cernuda; Poeta en Nueva York (1929-30, publicado en 1940) de Federico García Lorca; Gertrudis (1927) y $K R T U$ (1932) de Josep Vicenç Foix y muy cercanos a la poesía automática Poesía de perfil (1926), los poemas en prosa Flor de Californía ${ }^{141}$ (iniciado en 1926, pero publicado en 1929), y ya en verso Orillas de la luz (1927) y La sangre en libertad (1931) de José María Hinojosa; Jacinta la pelirroja (1929), Carambas (1931) y Puentes

${ }^{137} \mathrm{La}$ influencia surrealista fue negada por el propio poeta, aunque tuvo una relación estrecha con los dadaístas y los surrealistas franceses (Morelli 2007, 33).

${ }^{138}$ En esta obra se puede observar una crisis estética y una transformación de ciertos elementos estilísticos anteriores. En los años veinte algunos miembros de las Generación del 27 en un momento crítico abandonan su estilo poético anterior y llevan a su arte técnicas e imágenes surrealistas.

139 Conjunto de poesías en homenaje a los cómicos del cine: Charles Chaplin, Harold Lloyd, Buster Keaton, Laurel y Hardy. Respecto al libro, según el propio Alberti en sus memorías afirmaba, «Vivíamos entonces la Edad de Oro del gran cine burlesco norteamericano, centrada por la genial figura de Charles Chaplin. A todos esos tontos — verdaderos ángeles de carne y hueso- dedicaba yo los poemas de este libro» ([1959]1975, 274).

${ }^{140}$ Un año y medio después de terminar Un río, un amor, Cernuda escribió su segundo y último libro surrealista. Según Luis Antonio de Villena «Los placeres prohibidos es el libro más genuinamente surrealista de la poesía española» $(1997,156)$. En esta obra reivindica el amor y critica las convenciones de la sociedad, es un libro de protesta donde pide un nuevo mundo.

${ }^{141}$ Este es el libro más conocido de José Luis Hinojosa. Consta de dos partes: una primera parte formada por siete textos en prosa automática, dedicados a sus amigos, y una segunda que reúne una breve colección de siete textos oníricos (Sánchez Rodríguez 1987, 140; Morelli 2007, 237).

Según Alfonso Sánchez Rodríguez, esta obra es «una de las escasas contribuciones del surrealismo literario español al campo de la prosa, como lo es también Pasión de la tierra de Vicente Aleixandre. Ambas estás [sic] escritas en un estilo de lo más ortodoxamente puro desde el punto de vista de la estética bretoniana» $(1987,140)$. 
que no acaban (1933) de José Moreno Villa ${ }^{142}$; El tacto fervoroso (1930) y Dédalo (1932) de Juan José Domenchina y Seis estampas para un rompecabezas (1925) de Emilio Prados. Aún así, los poetas del 27 negaron en muchas ocasiones la influencia del surrealismo en su obra porque lo entendían como

un simple método que además ponía el acento en la inspiración y relegaba a un segundo lugar todo el aspecto del trabajo del poeta. Una escritura automática, no regida en absoluto por la razón sino fuera de todo tipo de control lógico, significaba que el poeta era un mero copista de lo que su imaginación le dictaba (Fernández 1999, 362).

Y, según Fuentes,

la "lógica poética" que esgrimía como arma el poeta queda dominada por las insólitas circunvalaciones de la metáfora y de un viaje siempre a punto de impedir los retornos, [...] los poetas del 27 extraen del surrealismo francés la base teórica donde apoyan su libertad de impulsos e instintos pero que la superan en un calidoscopio magnífico de símbolos irracionales donde sustentan sus sentimientos $(2004,218)$.

De todos los poetas de la generación, Luis Cernuda (Sevilla, 1902-Ciudad de México [México], 1963) es el único que reconoce su vinculación con el surrealismo. En 1958, en «Historial de un libro (La Realidad y el Deseo)» Cernuda muestra su simpatía por el surrealismo, y la fuerte impresión que le dejaron cuatro libros ${ }^{143}$ : Aniceto ou le panorama (1921) y Le Libertinage (1924) de Louis Aragon; Les pas perdus (1924) de André Breton y La mort difficile (1926) de Éluard Crevel y cómo mientras los leía, percibía «cómo eran míos también el malestar y osadía que en dichos libros hallaban voz» ([1958] 1991, 388). En 1928 viajará a Francia y, a su regreso de Toulouse, Luis Cernuda afirmará:

Al escribir el poema «Remordimiento en traje de noche», encontré de pronto el camino y forma para expresar en poesía cierta parte de aquello que no había dicho hasta entonces. [...] uno tras otro, surgieron los tres poemas primeros de la serie que luego llamaría «Un Río, un Amor», dictados por un impulso similar al que animaba a los superrealistas. [...] el superrealismo no fue sólo, según creo, una moda literaria, sino

\footnotetext{
${ }^{142}$ Forma parte, junto con Alberto Sánchez Pérez y Benjamín Palencia, de la tendencia conocida como la primera Escuela de Vallecas.

${ }^{143}$ De los cuatro libros, los tres primeros corresponden a la época Dadá.
} 
además algo muy distinto: una corriente espiritual en la juventud de una época, ante la cual yo no puede, ni quise, permanecer indiferente ([1958] 1991, 391).

Luis Cernuda solía utilizar el término surrealismo (prefería llamarlo superrealismo) para referirse tanto al movimiento surrealista inaugurado por Breton en 1924, como al movimiento predecesor, el dadaísmo. Aunque hubo cierta continuidad entre los dos movimientos, también existían diferencias importantes, sobre todo al tipo de rebeldía que proponían. La rebeldía de los dadaístas fue una rebeldía que caracteriza a la juventud, como un rechazo a todo lo convencional y, según los surrealistas, esta rebeldía no podía prolongarse indefinidamente. Según afirma James Valender, Cernuda «se sentía más atraído hacia la independencia moral y espiritual de Dadá que hacia el compromiso que propusieron los surrealistas, sobre todo a partir de la publicación de su Segundo Manifiesto (1930)» $(1987,147)$.

El rechazo del fenómeno surrealista es tanto por parte de los críticos como de los propios poetas. Cuando un autor reconocía su vinculación con el surrealismo se exponía a ser marginado, como es el caso de Luis Cernuda, o a crear enemistades entre sus contemporáneos. A José María Hinojosa ${ }^{144}$ (Campillos [Málaga], 1904-Málaga, 1936), se le puede considerar como el introductor de la poesía surrealista en España. Aunque perteneciente a una familia acomodada, conservadora y burguesa, su inconformismo de juventud hizo que durante un tiempo se acercara a ideologías de posiciones de izquierdas $^{145}$. Conoció personalmente a André Breton, del que aprendió la técnica del surrealismo y que aplicó a su obra, poco reconocida por sus coetáneos (Ruiz-Copete 2002, 189; Personneaux 1986, 449). Según afirma Juan de Dios Ruiz-Copete, «Gerardo Diego le hace, con el título de «Serranilla de la Jinojepa», unas letrillas demoledoras [...]. Y Moreno Villa [...] en sus memorias: «el pobre José María Hinojosa, que en verdad era un poeta pardillo, deslumbrado por una larga estancia en París» $(2002,192)$, palabras que se contradicen con las del prólogo que escribió a La flor de Californía en

\footnotetext{
${ }^{144}$ En 1931 escribe su última obra, La sangre de la libertad, y abandona toda relación con el mundo literario, tal vez por no sentirse reconocido entres sus compañeros de generación, y se dedica a la política en el Partido Nacionalista Español como candidato a diputado por la Unión Agraria de Derechas. A principios de la guerra civil, con tan sólo 32 años, es fusilado, el 22 de agosto de 1936, junto a su padre y hermano, ante la tapia del cementerio de San Rafael de Málaga (García Martín 2004).

${ }^{145}$ Llegó a viajar a Rusia, en 1928, para conocer los resultados de la Revolución soviética de 1917 y, una vez en España, intentar aplicarlas en la gestión de explotaciones agrícolas familiares (Ruiz-Copete 2002, 190-191).
} 
1928 en el que lo calificaba como «un delicioso viaje imaginativo» (citado en RuizCopete 2002, 192). Autores, como Joaquín Romero Murube o Luis Cernuda, reconocieron el valor surrealista en su obra (Ruiz-Copete 2002, 192).

Tanto Vicente Aleixandre como García Lorca negaron la etiqueta surrealista por entender que ésta implicaba aceptar la escritura automática y la conciencia de grupo. Vicente Aleixandre (Sevilla, 1898-Madrid, 1984), en el prólogo a la segunda edición de La destrucción o el amor (1944), dice: «No he creído nunca en lo estrictamente onírico, en la "escritura automática", en la abolición de la conciencia creadora» ([1944] 1978, 523), y en el prólogo a Mis poemas mejores (1956) también mantendrá la misma posición. De Pasión de la tierra dirá que es «el libro mío más próximo al suprarrealismo, aunque quien lo escribiera no se haya sentido nunca poeta suprarrealista, porque no ha creído en los estrictamente onírico, la escritura "automática", ni en la consiguiente abolición de la conciencia artística» (Aleixandre [1956] 1978, 11).

Aunque también reconoce la importancia que tuvo la figura de Freud y sus escritos «hace tiempo que sé, aunque entonces no tuviera conciencia de ello, lo que este libro [Pasión de la Tierra] debe a la lectura de un psicólogo de vasta repercusión literaria (Freud), que yo acababa de realizar justamente por aquellos años» (Aleixandre [1956] 1978, 31). En el prólogo de su libro Poesía superrealista escribió:

alguna vez he escrito que yo no soy ni he sido un poeta estrictamente superrealista, porque no he creído nunca en la base dogmática de ese movimiento: la escritura automática y la consiguiente abolición de la conciencia artística. ¿Pero hubo en este sentido, un verdadero poeta superrealista? (Aleixandre 1971, 3).

Respecto a la postura de Federico García Lorca con el surrealismo, podemos encontrar la carta de septiembre de 1928, dirigida, desde Granada a Sebastià Gasch, en la que le remitió dos poemas ${ }^{146}$ en prosa suyos, «Suicidio en Alejandría» y «Nadadora sumergida» (García-Posada 1981, 328) refiriéndose a que «responden a mi nueva manera espiritualista, emoción pura descarnada, desligada del control lógico, pero, ¡ojo!, ¡ojo!, con una tremenda lógica poética. No es surrealismo, ¡ojo!, la conciencia más clara los ilumina» (García Lorca 1997, 1080).

\footnotetext{
${ }^{146}$ Los dos poemas se publican en 1928 por L'Amic de les Arts, junto a dos dibujos también de Lorca.
} 
Limitar el surrealismo al automatismo cuestionaba a estos autores a llamarse surrealistas, ya que ellos querían tener el dominio sobre su obra y no dejarla sin control. Y, como afirma García Gallego, «que los mecanismos de creación fueran más o menos "ortodoxos" no desvirtuaba el resultado final de la obra [...], pues su producción era finalmente equiparable al mejor surrealismo literario del momento» $(1987,18)$.

También podemos encontrar la influencia surrealista en general en toda la prosa de Pablo Picasso; la novela Los senos de tinta (1934) de Pedro García Cabrera; En la vida del señor Alegre (1924), primera obra narrativa de Claudio de la Torre; Crimen (1923) de Agustín Espinosa, y la ya citada Yo, inspector de alcantarillas (1928) de Ernesto Giménez Caballero (Morelli 2007, 222).

La tesis de un surrealismo español sin escritura automática iba tomando cuerpo desde el momento en que Dámaso Alonso apuntó la posibilidad para el caso de Vicente Aleixandre (Navas 2009, 564). En 1935, Pedro Salinas encontraba la perfección de la lírica de tipo surrealista en el libro Espadas como labios de Aleixandre (Fernández 1999, 360).

Es evidente que los críticos se tomaron de una manera excesivamente literal la interpretación del Manifiesto. Por eso los poetas y, sobre todo los pintores, debido a sus visitas en París que conocían el surrealismo de primera mano, estaban más en contacto con la parte práctica que la teórica y, por tanto, acabarían estando mucho más cerca del verdadero surrealismo que los críticos. El automatismo del proceder poético nunca fue total desconexión del hombre con la palabra (Fuentes 2004, 216). En general, la crítica que se hará a las obras surrealistas durante estos años, «si se habla de la influencia surrealista en España, es siempre dejando claro que no fue influjo de la poesía francesa sobre la española sino necesidad del tiempo» (Fernández 1999, 360).

En 1935, para Dámaso Alonso no existe el surrealismo español y el francés tan sólo es «una sección particular de un no bien especificado hiperrealismo del siglo, al que todos los poetas de Europa y, por tanto, también los españoles, tuvieron libertad de acceso aun sin necesidad de Breton y sus compañeros» (Bodini 1971, 18). Las tesis de Pedro Salinas y Dámaso Alonso consideran al surrealismo una tendencia de tipo romántico, utilizan el término "neorromanticismo" para intentar desvincular del surrealismo francés la nueva poesía irracionalista y vitalista de Aleixandre. Ya que características como «el 
ansia de libertad, la importancia del propio yo, el desbordamiento emocional, la rebeldía contra la realidad» (Onís 1974, 83) se dan tanto en el surrealismo como en el romanticismo. No hay que olvidar que algunos de los maestros del surrealismo como Lautreamont o Rimbaud pertenecían al romanticismo.

Las teorías de Salinas y Alonso son las responsables de la negación del automatismo por parte de los poetas del 27. Según Navas,

una generación que había elevado la poesía al rango más alto de la escala literaria no podía renunciar tan fácilmente [...] a las prerrogativas que convertían en "poéticas" sus creaciones y era incapaz de adherirse sin ambages a una poesía, la surrealista, que relegaba al poeta a la función de mero transcriptor del dictado del subconsciente (2009, $556)$.

Como hemos repetido, el surrealismo en España no se dio como una escuela organizada, ya que los poetas no quisieron abandonar su propia individualidad. En ese momento la poesía española se caracterizaba por la diversidad de tendencias que coinciden, en lugar de sucederse una tras otra. Los poetas no quisieron renunciar a la tradición y la fundieron con el surrealismo (Onís 1974, 84).

El caso del surrealismo español presenta rasgos identificativos que lo diferencian de las otras prácticas surrealistas europeas. Aspecto fundamental es la vinculación con la tradición de la poesía pura, la tradición de la metáfora y la intención de ruptura de los cánones tradicionales. Estamos, pues, ante textos en donde se produce una interacción entre lo tradicional y lo vanguardista (Ferreyra 2004, 42).

\section{2.- La Vanguardia y el surgimiento del surrealismo en España}

En la época de las vanguardias se puede reconocer el origen de muchos de los elementos radicalmente nuevos que van a configurar todo el arte del siglo XX. En los países europeos, la importación y asimilación de movimientos extranjeros fue un comportamiento habitual y, entre ellos, encontramos el surrealismo.

El vanguardismo, en España, en sus comienzos se entendió en un primer momento como arte puro, como simplemente un modo de expresión, ya que los artistas españoles 
no habían vivido el horror de la Gran Guerra, pero luego se entiende que la vanguardia es algo más, es la búsqueda del hombre, de la verdad sobre sí mismos, la felicidad y la expresión de su yo (Fernández 1999, 364). Entre 1917 y 1930 fue un período de rupturas estéticas en el que se suceden distintas fases, que a la vez son complementarias entre ellas: de 1917 a 1923, transcurren las vanguardias propiamente dichas, donde se busca la liberación del signo y de las formas; de 1923 a 1930 se recupera la forma y la arquitectura de la obra y, a partir de 1928, surge el surrealismo (Salaün 1998, 41).

En la década de los años veinte, la literatura española está dominada por la poesía pura, cuya diferencia principal, según Antonio Blanch, con el Creacionismo y el Ultraísmo, es el carácter intelectual de la poesía pura. Aunque ambas tendencias, vanguardismo y poesía pura, marcan a todos los jóvenes poetas de la época, conocidos como la generación del 27. La influencia de la poesía pura en los poetas recibe un impulso adicional tras la conferencia dictada por Paul Valéry en la Residencia de Estudiantes en mayo de 1924 (Cao 1984, 54). En su primera etapa, que llega hasta finales de la década de los veinte, los poetas siguen el magisterio de Juan Ramón Jiménez y tratan de hacer poesía pura. Aunque éstos querían algo más que el afán de la perfección formal, al entrar en contacto con el surrealismo, se sintieron atraídos por él, como afirma Fernández,
la poesía, al menos en su intención, vuelve a acercarse al hombre que es y a los hombres que rodean al autor. Los poetas de la generación del 27 se encuentran con un lenguaje nuevo, una manera distinta y eficaz de tratar las palabras y las imágenes que les sirve para expresarse de manera radical, para manifestar sus problemas, sus inquietudes, sus pensamientos, sin miedo a ser sinceros $(1999,358-359)$.

En los inicios del surgimiento del surrealismo en España, la poesía española empezaba a mostrar elementos nuevos con tendencias surrealistas, muchos lo confundieron el Ultraísmo o el Creacionismo. El propio Juan Ramón Jiménez, tan determinante en la formación intelectual de los miembros de la Generación del 27, no ve diferencias entre los movimientos: 
¿El sobrerrealismo? Un romanticismo, un antiquísimo, un medievalismo, un renacentismo, un neoclasicismo, un parnasianismo, un simbolismo, todo abreviado en barroquismo, y con cualquier técnica de lo subconsciente (Jiménez 1967, 94) ${ }^{147}$.

Aunque tuvo una posición contraria al movimiento surrealista, Juan Ramón Jiménez fue un escritor acuciado por el mundo de los sueños y del subconsciente. En fechas tempranas, entre 1915 y 1916, muestra interés en transcribir y convertir en textos literarios sus sueños. En una conversación con Juan Guerrero, el 28 de abril de 1931, explicó su proyecto «Viajes y Sueños ${ }^{148}$, dónde están los viajes reales y los ilusorios escritos en esa forma de sueño subconsciente» (citado en Gómez Trueba 2003, 393). Pero, a diferencia del surrealismo, Juan Ramón Jiménez buscaba la inspiración en el sueño y sus escritos son una recreación poética del sueño, nada que ver con las técnicas surrealistas.

La primera vez que André Breton visitó a España fue con motivo de una exposición de Francis Picabia en las Galerías Dalmau de Barcelona, el 17 de noviembre de 1922. Para la ocasión, Breton pronunció una conferencia en el Ateneo de Barcelona con el título «Caractères de l'évolution moderne et ce qui en participe» publicada posteriormente en Les pas perdus (1924). Fue la primera vez que un surrealista venía a España y, según la prensa de la época, el hecho no tuvo gran repercusión (Solà Solé 2014, 215).

El año 1925 es decisivo en el panorama de la vanguardia artística española, tanto en la literatura y como en las artes plásticas. La Dictadura de Primo de Rivera es el marco histórico en donde se fraguarán las nuevas trasformaciones culturales que se llevarán a cabo, posteriormente, durante la época de la República. Durante este período, la realidad social que les rodea continúa ausente en el ámbito de las vanguardias. Como dice Brihuega, «1925 marca la puesta en marcha de un torrente de revistas, exposiciones, manifiestos, grupos, etc. que se extenderán como la pólvora por todo el territorio español» $(1983,208)$.

\footnotetext{
${ }^{147}$ En 1967 se edita el libro, Estética y ética estética, formado por una selección de prosa crítica fechada entre 1920-1954.

${ }^{148}$ Fueron publicados parcialmente tras la muerte de Juan Ramón Jiménez, un conjunto de sueños-relatos, experiencias oníricas que ocupaban un espacio dentro de su prosa autobiográfica.
} 


\section{BARCELONE}

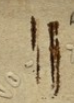

LE 18 NOVEMBRE 1922 OUVERTTUR DE L'

EXTOS I T I O N

FRANCIS PICABIA

À LA GALERIE DALMAU

LA VEILLE, À L'ATENEO BARCELONÉS

CONFÉR E N C E

PAR ANDRE BRETON:

CARACTÉRES

DE L'ÉVOLUTION MODERNE

ET CE QUI EN PARTICIPE

LA PEINTURE : Georges de Chirico, Marcel Duchamp, Max Ernst, Man Ray, Francis Picabia, Pablo Picasso.

LA POÉSIE : Guillaume Apollinaire, Louis Aragon, Jacques Baron, Robert Desnos, Paul Eluard, Richard Huelsenbeck, Alfred Jarry, Comte de Lautréamont, Germain Nouveau, Benjamin Péret, Francis Picabia, Pierre Reverdy, Arthur Rimbaud, Philippe Soupault, Tristan Tzara.

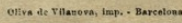

Fig. 51: Información de mano de la Exposición de Francis Picabia en las Galerías Dalmau, en la calle Portaferrisa, y de la conferencia de André Breton en el Ateneo.

Hasta el momento, la cuestión del surrealismo no pasaba de ser la noticia curiosa de una nueva línea de pensamiento con posibles implicaciones en el ámbito literario (Brihuega 1983, 207). La Exposición de la Sociedad de Artistas Ibéricos (E.S.A.I.) fue el arranque de una nueva etapa en el panorama cultural de Madrid. En Barcelona, el otro gran foco, lo encontramos en la ya nombrada galería Dalmau. José Ortega y Gasset aprovecha la onda expansiva de la E.S.A.I y publica La deshumanización del arte (1925); en el texto no utiliza, a propósito, el término de Vanguardia sino que se refiere al Arte Nuevo o Arte Joven. También Guillermo de Torre lanza sus Literaturas europeas de vanguardia (1925) y consagra a España en el vanguardismo internacional, con una visión retrospectiva del ultraísmo y un extenso capítulo sobre el surrealismo (Sánchez Vidal 1999, 347). Como afirma García Gallego, «el ámbito de recepción en España, se limita 
principalmente a los críticos y miembros del mundo literario y artístico. Se puede entonces hablar de una recepción limitada a un público especializado» $(1984,12)$.

\section{3.- La entrada del surrealismo en España: aparición de nuevas revistas literarias}

Los surrealistas franceses ya habían publicado varias de sus obras y empezaban a ser conocidos en España, cuando el 18 de abril de 1925, Louis Aragon visita España y dicta, por primera vez, una conferencia en la Residencia de Estudiantes ${ }^{149}$ con el título «Contre la science, le travail et la civilisation». Ese mismo año, la revista Plural. Revista Mensual de Literatura, publicaba un artículo de Guillermo de Torre, «Neodadaísmo y superrealismo», en el que se daban las primeras noticias ampliamente documentadas sobre la aparición del movimiento francés, interpretando al surrealismo como un simple movimiento continuación del Dadá y el carácter poco novedoso de su contenido teórico, derivado de la obra de Freud (Morelli 2007, 226).

En el año de la entrada del surrealismo en España, los grupos intelectuales se percataron de la importancia del nuevo movimiento y su actitud. La adquisición de ejemplares de La Révolution Surréaliste y de otras publicaciones del grupo surrealista fue algo inmediato, como ya había ocurrido en anterioridad con otros movimientos de la vanguardia. La aparición de artículos en torno al surrealismo continuaría sin cesar hasta 1936 (Brihuega 1983, 209).

El mundo catalán abre su primera ventana a la vanguardia en Sitges, en abril de 1926 en donde aparece una revista que luego será clave en este proceso: L'Amic de les Arts. Desde sus páginas Sebastià Gasch comienza a preparar el camino para la entrada del surrealismo en Cataluña (Brihuega 1983, 209). En marzo de 1928, Salvador Dalí, Lluís Montanyà y el propio Sebastià Gasch dan a conocer el «Manifest Antiartístic Català»» ${ }^{150}$, también conocido como «Manifest groc» por el color amarillo del papel de la única hoja grande en que lo imprimió. La revista con influencia futurista por la disposición de la

\footnotetext{
${ }^{149}$ Como ya hemos comentado, la Residencia de Estudiantes en Madrid fue el espacio físico donde tuvo lugar los primeros contactos con el Surrealismo y su posterior desarrollo en España (Scholz-Hänsel 1998, 56) ya estudiado con anterioridad.

${ }^{150} \mathrm{Su}$ versión española se publicó, posteriormente, en la revista Gallo.
} 
tipografía y la utilización de afirmaciones positivas hacia la modernidad y negativas contra la cultura tradicional catalana, tomaba una postura opuesta a la estética noucentista y ya solicitaban una vida moderna e industrial (Mainer 2013, 84; Anderson 2018, 277).

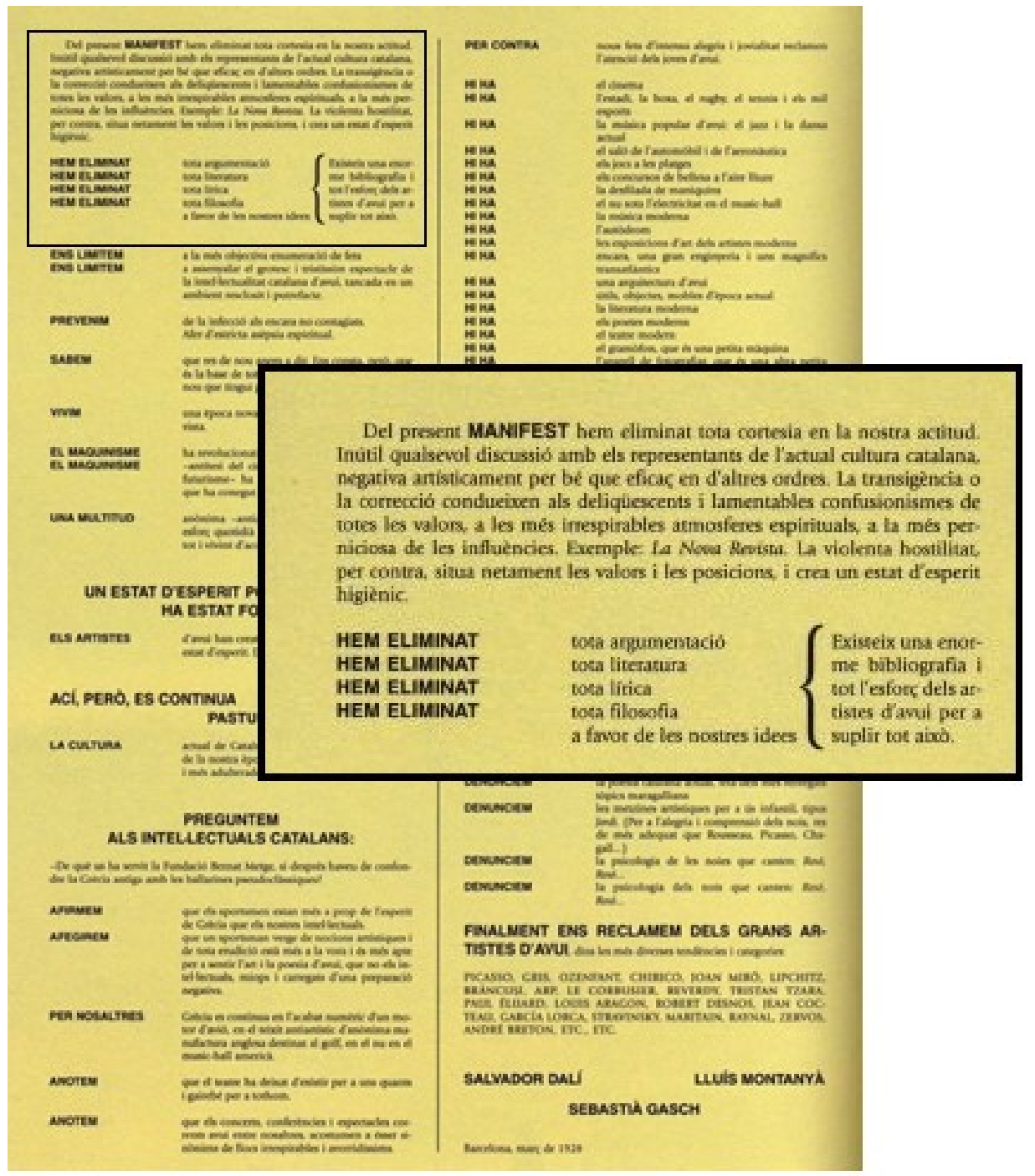

Fig. 52: Manifest groc (1928) en el que se presentan las principales ideas de la vanguardia catalana de los años veinte y treinta.

Un mes más tarde, L'Amic de les Arts organiza una serie de conferencias en el ateneo El Centaure. El grupo estaba formado por Josep Carbonell, J.V. Foix, Salvador Dalí, Sebastián Sánchez Juan, Lluís Muntanyà, M.A. Cassanyes y Sebastià Gasch. Con ese ciclo de conferencias querían exponer ante los asistentes las líneas del movimiento surrealista. El acto fue conocido por Els 7 davant el Centaure (Rodrigo 1975, 257). 


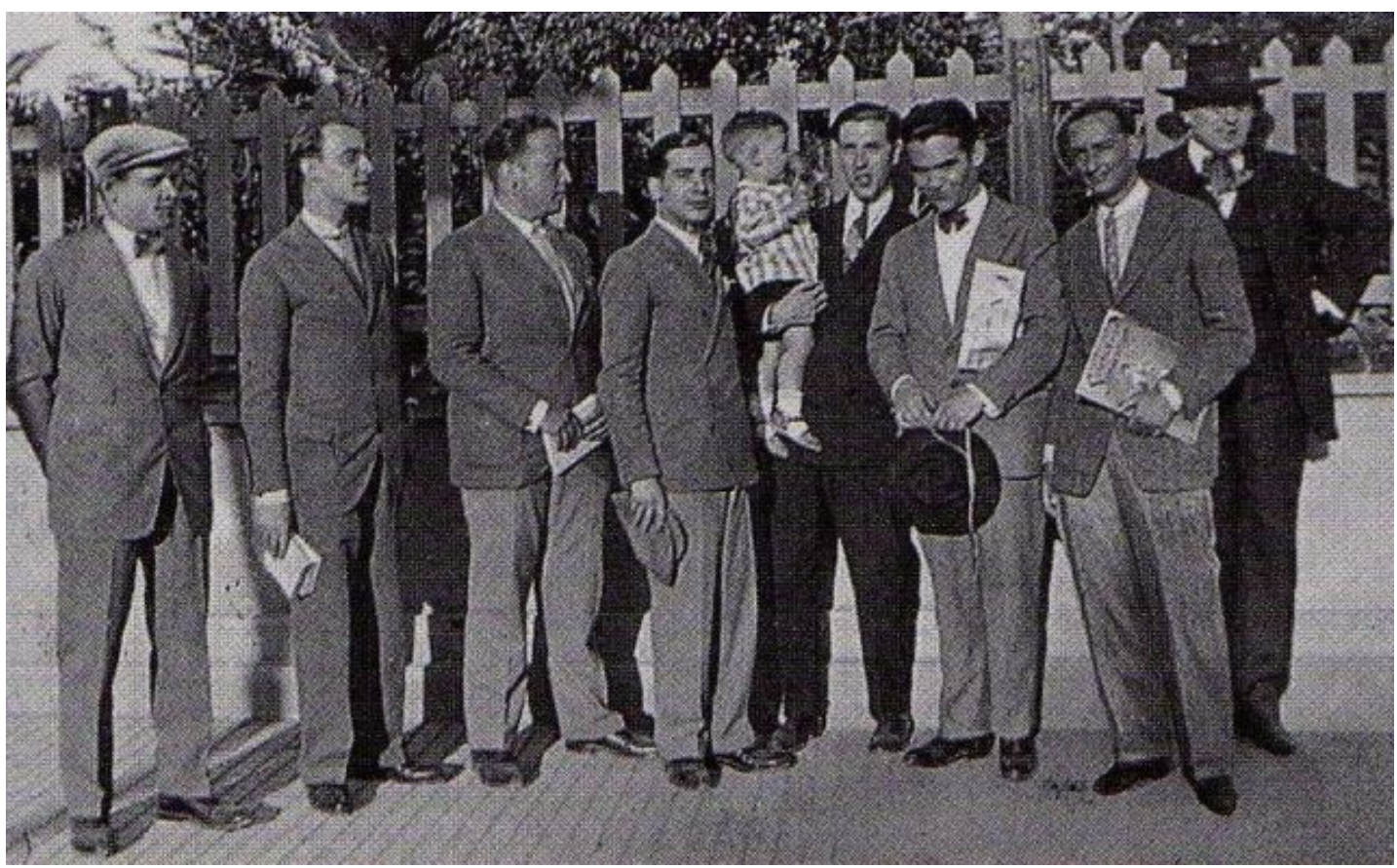

Fig. 53: Fotografía del grupo de la revista L'Amic de les Arts (Sitges, 1927).

De izquierda a derecha: Manuel Font, J. V. Foix, Sebastià Gasch, Lluís Muntanyà, Josep Carbonell, Federico García Lorca, Salvador Dalí y Magí A. Cassanyes

Colección: Fundación Federico García Lorca

Por su parte, en La Coruña, Alfar ${ }^{151}$, revista de «muy amplio criterio, en sus páginas siempre armónicas y espaciosas tenían cabida los más diversos nombres, representativos de todas las tendencias» (Alberti [1959] 1976, 153), dirigida y editada por el poeta uruguayo, Julio J. Casal. En la revista coruñesa aparecen diferentes intervenciones sobre el movimiento surrealista, por ejemplo, en el número 47 de Alfar, fechado en febrero de 1925, aparece el artículo titulado «Hacia un superrealismo musical» de César Muñoz Arconada, favorable al movimiento:

El superrealismo es ante todo una estética afirmativa. [...] Breton [...] ha recogido de Freud esta atmósfera misteriosamente procreadora y la ha adaptado a su método, queriendo dar así al arte [...] aquella sobreexcitación creativa, aquella tensión fluídica que había perdido (citado en Morelli 2007, 226).

En la revista Alfar (en el número 27, de abril de 1926), se publica por primera vez un texto surrealista de André Breton, «El desconfiado prodigioso» traducido por M. Núñez

151 Nacida en 1920 como Boletín de la Casa América-Galicia. En 1922, el cónsul de Uruguay la transforma en una Revista de la Casa América-Galicia en la que se observa un elevado aumento de las colaboraciones literarias. A partir del número 33, en 1923, la revista pasó a denominarse Alfar hasta 1926 (Mainer 2013, 177; Videla 1971, 61-62). 
de Arena y, en francés «Entre peau d'autres» de Paul Éluard (Bodini 1971, 22; Morelli 2007, 227).

En Málaga, aparece Litoral (desde 1926 hasta 1929) considerada la revista más emblemática de la década de los años veinte, reunió en mayor amplitud toda esa generación de jóvenes poetas. El primer número de Litoral salió en noviembre de 1926 y contenía treinta y seis páginas de la mejor poesía joven del momento. Las cuatro primeras entregas se suceden hasta abril de 1927 en el que ya no sólo aparecen los nuevos autores malagueños, sino también colaboradores de la talla de poetas como Rafael Alberti, Vicente Aleixandre, Manuel Altolaguirre, Luis Cernuda, Gerardo Diego, Federico García Lorca, José María Hinojosa y pintores como Salvador Dalí, Juan Gris, Pablo Picasso, etc. (Neira 2005, 216).

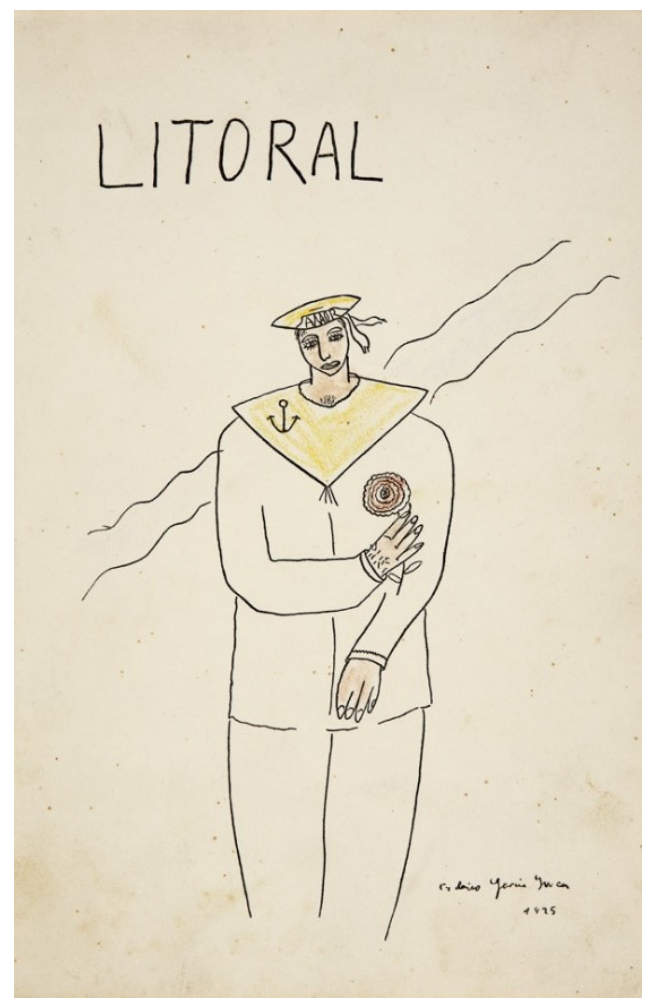

Fig. 54: Portada del $n^{\circ} 3$ de la revista Litoral, ilustración ${ }^{152}$ de Federico García Lorca.

Lápices de color sobre dibujo de 1925, 25,1 x $16,2 \mathrm{~cm}$.

Colección: Fundación Federico García Lorca.

152 Marinero de la revista Litoral en el número de marzo de 1927. Dada la fecha del dibujo, 1925, podemos deducir que Lorca adaptó el dibujo añadiendo la palabra LITORAL para ilustrar la revista. El barco al que pertenece este marinero tiene el nombre «AMOR» que, junto a la rosa roja que tiene entre sus manos, simboliza la pasión amorosa (Hernández 1986, 144). 
En sus números no incluyen ningún manifiesto, pero no cabía duda de la posición estética en la que se situaba la revista, ya que sus colaboradores pertenecían a las ideas renovadoras y vanguardistas. A finales de 1929, Litoral desaparece, debido a las dificultades económicas que siempre lastraron y por el distanciamiento ideológico progresivo entre Emilio Prados y José María Hinojosa, quien aportaba el capital para su publicación. Cuando Emilio Prados, «cada vez más radicalizado en su visión de la sociedad e identificado con el Segundo Manifiesto Surrealista» (Neira 2005, 231), y José María Hinojosa abandona la poesía y la subversión surrealista para convertirse en un terrateniente conservador militante de la derecha, se pierde la única ocasión en la península de incorporarse al surrealismo como colectivo (García Gallego 1987, 19).

En enero de 1927, aparece, en Madrid, La Gaceta Literaria, posiblemente la revista de mayor incidencia cultural de estos años $\mathrm{y}$, al mismo tiempo, surge la experiencia práctico-artística conocida como «Escuela de Vallecas» fundada por Alberto Sánchez y Benjamín Palencia, en la que se implican autores como la pintora Maruja Mallo, el poeta Miguel Hernández o el joven escritor Luis Felipe Vivanco (Scholz-Hänsel 1998, 56; Mainer 2013, 89). Entre 1927 y 1930, serán muchos los artistas que comienzan a introducir factores surrealistas en sus obras, aunque sea ocasionalmente (Brihuega 1983, 210). En el otoño de 1928, La Gaceta Literaria constituyó su cineclub con una sesión inaugural: L'Etoile de Mer de Man Ray y Robert Desnos.

En Granada, los hermanos Federico y Francisco García Lorca, junto a sus amigos de "El Rinconcillo ${ }^{153}$ " del café Alameda, editan los dos únicos números de la revista gallo (con minúscula inicial) con inspiración surrealista. El 8 de marzo de 1928, dos días antes de poner en venta el primer número, se celebra una comida literaria $\mathrm{y}$, entre los diferentes discursos, Lorca expone claramente los intereses de la revista

Un grupo nuevo de Granada [...] ser reúne en torno de este gallo y creo que ahora va de firme. Todos a una. Con el amor a Granada, pero con el pensamiento puesto en Europa $[\ldots]$.

\footnotetext{
${ }^{153}$ A principios de la década de 1920 nace la tertulia intelectual conocida como "El Rinconcillo". En el café Alameda de la plaza del Campillo. La idea era renovar el mundo de las ideas culturales de la ciudad. Entre el grupo de intelectuales granadinos que formaban esta tertulia se encontraban Federico García Lorca, su hermano Francisco, los periodistas Manuel de Falla, Melchor Fernández Almago, José Mora Guarnido y Constantino Ruiz Carnero y los pintores Manuel Ángeles Ortiz, Ismael González de la Serna, entre otros (Maurer 2018).
} 
Esta revista [...] es la voz más pura de Granada; la voz de su juventud, que mira al mundo, y, desde luego, la única que se oirá fuera de ella (citado en Jiménez Gómez 2005, 286-287).

Con fecha de «Febrero de 1928», aparece en la primera semana de marzo, el primer número de gallo. Revista de Granada. Era una publicación con portada sobria de cartulina gruesa, diseñada por el propio Federico García Lorca y con veinte páginas de textos, impresas en papel couché. Fuera de la revista, «insertadas entre la portada y los textos, ocho páginas de publicidad (cuatro al comienzo y cuatro al final) que han ayudada obviamente a financiar la publicación [...] y que dan a gallo un aire claramente provinciano» (Jiménez Gómez 2005, 288).

Entre los miembros de L'Amic de les Arts y los de gallo surge una gran amistad y complicidad. Esta gran conexión se puede observar por el gran número de cartas entre los miembros, en las que comentaban la posibilidad de iniciar nuevos proyectos de colaboración entre las dos ciudades, Barcelona y Granada.

El segundo ${ }^{154} \mathrm{y}$, último, número de la revista tiene fecha de publicación el mes de abril (aunque sale a la venta a principios de mayo) con el mismo formato pero su publicidad se ve aumentada. El punto rojo de la portada del número uno se convierte en verde, pero se mantiene la misma estética. En este segundo número, se incluye la traducción castellana del texto nombrado con el mismo nombre «Manifiesto antiartístico catalán ${ }^{155}$ » de los autores Salvador Dalí, Lluís Montanyà y Sebastià Gasch, estos dos, críticos de arte y literatura catalanes de la revista barcelonesa, Full Groc (Moreno 2001, 185; Jiménez Gómez 2005, 294).

\footnotetext{
${ }^{154}$ Uno de sus colaboradores es Francisco García Lorca, hermano del poeta, quien, en el segundo número, entrega un fragmento de la novela Encuentro. En una carta dirigida a Jorge Guillén desde Granada, en febrero de 1927, Federico García Lorca opina sobre esta nueva novela:

Paquito está escribiendo una novela maravillosa, así como suena, maravillosa. Y sin parecerse nada a mis cosas [...]. Mi hermano ha estado cohibido por mi personalidad (entiendes). A mi lado no podía brotar porque mi ímpetu y mi arte le sobrecogían un poco. Ha sido necesario que él salga viaje, y le den vientos contrarios en la cara. Pero ya está (citado en Hernández 1981, III).

155 En una carta de Pedro Salinas dirigida a Jorge Guillén, fechada en Madrid, el 25 de abril de 1928, expresa su posición en contra de dicho manifiesto: «La indignación mía más reciente es la causada por el segundo número de gallo, con el estúpido manifestó catalán y el articulito de Amigo en su defensa» (citado en Soria Olmedo 1992, 87). El manifiesto iba acompañado con un comentario de Joaquin Amigo Aguado.
} 
A finales del verano de 1928, se empieza a confeccionar un tercer número, para el que Gasch escribe un artículo sobre el artista Manuel Ángeles Ortiz, pero este número no ve la luz nunca. En marzo de 1928, entre los dos números de gallo, aparece la revista Pavo, impresa por Ventura Traveset, en el mismo taller que el gallo y realizada por el mismo equipo que imprimía gallo (Rodrigo 1976, 251-254).

En febrero de 1929, surge en Villafranca del Penedés la revista Hélix, que tendrá una vida de diez números (hasta marzo de 1930). Todo tipo de manifestaciones culturales, sobre todo vanguardistas, formarán parte de su contenido, dedicando un espacio privilegiado al Surrealismo, sobre todo en sus tres últimos números (Brihuega 1983, 212). En el décimo y, último, número publican la conferencia «Posició moral del surrealisme» pronunciada por Dalí en el Ateneo de Barcelona el 22 de marzo de 1930 (Morris [1972] 2000, 50-51).

En la revista Butlletí de l'Agrupament Escolar de l'Academia i Laboratori de Ciències Mèdiques de Catalunya, fundada en Barcelona, pese a ser una revista dedicada a temas médicos, en septiembre de 1930, Juan Ramón Masoliver coordinó un número especial con tema monográfico: el surrealismo. Hasta la aparición de gaceta de arte ${ }^{156}$, este número especial constituyó la publicación más extensa que se había dedicado al tema (Guerrero 2001, 206).

En 1930, aparecen los últimos artículos que La Gaceta Literaria dedica al surrealismo, antes del ataque frontal que desatará contra él al año siguiente. Respecto al cambio experimentado por La Gaceta Literaria, como afirma Brihuega, la revista realiza

un viaje radical politizándose muy por encima de los niveles habituales e iniciando ese desplazamiento hacia posiciones de extrema derecha que la caracterizará durante la República. La caída de Primo de Rivera a principios de año, [...] la vuelta a sus cátedras de los universitarios desterrados, el restablecimiento del Ateneo y de la F.U.E. (1983, 213).

Y todo ello permite una apertura a manifestaciones con nuevas preocupaciones y proyectos. Con un creciente conflicto social y una rápida organización política, junto a los nuevos rumbos en el pensamientos español, se produce la aparición de numerosas

\footnotetext{
${ }^{156}$ Respetamos el título en las «democráticas» minúsculas que usaba la revista.
} 
revistas ${ }^{157}$ que proviene de casi todos los puntos peninsulares, no sólo de las capitales de provincia sino incluso de ciudades pequeñas: las madrileñas como Bolívar y Nueva España, las valencianas como Cuadernos de Cultura, las catalanas como L'Hora; y libros como El nuevo Romanticismo, de José Díaz Fernández (Brihuega 1983, 214; Osuna 1978, 48). En este, Díaz Fernández expondrá la situación cultural de España que «tiene sobre sí los rigores del fanatismo, del analfabetismo, del cerrilismo. Se odia ferozmente a la inteligencia, se persigue al que no acepta la justicia llamada histórica» ([1930] 1988, 26). Y la responsabilidad del escritor con la juventud:

en el fondo de las provincias, perdida y anhelante en ciudades y pueblos oscuros, está una juventud que es espíritu vivo de la España que todos queremos. Juventud enemiga de la pobreza, ansiosa de cultura, adversaria de la injusticia, pero mal avenida también con los antiguos sistemas de educación o de política, con el caciquismo o el tópico (Díaz Fernández [1930] 1988, 26).

Encontramos cierto paralelismo entre la postura de Díaz Fernández sobre la juventud de los pueblos y su interés por la cultura y la política, con la obra de Vieja y nueva política (1915) de Ortega y Gasset, en la que afirmaba que

El pueblo ni es nunca viejo, ni es nunca infantil: goza de una perpetua juventud. De modo que decir que las generaciones nuevas no han acudido a la política es como decir que el pueblo, en general, vive una falta de fe y de esperanzas políticas gravísima (1915, 23-24).

Desde mayo de 1931, Ernesto Giménez Caballero ${ }^{158}$, director de La Gaceta Literaria, como hemos dicho, pone en marcha un agresivo ataque político contra el Surrealismo y el racionalismo arquitectónico, y llega a poner en duda la existencia de un movimiento surrealista.

\footnotetext{
${ }^{157}$ Durante la segunda República (desde 14 de abril de 1931 al 18 de julio de 1936) existió un esplendor en la aparición de numerosas nuevas revistas, en la que cada una de ellas estaba formada por un grupo pequeño de autores que compartían unas mismas ideas. Como afirma Rafael Osuna, «la creciente polarización política, junto con la creciente proliferación de revistas, son algunos de los rasgos más destacados de la hemerografía republicana» $(1978,48)$.

158 Es curioso cómo Ernesto Giménez Caballero en un principio también se sintió atraído por el Surrealismo, muestra de ello es su novela Yo, inspector de alcantarillas (1928) que puede clasificarse como prosa surrealista, en cuya historia muestra elementos freudianos y del subconsciente (Morelli 2007, 222).
} 
Ya se han celebrado numerosas exposiciones individuales o colectivas en las que la etiqueta surrealista de los artistas españoles está presente. Ese mismo año, aparece la compañía teatral La Barraca, bajo la dirección de Federico García Lorca, creada con la idea de un acercamiento del teatro clásico a las masas populares de los pueblos más olvidados de España. Con la importante colaboración de pintores-escenógrafos como Benjamín Palencia (diseñará la insignia de La Barraca), José Caballero, Ponce de León, Alberto Sánchez y Ramón Gaya, entre otros.

Fue en febrero de 1932 cuando aparece en Tenerife la revista gaceta de arte ${ }^{159}$ dirigida por Eduardo Westerdahl, y con un equipo de redactores fijos compuesto por Domingo Pérez Minik, Francisco Aguilar, Domingo López Torres, Oscar Pestaña Ramos y José Arozena y su secretario Pedro García Cabrera. La revista internacional de cultura tenía una regularidad mensual, con cuatro páginas y formato de periódico (Pérez Minik 1975, 15). Los miembros del grupo tinerfeño ${ }^{160}$, de filiación socialista, consiguen que sus actitudes se mantengan alejadas de la militancia política a diferencia de los grupos peninsulares. La situación geográfica de Tenerife permitía distanciarse de las tensiones sociales y políticas de la península y del resto de Europa, aunque «nunca renunció a una voluntad de intervención directa y alternativa en los debates sobre un nuevo horizonte para la cultura española» (Brihuega 1983, 215).

La creación y orientación de la revista se debió a tres motivos: el regreso de Eduardo Westerdahl después de un viaje de estudios por diferentes ciudades europeas (París, Berlín, Praga, etc.) y mantener contacto con las nuevas ideas estéticas vanguardistas; el triunfo de la Segunda República en España y el vínculo amistoso con el pintor surrealista Óscar Domínguez.

En los inicios de la revista, se puede observar que las referencias del surrealismo son nulas, habrá que esperar hasta finales de 1932 con los primeros contactos con el surrealismo francés. En el número 8 de gaceta de arte, aparece el primer texto dedicado al surrealismo, con el ensayo de Domingo López Torres «Surrealismo y Revolución» en

\footnotetext{
${ }^{159}$ gaceta de arte adoptó el uso sistemático de la minúscula como postura en contra de los viejos valores. A partir del número 23, en 1934, vuelven al sistema tradicional para facilitar su expansión social, aunque mantuvieron hasta el final las minúsculas para cabeceras y titulares.

${ }^{160}$ El grupo surrealista de Tenerife nació en torno a las revistas La Rosa de los Vientos (1927-1928), Cartones (1930), gaceta de arte (1932-1936) e Índice (1935) (Morelli 2007, 229).
} 
el que recalcaba la visión revolucionaria del Surrealismo, en su dimensión de práctica vital y en su valor como ideología. En el número 12, el mismo autor escribe «Psicogeología del surrealismo».

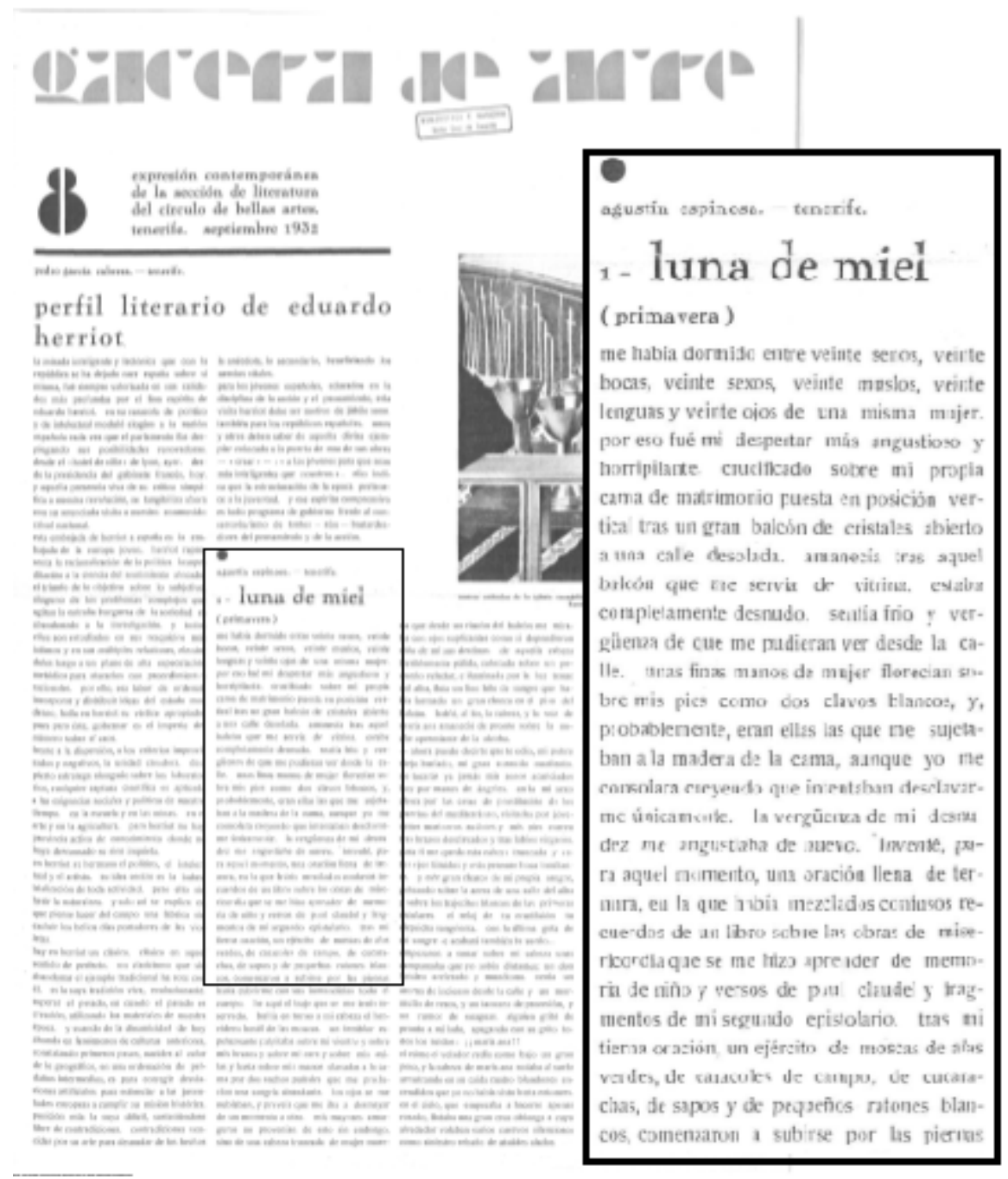

Fig. 55: Portada del número 8 de la revista gaceta de arte, en el que se puede leer la narración de «Luna de miel» de Agustín Espinosa.

También se publica una narración en prosa de un sueño «Luna de miel» de Agustín Espinosa, una especie de introducción a su famosa novela Crimen (1934) (Pérez Minik 1975, 35). La novela de Espinosa se sumerge totalmente dentro del Surrealismo, siendo ésta la más importante que se publicó en España dentro de la vanguardia surrealista. Así, como afirma Pérez Minik, en Tenerife, junto a la novela Crimen, encontramos la escuela de poetas surrealistas 
Pedro García Cabrera con «La cita abierta», «El reloj de mi cuerpo»y «Con la mano en la sangre». Emeterio Gutiérrez Albedo con «El enigma del invitado». Domingo López Torres con sus poemas «Catástrofe», «La langosta» y su «Torero». José María de la Rosa con su «Anatomía de Picasso», y Juan Ismael González con su «Desahucio» $(1974,8)$.

En ese mismo año, 1932, la actividad de la vanguardia catalana se reorganiza en torno a un pequeño grupo: los Amics De Les Arts Nous (ADLAN), más interesado con las artes visuales. Fueron los encargados de realizar la primera exposición de Pablo Picasso en Barcelona. También realizaron un número extraordinario (1934) de la revista $D^{\prime}$ ací $i$ d'allà dedicado a la elevación del arte moderno, cuya portada la realizó Joan Miró (Rodrigo 1975, 211). Lorca mantuvo relación con varios de sus miembros. A finales de 1935, Ángel Ferrant y Guillermo de Torre decidieron fundar en Madrid una especie de sucursal, ADLAN (“Amigos del Arte Nuevo”) (García 2009, 365). A finales de 1935, Lorca recibe una carta, firmada por Luis Blanco Soler, Norah Borges de Torre, Ángel Ferrant, José Moreno Villa, Gustavo Pittaluga y Guillermo de Torre, en la que le invitan a formar parte del grupo de los Amigos de las Artes Nuevas de Madrid:

Quienes formamos el comité organizador de ADLAN hemos creído oportuno dirigirnos a usted con el fin de invitarle para que se inscriba en dicha entidad. [...]

Una capital de la importancia de Madrid debería contar ya con un núcleo organizado, en el cual encontrase acogida y aliento la producción de todo espíritu innovador en el terreno de las artes (citado en García 2009, 367-368).

En marzo de 1933, aparece en Lérida la revista Art con más de ciento treinta colaboradores de todos los países. Aún así, debieron tener poca difusión y conexión con otros grupos españoles pues ninguna revista los mencionará (García 2001, 221).

Será en 1935, cuando aparezca en Madrid, Caballo Verde para la Poesía, revista editada e impresa por Concha Méndez y su marido, Manuel Altolaguirre, quienes entregaron su dirección a Pablo Neruda que favoreció un surrealismo renovado del modelo francés (Ramos Ortega 2005, 390). La revista poética tenía un cuidado diseño y tipografía a diferentes tintas y cosida a mano. De carácter mensual sólo se editaron 
cuatro números ${ }^{161}$, durante los meses de octubre, noviembre y diciembre de $1935 \mathrm{y}$ enero de 1936. Los tres primeros números fueron ilustrados por José Caballero y Moreno Villa. Se abría cada número con un breve texto en prosa, a modo de prólogo, dando paso a obras de diferentes poetas españoles, entre ellos varios relacionados con la generación del 27 (Nuez 1988, 212-213). Entre los poetas que colaboraron en la revista encontramos a Vicente Aleixandre, Federico García Lorca, Emilio Prados, Luis Cernuda, Jorge Guillén, Rafael Alberti, Manuel Altolaguirre, Concha Méndez, Rosa Chacel, etc. Como afirma Ramos Ortega, la revista daba cabida a «una diversidad de voces de distinta procedencia y estilos, aunque [...] haya un desequilibrio a favor de las dos tendencias que en aquel momento resultaban preponderantes: la poesía comprometida o rehumanizada y la surrealista» $(2005,389)$.

La mayoría de los acontecimientos surrealistas iban a tener lugar en las islas Canarias. Desde hacía unos años, la gaceta de arte continuaba informando y profundizando en distintas dimensiones del fenómeno surrealista y es, a través de Óscar Domínguez, cómo el grupo de gaceta de arte inició contactos con los surrealistas franceses:

En medio del periodo de crisis que culminará con la ruptura definitiva con el comunismo, consumada tras los sucesos de junio de la Mutualité durante el «Congreso de Escritores para la defensa de la Cultura», Breton y sus leales habían decidido iniciar una serie de embajadas tendentes a remachar sus alianzas internacionales en Praga, Zurich, Copenhague, etc. El 4 de mayo del 35, es decir, inmediatamente después de su estancia en Praga [...] el grupo surrealista se desplazará a Tenerife, un "grupo" que en realidad tan sólo estaba formado por Breton, su mujer y Benjamin Péret. Para recibirlos, Gaceta de arte había preparado una provocadora exposición de objetos surrealistas (Brihuega 1983, 217).

En la Exposición Surrealista organizada por gaceta de arte y el Ateneo de Santa Cruz de Tenerife se expusieron 76 obras. Representó la carta de presentación ante Europa del grupo de vanguardia de Gaceta de Arte. Con motivo de la exposición aparecen diferentes artículos de prensa de André Breton y Benjamin Péret, quienes imparten conferencias. En ese mismo mes, mayo de 1935, Breton, Péret y el grupo de Gaceta de Arte redactaron el manifiesto que posteriormente se publicó (Morris 1983, 10).

\footnotetext{
${ }^{161}$ Sólo salieron cuatro números aunque estaba previsto la publicación de un número doble (5-6) que se llegó a imprimir y, a falta de doblar, no llegó a ser cosido. Nadie vio sus páginas al estallar la guerra civil.
} 
En septiembre de 1935, gaceta de arte dedicó su número 35 a conmemorar esta visita, con varios textos de Breton, entre ellos su discurso que realizó en el I Congreso de los Escritores para la Defensa de la Cultura (celebrado en París del 21 al 25 de junio de 1935).

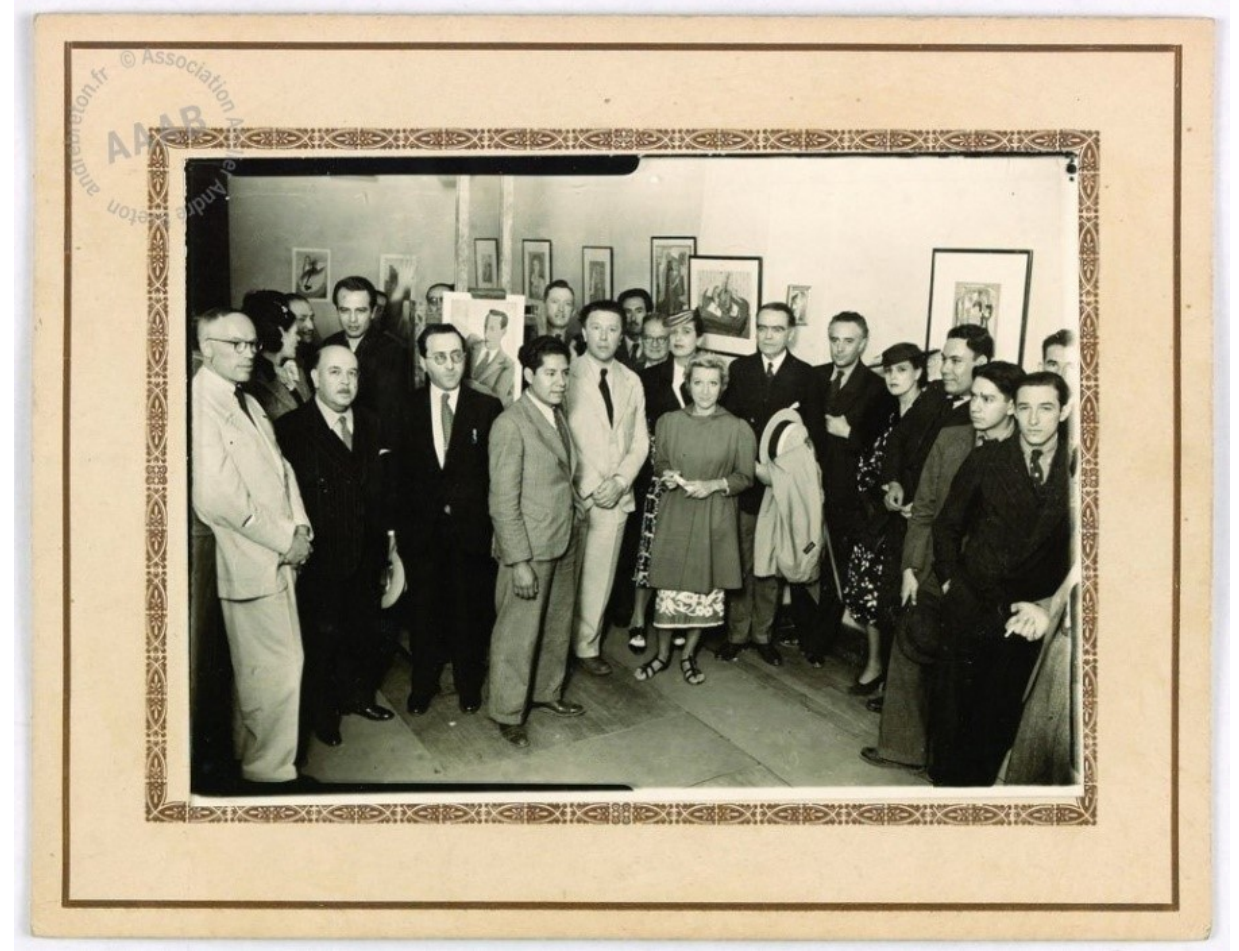

Fig. 56: Fotografía grupal tomada durante el viaje de André Breton y Jacqueline Lamba a Canarias en 1935.

Impresión plateada sobre cartón (13 x 17,9cm).

Autor anónimo.

Ese mismo año, también se publicó en Tenerife el número 2 del Boletín Internacional del Surrealismo, en octubre, consecutivo al de Praga, donde aparece el manifiesto que contiene nueve hojas de unos $20 \times 27 \mathrm{~cm}$. El manifiesto, escrito en dos lenguas, se presenta en dos columnas paralelas que «establecen visualmente una paridad entre el francés a la derecha y, a la izquierda, el español» (Morris 1983, 13). Entre otros temas encontramos la explicación del motivo de la expulsión de Louis Aragon del grupo:

El movimiento surrealista ha tenido que registrar en este urgente planteamiento de la cuestión, la deserción de un hombre tan cualificado en el terreno artístico como es Louis Aragon, que sometido a las rígidas consignas del P.C. no supo resolver a tiempo este claro problema de separar la acción social de esta corriente artística que exige la libre manifestación del espíritu. [...] Un espíritu determinado no puede abdicar tan 
vanamente a lo largo de toda su gestión, o debe inmediatamente dar cuenta pública en medida en que ésta ha sido pública, no puede tratarse, en caso contrario, sino de una conversión o de una traición (Breton et al. [1935] 1983, 23-24).

A partir de julio de 1936, la guerra civil estalla en España y con ella el surrealismo español tomará otros caminos en el exilio.

\section{4.- La aparición de nuevos estudios y la revisión del surrealismo español}

En 1948, la revista barcelonesa de arte, Cobalto: arte antiguo y moderno, dedica un monográfico al movimiento francés. El número se abre con un artículo del director Rafael Santos Torroella ${ }^{162}$, titulado «Genio y figura del surrealismo. Anécdota y balance de una subversión». El grupo francés se encontraba dividido en dos facciones (trotskistas y estalinistas) y el texto muestra una posición tajante respecto a la participación española en el movimiento y destaca el antipatriotismo surrealista y critica la incapacidad para someterse a una disciplina de partido.

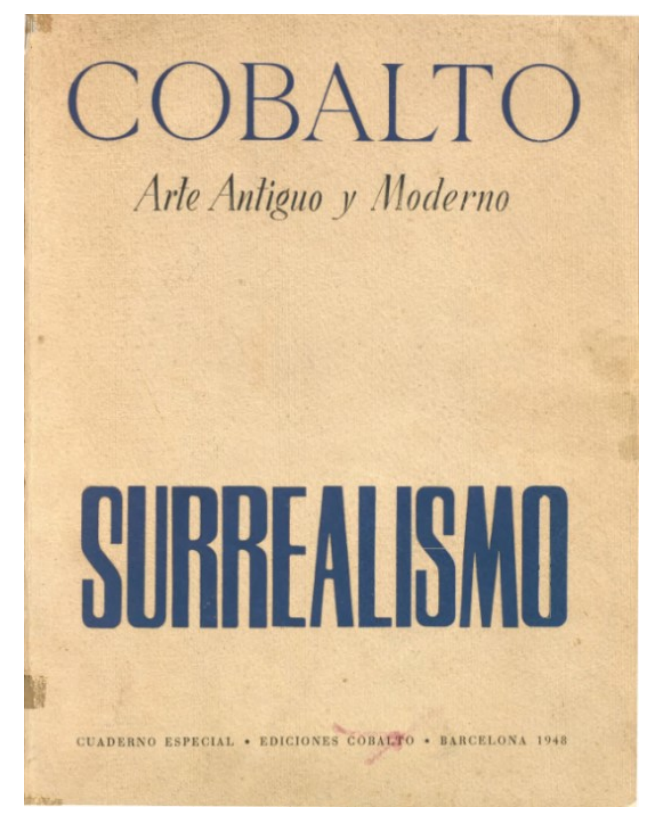

Fig. 57: Portada del monográfico dedicado al surrealismo (1947-1953a.).

\footnotetext{
${ }^{162}$ Hermano de la pintora surrealista Ángeles Santos (Portbou [Gerona], 1911-Madrid, 2013). Su obra maestra Un mundo [Un món] la realizó con tan sólo diecisiete años, en un gran formato de casi tres por tres metros (sus dimensiones estaban fuera de lo común).
} 
En este número de Cobalto, los diferentes artículos exponen muchos de los prejuicios que existían, en el momento, contra el surrealismo. Como afirma Isabel Navas Ocaña, buscaban en el surrealismo «el fin de la vanguardia, su carácter importado nacionalismo exacerbado, búsqueda de predecesores en los ámbitos más insospechados para así aminorar el impacto de la subversión surrealista, comportamientos políticos y sociales anticonvencionales, etc.» $(2009,569)$.

En 1949, Dámaso Alonso, por primera vez hablará de surrealismo español aunque sólo sea en un pie de página. Un año después, en su discurso de contestación a Vicente Aleixandre con motivo del ingreso de este en la Real Academia Española, volverá a mostrar sin disgusto su consentimiento (Navas 2009, 561). El autor de Hijos de la ira (1944) apunta la posibilidad de un surrealismo español sin escritura automática en el caso de Vicente Aleixandre y en su libro Poetas españoles contemporáneos (1952) expone que

en 1927 en adelante ocurren cosas muy graves. Por fuera bulle el surréalisme (cuyo manifiesto, por André Breton, es de fines de 1924). Suelen los historiadores de la literatura comparada sudar y trasudar la busca de influjos. Olvidan, sin embargo, algo muy importante: el hecho, evidente todos los días, por muy misterioso que sea, de las emanaciones difusas, de eso que está en el aire. Es evidente que los elementos oníricos son lo que da trasmundo y misterio a la poesía de Federico desde sus primeras canciones, mucho antes de todo superrealismo. Cuando Vicente Aleixandre, entre 1928 y 1929, escribe su Pasión de la Tierra, del surréalisme francés lo ignoraba todo. Con este libro y con Sobre los ángeles, de Alberti, ha comenzado una nueva era poética, Siguen Espadas como labios (1932) y La destrucción o el amor (1935), de Aleixandre, y Residencia en la Tierra (la primera parte, publicada en Chile, en 1933), de Neruda. Ha comenzado una nueva época de poesía española: época de grito, de vaticinio, o de alucinación, o de lúgubre ironía (Alonso [1952] 1999, 399).

En junio de 1950, José Luis Cano publica en Arbor un breve artículo titulado «Noticia retrospectiva sobre el surrealismo español» donde se puede observar la utilización de la expresión “surrealismo español” (Navas 2009, 562). En este artículo exponía

Existían, además, un par de revistas literarias que se inclinaban decididamente del lado surrealista: La Gaceta del Arte, que dirigía desde la lejana Tenerife Eduardo Westerhal y en la que intervenía activamente Guillermo de Torre, y Litoral, publicada en Málaga 
por el poeta Emilio Prados. [...] Hinojosa trajo de un viaje a París, donde estuvo en contacto con el grupo francés, la ardiente ilusión surrealista [...] (40) (Citado en Onís 1974).

Carlos Bousoño, en su libro La poesía de Vicente Aleixandre (1950), sostiene la misma tesis que Dámaso Alonso había venido formulando desde 1932, la de un surrealismo español sin escritura automática y afirmaba:

En la práctica, el superrealismo puro no existió nunca (y en España, desde luego, ningún poeta en sus versos parece haber pretendido aquella extremosidad). [...] Si no existe una conciencia creadora, el poema no se produce. [...]

La escuela superrealista española [...] nació con independencia de la escuela francesa de análoga tendencia, y sólo después, en marcha ya el movimiento hispano, puede hablarse de contactos entre una y otra (Bousoño [1950] 1977, 225-226).

El primer estudio monográfico sobre el tema es una tesis de licenciatura presentada, en 1950, por Manuel Durán Gili, en la Universidad de Ciudad de México: El superrealismo en la poesía española contemporánea, que desarrolla la tesis de Dámaso Alonso sobre el automatismo y, diferencia «entre escritura automática y poema surrealista, entre poesía surrealista y "surrealismo a secas", convencido de que la utilización de los materiales del subconsciente con un fin estético siempre implica un “esfuerzo consciente"» (Navas 2009, 564).

Ya iniciada la década de los cincuenta, José Albi y Joan Fuster dedican un número triple (23-24-25) de la revista alicantina Verbo (1952) al surrealismo español en su Antología del surrealismo español. En un país que se negaba a admitir que hubiera existido el surrealismo, se atreven a publicar este estudio y, como se observa, con la utilización del galicismo surrealismo en su título. Albi y Fuster reivindican el uso de un concepto amplio de surrealismo, sin el cual será imposible etiquetar como tal la obra de la generación del 27. Establecerán la singularidad de la no escritura automática del surrealismo español. No hay que olvidar que, aunque en los inicios del surrealismo francés el automatismo es importante, posteriormente Paul Éluard «distinguirá entre escritura automática, relato de un sueño y poema surrealista. [...] Habría, por tanto, “dos tipos opuestos de surrealismo", que encarnarían Joan Miró (pura espontaneidad) y Salvador Dalí (“aprovechamiento racional” del subconsciente)» (Personneaux 1986, 
449). Pero Alicante se encuentra muy alejado de Madrid o París, y el monográfico de la revista alicantina no consigue la resonancia deseada.

La guerra española y las orientaciones literarias de la posguerra relegarán al olvido al surrealismo español. Los motivos por los cuales el surrealismo se suprime de los estudios son debidos a que es un movimiento ligado a una política de izquierdas, anticlerical y considerado carente de seriedad. En palabras de Personneaux

en la España de la era franquista había que negar o borrar en cuanto fuera posible todo lo que podía turbar el orden nuevo y las conciencias. [...] Porque el surrealismo es un fermento "revolucionario", con su principio de puesta en cuestión continua, de duda incesante, la plaza preponderante dada al amor y al erotismo, esta ametralladora introducida "en el corazón del mundo burgués de los años veinte" y constantemente apuntada sobre él $(1986,454)$.

La revisión del concepto de surrealismo en España empieza a imponerse en la década de los setenta. Los estudios del italiano Vittorio Bodini, Los surrealistas españoles (1963), del norteamericano Paul Ilie, Los surrealistas españoles (1968) y del inglés Cyril Brian Morris, El surrealismo y España 1920-1936 (1970) (tendrá que esperar su traducción al español hasta el año 2000) favorecen una puesta al día de la problemática del surrealismo en España que, si en cierta forma continúa la línea establecida por Dámaso Alonso, Manuel Durán Gili o José Albi y Joan Fuster, abre también otras posibilidades (Personneaux 1986, 449).

Ante la posibilidad de un surrealismo español, la crítica se dividió en dos. Por una parte, «la tendencia tradicional, que hace un análisis clásico, aun teniendo en cuenta teóricamente todas las novedades que el surrealismo supone, de símbolos y figuras. Este es el caso de autores como Bousoño o Marcial de Onís». Y por otra, «los autores que utilizan tesis freudianas prácticamente sin matices, descontextualizando así precisamente lo que de poético tiene la poesía y reduciéndolo a una materialidad amorfa y al cabo incomprensible» (Fernández 1991, 363). Entre ellos encontramos a Paul Ilie, Cyril Brian Morris, Vittorio Bodini y Pablo Corbalán. No podemos dudar de que el surrealismo español tuvo una serie de diferencias respecto del francés, pero los autores se dejaron influenciar del surrealismo, los sueños, el subconsciente y la escritura 
autómatica, sin dejar de compartir la posición de Bousoño según la que el poeta no pierde el control sobre su obra.

A partir de 1970, ya no es posible dudar acerca de la existencia del surrealismo en España. Alberto Adell publica, en 1970, en Ínsula un artículo titulado «Inquisición del surrealismo español» aunque sigue afirmando que no hubo surrealismo estricto en España, abre la puerta a las dudas. En 1971, Cyril Brian Morris publica en Ínsula del mes de octubre ( ${ }^{\circ}$ 299) un artículo titulado «Un poema de Luis Cernuda y la literatura surrealista». En 1972, en Madrid, en el número 261 del mes de marzo de Cuadernos Hispanoamericanos, aparece el artículo «¿Surrealismo en España?» de Carlos Edmundo de Ory y, el mismo mes, Jenaro Talens trata en Ínsula (n. ${ }^{\text {o } 304) ~ d e ~ « V i c e n t e ~ A l e i x a n d r e ~}$ y el surrealismo». En 1973, Joaquín Marco escribe un artículo en Ínsula en marzo y abril, donde trata de «Muerte o resurrección del surrealismo español» (Personneaux 1986, 450). Vicente Aleixandre, poeta que había rechazado la etiqueta surrealista, publica en 1971, una antología bajo el título de Poesía superrealista, libro que reúne poemas de todas sus épocas.

Se extiende el interés por los movimientos de vanguardia y se multiplican tanto las traducciones como los estudios sobre la poesía surrealista de la generación del 27. Las diferentes publicaciones pondrán al descubierto la abundante información que tuvieron los poetas de la generación 27 sobre las actividades del grupo francés. Y la aparición en 1975 de Facción surrealista española de Tenerife de Domingo Pérez Minik demostrará la existencia de un grupo surrealista organizado en España. (Navas 2009, 572).

La discusión crítica en torno a la existencia o no del surrealismo español se inicia en el año 1974, con el cincuentenario del Manifiesto Surrealista francés. Varias revistas dedican un número completo al surrealismo. Así, El Urogallo en septiembre-diciembre de 1974 y, en el número 337 (diciembre) de Ínsula, Ramón Buckey celebró el cincuentenario del surrealismo en el número monográfico conmemorativo (Personneaux 1986, 448). Buckley pretende dar

«una "visión regionalista del surrealismo" (1974: 3), distinguiendo un "surrealismo ortodoxo", que sería el del grupo catalán, un "surrealismo vanguardista", el del grupo madrileño, un "surrealismo telúrico" propio de los poetas andaluces y un "surrealismo 
expresionista", el del grupo canario de Gaceta de arte, más directamente comprometido desde el punto de vista político-social» (Navas 2009, 572).

También Pablo Corbalán realizará un estudio del surrealismo en España en Poesía surrealista en España. A su vez, Carlos Feal en su artículo «Un caballo de batalla: el surrealismo español» nos plantea que el superrealismo no fue tan sólo una moda literaria, también fue una corriente espiritual en la juventud de una época. El surrealismo trata de resolver la tensión que existe entre la realidad y el deseo, haciéndolos coincidir. La razón principal de la resistencia a admitir un surrealismo español es la ausencia de espíritu colectivo y teorías correspondientes a la práctica surrealista, entre ellas la postura en contra de la escritura automática (Feal 1979, 274276).

Ricardo Gullón, en su artículo «¿Hubo un surrealismo español?» (1975), rechaza que hubiera un surrealismo español, ya que, al contrario que el surrealismo francés, en España no existía la conciencia de grupo ni aceptaban la escritura automática a excepción del grupo canario. En el artículo Gullón admite dos supuestos:

1) el surrealismo fue una escuela de la que se originó un movimiento artístico, y 2) los principios y métodos del grupo surrealista francés coinciden, en parte, con los practicados por unos cuantos escritores españoles en las décadas del veinte y del treinta. $\mathrm{Y}$ es precisamente la circunstancia de que en pocas excepciones (tal, la del grupo Mandrágora, en Chile) fuera de Francia no se movieron los poetas dentro de una escuela con principios y actividades bien definidos, lo que hace parecer dudosa la realidad de un surrealismo español, o argentino, o mejicano ([1975] 1982, 77).

Así como en el grupo francés compartían una misma ideología, en el caso español las ideologías eran muy diferentes, y de ahí se deriva no pensar en una acción colectiva. «Liberales, socialistas, conservadores o comunistas, todos compartían independencia de espíritu y la resistencia al dogma. Ideológicamente están donde están, sin renunciar a nada, sin abdicar al derecho a cuestionar el absolutismos de la propia creencia» (Gullón [1975] 1982, 87) 


\section{5.- Estudios más recientes}

A partir de los años ochenta, la influencia del surrealismo en España es ya un hecho indiscutido para la crítica especializada. La aparición de compilaciones de artículos de carácter más teórico en libros y revistas como El surrealismo (1982), dirigido y editado por Víctor García de la Concha, en el que presenta un completo estudio de diferentes artículos dedicados al movimiento surrealista en su vertiente tanto literaria, plástica como cinematográfica; un año más tarde, también con el mismo nombre, El surrealismo (1983) editado por Antonio Bonet Correa, en el que muestra un principal interés hacia una visión plástica del movimiento, aunque también incluye el artículo de Jaime Brihuega titulado «Fuentes literarias del surrealismo español, 1924-1936»; la revista Litoral publica, ese mismo año, un volumen llamado Surrealismo. El ojo soluble, donde Jesús García Gallego es el compilador del volumen con nuevas aportaciones sin limitarse al aspecto literario; son una muestra del interés por el movimiento, ya que son numerosas las diferentes publicaciones que aparecen durante los años ochenta.

Estos estudios no sólo se centran en la literatura, sino que éstos también se amplifican a las artes visuales y cinematográficas. En 1986, Lucía García de Carpi, autora del libro La pintura surrealista española (1924-1936), afirmará que existía una actividad surrealista colectiva, cuyas coordenadas eran Madrid, Cataluña, Tenerife y Zaragoza, demostrando que en España no existía un único núcleo como en París (Morris [1972] 2000, 21).

En los años noventa los estudios y las exposiciones son numerosos como las exposiciones del Centro de Arte Reina Sofía sobre "La palabra surrealista" (1994) y sobre "El surrealismo en España" (1995). O las diversas publicaciones del tema, como la publicación, en 1995, de Juan Manuel Bonet El Diccionario de las vanguardias en España (1907-1936); la compilación de Gabriel Morelli, Treinta años de vanguardia española; el monográfico coordinado por Patricio Hernández que Ínsula dedica al surrealismo español en abril de 1996, bajo el título «Imagen en libertad»; o el suplemento a la primera parte de la época contemporánea de la Historia de la literatura de Francisco Rico, aparecido en 1997 y dirigido por Agustín Sánchez Vidal (Fernández 1999, 365). 
Ya entrado este nuevo siglo, en octubre del año 2000, se celebró un Congreso Internacional en la Universitat de Lleida, con el nombre de «Surrealismo y Literatura». Un año más tarde, sus actas se publican en dos volúmenes, Surrealismo y literatura en España y, Surrealismo y literatura en Europa, cuya edición estuvo a cargo de Jaume Pont.

A finales del 2013, tuvo lugar, en el Museo Thyssen-Bornemisza de Madrid, la exposición «El surrealismo y el sueño». No se presentaba de una forma lineal, cronológica o historicista, sino como un recorrido en espiral a través de los ejes que la guiaban. Destacaba un buen número de obras de mujeres artistas. En el surrealismo y, a pesar de los surrealistas varones, las mujeres pudieron salir de sus roles de musa y tener un papel protagonista. La exposición estaba acompañada de un ciclo de películas, que completaban de manera muy adecuada la propuesta. Paralelamente a la muestra, en el mes de octubre de ese mismo año, tuvo lugar el Congreso Internacional «El surrealismo y el sueño», con la participación de destacados especialistas, que completaron teóricamente lo que las imágenes mostraban.

Por su parte, en la Fundación Juan March de Madrid, de octubre del 2013 a enero del 2014, se pudo ver la exposición «Surrealistas antes del surrealismo»; una muestra que trazaba un recorrido desde mediados del siglo XV hasta la actualidad, con la base común de la fantasía, y la conexión del mundo fantástico y de los sueños. Le acompañó un ciclo de conferencias: «Surrealismos...» que tuvo lugar en la sede de la Fundación.

Los diferentes cursos universitarios, congresos, simposios y exposiciones relacionados con el surrealismo español, en los últimos años, son una muestra del interés que sigue vigente a día de hoy. 


\section{7.- El Surrealismo en Federico García Lorca}

Los textos lorquianos inscritos dentro del ciclo surrealista corresponden mayoritariamente al período comprendido entre 1928 y 1931: de los Poemas en prosa al drama Así que pasen cinco años. Esta fase se produce en dos etapas, marcadas por su viaje a Nueva York y La Habana: la primera, que abarca la redacción de los Poemas en prosa y los Diálogos, y la segunda, que contiene el poemario Poeta en Nueva York, el guión cinematográfico Viaje a la luna y el teatro "irrepresentable", El público y Así que pasen cinco años. También debemos incluir la obra teatral inconclusa Comedia sin título escrita años más tarde, entre 1935 y 1936.

A finales de julio de 1928, se publica en Ediciones de la Revista de Occidente el Primer Romancero gitano (1924-1927) ${ }^{163}$. Obra cumbre de Federico García Lorca que, a sus treinta años, lo va a convertir en el poeta más aplaudido de España. Pero el poemario había recibido mucho rechazo entre sus amigos, Luis Buñuel y Salvador Dalí, quienes no compartían ese entusiasmo. También, a principios de septiembre de 1928, Dalí le envía una carta desde Cadaqués:

Tu poesía actual cae de lleno dentro de la tradicional, en ella advierto la substancia poética más gorda que ha existido: pero! [sic] Ligada en absoluto a las normas de la poesía antigua, incapaz de emocionarnos ya ni de satisfacer nuestros deseos actuales. Tu poesía está ligada de pies y brazos a la poesía vieja - Tu [sic] quizás creerás atrevidas ciertas imágenes, o encontrarás una dosis crecida de irracionalidad en tus cosas, pero yo puedo decirte que tu poesía se mueve dentro de la ilustración de los lugares comunes más estereotipados i $[\mathrm{sic}]$ mas $[\mathrm{sic}]$ conformistas...

[...] El surrealismo es uno de los medios de Evasión.

Es esa evasión lo importante.

Yo voy teniendo mis maneras al margen del surrealismo, pero esto es algo vivo (citado en Sánchez Vidal 1988, 177-178).

En la correspondencia que mantiene Luis Buñuel con Pepín Bello se puede observar la posición en contra de Lorca. En la extensa carta fechada el 17 de febrero de 1929, desde París, dirigida a José Bello se puede leer «Federico quiere hace cosas surrealistas pero

\footnotetext{
${ }^{163}$ El poemario fue escrito entre 1924 y 1927 y coincide con los años del primer Manifiesto Surrealista de André Breton.
} 
falsas, hechas con la inteligencia, QUE ES INCAPAZ DE HALLAR LO QUE HALLA EL INSTINTO» (citado en Sánchez Vidal 1988, 198).

Siete años más tarde de la publicación del Romancero gitano, Lorca aún no había olvidado las críticas tan duras recibidas por sus amigos, y por eso su conferencia recital $^{164}$ del Romancero gitano comienza desacreditando la interpretación de lo gitano y costumbrista del poemario. En esa conferencia, Lorca efectúa una lectura irracionalista o surrealista del Romancero en la que expone:

Un libro en conjunto, aunque se llama gitano, es el poema de Andalucía, y lo llamo gitano porque el gitano es lo más elevado, lo más profundo, más aristocrático de mi país, lo más representativo de su modo y el que guarda el ascua, la sangre y el alfabeto de la verdad andaluza universal. [...] Un libro donde apenas si está expresada la Andalucía que se ve, pero donde está temblando lo que no se ve [...]. Un libro antipintoresco, antifolclórico, antiflamenco, donde no hay ni una chaquetilla corta, ni un traje de torero, ni un sobrero plano, ni una pandereta (García Lorca 1997, 179).

Como afirma Miguel García-Posada, «se reconoce en la formulación el eco del concepto de evasión de la realidad, tal como el autor lo había expresado en su conferencia «Imaginación, inspiración, evasión» $(1997,161)$. El texto de la conferencia no se conserva íntegro, pero de las diversas partes que se guardan, gracias a las publicaciones en la prensa ${ }^{165}$, entre finales de 1928 y principios de 1929, se puede entender que el concepto de evasión para Lorca se acercaba al concepto de evasión de la realidad del surrealismo, sin ser exactamente el mismo método para alcanzarla (Cao $1984,61)$.

Pero empecemos por el principio: en la conferencia, Lorca hace un recorrido desde la imaginación hasta llegar a la evasión, pasando por la inspiración. Para Lorca la imaginación es «sinónima de aptitud para el descubrimiento. Imaginar, descubrir, llevar nuestro poco de luz a la penumbra viva donde existen todas las infinitas posibilidades, formas y números» $(1997,98)$. La imaginación era la base y fuente de toda poesía, pero

\footnotetext{
${ }^{164}$ Esta conferencia la pronunció en numerosas ciudades de España (el 9 de octubre de 1935 en Barcelona y el 7 de marzo de 1936 en San Sebastián), en Buenos Aires y en Montevideo (Villanueva 2015, 211).

165 Entre la prensa que recoge partes del texto de la conferencia que dictó en diversas ocasiones encontramos: El Defensor de Granada, el 11 de octubre de 1928; El Sol, Madrid, 16 de febrero de 1929; El Imparcial, Madrid, 17 de febrero de 1929; La prensa, Nueva York, 10 de febrero de 1930 y Diario de la Marina, La Habana, primavera de 1930.
} 
esa imaginación tenía unos límites, y estos eran la realidad, ya que no se puede imaginar aquello que no existe. Por eso para Lorca, la imaginación poética era una técnica pobre y falta de emoción a la hora de crear imágenes nuevas.

Para superar las limitaciones de la imaginación, según Lorca, el poeta debe «vivir exclusivamente de la imagen que producen los objetos reales. [...] Así como la imaginación es un descubrimiento, la inspiración es un don, un inefable regalo» (1997, 101). Del mismo modo, se puede leer en el texto recogido por el periódico El Sol de Madrid, el 16 de febrero de 1929:

la inspiración ataca de plano muchas veces a la inteligencia y al orden natural de las cosas. Hay que mirar con ojos de niño y pedir la luna. Hay que pedir la luna y creer que nos la pueden poner en las manos. [...]

La imaginación es inteligente, ordenada, llena de equilibrio. La inspiración es incongruente en ocasiones, no conoce al hombre y pone muchas veces un gusano lívido en los ojos claros de nuestra musa. [...] La imaginación lleva y da un ambiente poético y la inspiración inventa el hecho poético $(1997,103)$.

El poeta debe encontrar un nuevo lenguaje fuera de la lógica conocida y real, y es necesario dar paso a la inspiración para superar esa lógica de la imaginación, Esta inspiración no se puede buscar, es un don que recibe el poeta que sostiene y mantiene vivo el deseo, por eso Lorca expone que ese hecho poético no se puede controlar por nada y se puede alcanzar mediante la evasión poética:

de la realidad por el camino del sueño, por el camino del subconsciente, por el camino que dicte un hecho insólito que regale la inspiración.

El poema evadido de la realidad imaginativa se sustrae a los dictados de feo y bello como se entiende ahora y entra en una asombrosa realidad poética, a veces llena de ternura y a veces de crueldad más penetrante $(1997,101-102)$.

La evasión de la realidad se alcanza a través de lo inconsciente. En la conferencia, Lorca explica las posibles diferencias entre la evasión poética que propone con la que buscan los surrealistas: «El surrealismo emplea el sueño y su lógica para escapar [...], esta evasión [...] es, aunque muy pura, poco diáfana. Los latinos queremos perfiles y misterio visible. Forma y sensualidad» $(1997,104)$. 
Encontramos un eco de la dualidad entre la conferencia «Imaginación, inspiración y evasión» y la conferencia de «Juego y Teoría del duende ${ }^{166} 》$ y los términos que allí describe. La evasión y el control de la primera, con la fuerza del duende que escapa a toda razón de la segunda. Para Lorca, «el duende es un poder y no un obrar, es un luchar y no un pensar. [...] No es cuestión de facultad, sino de verdadero estilo vivo; es decir, de sangre; de viejísima cultura, y, a la vez, de creación en acto» (1997, 151). Claramente podemos relacionar ese duende con esa liberación que los surrealistas buscaban en el mundo de los sueños fuera de la lógica y la razón, ya que el duende lo llevamos dentro. Y es mediante el duende como romperemos con las reglas establecidas y con todo lo aprendido.
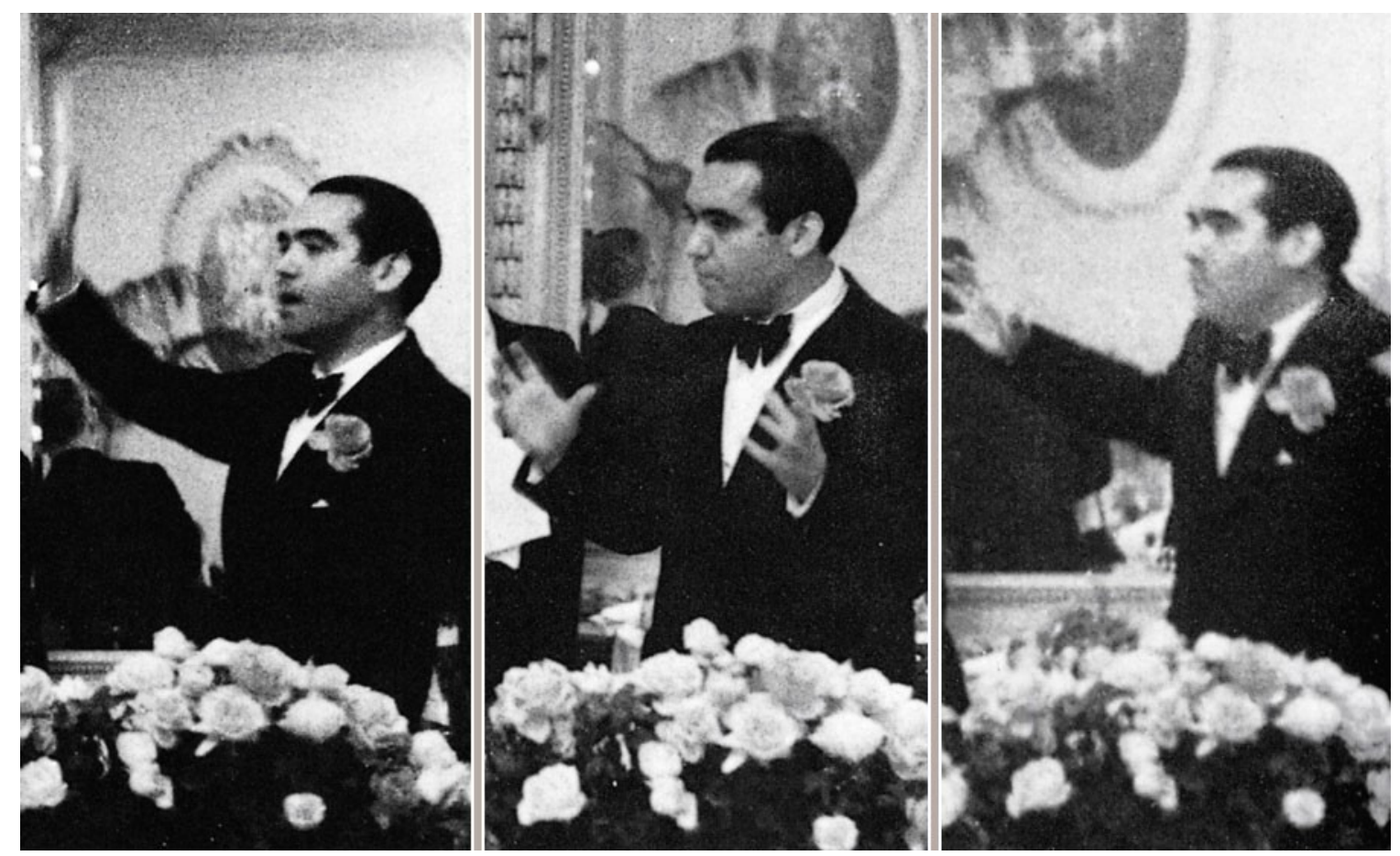

Fig. 58: Fotografía de Federico García Lorca mientras pronuncia una conferencia (1933).

Extraída del catálogo de la exposición que tuvo lugar en el Centro Federico García Lorca de Granada, del 30 de octubre del 2015 al 10 de enero del 2016, con título «Teoría del duende».

En esta conferencia, Lorca nos presenta al ángel, a la musa y al duende. El ángel es el que nos guía y alumbra, mientras que la musa es la que nos dicta:

\footnotetext{
${ }^{166}$ Durante su viaje a Buenos Aires, entre octubre 1933 y marzo de 1934, es invitado por la Sociedad de Amigos del Arte a pronunciar una serie de conferencias sobre el arte español. El 20 de octubre dicta la conferencia «Juego y teoría del duende» (Maurer 2018).
} 
La musa dicta y en algunas ocasiones sopla. [...] La musa despierta la inteligencia [...] y la inteligencia es muchas veces la enemiga de la poesía, porque limita demasiado.

Ángel y musa vienen de fuera; el ángel da luces y la musa formas. [...] En cambio, al duende hay que despertarlo en las últimas habitaciones de la sangre. Y rechazar al ángel, y dar un puntapié a la musa (García Lorca 1997, 152).

La musa y el duende son extremos opuestos: el duende es el instante, la fugacidad; la musa es la espera, la duración y el orden. Según afirma Christoph Eich, el duende es

frescura de nacimiento y oscuridad de muerte. [...] El duende es [...] el demonio del instante.

[...] Lo sensorial y lo espiritual, la muerte y la vida, la miseria y la grandeza de lo humano se descubren en tales momentos de una manera simultánea e indistinta (1970, 40-41).

En las dos conferencias encontramos un paralelismo entre la imaginación, la inspiración y la evasión, con el ángel, la musa y el duende, respectivamente. Para Lorca la verdadera lucha es con el duende, mientras que

la musa permanece quieta [...] El ángel puede agitar [...] El duende... ¿Dónde está el duende? Por el arco vacío entra el aire mental que sopla con insistencia sobre las cabezas de los muertos, en busca de nuevos paisajes y acentos ignorados; un aire con olor de saliva de niño, de hierba machacada y velo de medusa, que anuncia el constante bautizo de las cosas recién creadas $(1997,162)$.

Aunque busquemos el duende, no lo podemos encontrar, ya que es un sentimiento interno del ser humano que aparece como un juego. Es un deseo, y en su llegada «presupone siempre un cambio radical en todas las formas. Sobre planos viejos, da sensaciones de frescura totalmente inéditas, con una calidad de cosa recién creada, de milagro, que llega a producir un entusiasmo casi religioso» (García Lorca 1997, 155).

José Javier León en su reciente estudio, publicado en 2018, sobre la figura del duende, nos afirma que el duende vence ${ }^{167}$ a las figuras del ángel y la musa, y nos describe las tres imágenes, y como

\footnotetext{
${ }^{167}$ Lorca toma prestadas las ideas nietzschianas de superación de lo apolíneo y lo dionisíaco, y «las ideas de inspiración y transmisión poética, representadas en el ángel y la musa, han sido postergadas por las de posesión y contagio tenebroso del duende» (León 2018b, 78).
} 
la musa la que mayor grado de entidad presenta, la más concienzudamente construida, seguida muy a la zaga por el ángel; el duende, mucho más abstracto y vacío, gracias en buena medida a su prolongado cotejo con ellas, se concretiza, adquiere perfil y se consuma. El logro es sobre todo de un tropo, la personificación, que convertirá a un ser de características humanoides y perfil ingenuo y hasta grotesco (León 2018b, 80).

Cabe destacar cómo el propio Lorca daba cuerpo a la figura del duende y, aunque sea extensa, transcribimos por la importancia de la aparición de duende en un duermevela. Es en diciembre de 1933, en una entrevista realizada, en Buenos Aires, por Narciso Robledal para Aconcagua. El Magazine para Todos, número 47, cuando Federico García Lorca contaba la anécdota de cómo el duende se hizo carne:

Hace tres noches, al acostarme quise revisar los apuntes de mi conferencia acerca del juego y teoría del duende. Usted sabe: el duende que algunos llevamos dentro, ese ser misterioso, entre diabólico y angélico - las dos cosas - que suele inspirarnos a los que en él creemos. Eran ya las dos de la madrugada y el dulce beleño no entornaba mis párpados. El sueño no acudía. Apagué la luz. Casi inmediatamente, a los pies de mi cama, se dibujó una figura..., una especie de muñeco estrafalario de agilidad sorprendente, que se puso a dar saltos sobre el borde del armazón del lecho. Mediría unos treinta centímetros de estatura. Vestía una ropilla rojo y gualda. Calzaba unas chinelas de punta curvada y sobre la cabecita lucía una caperuza verde, de cuya punta colgaba un cascabel retozón. ¡Lo estoy oyendo! El rostro, de blancor de luna, tenía la penetrante expresión de un ave humanizada... Un escalofrío me recorrió la espina dorsal, pero logré dominarme. No me moví. Con los ojos muy abiertos y fijos, seguí sus movimientos en la obscuridad. En su torno, como nimbo de luz melancólica, advertíase una nube de lechosa diafanidad. Y... oiga usted. Le juro que estaba tan despierto como ahora... el duende (¿qué otra cosa podía ser?), se trepó luego, con una fantasía cabriola, sobre el ropero. Percibí el golpe, el impacto macizo de sus pies sólidos al chocar contra la madera. Desde allí, con los brazos en jarras, muy tieso y muy vivo, me clavó sus diminutas pupilas de reflejos purpurinos, en tanto que, con cómica gravedad, movía sus rostro de izquierda a derecha y el cascabel de la caperuza resonaba. Y ahora viene lo inaudito, con ser ya tan fantásticamente real lo dicho; el duende avanzó dos pasitos hacia el borde y se lanzó al aire con los bracitos extendidos. Descendió —entérese bien - muy despacio, contraviniendo, al parecer, las leyes de la gravedad, y su descenso no fue de caída sino parabólico, pues como si caminara por el aire, o mejor, como si nadase en la atmósfera describió una curva para luego elevarse trazando un perfecto 
semicírculo de arriba abajo... para quedarse con el cascabel tocando el techo. Vi con toda claridad, porque el óvalo nebuloso que lo envolvía era radiante... Vi que abría los labios y que soltaba una carcajada tan límpida como los chorros del agua de los manantiales de Sierra Morena; una carcajada musical, como tónica $a-i$, que se desgranaba en el silencio de la noche como un juego de cristalería que correteara al escondite dentro de una campana bruñida por muchas centurias. Cállese usted, hombre... Un regalo auditivo como nunca escuché otro, se lo juro. Duró eso, me parece, más de dos minutos. Luego advertí que, semejante a un abanico plumado que se va desplegando, le nacían alas atrás de ambos brazos... y que su figurilla se desintegraba para confundirse con la nube circundante, la cual se desvaneció por el techo con un último y prolongado alarido cantarino..., no de agonía astral, como pudiera suponerse, sino de exaltada jocundidad, de aleluya saludadora (citado en Inglada 2017, 212-213).

Según afirma Cayetano Aranda Torres, «la lógica interna de lo poético viene representada por la voz corporal de la naturaleza que resuena con fuerza más allá de sus ataduras y represiones culturales» $(2001,107)$, y es que «el duende se encarga de hacer sufrir, por medio del drama sobre formas vivas, y prepara las escaleras para una evasión de la realidad que circunda» (García Lorca 1997, 160). En los surrealistas, el amor era un amor romántico que liberaba al ser humano, mientras que la gran diferencia que nos presenta Lorca en esta conferencia es que este amor que alcanzamos con el duende surge del dolor y de la agonía. El deseo no es un impulso consciente, es una evasión de la realidad mediante un ensueño, que motiva la creación poética. Según García Lorca,

la virtud mágica del poema consiste en estar siempre enduendado para bautizar con agua oscura a todos los que lo miran, porque con duende es más fácil amar, comprender, y es seguro ser amado, ser comprendido, y esta lucha por la expresión y por la comunicación de la expresión adquiere a veces en poesía caracteres mortales (1997, 158-159).

Aunque en todas las artes se puede alcanzar la evasión o son capaces de ser poseídas por el duende, según afirma Lorca,

donde encuentra más campo, como es natural, es en la música, en la danza, y en la poesía hablada, ya que éstas necesitan un cuerpo vivo que interprete, porque son formas que nacen y mueren de modo perpetuo y alzan su contornos sobre un presente exacto $(1997,155)$. 
Tan importante fue para García Lorca el control sobre su arte y la figura del duende en la creación, que pensó, ya que este se esconde en el interior de cada uno, en la posibilidad de que «si es mi creación y si he logrado materializarlo, entonces podré ordenarle y él me obedecerá. ¿Comprende usted las consecuencias..., se atreve usted a imaginárselas..., mi duende sobre mi hombre mientras yo pronuncio mis conferencias?» (citado en Inglada 2017, 213).

Respecto a la relación de Lorca con el movimiento surrealista y sus posibles diferencias, según opinión de García-Posada,

El surrealismo lorquiano es en buena medida una máscara: máscara del comentario — la conferencia de 1935- o máscara en cuanto a la adopción de cierto utillaje de origen surreal. [...]. Pero por debajo de ella está el escritor que es siempre fiel a sus propias claves, que estructura poemas y dramas con enorme coherencia: una coherencia racional $(1997,167)$.

El propio Carlos Edmundo de Ory, en su ensayo sobre Federico García Lorca, afirmaría:

Los movimientos de vanguardia europeos le interesaron marginalmente. Ni futurismo, ni dadaísmo ni los demás «ismos» anárquicos llegarían a importarle como ejemplos a seguir. Solo el cubismo, a lo Cocteau y Juan Gris, calmó un momento su sed de geometría y orfismo. La faceta surrealista de su obra — en teatro o en verso- supuso para él una válvula de escape de su ortodoxia poética. Requerido por el juego abisal de las imágenes oníricas, con toda su descarga irracional, intentó una síntesis equívoca entre la frase automática y la discursiva conceptual. No pasó de ser un surrealismo falsificado. Antes de enfrentarse con la circunstancia de Nueva York, que produjo el libro tachado de surrealista, no cesó de aclarar su posición respecto al movimiento revolucionario de Breton, infiltrado en España ([1967] 2019, 159).

Abiertamente, Lorca nunca se declaró surrealista, sin embargo sí llegó a admitir haber realizado dibujos automáticos. En la carta fechada el 2 de septiembre de 1927, dirigida a Sebastià Gasch desde Lanjarón, describe la técnica y el procedimiento para realizarlos:

Estos últimos dibujos que he hecho me han costado un trabajo de elaboración grande. Abandonaba la mano a la tierra virgen y la mano junto con mi corazón, me traía los elementos milagrosos. Yo los descubría y los anotaba. Volvía a lanzar mi mano y así, 
con muchos elementos, escogía los característicos del asunto o los más bellos e inexplicables y componía mi dibujo. Así he compuesto el «Torero sevillano», la «Sirena», el «San Sebastián» y casi todos los que tienen un crucecita. Hay milagros puros como «Cleopatra», que tuve un verdadero escalofrío cuando salió esa armonía de líneas que no había pensado ni soñado, ni querido, ni estaba inspirado, y yo dije «Cleopatra!» al verlo. ¡Y es verdad! Luego me lo corroboró mi hermano. Aquellas líneas eran el retrato exacto, la emoción pura de la reina de Egipto ([1997] 2006, 391).

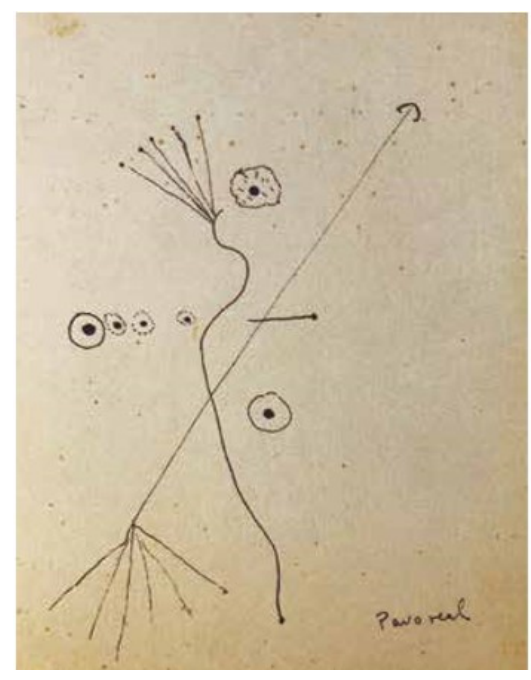

Fig. 59: Pavo real (1927)

Tinta china sobre papel verjurado recortado, $15,7 \times 12 \mathrm{~cm}$.

Colección Particular, Madrid.

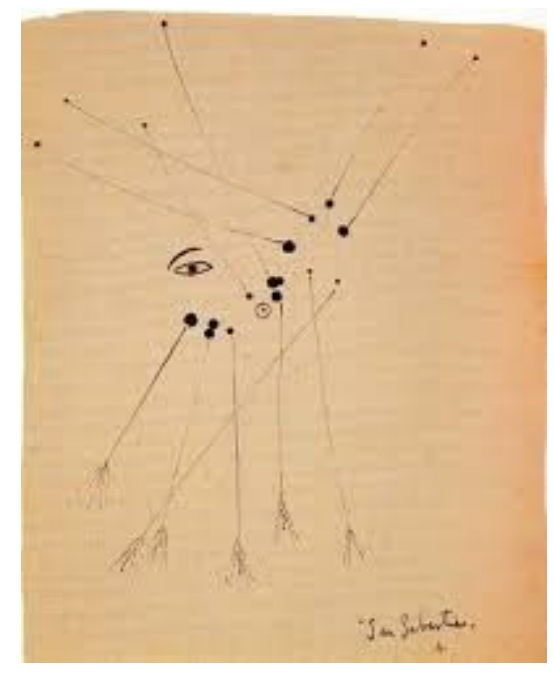

Fig. 60: San Sebastián (1927)

Tinta china sobre papel verjurado recortado, 15,5 x 12,5 cm.

Colección Particular, Madrid.

En la misma carta, describe de dónde surgen esos dibujos y expone una declaración de intenciones respecto a su concepción del arte y de su teoría estética:

Unos dibujos salen así como las metáforas más bellas y otros buscándolos en el sitio donde se sabe de seguro que están. Es una pesca. Unas veces entra el pez sólo en el cestillo y otras se busca la mejor agua y se lanza el mejor anzuelo a propósito para conseguirlo. El anzuelo se llama realidad. Yo he pensado y hecho estos dibujitos con criterio poético-plástico o plástico-poético en justa unión. Y muchas metáforas lineales o tópicos sublimados como el «San Sebastián»y el «Pavo real». He procurado escoger los rasgos esenciales de emoción y de forma, o de super-realidad y super-forma para hacer de ellos un signo que como llave mágica os lleve a comprender mejor la realidad que tienen en el mundo ([1997] 2006, 391-392).

Aunque utiliza términos como «super-realidad» y «super-forma» no quiere abandonarlos sin control de la razón. Por eso, escoge entre todos sus dibujos 
automáticos los que consigue plasmar la emoción y la forma. Como ya hemos apuntado en capítulos anteriores, André Breton afirmaba que toda la producción artística automática había que pasarla por un filtro de la razón para mostrar las obras de calidad surgidas fuera del control de la lógica y la razón.

En un principio, gran número de estos dibujos espontáneos eran de carácter privado, de tamaño reducido $12 \times 15 \mathrm{~cm}$, aproximadamente el tamaño de un sobre y Lorca los incluía en las cartas dirigidas a sus amigos. La amistad con el pintor uruguayo Rafael Pérez Barradas ${ }^{168}$ influyó en la forma de componer dibujos, figurines y bocetos para el teatro. Como afirma Mónica Hurtado Hernández,

los dos artistas conectaron de manera estética en algunas de sus ideas y en el arte del dibujo. [...] Su estilo sencillo y esquemático, el diseño de grandes superficies pintadas con colores planos y luminosos, la reducción de detalles a los imprescindible, en colores netos para no distraer la atención de los personajes $(2019,105)$.

También la opinión del crítico de arte Sebastià Gash fue importante para su formación plástica. En 1927, con motivo de la exposición de sus dibujos en las Galerías Dalmau, el 31 de julio, Sebastià Gasch escribía, en la revista L'amic de les Arts:

¡Dibujos de Federico García Lorca en las Galerías Dalmau! ¡Que los burócratas del arte, los miedosos, que los sedentarios pasen de largo!

¿Que los trascendentes, que los engreídos, que los responsables pasen de largo!

¡Que los temerosos del ridículo, y de las aventuras inéditas, y los grávidos de preocupación pasen de largo!

Los dibujos de García Lorca se dirigen exclusivamente a los puros, a los sencillos, a los que son capaces de sentir sin comprender. [...] Productos de la intuición pura, con la inspiración que guía la mano de su mano. Una mano que se entrega. Una mano que deja hacer, que no opone resistencia, que no sabe, no quiere saber adónde se la conduce. Poesía, mucha poesía. Plástica, pero muy plástica. Equilibrio de líneas, dimensión, relación de tonos (citado en Rodrigo 1975, 115-116).

\footnotetext{
${ }^{168}$ Lorca y Barradas se conocieron en Madrid en 1919 con el motivo de la realización de los figurines para El maleficio de las mariposas. Barradas creó un movimiento fundamental para la vanguardia española: el vibracionismo. Según Plaza Chillón, dicho movimiento «partía de la incorporación fragmentaria de distintos lenguajes de la vanguardia europea [...] el cubismo y el futurismo» $(2014,219)$.
} 
Sus dibujos muestran una gran ingenuidad, de líneas delicadas, finas y ondulantes. Su hermano Francisco García Lorca califica su obra plástica como

el espontáneo fluir de una línea obediente sólo al instinto, libre la mano de toda responsabilidad profesional, el trazo con la misma pluma con que escribía los versos, y coloreado el dibujo con los lápices escolares que rodeaban por la casa, era muy el gusto del poeta. [...]. Llegó a formar parte de su personalidad, como quizá lo pruebe el hecho de que acabó dibujando su propia firma, en una última liberación de la caligrafía (1981, 433-434).

Pero, gracias a los consejos y al ánimo de sus amigos, el número de dibujos fue aumentado. En estos se entrecruzaba el arte primitivo, el arte oriental y el arte musulmán. Dibujos esquemáticos, líneas sinuosas y entrecruzadas surgidas del inconsciente y del mundo onírico, «sin duda, algo se traducía en sus dibujos de la intensa visión plástica que dominaba su obra poética» (García Lorca, 1981, 434).

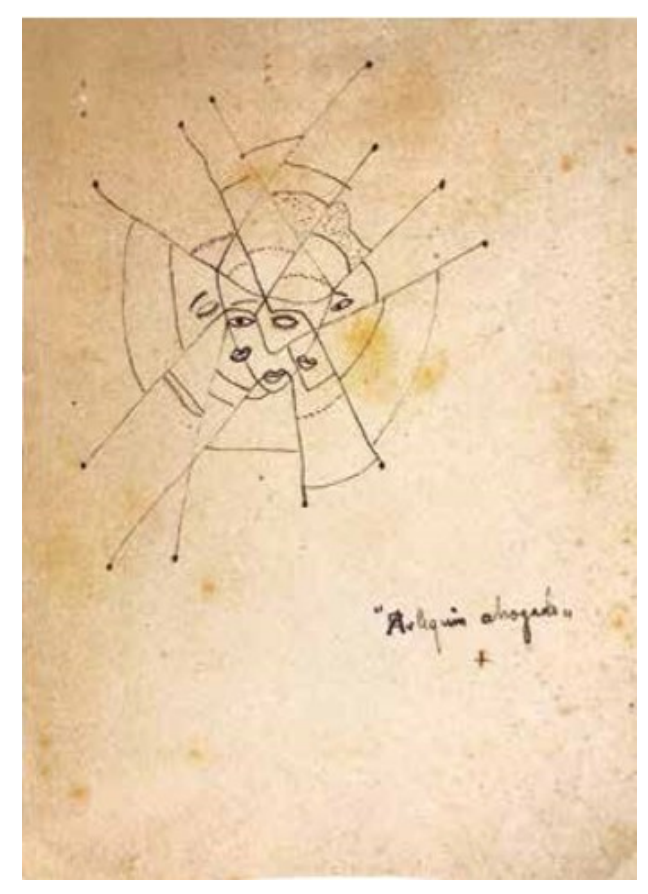

Fig. 61: Arlequin ahogado (h. 1927-1928) Tinta china sobre papel verjurado recortado, $16 \times 12 \mathrm{~cm}$.

Colección Particular, Madrid.

El dibujo Arlequín ahogado (1927) contiene los elementos que presenta en su obra dramática, como son los planos y las órbitas, el desdoblamiento y la multiplicación. El dibujo está compuesto por un rostro fragmentado en múltiples pedazos como si se 
tratara de un espejo roto, que nos recuerda el mundo de la máscara y el desdoblamiento de los personajes, tan presente en El público. Como afirma Plaza Chillón, «un rostro fragmentado que mira y duerme, un rostro que proyecta la doble tragedia lorquiana de su vida y su anunciada muerte, de su sexualidad tanática y de su Eros castrado» (2014, 26). Lorca representa la dualidad entre el sueño y la vigilia, la vida y la muerte, representada en unos ojos abiertos y cerrados.

\section{1.- Diálogos}

Los diálogos escritos antes de su viaje a Nueva York ya muestran un primer contacto con ese nuevo estilo que desarrollará a partir de 1929. Escritos en el verano de 1925, iban a formar un libro bajo el título de Diálogos, pero nunca fue publicado en vida del autor. Según señala Anderson, los diálogos «no son [...] transcripciones de palabras pronunciadas por sus personajes, sino parlamentos ficticios creados por Lorca» (2005, 17). Como afirma Soria Olmedo, estos diálogos «son formas abiertas, diálogos no comunicativos de ritmo acelerado y planos simultáneos, correspondientes en cierto modo al experimentalismo de los coetáneos poemas en prosa» (2016).

Se tiene noticia de un total de catorce de estas composiciones experimentales. Como señala Daniel Herrera Cepero, «género híbrido a caballo entre el diálogo platónico, la pieza teatral vanguardista y el guion cinematográfico» $(2017,23)$. De estas catorce, se conservan ocho diálogos completos, cuatro incompletos y dos se han perdido.

7.1.1.- Diálogos publicados en vida: «El paseo de Buster Keaton», «La doncella, el marinero y el estudiante», «Escena del teniente coronel de la Guardia Civil»y «Diálogo del Amargo» (1925)

La primera referencia documentada sobre estos diálogos la encontramos en una carta de Federico García Lorca dirigida a su amigo y crítico literario Melchor Fernández Almagro, en julio de 1925 desde Granada:

Hago unos diálogos extraños, profundísimos de puro superficiales, que acaban todos ellos con una canción. Ya tengo hecho «La doncella, el marinero y el estudiante», «El loca y la loca», «El teniente coronel de la guardia civil», «Diálogo de la bicicleta de 
Filadelfia» y «Diálogo de la danza», que hago estos días. Poesía pura. Desnuda. Creo que tienen un gran interés. Son más universales que el resto de mi obra... (García Lorca 1997, 843-844).

En 1925, Lorca terminó de redactar «El paseo de Buster Keaton» ${ }^{169}$ que publicó tres años después en el número 2 de la revista Gallo, en abril de 1928. La base de este diálogo son los cortometrajes ${ }^{170}$ del cómico norteamericano que Lorca vio y se inspiró para transformarlos. Los estudiantes de la Residencia preferían la comicidad compleja y seria de Buster Keaton a la de cualquier otro actor, entre ellos Charles Chaplin ${ }^{171}$. El impasible rostro de Keaton, su estoica expresión, ya que eliminaba la risa facial, era lo que más atraía a sus seguidores. Según expone María del Carmen Molina Barea,

discreto, despreocupado, [...] Keaton es la infancia libre, sin remordimientos ni dobleces. Es amoral, que no inmoral [...]. Aquel niño, de imaginación y asombro sin límites, que [...] comienza el día sin el peso de la tradición o las normas, sin las tribulaciones del adulto $(2013,32-33)$.

En una carta dirigida a Guillermo de la Torre, en febrero de 1927, Federico García Lorca nombra los diálogos con que está trabajando, «estoy copiando varios diálogos en prosa que tengo, que irán bien en la Gaceta. «Diálogo de Buster Keaton», «Diálogo fotografiado», etc.» (García Lorca 1997, 953). En abril 1928, se publican, en el segundo y último número de la revista gallo, dos de los diálogos, «El paseo de Buster Keaton» y «La doncella, el marinero y el estudiante» (Alberti 1984, 204).

Inicialmente, se tituló «Diálogo de la bicicleta de Filadelfia», pero después se publicó como «El paseo de Buster Keaton». Aunque fue escrito antes de su estancia en Nueva York y de poder conocer la metrópolis y la vida incesante de la ciudad de negocios, ya se puede observar en el diálogo una crítica negativa sobre esas grandes ciudades que

\footnotetext{
169 Aparece al final del texto la fecha de composición «julio 1925». Se conservan tres autógrafos fragmentarios en la Fundación Federico García Lorca. Originariamente, según aparece en uno de los borradores, iba a titularse «Buster Keaton» y luego «Diálogo tiernísimo de Buster Keaton» (Anderson 1998, 63).

${ }^{170}$ El 9 de octubre de 1924, en el número 9 del periódico madrileño El cine, venía anunciado el estreno del cortometraje Tres edades (1923); meses más tarde, el mismo periódico anunciaría El navegador. Estas proyecciones cinematográficas debían ofrecerse para un círculo reducido de amigos.

${ }^{171}$ A diferencia de los estudiantes de la Residencia que preferían a Keaton antes que a Chaplin, los surrealistas franceses, incluso los dadaístas, demostraron mayor interés por Charles Chaplin y el absurdo de las situaciones del personaje de Charlot. Los surrealistas franceses no supieron apreciar en Buster Keaton el espíritu surrealista.
} 
destruyen las relaciones humanas en la sociedad y provocan la incomunicación y la soledad del ser humano en la misma.

Es un diálogo dramático de extrema brevedad. El canto de un gallo da inicio al diálogo, con la salida a escena de Buster Keaton con sus cuatro hijos, a quienes asesina con un puñal de madera. Al cometer el parricidio, pone fin a su descendencia. A continuación, Buster Keaton coge una bicicleta y se va a pasear por las afueras de Filadelfia. Durante el paseo se cruzará con un negro, «entre las viejas llantas de goma y bidones de gasolina, un negro come su sombrero de paja» (Obras completas II [1996] 2006, 153) y entablará un breve diálogo con una americana «con los ojos de celuloide [que] viene por la hierba» (Obras completas II [1996] 2006, 154). Hacia el final aparece un ciclista con cabeza de ruiseñor que se desmaya de la emoción de conocer al famoso Buster Keaton. Concluye la pieza con una alusión a la policía por las luces que se ven brillar al fondo de Filadelfia.

Según afirma Rojas Yedra, en el texto se puede observar «la falta de lógica natural y el desdén a la máquina en la base de su propio surrealismo, donde la bicicleta adquiere propiedades extraordinarias y es capaz de ejecutar contorsiones incoherente» (2014, 183). Más que en los diálogos, donde aparecen las metáforas, los absurdos y los giros surrealistas, es en el elevado número de acotaciones en las que se puede observar un gran carácter plástico y visual. Según afirma José Agustín Mahieu, el texto «no sólo está pensado con Buster Keaton como protagonista, sino que sus acotaciones se aproximan bastante a las de un guión cinematográfico» $(1986,124)$. En el texto, Lorca consigue mostrarnos la personalidad del personaje de Keaton «su naturaleza onírica y cierto aire andrógino» (Molina Barea 2013, 44).

El segundo de los diálogos, «La doncella, el marinero y el estudiante», como ya hemos dicho, se publicó en la revista gallo junto a «El paseo de Buster Keaton». El mundo en el que transcurre esta historia es más reconocible que en el primero de los diálogos. Sus personajes son una doncella que borda todas las letras del alfabeto porque no sabe cuál será su novio; un Estudiante que huye del tiempo y el Marinero que habla de la belleza de su cuerpo desnudo mientras rema. De nuevo, en las acotaciones se pueden observar numerosos objetos y situaciones con características surrealistas: «una canoa automóvil», «el Marinero [...] cansado como un siglo VII», «Alrededor de la luna, gira 
una rueda de bergantines oscuros», «la Doncella [...] piensa dar un salto desde la letra Z». Finaliza el diálogo con una referencia a sus amigos en la última acotación «Emilio Prados, Manolito Altolaguirre, enharinados por el miedo del mar, la quitan suavemente de la baranda» (Obras completas II [1996] 2006, 152).

Los diálogos «Escena del teniente coronel de la Guardia Civill» ${ }^{172}$ y «Diálogo del Amargo» ${ }^{173}$ aparecen publicados en Poema de cante jondo ${ }^{174}$ a manera de escenas breves. Fueron añadidos en 1925, seguidos cada uno de una canción: «Canción del gitano apaleado» $\mathrm{y}$ «Canción de la madre del Amargo», respectivamente.

Los cuatro diálogos publicados póstumamente fueron «Quimera» (1940), «Diálogo mudo de los cartujos» y «Diálogo de los dos caracoles (1985), compuestos casi exclusivamente de acotaciones, y «El loco y la loca» (1997).

7.1.2.- Diálogos publicados póstumamente: «Quimera» (1940), «Diálogo mudo de los cartujos», «Diálogo de los dos caracoles (1985) y «La sabiduría. El loco y la loca» (1997)

En un principio, «Quimera» iba a publicarse en el número 3 de gallo, proyectado para el otoño de 1928, pero, finalmente, fue publicado en el número 3-4 de la Revista Hispánica Moderna de Nueva York, en julio-octubre de 1940, a partir de un autógrafo conservado, actualmente, en la Fundación Federico García Lorca (Anderson 1998, 63). Es una pieza breve, compuesta por un único cuadro, en la que intervienen cuatro personajes y una serie de voces procedentes de fuera del escenario. La obra se desarrolla, como afirma Sarah Turel, «en una atmósfera sonámbula, sin elementos que sugieran una realidad tangible. Los personajes no tienen contornos rotundos, son más bien voces que parecen fluctuar en un limbo extra espacial y temporal» $(1986,352)$. Mediante las asociaciones y disociaciones superpuestas, Lorca crea una realidad que se nutre del subconsciente.

\footnotetext{
172 Al final del texto aparece la fecha de composición: «5 de julio de 1925».

${ }^{173}$ Al final del texto aparece la fecha de composición: «9 de julio de 1925».

${ }^{174}$ Poema de cante jondo fue escrito en 1921 y publicado en 1931 en la editorial Ulises de Madrid.
} 
Introduce el tema de la separación entre un hombre y una mujer, casados, y su viaje hacia la soledad. El personaje central se llama Enrique, no por casualidad, y la Mujer expresará su soledad y su deseo. El amor entre Enrique y la Mujer está roto por la ausencia. La Mujer es el prototipo de la mujer sexual, posesiva y devoradora:

MUJER.- [...] Él tiene unos ojos maravillosos: pero lo que yo amo es su fuerza (Se desnuda.) Me duele un poco la espalda. ¡Ah! ¡Si me pudiera despreciar! Yo quiero que él me desprecie... y me ame. Yo quiero huir y que me alcance. Yo quiero que me queme... que me queme.

(Alto.) Adiós, adiós...

Enrique. Enrique... Te amo. Te veo pequeño. Saltas por las piedras. Pequeño. Ahora te podría tragar como si fueras un botón. Te podría tragar, Enrique... (Obras completas II [1996] 2006, 159).

Se podría afirmar que «Diálogo mudo de los cartujos» y «Diálogo de los dos caracoles» ${ }^{175}$ mantienen una conversación sin palabras. Las acotaciones indican la acción que está ocurriendo. El primer diálogo - al final del manuscrito, aparece la fecha de composición el 9 de julio de 1925 - es entre unos cartujos que pasean vestidos de blanco por el patio de la Cartuja y el segundo diálogo, fechado en febrero de 1926, se da entre dos caracoles que se mantienen en silencio mientras otros personajes, indicados en las acotaciones, realizan acciones o pronuncian algunas palabras.

Esta serie de diálogos, con un texto breve y con argumentos y personajes con características no pertenecientes a la realidad, nos recuerda la pieza breve «El encanto de una hora ${ }^{176}$ de Jacinto Benavente. Esta obra forma parte de su Teatro Fantástico, sus personajes son dos figuras de porcelana que cobran vida durante una hora mágica. Aquí las figuras son marionetas utilizadas como instrumento de una expresión no realista.

\footnotetext{
175 Ambos diálogos, junto al «Diálogo con Luis Buñuel» aparecen juntos formando el libro Tres diálogos. Publicado, en 1985, por la Universidad de Granada, en el número III, de la colección Aula de Poesía 176 Obra editada en 1892, nunca representada y enmarcada dentro del teatro modernista.
} 
«La sabiduría. El loco y la loca» ${ }^{177}$. Este diálogo que viene encabezado por dos títulos, parece indicar que el autor no se decidió por ninguno. Los espacios escénicos en los que transcurre la acción son la calle y la escuela. En la calle, una conversación surge de un encuentro fortuito entre dos amigos, y narra cómo uno de ellos sí puede oír el jaleo que sale de la escuela y el otro no. En la escuela, se establece un diálogo entre un maestro, los niños y un inspector. La conexión entre las dos escenas es la asignatura de geografía: el profesor está impartiendo una lección, mientras que el amigo, que consigue ver y oír la escuela, está preparándose las oposiciones de profesor de geografía. Debemos destacar la acotación surrealista de «Un ruiseñor de tinta declama líricamente las letras minúsculas» (Obras completas II [1996] 2006, 610).

\subsection{3.- Diálogos inconclusos: «Diálogo con Luis Buñuel», «Diálogo de la Residencia de Estudiantes», «Diálogo de don Fabricio y la señora» y «Diálogo del dios Pan»}

Lorca pretendía reunir en un único volumen los diferentes diálogos, bajo el título de Diálogos, pero el proyecto nunca se llevó a cabo. Se reúnen todos en la edición de 1998. Andrew A. Anderson es el encargado de editar este volumen bajo el título de Diálogos. Según sus palabras:

La colección presente es, por ende, una reconstrucción parcial e hipotética de lo que pudiera haber sido Diálogos, donde hemos incluido no sólo los textos acabados y editados, sino también borradores y textos inconclusos conservados en los fondos de la Fundación Federico García Lorca. Es la primera vez que ven la luz recogidos en un solo volumen $(1998,63)$.

Entre estos, «inconclusos o mutilados por la pérdida de hojas manuscritas, todos sin título autorizado» (Herrera Cepero 2017, 23), encontramos los arriba indicados, títulos con relación al tema del argumento de los diálogos o a los personajes presentes en los mismos.

\footnotetext{
177 Aparece publicado, en 1997, en sus Obras completas, vol. II: Teatro, en la edición de Miguel GarcíaPosada, en la editorial Galaxia Gutenberg/Círculo de Lectores, Barcelona. El autógrafo se conserva en la Fundación Federico García Lorca.
} 


\subsection{4.- Diálogos desaparecidos: «Diálogo de la danza» $\mathbf{y}$ «Diálogo fotografiado»}

Los dos diálogos en lugar desconocido, solamente atestiguados porque se mencionan en cartas de Lorca dirigidas a sus amigos, son: «Diálogo de la danza» y «Diálogo fotografiado»».

Según Soria Olmedo, «hay una continuidad indudable entre los diálogos y los poemas en prosa de hacia 1928, con su apertura al surrealismo y su búsqueda de una "manera espiritualista", “evadida”, y las piezas irrepresentables» (2016).

7.2.- Poemas en prosa: «Santa Lucía y San Lázaro», «Nadadora sumergida. Pequeño homenaje a un cronista de salones», «Suicidio en Alejandría», «Amantes asesinados por una perdiz», «Degollación de los inocentes», «Degollación del Bautista», «La gallina. Cuento para niños tontos» $y$ «Meditaciones a la muerte de la madre de Charlot» (1927-1928)

La gran ciudad y el mundo moderno son dos de los temas recurrentes en casi toda la serie de estos poemas. Aunque Lorca aún no había visitado Estados Unidos, las ciudades que aparecen en los textos de Lorca son ciudades norteamericanas al ser las películas que llegan a los cines españoles, en su gran mayoría, estadounidenses, y de ahí su inspiración. En los poemas en prosa están presentes el cosmopolitismo, la lucha entre la estética tradicional y la vanguardista y, como afirma Luis García Montero, «lo tradicional (por tanto lo culto) y lo vital (por tanto lo popular y la vanguardia) tendían a unirse como fruto de una sola heredad» $(1984,32)$.

El carácter violento, las metamorfosis, la fusión de objetos diferentes, entre otros, son comunes al surrealismo. Como afirma Rebeca Sanmartín Bastida, en los poemas en prosa se puede observar cómo existe «una pasión por los contrastes, por unir mundos contrarios» (2004, 91-92), en los que Lorca mezcla objetos de la modernidad (automóviles, aviones, etc.) con objetos tradicionales. Esta búsqueda de relacionar contrastes era uno de los objetivos que querían alcanzar los surrealistas, y que nos hace recordar la muy conocida frase que aparece en Los Cantos de Maldoror (1868) de Lautréamont: «Es bello como [...] el encuentro fortuito de una máquina de coser y un paraguas en una mesa de disección» $(2012,295)$, en el que, de una forma fortuita, con la 
unión de varios objetos ajenos entre sí, se da la aparición de uno nuevo (surrealista). Según afirma André Breton en el Primer Manifiesto:

Pierre Reverdy [...] escribía:

La imagen es una creación pura del espíritu.

No puede nacer de una comparación sino del acercamiento de dos realidades más o menos alejadas.

Cuanto más distantes y precisas sean las relaciones entre las dos realidades que se ponen en contacto, más intensa será la imagen, y tendrá más fuerza emotiva y realidad poética...

Estas palabras, aunque sibilinas para los profanos, eran profundamente reveladoras [...]. Del acercamiento fortuito de dos términos ha brotado un fulgor particular, el fulgor de la imagen, a cuyo brillo somos infinitamente sensibles. El valor de la imagen depende de la belleza de la chispa obtenida, y por lo tanto es función de la diferencia de potencial entre los dos conductores. Cuando esta diferencia es mínima, como pasa en la comparación, la chispa no se produce (2001, 38-57).

Como García-Posada añadirá, «Lorca converge con lo que los surrealistas venían diciendo sobre la arbitrariedad de la imagen. [...] Su idea de la poesía, basada en el acercamiento de los objetos muy distintos, antes nunca relacionados» $(1997,173)$.

Con estos nuevos textos, Lorca escapa de la sujeción de la métrica versificada y por eso utiliza el poema en prosa que, según Sanmartín Bastida, es «por su especial carácter híbrido en verso y prosa, se constituye como género de ruptura con la poesía lírica en verso y con la unidad orgánica de la narración» (2004, 97). En septiembre de 1928, desde Granada, dirige una carta a Sebastià Gasch en la que comenta sus primeros poemas en prosa y el motivo por el que utiliza este género «están en prosa porque el verso es una ligadura que no resisten» (Lorca 1997, 1080). También desde Granada y en ese mismo mes, escribe a Jorge Zalamea en el que le explica en qué está trabajando: «Ahora hago una poesía de abrirse las venas, una poesía evadida ya de la realidad con una emoción donde se refleja todo mi amor por las cosas y mi guasa por las cosas. Amor de morir y burla de morir. Amor. Mi corazón. Así es» (Obras completas IV [1996] 2006, 445).

Entre 1927 y 1928, Federico García Lorca escribió una serie de poemas en prosa. En total se publicaron seis, en vida del autor, en diversas revistas de manera independiente. 
Aunque existen otros, varios fragmentos o en versiones no definitivas (Sanmartín Bastida 2004, 86). En los poemas reunidos en la edición del año 2000 de Andrew A. Anderson, se incluyen, junto a estos seis, «cinco textos adicionales - tres poemas completos y dos inconclusos - que guardan un parentesco cronológico, genérico y/o estético con las seis» (Herrera Cepero 2017, 27). La idea de agruparlos bajo el nombre Poemas en prosa aparece en 1928 cuando se presentan para la revista Verso y prosa. Y en 1936, el propio Lorca en una entrevista, realizada por Antonio Otero Seco para la revista Mundo gráfico, entre sus libros finalizados cita a: «De poesía, cinco. [...] Los títulos de esos cinco libros son: Tierra y luna, Diván del Tamarit, Odas, Poemas en prosa. Y Suites» $(1937,10)$.

El poema «Santa Lucía y San Lázaro» escrito entre agosto y octubre de 1927 y publicado por primera vez en Revista de Occidente, número LIII, de noviembre de 1927, es un relato lleno de imágenes, habituales en toda su poesía posterior, en el que introduce el tema del viaje hacia la soledad y el dilema del paso del tiempo (Laffranque 1987, 32).

Tras publicar Primer Romancero gitano, el 30 de septiembre de 1928, aparecen publicados, en el número 28 de la revista L'amic de les arts de Sitges, «Nadadora sumergida. Pequeño homenaje a un cronista de salones» y «Suicidio en Alejandría», acompañados por dos dibujos surrealistas del autor, el mismo año en el que dicta por primera vez, el 11 de octubre, la conferencia «Imaginación, inspiración, evasión» (Millán 1986b. 60).

El «Suicidio en Alejandría» es un texto dividido en varios fragmentos breves, numerados de manera arbitraria $\mathrm{y}$, como «Nadadora sumergida», son asimismo narraciones fieles a la estética surrealista.

«Amantes asesinados por una perdiz. Homenaje a Guy Maupasant» ${ }^{178}$ es un breve texto formado con palabras inconexas, publicado en el número XI de Planas de Poesía de Las Palmas, en 1950, junto a otras colaboraciones que rindieron homenaje en el centenario del nacimiento del cuentista francés (Ruiz-Copete 2002, 161; Babín 1976, 436) y en el que a la transcripción del texto se le adjuntan las imágenes del manuscrito.

\footnotetext{
${ }^{178}$ Su original estuvo en poder de Rafael Roca Suárez.
} 
Los poemas en prosa «Suicidio en Alejandría», «Nadadora Sumergida», y «Amantes asesinados por una perdiz» tienen en común el tema de la muerte de una forma muy similar. El primero, «Suicidio en Alejandría», trata sobre un suicidio pactado entre dos amantes que desaparecen entre las olas del mar de una playa de Alejandría. En «Nadadora sumergida», nos sitúa en un escenario marítimo, de lujos refinados frente a la costa francesa. Es el diálogo de un hombre sobre sus aventuras amorosas con una condesa que al final aparece asesinada. Y por último, en «Amantes asesinados por una perdiz», breve entreacto para ser leído, Lorca parte del recuerdo nebuloso de algunas narraciones de Guy Maupassant y los amantes asesinados.

La narración «Degollación de los inocentes» fue publicada por primera vez en $L a$ Gaceta Literaria, número 50, el 15 de enero 1929. Como afirma Juan de Dios RuizCopete, el texto es «fiel a la estética surrealista, la narración deja su ligera gravitación argumental en un leve hilo metafórico, que exige, para su cabal entendimiento, la predispuesta complicidad del lector» $(2002,161)$.

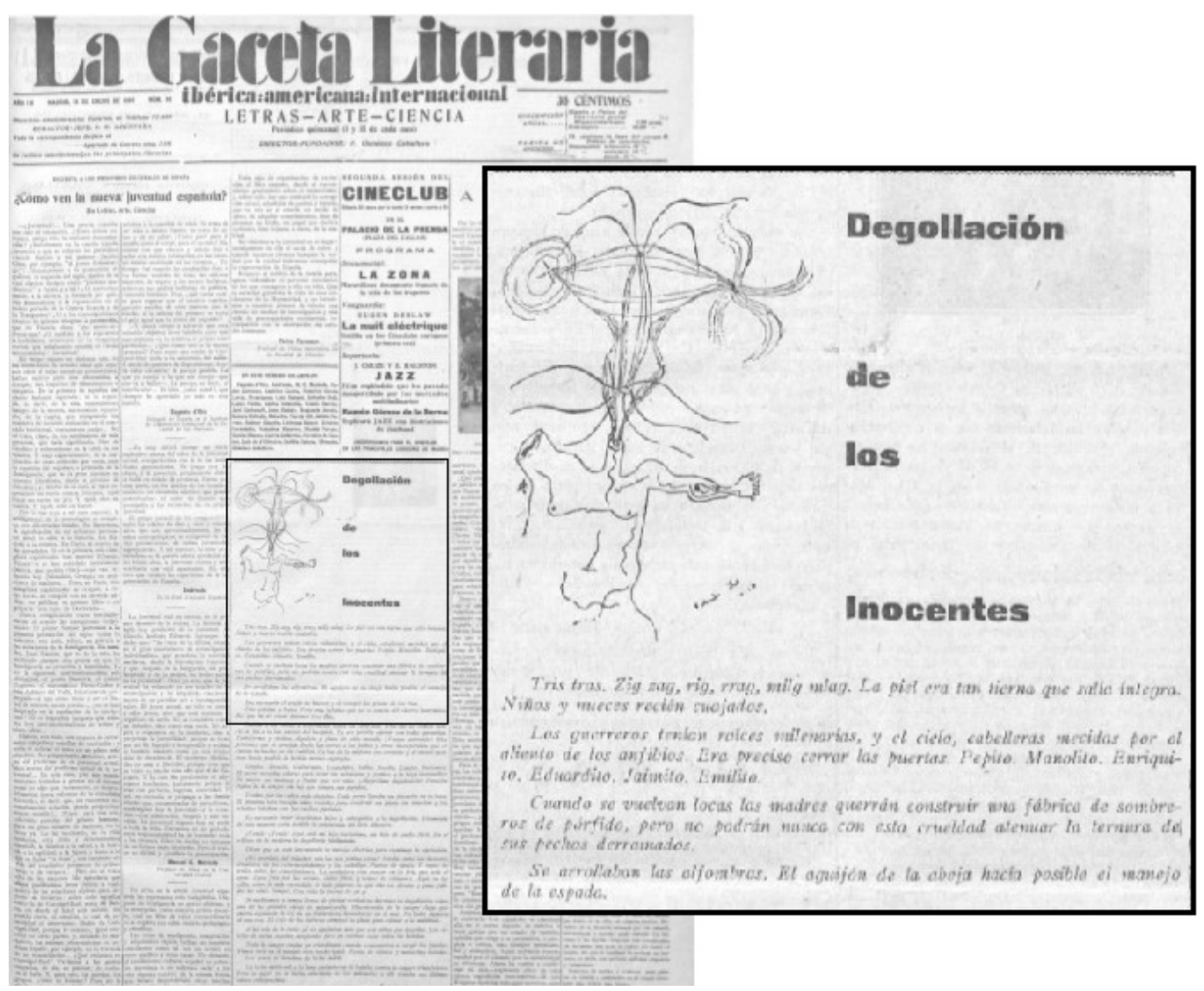

Fig. 62.: El poema en prosa «Degollación de los Inocentes» de Federico García Lorca y dibujo de Salvador Dalí, publicado en La Gaceta Literaria, el 15 de enero de 1929, en primera página. 
El texto «Degollación del Bautista» publicado en el número 47 de la Revista de Avance, de La Habana, el 15 de abril de 1930, junto a «Degollación de los inocentes» constituyen un «todo conceptual y semántico» (Ruiz-Copete 2002, 161).

«La gallina. Cuento para niños tontos» es más un cuento que un poema en prosa pero coincide cronológica y estéticamente con el resto de poemas. Fue publicado en el número 3 de 5, Revista quinquenal de Vitoria, en mayo de 1934 (Ruiz-Copete 2002, 162). El mundo de la infancia siempre atrajo a Lorca, prueba de ello son sus nanas y canciones. En este texto Lorca trata la ingenuidad y la inocencia de los niños como signo determinante y definitorio de la infancia.

El texto «Meditaciones a la muerte de la madre de Charlot» fue escrito pocos días de la muerte real de la madre de Charlie Chaplin (Herrera Cepero 2017, 35). De difícil clasificación, se puede incluir en los poemas en prosa aunque sea de género confuso, dado que incluye verso, narraciones fantásticas y ensayo estético. Según afirma Herrera Cepero, este poema en prosa es «relevante por sus espacios urbanos de ambiente americano» $(2017,27)$.

\section{3.- Poemario: Poeta en Nueva York (1929-1930)}

Al existir amplia y numerosa bibliografía dedicada al estudio del poemario, no profundizaremos en el tema. Haremos una breve explicación para situar la importancia de este nuevo estilo en la obra del poeta.

Su estancia en Nueva York — como se verá en un capítulo más adelante- marcó un cambio en su estilo y le hizo adoptar técnicas surrealistas como son la metamorfosis o las construcciones sintácticas complejas para buscar nuevas imágenes en su poesía (Ferreyra 2004, 41). Poeta en Nueva York constituye la plasmación del acercamiento del Lorca a la órbita surrealista (Correa Ramón 2019, 115-116). En estos poemas se puede ver claramente un cambio personal y estético en su escritura. Aún así, según afirma Ferreyra, «la dualidad entre los recursos estéticos de ascendencia netamente española y los de origen extranjero componen el entramado textual del mundo lorquiano» (2004, 40). 
Entre 1954 y 1958 algunos críticos se posicionan viendo en esta obra un estilo surrealista, como son:

Díaz-Plaja: "La etapa superrealista de García Lorca se abre resueltamente con sus poemas americanos". Ángel del Río: "En aquella obra, Lorca se inclinaba hacia el surrealismo, y se puede decir que es la suya la primera obra importante que produce el movimiento en España" (citado en Ory [1967] 2019, 69).

$\mathrm{Su}$ versificación, a base de versículos o versos libres y semejantes a los de Walt Whitman, son fragmentos en los que arroja todo sus sentimientos y emociones, en los que siente el desarraigo y la pérdida de sus raíces. Llega a la gran ciudad con una auténtica crisis y su experiencia lo transformó, pudiéndose observar en sus poemas neoyorquinos una madurez artística.

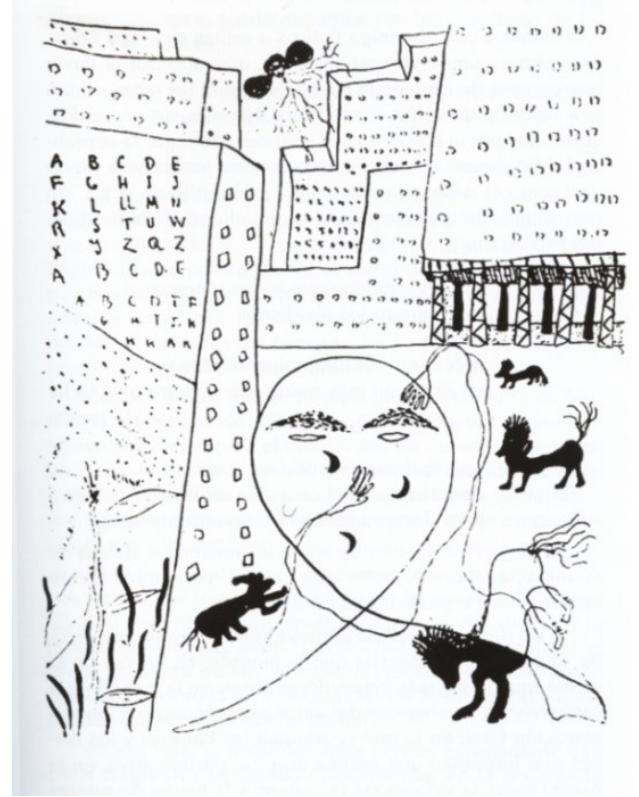

Fig. 63: Autorretrato en Nueva York ${ }^{179}$ (h. 1929-1931).

Medidas y paradero desconocidos.

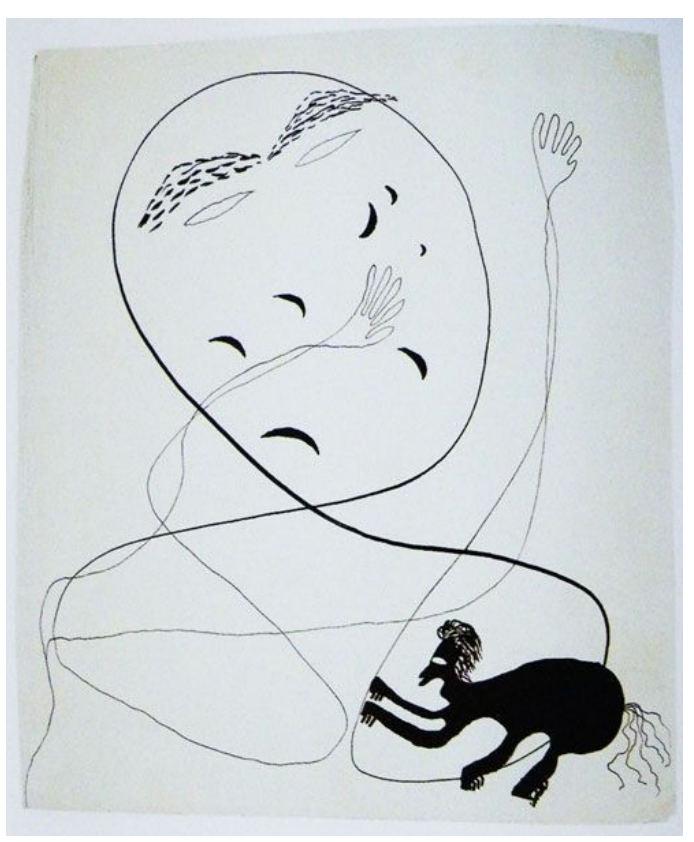

Fig. 64: Autorretrato con animal fabuloso en negro (h. 1929-1931).

Tinta china sobre cartulina recortada, $19,5 \times 16 \mathrm{~cm}$. Colección: Fundación Federico García Lorca.

Nueva York es una ciudad en la que la humanidad ha perdido su identidad y se siente alienada. Una civilización mecanicista que va perdiendo sus orígenes primitivos. En su

\footnotetext{
179 Tras su aparición en la revista francés Verve (1938) como ilustración que acompañaba al poema «Granada (paraíso cerrado para muchos)», José Bergamín lo incluye en su edición de Poeta en Nueva York (1940). En el dibujo ya puede observarse la aparición del animal fabuloso, que lo encontramos en diferentes dibujos de su periodo neoyorquino (Hernández 1986, 177). El poeta viene acompañado de este animal fantástico de procedencia desconocida.
} 
poema «Vuelta a la ciudad. Nueva York. Oficina y denuncia», Lorca nos describe esas calles neoyorquinas y cómo le parecen escenarios infernales, cuya luz artificial no muestra la verdadera vida, con una civilización tan alejada de la naturaleza:

No es el infierno, es la calle.

No es la muerte. Es la tienda de frutas.

$[\ldots]$

Óxido, fermento, tierra estremecida.

Tierra tú mismo que nadas por los números de las oficinas.

$[\ldots]$

Yo denuncio la conjura de estas desiertas oficinas

que no radian las agonías

(Poeta en Nueva York, [1929] 2013, 189)

El 16 de marzo presentó, por primera vez, en la Residencia de Señoritas, su obra Poeta en Nueva York. A la conferencia ${ }^{180}$, organizada por el Comité de Cooperación Intelectual de Madrid, sólo podían asistir sus miembros o mediante invitación. La conferencia fue acompañada con la lectura de los poemas aún inéditos.

En Poeta en Nueva York, Lorca muestra su angustia interior en sus versos y nos revela una visión apocalíptica de la ciudad, donde la civilización es cruel y destructora del hombre y de todo valor cultural (Ucelay [1995] 2008, 13) y, en contrapunto, nos muestra el mundo salvaje de la naturaleza para buscar ese origen primigenio del ser humano. Respecto a esa visión negativa de la ciudad, Ricardo Gullón expone:

Lorca encuentra en la visión una verdad radical. En el Nueva York transfigurado por su mirada, esa verdad se impone en las metáforas, en los símbolos, en el tono. Su libro refiere una pesadilla cotidiana: la realidad de una civilización opresora presente muy a lo vivo en la ciudad americana por el enfrentamiento del hombre blanco y el hombre negro. Ni inducida, ni consecuencia de un asalto a la razón, la pesadilla convoca a las imágenes en forma dispersa, inconexa y se resuelve en una denuncia de la sociedad contemporánea» ([1975] 1982, 85).

Según señala el mismo escritor, poetas como Rafael Alberti, Vicente Aleixandre y Federico García Lorca dejan «oír la voz del inconsciente para así liberar las represiones

${ }^{180}$ La conferencia de García Lorca fue anunciada en la prensa. El 12 de marzo de 1932, en el periódico $L u z$, en la página 11, y también en el mismo periódico, el 14 de marzo de 1932, en la página 7. 
y conocer la sustancia y la consistencia de lo reprimido» ([1975] 1982, 85). Lorca en Poeta en Nueva York mediante

la subversión del lenguaje revela, ante todo, la exigencia de crear imágenes en que el autor — y el lector - reconozcan la realidad oculta. Si este libro parece a muchos el más surrealista de la época, lo debe a la exaltación de lo visionario y de lo onírico (Gullón [1975] 1982, 85).

Federico García Lorca quería acabar con el carácter popular tradicionalista que había alcanzado con Romancero gitano, y con Poeta en Nueva York se dejó influir de la estética surrealista rupturista y de toda la literatura sobre la gran ciudad neoyorquina (en 1925, se había publicado Manhattan Transfer, novela coral de John Dos Passos). En la entrevista realizada por Luis Méndez Domínguez, el 5 de marzo de 1933, para la revista Blanco y negro, Lorca expresa qué quería mostrar con su poemario:

No he querido hacer una descripción por fuera de Nueva York, como no la haría de Moscú. Son dos ciudades sobre las que se vierte un río de libros descriptivos. Mi observación ha de ser, pues lírica. Arquitectura extrahumana y ritmo furioso, geometría y angustia. Sin embargo, no hay alegría, pese al ritmo. Hombre y máquina viven la esclavitud del momento. Las aristas suben al cielo sin voluntad de nube ni voluntad de gloria. Nada más poético y terrible que la lucha de los rascacielos con el cielo que los cubre.

$[\ldots]$

Ejército de ventanas, donde ni una sola persona tiene tiempo de mirar una nube o dialogar con una de las delicadas sonrisas que tercamente envía el mar, sin tener jamás respuesta... (1933a, s/p).

\section{4.- Guión cinematográfico: Viaje a la luna (1929)}

Entre diciembre de 1929 y los dos primeros meses de 1930, en menos de dos días, Lorca escribe el guión para una película, Viaje a la luna ${ }^{181}$, junto al cineasta y pintor mexicano Emilio Amero que había dirigido un corto vanguardista de cine abstracto

\footnotetext{
${ }^{181}$ Película concebida dentro de los cánones más puros del cine mudo, cuyo título hace referencia a la obra de Georges Méliès (1861[París] Francia-1938 [Francia] París) Le voyage dans la lune (1902), basada en la novela de Jules Verne.
} 
titulado $777^{182}$ sobre el tema del maquinismo en el que quería captar el movimiento de la vida moderna (Villanueva 2015, 171; Gómez Torres 1999, 45). Según el propio Amero, Lorca «trabajó una tarde en mi casa para escribirlo. Cuando tenía una idea, tomaba un trozo de papel para apuntarla, tomando notas según le venían. Este era su sistema de escribir. Al día siguiente, vino de nuevo, añadió unas escenas» (citado en Mahieu 1986, 124). Al terminar el guión, se lo regaló a Armero. Tras la muerte de Lorca, a modo de homenaje, el cineasta empezó el rodaje en México pero nunca lo concluyó (Monegal 1994, 9).

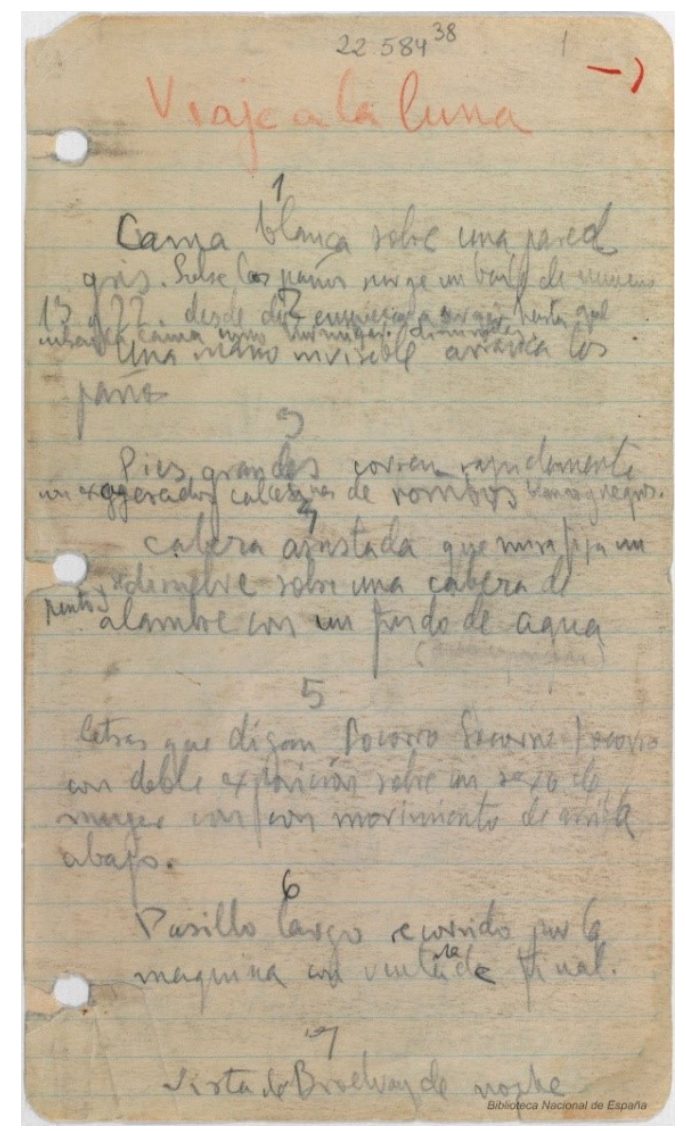

Fig. 65: Primera página del manuscrito ${ }^{183} \mathrm{del}$ guión cinematográfico de Viaje a la luna (1929).

En Viaje a la luna se encuentran resonancias del poemario Poeta en Nueva York y la obra de teatro El público. Las tres obras, escritas e incluidas en su periodo neoyorquino,

\footnotetext{
${ }^{182}$ En Norteamérica eran los números clave de las máquinas expendedoras.

${ }^{183}$ Compuesto por doce hojas de $19 \times 11 \mathrm{~cm}$. En la primera página aparece el título a lápiz rojo. Las dos primeras hojas están escritas por ambas caras y el resto a una sola cara. Escrito a lápiz y a tinta. Se encuentra digitalizado en la Biblioteca Nacional de España.
} 
comparten obsesiones, técnicas e imágenes. Viaje a la luna es una historia de amor, sexo y muerte en la que surgen imágenes visuales que encontramos en las tres obras. En la actitud de Lorca hallamos el espíritu revolucionario y rupturista del surrealismo, en contraposición a la razón y la moral burguesa. Según Frederic Amat, en esta obra nos encontramos ante el diálogo del sueño y la razón $(1998,23)$.

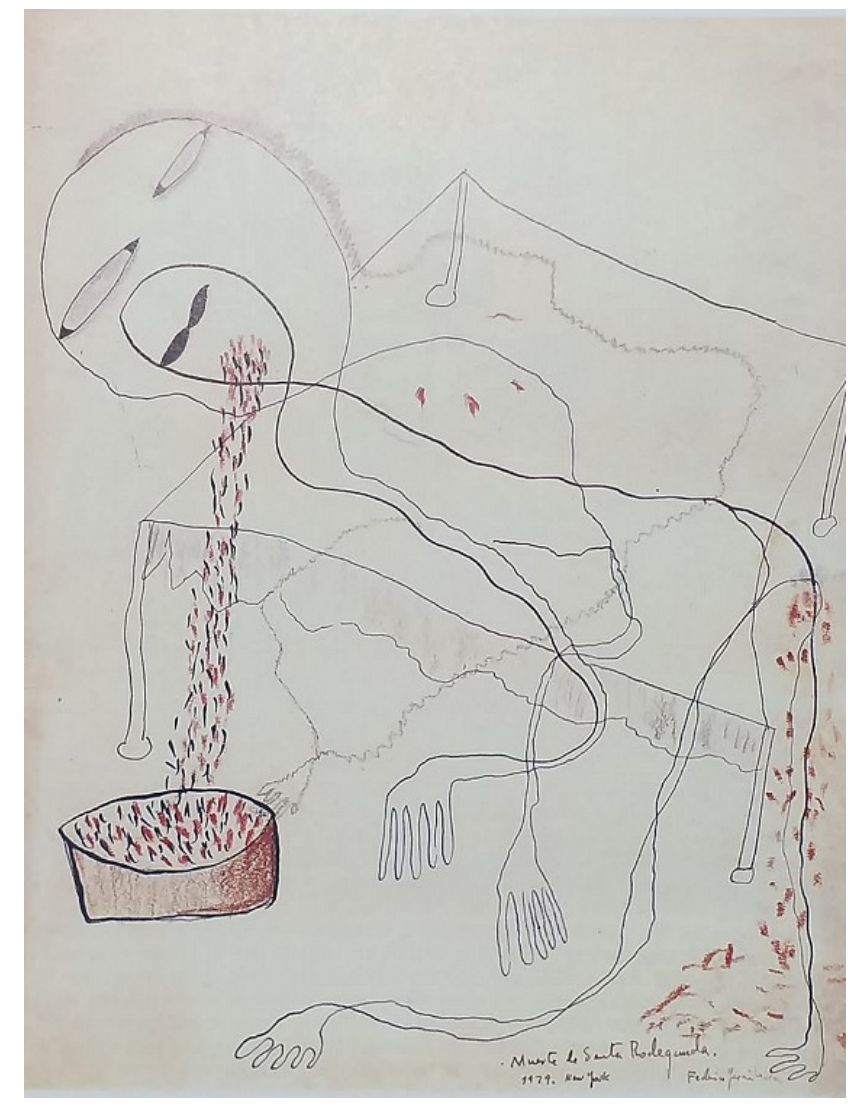

Fig. 66: Muerte de Santa Rodegunda ${ }^{184}$, Nueva York, 1929.

Tinta china, lápiz y lápices de color sobre papel de dibujo, 28,4 x 22,4 cm.

Colección: Fundación Federico García Lorca

Antes de partir a Nueva York, Federico García Lorca asistía con asiduidad a las sesiones del Cine Club Español ${ }^{185}$ creado por Ernesto Giménez Caballero, siendo

\footnotetext{
${ }^{184}$ Este dibujo, fechado y firmado por el autor, ayuda a datar el guión, ya que en el plano número 36 aparece dicho dibujo: «Doble exposición de barrotes que pasan sobre un dibujo: Muerte de Santa Rodegunda» (Viaje a la luna, Plano 36, 68).

${ }^{185}$ En sus ciclos se pudo ver los proyectos cinematográficos de cineastas como La hija del agua (1924) de Jean Renoir, El acorazado Potemkim (1925) de Serguéi Eisenstein, El gabinete del Dr. Caligari (1929) de Robert Wiene, Bajo los techos de París (1930) de René Clair, y por supuesto, Viaje a la luna (1902) de Méliès. En la sexta sesión, organizada por Luis Buñuel, dedicada a los cómicos del cine, se proyectaron, entre otras, la película El navegante (1924) de Buster Keaton, que inspiró el diálogo de Lorca «El paseo de Buster Keaton» (1925).
} 
conocedor del cine vanguardista norteamericano y europeo (Gómez Torres 1999, 48). Este dominio y conocimiento del cine lo muestra en el texto con la utilización de algunas técnicas cinematográficas muy visuales.

Lorca crea este guión cinematográfico a partir de su cosmovisión plástica y literaria, en el que buscó la plasticidad de las imágenes sin palabras. Con la utilización de la opción cinematográfica de las sobreimpresiones, nos muestra el cambio constante en el aspecto externo de los personajes. Como afirma Marie Laffranque, este guión

de recurso vanguardista está repleto de dobles y triples sobreimpresiones; transformaciones de objetos a la vista; guiños de ojos y luces, positivo y negativo de una imagen en rápida sucesión [...]; inversión de movimientos e imágenes; cambios ritmos que liberan la mente hasta del "tempo" de los cuerpos vivientes; unión de la imagen y de la letra, etc. (citado en Millán 1986a, 405).

Entre esta obra y El público existe una similitud temática, ya que ambas representan la búsqueda del amor humano. También existe la coincidencia de motivos al aparecer, en las dos obras, la presencia del personaje de Elena, la aparición del “ojo de lucidez genuina", el pez, animal símbolo de la libertad sexual, el Arlequín, los tres hombres vestidos de igual manera y el hecho de que ambas producciones terminen con la repetición de imágenes o situaciones aparecidas al comienzo de la pieza, dándole un carácter cíclico.

A principios de 1989, aparece en Oklahoma, el original del guión de Viaje a la luna ${ }^{186}$, compuesta de setenta y dos escenas escritas por Lorca en pequeñas hojas de agenda. En el texto concurren tres artes: la poesía, el cine y el dibujo. Como afirma Antonio Monegal, «Lorca opta por un cine no narrativo, por un lenguaje esencialmente poético, con la textura del sueño» $(1994,15)$, en el que «renuncia a dramatizar las situaciones y los personajes. Renuncia a construir una diégesis mínimamente verosímil y se apoya exclusivamente en el valor de las imágenes, explorando al máximo las posibilidades del

Las sesiones venían anunciadas en la prensa. Por ejemplo, en su decimoséptima sesión la proyección en el Palacio de la Prensa, a las cuatro de la tarde, fue la película El gabinete del doctor Caligari de Robert Wiene. Este anuncio se publicó en el periódico La Libertad de Madrid, en la página 8 del 31 de enero de 1931.

186 A título de anécdota, la viuda, Bárbara Amero, a petición de Christopher Maurer que preparaba la edición en inglés de la obra poética de Lorca, lo buscó por su casa de Norman, en Oklahoma, hasta que después de unos meses lo encontró en una mesilla de noche (Monegal 1994, 10). 
cine mudo» $(1987,244)$. No tiene una línea argumental, sino escenas y cuadros cuya conexión no sigue las reglas de la lógica tradicional, sino más bien la del inconsciente.

En 1998, el pintor y escenógrafo Frederic Amat realizará el proyecto para llevarlo a la pantalla, dando importancia a la dimensión pictórica del guión que el propio poeta había acompañado de diversos dibujos.

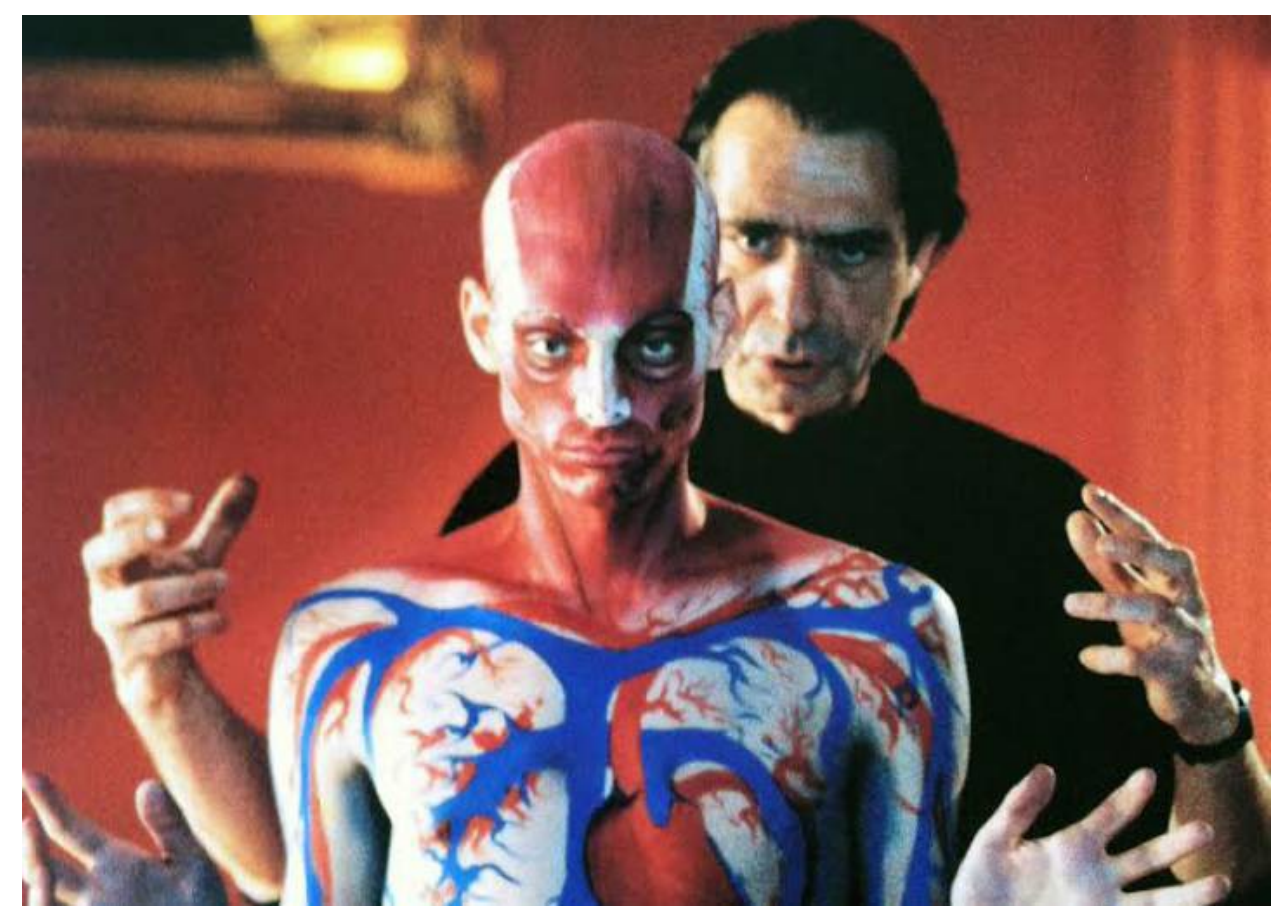

Fig. 67: Fotografía en la que Frederic Amat da instrucciones a un actor para rodar una escena del guión Viaje a la luna.

Elaboró un story-board que rodó en $35 \mathrm{~mm}$. y lo presentó en el Museo Nacional Centro de Arte Reina Sofía el 17 de junio de 1998. En la conferencia, pronunciada el 13 de mayo de ese mismo año, en el Auditori Centre Cultural Caixa Catalunya de Barcelona, dentro del ciclo realizado por la exposición Los putrefactos de Lorca y Dalí, Frederic Amat explicará:

Viaje a la luna és una pel·lícula muda que parla per si mateixa, una translació de la poesía a imatges en moviment que eludeix qualsevol discurs narratiu. El guió lorquià troba el seu sentit en la succesió i el contrast mateixos de les escenes, i invita l'espectador a la reinvenció d'un mosaic d'imatges al.legòriques, un "teorema de la Luna" en el qual no contemplen evidències, sinó angoixants vidències com radiografies $(1998,23)$. 
Meses antes del proyecto de Amat, se había estrenado en el Northfolk Art Center de Nueva York otra versión a cargo de Javier Martínez-Domínguez, producida por Eclipse, con fotografía de Javier Aguirresarobe y música original de Juan Bardem, con una plasticidad más cinemática que pictórica.

La última versión tiene lugar en 1993, dirigida por Ángel Gil Orrios y premiada en el San Francisco Poetry Film Festival. Como afirma Darío Villanueva, el cortometraje «consiste en la ilustración mediante imágenes cinematográficas de algunos textos lorquianos de Poeta en Nueva York recitados por el puertorriqueño Raúl Juliá» (2015, 172-173).

La crítica coincide en la lectura de Viaje a la luna como «la expresión de una conflictividad personal vivida por el poeta y vinculada a las distintas opciones sexuales y a la polaridad, que aquí se intuye amenazante, entre lo masculino y lo femenino» (Villanueva 2015, 174).

\section{5.- Comedias imposibles: El público (1929) y Así que pasen cinco años} (1931)

La producción dramática de Lorca que se engloba dentro de su teatro irrepresentable, buscaba renovar las fórmulas teatrales de la época, a través de un cambio en los esquemas convencionales de la escritura y de la recepción teatral, y así, rechazar el modelo del teatro burgués, como hemos visto en secciones anteriores. Entre estas piezas encontramos, El público, drama en cinco cuadros, cuya redacción fue iniciada en Cuba y finalizada el 22 de agosto de 1930, como indica en la última página del manuscrito, y Así que pasen cinco años cuya fecha de conclusión fue el 19 de agosto de $1931^{187}$, son dos de las obras teatrales que se incluyen en su ciclo neoyorquino. Están escritas en un momento en el que los dramaturgos renovadores quieren hacer un teatro rupturista respecto al teatro comercial. Al ser El público, junto a Comedia sin título, el tema principal de estudio de esta investigación, en este apartado desarrollaremos la obra teatral Así que pasen cinco años.

\footnotetext{
${ }^{187}$ En la última página del manuscrito puede leerse «Granada 19 de agosto de 1931 — Huerta de San Vicente $\longrightarrow$ como fecha de conclusión.
} 
La concepción circular de Así que pasen cinco años y de El público es innegable, ya que las dos obras terminan en el mismo lugar donde comenzaron, y así se cierra un círculo vital sin salida posible. También coinciden en las dos obras la posibilidad de que todo lo que sucede en la acción, en realidad ocurre en la mente de los protagonistas, como si se tratara de un sueño o pesadilla (Martínez Nadal 1976, 247-248).

Con el subtítulo de Leyenda del Tiempo, Así que pasen cinco años ${ }^{188}$ es la única de las obras llamadas por el autor como "teatro imposible" que ha llegado completa. En abril de 1936, en unas conversaciones literarias con Felipe Morales, Lorca confesaba ${ }^{189}$ : «Mis primeras comedias son irrepresentables. [...] En estas comedias imposibles está mi verdadero propósito. Pero para demostrar una personalidad y tener derecho al respeto he dado otras cosas» (citado en Inglada 2017, 459). Aunque las clasificara como teatro imposible o teatro irrepresentable, no olvidemos que nunca las nombró como surrealistas. Las clasificó con ese adjetivo porque para él este teatro no sería entendido por el público acostumbrado a un teatro de diversión, de ahí la difícil puesta en escena y su irrepresentabilidad. Como afirma Margarita Ucelay, «toda la obra del ciclo de Nueva York se enfrentaba con la incomprensión del público. Lorca sabía bien que tenía que luchar por hacerla entender» ([1995] 2008, 25).

Pero Lorca no renunciaba a la posibilidad de educar al público, ya en su charla sobre el teatro insistirá en que «el teatro se debe imponer al público y no el público al teatro» ([1935] 1989, 7). En la primavera de 1936, intentó estrenar Así que pasen cinco años, con el Club Teatral Anfistora, en el Teatro de La Latina, frente al Mercado de la Cebada (Salvat, Ciurans y Salvat 1997, 70). Federico García Lorca afirmaba: «Así que pasen cinco años será estrenada por el Club Teatral de Cultura, fundado por mí, cuya alma es una gran artista: Pura Ucelay» (1933b, 5). La primera representación en España tuvo lugar en el teatro Eslava de Madrid en el año 1978, a cargo de Miguel Narros (Cuadernos Pedagógicos 2016, 10).

Históricamente, la aparición de esta nueva estética en sus obras, surge en el periodo de entreguerras que es un tiempo en el que coinciden ideas y estudios del filósofo Henri

\footnotetext{
${ }^{188}$ Lorca también la llegó a subtitular Misterio del tiempo, ya que el paso del tiempo es una de las claves de la obra (Cuadernos Pedagógicos 2016, 11).

${ }^{189}$ Publicada en La Voz de Madrid, el 7 de abril de 1936, página 2.
} 
Bergson con lo instantáneo, los primeros estudios del psicoanálisis de Sigmund Freud con lo inconsciente y las publicaciones del físico Albert Einstein con lo relativo (la teoría de la relatividad). Todo ello hace que la realidad se pone en duda y como afirma Ivette Fuentes «ya nada es aquello que decía ver el ojo "físico". La realidad es tan solo su probabilidad. La actitud agnóstica ante la dificultad de aprehensión real cede a su paso a la "infinita posibilidad" de la imagen poética» (2004. 212-213).

Entre las diferentes conferencias que se celebraron en la Residencia de Estudiantes hay que destacar la que impartió Einstein en 1923 titulada «Resumen de las teorías de la relatividad», que fue presentada y traducida simultáneamente por José Ortega y Gasset: la difusión de la idea de la teoría de la relatividad modificaba las nociones de tiempo y espacio (Soria Olmedo 2016; Abella 2010, 16). Aunque pudiera ser que los presentes no entendieran lo que planteaba la teoría de la relatividad, que modificaba la percepción del tiempo y el espacio y la simultaneidad que alteraba la perspectiva visual, causó gran impacto y curiosidad (Ferreyra 2004, 36). Lorca no pudo asistir a la conferencia pero todas estas nuevas ideas y conceptos le tuvieron que llegar, y con posterioridad, se verán reflejados en sus obras y en su concepción teatral.

Albert Einstein demostró que los conceptos de espacio y tiempo, que hasta entonces permanecían separados y ser absolutos, estaban entrelazados y eran relativos. En su obra Sobre la teoría de la relatividad especial y general, publicada por primera vez en 1916, Einstein afirmaba que

El espacio aparece como un medio limitado (continente) en cuyo seno nadan los objetos corpóreos. Ahora, sin embargo, hay que pensar que existen infinitos espacios que se hallan en mutuo movimiento. [...]

Este concepto tiene indudablemente que ver con el hecho del «recordar», así como con la distinción entre experiencias sensoriales y el recuerdo de las mismas. [...] Cualquiera de nosotros conoce la duda entre si ha vivido algo con los sentidos o si sólo lo ha soñado. Es probable que esta distinción no nazca sino como acto del entendimiento ordenador.

$\mathrm{Al}$ «recuerdo» se le atribuye una vivencia que se reputa «anterior» a las «vivencias presentes». Es éste un principio de ordenación conceptual para vivencias (imaginadas) cuya viabilidad da pie al concepto de tiempo subjetivo, es decir, ese concepto de tiempo que remite a la ordenación de las vivencias del individuo (1999, 122-123). 
Como afirma Brian Randoph Greene ${ }^{190}$, «el principio de relatividad: el concepto de movimiento es relativo. Podemos hablar sobre el movimiento de un objeto, pero sólo en relación o por comparación con otro» $(2012,51)$. Y es la velocidad con la que un sujeto se mueve, la que muestra las diferentes percepciones del espacio y del tiempo (la diferencia entre individuos parados o en movimiento).

La dimensión temporal en las obras de Lorca es esencial. El tema del tiempo, de lo efímero y del amor son los que nos vertebran la obra. En Así que pase cinco años, el pasado, el presente y el futuro coexisten. A lo largo de toda la obra, la hora siempre es la misma: las seis de la tarde. El tiempo no pasa, se ha detenido en un sufrimiento sin límites, el tiempo de los personajes se convierte en una maldición. El pasado y el futuro irrumpen en el presente. La espera y el recuerdo se manifiestan en un presente estéril. Como afirma Eich, el drama surrealista «intenta dar estructura dramática al reverso del tiempo, al ámbito del vacío, el sueño y la ausencia de intensidades» $(1970,171)$.

Desde el punto de vista realista, Así que pasen cinco años tiene dos acciones: la acción principal, la de la historia de amor entre el joven, la novia y la mecanógrafa y la acción secundaria, con una atmósfera más onírica y lírica entre la portera y madre del niño muerto. Pero si nos fijamos en el subtítulo Leyenda del tiempo, el simbolismo está muy presente, aparecen diferentes personajes como alegorías del tiempo: Amigo 1 es el presente, Amigo 2 es el pasado y Viejo es el futuro.

Lorca rompe con la secuencia convencional del tiempo lineal, tanto en el mundo real como en el inconsciente. El niño, el joven y el viejo son el mismo personaje principal en diferentes momentos del tiempo, pero durante la representación, estos personajes rompen la concepción del tiempo como proceso lineal para aparecer simultáneos desde todas las perspectivas: el pasado, el presente y el futuro. En los actos y escenas de la obra todo sucede siempre en presente. Como afirma Martínez Nadal, «Lo que pasó, pasa y seguirá pasando siempre, porque solo hay una hora en el reloj de la vida del hombre» $(1979,230)$.

\footnotetext{
${ }^{190}$ Para entender mejor la teoría de la relatividad recomendamos la consulta de los diversos libros divulgativos publicados por Brian Randolph Greene, físico teórico y matemático, ampliamente reconocido por su serie de descubrimientos sobre la teoría de cuerdas. Entre sus libros más conocidos encontramos El Universo Elegante. Supercuerdas, dimensiones ocultas y la búsqueda de una teoría final (1999).
} 
La vejez y la juventud son un juego dramático. El personaje del viejo representa el destino, que se encuentra atrapado dentro de la eterna rueda del tiempo que gira en un círculo, en el que se ve obligado a revivir su destino hasta la eternidad o hasta que empiece otra vez el día. La obra intenta ser cíclica tanto en su concepción como en su representación. Según afirma Estela Harretche,

Así que pasen cinco años no sólo está planteando una nueva manera de expresar la realidad, a través de una originalísima utilización de los elementos constructivos; lo renovador de la obra está también, y sobre todo, en la aparentemente anárquica concepción de la estructura. Y aquí no debemos olvidar que el texto dramático es sólo un elemento, entre otros, del hecho teatral; y que, por lo tanto, esa nueva concepción estructural habrá de verse — tratándose de teatro— sobre el escenario $(1987,260)$.

Según afirma Aranda Torres, el lector-espectador «siente que su horizonte espaciotemporal se desvanece, porque el espacio de la representación es el espacio de nuestra vida pasada, de nuestro vivir reminiscente, de nuestro sentir que evoca otros sentires y padeceres» $(2001,110)$. En el texto su autor intenta representar las cuatro dimensiones: las tres del espacio y la cuarta dimensión, el tiempo:

Lorca no intenta mostrar un solo plano de la realidad. En Así que pasen... confluyen todas las posibilidades y todas están expresadas [...].

La espera, el sueño y el recuerdo no son sino caras de la muerte, anticipada presencia de ella. La espera es el no-amor, y la muerte es la forma en la que ya no se puede ni amar ni dejar de amar (Harretche 1987, 262).

El tema principal es el paso del tiempo muy unido al de la frustración amorosa, temas también muy presentes en el resto de su obra dramática. En Así que pasen cinco años surgen elementos oníricos estéticamente afines al surrealismo. Como afirma Uta Felten, el sueño lorquiano está sometido a

códigos culturales que forman su imaginario palimséstico, imaginario que nos invita a ver en él los cuerpos despedazados de la pintura bosquiana, los rituales dionisíacos, los cuerpos grotescos y fragmentados del Sueño del juicio final de Quevedo, el teatro de Shakespeare y Calderón y la puesta en escena de los martirios cristianos de Valdés Leal y Zurbarán $(1998,79)$. 
Hay diversidad de opiniones a la hora de clasificar Así que pasen cinco años. El crítico Guillermo de Torre considera que es una creación dictada por la intuición, mediante escritura automática sin corrección posterior. Su amigo Carlos Morla Lynch tuvo la impresión que estaba ante una obra surrealista. El crítico Ricardo Doménech la sitúa en la cima del teatro de vanguardia o surrealista (Harretche 1987, 260). Pero volvamos a su conferencia «Imaginación, Inspiración, Evasión» para retomar el término «lógica poética» ya que para Lorca sería la inspiración el único medio para que la poesía se liberara de todos los límites en el que la imaginación está ligada a la lógica y la razón, liberarse del mundo real y conseguir una verdadera evasión.

El control poético era la gran preocupación de Lorca y la idea por la que se resistía a reconocer su influencia y vinculación con el movimiento surrealista. Pero como ya hemos referido, el automatismo nunca fue una total desconexión del control y, como afirma Fuentes, «el automatismo del proceder poético, ni en la más ortodoxa exaltación surrealista, nunca fue total desconexión del hombre con la palabra, a pesar de su laxitud, sino más bien la comprensión de sus nuevas ilaciones y dependencias. De no ser así, la palabra habría muerto con su sola libertad» (Fuentes 2004, 216).

El personaje del Maniquí entrelaza las obras de Así pasen cinco años con El público, ya que se trata de un personaje sin cuerpo, vacío, tipo de personajes que también aparecerá en poemas de Poeta en Nueva York. El Maniquí sólo interviene en una única escena, escrita en verso, pero es clave para entender la obra. En el diálogo con el Joven se confrontará para hacerle ver el fracaso por la pérdida del amor y de una futura paternidad:

(Canta y llora). ¿Quién usará la plata buena

de la novia chiquita y morena?

Mi cola se pierde por el mar

y la luna lleva puesta mi corona de azahar.

Mi anillo, señor, mi anillo de oro viejo,

se hundió por las arenas del espejo.

¿Quién se pondrá mi traje? ¿Quién se lo pondrá?

Se lo pondrá la ría grande para casarse con el mar.

(Así que pasen cinco años, Acto II, 277). 
El personaje busca quien vista ese vestido vacío y sin vida. En el poema señala el verdadero tema del poema, la aparición de un traje de novia sin novia, y culpa al Joven por su falta de decisión, por perder la ocasión de cumplir su sueño y el fracaso ante el amor y la vida:

Pudiste ser para mí

potro de plomo y espuma,

el aire roto en el freno

y el mar atado en la grupa.

Pudiste ser un relincho

y eres dormida laguna,

con hojas secas y musgo

donde este traje se pudra.

Mi anillo, señor, mi anillo de oro viejo

(Así que pasen cinco años, Acto II, 280-281).

\section{6.- Obra teatral inconclusa: Comedia sin título o El sueño de la vida (1935-1936)}

Comedia sin título pertenece a toda aquella producción dramática de Federico García Lorca que se quedó inconclusa. Fue compuesta durante los últimos años de vida del dramaturgo. En ella aparece el concepto teatral en toda su dimensión y plantea un teatro nuevo, alejado del convencional de la época, influenciado por el modelo dramatúrgico neoyorquino, descubierto durante su viaje a finales de los años veinte, en el que quiere comprometerse con la situación social que se vive, principalmente, en España en esos años.

Junto a El público, esta obra inacabada forma parte de nuestra investigación principal, y por tanto, la desarrollaremos y ampliaremos en capítulos siguientes de análisis semiótico. 


\section{ANÁLISIS SEMIÓTICO TEATRAL DE EL PÚBLICO}




\section{8.- El origen de El público}

Antes de iniciar el análisis semiótico teatral de la obra teatral El público, presentaremos cómo surgió y cuál fue el origen de la obra. Haremos un recorrido, a partir del primer viaje trasatlántico de Lorca a Nueva York y a La Habana, por las experiencias vividas durante los meses de finales de 1929 y principio de 1930: como se dejó influenciar en Nueva York, por la gran ciudad, la velocidad, el progreso, etc., y, meses más tarde, en La Habana, como descubrió la música cubana, sus ritmos y su gente. Todos estos hallazgos musicales, los colores y las luces de las diferentes ciudades cubanas que visitó, ayudaron a Lorca a nutrirse y presentar una nueva estética en su escritura. Sin dejar de exponer, las primeras reacciones de la lectura de la obra entre sus amigos, así como la historia del manuscrito y sus posteriores ediciones.

\section{1.- Antecedentes a su viaje a América}

Federico García Lorca se despidió por primera vez de su familia en 1916 cuando emprendió un viaje por las tierras españolas con Martín Domínguez Berrueta, su profesor de la Universidad de Granada y sus compañeros de clase. De este viaje surgió el libro en prosa Impresiones y paisajes (1918). Pero el viaje, que marcó su nueva manera de plantear su obra, fue el primero al extranjero. Tuvo una duración de un total de doce meses, de los cuales pasó nueve en Estados Unidos (de junio de 1929 a marzo de 1930) y tres más en Cuba (de marzo a junio de 1930). De esta aventura transatlántica nació un tomo de poemas, Poeta en Nueva York (editado póstumamente), dos obras teatrales Así que pasen cinco años y El público así como experiencias e ideas nuevas (Katona 2015, 118).

Federico García Lorca inicia su gran aventura de ultramar en un estado melancólico, debido a una crisis afectiva y profesional. En el aspecto afectivo, acaba de sufrir el fracaso amoroso con su amigo, el escultor Emilio Aladrén Perojo que dejó al poeta al iniciar una relación con Eleanore Dove, una muchacha inglesa con quien se casará en 1931. En mayo de 1928, Lorca escribe a su amigo Jorge Guillén: «Mi estado espiritual no es muy bueno que digamos. Estoy atravesando una gran crisis sentimental de la que espero salir curado» (citado en Bianchi Ross 1997, 12). 
Familiares y amigos se percatan de esta aguda depresión. En la primavera de 1929, en Madrid, en una conversación transcrita entre Rafael Martínez Nadal y el padre del poeta, Federico García Rodríguez, se puede pensar que su estado de ánimo fuera el motivo de su viaje a América:

— Vengo de "Graná" para asuntos particulares y para enterarme de una cosa que me interesa. Yo sé que tú eres de los pocos buenos amigos de mi hijo y vengo a verte aquí porque sé que me vas a decir la verdad. ¿Qué le pasa a mi Federiquito?

— Nada grave, don Federico — dije—, la resaca del éxito; quizá un poco de depresión. $[\ldots]$

- Basta, Rafaé. Yo no te pido detalles. Pero contéstame como amigo de mi hijo, y mío, que ya lo eres. ¿Tú crees que a mi hijo le sentaría bien una temporadita fuera de España?

- Pues sí, don Federico. Creo que no le sentaría nada mal (Martínez Nadal 1975, XXX).

En una carta fechada, el 18 de agosto de 1928, dirigida a Joaquín Montaner, desde San Sebastián, Margarita Xirgu comentaba el estado de ánimo en el que se encontraba Lorca:

He recibido una carta de Lorca graciosísima. [...] Se ve que la publicación y el éxito de sus romances no le ha bastado y está disgustado por cosas sentimentales. La carta tiene un tono de ma... cito muy gracioso. No se salvará y creo, como usted, que vale, pero no se salvará (citado en Aznar Soler y Foguet i Boreu 2018, 165).

Pero profesionalmente no pudo gozar del éxito clamoroso del Romancero gitano, ya que la popularidad del poemario amenazaba de tildarle de poeta regional con el mito de la gitanería. El propio Lorca, años más tarde, se defenderá ${ }^{191}$ de las acusaciones:

El Romancero gitano no es gitano más que en algún trozo al principio. En su esencia es un retablo andaluz de todo el andalucismo. Al menos como yo lo veo. Reúno todos los elementos poéticos locales y les pongo la etiqueta más fácilmente visible. Romances de varios personajes aparentes, que tienen un solo personaje esencial: Granada... (citado en Soria Olmedo 2017, 37).

\footnotetext{
${ }^{191}$ En la entrevista titulada «Estampa de García Lorca» realizada por Gil Benumeya y publicada en $L a$ Gaceta literaria, el 15 de enero de 1931.
} 
En enero de 1927, en una carta dirigida a Jorge Guillén y remitida desde Granada, ante la propuesta de colaborar en la revista Verso y Prosa, se ofrece siempre que no esperen romances con el tema de los gitanos, y expone:

Me va molestando un poco mi mito de la gitanería. Confunden mi vida y mi carácter. No quiero, de ninguna manera. Los gitanos son un tema. Y nada más. Yo podía ser lo mismo poeta de agujas de coser o de paisajes hidráulicos. Además el gitanismo me da un tono de incultura, de falta de educación y de poeta salvaje que tú sabes bien que no soy yo. No quiero que me encasillen, Siento que me van echando cadenas. No (como diría [Eugenio D’] Ors) (citado en León 2018a, 324).

Además, se había distanciado de su amigo íntimo, Salvador Dalí, y no tardó en sospechar la sátira en Un perro andaluz (1929) película surrealista dirigida por Luis Buñuel y Salvador Dalí, en la que Lorca interpretaba una serie de alusiones personales. Aunque Buñuel lo negó años más tarde:

La gente encuentra alusiones donde quiera si se empeña en sentirse aludida. Federico García Lorca y yo estuvimos enfadados por algunos años. Cuando en los años treinta estuve en Nueva York, Ángel del Río me contó que Federico, que había estado también por allí le había dicho: "Buñuel ha hecho una mierdecita así de pequeñita que se llama Un perro andaluz; y el perro andaluz soy yo" (citado en Sánchez Vidal 1988, 67).

Sufrió el rechazo de sus mejores amigos, Salvador Dalí y Luis Buñuel (Bianchi Ross 1997, 12-13). El 14 de septiembre de 1928, Luis Buñuel, en carta dirigida a J. Francisco Aranda le escribe y enjuicia:

Su libro de romances El romancero gitano, me parece [...] muy malo. Es una poesía que participa de lo fino y aproximadamente moderno que debe tener cualquier poesía de hoy para que guste a los Andrenios, a los Baezas y a los Cernudas de Sevilla [...] Hay dramatismo para los que gusten de ese clase de dramatismo flamenco; hay alma de romance clásico para los que gusten de continuar por los siglos los romances clásicos; incluso hay imágenes magníficas y novísimas, pero muy raras y mezcladas con un argumento que a mí se me hace insoportable (citado en Mahieu 1986, 120).

Posteriormente, en Mi último suspiro, memorias de Luis Buñuel recordará: 
Dalí me anunció, entusiasmado, que Lorca había escrito una obra magnífica, Amor de don Perlimplín con Belisa en su jardin. [...] Lorca empezó la lectura. [...] Yo interrumpo la lectura dando una palmada en la mesa y sigo:

- Basta, Federico. Es una mierda.

Él palidece, cierra el manuscrito y mira a Dalí. Este, con su vozarrón, corrobora:

— Buñuel tiene razón. Es una mierda ([1982] 2015, 126-127).

Aunque también recibió el apoyo y las alabanzas de sus compañeros ${ }^{192}$, como el caso de Vicente Aleixandre que después de recibir el libro del Romancero gitano, en carta fechada el 7 de septiembre de 1928, desde Miraflores de la Sierra, dirigida al propio Lorca, opinaba que sobre la obra:

Pocas veces — iqué pocas! - puede uno tan totalmente abandonarse a una fruición de belleza tan íntegra con tan absoluto contento. No hay más remedio - iy qué bien que no lo haya! - que sentirse desarraigado de todo suelo propio, extraído de toda impasibilidad y arrastrado por el vigoroso ímpetu, corriente poderosa, marcialísima, abrazadora, que nada consiente ajeno. Al abrir el libro, de pronto qué caño redondo, irrestañable, dramático, en el pecho. ¡Qué muerte de belleza! ¡Qué muerte a fuerza de belleza![ ...].

Esto de enajenarse uno en el poeta, de sentirse uno fuera de sí, en él, creo que no ocurre en la poesía de hoy con nadie con la intensidad que contigo. A fuerza de intensidad es aniquiladora: desplaza toda sensación de ser autónomo para trocar al lector en pura y pasiva lira, frenética de resonancias, en las manos del poeta creador. Es una maravilla. Es una delicia y un tormento [...]. Muerto de poesía: hermosura: Entre la vida y la muerte, tu poesía, en trance, tiene de las dos aunque triunfe la vida. Tu poesía duele. ¿Por qué duele?

[...] Creo en auténtica poesía y en tu poesía inimitable. Creo que fracasarán cuantos intenten captar lo externo y que derivarán peligrosamente. Creo que sólo tú puedes hacer tu poesía. Creo que eres magnífico (2001, 53-55).

Le llegó la oferta de Fernando de los Ríos, profesor y amigo, que pidió a Lorca que le acompañara durante su viaje a América para ocupar un puesto de profesor visitante en la Columbia University de Nueva York. Antes de iniciarlo, realizan unas breves visitas en

${ }^{192}$ En sus memorias, La arboleda perdida, Rafael Alberti recuerda: «El Romancero de García Lorca fue un éxito más grande de toda aquella década. Antes de aparecer, había ya recorrido parte de su camino para esta inmensa resonancia. El secreto de ella estaba en la claridad, envuelta a veces en un dramático misterio, de estos poemas» ([1959] 1976, 270-271). 
París, Londres y Oxford (Bianchi Ross 1997, 13). El transatlántico HMS Olympic, de la línea White Star, salió del puerto de Southampton a las once de la mañana el 19 de junio de 1929 y desembarcó en Nueva York el 26 del mismo mes, después de una travesía de seis días de duración (Katona 2015, 120; Martínez Carmenate 2002, 27).
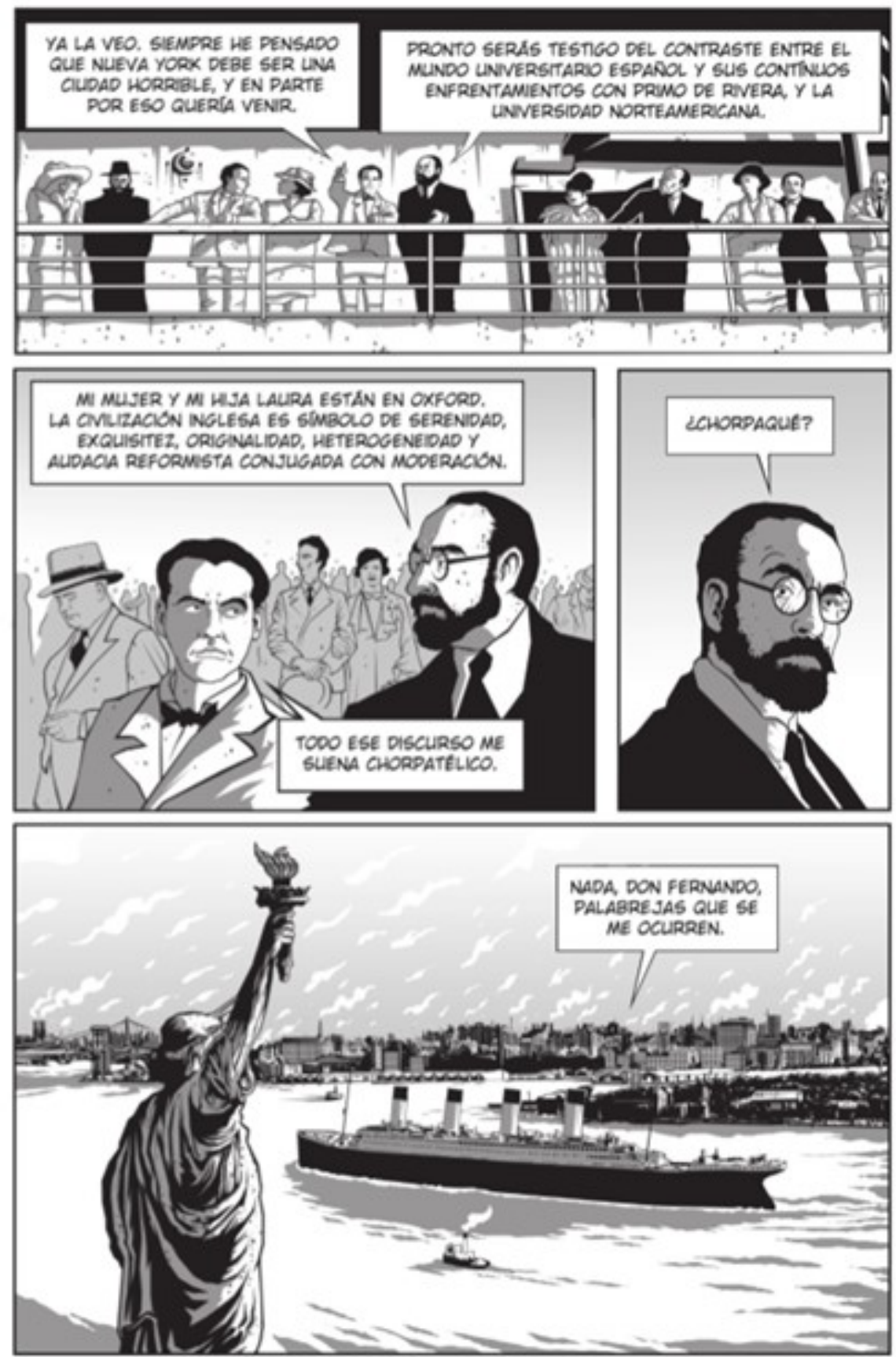

$-025-$

Fig. 68: Viñetas de la novela gráfica Lorca. Un poeta en Nueva York (2016) en la que el ilustrador Carles Esquembre hace un recorrido del viaje que Lorca realizó a Nueva York, como una crónica personal y anecdótica durante los meses vividos en la gran metrópoli. 


\section{2.- EI viaje a Nueva York}

En Nueva York los recibe Ángel del Río, viejo amigo de Lorca; Federico de Onís profesor en la Universidad de Columbia; el poeta León Felipe y profesor en Cornell; el pintor Gabriel García Maroto y varios periodistas, entre ellos José Camprubí, director del diario neoyorquino La Prensa (Gibson 1998, 318). Se reencuentra con Philip Cummings y Campbell Hackforth-Jones, con quienes había coincidido días en la Residencia de Estudiantes y con Mildred Adams, a quien conoció en Granada.

Las primeras semanas en Nueva York son de gran intensidad y, durante su visita, pudo encontrarse con compatriotas suyos. Las primeras impresiones están llenas de entusiasmo, y las descripciones del lugar y de la gente americana son positivas.

En su primera carta desde Nueva York, dirigida a su familia el 28 de junio, expondrá la grandiosidad de la ciudad:

La llegada a esa ciudad anonada pero no asusta. A mí me levantó el espíritu ver cómo el hombre con ciencia y con técnica logra impresionar como un elemento de naturaleza pura. Es increíble. El puerto y los rascacielos iluminados confundiéndose con las estrellas, las miles de luces y los ríos de autos te ofrecen un espectáculo único en la tierra [...]. Nueva York es alegrísimo y acogedor. La gente es ingenua y encantadora (García Lorca [1929] 2013, 10).

Describe positivamente Nueva York donde el hombre domina a la naturaleza mediante la ciencia y la técnica. Le impresionó el orden dentro de una ciudad caótica, ya que Nueva York fue construida con una estructura cuadriculada y sus calles y avenidas están indicadas con números, muy diferente a las ciudades españolas. Todas esas impresiones de la metrópolis se concentran en uno de sus primeros poemas «Vuelta al paseo» donde describe el paisaje dominado por las luces de los anuncios de neón y las ventanas de los edificios cuyo asesino es el propio cielo (Jaén Urban 2014, 52).

En los años veinte, el esplendor de la metrópoli norteamericana, su pujante crecimiento comercial la colocaban en una posición privilegiada dentro de las relaciones internacionales (Ferreyra 2004, 141). Lorca llega a Nueva York en un período de 
conflictos políticos y sociales en el mundo occidental: la crisis económica que da fin a los felices años veinte, el crack del 29 en la bolsa norteamericana, la consolidación de la ideología fascistas en Europa y las tensiones sociales.

El choque entre las dos culturas, la estadounidense y la hispana, causa un importante impacto para Lorca. Se siente extranjero en el lugar y sufre la ausencia de la lengua materna, como afirma Ferreyra «escribir en castellano es pensar en castellano; codifica la metrópolis norteamericana y su cultura desde parámetros latinos» $(2004,137)$. En compañía de los hispanohablantes se movía con mayor soltura que entre los que hablaban solamente el inglés.

Después de pasar la primera fase de acomodarse, por indicación de su maestro Fernando de los Ríos, el 5 de julio se matrícula en una clase de inglés English V1. Federico García Lorca empieza a seguir los cursos de inglés para extranjeros e ingresó como estudiante en la Escuela de Verano de la Universidad de Columbia, pero sin ninguna aplicación. Federico de Onís hizo también todo lo posible para que aprendiera el idioma. García Lorca, en una carta dirigida a su familia, el 6 de julio de 1929, expresaba su optimismo en cuanto al aprendizaje «Ya he empezado mis clases de inglés en la Universidad. [...] Yo creo que tengo cierta facilidad para el inglés. ¡Veremos a ver!» (García Lorca [1929] 1985, 41).

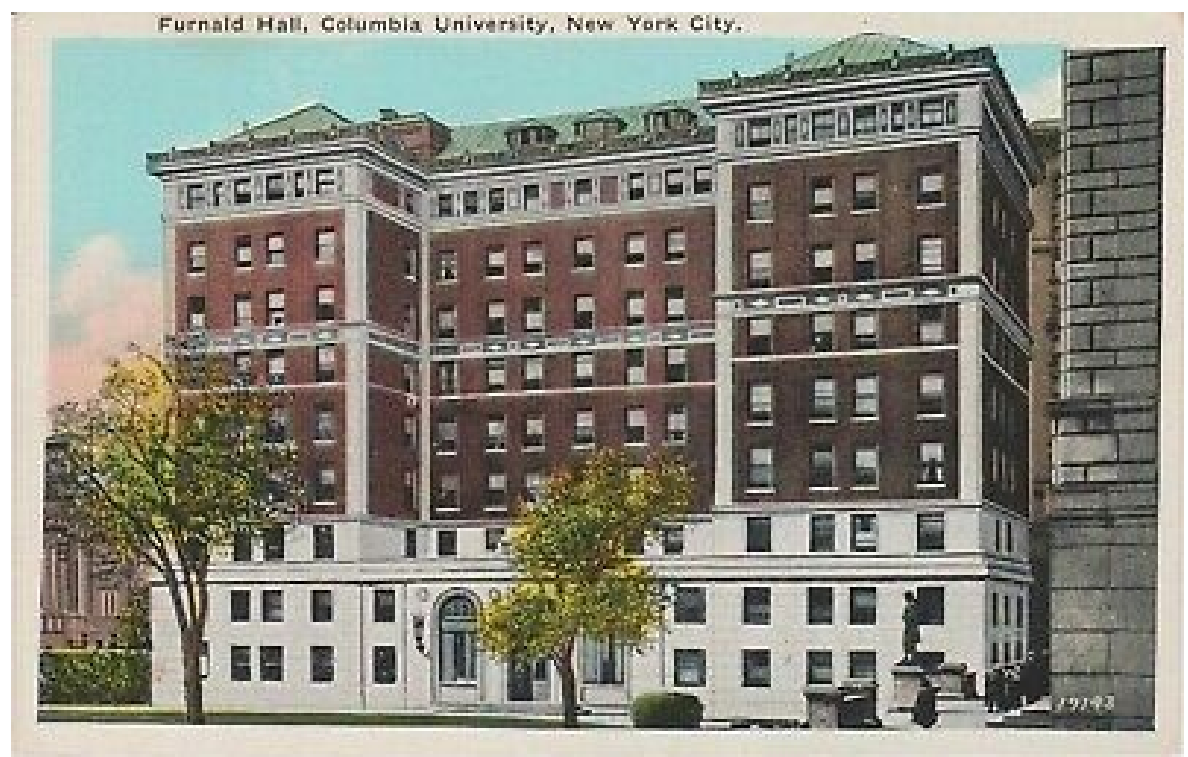

Fig. 69: Tarjeta postal, Furnald Hall, Columbia University, donde Federico García Lorca vivió durante el verano de 1929. Colección privada. 
Campbell (Colin) Hackforth-Jones, un inglés que conoció unos años antes en la Residencia de Estudiantes (a quien había dedicado uno de los poemas de Canciones) se convirtió también en maestro de inglés ayudándole en las traducciones (Katona 2015, 124; Gibson 1998, 320). Al final, no logró superar las dificultades de la lengua. A pesar de todas las intenciones y el esfuerzo de muchas personas, el dominio del inglés, adquirido por García Lorca durante su estancia en Nueva York, fue mínimo, pero su don musical y su carisma personal no le impidieron relacionarse con la gente.

Otro de los centros frecuentados por el poeta, a través de León Felipe, Gabriel García Maroto y Ángel Flores, es la Alianza Hispano-Americana, cuya sede se encontraba en 1 East 42nd Street, esquina con la Quinta Avenida (Gibson 1998, 323).

El 16 de agosto de 1929, acaban las clases en la Escuela de Verano de la Universidad de Columbia. Acepta la invitación de Philip Cummings, ocho años más joven, para visitarlo en Eden Mills, en el estado de Vermont, un pintoresco pueblo fronterizo con Canadá. Un grupo de amigos lo acompañan a la Grand Central Station para despedirlo. Realiza el viaje en tren y sin compañía (Katona 2015, 124). A la mañana siguiente, Philip Cummings y su padre lo están esperando en Montpelier Junction para recogerlo con su coche Ford Model-T (Gibson1998, 330). La cabaña alquilada para pasar el verano estaba situada en la orilla del lago Eden. Durante los diez días escribe diversos poemas y conoce amistades de la familia Cummings (Maurer y Anderson 2013, 154).

En la primera quincena de septiembre de 1929 continúa sus días de verano en casa de Ángel del Rio y su mujer, en Bushnellsville (cerca de Shandaken) en las Catskill Mountains, estado de Nueva York. Son semanas muy fructíferas en cuanto a creación poética. En esta casa el poeta escribió algunas composiciones de Poeta en Nueva York y leyó a sus amigos Amor de don Perlimplin y partes de La zapatera prodigiosa (Maurer $1985,29)$.

El 18 de septiembre visita la casa de campo de Federico de Onís, Gardnertown Road, Newburgh, Nueva York. Disfruta de la hospitalidad, primero de Ángel del Río y, luego, de Federico de Onís y aprovecha el tiempo para seguir con un buen ritmo de trabajo. En total, pudo pasar cinco semanas fuera de la ciudad y regresará cuando empieza el nuevo semestre (Katona 2015, 124-125). 
Vuelve con Onís y su familia a Nueva York, hospedándose ahora en la residencia John Jay Hall, de la Universidad de Columbia. El 26 de septiembre empiezan las clases del semestre de otoño, pero antes del 5 de octubre abandona las clases de inglés (Maurer y Anderson 2013, 155). Escribe el guión cinematográfico Viaje a la luna que proyecta realizar con la colaboración del mexicano Emilio Armero.

La verdadera vida social empezó a partir del otoño de 1929. El teatro fue uno de los divertimentos preferidos. Entre los teatros visitados destacan Neighborhood Playhouse, el Theater Guild y el Civi Repertory. También visitó el teatro chino ${ }^{193}$, la revista negra y otros espectáculos de teatros negros (Katona 2015, 127-128). Lorca llega a Nueva York en plena época del "Jazz Age" y de las comedias negras de Broadway. Quedó impresionado con estos musicales y espectáculos (Rabassó 1995, 212). Los primeros días visita el barrio en compañía de León Felipe, Gabriel García Maroto y Ángel Flores. En la carta del 28 de junio de 1929, dirigida a su familia, describe sus impresiones

El espectáculo del Broadway de noche me cortó la respiración. Los inmensos rascacielos se visten de arriba debajo de anuncios luminosos de colores que cambian y se transforman con un ritmo insospechado y estupendo, chorros de luces azules, verdes, amarillas, rojas, cambian y saltan hasta el cielo (García Lorca [1929] 2013, 12).

Pese a la belleza del otoño de Manhattan, en la carta fechada el 21 de octubre marca una decisiva inflexión en las impresiones neoyorquinas del poeta. Aparece por vez primera la palabra angustia (Villanueva 2015, 204) para describir lo que Federico experimenta al saberse perdido en el barrio chino sin encontrar la estación de metro que le devolviera a Columbia.

El otro día tuve al fin mi primera pérdida en la ciudad. [...] Yo me vi perdido y me dediqué a ver las calles y a recorrer las tiendas chinas. En esto se hizo la hora de comer, y comí en un restaurant chino [...]. Después corrí esta ciudad [...] me consideré perdido [...]. Entonces tuve cierta angustia, cierta sensación de estar en el bosque virgen o en una isla de otro planeta que no era el mío (Lorca [1929] 2013, 72).

\footnotetext{
${ }^{193}$ Según afirman Ricard Salvat, Enric Ciurans i Núria Salvat «todo hace pensar que fue el de Sun Sai Gai en el Gran Street, al sur de Manhattan. Es probable que pudiera ver también a Mei-Lang-Fang, el más grande actor chino de este siglo» $(1997,63)$.
} 
Durante el otoño, visita Wall Street de noche con Federico de Onís y con Ángel del Río, realiza excursiones a Harlem con Crow y Francis Hayes (Maurer y Anderson 2013, 155). Tuvo la posibilidad de conocer también el mundo inhumano y feroz de Wall Street, el centro de los negocios financieros, la Bolsa, los bancos y los grandes rascacielos de oficinas. El 29 de octubre fue testigo del «martes negro», el crac de la bolsa que Lorca observa en Wall Street. Según escribe a su familia a principios de noviembre de 1930,

yo estuve más de siete horas entre la muchedumbre en los momentos de pánico financiero. [...]. Las calles, o mejor dicho los terribles desfiladeros de rascacielos, estaban en un desorden y un histerismo que solamente viéndolo se podía comprender el sufrimiento y la angustia de la muchedumbre (Lorca [1929] 2013, 80).

He aquí la versión que ofrece en su conferencia-recital de «Poeta en Nueva York» de 1932:

yo tuve la suerte de ver por mis ojos el último crack en que se perdieron billones de dólares, un verdadero tumulto de dinero muerto que se precipitaba al mar, y jamás, entre varios suicidas, gentes histéricas y grupos desmayados, he sentido la impresión de la muerte real, la muerte sin esperanza, la muerte que es podredumbre y nada más, como en aquel instante, porque era un espectáculo terrible pero sin grandeza ([1932] 2013, 140).

El trágico acontecimiento del mundo del dinero sirvió para reforzar la aversión de Lorca hacia el capitalismo. El 5 de marzo de 1933, en una entrevista realizada por Luis Méndez Domínguez para la revista Blanco y Negro, Lorca afirmará:

Lo verdaderamente salvaje y frenético de Nueva York no es Harlem [...] [es] Wall Street. Impresionante por frío y por cruel. [...]. En ninguna parte del mundo se siente como allí la ausencia total del espíritu [...]. Nadie puede darse idea de la soledad que siente allí un español, y más todavía un hombre del Sur (García Lorca 1933a, s/p).

Sus vivencias están mucho más cercanas a la experiencia de la marginalidad que a la de la aceptación social. Como afirma Díez de Revenga,

Lorca [...] desprecia, el Nueva York próspero y capitalista, la ciudad de la riqueza y del progreso, y prefiere los barrios de los negros, de los judíos, los lugares abandonados de 
la sociedad. Descubre y se agobia ante el desorden, la aglomeración del hierro y del cemento, ante la suciedad física y moral de la gran ciudad $(1974,57)$.

Según afirma Morris «agudo observador social, Lorca veía a los parados blancos, y veía a muchos más negros en Harlem, porque el desempleo era cinco veces más alto en el barrio negro que en cualquier otra parte de Nueva York» $(2000,18)$. Durante los años veinte, casi 88.000 inmigrantes se instalaron en el barrio, viviendo en condiciones insalubres. El barrio de Harlem tenía «más de quinientos cabarets e innumerables bares ilícitos para los que querían trasnochar, era también el barro plagado de criminales, prostitutas y delincuentes» (Morris 2000, 19). Sus visitas a los teatros del Harlem (El Lafayette, el Lincoln y el Alhambra) y «su contacto con el mundo afro-americano dejarán en su espíritu y su obra un claro valor del arte negro en América» (Rabassó 1995, 213).

Lorca se solidarizó con los negros norteamericanos no sólo desde un plano social, sino también por la música. Encontró ciertas semejanzas entre el jazz y el flamenco. Según José Ortega, «el flamenco y el jazz presentan semejanzas y diferencias. Ambas son expresiones telúricas de un pueblo (hindú/africano) que ha sido aislado social y geográficamente de su medio natural, y que expresa musicalmente la memoria cultural de su pasado colectivo» (1986, 161-162). El rechazo a estas culturas, tanto a la gitana como a la negra, les obliga a expresarse a través de las tradiciones orales. En Lorca la tradición oral constituye la base de su poesía.
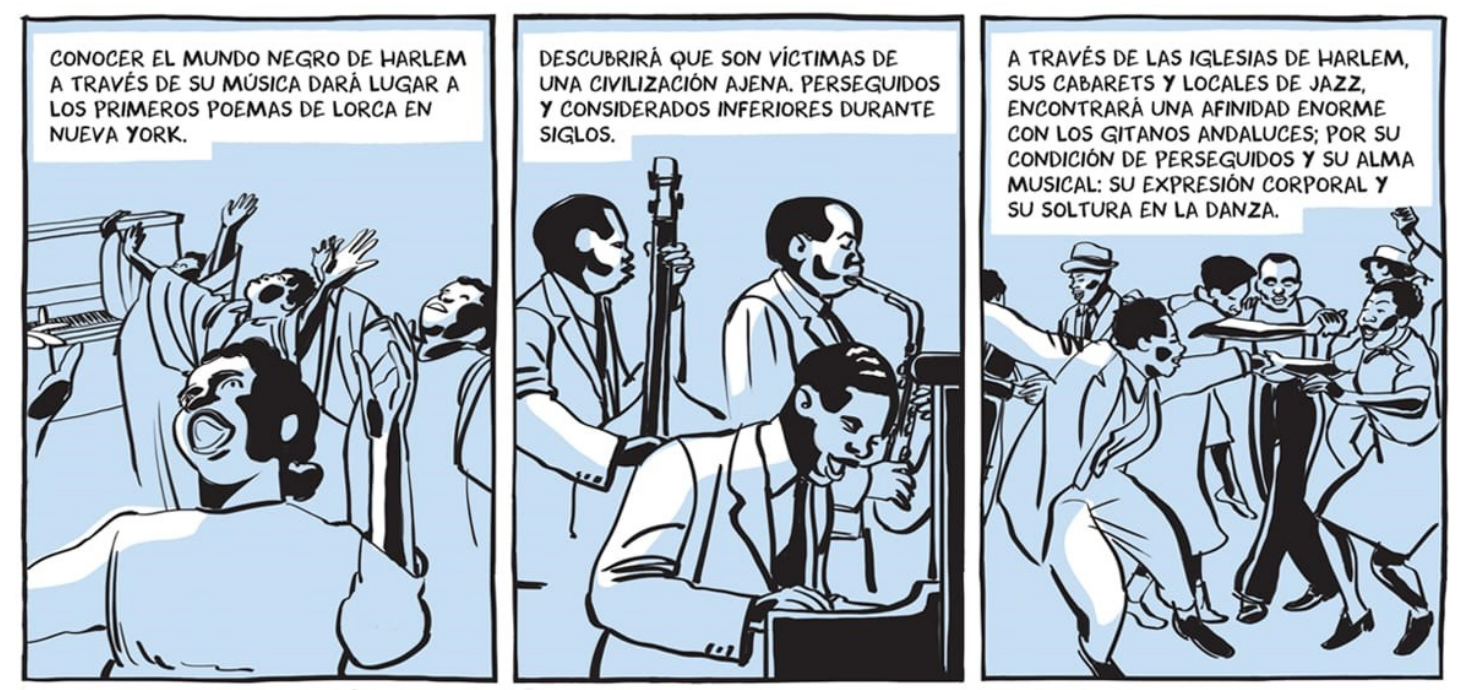

Fig. 70: Conoce la noche neoyorquina, visitando los clubs nocturnos en los que podía escuchar música jazz. Viñeta extraida de Vida y muerte de Federico García Lorca que ilustra el momento. 
Al llegar a Nueva York, conoce a la escritora Nella Larsen, de padre negro y madre danesa. Con ella inicia el contacto directo con este mundo. En una carta dirigida a su familia, el 14 de julio de 1929, desde Nueva York, describía sus impresiones:

He conocido también a una famosa escritora negra, Nella Larsen, de la vanguadia literaria de los Estados Unidos, y con ella visité el barrio negro, donde vi cosas sorprendentes.

Esta escritora es una mujer exquisita, llena de bondad y con esa melancolía de los negros, tan profunda y tan conmovedora.

Dio una reunión en su casa y asistieron sólo negros. [...] Los negros cantaron y danzaron.

[...] Con la misma escritora estuve en un cabaret — también negro- (citado en Maurer y Anderson 2013, 22-23).

Nella Larsen le regala unos ejemplares de sus dos novelas, Quicksand (1928) y Passing (1929). En esta segunda novela, explora el tema de la discriminación y el maltrato contra los negros, tema que también será tratado por Lorca en la «Oda al rey de Harlem» aunque es extraño que antes de escribir el poema la hubiera leído, pero la personalidad de la escritora sí le causó una fuerte impresión (Maurer y Anderson 2013, 202).
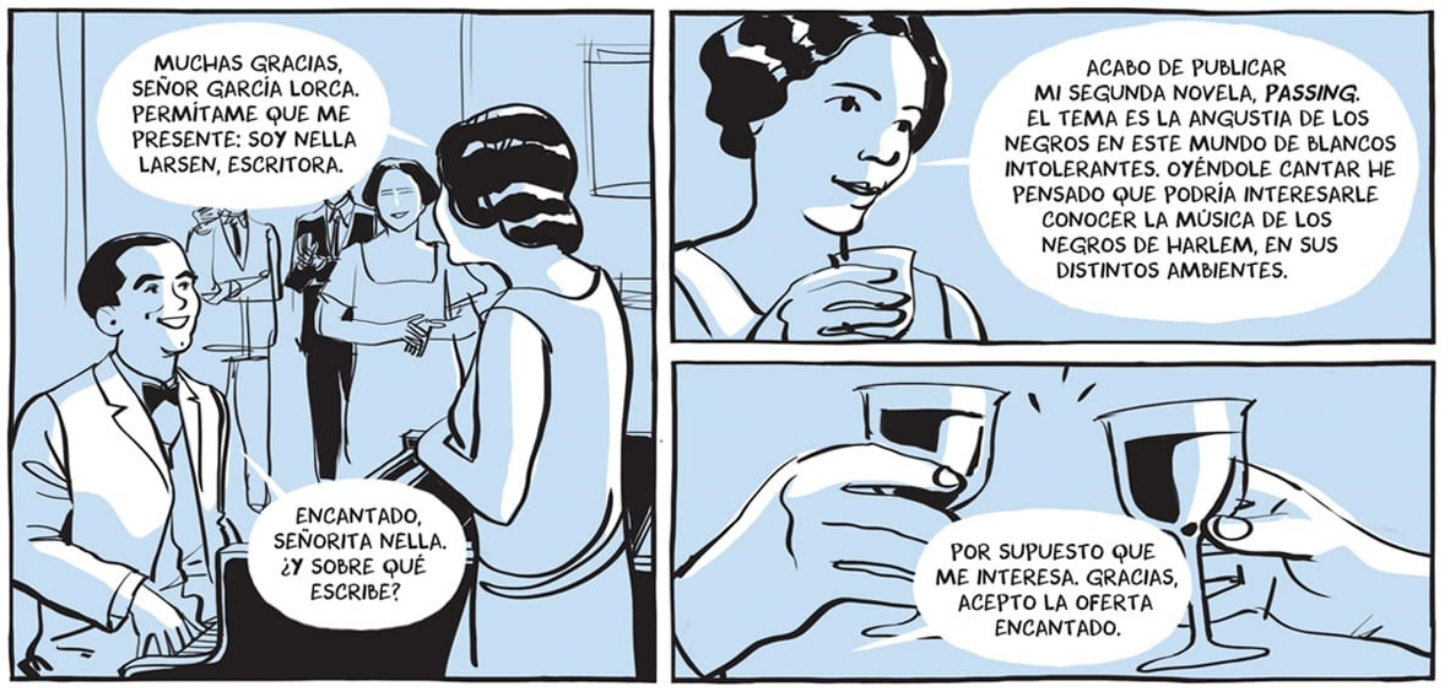

Fig. 71: Durante un encuentro social, conoce a la escritora Nella Larsen.

En la misma carta, dirigida a su familia, nombra la gran variedad de razas, costumbres y religiones, y cómo asiste a oficios religiosos de diferentes religiones, entre ellos, los 
cultos protestantes. Como afirma Carlos A. Rabassó, «visita además iglesias metodistas para el culto de los afro-americanos, los barrios negros en las zonas más paupérrimas de la ciudad y cabarets como el Small's Paradise» (1995, 210). Sus primeras composiciones con temática de los negros fueron «El rey de Harlem»y «Norma y paraíso de los negros».

A su vuelta del Nuevo Mundo, Federico García Lorca realizó numerosas entrevistas sobre su experiencia trasatlántica. En la realizada por Luis Méndez Domínguez, confiesa la experiencia de conocer el barrio negro de Harlem y su inspiración para sus poemas:

En Nueva York se dan cita las razas de toda la tierra; pero chinos, armenios, rusos, alemanes, siguen siendo extranjeros. Todos menos los negros Es indudable que ellos ejercen enorme influencia en Norteamérica, y pese a quien pese, son lo más espiritual y lo más delicado de aquel mundo. Porque creen, porque esperan, porque cantan y porque tienen una exquisita pereza religiosa que los salva de todos sus peligrosos afanes actuales. $[\ldots]$

Lo que yo miraba, y paseaba, y soñaba era el gran barrio negro de Harlem, la ciudad negra más importante del mundo, donde lo más lúbrico tiene un acento de inocencia que lo hace perturbador y religioso [...].

Yo quería hacer el poema de la raza negra en Norteamérica y subrayar el dolor que tienen los negros de ser negros en un mundo contrario; esclavos de todos los inventos del hombre blanco y de todas sus máquinas, con el perpetuo susto de que se les olvide un día encender la estufa de gas, o clavarse el tenedor en un ojo. Porque los inventos no son suyos... (García Lorca 1933a, s/p).

Como afirma Katona, «la soledad, la enajenación en un mundo material e inhumano, la tristeza por la infancia y la inocencia perdidas, la muerte, el asco y el horror de estas poesías se alejan mucho de lo que el poeta comunicaba a su familia en las cartas» (2015, 121). Lorca quería ofrecer a su familia una visión positiva de su estancia americana. En los mensajes enviados a algunos de sus amigos más íntimos, como eran Rafael Martínez Nadal y Carlos Morla Lynch, también ocultaba sus verdaderos sentimientos. Esos sentimientos ocultos y oscuros aflorarán en los poemas de Poeta en Nueva York, donde intentará desmitificar la ciudad. 
En definitiva, durante los nueve meses de estancia neoyorquina, logró superar su crisis por la que había huido de España, consolidó su personalidad, forjó su nuevo estilo surrealista y reforzó su compromiso social. La última carta remitida por Lorca a su familia desde Nueva York, data del 30 de enero de 1930, y la siguiente, desde La Habana, el 8 de marzo de 1930 (Bianchi Ross 1997, 75).

\subsection{1- La influencia americana en El público: Nueva York}

Lo americano, tanto del Norte como del Sur, descubierto en su viaje al Nuevo Mundo, marcará una gran influencia en sus nuevos proyectos. Su viaje a Nueva York cambió sus ideas sobre el teatro, en cuanto a la organización del teatro como empresa y como espectáculo. Como afirma Christopher Maurer, «la estancia en Nueva York le permite distanciarse del teatro español y enjuiciarlo desde una perspectiva independiente y lejana» $(1978,133)$. El propio Lorca, en una entrevista realizada por Gil Benumeya y publicada en La Gaceta literaria el 15 de enero de 1931, expondrá, respecto al teatro neoyorquino y la revista negra, que

el teatro nuevo, avanzado de formas y teorías, es mi mayor preocupación. Nueva York es un sitio único para tomarle el pulso al nuevo arte teatral. Los mejores actores que he visto han sido también negros. Mimos insuperables. La revista negra va sustituyendo la revista blanca. El arte blanco se va quedando para las minorías. El público quiere siempre teatro negro, deliran por él (citado en Soria Olmedo 2017, 35-36).

La ciudad de Nueva York era considerada la más moderna del mundo con una arquitectura inmensa, que demostraba el progreso neoyorquino y la agresividad del mundo financiero. Lorca fue testigo de la construcción de Chrysler Building, «ambicioso proyecto constructivo iniciado con la intención de conseguir el récord del edificio más alto del mundo» (Correa Ramón 2019, 125) y quedó absorto ante el ritmo de las obras urbanísticas y el movimiento constante. Pero no dejó de ver el lado oscuro de la modernidad y se estremecía por aquella esclavitud dolorosa del hombre en la que es perdonable hasta el crimen. 


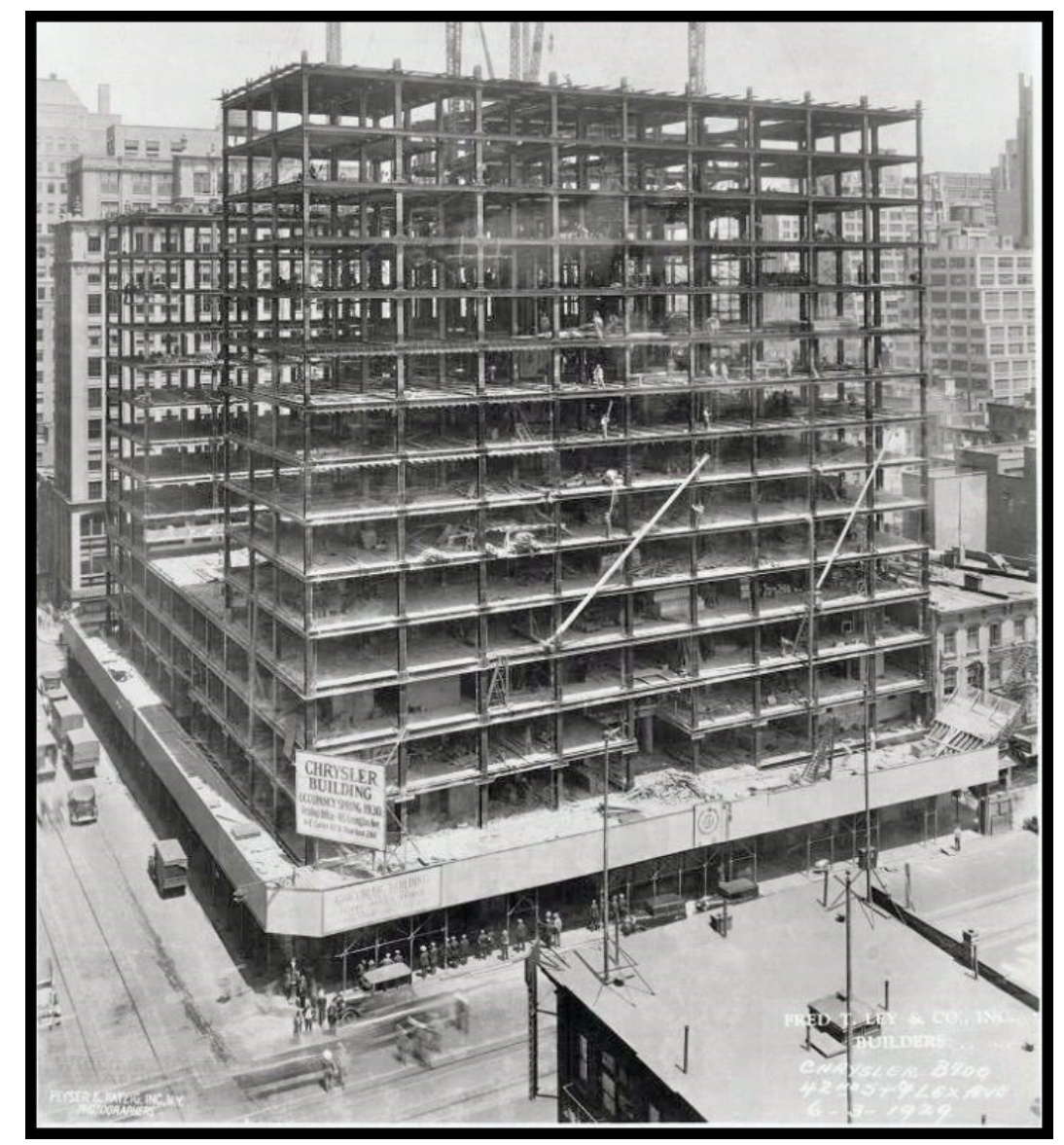

Fig. 72: El edificio Chrysler en construcción. Fotografía fechada el 3 de junio de 1929.

Autores: Peyser y Patzig.

Archivo: New York Public Library (NYPL).

Lorca admira la modernidad, la velocidad, la riqueza de razas y religiones de Nueva York, pero a su vez se horroriza por esa ciudad cruel y violenta. La noción de aislamiento y de soledad, en medio de la multitud, provoca una preocupación en Lorca, y observa cómo ese aislamiento emerge de la metrópolis y de ese tráfico incesante de movimiento de gente, dinero, poder, etc. (Ferreyra 2004, 139). Según Villanueva, esa soledad, como condición desoladora de la vida urbana, se puede observar en los poemas escritos en Nueva York. Lorca muestra «la denuncia de la soledad y la anonimia en el seno de la gran ciudad y el conflicto entre el individuo y la masa que en ella se produce» $(2015,203)$.

En julio de 1929, durante un fin de semana, visita Coney Island, que se encuentra en la desembocadura del río Hudson dedicada al entretenimiento de la multitud. En Coney 
Island se situaba el ciclorama llamado «Viaje a la luna» ${ }^{194}$ que seguramente atrajo la atención del García Lorca, ya que el título del guión que escribió para el cineasta Emilio Amero era el mismo. Junto a la diversión, durante el tiempo de ocio de los norteamericanos, le sorprendió el comportamiento primitivo de éstos que, muy borrachos, vomitaban y orinaban en grupo (Katona 2015, 129).

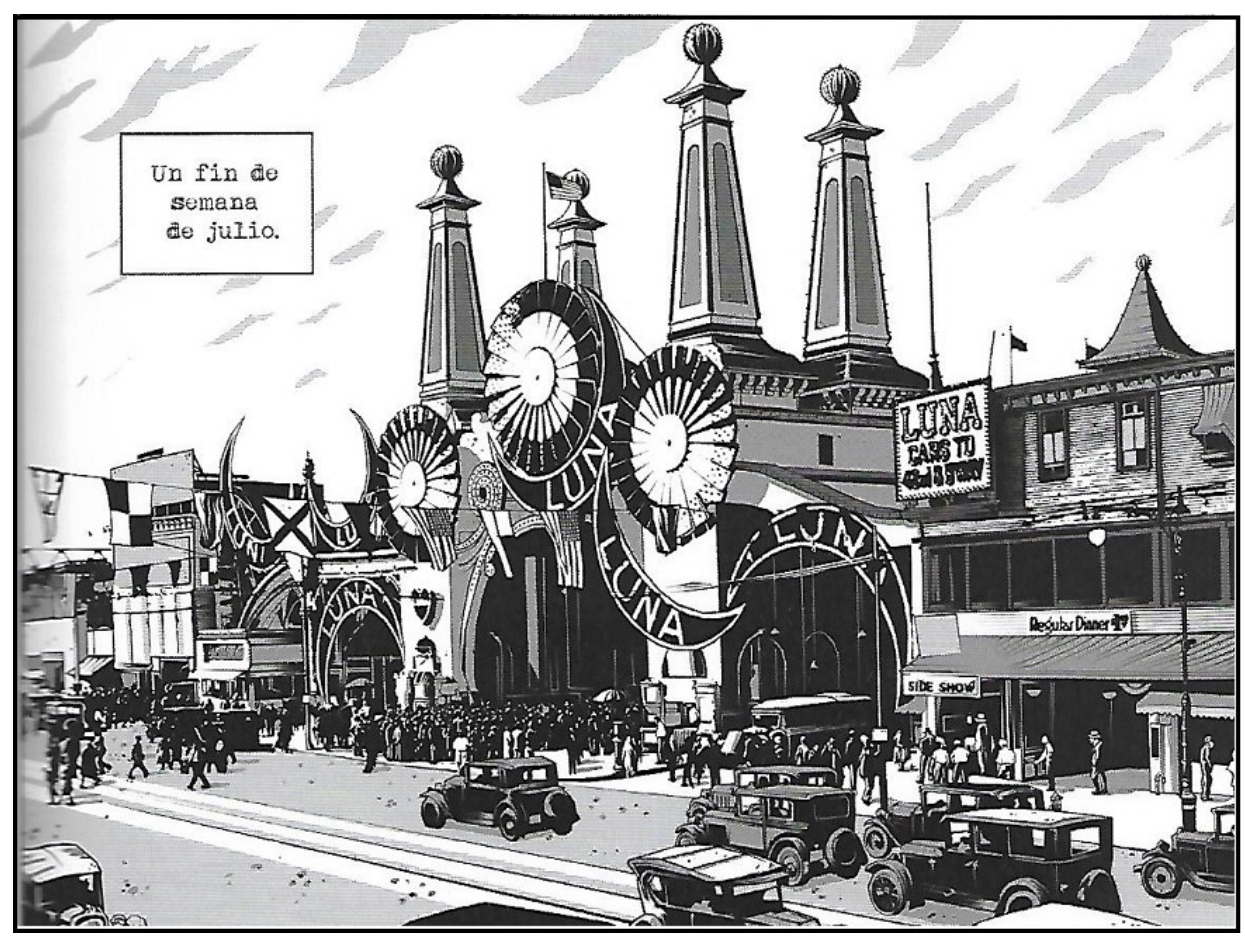

Fig. 73: Viñeta extraida de Lorca. Un poeta en Nueva York que ilustra la visita de Lorca al parque de atracciones de Coney Island y la atracción de Luna Park.

También le fascinó la variedad de razas y de religiones que convivían en la ciudad. Asimismo, le sorprendió la tolerancia que se practicaba en los Estados Unidos (Ferreyra 2004, 133). En «Nueva York se siente no solo profundamente español sino también profundamente católico español [...]. Cree [...] que el catolicismo norteamericano está siendo viciado por su contacto con la frialdad protestante» (Gibson1998, 325). La mirada de Lorca y todos sus sentidos quieren comprender la cultura de ese mundo urbano que se corporiza en múltiples formas. La idiosincrasia española se enfrenta con la estadounidense. Como afirma C. Brian Morris,

\footnotetext{
${ }^{194}$ Este ciclorama se estrenó en 1902. Era una mezcla de espectáculo teatral y atracción mecánica realizada por Frederick Thompson, con tal éxito que el ciclorama sería la principal atracción de su Luna Park durante un par de décadas.
} 
las categorías, junto con los prejuicios y estereotipos que les engendran, eran parte de la mentalidad de Federico [...]. El contexto religioso en que se crió le condicionó a pensar y escribir de una manera hostil sobre protestantes y judíos, a quienes junta como enemigo común del catolicismo $(2000,14)$.

\section{3.- EI viaje a La Habana}

Antes de regresar a España visitó La Habana por invitación del etnólogo y antropólogo cubano Fernando Ortiz (1881-1969). La estancia cubana le permitió recuperar su lengua, - en Nueva York el idioma siempre le fue una barrera para conocer a más gente-, y sentirse como en España ya que el espacio urbanístico es muy similar al español. Según afirmaba Juan Marinello,

lo andaluz es lo más cercano a lo criollo, en su arranque europeo; a lo criollo antillano singularmente, porque allá como acá se entrecruza lo español con lo africano. Lo negro posee comunicaciones subterráneas con lo gitano, dentro de sus diferencias radicales. Federico encontraba un molde ajustado y gozoso en la Cuba de 1930. La isla fue para él como el puente de un velero resonante. Venía del New York violento y sombrío, que tan hondamente lo había removido; partía hacia sus plenas y duraderas hazañas teatrales; se prometía el conocimiento ahincado y moroso de las tierras hispanoamericanas (1964, 203-205).

En enero de 1930, durante un breve viaje de Fernando Ortiz a Nueva York, tuvo lugar el encuentro con Lorca y se confirma personalmente la invitación para visitar Cuba e impartir una serie de conferencias. En un principio, lo habían invitado para que impartiera tres charlas en La Habana, a las que se sumaría dos más al programa (Sarabia 2007, 12).

En los primeros días de marzo de 1930 se anunciaba en La Habana la llegada de un joven y prometedor poeta andaluz Federico García Lorca. Casi todos los periódicos y revistas de la época reflejaron con gran espacio la llegada del poeta. Invitado por la Institución Hispanocubana ${ }^{195}$ de Cultura que presidia el doctor Fernando Ortiz (Pérez

\footnotetext{
${ }^{195}$ La Hispanocubana surgió a raíz de una propuesta que Fernando Ortiz hiciera en el seno de la junta de gobierno de la Sociedad Económica de Amigos del País, y se constituyó oficialmente, con carácter
} 
Coterillo 1984, 39). Fernando Ortiz fue el gran promotor de la cultura cubana de su tiempo. La Institución Hispanocubana de Cultura que entonces presidía, tenía filiales en varias ciudades de la Isla.

Federico García Lorca llega a La Habana el viernes 7 de marzo de 1930; acudieron a recibirlo varios integrantes de la institución, periodistas y fotógrafos. La comitiva fue encabezada por el escritor y poeta cubano José María Chacón y Calvo ${ }^{196}$, el periodista español Rafael Suárez Solís, el ensayista cubano Félix Lizaso, el joven poeta cubano Juan Marinello, el diplomático y escritor cubano Luis Rodríguez Embil y Santiago Guardiola, administrador de la Institución Hispanocubana de Cultura (Sarabia 2007, 18; Martínez Carmenate 2002, 41).

Federico García Lorca llega a Cuba al final de la denominada «década crítica que transcurre de 1920 a 1930 [...]. Durante este período aparece la revolución universitaria y se funda la Universidad Popular José Martí» (Rabassó y Rabassó 1998, 418). A su llegada, la situación política en la isla es de indignación por parte de la población ante el segundo periodo presidencial del general Gerardo Machado y Morales. La oposición se encuentra coartada y sin libertad para actuar contra el gobierno, debido al miedo de las represiones que puedan sufrir los sectores universitarios que eran los únicos que se enfrentaban al régimen (Rabassó y Rabassó 1998, 419).

Como afirma Martínez Carmenate, «el crimen, la coacción política, las violaciones jurídicas y el entreguismo a Norteamérica crearon un rechazo generalizado en la población. Huelgas, manifiestos públicos y protestas ciudadanas dominaron el ambiente cubano» $(2002,33)$. Lorca no permaneció indiferente a ese clima político, llegando a desfilar en algunas manifestaciones populares contra el gobierno de Machado (Serrano 2012, 71). La situación ante «la quiebra del mercado de valores de Nueva York (1929)

autónomo, el 22 de noviembre de 1926. El principal objetivo de la Institución fue el incremento de las relaciones intelectuales entre Cuba y España y el resto de las naciones hispanoamericanas a través del intercambio con intelectuales, hombres de ciencia, artistas y estudiantes (Bianchi Ross 1997, 26; Sarabia 2007, 13).

196 José María Chacón y Calvo, promotor e investigador de la cultura hispánica. Había llegado a Madrid en 1918 para cumplir funciones diplomáticas. En 1922, en el transcurso de la Semana Santa sevillana, Federico García Lorca y él se conocieron. En Madrid, Lorca le visitaba en su casa de la calle Pardiñas número 32 creciendo un gran afecto entre ambos (Martínez Carmenate 2002, 16-17). 
desencadena en Cuba una grave crisis económica con la secuela consiguiente de desempleo» (Bianchi Ross 1997, 18).

En el panorama cultural, Cuba vive una atmósfera agitada por las ideas rebeldes y renovadoras. Desde los años veinte empieza un clima de protesta en el escenario cultural, con la reacción de los grupos intelectuales. En 1926, acontece la Protesta de los Trece, suceso que enmarca la primera acción rebelde en oposición al gobierno, entre los que se encontraban Juan Marinello y Rubén Martín Villena (Martínez Carmenate 2002, 32), el surgimiento del Grupo Minorista en 1924, la creación del movimiento ABC en 1931 y la presencia, cada vez mayor, del movimiento comunista (Serrano 2012, 71). También aparece el Manifiesto Minorista en mayo de 1927 y es cuando

los intelectuales deciden manifestar por primera vez su solidaridad con los pueblos latinoamericanos, condenándose las dictaduras, rechazando el imperialismo yanqui y solicitando un gobierno del pueblo. Coinciden entonces en el Grupo Minorista todo tipo de artistas, músicos, pintores, escritores (Rabassó y Rabassó 1998, 420).

La Habana se encuentra en un especial momento cultural con revistas como Musicalia o la Revista de Avance (1927-1930). En estos años, en la literatura cubana se da la Segunda Generación Republicana, un periodo en el que conviven la poesía pura y la poesía social (Serrano, 2012, 71-72).

En tres décadas de régimen republicano, la burguesía construyó con lujo. La Habana creció y se modernizó. Era una ciudad alegre que contaba con hoteles y restaurante modernos, con bares y cafeterías permanentemente abiertos. Pero la capital de la Isla no era únicamente eso, «es también población con precarias barradas marginales, plenas de chozas artesanales alejadas del primoroso escenario del chalé burgués o de las mansiones palaciegas de la emergente aristocracia cubana» (Martínez Carmenate 2002, 34-35).

El poeta fue alojado en el Hotel La Unión, situado en la calle de Cuba número 55, esquina a Amargura, frente a la iglesia de los franciscanos. Un modesto alojamiento a donde la Hispanocubana de Cultura llevaba a todos sus invitados. Lorca permanecía en La Unión sólo el tiempo imprescindible que dedicaba al descanso (Bianchi Ross 1997, 22). 


\subsection{1.- Las conferencias}

La sede del ciclo de conferencias sería en el Teatro Principal de la Comedia en la calle Ánimas, entre Zulueta y Prado. En un principio, García Lorca había sido contratado sólo para tres conferencias pero, dado el éxito, en la tercera presentación se anunciaban dos disertaciones adicionales. (Martínez Carmenate 2002, 47). Las cinco conferencias las impartió entre el 9 de marzo y el 6 de abril junio. La recaudación de taquilla, unida a la ayuda económica de sus amigos, permitió a Lorca ampliar su estancia en La Habana.

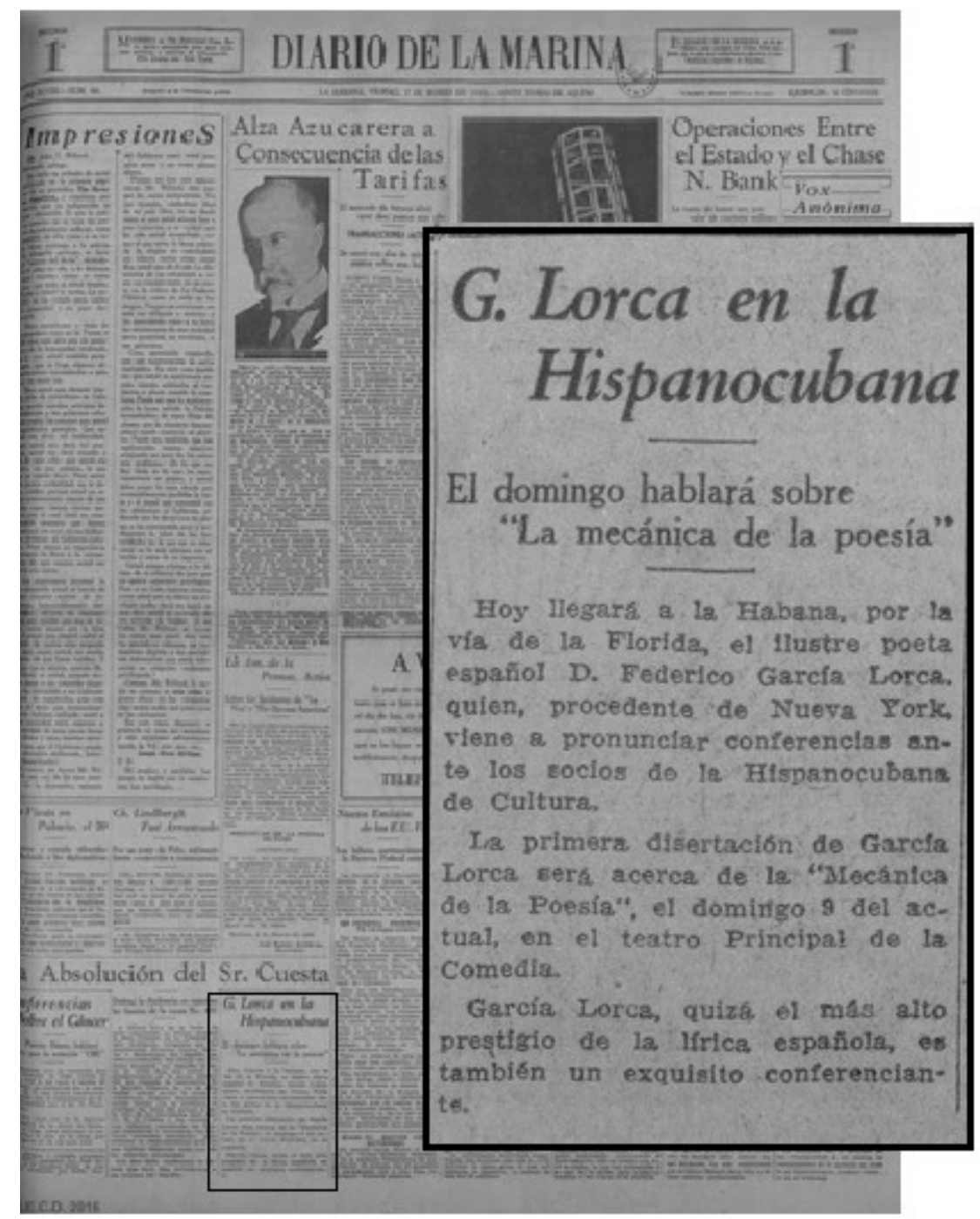

Fig. 74: Anuncio de la llegada del poeta a la Isla y su primera conferencia, publicado en la prensa cubana (14 de marzo de 1930).

Dos días después de su llegada, el domingo 9 de marzo, en sesión matinal, tal y como se había anunciado en la prensa cubana, Federico García Lorca se presentaba por primera vez ante los socios e invitados de la Hispanocubana de Cultura (Bianchi Ross 1997, 27) 
presentado por el poeta Francisco Ichaso. La primera de las conferencias fue titulada «Mecánica de la poesía». Originalmente se había publicado en un periódico de Granada el Defensor de Granada, el 12 de octubre de 1928, con el título: «Imaginación, inspiración, evasión» (Sarabia 2007, 25). El 10 de marzo se publicó en la página 12 del Diario de la Marina el artículo «"La Mecánica de la Poesía”. Sirvió de Tema al Poeta Español Sr. F. García Lorca Para su Conferencia». El texto estaba dividido en tres partes: las diversas presentaciones y a cargo de quiénes, un extenso resumen de las partes de esta primera conferencia y la reacción de los asistentes, cuyos aplausos obligaron a salir al escenario para recibir las felicitaciones del público.

La segunda conferencia ${ }^{197}$ tuvo lugar el 12 de marzo cuyo título se abrióa con el nombre de un poemario «Paraíso cerrado para muchos. Jardines abiertos para pocos» del autor Pedro Soto de Rojas, poeta gongorino del siglo XVII. Ya en 1927, en el Ateneo de Granada, Lorca había disertado por primera vez sobre la lírica de este poeta (Martínez Carmenate 2002, 43).

El domingo 16 de marzo, también con horario matinal, se presentó nuevamente en el Teatro Principal de la Comedia con la tercera conferencia ${ }^{198}$, anunciada en la prensa como «Canciones de Cuna españolas», aunque fue el mismo texto que la conferencia «El patetismo de la canción de cuna española» pronunciada en la Residencia de Estudiantes, en diciembre de 1928 (Martínez Carmenate 2002, 44). La conferencia estuvo acompañada de la intérprete María Tubau en el cante y el propio García Lorca al piano (Rabassó y Rabassó 1998, 429).

Cinco días más tarde, el miércoles 19 de marzo, por la tarde, se celebró la cuarta conferencia bajo el título «La imagen poética de Don Luis de Góngora» (Martínez Carmenate 2002, 45; García 2009, 335), leída por primera vez en Granada el día 13 de febrero de 1926 (Pellón 1998, 135).

\footnotetext{
${ }^{197}$ La prensa alabó la erudición en el análisis y la emoción de Lorca en su segunda conferencia y cómo el público aplaudió al finalizar la intervención. «En el Principal de la Comedia». En Diario de la Marina: periódico oficial del apostadero de La Habana, 13 de marzo de 1930, 1.

${ }^{198}$ Anunciada en la prensa la conferencia, dirigida a los socios para la Hispanocubana a las diez y media de la mañana «García Lorca en la Hispanocubana». En Diario de la Marina: periódico oficial del apostadero de La Habana, 14 de marzo de 1930, 1 y en «Las Conferencias de García Lorca». En Diario de la Marina: periódico oficial del apostadero de La Habana, 15 de marzo de 1930, 1.
} 
El ciclo de conferencias en La Habana concluyó el 6 de abril ${ }^{199}$ con «Arquitectura del cante jondo», sobre el canto popular andaluz. La materia era un resumen de la conferencia celebrada en el Centro Artístico de Granada, el 19 de febrero de 1922, con el tema «Importancia histórica y artística del primitivo canto andaluza llamado cante jondo ${ }^{200} \gg$ encargada por el maestro Falla, con motivo de la celebración del Primer Concurso de Cante Jondo ${ }^{201}$ durante las fiestas del Corpus Christi, organizado por el Centro Artístico y Literario de Granada y subvencionado por el Ayuntamiento (Salvat, Ciurans y Salvat 1997, 67).

Al día siguiente, la prensa local ensalzaba la conferencia comentando que «pronunció un admirable trabajo, sobre la esencia de la música popular andaluza. Estudió sus orígenes, sus diversas manifestaciones. Sus alteraciones al cruzar un mismo tema diversas regiones» (Diario de la Marina 1930, 13) ${ }^{202}$.

$\mathrm{Su}$ estancia, que estaba prevista que durara unos días, se prolongó unos meses por el interés que suscitó el poeta en la Isla. Incluso la prensa española se hizo eco del interés entre los cubanos. Así, en el diario El Defensor de Granada ${ }^{203}$ de mayo de 1930 aparece el artículo titulado «García Lorca triunfa en Nueva York y en Cuba», en el que relata el interés tanto entre los neoyorquinos como en los cubanos por la visita. El texto también incluye la transcripción de la crítica de su última conferencia en la ciudad, que aparece en el diario La Correspondencia de Cienfuegos.

\footnotetext{
${ }^{199}$ Venía anunciada en prensa la quinta conferencia para el domingo 6 de abril a las diez y media de la mañana y que iría ilustrada con números de música. «La Conferencia de García Lorca». En Diario de la Marina: periódico oficial del apostadero de La Habana, 3 de abril de 1930, 1 y en «G. Lorca en la Hispanocubana». En Diario de la Marina: periódico oficial del apostadero de La Habana, 5 de abril de $1930,1$.

${ }^{200}$ Esta conferencia fue publicada como folletón por el Noticiero Granadino en febrero de 1922. En ella García Lorca «menciona, de los poemas traducidos al castellano por Noroña, a tres de sus autores: Serage al Warak, Ibni Ziati, ambos árabes, y a Hafiz, persa» (Fortuño Llorens 2003, 39)

${ }^{201}$ El 31 de diciembre de 1921 un grupo de intelectuales, entre ellos Manuel de Falla, Juan Ramón Jiménez, Federico García Lorca y Adolfo Salazar presentaron una instancia en la que solicitaban al ayuntamiento de Granada «la necesidad de un gran Concurso de Cante Jondo que promoviese un despertar de las tradiciones líricas, exponiendo el detenido plan de trabajo a seguir» (Molina Fajardo 1990, 53). Dicho concurso se celebró en la Placeta de San Nicolás de Albayzín las noches del trece y catorce de junio del mismo año 1922 (Fortuño Llorens 1995, 73).

202 «Muy brillante la Conferencia de García Lorca». En Diario de la Marina: periódico oficial del apostadero de La Habana, 7 de abril de 1930, 13.

203 «García Lorca triunfa en Norteamérica y en Cuba». En El defensor de Granada, 8 de mayo de 1930, 1.
} 


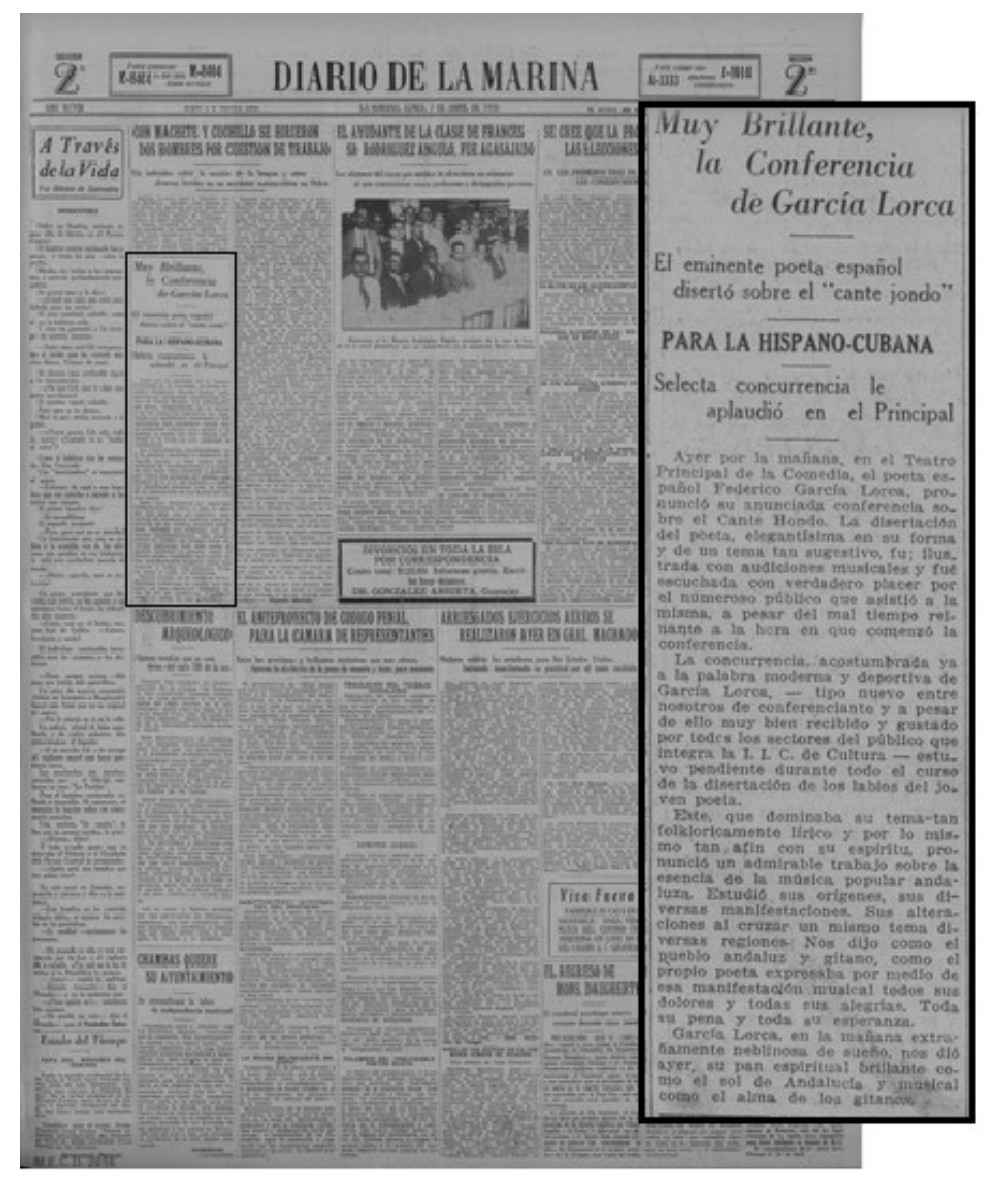

Fig. 75: Página completa y ampliación de la noticia del Diario de la Marina: periódico oficial del apostadero de La Habana, 7 de abril de 1930, 13.

Otros centros de cultura de las filiales de la Hispanocubana le invitaron a que visitara sus ciudades y a realizar diferentes conferencias. De este modo, es cómo empieza su viaje de descubrimiento por el interior del país.

\subsection{2.- Los días cubanos: amistades y viajes por la isla}

Tres fueron los círculos en los que transcurrió su vida privada. El primero, en torno al matrimonio español de Antonio Quevedo y María Muñoz. Antonio Quevedo, escritor y musicólogo, creó la revista Musicalia y María Muñoz fundó la Coral del Conservatorio de La Habana y el Conservatorio Bach (Sarabia 2007, 19; Leante 1986, 237). Desde 1918 la pareja de musicólogos se encontraba instalada en Cuba, debido a que fue el destino de su viaje de luna de miel, regalo del Marqués de Comillas, propietario de la Compañía Transatlántica y tío de ella. El lugar les entusiasmó de tal manera que hizo 
que fijaran su residencia definitiva en la Isla (Martínez Carmenate 2002, 55). Vivían en el Conservatorio Bach situado en la calle de Concordia, esquina Lealtad.

Entre los cuatro hermanos Loynaz del Castillo (Carlos Manuel, Dulce María ${ }^{204}$, poeta muy notable, Enrique y Flor), se sentía más atraído por los versos del tercero, Enrique Loynaz, de quien ya conocía ciertos poemas publicados en España. Federico García Lorca acudió a la casa de El Vedado, situada justo al lado del final del Malecón:

y se presentó en la aristocrática mansión de la Calle Calzada, entre 14 y 16, donde habitaban los cuatro poetas hermanos, [...] hijos de un respetado general mambí [...]. La casa resplandecía entre columnas y balcones, con un jardín tupido de cactus y plantas tropicales, bajo cuya sombra paseaban pavos y flamencos (Martínez Carmenate 2002, 57).

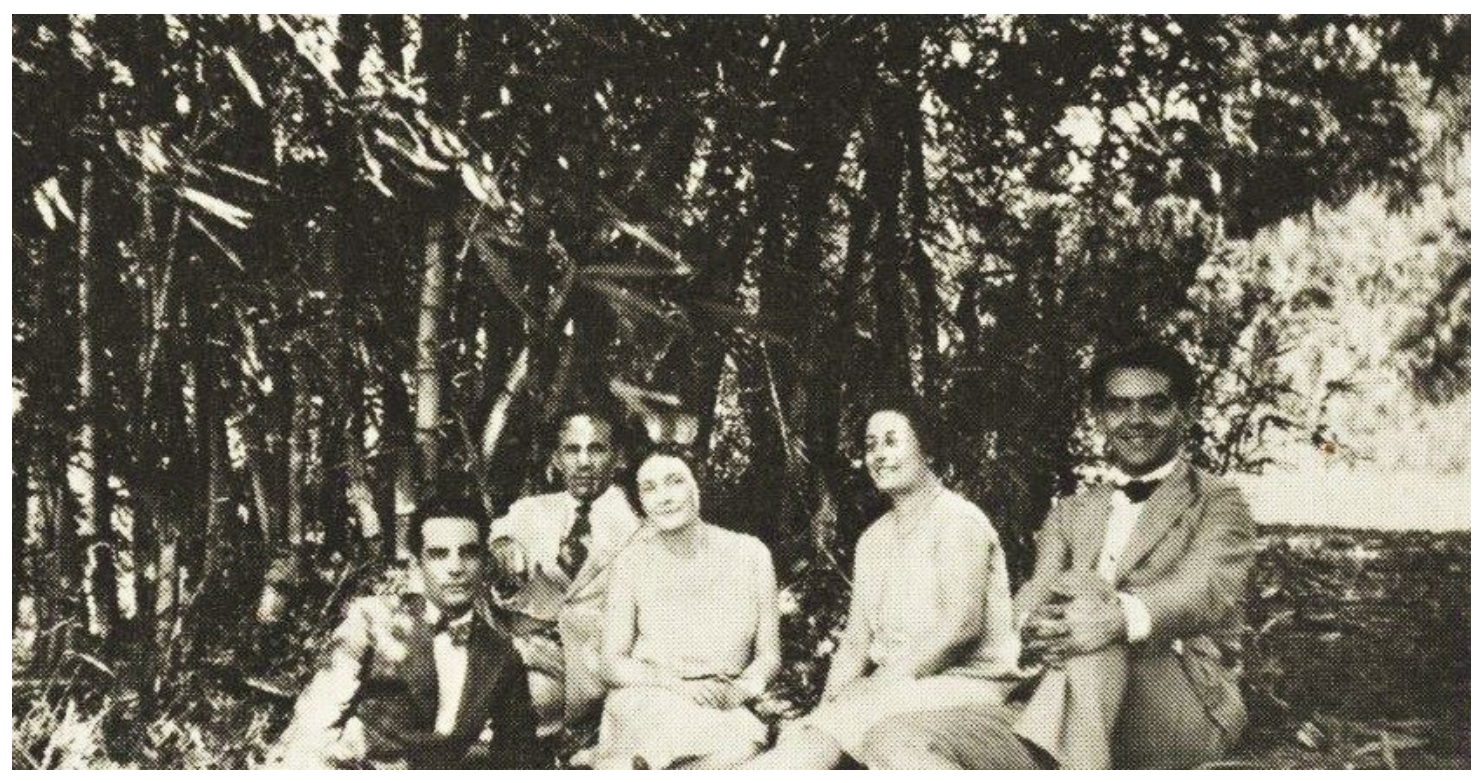

Fig. 76: Fotografía ${ }^{205}$ de Lorca con un grupo de amigos durante sus días en Cuba, 1930.

Los hermanos Loynaz le abrieron las puertas de su casa que «para Lorca sería "la casa encantada" y, fascinado por ese ambiente, se convirtió en visitante asiduo del lugar. En

${ }^{204}$ Ganadora del Premio Cervantes en 1992, autora de poemarios como Eternidad o Juegos de agua.

${ }^{205}$ En el dorso de la fotografía dirigida a su familia viene escrito:

Con este fondo admirable de cañas bravas estoy ya, como dicen los periódicos de Cuba, "aplatanado". Mañana me dedicaré a recortar con tijeras los artículos para enviaros y las revistas. Todos los días leo la situación de España con gran interés. Aquello es un volcán. Estuve en casa del músico Sánchez de Fuentes, que es autor de la habanera "Tú”, que me cantabais de niño, "La palma que en el bosque se mece gentil”, y dedicó un ejemplar para mamá. Conservarse buenos. Yo lo estoy. Abrazos y besos de vuestro hijo y hermano, Federico.

¡Besos! Y abrazos a Manolo [Fernández-Montesinos] (citado en García Lorca, Francisco 1981). 
aquella casa Lorca escribió El público, algunos de los poemas de Poeta en Nueva York y fragmentos de Yerma y Doña Rosita la soltera» (Serrano 2012, 73-74). La vida de los cuatro hermanos en esa casa se caracterizaba por su

extravagancia, rareza y fantasía lírica se entremezclaban en sus vidas como una fluencia normal y diaria. No tropezaban con guijarros, sino con piezas artísticas diseminadas por las habitaciones. No tenían especial gusto por los ropajes modernos, pero sí por el vestuario excéntrico, afiliado a tendencias arcaicas de la moda. Su estado natural venía a ser el delirio. Eran una familia surrealista, quizás desde mucho antes de haberse inventado el surrealismo. Convivían con los animales y las plantas sin delimitar cotos infrahumanos (Martínez Carmenate 2002, 58).

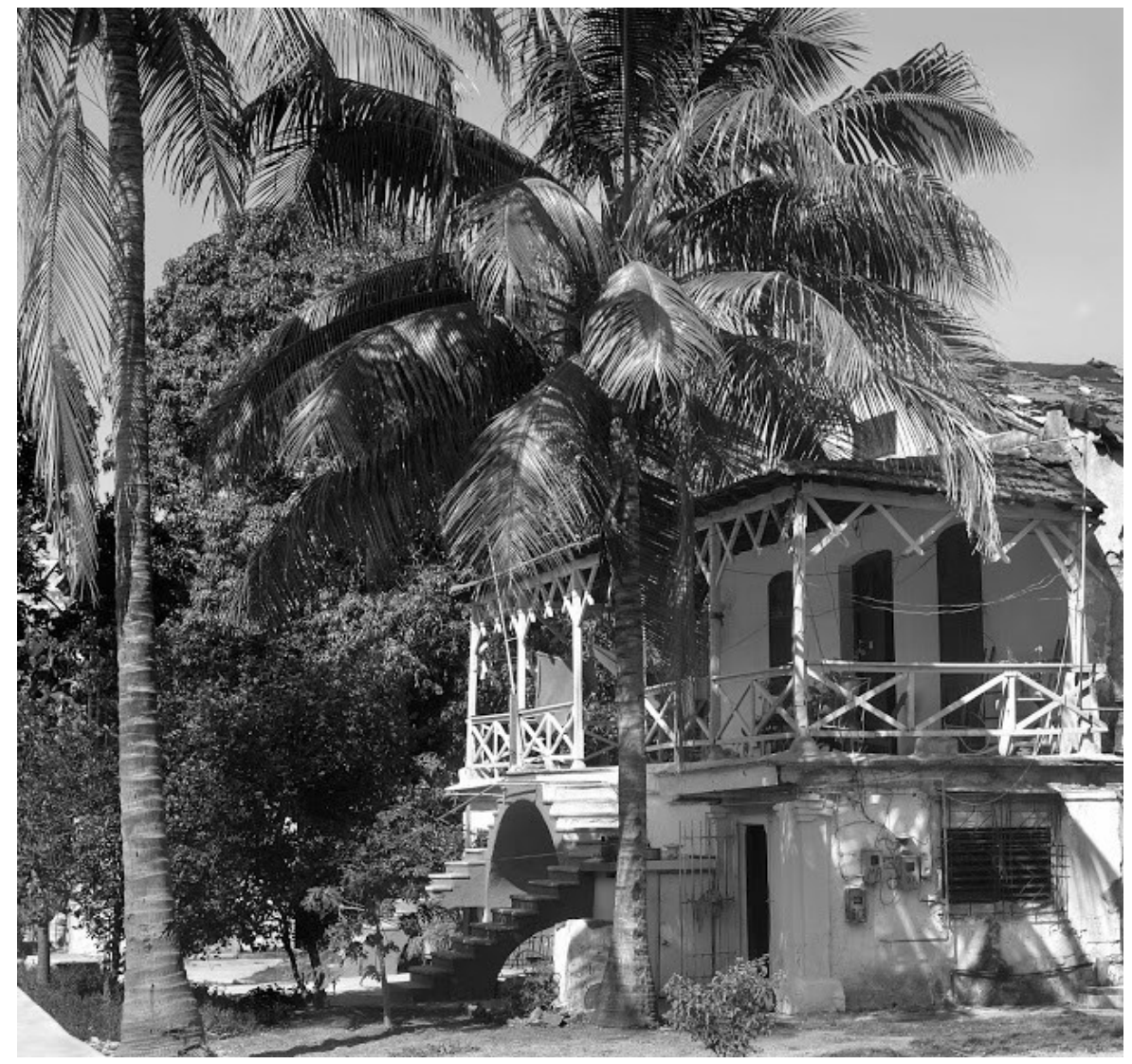

Fig. 77: Fotografía de «la casa encantada» ${ }^{206}$ en la actualidad.

Entre la familia Loynaz, Lorca estuvo más cerca de los hermanos Flor y Carlos Manuel que fueron «compañeros de correrías nocturnas, conduciendo el coche Carlos Manuel,

${ }^{206}$ El documental de corta duración Últimos días de una casa (2005) dirigido por Lourdes de los Santos. Podemos visualizar el documental en línea en el siguiente enlace: https:/vimeo.com/128668530 En la siguiente página podemos acceder a una entrevista realizada a la directora: http://www.cubadebate.cu/opinion/2015/05/04/perdera-la-habana-la-casa-encantada/\#.XXUa1nvtbIV 
por los antros de diversión de La Habana Vieja, las tascas del puerto o las afueras de la ciudad» (Pérez Coterillo 1984, 40-41). Para Federico García Lorca, Carlos Manuel era el mejor poeta entre los cuatro hermanos Loynaz y, según Bianchi Ross, «la amistad entre Federico y Flor fue una amistad difícil de lograr entre un hombre y una mujer» $(1997,71)$.

La aceptación de Federico por la intelectualidad habanera vino a ser casi unánime y se manifestó en muestras apasionadas de calor y entusiasmo. Del brazo de José María Chacón y Calvo, visitó con asiduidad el Havana Yacht Club frecuentado por la alta aristocracia capitalina. Pero Lorca no sólo frecuentó «los medios intelectuales cultos, las instituciones públicas y los salones aristocráticos. Además de eso, de sus conferencias y recitales, halló tiempo suficiente para el disfrute del ambiente popular y callejero de una capital caribeña» (Martínez Carmenate 2002, 73).

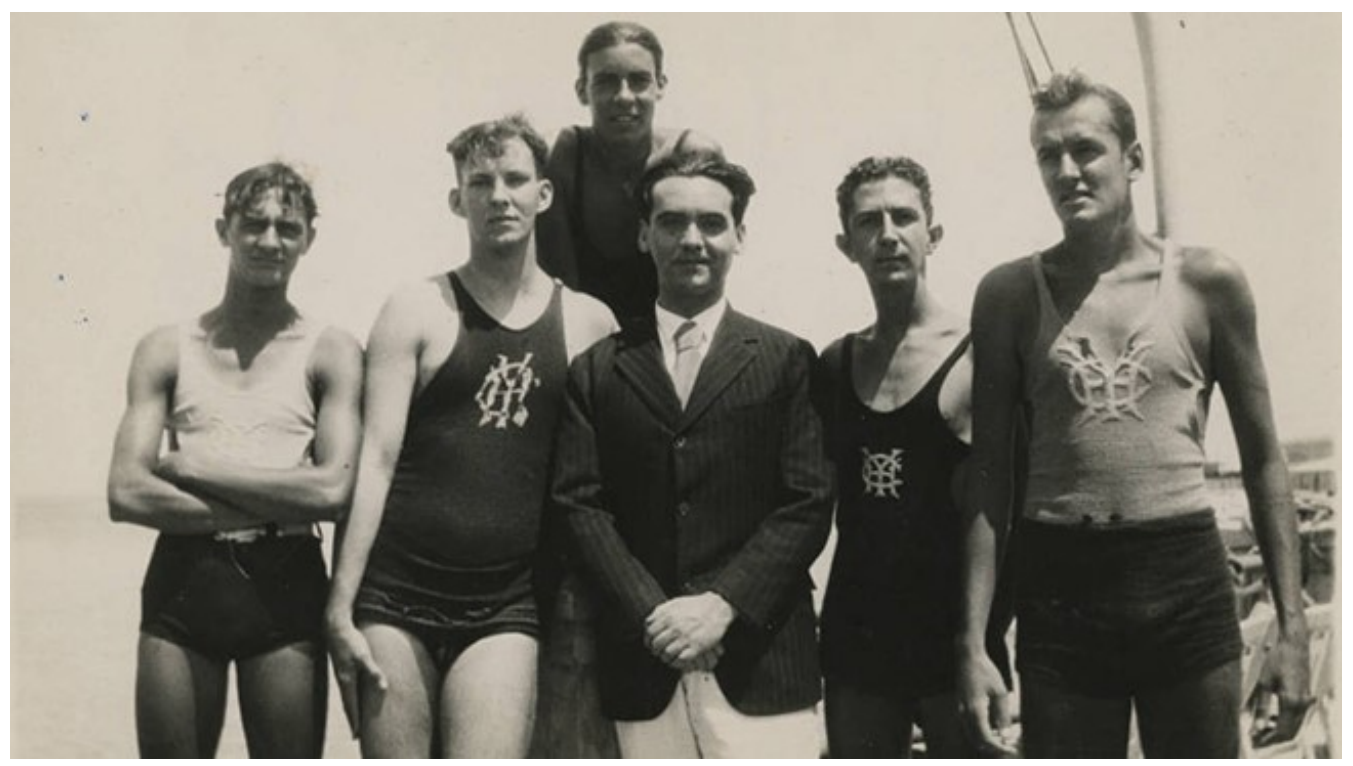

Fig. 78: Federico García Lorca con un grupo de remeros del Habana Yacht Club, Miramar, La Habana. Durante su estancia en Cuba en 1930.

Fotografía ${ }^{207} 11$ x $16 \mathrm{~cm}$. Archivo de la Fundación Federico García Lorca.

Y en el tercer círculo de amistades se encontraban los más íntimos: el grupo formado por el joven poeta guatemalteco Luis Cardoza y Aragón y, sus amigos españoles, el musicólogo Adolfo Salazar y el pintor Gabriel García Maroto con quienes descubrió la

\footnotetext{
${ }^{207}$ El fotógrafo es María Chacón y Calvo. En la parte de atrás está escrito con su propia letra: «Federico García Lorca en el Habana Yacht Club, en abril (o marzo) de 1930. Identifico de derecha a izquiera a uno de los hermanos Miyares, al lado un joven que no reconozco, Federico (al centro), Julio J. Castellanos y Ramiro Cabrera y Du Quesne. Detrás de Federico creo renocer a Guillermo Carricaburro, a quien no veo desde hace cerca de veinta años. Ch.»
} 
noche habanera. Frecuentaba el edificio Montes de la calle Línea, residencia de Cardoza y Aragón, donde eran habituales las jornadas con invitados de procedencia diversa como poetas jóvenes, periodistas o amigos (Martínez Carmenate 2002, 145).

Lorca se acercó al ambiente teatral de la ciudad donde entonces florecía el género de variedades. Visitó los bares nocturnos del puerto, zona poco virtuosa con rincones solitarios y penumbrosos. Con ellos, conoció «la intensidad de la noche marginal habanera, con ellos visitó por primera vez el popular Teatro Alhambra, sólo para hombres» (Serrano 2012, 73-74).

Se sabe que frecuentaban el Teatro Alhambra, en su escenario se alternaba «lo vulgar con lo grosero, la politiquería con la sátira social» (Martínez Carmenate 2002, 80), y como afirma Bianchi Ross,

cuyas funciones para «hombres solos» $[\ldots]$ gozaron de enorme popularidad hasta 1935, y que dieron lugar a lo que hoy algunos llaman el género alhambresco [...] que satirizaba la realidad del momento y que tenía como protagonistas a los personajes típicos del negrito, el gallego y la mulata $(1997,49)$

Entre sus mejores sorpresas estuvo el haber conocido en La Habana a Eduardo Sánchez de Fuentes, autor de la habanera «Tú». Se sintió hipnotizado por esta nueva música para Lorca, cuando el $\operatorname{son}^{208}$ cubano aún no había llegado a España. Fue un gran descubrimiento y llegó a ser un excelente conocedor de sones y soneros. Entabló amistad con viejos y jóvenes soneros (Bianchi Ross 1997, 50). Esa música estaba por todas partes, sin embargo «su principal centro difusor se localizaba en las famosas "fritas", conjunto de humildes y sencillos cabareses en los cuales el frescor de la nocturnidad se combinaba con la incitación de los juegos, los bailes y las variadas comidas» (Martínez Carmenate 2002, 80).

Este era su lugar preferido y en el que concluían casi todas sus noches habaneras. Eran las llamadas Fritas de Marianao, «un hilera de cabaretuchos ya desaparecidos, situados frente al parque de diversiones de la Quinta Avenida, y que debían el nombre por el que se les conocía a los numerosos expendios de frituras emplazados en la acera» (Bianchi

\footnotetext{
${ }^{208}$ El son cubano es el género musical cubano de mayor importancia. Está compuesto por dos aspectos: su forma musical, para bailar y su forma literaria, para cantar. De ahí que se pueda hablar de un son musical para la danza y un son poético literario (Rabassó 1995, 213).
} 
Ross 1997, 50). Entre aquellos bares donde mejor se sintió Lorca fue en el bar de Chori (dueño de uno de los establecimientos montados allí). Los sones escenificados en este bar atrajo a gran número de público durante varias décadas (Serrano 2012, 74). En las memorias del poeta y periodista cubano Nicolás Guillén asevera que a Lorca «le gustaba irse en las noches a las "fritas", a los cafetines de Mariano, donde ya está el Chori, y allí se hizo amigo de treseros y bongeseros» (citado en Leante 1986, 238).

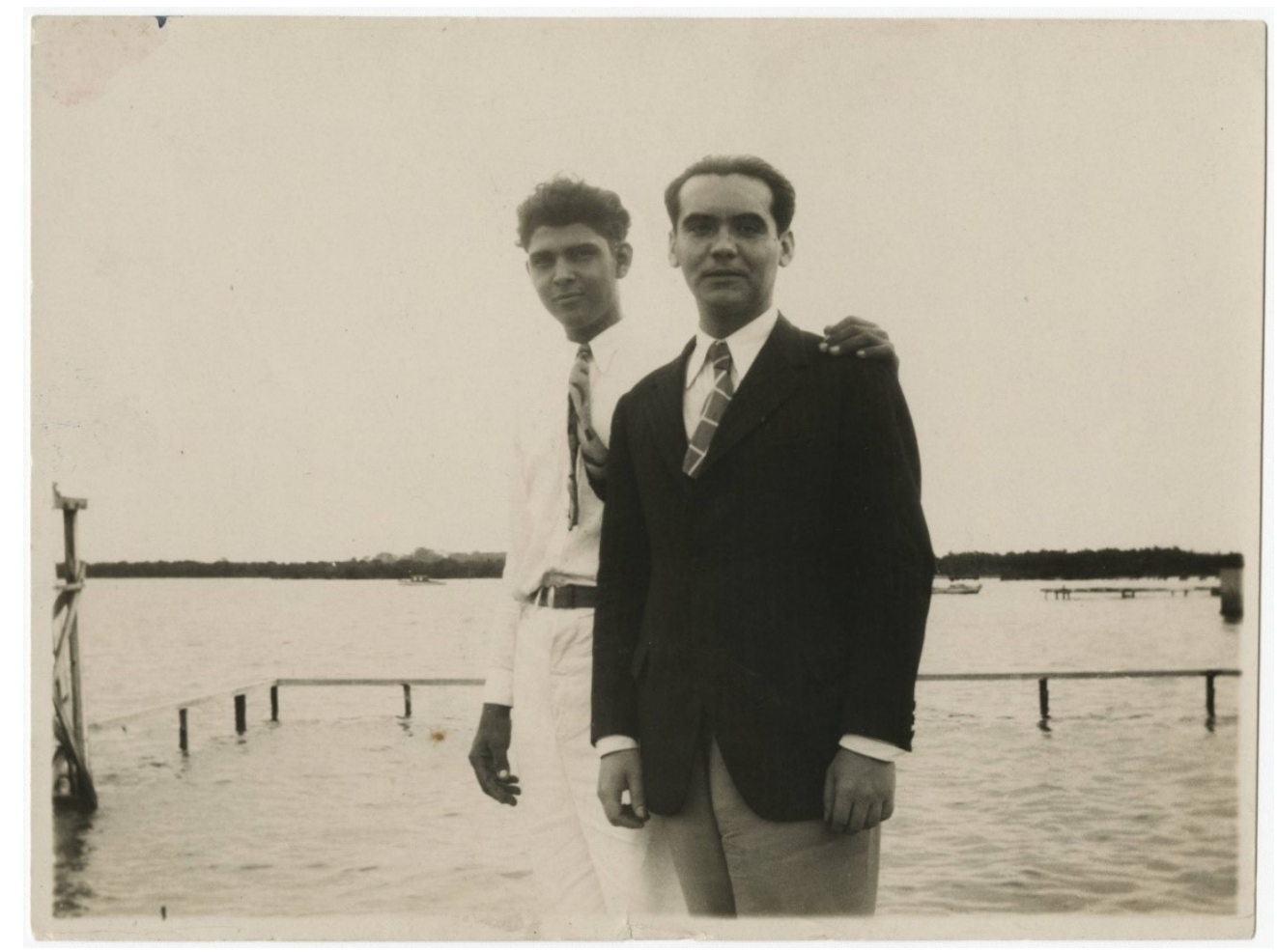

Fig. 79: Federico García Lorca con un amigo en la playa de Marianao en La Habana, Cuba, 1930. 14 x $18 \mathrm{~cm}$. Fotógrafo: José María Chacón y Calvo.

Su estancia cubana tuvo una duración de noventa y ocho días. Gran parte de ellos los dedicó a descubrir los paisajes, la vida del lugar y sus encantos criollos. A los quince días de su llegada a La Habana, se adentra y explora la isla. Estuvo en Caibarién, Cienfuegos, Matanzas, Santiago de las Vegas, en antiquísimas poblaciones habaneras como Santa María del Rosario, villa condal; Guanabacoa, primitiva aldea de indígenas; Batabanó, criadero de esponjas; también en el Valle de Güines, un terreno de especial fertilidad; Caimito del Guayabal, Guanajay, Mariel, Pinar del Río, Santa Clara y Santiago de Cuba (Hernández 2009, 73; Martínez Carmenate 2002, 126).

Visitó Sagua la Grande, los días 22 y 23 de marzo, en la antigua provincia de Las Villas, en la región central de la isla, invitado por la filial de la Institución 
Hispanocubana de Cultura. Lo acompañaron José María Chacón y Calvo, Juan Marinello y su esposa María Josefa Vidaurreta. El sábado 22, en el Teatro Principal de Sagua, Lorca repite su conferencia sobre la «Mecánica de la Poesía» e ilustra «la disertación con algunos de sus poemas y motivos musicales que interpreta al piano» (Bianchi Ross 1997, 40; Martínez Carmenate 2002, 87; Leante 1986, 236).

A fines de marzo vuelve a la región central, ahora a Caibarién, donde el 30 de marzo pronuncia una de sus conferencias, fue presentado por José María Chacón y Calvo ante los miembros de la Hispanocubana de esa ciudad (Bianchi Ross 1997, 41; Rabassó y Rabassó 1998, 434).

Cienfuegos, situada en la zona central de la Isla, al borde de la costa Sur, fue la única localidad cubana que visitó dos veces: primero, en abril ${ }^{209} \mathrm{y}$, después, en junio poco antes de irse de Cuba. Invitado también por la filial de la Hispanocubana de Cultura, la noche del 7 de abril, ante un auditorio conformado por los socios de la Hispanocubana y sus familiares y también los del Ateneo y del Casino Español, ofreció una conferencia en los salones del Casino Español. La conferencia anunciada era «Mecánica de la Poesía», pero Lorca cambió el tema por la conferencia titulada «La imagen poética en don Luis de Góngora». Hizo la presentación Francisco Campos Aravaca, ex-catedrático de la Universidad de Granada y en ese momento cónsul de España en Cienfuegos. Se acercó a Palmira, un pueblo cercano a Cienfuegos en el que fue recibido por las instituciones y la prensa (García 1930a, 5; Bianchi Ross 1997, 41-43). El día siguiente lo dedicó a recorrer la ciudad, de casi 88.000 habitantes y con una actividad cultural importante.

Regresó a Cienfuegos en los primeros días de junio. En esta ocasión, ofreció la prometida conferencia el 5 de junio, por la tarde, en el teatro Luisa Martínez Casado. El tema sí fue «Mecánica de la Poesía». De nuevo la presentación estuvo a cargo de Francisco Campos Aravaca. Los dos fueron aplaudidos con efusión, incluso Lorca tuvo que detener la lectura en varias ocasiones por la ovación del público (García 1930b, 20; Martínez Carmenate 2002, 101). Esta segunda conferencia fue abierta, sin restricciones de acceso (en la primera era necesario pertenecer al Ateneo) (Rabassó y Rabassó 1998,

\footnotetext{
${ }^{209}$ En la prensa se anuncia la cancelación de la conferencia que hubiera tenido lugar a finales de marzo y el aplazamiento para abril. «La conferencia de García Lorca». En Diario de la Marina: periódico oficial del apostadero de La Habana, 26 de marzo de 1930, 1.
} 
448). Esa misma noche regresó a La Habana siendo acompañado a la estación del tren por un gran número de representantes del mundo intelectual de Cienfuegos (García 1930b, 20).

El 19 de abril Lorca lo pasaría en Santiago de las Vegas, localidad cercana a La Habana, invitado por la Asociación Artística Euterpe que dirigía el escritor Marcelo Salinas (Bianchi Ross 1997, 42). Asistió junto a Fernando Ortiz y José Antonio Fernández de Castro, profesor de Historia de Cuba en la Universidad de La Habana. Después, un grupo de escritores y artistas locales se dirigieron a visitar los lugares más representativos, como el parque José Martí; a la calle 11, calle principal de la ciudad, al parque Juan Delgado y también a la Iglesia Parroquial de Santiago Mayor. Visitó el Casino Español y el Centro de Instrucción de Recreo (Rabassó y Rabassó 1998, 453).

Lo que más le gustaba a Lorca era pasar desapercibido y disfrutar al pasear por las calles manteniendo el anonimato. De ahí que intentara que la mayoría de sus viajes fueran improvisados y sin programación.

El 31 de mayo, Federico García Lorca salió de La Habana en el tren central que le condujo a Santiago de Cuba el 1 de junio. El 2 de junio, por la noche, en el pabellón Barceló de la Escuela Normal, dictó de nuevo la conferencia «Mecánica de la Poesía», que había leído también en La Habana (Hernández 2009, 74) a la que asistieron, entre otros, profesores y discípulos de la Escuela Normal para Maestros de Oriente. Lorca «fue aplaudidísimo por el selecto público que lo escuchó» (Vega 1930, 12). Junto a Max Henríquez Ureña y otros intelectuales miembros del Grupo $\mathrm{H}^{210}$, transitó por los barrios y calles de la población (Martínez Carmenate 2002, 117). En su visita a Caimito de Guayabal, un pueblo situado al oeste de La Habana, en el límite entonces con la provincia de Pinar del Río, provincia del extremo oeste cubano, lo acompañaron María Muñoz y Antonio Quevedo, el matrimonio Callejo-McKenna, las hermanas Freyre, Gabriel García Maroto y Adolfo Salazar (Bianchi Ross 1997, 52). La excursión fue patrocinada por un grupo de amigos de Vuelta Abajo, tabaqueros ricos. La verdadera razón de la expedición era conocer el Valle de Viñales, como afirman Rabassó y Rabassó:

${ }^{210}$ Grupo literario vanguardista de Santiago de Cuba que frecuentaba parques y cafetines. 
Se quedó ensimismado ante el drama natural que se le presentaba delante, la fuerza de los mogotes, el verde tan tierno de las hojas, las formas sexuales de las orquídeas, las innumerables yerbas medicinales y curativas que poblaban la región, las flores aromáticas, los helechos y los fósiles impregnados en sus rocas, las temerosas grutas del lugar cuyas cuevas $(1998,434)$

Lorca disfrutó en esos días del aire fresco, la libertad del espíritu, la tranquilidad de la región y la sencillez de los pobladores que habitaban la zona. El impacto que causó en Federico García Lorca la visita a Caimito del Guayabal fue tan hondo, que en cervecerías y restaurantes de España el nombre de ese pueblo se hizo célebre en los círculos frecuentados por el poeta donde evocaba anécdotas y paisajes del lugar (Bianchi Ross 1997, 53; Martínez Carmenate 2002, 197).

El 12 de junio de 1930, después de tres meses de estancia en la isla, embarcó hacia España junto a Salazar, a bordo del vapor correo Manuel Arnús de la Compañía Trasatlántica Española, con escala en Nueva York-Cádiz-Barcelona (Hernández 2009, 80). La noche antes de la partida, Revista de Avance convocó a una comida de despedida a García Lorca, a Adolfo Salazar y a Luis Cardoza y Aragón. Los tres saldrían de La Habana el mismo día. Lorca se despidió de la isla sin cumplimentar en el consulado norteamericano de La Habana el trámite que le permitiría desembarcar en Nueva York, y por ello se vio obligado a permanecer a bordo. Sin embargo, envió telegramas a todas sus amistades neoyorquinas que acudieron a verlo (Bianchi Ross $1997,80)$.

A su regreso, Cuba y lo cubano formarán parte del imaginario del poeta. Según Juan Marinello,

los días cubanos de Federico fueron sedientos y desbordados. Quería entenderlo todo, absorberlo todo. En Cuba [...] se sentía liberado de la cárcel neoyorquina y había vuelto a encontrar el sol, la luz y la alegría... Había dialogado a campo traviesa con las gentes del pueblo en la aldea y en la ciudad. Se había metido en las cadencias negras y en la risa de los niños $(1964,213)$. 


\subsection{3.- La influencia americana en $E l$ público: La Habana}

La Habana que descubre Federico no tiene nada que ver con la ciudad neoyorquina y las miserias de Harlem. Las situaciones grandilocuentes y materialistas de la sociedad de Nueva York hicieron nacer una visión surrealista del sufrimiento que podía sentir ante la ciudadanía norteamericana. En cambio, la agresividad de Nueva York se vuelve gozo en La Habana (Marinello 1975, 172). Lorca dirá ${ }^{211}$ :

La influencia de Estados Unidos en el mundo se cifra en los rascacielos, en el jazz y en los cock-tails. Eso es todo. Nada más que eso. Y en cock-tails, allá en Cuba, en nuestra América hacen cosas mucho mejores que los yanquis. En Cuba, sí, donde precisamente cree tener potencialidad el espíritu norteamericano (1933a, s/p).

Lorca encontró en Cuba la cercanía de su tierra andaluza y la presencia de los surreal en el ambiente y en la naturaleza. Según Rabassó y Rabassó,

el mestizaje caribeño, los elementos criollos antillanos y todo lo relacionado con lo negro dieron armonía a su obra. [...] Cuba se convierte en el punto de referencia que da sentido a todo su discurso. El duende y la pena, el ángel y la alegría propios de su tierra tendrán un sentido tanto en Nueva York como en La Habana. La poesía y el teatro reflejarán una misma preocupación utilizando discursos aparentemente distintos pero complementarios $(1998,451)$.

En la carta enviada desde Nueva York a su familia el 21 de octubre de 1929, manifestó su intención de crear un teatro nuevo, en la que expresaba «He empezado a escribir una cosa de teatro que puede ser interesante. Hay que pensar en el teatro del porvenir. Todo lo que existe ahora en España está muerto. O se cambia el teatro de raíz o acaba para siempre. No hay otra solución» (García Lorca [1929] 1985, 78). Las obras El público y Así que pasen cinco años se alejaban mucho de su anterior producción teatral $\mathrm{y}$ responden a un nuevo espíritu dramatúrgico, como veremos.

\footnotetext{
${ }^{211}$ En la entrevista titulada «"Iré a Santiago...”. Poema de Nueva York en el cerebro de García Lorca» realizada por Luis Méndez Domínguez y, publicada en la revista Blanco y Negro, el 5 de marzo de 1933.
} 


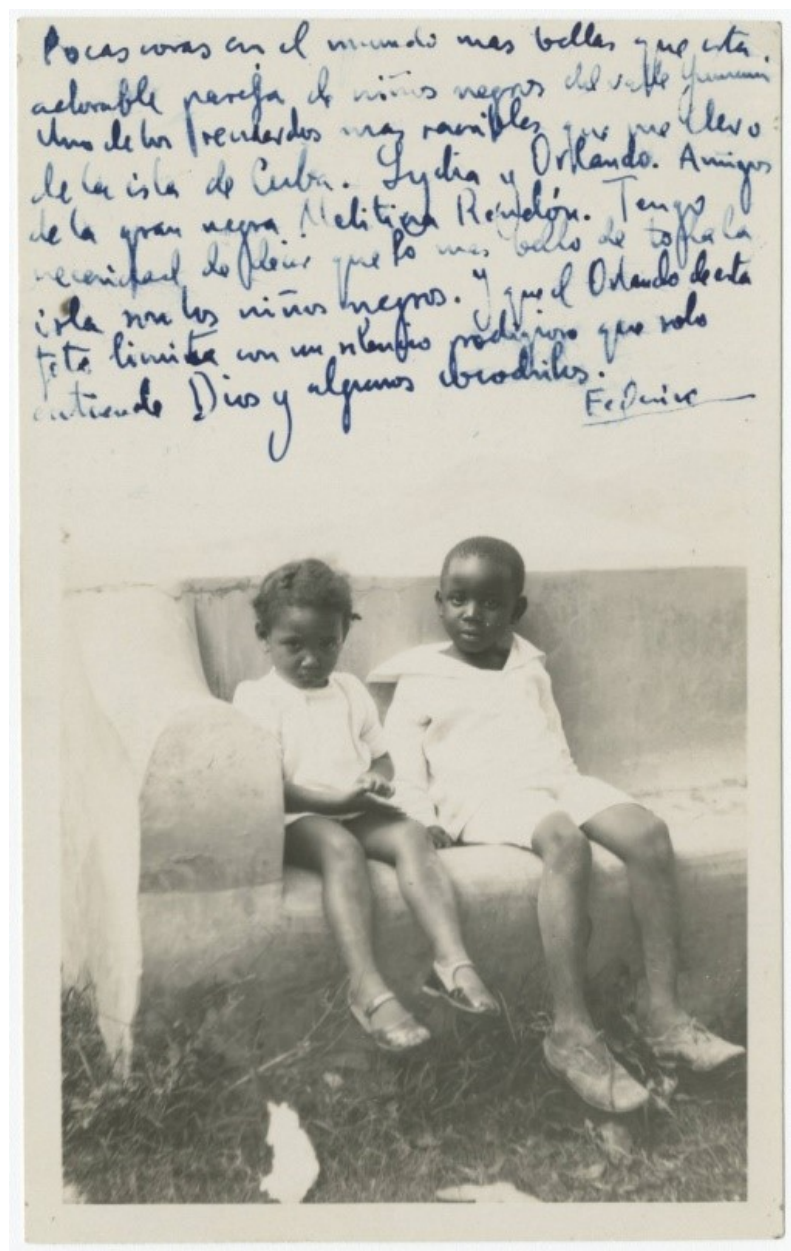

Fig. 80: Fotografía ${ }^{212}$ realizada por Federico García Lorca durante su estancia en Cuba de los niños cubanos.

El teatro cubano y el descubrimiento del mundo dramático en el teatro de la Alhambra constituyen una de las bases en la inspiración del artista. Según Rabassó, «el teatro dadaísta y surrealista junto a las representaciones pirandelianas vividas en el Teatro Alhambra constituyen una de las bases en la inspiración del artista» (1995, 217). Se pueden rastrear expresiones de alusión cubana: en El público, en el cuadro tercero, el Director dice: «Yo soy la Dominga de los negritos» (Cuadro III, 102), en alusión a una famosa bailarina cubana, citada por Rubén Darío; en Prosas Profanas (1892) «La negra

\footnotetext{
${ }^{212}$ Trascripción «Pocas cosas en el mundo más bello que esta adorable pareja de niños negros del valle Yumurí Uno de los recuerdos más [¿sensibles?] que me llevo de la isla de Cuba. Lydia y Orlando. Amigos de la gran negra Melitina Rendón. Tengo necesidad de decir que lo más bello de toda la isla son los niños negros. Y que el Orlando de esta foto limita con un silencio prodigioso que solo entiende Dios y algunos cocodrilos. Federico».
} 
Dominga $^{213}$ » a quien debió verla bailar y que el poema ilustra el tema de la prostitución, y sobre la quien seguramente Lorca oyó relatar historias en La Habana. Los versos de Darío no muestran ninguna connotación despectiva, sino expresa la sensualidad y la belleza de la piel oscura de la negra Dominga. También nos evoca del mestizaje que se produjo entre los antepasados africanos y españoles.

\section{4- La historia del manuscrito}

La primera referencia explícita al argumento de drama la encontramos en una carta dirigida a su amigo Rafael Martínez Nadal, a su vuelta de Granada, en julio de 1930, en la que describe:

Yo estoy satisfechísimo de mi viaje. He trabajo mucho. Tengo muchos versos de escándalo y teatro de escándalo también. [...]

He escrito un drama que daría algo por leértelo en compañía de Miguel. De tema francamente homosexual. Creo que es mi mejor drama (Obras completas IV [1996] 2006, 537).

Cuando regresa de Nueva York y Cuba, en la entrevista realizada por Miguel Pérez Ferrero, sobre su experiencia vivida durante esos meses y sobre el drama que había escrito, Lorca respondía: «Pues se titula "El público". Y se compone de seis actos y un asesinato. [...] No sé si será muy representable en el orden material. Los principales personajes del drama son caballos» (García Lorca 1930, 8).

Otra noticia la encontramos, el 11 de enero de 1931, en una entrevista realizada con motivo del estreno de La zapatera prodigiosa, en la que el periodista César González Ruano le preguntó sobre su obra teatral inédita, a lo que Lorca respondió: «Sí. Tengo [...] un drama en seis actos. El público, donde se plantea el conflicto de las máscaras y el espíritu» (García Lorca 1931, 5).

\footnotetext{
${ }^{213}$ El 27 de julio de 1892, Rubén Darío llegó, por primera vez, a La Habana para pasar unos días con el poeta cubano Julián del Casal. Existe la anécdota sobre cuál es el origen de la composición del poema: Después de que Casal le mostrara los lugares y costumbres del lugar y de quedarse sin dinero, decidió escribir una colaboración anónima en La Caricatura para invitar a Darío a un buen restaurante. Mientras esperaba a que su amigo terminara la colaboración, él escribió el poema sobre la negra Dominga. El 30 de julio, Rubén Darío parte con destino a España. El 14 de agosto aparece en el semanario La Caricatura el poema «La negra Dominga» (Carrero Eras 2010, 217).
} 
Según los testimonios de Adolfo Salazar, de las hermanas Loynaz y de Luis Cardoza y Aragón, la gestación de El público tuvo lugar en La Habana, al igual que Así que pasen cinco años (Bianchi Ross 1997, 73). La única copia del texto que se conoce está escrita parcialmente en hojas timbradas del hotel La Unión y Federico García Lorca dejó una versión manuscrita en la Isla, regalada a Carlos Manuel, que, en opinión de Dulce Loynaz, «ninguno de nosotros apreció mucho el regalo: Otras obras de él nos entusiasmaban — a mí particularmente "Doña Rosita la soltera"-, pero la verdad es que "El Público" nunca fue entendido, ni siquiera por el obsequiado» $(1989,24)$.

En los años ochenta, se acusó a Dulce Loynaz de destruir el manuscrito regalado por Lorca. Ella desmintió la acusación y aclaró el malentendido. Su hermano Carlos Manuel comenzó a dar señales de perturbación mental a finales de los años treinta. Su enfermedad fue diagnosticada desde el principio como esquizofrenia, forma paranoide crónica y nunca recuperó la razón.

Destruía cuanto se hallaba a su alcance. En una ocasión prendió fuego a todos los papeles que constituían su obra musical y literaria [...]. No puedo afirmar que entre lo consumido por las llamas se encontrara el manuscrito regalado por el autor, pero lo más probable es que así fuera, ya que nunca apareció (Loynaz 1987, 42).

La versión de El público, que dejara Lorca en manos de Carlos Manuel Loynaz, nunca fue encontrada, aunque lo más probable es que fuera destruida por el propietario entre su propia obra, en un arrebato pirómano al estar sumido en una profunda depresión durante los últimos años de su vida.

Antes de su viaje en julio de 1936 a Granada en tren, Lorca le entregará un paquete cerrado a Rafael Martínez Nadal; entre otros papeles se encontraba el posible primer borrador de El público. En 1958, recibió en Londres el paquete que contenía el documento, hasta entonces se mantuvo en Madrid. El manuscrito estaba incompleto, faltaba el cuadro cuarto. Aun así, la obra en su versión actual «es bastante coherente y no se echa demasiado en falta la ausencia del cuadro perdido», opina María Clementa Millán, autora de la edición crítica de El público que diera a conocer la editorial Cátedra de Madrid ([1987] 2012, 109). 


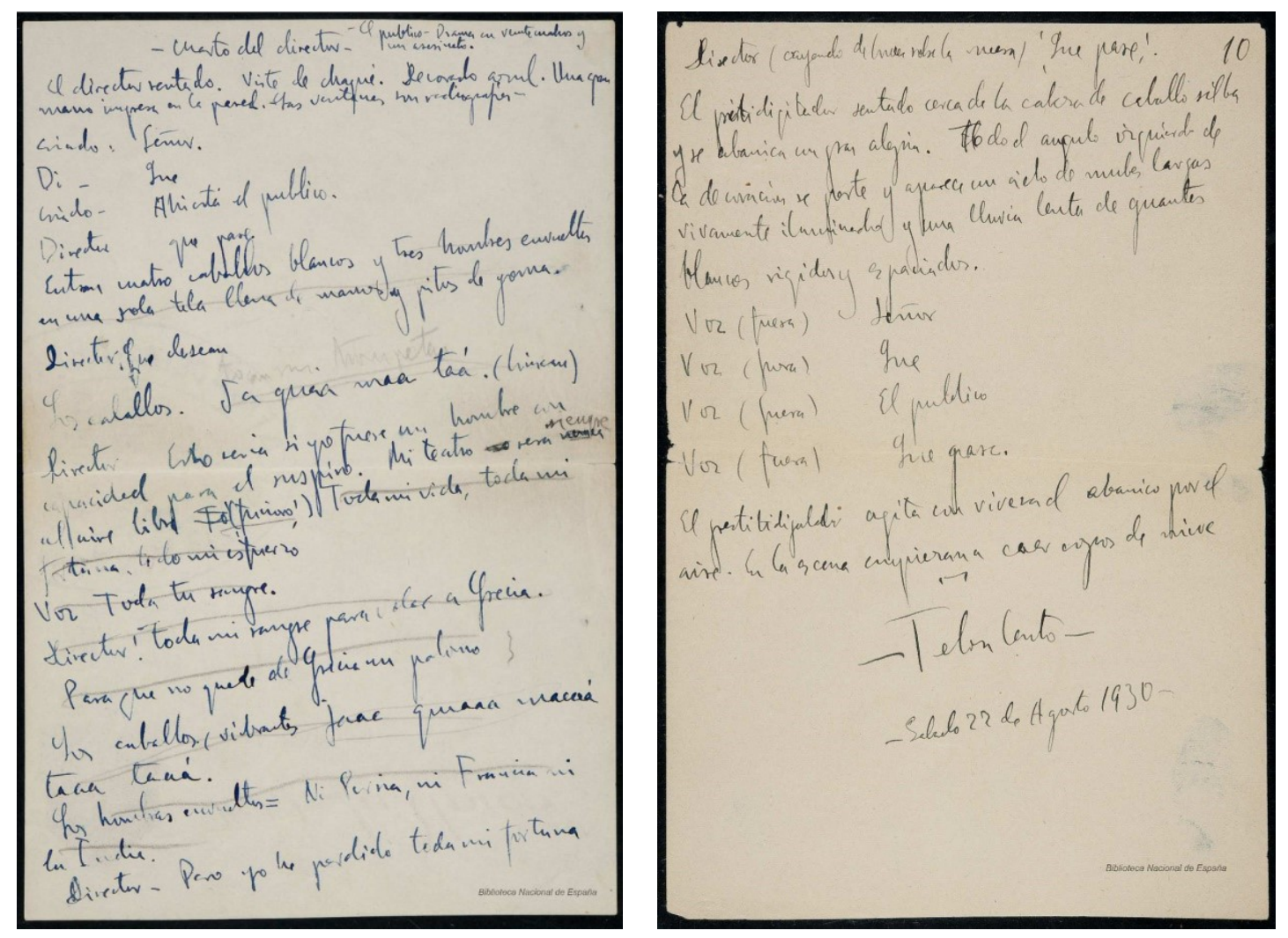

Fig. 81 y 82: Primera y última página del manuscrito de El público (1930).

El manuscrito, entregado a Martínez Nadal, está formado por 62 hojas que están escritas en su integridad a mano por Federico García Lorca. El borrador lleva fecha, a pie de la última página, de sábado 22 de agosto de 1930, unos cuarenta días después de la salida de Lorca de Cuba.

Rafael Martínez Nadal ha sugerido dos hipótesis del origen del manuscrito,

a) En Nueva York, o en Cuba, Lorca escribió el primer borrador de El público en ese álbum de papel rayado. En La Habana empezaría a poner en limpio las partes que tuvieran más tachaduras o correcciones. Apoya tal hipótesis la extraña forma de ligar el texto de la tercera hoja en octavo del cuadro "Ruina romana" con el texto que sigue en las hojas del álbum.

b) Lorca empezó a escribir la obra en La Habana y en el papel de cartas del hotel La Unión. Terminado el primer cuadro, compraría el álbum en que escribió "Ruina romana" y el cuadro sin identificar. En este caso, el comienzo del cuadro sin identificar estaría tan lleno de correcciones que lo pasó al papel del hotel. El cuadro quinto, escrito a lápiz con letra nerviosa y rápida, da la impresión de primer 
borrador, igual que el cuadro final a pesar de las escasas correcciones. ([1970] 1974, 22-23).

En este manuscrito ${ }^{214}$ hay varias foliaciones, según las partes de la obra: unas cuartillas con timbradas del Hotel La Unión de la Habana, otras cuartillas sin membrete y otras rayadas de mayor tamaño, según afirma María Clementa Millán, «probablemente de dimensiones tipo de papel americano, agrupadas, tal vez, en forma de cuaderno pegado por un lateral, lo que explicaría su ausencia de numeración» ([1987] 2012, 110); unas paginadas y otras sin numerar; con tachaduras y enmiendas, y en cuya caligrafía se puede observar la alternancia en el empleo de pluma y grafito. Los dos únicos cuadros perfectamente identificables, que vienen asignados por el autor, son el cuadro quinto y el sexto. El resto no viene numerados ni ordenados y en gran número de las páginas que lo forman, se observa una falta de numeración.

En las primeras ocho hojas está escrito todo el cuadro primero, «Cuarto del director», cuyas páginas están numeradas de la 1 a la 12 . Escrito en tinta azul con correcciones a lápiz y tinta azul, sobre papel de cartas con membrete del Hotel La Unión de La Habana de tamaño cuartilla, a excepción de la última hoja sin numerar, arrancada de una libreta también de tamaño cuartilla pero sin el membrete del Hotel. En la primera página del cuadro aparece el título El público. Drama en veinte cuadros y un asesinato (escrito en una esquina en letra más pequeña).

$\mathrm{La}$ «Ruina romana» consta de siete hojas numeradas de la página 1 a la 9 . Es muy posible que sea el cuadro segundo ya que las cinco primeras páginas están escritas sobre papel tamaño cuartilla con membrete del mismo Hotel La Unión de La Habana como continuación del primero, escrito en tinta azul, como si se tratara de una segunda reescritura ya que se pueden observar pocas correcciones a lápiz y tinta. La repetición de la frase «me convertiré en pez luna y tu? [sic]...» es el nexo de unión entre un modelo de papel y el siguiente tamaño folio rayado. Se observa, de la página sexta a la novena, la utilización de papel de rayas azules tamaño folio, estas hojas son más viejas y están

\footnotetext{
${ }^{214}$ En la actualidad el manuscrito se encuentra en la Biblioteca Nacional de España, adquirido mediante compra, en 1997, a Rafael Martínez Nadal. La versión digitalizada se encuentra en acceso libre en la Biblioteca Digital Hispánica «http://bdh.bne.es/bnesearch/detalle/bdh0000206841».
} 
escritas a lápiz y las correcciones también. Con un trazo veloz, que muestra la intención de premura en la escritura, por el gran número de correcciones posteriores.

El «Muro de arena» está formado por 18 hojas numeradas de la 1 a la 18, también escrito con el mismo papel, hojas de rayas azules de tamaño folio, con el final de la «Ruina romana», de ahí que el orden propuesto por Rafael Martínez Nadal sea el correcto. Escrito en lápiz, en las primeras páginas las correcciones son también a lápiz; a partir de la página sexta, empieza a escribir con tinta negra (se observa en el autógrafo que hay dos tonos claramente diferenciados de tinta negra), las correcciones son a tinta negra y a lápiz.

Como hemos observado, el Cuadro Quinto viene numerado por el autor, formado por 17 hojas numeradas de la página 1 a la 17 sobre papel tamaño cuartilla sin membrete, escrito a lápiz y corregido del mismo modo. A continuación, viene una hoja suelta sin numerar, escrita a lápiz y con correcciones a tinta y lápiz, con el título de Cortina azul correspondiente al «Solo del Pastor Bobo».

Y por último, el Cuadro Sexto, también acotado por el autor, formado por once hojas tamaño cuartilla sin membrete y sin numerar. Escrito en tinta negra y corregido del mismo color. Estos dos últimos cuadros podrían haber sido ya escritos en su totalidad a su vuelta en España, a la vista también de la fecha de cierre del último cuadro.

Este manuscrito debió de servir de base para la versión de finales de otoño de 1930 o comienzos de 1931 (Bianchi Ross 1997, 71). Debieron de existir dos versiones completas del drama: la que leyó en casa de los Morla en 1930, escrita a tinta en pequeñas hojas en octava, y la que leyó en 1936 en el restaurante Buenavista, escrita a máquina en papel tamaño folio y que podemos considerar la definitiva (Martínez Nadal 1978a, 23).

\section{5.- La recepción de $E l$ público}

Durante los días que pasó en La Habana tuvo lugar la primera lectura de El público en la casa de los hermanos Loynaz, donde Lorca pasó grande parte de su tiempo y allí se dedicó a escribir poemas y también a corregir páginas de la obra teatral. 
De sus obras, Flor prefería Yerma y a Dulce María le gustaba más Doña Rosita la soltera, en cambio El público nunca tuvo la preferencia de los hermanos. Cuando Federico García Lorca leyó fragmentos de la obra, ni a Flor ni a Carlos Manuel les gustó

pero Federico continuó su lectura hasta el final, sin preocuparse de sus comentarios y de sus interrupciones. [...] El público no les pareció interesante. Durante la lectura Carlos Manuel y Flor rompieron a carcajadas, sin que a Federico pareciera importarle demasiado, porque continuó leyendo el manuscrito (Pérez Coterillo 1984, 41).

En Madrid, Lorca realizó diversas lecturas entre sus amigos, como la que recuerda José María Alfaro una tarde calurosa de primavera junto a un grupo de amigos, entre los que se encontraba el pintor Juan Manuel Díaz Caneja, Jesús Olasagasti y el guitarrista Regino Sainz, en su piso:

Federico $[\ldots]$ fue un meditador de los detalles y un meticuloso director de escena. «El público»—sobre todo para el comienzo de la década de «los treintas»— resultaba un teatro inusitado. Pese a la embriaguez que por aquellos años nos provocaba el sucesivo pasmo de los deslumbramientos del surrealismo, la lectura de la obra nos iba sumiendo en el estupor. Federico nos arrollaba con el «crescendo» de sus arrebatados transportes y de sus teatralizadas graduaciones. [...] Con «El público» [...] tuvimos la sensación de estar asistiendo a una consciente apertura de puertas hacia el misterio, andar pisando territorios que [...] se nos mostraban casi vírgenes (Alfaro 1978, 28).

Una noche, a finales de otoño de 1930 o principio de 1931, leyó El público a un grupo de amigos reunidos en la casa de los Morla. Carlos Morla Lynch $^{215}$ era un diplomático chileno destacado en Madrid. La obra fue mal acogida entre el grupo de amigos (Gullón 1987, 73; Bianchi Ross 1997, 74-75). Según Martínez Nadal, Federico García Lorca

leyó con entusiasmo y maestría, utilizando todos los registros de su voz, matizando la entonación, perfecto el ritmo, pero al terminar se produjo un silencio que no lo motivaba honda impresión, sino desorientación o sorpresa. "Estupendo", dijo alguien, "pero irrepresentable". Y otro, más sincero: "Yo, la verdad, confieso que no he entendido nada".

${ }^{215}$ Carlos Morla Lynch fue consejero de la embajada de Chile en España entre 1928 y 1939. Decidió no irse de Madrid al estallar la guerra civil en 1936. Y ofreció refugio a más de dos mil personas que huían de la violencia política. Su figura aparece recreada en las novelas de Antonio Muñoz Molina. 
Terminada la velada salimos juntos. Federico hablaba sin resentimiento pero con seguridad: "No se han enterado de nada o se han asustado, y lo comprendo. La obra es muy difícil y por el momento irrepresentable, tienen razón. Pero dentro de diez o veinte años será un exitazo; ya lo verás". ([1970] 1974,17).

También Marcelle Auclair, amiga de Lorca, recoge el testimonio en su obra Enfances et mort de García Lorca (1968):

El desconcierto del círculo íntimo del poeta aquel día en que les fue leído el texto por primera vez, ante la violencia y la abierta homosexualidad de los primeros actos de la obra. Según este testimonio, Bebe, la mujer de Morla Lynch, habría espetado: "Federico, me imagino que no pensarás representar esta obra. No se puede. Aparte del escándalo, no es representable". A lo que Lorca contestó: "Esta obra es para el teatro pero para dentro de muchos años" (García 2020).

En el periódico el Heraldo de Madrid del 2 de julio de 1931, se reseña la lectura de «El público para unos pocos» en el que se anunciaba: «Dentro de breves días el poeta Federico García Lorca leerá «El público» para unos pocos: Vico, Outañon, Sainz de la Maza, Samuel Ros, Pérez Ferrere, Arniches, etc.».

En una carta de 1931 se puede leer cómo García Lorca comenta a sus padres el posible estreno de El Público, aunque el proyecto no cuajó:

Un grupo de amigos y poetas jóvenes quieren representar mi drama 'El Público' si la Irene López Heredia a quien se lo han llevado no aceptara. Desde luego este estreno sería sensacional y una de las batallas literarias mayores de una época. ¡Veremos a ver! (citado en Vilches de Frutos y Dougherty 1992a, 17).

El primer intento de representación, en el verano de 1932, se anuncia en el Heraldo de Madrid de 4 de mayo de 1932. El Ayuntamiento de Madrid cedía el teatro del Español para el empresario Cipriano Rivas Cherif en colaboración con Valle-Inclán, Salvador Bartolozzi y Ricardo Canales. Se pretendía representar las obras de El alcalde de Zalamea de Calderón de la Barca, Luces de bohemia de Valle-Inclán, 14 de Julio de Romain Rolland y El Público de Federico García Lorca. Al final, no se llevó a cabo. 


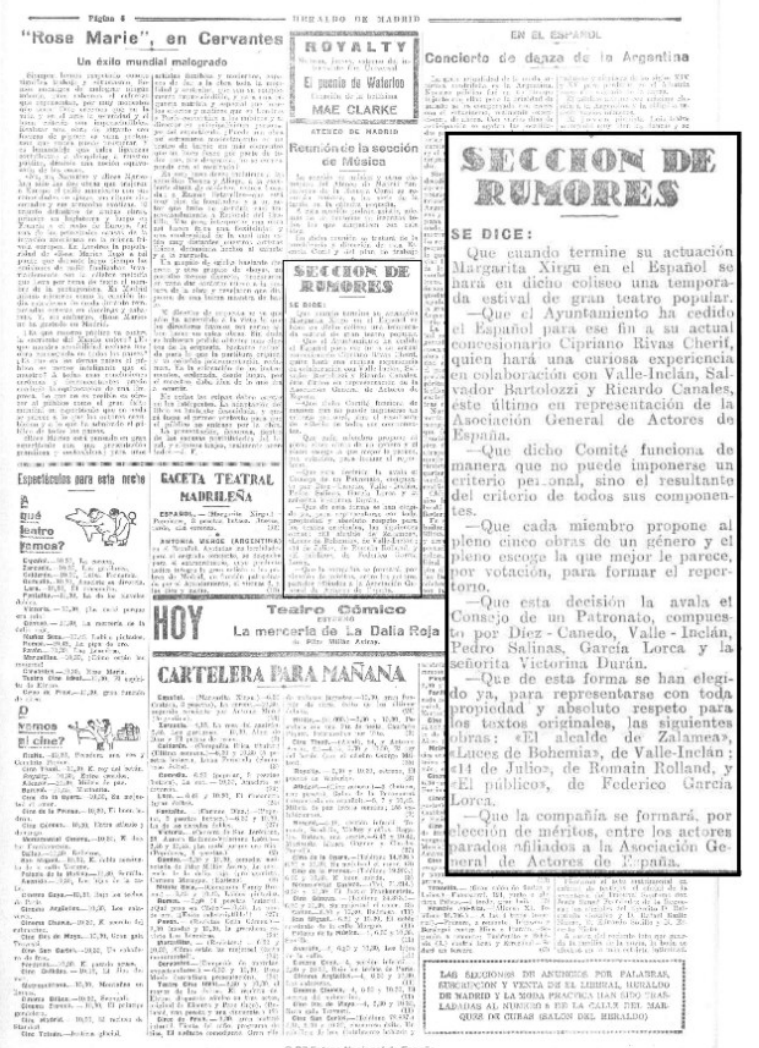

Fig. 83: Anuncio que aparece en la Sección de Rumores del Heraldo de Madrid, del 4 de mayo de 1932, en el que se anuncian las obras elegidas para representar.

El 12 de julio de 1936, lee por primera vez ante unos amigos la versión definitiva de $E l$ público en el restaurante Buenavista escrita a máquina en cuartillas. Según expone Martínez Nadal:

Alrededor del doce de julio de 1936. A eso de las diez de la noche me llamó por teléfono. "Ven corriendo a cenar al Buenavista. Estoy con un amigo y os voy a leer por primera vez la versión definitiva de El público". [...] Cuando llegué, Federico empezaba a leer el último cuadro. No recuerdo que difiriera mucho del texto que conservo en mi poder. Tuve en mis manos y hojeé todas las cuartillas; estaban escritas a máquina, y con bastantes correcciones ([1970]1974, 17).

Según afirma Antonio Monegal, «podría tratarse de una revisión sobre el original preparado para Los Cuatro Vientos» ([2010] 2017, 17). En fecha del 20 de septiembre de 1933, Vicente Aleixandre escribe a Jorge Guillén comentando una de esas lecturas y la solicitud, por parte de Dámaso Alonso, de un resumen de la obra teatral El Público 
para encabezar el número 3, y acompañar dos cuadros publicados en la revista Los Cuatro Vientos:

Lo que yo resumiría El Público de Federico es una fantasía de Dámaso. No puedo hacerlo, sencillamente porque no sé el argumento. Federico me leyó —no íntegrohace tres años y, naturalmente, no tengo más que una remotísima idea de la anécdota, mejor dicho no tengo más que una confusión; mi recuerdo es sólo de partes plásticas. Sí creo, en cambio, que el valor de las escenas (por lo menos sé de una en el fondo de la tumba de Julieta) es independiente del desarrollo dramático del asunto. Quizás no fuera necesario ese resumen. En último caso, Federico podría hacerlo. Yo siento en el alma no tener datos $(2001,99-100)$.

\section{6.- La publicación y posteriores ediciones}

En junio de 1933, Federico García Lorca publica dos cuadros de los cinco: Reina Romana $^{216}$ y el Cuadro Quinto, en el número 3 de la revista madrileña Los Cuatro vientos, bajo el epígrafe El público (De un drama en cinco actos). La puntualización del autor, posterior a la fecha del manuscrito, nos hace dudar si en realidad falta un cuadro en el texto de Lorca. Rafael Martínez Nadal, en 1978, en la «Introducción» a El público y Comedia sin título. Dos obras teatrales póstumas de Federico García Lorca, explica el motivo de que fueran únicamente dos cuadros los publicados, «le pregunté por qué no publicaba ya el drama íntegro. "Porque lo estoy retocando y va a quedar formidable"»" (Martínez Nadal 1978a, 23).

A partir de la información extraída de la correspondencia mantenida entre Dámaso Alonso y Jorge Guillén entre 1926 y 1986, se puede afirmar que en 1933 se gesta «el proyecto de una colección de libros aneja a Los Cuatro vientos, destinada a la editorial Signo, en la que iba a incluirse una obra de Lorca» (Monegal [2000] 2017, 16). Según una carta, con fecha 26 de septiembre de 1933 de Jorge Guillén a Dámaso Alonso, se entiende que esta obra era El público, en la que se especificaba el anticipo económico que pedía Lorca y una tirada de 2.000 ejemplares. El libro nunca llegó a imprimirse (Monegal [2000] 2017, 16-17).

\footnotetext{
${ }^{216}$ Debe tratarse de un error de imprenta ya en el manuscrito se observa claramente «Ruina romana» y, a través del texto, aparecen en repetidas ocasiones cómo los personajes en su diálogo aluden a unas ruinas.
} 
Entre 1938 y 1946, Guillermo de Torre se encarga de recopilar la obra completa de Federico García Lorca en ocho tomos para la edición Losada en Buenos Aires. En 1940, en el volumen $\mathrm{V}$ de esta edición, se publican los dos cuadros que aparecían en la revista Los Cuatro Vientos bajo el título «Escenas de un Drama en cinco actos». En correspondencia entre Pedro Salinas a Jorge Guillén, el 16 de marzo de 1940, desde Wellesley, mostraba la complicada situación para conseguir los derechos de autor para poder editar la obra:

Espero los primeros tomos de Séneca. De seguro serán bonitos respondiendo a la tradición de Bergamín, si tiene elementos con Méjico. Pero anda en unos líos morrocotudos con la cuestión de la propiedad. Ha inventado el comodín del «derecho moral» y en virtud de él va a editar las obras de Federico, a pesar de que están contratadas por la familia con Losada. Creo que hace mal (citado en Soria Olmedo 1992, 229).

En España, el régimen franquista, sin haber entrado en la Segunda Guerra Mundial, había apoyado las iniciativas políticas e ideológicas de las potencias fascistas pero en los años cincuenta empieza un cambio de discurso ${ }^{217}$. Es el final de una etapa en la situación política, siendo el fin del aislamiento internacional y el paso «desde una "dictadura" inicial a una posterior "monarquía representativa", que busca ya una cierta legitimidad de carácter democrático» (Díaz 1974, 84).

El clima de cierta apertura hacia las nuevas formas políticas y culturales siguió en paralelo a las ideas reformadoras que algunos falangistas pretendían llevar a cabo dentro del Régimen, y que tenían que ver, casi enteramente, con recuperar la cultura más valiosa de los derrotados en la Guerra Civil. El propósito de personalidades como Pedro Laín Entralgo, Antonio Tovar o Dionisio Ridruejo fue el de reintegrar en el Estado que surgió del 18 de julio, las ideas de los maestros intelectuales de toda esa generación (Gracia 2006, 78).

\footnotetext{
${ }^{217}$ Las ideas anti-comunismo, el cambio de discurso franquista, que rechazaba totalitarismos y racismos extranjeros para fundamentarse en su intrínseco catolicismo regenerador, permitieron al Régimen sobrevivir tanto tiempo, incluso integrarse en organismos internacionales, gracias al apoyo recibido de Estados Unidos. La situación geoestratégica de España y la ambigüedad ideológica propiciaron ese entendimiento, debido al comienzo de la Guerra Fría y a la idea de frenar el avance comunista iniciado por la otra parte vencedora en la Segunda Guerra Mundial, la Unión Soviética (Gracia 2006, 43-44).
} 
Entre los cambios ministeriales de 1951 se encuentra el de Joaquín Ruiz-Giménez, en el Ministerio de Educación Nacional, cargo que ocupa entre 1951 y 1956. La política del joven ministro, proveniente de la Asociación Nacional de Propagandistas Católicos (ANPC), era «un proyecto de apertura claramente diferenciado de las fuerzas católicas más integristas y del falangismo profranquista más conservador» (Gracia y Ruiz Carnicer 2004, 216; Díaz 1974, 87). La nueva sensibilidad política ${ }^{218}$ tiene que ver con la conciliación de las dos Españas y, como afirma Jordi Gracia, «gestos retóricos que, aun con serlo, introducen una novedad objetiva en el discurso político del régimen y significan un modo de enfocar la historia reciente con alguna menor intransigencia: ya no basta el triunfalismo de la Victoria, de la denostación integral de la cultura derrotada, ni el descrédito pleno de las mejores cabezas de aquel exilio» $(2006,143)$.

Con estos cambios aperturistas de España, aparece, en 1954, la primera edición española de las obras completas de Federico García Lorca, publicada por la editorial Aguilar de Madrid. José Aguilar, sobrino del editor, obtuvo el contrato de publicación de los herederos, firmado el 19 de mayo de 1952. Arturo del Hoyo fue el encargado de la edición que reunía en un solo tomo, encuadernado en piel, con 1.730 páginas (Gallego Morell 1955, 13). Según afirma el propio Arturo del Hoyo,

El proyecto inicial consistía en reunir en un solo volumen las obras de Lorca dispersas en los ocho volúmenes de la edición argentina de Losada, organizándose por gruposverso, teatro, prosa-, cronológicamente. Al revisar la edición de Losada con los libros publicados en vida del autor descubrí que, por motivos explicables — la edición de Losada salió en plena guerra de España-, gran número de dedicatorias habían sido eliminadas en ella $(1986,133)$.

Aún así no dejó de haber problemas con la censura. Pese a la autorización previa, la edición sufrió recortes, tanto en esta primera edición como en las sucesivas ediciones hasta que en la decimoctava de 1973 empezaron a aparecer algunos textos completos que fueron ampliando en posteriores ediciones (Hoyo 1986, 133).

\footnotetext{
${ }^{218}$ La situación de la enseñanza en España era muy difícil. Para corregir las deficiencias del sistema educativo, tuvo la iniciativa de reincorporar a sus puestos a algunos profesores exiliados, siempre los más moderados. El SEU, Sindicato Español Universitario, de presencia falangista, apoyó estos cambios. La aventura reformista de Ruiz-Giménez culminó en 1956 tras varias revueltas universitarias de importante calado y, tras las presiones de los sectores más integristas y excluyentes del Gobierno, Franco decidió cesarle. Pero aunque Ruiz-Giménez fuese fulminantemente despedido del Ministerio, su acción abrió una brecha en la conciencia de la juventud universitaria (Gracia y Ruiz Carnicer 2004, 217-219).
} 
Tanto en la edición de Losada como la de Aguilar aparece el error en el título de "Ruina romana" ya que debieron recoger el texto de la revista Los Cuatro vientos para sus ediciones y, de este modo, el cuadro apareció con el título erróneo «Reina romana» (Martínez Nadal [1970]1974, 20).

El primer estudio y publicación fragmentaria del texto, todavía inédito, fue en 1970 y estuvo a cargo de Rafael Martínez Nadal que conservaba en su poder un manuscrito autógrafo. Dio a conocer algunos fragmentos en un estudio crítico con el título $E l$ público, amor, teatro y caballos en la obra de Federico García Lorca en la editorial The Dolphin Book Company Ltd. de Oxford.

En 1974, Rafael Martínez Nadal edita una segunda edición de este primer libro pero, al aparecer muy corregido y aumentado con un nuevo capítulo «La muerte en la obra de Federico García Lorca», se ve obligado a modificar y simplificar el título El público, amor y muerte en la obra de Federico García Lorca en la editorial mexicana Joaquín Mortiz. Ese mismo año, aparece su traducción inglesa Lorca's The Public. A Study of His Unfinished Play El Público and of Love and Death in the Work of Federico Garcia Lorca en la editorial londinense Calder Boyars.

En 1976, la editorial The Dolphin Book Co. Ltd., Oxford publica García Lorca. Autógrafos II. El público. Es la primera edición de la obra formada por la transcripción íntegra del manuscrito, por la reproducción del facsímil del manuscrito autógrafo fechado en 1930, con prólogo, versión depurada y transcripción de Rafael Martínez Nadal. En la introducción explica el orden propuesto de los cuadros: «la ordenación que ofrecemos está basada en pruebas internas y en el recuerdo de lecturas oídas al autor. Pero aquéllas y éste no son infalibles» (Martínez Nadal 1976, IX).

En marzo de 1978, la editorial Seix Barral, en la colección Biblioteca Breve de Barcelona, publica Federico García Lorca. El público y Comedia sin título. Dos obras teatrales póstumas con la transcripción del manuscrito de El público y la versión depurada que ya aparecían en Federico García Lorca. Autógrafos II. El público en 1976 y la «Guía del lector de El público», basada en el estudio aparecido en las publicaciones de 1970 y 1974 a cargo de Rafael Martínez Nadal. Publicada, a su vez, con Comedia sin título, cuya transcripción y estudio estaban al cuidado de Marie Laffranque. 


\subsection{1.- Ediciones actuales}

En 1986, la editorial Aguilar, en la edición 22a de Federico García Lorca. Obras completas, publica una edición conmemorativa en el cincuentenario de la muerte del poeta. Desde la primera edición de 1954 han pasado treinta y dos años, y el único tomo se convirtió en tres de más de 3.700 páginas. Arturo del Hoyo redistribuyó el material de esta nueva edición, y la obra está dividida en tres tomos: el primero incluye las obras en verso, el segundo, las obras de teatro, entre ellas El público, cine y música y el tercero recoge la obra en prosa y los dibujos (El País 2002) ${ }^{219}$. El prólogo es de Vicente Aleixandre. Esta edición El público. Drama en veinte cuadros y un asesinato aparece con el siguiente orden: el cuadro primero (cuarto del director), el cuadro segundo (ruina romana), el cuadro tercero (muro de arena), el cuadro quinto (el cuadro cuarto no aparece porque en el manuscrito autógrafo está falto del cuadro cuarto), un cuadro sin numerar (cortina azul) que correspondería al «Solo del pastor bobo» propuesto por Rafael Martínez Nadal y termina con el cuadro sexto y último (cuarto del director).

Coincidiendo con el estreno de El público, bajo la dirección de Lluís Pasqual, en el Teatro Nacional María Guerrero del Centro Dramático Nacional, el 15 de enero de 1987, el Ministerio de Cultura, el Instituto Nacional de las Artes Escénicas y de la Música y el Centro Dramático Nacional editan el programa que contiene la ficha técnica, una selección de textos a cargo de Andrés Amorós, una serie de fotografías (72 páginas) correspondientes a las representaciones de Milán, Madrid y Gerona en las dos últimas temporadas, la versión depurada del texto realizada por Rafael Martínez Nadal y la ficha técnica de todos los actores del reparto.

En 1987, la editorial Cátedra presenta una nueva propuesta de El público cuyo estudio preliminar y la edición crítica corren a cargo de María Clementa Millán, especialista rigurosa del autor. En ella se trabaja a partir del único manuscrito conocido de $E l$ público, de los dos cuadros publicados en Los Cuatro Vientos y de la versión publicada por Rafael Martínez Nadal. En la introducción, María Clementa Millán muestra los distintos problemas literarios que plantea el texto.

\footnotetext{
${ }^{219}$ El artículo «Nueva etapa de Aguilar con las 'Obras completas' de Lorca» apareció en la edición impresa de El País, el martes, 16 de diciembre de 1986. http://elpais.com/diario/1986/12/16/cultura/535071601_850215.html.
} 
En 1992, aparecen las obras completas en tres volúmenes en la editorial Akal bajo el título de Obras. En el volumen tercero, Teatro 3 (Teatro Imposible), Cine, Música, aparece El público con varias obras más. La edición estaba a cargo de Miguel GarcíaPosada quien propone una versión completa del texto, numerando consecutivamente los cuadros que se conservan,

En 1993, Clásicos Taurus Ediciones publica El público, acompañado de Romancero gitano y Poeta en Nueva York, en una edición a cargo de Derek Harris. El texto, que se adopta en esta edición, es el que estableció María Clementa Millán en el manuscrito entregado a Rafael Martínez Nadal, con mínimas correcciones efectuadas.

En 1996, la Editorial Comares, junto a la Fundación Federico García Lorca, presentan una nueva edición depurada, del manuscrito existente a cargo de Andrew A. Anderson, quien, junto a otros estudiosos, como Piero Menarini, consideran que lo que se ha dado en llamar apócrifamente el «Solo del pastor bobo» es como un prólogo o "loa" a manera de las obras de teatro del siglo XVI. Aun así, sigue la estructura de las ediciones aparecidas hasta el momento.

La opción que propuso Miguel García-Posada, en la edición de 1992, en la editorial Akal, es la que seguirá también en su edición de las Obras Completas en el Volumen II. Teatro en la editorial Galaxia Gutenberg-Círculo de Lectores en 1997.

En 1998, ante la proximidad del centenario del poeta, el Instituto Cubano del Libro patrocinó la primera edición de El Público en Cuba. La obra todavía no se había publicado en la Isla hasta la fecha (Martínez Carmenate 2002, 218).

En 2000, Alianza editorial publica la obra El público junto El sueño de la vida a cargo de Antonio Monegal. Al no tratarse de una edición crítica en un sentido estricto, Monegal pretendía que fuera «un texto manejable y fluido, al que cualquiera se pueda acercar sin ver su lectura entorpecida por la duda y la confusión» ([2010] 2017, 42-43). La edición de El público. El sueño de la vida parte del manuscrito original y se interviene en él lo mínimo. El texto está muy próximo a las transcripciones literales de los autógrafos realizadas por Rafael Martínez Nadal, en el caso de El público, y Marie Laffranque en Comedia sin título, pero difieren en sus ediciones depuradas posteriores. 
En 2006, la editorial Espasa Calpe publica la edición de Javier Huerta Calvo de El público. Huerta Calvo afirma que la obra está completa y no le falta ningún cuadro, cita a Julio Huélamo para argumentar esa afirmación «cree que tal cuadro es innecesario desde el punto de visita de la coherencia estructural y temática del drama, pues la acción a la que se alude, la repetición de la escena del sepulcro de Julieta ya está desarrollada en el cuadro 3» (Huerta Calvo 2006, 22). Después de aseverar que la obra está completa - hasta el momento se consideraba que la obra estaba formada por seis cuadros y el penúltimo era una breve canción-, Huerta Calvo añade que la obra estaría formada por cinco cuadros (como lo anticipado, en 1933, en la publicación de dos de ellos en la revista Los Cuatro Vientos) y el cuadro quinto pasaría a ser el cuarto y el sexto correspondería al quinto, numeración que ya hizo Miguel García-Posada en su edición de 1997. La diferencia es que el llamado «Solo del Pastor Bobo», —en esta edición «Loa del Pastor Bobo»— lo sitúa al principio de la obra en función de prólogo. Según Huerta Calvo,

este breve texto, situado entre el cuadro 5 y 6 del manuscrito, no lleva más título que la indicación general del escenario que tiene lugar: «Cortina azul». Martínez Nadal lo bautizó con el sugestivo título de «Solo del Pastor Bobo», denominación que aceptan todos los editores posteriores (Millán, Harris, García-Posada), a excepción de Antonio Monegal, que prefiere la más objetiva de «Canción del Pastor Bobo». Ahora bien, lo importante — a nuestro juicio - no es el problema nominal sino su colocación y función en la obra. En este sentido, ya José Rubia Barcia indicó que este texto «debiera ofrecérsele al público como "estampa inicial”》 (2006, 24).

La editorial Arola Editors de Tarragona publicó, en 2015, el texto de Lorca dentro de la colección Textos a part. Teatre Contemporani y con el soporte del Teatre Nacional de Catalunya. Con el título El público: drama en cinco cuadros el libro no consta de ninguna aclaración, introducción o conclusión ya que es un texto para ser leído o representado. El orden es el clásico presentado por Rafael Martínez Nadal, compuesto de cinco cuadros y el «Solo del pastor bobo» lo sitúa entre el cuadro cuarto y quinto con el mismo título que propuso Martínez Nadal.

En 2016, la editorial Galaxia Gutenberg presenta la obra Teatro completo en un único volumen donde recoge toda la producción teatral de Lorca así como textos inacabados, 
apéndices, versiones alternativas y canciones. La presentación de El público sigue la misma propuesta de Rafael Martínez Nadal.

El 1 de enero de 2017 220, la obra de Federico García Lorca quedaba para el dominio público. El 18 de agosto del 2016 se cumplían ochenta años ${ }^{221}$ de la muerte del autor, aunque la muerte de Federico García Lorca no se inscribió de manera oficial hasta el 21 de abril de 1940 (la familia empezó los trámites de su muerte a finales de 1939), cuatro años después de su muerte. En el certificado de defunción del Registro Civil de Granada, se puede leer que el fallecimiento de Federico García Lorca ocurrió «a consecuencia de heridas producidas por hechos de guerra».

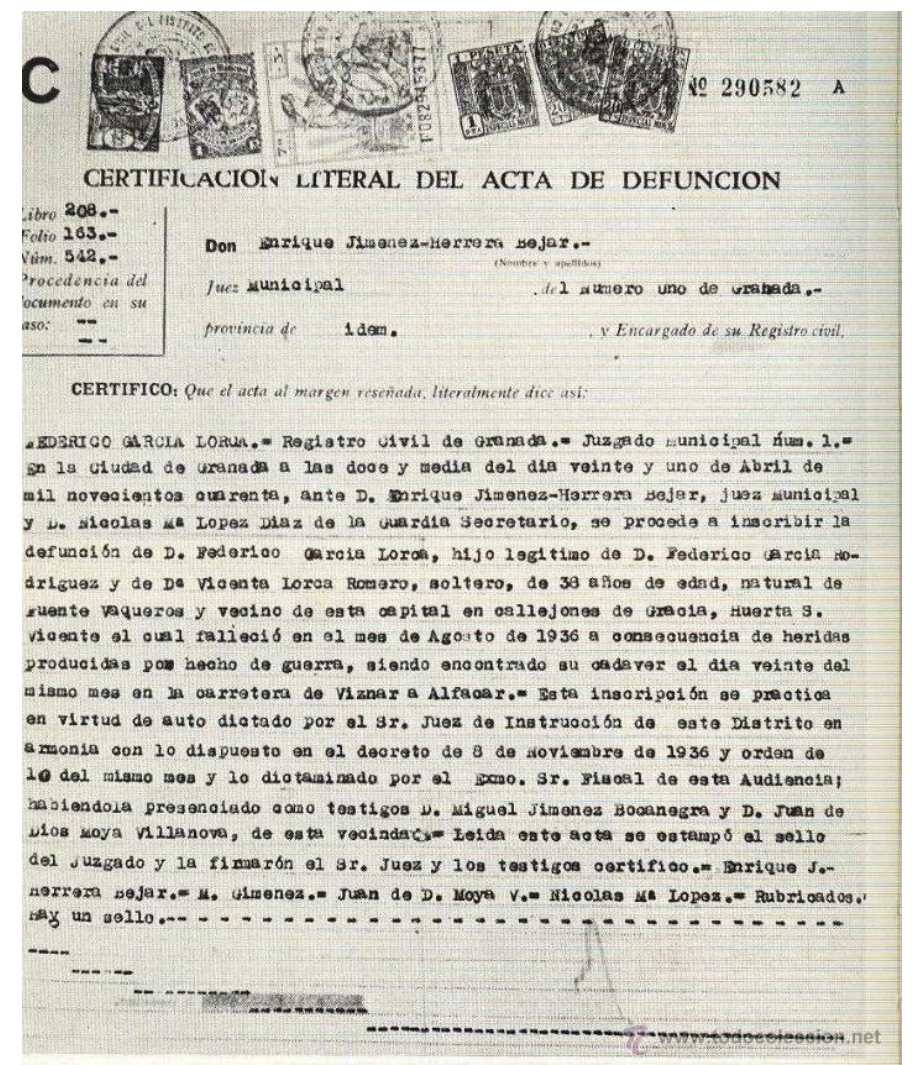

Fig. 84: Certificado del acta de defunción, en el que se puede leer «falleció en el mes de Agosto de 1936 a consecuencia de heridas producidas por hecho de guerra, siendo encontrado su cadáver el día veinte del mismo mes en la carretera de Víznar a Alfacar»

\footnotetext{
${ }^{220}$ Primer día del año siguiente a los ochenta años después de su muerte.

${ }^{221}$ Hasta el año 1987, en España, la Ley de Propiedad Intelectual se regía por la aprobada en 1879, que fijaba la liberación de los derechos hasta los ochenta años después de la muerte del autor. Por ese motivo, para todos los autores españoles fallecidos antes del 7 de diciembre de1987, fecha en la que se aprobó la Ley actual de Propiedad Intelectual, equiparándose a la mayoría de países occidentales, la modificación no debe aplicarse y su dominio público se alcanza a los ochenta años.
} 
Aunque legalmente el dominio público de su obra se alcanzaría en el 2021, los herederos han querido liberarla a los ochenta años de su muerte. De este modo, en la actualidad, cualquier editorial puede reproducir parcial o totalmente la obra de Lorca sin la necesidad de pagar derechos de autor, con la condición de respetar el derecho moral y la autoría. 


\section{9.- Análisis semiótico teatral: Nivel sintáctico}

Como hemos expuesto al principio de nuestra investigación en la Metodología, nuestro análisis semiótico teatral lo dividiremos en tres niveles: nivel sintáctico, nivel semántico y nivel pragmático. Son varios los libros utilizados - ya comentados en la metodología - para realizar el análisis semiótico: Análisis de la Semiótica Teatral (1987) de Manuel Sito Alba, Semiótica teatral (1993) de Anne Ubersfeld, El signo y el teatro (1997) de Tadeusz Kowzan y Semiología de la obra dramática (1997) de Carmen Bobes Naves. Hemos de destacar, además, los artículos de Antonio Tordera Sáez, «Teoría y técnica del análisis teatral», en Elementos para una semiótica del texto artístico (1978) y el de Fabián Gutiérrez Flórez, «Aspectos del análisis semiótico teatral» (1989), en la revista Estudios de literatura.

Iniciaremos el análisis de El público por el nivel sintáctico, los elementos del texto y su relación entre ellos. A partir del texto teatral analizaremos los códigos verbales y no verbales que aparecen en el mismo. En el siguiente capítulo, abordaremos el estudio del nivel semántico, el signo del texto y sus componentes, en el que examinaremos el espacio teatral, el tiempo en el que trascurre la acción y la función simbólica de los personajes. Y finalizaremos el análisis semiótico con el último capítulo correspondiente al nivel pragmático, la relación del autor con la obra y el destinatario, en el que haremos un estudio de las representaciones de El público, desde las primeras puestas en escena realizadas por aficionados universitarios, para detenernos más detenidamente en el estreno oficial, llevado a cabo por Lluís Pasqual, en 1987, hasta llegar a la llevada a tablas por Álex Rigola, en 2010. Analizaremos las dos puestas en escena, por parte de Lluís Pasqual y la de Àlex Rigola. Entre ambas representaciones escénicas realizaremos un recorrido cronológico por las diferentes representaciones, incluida la propuesta de Mauricio Sotelo al convertirla en ópera. Y concluiremos el capítulo, con la última propuesta presentada por la compañía teatral japonesa Ksec Act.

El espacio escénico está compuesto por un conjunto de signos interrelacionados con una intencionalidad significativa. Dentro del nivel sintáctico se analizan las relaciones de los signos entre sí. Como afirma Jenaro Talens, la relación entre los signos se puede abordar desde dos perspectiva diferentes: «a) la combinación de entidades conceptuales (dimensión semántica) y b) la combinación de elementos de expresión que son clases de 
elementos perceptibles por los sentidos físicos (visual, auditivo, táctil, etc.)» $(1978,58)$. Es decir, los códigos verbales en los que se estudia la palabra (el texto) que encontramos en los diálogos de los personajes y en las acotaciones, que nos describen la acción que transcurre en la obra dramática, y los códigos no verbales que acompañan a la palabra, y nos ayudan a situar la acción en un contexto (decorado, luz, música, etc.) junto a la descripción de los personajes ante situaciones concretas (gestos, tono, maquillaje, vestuario, etc.).

Antes de iniciar este análisis, nos situaremos ante el texto para exponer su argumento y mostrar su estructura. Aunque a lo largo de la obra aparecen diversidad de temas secundarios, los dos principales de la misma son: el amor, involuntario y accidental y la contraposición de dos tipos de teatro: al aire libre y bajo la arena. Ambos temas vienen cubiertos por diferentes máscaras, que al ir desprendiéndose una a una se alcanza la meta propuesta.

A lo largo de la historia, aparecen diferentes luchas entre personajes. El tema del amor viene envuelto en una disputa entre personajes y en sí mismo, para desprendernos de la máscara y así alcanzar el verdadero amor, tras el reconocimiento de nuestra identidad personal. Este tema del amor, como algo involuntario y accidental, viene inspirado por la comedia romántica de William Shakespeare El sueño de una noche de verano (1595) en la que Titania, reina de las hadas, como consecuencia del embrujo de «la flor de Diana», se enamora de Nick Bottom, a quien el duendecillo Puck, mediante un hechizo, transforma su cabeza en otra de asno. Esta obra es la elegida para representar en la Comedia sin título, en la que el tema de no poder elegir ante el amor es una cuestión principal. Así, en una carta de Federico García Lorca dirigida al escultor Ángel Ferrant $^{222}$, desde Madrid, entre noviembre de 1930 y febrero de 1931, hace un clara referencia al autor inglés, al afirmar que «el Mosquito, es el Puck de Shakespeare, mitad duende, mitad niño, mitad insecto» (Obras completas IV [1996] 2006, 546) personaje que aparece en Tragicomedia de don Cristóbal y la señá Rosita. Estas referencias no dejan dudas de la influencia de la obra de Shakespeare en su producción teatral, y, en concreto, el factor del azar en el surgimiento del amor.

${ }^{222}$ Escultor vanguardista (1890-1961) relacionado con el surrealismo y el arte cinético. 
El segundo tema principal es la importancia de un teatro fuera de las ataduras del gusto del público y lejos de ser tratado como mera mercancía comercial por parte de los empresarios teatrales. El autor entra en conflicto a la hora de proponernos un teatro renovador y vanguardista, por eso la obra El público «ha de entenderse como un ataque a los valores sociales vigentes en el tiempo de la escritura y como proclamación del derecho a decir lo indecible» (Gullón 1987, 78). Lorca quiere romper con el orden establecido en el teatro comercial del momento y propone un nuevo teatro en el que hay que desprenderse de todas esas máscaras teatrales y sociales en las que viven sujetos todos los individuos (tanto los espectadores como los dramaturgos).

\section{1.- Códigos verbales}

Estos códigos vienen reflejados en la propia palabra. En el texto encontramos una serie de acotaciones y diálogos que nos ayuda a entender como espectador la obra representada. Las acotaciones son indicaciones que el dramaturgo va añadiendo al texto dialogado, dirigidas al director de escena para ayudar en la representación y, también, en la interpretación de los actores y actrices.

\subsection{1.- Estudio de la acción y de las acotaciones}

La obra El público aborda diversos temas como la relación del teatro dentro del teatro, la identidad del yo, la máscara, la verdad, etc. En el texto «no es la acción la que da coherencia a la pieza, sino el tema que se nos quiere transmitir» (Millán 1986a, 399). De entre esos temas, como ya hemos indicado, los dos fundamentales son: la verdad encima del escenario y el no sometimiento al gusto del gran público. Para ello, el autor construye la oposición entre el teatro al aire libre y el teatro bajo la arena, el teatro convencional frente al verdadero teatro que hay que buscar y mostrar al nuevo público. De igual manera, para María Clementa Millán, la originalidad de García Lorca consiste en

sentarse en la propia esencia del género literario que está presentado, haciendo del público (elemento esencial y necesario en cualquier creación teatral) el protagonista de la obra. Lorca resuelve la oposición mediante el triunfo del teatro bajo la arena, en el 
que "se han sostenido dramas auténticos", si bien este verdadero combate "ha costado la vida a todos los intérpretes" $(1986,401)$.

En El público el autor no busca la acción del drama sino la reacción del espectador, el propio título de la obra teatral nos quiere mostrar a esos espectadores, a ese público, como un elemento teatral principal dentro de la propia obra, adquiriendo una importancia en la comprensión del texto. Según afirma Ricardo Gullón, Lorca nos presenta al «espectador como una unidad cuyos condicionamientos morales, intelectuales y sociales los contradecía un texto que necesariamente convertía la representación en reto» $(1987,77)$.

Aunque con esta vía experimental, el autor pierde el diálogo entre la obra y el espectador y se distancia del entendimiento. El diálogo entre el autor y el público era importante para Lorca y al conprobar que con este teatro se aleja de la compresión del público, quiso constuir un teatro más cercano a este, sin perder ese punto de vista vanguardista y renovador, lleno de imágenes poéticas y revelador de una nueva escena.

\subsubsection{1- La acción. Argumento}

Aunque en el manuscrito de El público, en el borde superior derecho, aparece en letra más pequeña que en el resto, un subtítulo de «drama en veinte cuadros y un asesinato», sólo ofrece seis partes, de las que únicamente vienen numeradas dos, estructurándose ${ }^{223}$ según Rafael Martínez Nadal:

\begin{tabular}{|c|}
\hline Cuarto del Director \\
\hline Ruina romana \\
\hline Muro de arena \\
\hline Cuadro 5 \\
\hline
\end{tabular}

\footnotetext{
${ }^{223}$ Julio Huélamo propone una nueva estructuración, al ser excesivo el Cuadro 3 y divide la obra en tres actos: Acto I, formado por el Cuarto del Director y la Ruina romana; el Acto II formado por el Muro de arena y el Acto III formado por el Cuadro 5, Cortina azul y Cuadro 6. En la introducción de la edición de Javier Huerta Calvo de El público, en la editorial Espasa de 2006, expone una clara explicación de la propuesta de Huélamo.
} 
Cortina azul

Cuadro 6

Rafael Martínez Nadal entendió la obra como inacabada porque faltaría al menos el Cuadro 4, pero nosotros, siguiendo la propuesta de Javier Huerta Calvo, proponemos que la obra estaría dividida en cinco cuadros, y Cortina azul, correspondiente al «Solo del Pastor Bobo», la situaríamos al principio de la obra como prólogo u obertura del espectáculo y, de este modo, podría conseguirse una obra conclusa. Su estructura sería la siguiente:

\begin{tabular}{|c|}
\hline Loa del Pastor Bobo (Cortina azul) \\
\hline Cuadro 1 (Cuarto del Director ) \\
\hline Cuadro 2 (Ruina romana) \\
\hline Cuadro 3 (Muro de arena) \\
\hline Cuadro 4 (Cuadro 5) \\
\hline Cuadro 5 (Cuadro 6) \\
\hline
\end{tabular}

\section{La Estampa inicial}

El manuscrito se presenta en hojas sueltas y, aunque está situado entre el Cuadro 5 y 6 , sólo viene la indicación de «Cortina azul», información que nos ayuda a presentarnos el decorado del escenario. No podemos asegurar su situación en la estructura pero nosotros, junto a otras propuestas de estudiosos como José Rubia Barcia o Javier Huerta Calvo, lo situaremos como una Estampa inicial que condensa la idea central de la obra, y en la que el Pastor Bobo nos ofrece una presentación de lo que estamos a punto de ver en escena.

Se trata de un prólogo dramático similar al que antecede a El maleficio de las mariposas, La zapatera prodigiosa, El Retablillo de don Cristóbal o El sueño de la vida. Pero, a diferencia de estas cuatro obras, no es el Autor quien recita, sino un 
personaje que no vuelve a aparecer en el resto del drama: el Pastor Bobo. Este tipo de prólogos dramáticos ya tenían una tradición en el teatro de Jacinto Benavente, incluso en el teatro épico de Bertolt Brecht, donde el autor no buscaba una gran dramatismo con tensiones y conflictos, sino que pretendía que el espectador reflexionara, meditara y tomara decisiones ante la representación de sus obras,

En la acotación inicial, Lorca nos describe el decorado. Encontramos en el centro del escenario «un gran armario lleno de caretas blancas de diversas expresiones. Cada careta tiene una lucecita delante» (Loa del Pastor Bobo, 99), todas esas máscaras representan a toda la humanidad que para vivir en sociedad adquiere un papel. Según afirma José Rubia Barcia, la estampa inicial es una clara alusión a la «humanidad caracterizada por la máscara que a cada individuo le viene dada o adquirida para convivir con sus semejantes. [...] Lo que siglos antes había ya mostrado, [...], Calderón de la Barca en su El gran teatro del mundo» $(1986,391)$. La humanidad se muestra tras una máscara y un traje para ocultarnos su verdadera identidad. Debemos fijarnos en las diferentes acotaciones en las que nos indica que «las caretas balan imitando las ovejas y alguna tose» (Loa del Pastor Bobo, 101), dándole el simbolismo de rebaño que se deja guiar sin poner resistencia, incluso alguna tose como recordándonos a los espectadores de un teatro.

\section{Cuadro primero}

$\mathrm{Su}$ argumento se desarrolla en la habitación del Director, que simboliza el mundo objetivo donde se plantea si es posible representar un teatro bajo la arena: un teatro fuera del orden establecido del conservadurismo acomodado burgués. Se inicia con dos únicos personajes sobre el escenario: el criado y el director. El criado realiza la presentación del público, personaje colectivo presente de principio a fin de la obra, que asiste al espectáculo del director de un teatro al aire libre y convencional. De repente, sobreviene la entrada, brusca, a escena de los cuatro caballos blancos. Aquí Lorca nos presenta el primer juego de personajes y símbolos que durante todo el texto irán apareciendo, ¿el público que ha presentado el criado, al inicio, corresponde a aquellos espectadores que se encuentran sentados en las butacas de platea o estos cuatro caballos blancos que son su alegoría/representación sobre el escenario? ¿Son los caballos 
blancos los instintos ocultos del director de escena y que le exigen que se libere? El autor no dicta sino alude.

Cuando los espectadores forman parte de la puesta en escena, se produce una ruptura en las convenciones existentes para la representación teatral. El Autor no quiere que el público se mantenga distante, como un espectador pasivo, conformista, sentado en sus butacas (típico espectador de los años treinta, del teatro a la italiana, distanciado del escenario), sino que cuenta con él para que forme parte de la representación. Ejemplo más claro de ello lo encontramos en Comedia sin título, cuando los propios actores comparten espacio y papel entre los espectadores. Lorca, con esta provocación, busca un espectador diferente, ya que la obra El público está pensada como un revulsivo al teatro comercial y contra un público conservador, aspecto expuesto ya en la primera parte de la tesis.

En un principio, el Director es partidario de un teatro al aire libre, tiene miedo de representar cualquier ejemplo de verdadera realidad, todo es una actuación, una apariencia, una representación de la realidad. Muy similar al teatro tradicional, que se representaba en los teatros españoles de las primeras décadas del siglo XX:

DIRECTOR. - [...] Mi teatro será siempre al aire libre. (Furioso). Pero yo he perdido toda mi fortuna.

$[\ldots]$

DIRECTOR.- ( $A l$ CRIADO): ¡Abre las puertas!

$[\ldots]$

DIRECTOR.- ¡Teatro al aire libre! ¡Fuera, vamos! ¡Teatro al aire libre! (Cuadro I, 104-106).

La conversación, que mantiene el Director con los Caballos, muestra una fuerte contradicción entre las apariencias y los verdaderos instintos. Los cuatro Caballos reprenden al Director, ya que este defiende un teatro al aire libre, un teatro con apariencia real pero lejos de la verdad. El Director expulsa del escenario a los Caballos:

LOS DOS CABALLOS [1 Y 2].-- (Furiosos.) Abominable.

LOS CABALLOS [3 Y 4].- Benamiboá 224 .

LOS CABALLOS [1 Y 2].- (Reproche.) Abominable.

\footnotetext{
${ }^{224}$ Benamiboá es un juego de los espejos de las sílabas de la palabra Abominable (anagrama).
} 
LOS CABALLOS [3 Y 4].- Benamiboá (Cuadro I, 106).

En un principio, los caballos blancos no se expresan con palabras significativas, sino con sonidos guturales como onomatopeyas o anagramas. Irán evolucionando según avance la obra y, según se profundice más en el mundo subconsciente y subjetivo, lejos de la lógica y la razón.

De nuevo, Lorca realiza por parte del Criado la presentación del público al Director, se inicia el juego de las duplicidades, las máscaras, las metamorfosis, falsedades y verdades. Pero en esta ocasión, entran tres hombres vestidos de igual manera y de aspecto físico similar. La entrada de los tres hombres, muy semejante a la de los caballos, tiene un valor de réplica. Los tres hombres llegan para felicitar al Director por el montaje tradicional de la obra que acaban de ver representada Romeo y Julieta ${ }^{225}$, que es el exponente de un teatro clásico de un teatro al aire libre en el que el tema principal es el del amor más allá de las apariencias. Pero en este diálogo cabe destacar la postura del personaje del Hombre 1, que exige al Director que abandone el teatro al aire libre y le reclama que inaugure el verdadero teatro con una transformación de su teatro:

HOMBRE 1.- [...] Tendremos necesidad de enterrar el teatro por la cobardía de todos. $[\ldots]$

HOMBRE 1.- (Lentamente) Tendré que darme un tiro para inaugurar el verdadero teatro, el teatro bajo la arena. (Cuadro I, 109).

Pero el Director tiene el miedo ante las exigencias del Hombre 1, que quiere cambios en el teatro, dejando atrás ese otro que respeta las normas convencionales y morales establecidas por la sociedad burguesa. Un teatro fácil de representar y de entender, del gusto del público que asiste al teatro con asiduidad:

DIRECTOR.- (Reaccionando) Pero no puedo. Se hundiría todo. Sería dejar ciego a mis hijos y luego ¿qué hago con el público? ¿Qué hago con el público si quito las barandas al puente? Vendría la máscara a devorarme. Yo vi una vez a un hombre devorado por la máscara. Los jóvenes más fuertes de la ciudad, con picas ensangrentadas, le hundían por el trasero grandes bolas de periódicos abandonados, y en

${ }^{225}$ Con la elección de esta obra, Lorca intenta unir tradición y modernidad y, al mismo tiempo, da referencia cultural (inter-textualidad). 
América hubo una vez un muchacho a quien la máscara ahorcó colgado de sus propios intestinos.

HOMBRE 1.- ¡Magnífico!

$[\ldots]$

DIRECTOR.- - [...] No me supondrá usted capaz de sacar la máscara a escena.

HOMBRE 1.- ¿Por qué no?

DIRECTOR.- ¿Y la moral? ¿Y el estómago de los espectadores? (Cuadro I, 110-111).

El Director expondrá sus miedos a esa máscara que toda persona utiliza para ocultar su verdadera identidad y, viéndose acorralado por el Hombre 1, pedirá ayuda a Elena. Es la primera vez que es nombrada en la obra, pero no la última. El Director muestra en Elena la referencia de lo normativo, lo socialmente correcto y aceptado, lo más cercano a la máscara:

DIRECTOR.— - [...] (A voces.) ¡Elena! ¡Elena! (Corre a la puerta.)

HOMBRE.- Pero te he de llevar al escenario quieras o no quieras. Me has hecho sufrir demasiado. ¡Pronto! ¡El biombo! ¡El biombo! (El HOMBRE 3 saca un biombo y lo coloca en miedo de la escena.)

DIRECTOR.- (Llorando.) Me ha de ver el público. Se hundirá mi teatro. Yo había hecho los dramas mejores de la temporada, pero ahora...!

(Cuadro I, 113-114).

El biombo es un elemento fundamental en la obra El público que lo analizaremos con mayor profundidad en el siguiente capítulo, en el apartado del espacio teatral. El biombo tiene la virtud de descubrir la verdadera personalidad de aquel que lo atraviese. Por un lado, facilita a los diferentes personajes a desprenderse de la máscara que, de manera voluntaria o forzada, al atravesarlo eliminarán las diferentes máscaras que poseen, mediante transformaciones o metamorfosis. Y, así, se desprende de las apariencias y descubre su personalidad y su verdadero amor. Según afirma María Clementa Millán, la idea de que lo trascendental es

la autenticidad de la persona, y no la máscara que la encubre, es la que provoca en esta obra las sucesivas transformaciones en la apariencia externa de los personajes. [...] Así, el autor, a través del disfraz y de la ilusión que siempre implica el teatro [...] expone la principal preocupación de esta obra: manifestar la importancia del amor, no importa cuál sea su forma externa $(1986,403)$. 
Estas transformaciones también ayudan a que el teatro al aire libre se convierta en el teatro bajo la arena, en el que nos encontraremos ya en el siguiente cuadro, con la representación de Julieta en el sepulcro en la ruina romana.

Según avance la obra y vayan sucediendo las diferentes metamorfosis del Director, este irá descubriendo su verdadera identidad, y sus ideas acerca de un teatro nuevo irán cambiando. En un principio, el Director no quiere comprometerse y presenta un teatro realista y al gusto del público, pero, poco a poco, sus cambios no sólo los mostrará en su personalidad e identidad, sino que también quiere arriesgar y transformar el teatro enfrentándose al modelo imperante hasta el momento, al presentar una propuesta innovadora y diferente. Un cambio desde dentro del teatro, aún teniendo miedo al fracaso económico y de público.

\section{Cuadro segundo}

En el manuscrito, al inicio de este segundo cuadro, se puede leer el título de «Ruina romana» que nos proporciona la referencia clásica y de una imagen de la destrucción de lo antiguo, de lo anterior. Unas ruinas de un modelo sobre las que hay que construir algo nuevo. Nos situamos ya más cerca del teatro bajo la arena.

Desde el comienzo del cuadro, nos hallamos en un espacio lúdico, en donde la acción se inicia con una danza entre dos figuras: sentada sobre un capitel, una cubierta de pámpanos rojos toca una flauta, mientras la otra, cubierta de cascabeles dorados, danza en el centro del escenario. El baile de los personajes también es una coreografía dialogada, que se transformará en una lucha verbal entre dos personajes opuestos: la Figura de Cascabeles y la Figura de Pámpanos. Si analizamos la conversación entre los dos personajes, comprobamos que, mediante un diálogo corto y rápido, Lorca nos proporciona el tono enérgico y de disputa de este enfrentamiento:

FIGURA DE CASCABELES.- Si yo me convirtiera en nube...

FIGURA DE PÁMPANOS.- ... Yo me convertiría en ojo.

FIGURA DE CASCABELES. - Si yo me convirtiera en caca...

FIGURA DE PÁMPANOS. - . ..Yo me convertiría en mosca.

FIGURA DE CASCABELES.- Si yo me convirtiera en manzana...

FIGURA DE PÁMPANOS. - ... Yo me convertiría en beso.

FIGURA DE CASCABELES.— Si yo me convirtiera en pecho... 
FIGURA DE PÁMPANOS._. ... Yo me convertiría en sábana blanca.

$[\ldots]$

FIGURA DE CASCABELES.- Y si yo me convirtiera en pez luna...

FIGURA DE PÁMPANOS._. . . Yo me convertiría en cuchillo.

FIGURA DE CASCABELES.- (Dejando de danzar.) Pero ¿por qué? ¿Por qué me atormentas? (Cuadro II, 122-125).

Las ruinas no sólo representan la destrucción de ese modelo teatral tradicional, sino que también buscan el cambio de actitud del individuo. Hay que luchar dentro de uno mismo para sacar la verdad y mostrarse como uno es en realidad. En ese juego apasionado entre las dos figuras, las voces van cambiando de tono, y el diálogo finaliza cuando la Figura de Cascabeles deja de danzar. Podríamos afirmar que la música y la danza permiten a los dos personajes liberar sus pasiones y desprenderse de la parte apolínea del ser y mostrar la dimensión dionisíaca.

En la disputa entre las dos figuras, se ve reflejada la oposición entre lo femenino o afeminado y lo masculino o viril. Se identifica, pues, cada una de ellas con los principios de lo femenino y de lo masculino. Como afirma Pedrosa, «cada una de estas figuras constituye una metáfora respectiva de la ingenuidad y de la prostitución, de la marginación y del acomodo en el poder, de la virilidad consecuente y del afeminamiento desviado» $(1998,372)$.

En este segundo cuadro, encontramos, además, el punto álgido al aparecer el personaje del Emperador buscando a Uno:

CENTURIÓN. - El Emperador busca a uno.

FIGURA DE PÁMPANOS.- Uno soy yo.

FIGURA DE CASCABELES.- Uno soy yo.

CENTURIÓN.—_Cuál de los dos?

FIGURA DE PÁMPANOS.-Yo.

FIGURA DE CASCABELES.- - Yo (Cuadro II, 133).

Como afirma Antonio Monegal, «el uno es el número de la soledad y el aislamiento» (1994, 29), el Emperador busca a Uno porque es algo inalcanzable. Ese Uno es quien mejor representa al homosexual masculino. Tanto la Figura de Pámpanos como la de Cascabeles quieren ser ese Uno elegido por el Emperador. La Figura de Pámpanos "se 
despoja de los pámpanos" y es aceptado por el Emperador, mientras la Figura de Cascabeles, que no renuncia a sus atributos, queda rechazada y exclama traición ante la actitud de su compañero Pámpanos.

FIGURA DE PÁMPANOS.— Tú me conoces. Tú sabes quién soy. (Se despoja de los pámpanos y aparece un desnudo blanco de yeso.)

EMPERADOR.- (Abrazándolo.) Uno es uno.

FIGURA DE PÁMPANOS.- Y siempre uno. Si me besas, yo abriré mi boca para clavarme después tu espada en el cuello.

EMPERADOR.- Así lo haré.

FIGURA DE PÁMPANOS.- Y deja mi cabeza de amor en la ruina, la cabeza de uno que fue siempre uno.

EMPERADOR.- (Suspirando.) Uno (Cuadro II, 135-136).

La figura del Emperador podemos identificarla con el poder, incluso en un sentido negativo con la dominación y la tiranía. Es un personaje que tiene todo aquello que desea sin pensar en las consecuencias:

EMPERADOR.- Uno es uno y siempre uno. He degollado más de cuarenta muchachos que no lo quisieron decir.

$[\ldots]$

EMPERADOR.- (Al CENTURIÓN): ¡Desnúdalos! (Cuadro II, 135).

\section{Cuadro tercero}

La primera acotación nos sitúa el lugar de la acción «Muro de arena», elemento que pertenece al teatro bajo de la arena. En un primer momento, tres hombres dialogan con el Director sobre la actuación que acaban de ver, y vienen a felicitarlo por su Romeo y Julieta, una nueva referencia culturalista shakesperiana. A partir de aquí, todos los personajes se convertirán en actores y en espectadores. Tras la discusión, se abre el muro y aparece una decoración realista del sepulcro de Julieta: «El muro se abre y aparece el sepulcro de JULIETA en Verona. Decoración realista» dando paso al teatro bajo la arena. Julieta dialogará con los tres caballos blancos y se refugiará entre los brazos del caballo negro. Al final del cuadro, se producirá la simultaneidad de acciones: por un lado, los tres hombres y el Director y, por otro, Julieta y los caballos, sin 
mantener relación entre ellos. Este efecto de coexistencia de acciones se repetirá en el siguiente cuadro, e incluso en el último.

\section{Cuadro cuarto}

El escenario se encuentra dividido en tres espacios, descritos claramente en las acotaciones, con tres acciones independientes entre ellas. En la acotación inicial del cuadro, se nos muestra qué encontramos en el escenario y quién se halla en el centro del mismo. El escenario lo ocupa un Desnudo Rojo y un Enfermero, cuya acción simboliza el sacrificio por las ideas. El diálogo y las posturas de sus personajes serán analizados pormenorizadamente en el punto del análisis simbólico.

A continuación, aparecen cuatro Estudiantes, en la parte derecha de la escena, decorada con la portada de una universidad. Estos comentarán todo lo que han vivido en los cuadros anteriores, hasta el momento. Durante la representación de Romeo y Julieta, el público se ha rebelado al descubrir la mentira de la puesta en escena. Los estudiantes discuten sobre la verdadera Julieta, un joven muchacho de quince años asesinado por el público violento, y la Julieta del escenario, creada por el teatro (metateatralidad).

Sobre el escenario siguen todos los personajes: en el centro se encuentra el Desnudo rojo sobre la cama en posición vertical que se gira y, en el reverso, aparece el Hombre 1 - con frac y barba negra, sin máscara y con nombre propio, Gonzalo- que sustituye al Desnudo rojo que ha desaparecido. Exclama agonía y muestra la soledad del hombre. La escena permanece a oscuras, mientras el Muchacho 1 con una linterna ilumina la cara muerta del Hombre 1.

\section{Cuadro quinto}

Para darle este carácter cíclico y cerrado, un nonsense de la obra, Lorca nos describe el lugar en que transcurre este último cuadro que es el mismo decorado que el del inicio, según acotación «la misma decoración que en el primer cuadro». En este cuadro, encontramos una atmósfera diferente, el público es el personaje anónimo y necesario para poder representarla.

De nuevo, en un mundo objetivo, entran en escena los personajes del Director y el Prestidigitador que reflexionan sobre lo vivido, qué consecuencias ha tenido la función 
del teatro y si es necesario mostrar un teatro nuevo o no. El Director podría ser el autor físico del mundo real, en cambio el Prestidigitador tiene las características de un mago procedente de un mundo no real. Entonces, aparece en escena una Señora, que es la madre de Gonzalo, buscando a su hijo muerto sacrificado por mantener unos ideales. El Prestidigitador la hace desaparecer como por arte de magia. El Director y el criado empiezan a sentir frío, como anticipo y presagio de su propia muerte que está a punto de llegar.

Como hemos dicho, la obra termina como empieza, con una invitación a que el público pase a ver la obra, como si nada hubiera ocurrido todavía, y tornáramos al principio. Tenemos de nuevo la oportunidad de ver la representación y con nuestra voluntad podemos elegir entre un teatro al aire libre o bajo la arena, y asimismo cambiar con nuestra fuerza las normas establecidas de un teatro conservador, pasivo e inmutable.

\subsubsection{2.- Las acotaciones}

En el texto teatral encontramos el diálogo, la conversación, a lo largo de la obra, entre los personajes y la acotación, donde el autor indica cómo ha de transcurrir la representación.

Las acotaciones teatrales tienen la forma del lenguaje funcional ya que se utiliza para mandar u orientar y para facilitar a la hora de representarse. Como afirma Bobes Naves, «son mandatos, bajo formas más o menos lenificadas, que el autor del texto da al director de escena o a los actores para que preparen el espacio escénico en el que situará la acción de la historia que se construye con el diálogo, o «texto principal»» (1988, 133). Las acotaciones generalmente crean el espacio y el tiempo en los que transcurre la acción, también se recogen signos no-verbales que emiten los personajes con sus movimientos, actitudes o forma de hablar.

Si hiciésemos un repaso de las acotaciones de la obra podríamos observar de un modo directo los diferentes signos que describen las acciones y sentimientos de los personajes y la descripción del espacio y el tiempo.

En el Cuadro Primero, antes del inicio del diálogo, encontramos la primera acotación, «Cuarto del DIRECTOR. El DIRECTOR sentado. Viste de chaqué. Decorado azul. 
Una gran mano impresa en la pared. Las ventanas son radiografias». Es una acotación descriptiva, en la que el autor nos indica dónde nos encontramos, cómo es el despacho del Director y cuál su vestimenta.

También encontramos acotaciones dentro del diálogo, en las que nos indican la aparición a escena de los diferentes personajes, «Entran cuatro CABALLOS BLANCOS», «Entra el CRIADO»; también indican la acción de esos personajes «Los CABALLOS tocan sus trompetas», «El CRIADO abre la puerta»; su vestimenta «Vestidos de frac exactamente iguales»; sentimientos «Llorando», entre los diferentes códigos no verbales.

No debemos olvidar que en el diálogo no siempre se recoge en las palabras los matices que aparecen en las acotaciones, que ampliaremos más adelante en el punto de los códigos no verbales no lingüísticos, en las que se indica modos de actuar o situar al actor en escena.

\subsection{2.- Estudio y caracterización funcional de los personajes}

El personaje, junto con el tiempo y el espacio, es una de las unidades fundamentales en la sintaxis de un relato. El personaje es el elemento que enuncia un discurso mediante la palabra o los gestos. La noción de personaje varía según la cultura del espectador, como afirma María del Carmen Bobes Naves, «el sentido que adquieren los personajes de una misma obra es diferente [...] en las distintas lecturas, en las distintas interpretaciones» ([1987] 1991, 191).

Cuando los personajes no actúan como podría esperarse —en el caso de El público ocurre constantemente- producen desconcierto en los espectadores, encontramos muestras de ello en el teatro del absurdo. Y es cuando se necesita de un estudio o una valoración crítica para señalar esos nuevos marcos teóricos $\mathrm{y}$, de este modo, facilitar al espectador su comprensión. Sin embargo, la crítica, en ocasiones, no acierta en la nueva clasificación del texto. Afirma Millán que

esta obra representa una gran innovación con respecto al panorama teatral de su tiempo.

[...] Cambia la voz única del protagonista convencional por una gran variedad de voces [...], la única voz es sustituida por distintas perspectivas [...]. A través de estas voces, 
Lorca no sólo expresa las diferentes facetas del sentimiento amoroso, sino también los variados niveles de significación de esta obra $(1986,404)$.

La mayoría de los personajes que interviene en la obra, utiliza nombres genéricos, en vez de nombres propios que particularizan. Son figuras arquetípicas. Estos nombres genéricos y abstractos, impersonalizan y engloban a todos y, así, se elimina el carácter individualizador que tiene el aludir a los personajes por sus nombres. En la obra aparece un total de treinta y cinco personajes: Criado, Director, los Caballos Blancos 1, 2, 3 y 4, Hombre 1, Hombre 2, Hombre 3, Elena, Figura de Cascabeles Figura de Pámpanos, Niño, Centurión, Emperador, Julieta, Caballo Negro, el Traje de Arlequín, el Traje de Bailarina, Desnudo Rojo, Enfermero, Estudiante 1, Estudiante 2, Estudiante 3, Estudiante 4, Dama 1, Dama 2, Dama 3, Dama 4, Muchacho 1, Ladrones: Ladrón 1 y Ladrón 2, Traspunte, Prestidigitador y Señora. Algunos de ellos sufren diversas metamorfosis.

Con la ayuda de las acotaciones y el diálogo entre los personajes, podemos caracterizar a los diferentes que van formando parte del conjunto de la obra teatral. A continuación, definiremos física y emocionalmente, por los datos que se nos muestran en el texto, a los personajes por orden de aparición en este:

\subsubsection{1.- El Pastor Bobo}

El teatro, como representación, como máscara que encubre ciertos aspectos superficiales de la realidad está unido al carnaval. «Lo carnavalesco es un signo de liberación del peso ejercido por la norma oficial sobre el comportamiento humano» (Hermenegildo 1995, 13) Este espíritu festivo y popular lo encontramos en los pastores simples, bobos y graciosos del teatro clásico español. Según expone Alfredo Hermenegildo, la línea evolutiva del Pastor Bobo tiene sus inicios en el pastor rústico de los primitivos autos, farsas, y comedias de finales del siglo XV y principios del XVI, hasta llegar al pastor simple, al bobo y al gracioso de Lope de Vega, Tirso de Molina o Calderón de la Barca. Los rasgos característicos del pastor rústico bufón, de la figura carnavalesca y del loco festivo se manifiestan en forma de pastor simple, de bobo, de gracioso $(1995,10)$. 
La figura del Pastor Bobo tiene influencia del bufón o la figura del donaire clásico. La figura del bufón nos llega de la Edad Media, en una época en que la vida estaba reprimida y subyugada a la jerarquía, donde el siervo sólo podía obedecer al señor, el bufón permitía romper esquemas, alterar el orden establecido y reírse del poder y de la vida seria (Bajtin [1987] 1995, 88).

La descripción del personaje, «el PASTOR BOBO viste de pieles bárbaras y lleva en la cabeza un embudo lleno de plumas y ruedecillas» (Loa del Pastor Bobo, 99). Según Rubia Barcia,

el Pastor nos hace patente que se trata de una humanidad de ovejas, ante las cuales la inteligencia es superflua, de ahí el calificativo de bobo del Pastor y la reacción de sus ovejas en balidos de aprobación y suspiro, mientras él se entretiene y piensa entretener a sus seguidores con canto y música $(1986,393)$.

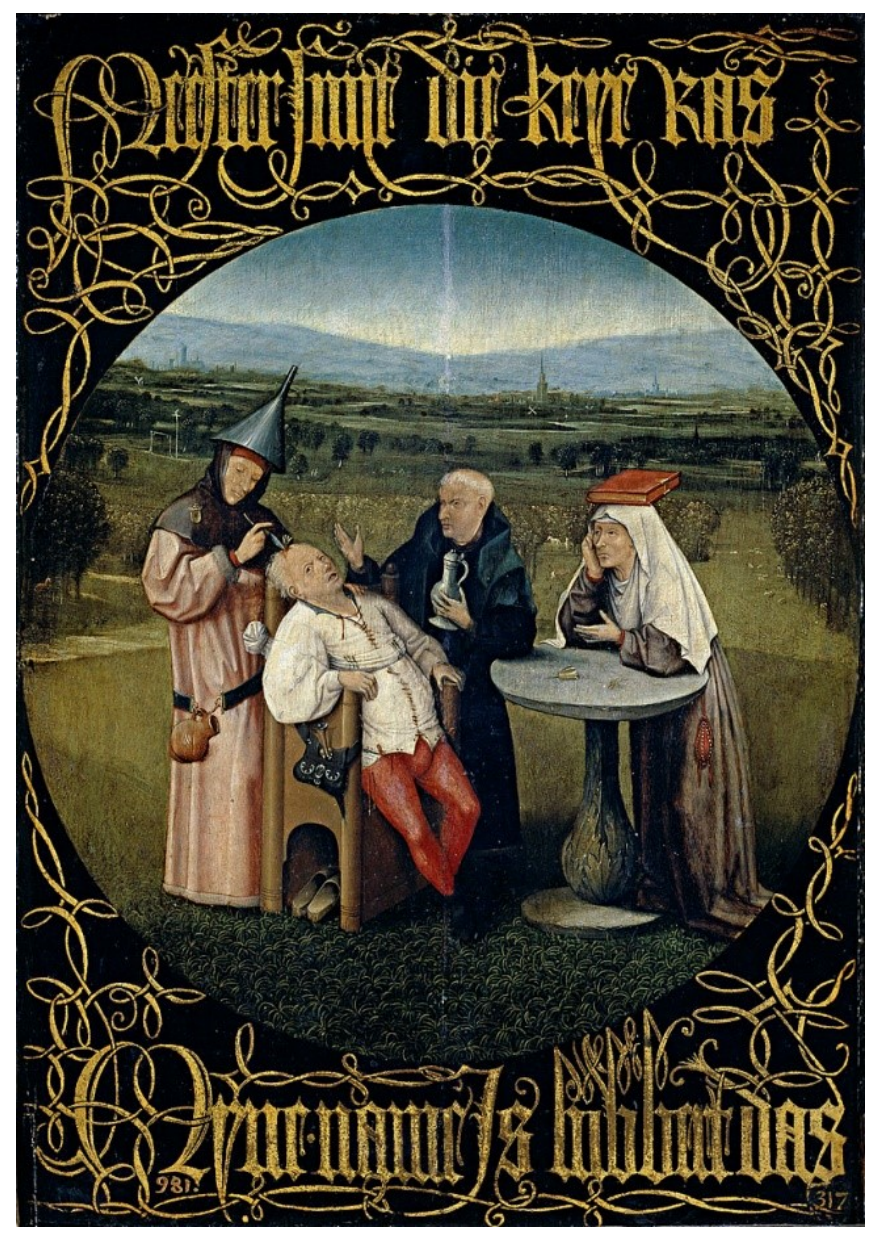

Fig. 85: La extracción de la piedra de la locura (1501-1505). Óleo sobre tabla de madera de roble, 48,5 x $34,5 \mathrm{~cm}$. 
El embudo de la cabeza del Pastor nos recuerda a la obra pictórica de El Bosco en la Extracción de la piedra de la locura (entre 1475 y 1480). En la Edad Media, según la tradición popular, la locura se asociaba a una piedra alojada en el cerebro. En la pintura, el Bosco nos muestra una operación quirúrgica, en la que el charlatán o falso cirujano lleva un embudo invertido por birrete, y extrae al paciente un tulipán de lago, una especie de nenúfar, en vez de una piedra. El embudo invertido era símbolo del engaño; de este modo, El Bosco pone al descubierto que el falso cirujano no es un sabio, sino un estafador.

\title{
9.1.2.2.- Criado
}

El criado, al pasar tras el biombo, no sufre ningún cambio, ya que es un personaje primitivo y sincero «pasa por detrás del biombo y sale de la misma manera» (Cuadro I, 119). Es un personaje extraño, que apenas habla y que «acompaña siempre al Director, impasible espectador hasta la muerte» (Martínez Nadal [1970] 1974, 70). Es quien indica el inicio y el final de la obra y quien anuncia al director de escena al público que asiste a la representación:

\author{
CRIADO: Señor \\ DIRECTOR: ¿Qué? \\ CRIADO: Ahí está el público \\ DIRECTOR: Que pase (Cuadro I, 103-104).
}

En el último cuadro, como hemos dicho, Federico García Lorca da un carácter cíclico, con el mismo diálogo y personajes.

CRIADO: (Asoma a la puerta temblando, con las manos sobre el pecho.) Señor

DIRECTOR: ¿Qué?

CRIADO: (Cayendo de rodillas.) Ahí está el público

DIRECTOR: (Cayendo de bruces sobre la mesa.) Que pase (Cuadro V, 197-198).

Esta característica circular de la obra ya la había utilizado el autor en diversas situaciones o presentaciones de obras teatrales, Este recurso es utilizado por Lorca para dar una sensación de algo inacabado, o incluso de una acción estática, una situación 
histórica perenne. Como sucede en la primera aparición de Bernarda en la obra teatral La casa de Bernarda Alba:

BERNARDA (a la CRIADA): ¡Silencio!

CRIADA (llorando): ¡Bernarda!

BERNARDA: Menos gritos y más obras. Debías haber procurado que todo estuviera más limpio para recibir al duelo. Vete. No es éste tu lugar (Acto I, 49).

En la última intervención Bernarda, exigirá de nuevo ese silencio del inicio, creando un círculo cerrado en el drama:

BERNARDA: Y no quiero llantos. La muerte hay que mirarla cara a cara. ¡Silencio! ( $A$ otra hija.) ¡A callar he dicho! (A otra hija.) ¡Las lágrimas cuando esté sola! Nos hundiremos todas en un mar de luto. Ella, la hija menor de Bernarda Alba, ha muerto virgen. ¿Me habéis oído? ¡Silencio, silencio he dicho! ¡Silencio!

TELÓN

(La casa de Bernarda Alba, Acto III, 106)

Al igual que en el «Romance sonámbulo» cuya estrofa inicial se repite al final del poema, dándole un carácter de circularidad, de eterno retorno:

Verde que te quiero verde.

Verde viento. Verdes ramas.

(Romancero gitano [1925] 2012, 67-71).

\subsubsection{3.- Director (Enrique)}

Toda la obra El público gira en torno a un personaje principal, el Director. Lorca nos presenta una realidad confusa, difícil de delimitar, ya que toda la acción podría estar ocurriendo en la mente del Director, siendo un sueño, una pesadilla o incluso el delirio antes de la muerte del propio personaje. Por sus acciones y pensamientos, también podemos comparar al personaje del Director con el propio Federico García Lorca. Según Martínez Nadal, se debe a que el personaje «por las ideas que expresa sobre el teatro, sobre la soledad del hombre, sobre la libertad amorosa, sobre la muerte, son, en gran medida, ideas de Lorca» ([1970] 1974, 70). 
El Director, protagonista del drama, es un hombre con un doble problema: el individual y el social. Individualmente, el Director tiene un conflicto de identidad amorosa, él quiere renunciar a la condición de un amor heterosexual con Elena y poder tener un hijo, y mostrar su verdadero sentimiento homosexual. En el ámbito social y colectivo, el Director debe abandonar su teatro convencional, «el teatro al aire libre», y sustituirlo por un teatro vanguardista, «el teatro bajo la arena».

Estos conflictos provocarán que el Director sea el personaje que más metamorfosis experimenta durante la obra. Algunas de ellas ocurren al verse forzado por otros personajes a realizarlas, por ejemplo en el Cuadro Primero: el Hombre 2 y el Hombre 3 «empujan al DIRECTOR. Éste pasa por el biombo y aparece por otra esquina un muchacho vestido de raso blanco un una gola blanca al cuello. Debe ser una actriz. Lleva una pequeña guitarrita negra» (Cuadro I, 114-115). Aun siendo una metamorfosis del Director, este sigue estando presente en el escenario y, de este modo, encontramos un nuevo personaje que surge al profundizar dentro del mismo. Según avanza la obra, va adentrándose en su interior.

A partir de ahora, el Hombre 1, al dirigirse al Director, utiliza el nombre de Enrique ${ }^{226}$. Como hemos dicho, casi todos los personajes utilizan nombres genéricos, son pocos los nombres propios que aparecen en el texto. Entre los primeros que surgen en la obra, encontramos a Enrique ${ }^{227}$ (hacia la mitad del primer cuadro). El Director se resiste a esas transformaciones y llama a Elena, a la que el Hombre 1 se niega a su venida, porque ella representa todas las máscaras de las que quiere desprender al Director.

DIRECTOR: [...] ¡Elena! ¡Elena!

HOMBRE 1: (Fuerte) No llames a Elena.

DIRECTOR: ¿Y por qué no? Me ha querido mucho cuando mi teatro estaba al aire libre. ¡Elena! (Cuadro I, 117).

Elena representa a la mujer que amaba al Director cuando este sólo dirigía el teatro al aire libre, cuando todo era más superficial y falso, ocultando todos los seres, debajo de una máscara tras otra, sin reconocerse a uno mismo ni al otro. Por eso, cuando el

\footnotetext{
${ }^{226} \mathrm{El}$ nombre Enrique aparece en el poema neoyorquino «Fábula y rueda de los tres amigos», en el que también se observan los continuos desdoblamientos de los personajes y en Comedia sin título.

${ }^{227}$ Etimológicamente el nombre Enrique tiene un origen germánico heim-riech [casa poderosa] que significa el que manda o gobierna en la casa (Rubia Barcia 1986, 393; Bas i Vidal 2004, 112).
} 
Director tiene miedo a quitarse la máscara, pide auxilio y grita su nombre. Más adelante, desarrollaremos con mayor amplitud el análisis del personaje de Elena.

\subsubsection{4.- Los cuatro caballos: Caballo Blanco 1, Caballo Blanco 2, Caballo Blanco 3 y Caballo Blanco 4}

Los cuatro caballos: Caballo Blanco 1, Caballo Blanco 2, Caballo Blanco 3 y Caballo Blanco 4, «entran cuatro CABALLOS BLANCOS [...] tocan sus trompetas» (Cuadro I, 105) a escena. La siguiente acotación que describe a los caballos nos informa de la acción de estos: «los CABALLOS sacan largas trompetas doradas y danzan lentamente al son de su canto» (Cuadro I, 105). Estos caballos irán evolucionando desde el comienzo, que representan más la parte animal y no racional, hasta llegar a su parte más dialogada y racional para intentar convencer tanto al Director como a Julieta. Los cuatro caballos encarnan los deseos reprimidos.

En un principio los cuatro caballos son un grupo que actúan al unísono, sin presentar ninguna personalidad diferenciada, aunque luego uno de ellos destacará, se trata del Caballo Blanco 1 que intentará conquistar a Julieta en el Cuadro de la «Ruina romana». Podríamos relacionar este caballo con impulso erótico indómito con el que aparece en Bodas de Sangre en el que monta Leonardo, o también a Garañón todo blanco, golpeador del muro y tentación de Adela, el caballo de Pepe el Romano en La casa de Bernarda Alba.

\subsubsection{5.- Los tres hombres: Hombre 1, Hombre 2 y Hombre 3}

Desde el Cuadro Primero aparecen los tres hombres: Hombre 1, Hombre 2 y Hombre 3. Entran por vez primera a escena «vestidos de frac exactamente iguales. Llevan barbas $^{228}$ oscuras» (Cuadro I, 106). De entre los tres hombres sólo uno quiere desenmascarar al Director: el Hombre 1, que podría encarnar el tipo de homosexual que

\footnotetext{
${ }^{228}$ Según Morales y Marín, en simbología la barba significa «autoridad. También virilidad y sabiduría» $(1984,71)$. Mal cuidada es símbolo de locura. En el Cantar del Mio Cid se hace referencia durante todo el poema al tamaño de la barba de la figura del Cid «el de la barba vellida», «la barba tenía larga», «barba tan cumplida», «bien barbado», «el de la luenga barba», y «el de la barba» para reflejar la personalidad de alguien con sabiduría, que sabe mediar, dar consejos, y poner fin a los enfrentamientos. Acceso en abierto al Cantar del Mio Cid en la página del Instituto Cervantes http://www.cervantesvirtual.com/portales/cantar_de_mio_cid/.
} 
en la «Oda de Walt Whitman» Lorca los define como « los puros, los clásicos» ([1988] 2013, 207) en contraposición al Hombre 2 y Hombre 3 que representan al homosexual que Lorca desprecia.

Durante la obra son varios personajes los que se dirigen al Hombre 1 con el nombre de Gonzalo $^{229}$, según afirma Rafael Martínez Nadal, quien está concebido como «el buscador de una belleza ideal» $(1970,67)$.

Como expone María Clementa Millán, «el Hombre 1 basa la autenticidad de su amor por el Director precisamente en la ausencia de la máscara y, por tanto, en la falta de hipocresía en su relación» ([1987] 2012, 50). El Hombre 1 expresa la hipocresía y falsedad en la vida personal:

HOMBRE 1: Yo no tengo máscara.

DIRECTOR: No hay más que máscara.

$[\ldots]$

HOMBRE 1: (Al DIRECTOR) Mi lucha ha sido con la máscara hasta conseguirte verte desnudo. (Lo abraza) (Cuadro III, 158).

Como ya hemos destacado, el personaje del Hombre 1 es el único sin máscara y de los pocos con nombre propio, Gonzalo. Al darle nombre, Lorca quiere individualizarlo y personalizarlo. El Hombre 1 obliga a los personajes a pasar por detrás del biombo que revela al verdadero yo que llevamos dentro, despojado de la apariencia y la máscara que es como un escudo en la sociedad para ocultar la verdadera identidad:

HOMBRE 1: Pero te he de llevar al escenario quieras o no quieras. Me has hecho sufrir demasiado. ¡Pronto! ¡El biombo! ¡El biombo!

$[\ldots]$

HOMBRE 1: [...] (Al DIRECTOR.) Y tú, pasa por detrás del biombo (Cuadro I, 113114).

El Hombre 1 no tiene la necesidad de atravesar el biombo, ya que él no oculta sus deseos ni su verdadera personalidad. Él es fiel al teatro bajo la arena y lucha por la

\footnotetext{
${ }^{229}$ Etimológicamente el nombre Gonzalo tiene un origen germánico procede del medieval gundisalvus (gundi, [lucha]; all, [todo, total]; vus, [dispuesto]) que significa hombre dispuesto totalmente para la lucha (Rubia Barcia 1986, 393; Bas i Vidal 2004, 146).
} 
eliminación de las máscaras. Aunque es el personaje derrotado y cuya agonía finalizará con su muerte.

El Hombre 2 experimenta una metamorfosis cuando «el DIRECTOR empuja bruscamente al HOMBRE $2 y$ aparece por el otro extremo del biombo una mujer vestida con pantalones de pijama negro y una corona de amapolas en la cabeza»:

HOMBRE 2.- (Secamente.) Dame el lápiz.

DIRECTOR.- ¡Ja, ja, ja! ¡Oh Maximiliana, emperatriz de Baviera! ¡Oh mala mujer!.

Hombre 2: (Poniéndose el bigote sobre los labios.) Te recomendará un poco de silencio.

Director: ¡Oh mala mujer! [...] (Cuadro I, 117).

El Director se dirige al Hombre 2 con el nombre de Maximiliana ${ }^{230}$, personaje que encarna a los homosexuales que en la «Oda a Walt Whitman» Lorca los describe como

[...], maricas de las ciudades,

De carne tumefacta y pensamiento inmundo.

Madres de lodo. Arpías. Enemigos sin sueño

del Amor que reparte coronas de alegrías.

Contra vosotros siempre, que dais a los muchachos

Gotas de sucia muerte con amargo veneno.

Contra vosotros siempre,

$[\ldots]$

¡Maricas de todo el mundo, asesinos de palomas!

Esclavos de la mujer. Perras de sus tocadores.

(Poeta en Nueva York [1929] 2013, 206-207).

El Hombre 3 se encuentra en lucha constante con su instinto. Se avergüenza de sus sentimientos, está dispuesto a negar su verdadera naturaleza y finge atracción por el sexo opuesto.

\footnotetext{
${ }^{230}$ El nombre de Maximiliana tiene raíces grecolatinas y significa máximo encanto (Rubia Barcia 1986, 393). Según Javier Huerta Calvo, con este nombre podría referirse a Maximiliana de Baviera, «la condesa de Bayreuth, a la que se debe la construcción del teatro de la ópera de esta ciudad alemana» $(2006,117)$.
} 


\subsubsection{6.- Elena ${ }^{231}$}

Este personaje entra en escena desde el principio de la obra, «viste de griega. Lleva cejas azules, el cabello blanco y los pies de yeso. El vestido, abierto totalmente por delante, deja ver sus muslos cubiertos con apretada malla rosa» (Cuadro I, 117).

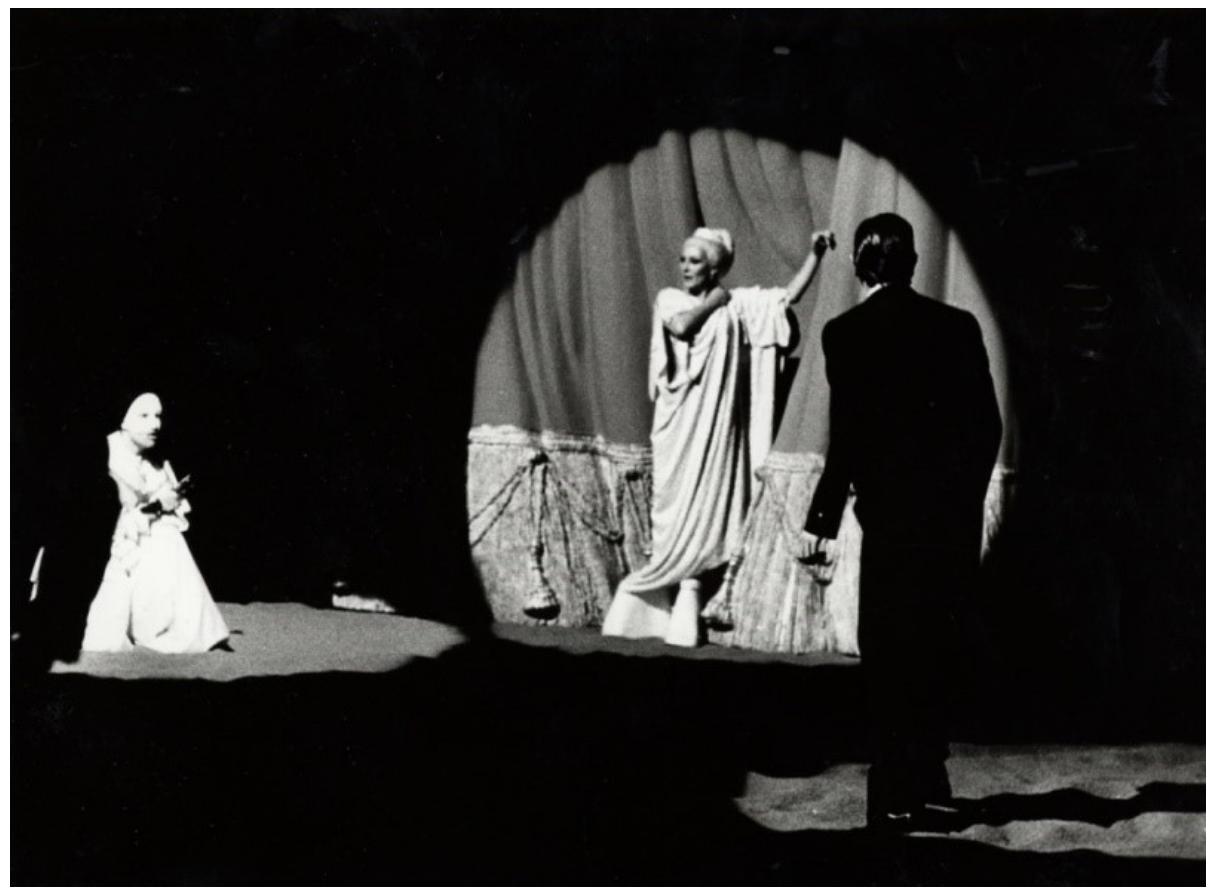

Fig. 86: El momento en que Elena aparece en escena, después de que es llamada a voces. Representación en el Teatro María Guerrero de Madrid, 1987.

Fotografía de Manuel Martínez Muñoz.

Es un personaje que es reclamado en diferentes momentos de la obra, cuando los personajes (el Director, la Figura de Cascabeles y el Hombre 3) se sienten incómodos en situaciones extremas en las que están a punto de descubrir su verdadera identidad y, ante el miedo de desprenderse de la máscara, piden ayuda a Elena que encarna a la mujer en su faceta más negativa, con su vestimenta clásica y marmórea, con sus pies de yeso que la inmovilizan provocando rigidez y falta de libertad, como si se tratara de una escultura clásica.

\footnotetext{
${ }^{231}$ Nombre de origen griego, Helena, con el significado de «luz, brillante, resplandeciente» (Bas i Vidal 2004, 105). Históricamente, el nombre de Elena puede hacer referencia a Helena de Troya, hija de Zeus y Leda, prototipo en la antigüedad como una de las más hermosas mujeres, de irresistible belleza femenina (Rubia Barcia 1986, 393). Como afirma Federico Revilla, aunque es un personaje importante en el ciclo troyano, en la iconografía de «aquel tiempo es más bien escasa. El personaje no sería reactualizado hasta mucho más adelante» ([1990] 2009, 308).
} 


\subsubsection{7.- Figura de Pámpanos}

Así como en el primer cuadro encontramos la dualidad de la pareja del Director y el Hombre 1, en el cuadro segundo, «Ruina Romana», esta dualidad aparece entre las Figuras de Cascabeles y de Pámpanos. En el inicio del cuadro, aparece la acotación con la descripción de este personaje: «una figura, cubierta, totalmente de pámpanos rojos, toca una flauta sentada sobre un capitel» y opinamos, como Ricardo Gullón, que «la figura de pámpanos — alusión a la figura mitológica romana Baco, al vino, a la embriaguez - es el Hombre $1^{\circ}$, Gonzalo, el que cree sin máscara» $(1987,76)$. La flauta es un instrumento musical símbolo del erotismo y de la fecundación (Morales y Marín 1984, 151).

También la Figura de Pámpanos «se despoja de los pámpanos y aparece el desnudo blanco de yeso» (Cuadro II, 135), de ahí su alusión al Hombre 1, incluso al Desnudo Rojo, que muestra todo su desnudez liberándose de todos los trajes y artificios que ayudan a ocultarse tras la máscara.

\subsubsection{8.- Figura de Cascabeles}

Como indica en las acotaciones, la Figura de Cascabeles es «una figura cubierta de cascabeles dorados, [que] danza en el centro de la escena». Según afirma Ricardo Gullón, «la Figura de cascabeles - tintineo sin estridencia, asociado a ligereza, suavidad - es el Director; aquel actúa primero como dominador, habla enérgico, mas cuando el tierno y débil replica “más fuerte”, empieza a ceder» $(1987,76)$.

Según las diferentes acotaciones, este personaje con su juego con Pámpanos es más tímido, y con su danza intenta ocultar su personalidad por miedo a mostrarse ante los demás.

Aunque la Figura de Cascabeles no es exactamente una metamorfosis del Director, sí que advertimos muchas similitudes entre las personalidades de los dos personajes. En la última transformación del Director, él mismo dice ser la Dominga de los negritos y observamos en la acotación cómo «aparece vestido con un maillot todo lleno de pequeños cascabeles» (Cuadro III, 161), para conectar con la Figura de Cascabeles del Cuadro segundo. 


\subsubsection{9.- Niño}

En gran parte del teatro y de la poesía de Lorca aparecen la figura del niño y lo infantil en diferentes manifestaciones. Mariana Pineda tiene dos hijos; Yerma anhela ser madre; la Zapatera tiene, como único amigo, un niño; en Bodas de Sangre se cantan unas nanas: la que canta la Suegra de Leonardo al niño para que se duerma, en el segundo cuadro del acto primero, y la nana dialogada del primer acto entre la Suegra y la Mujer que anticipan los acontecimientos dramáticos que van a ocurrir. Otro tanto en La casa de Bernarda Alba con su madre María Josefa.

Lorca expresa la inocencia de los niños mediante los juegos infantiles, en el vocabulario y en las canciones populares. En su conferencia «Canciones de cuna españolas» ${ }^{232}$ hace un recorrido por toda España a través de todas las canciones y melodías que cantan las mujeres mientras adormecen a sus hijos, y recoge todas estas canciones de cuna en las que «hay una relación delicadísima entre el niño y la madre en el momento silencioso del canto» (Canciones de cuna española [1928] 2020, 45).

Como explica en dicha conferencia, entre las seis versiones que existen de la misma nana popular, Lorca se inspiró en la nana de Granada:

A la nana, nana, nana,

A la nanita de aquel que llevo el caballo al agua

Y lo dejó sin beber

(Canciones de cuna española [1928] 2020, 47).

de la que toma sólo, como motivo, el caballo que no bebe por temor a la presencia de algo misterioso al detenerse el curso del agua. Con la nana se quiere dormir al niño alejarlo del ruido y del mundo exterior.

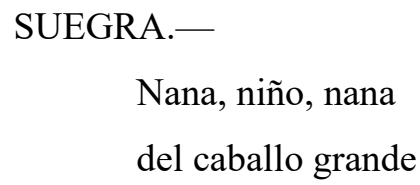

\footnotetext{
232 Desde finales de 2019, la compañía de teatro Ultramarinos de Lucas, con la colaboración de Elena Aranoa, representa dicha conferencia bajo el título Las nanas según Lorca. Conferencia cantada. En junio de 2020, la compañía de teatro El Patio, a partir del trabajo de Ultramarinos de Lucas y Elena Aranoa, realizó una breve adaptación audiovisual de esta conferencia para el Centro Dramático Nacional (León 2020, 65-67).

En el siguiente enlace puede verse la pieza: https://www.youtube.com/watch?v=sCt5tAqDJ_o
} 
que no quiso el agua.

$[\ldots]$

MUJER.-

$[\ldots]$

¡Ay caballo grande

que no quiso el agua!

SUEGRA.-

¡No vengas, no entres!

Vete a la montaña.

Por los valles grises

donde está la jaca.

MUJER (mirando).-

Mi niño se duerme.

SUEGRA.-

Mi niño descansa

(Bodas de sangre [1933]1990, 101-102).

En Yerma, cita una nana de la región de Guadix, también analizada por Lorca en su conferencia:
A la nana, niño mío,
a la nanita y haremos
en el campo una chocita
$y$ en ella nos meteremos

(Canciones de cuna española [1928] 2020, 51).

En la obra teatral Yerma, Lorca expresa el ansia apasionada de la maternidad por parte de la madre en forma de canción lírica mediante un diálogo imaginario entre Yerma y su esperado niño. El niño busca una madre y Yerma se entrega a él:

([...]YERMA se dirige a la costura, se pasa la mano por el vientre, alza los brazos en un hermoso bostezo y se sienta a coser.)

¿De dónde vienes, amor, mi niño?

«De la cresta del duro frío.»

¿Qué necesitas, amor, mi niño?

«La tibia tela de tu vestido.»

$[\ldots]$ 
¿Qué pides, niño, desde tan lejos?

(Pausa)

Los blancos montes que hay en tu pecho

$[\ldots]$

Te diré, niño mío, que sí,

tronchada y rota soy para ti.

¡Cómo me duele esta cintura

donde tendrás primera cuna!

¿Cuándo, mi niño, vas a venir?

(Yerma, Acto I, Cuadro I, 45).

También está presente la figura del niño en el poemario Poeta en Nueva York, con referencias a la muerte del niño, la niñez desamparada, el niño recién nacido, etc. La idea de la muerte del niño está presente en el poema «Ciudad sin sueño»:

y el niño que enterraron esta mañana lloraba tanto

que hubo necesidad de llamar a los perros para que callase.

(Poeta en Nueva York, [1929] 2013, 143).

Y también en el poema «El niño Stanton» con una visión negativa de la madre:

Hay nodrizas que dan a los niños

ríos de musgo y amargura de pie

$\mathrm{y}$ algunas negras suben a los pisos para repartir filtro de rata

(Poeta en Nueva York, [1929] 2013, 143).

En Así que pasen cinco años buscan a un niño que lleve trajecito. Los personajes del Niño y el Gato (que en realidad es gata) acaban de morir, y esperan a ser enterrados. La muerte de un niño, el de la portera en Así que pasen cinco años, representa la muerte de la infancia y la inocencia.

En El público, su intervención es casi mínima, su entrada en escena, según indica la acotación, «Del techo cae un NIÑO vestido con una malla roja», anunciando la llegada del Emperador romano:

NIÑO.— ¡El Emperador!, ¡el Emperador!, ¡el Emperador! (Cuadro II, 131-132). 
El niño muere en manos del Emperador. El poder destruye la inocencia y la infancia y, con el engaño y la violencia, consigue acabar con su vida.

\subsubsection{0.- El Emperador y el Centurión}

El Centurión «de túnica amarilla y carne gris» (Cuadro II, 133), nos recuerda al centurión de la Semana Santa, ya presente en el poema del «Martirio de Santa Olalla»:

Centuriones amarillos

de carne gris, desvelada,

llegan al cielo sonando

sus armaduras de plata.

(Romancero gitano [1981] 2012, 113).

El Centurión representa la visión grotesca de la potencia masculina:

CENTURIÓN. - [...] Mi mujer es hermosa como una montaña. Pare por cuatro o cinco sitios a la vez, [...] Yo tengo doscientos hijos y tendré todavía muchos más (Cuadro II, 134).

La exageración con el número de hijos no deja dudas de su fertilidad. Acompaña al Emperador, personaje que encarna la sexualidad impuesta desde el poder.

\subsubsection{1.- Julieta}

La Julieta de Shakespeare muere trágicamente, su belleza femenina es sacrificada por amor. La Julieta de El público es esa virgen que sale del sepulcro para encontrarse en el teatro bajo la arena y, como afirma Rubio Barcia, sólo resucita en apariencia:

no ha podido resucitar porque no ha vivido, no ha sido fuente de vida ni alimentadora de muerte. Su papel es encarnación o máscara de un amor radical, causa sin efecto. Al final de todo lo que queda del pasado es su pureza virginal, claridad del amianto y la soledad sin puertas navegando por un mar de sueño.

$[\ldots]$ 
Amor estéril e inmortal el de Julieta, de antes de la manzana tentadora de pecado y del tiempo que corre, en contraste con el amor fructífero de la vida temporal. Uno extendido hacia fuera y el otro hundido hacia dentro (1986, 394-395).

Julieta habla con los tres caballos blancos y con el caballo negro, alegorías de Eros y Tánatos.

\subsubsection{2.- Caballo Negro}

«Lleva un penacho de plumas del mismo color y una rueda en la mano» (Cuadro III, 151). La rueda es emblema del tiempo. El paso del tiempo, la muerte. La rueda es un elemento surrealista que aparece en diferentes obras pictóricas, incluso Salvador Dalí recurre a la rueda líquida, como uno de los elementos que aparecen durante el sueño del personaje principal de la película Recuerda (1945) de Alfred Hitchcock.

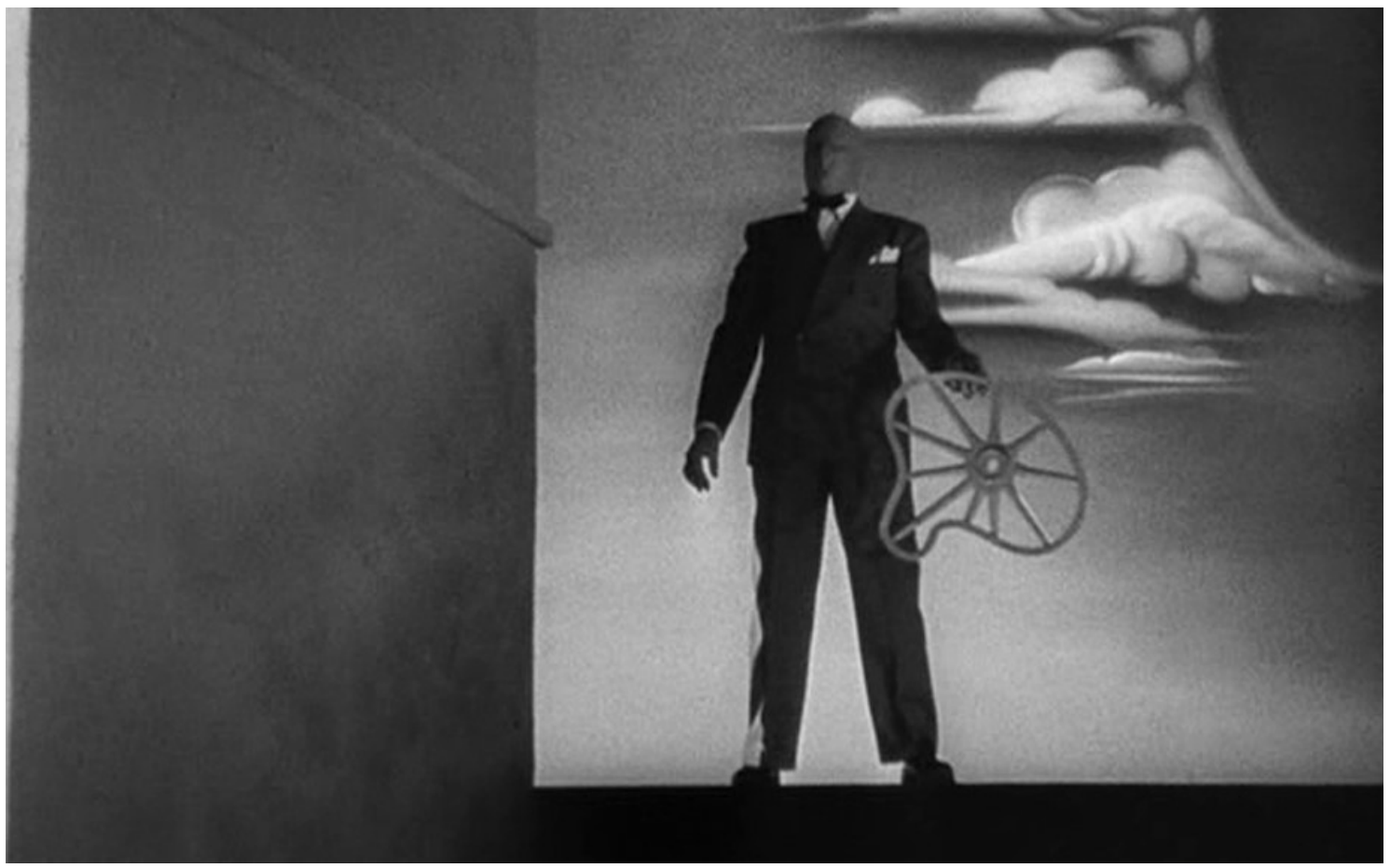

Fig. 87: Personaje misterioso que aparece en el sueño y oculta el motivo de la amnesia del protagonista.

Muchos de los elementos surrealistas utilizados por Lorca en diferentes obras son utilizados posteriormente por otros artistas, como en el caso de Salvador Dalí o René Magritte, entre otros. 


\subsubsection{3.- EI Traje de Arlequín}

El Arlequín es un personaje muy representado en el teatro. En sus inicios, el teatro de Arlequín recibió varios nombres, hasta que en el siglo XVIII adoptó la denominación de la commedia dell'arte. La comedia del arte italiana apareció a mediados del siglo XVI y se extendió rápidamente por casi todos los países de Europa, influyendo en numerosos escritores de la época. Lo que se buscaba era la risa provocada por la comedia derivada del ingenio y del diálogo inteligente, basados en una combinación de lenguaje y acción, no solamente en la mímica (Nicoll 1977, 26-27), lo que ocasionaba la deshumanización de la interpretación de los personajes.

En cambio, en el resto de obras dramáticas, el espectador desconocía a los personajes y por eso, el autor necesitaba presentarlos mediante palabras: su vida y naturaleza. En la commedia dell'arte ${ }^{233}$ «los propios trajes de los comediantes informaban inmediatamente al auditorio sobre quiénes eran y, en consecuencia, dichos actores no tenían que buscar palabras para explicar y caracterizar algo completamente desconocido» (Nicoll 1977, 48). Según representaciones, la cantidad de personajes variaban, ya que estos dependían del número de los actores que formaban la compañía que representaba la obra, normalmente, entre diez o doce personas principales.

El Arlequín mantuvo la misma estética durante el tiempo, destacaba por su agilidad y acrobacias. Joven gracioso, bufón, malicioso que «encarna el temperamento bullicioso, versátil y activo, pero superficial» (Revilla [1990] 2009, 58). La estética visual clásica del Arlequín estaba compuesta por un traje ${ }^{234}$ colorido con rombos. Llevaba un antifaz negro delante de los ojos y un sable de madera en el cinturón. «Es la imagen de lo indeterminado y de lo inconsciente, sin ideas, sin principio, sin carácter. [...] Ser que no

\footnotetext{
${ }^{233}$ Entre los personajes que componían el centro de la acción de las obras de la commedia dell'arte se encontraban "las cuatro máscaras": dos viejos (vecchi) y dos criados (zanni). Entre los dos viejos hallamos a Pantalone e il Dottore y entre los dos criados a Brighella y Arlechino. Pantalone era el viejo veneciano, comerciante tacaño, avaricioso y crédulo. Su máscara correspondía con el águila. Il Dottore era el otro viejo verde de profesión liberal, vecino y compañero de Pantalone. Vestido con un decoroso traje negro, con capa corta, bonete de doctor, gorguera, un par de guantes blancos y un pañuelo metido en el cinturón. Su máscara corresponde con la del toro. Los dos criados eran, uno, astuto y, el otro, bobo. Brighella, el primer criado bufón, cómico y astuto. Vestido con pantalones o calzas ceñidos, lisos, a rayas o con flecos y una chaqueta. Arlechino, el segundo cómico o criado tonto.

Junto a Brighella y Arlechino, la pícara Colombina formaba el grupo de los zannis, el conjunto de los criados. El resto del reparto de la commedia dell'arte lo formaba una serie de criados, como Sacapino, Polichinela, principal rival de Arlequín, y Pierrot; las criadas (serve, servette o fantesche); el Capitano y los Amantes.

${ }^{234}$ Con colores diferentes de paralelogramos romboidales o losanges de distintos colores.
} 
ha conseguido individualizarse, personalizarse, desligarse de la confusión de los deseos, de los proyectos y de los posibles» (Chevalier y Gheerbrant 1993, 139).

La semejanza entre el Pierrot francés y el Arlequín no es sorprendente ya que los dos tenían el mismo origen. Pierotto o Pedrolino era originalmente un criado pero muy diferente al resto de criados. A finales del siglo XVII, pasó a Francia tomando el carácter y la apariencia que le harían universal. En la iconografía, Pierrot suele ir maquillado de blanco con un vestido claro y brillante a juego con una gran gorguera. Pierde las características italianas originales, astucia e ironía, y se convierte en una víctima melancólica del amor no correspondido.

En los años veinte del siglo XX, pintores vanguardistas como Juan Gris y Pablo Picasso, empiezan a representar en sus pinturas a un Arlequín muy distinto al tradicional de la Commedia dell'Arte. Se trata de un personaje más estilizado y con rasgos femeninos.

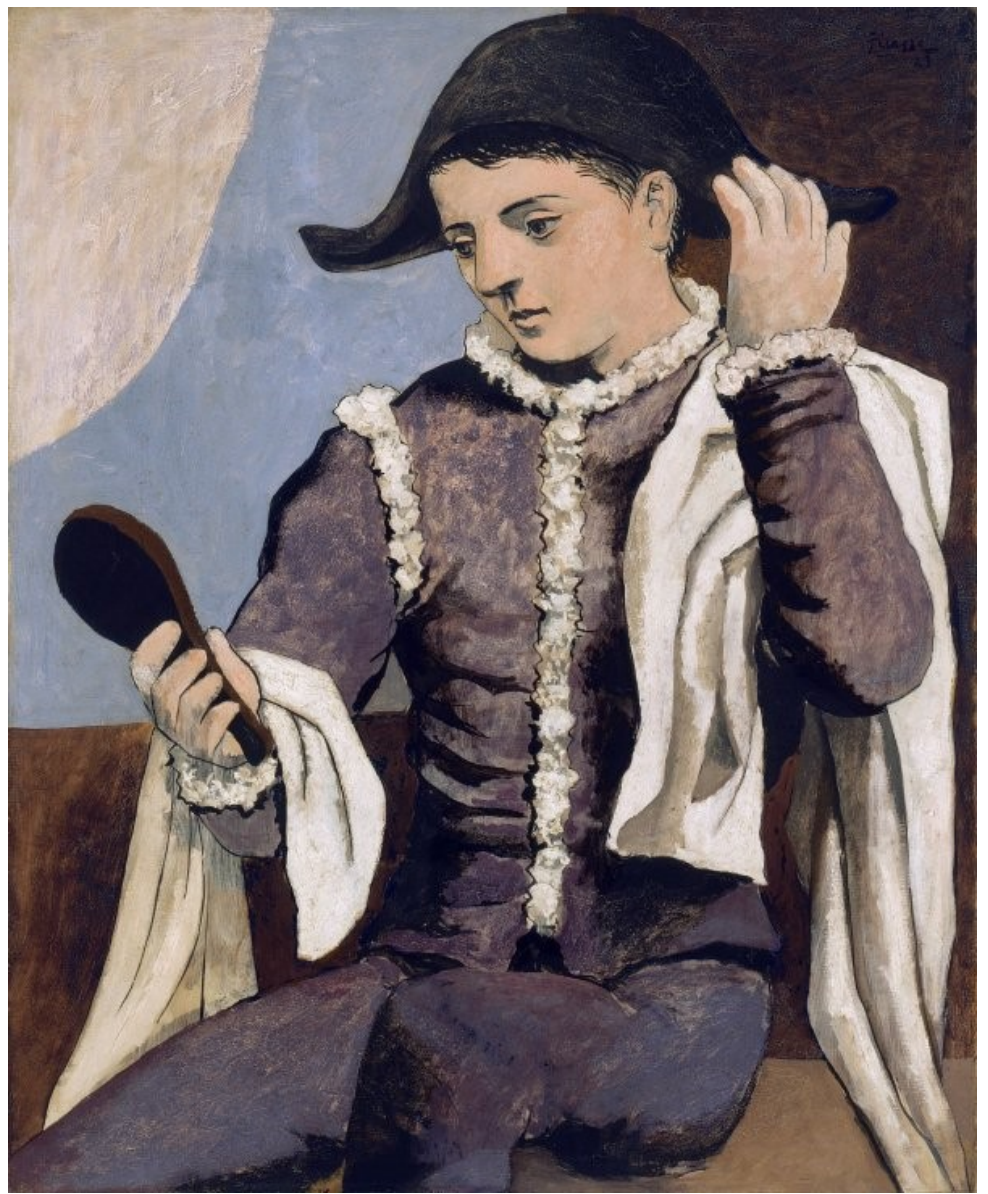

Fig. 88: Arlequín con espejo (1923) de Pablo Picasso. Óleo sobre lienzo, $100 \times 81 \mathrm{~cm}$.

Museo Nacional Thyssen-Bornemisza, Madrid. 
Tanto Salvador Dalí como García Lorca también se sienten atraídos por la moda del arlequín, y en algunas de sus obras lo tratan. Así, Dalí con sus pinturas «Pierrot tocant la guitarra (Pintura cubista)» (1925) y Lorca con sus dibujos de «Pierrot priápico» (1933) (Plaza Chillón 2019, 266-267).

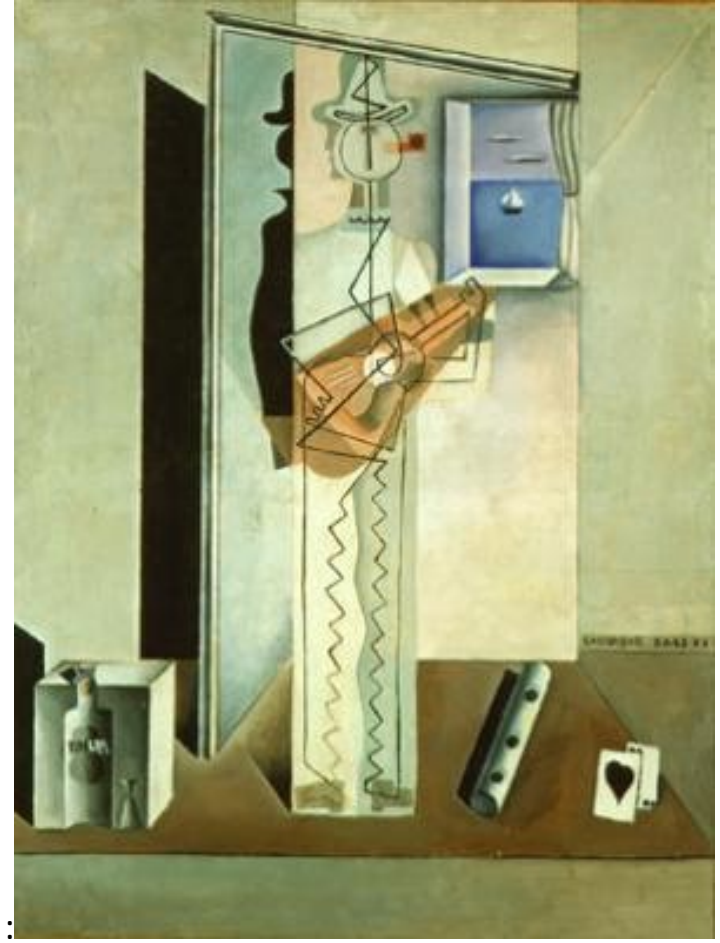

Fig. 89: Pierrot tocant la guitarra (Pintura cubista) (1925) de Salvador Dalí. Óleo sobre lienzo 198 x $149 \mathrm{~cm}$. Museo Nacional Centro de Arte Reina Sofía.

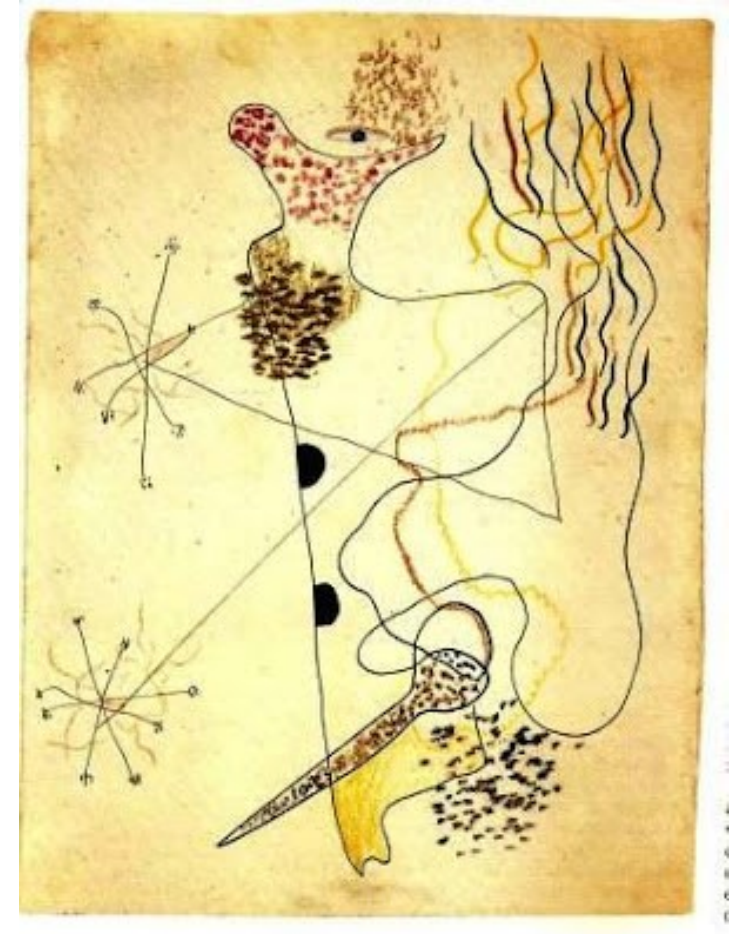

Fig. 90: Pierrot priápico (L'oeil et la rose des vents, según el autor) (ca. 1932-1936) de Federico García Lorca.

Tinta china y lápices de color sobre cartulina recortada, 24,5 x 18,4 cm.

Colección Fundación Federico García Lorca (Legado Jean Gebser).

Aunque en Lorca en la obra teatral El público se dirige al personaje como Traje de Arlequín, toma la apariencia y el carácter del Pierrot francés. Observamos que en el manuscrito, en un principio, utiliza la palabra Pierrot, aunque lo tacha para darle el nombre de Arlequín. Pero en la acotación su vestimenta es más parecida, como hemos dicho, al Pierrot así como por su personalidad melancólica.

El Traje de Arlequín aparece en escena cuando el Director se quita el traje de Enrique y aparece el Traje de Arlequín. Aunque se mueva y hable, no tiene cuerpo, está hueco y vacío, es un personaje deshabitado, despersonalizado y coincide en el escenario con el Director. 
Al quitarse el traje de arlequín, el Director aparece una nueva metamorfosis del mismo vestido de bailarina. El Director niega ser Guillermina (Traje de Bailarina) y afirma ser la Dominga de los negritos, cuando Lorca acota «se arranca las gasas y aparece vestido con un maillot todo lleno de pequeños cascabeles» (Cuadro III, 161) y, al arrojar las gasas detrás de la columna, aparece el personaje de Traje de Bailarina.

Aunque los personajes del negro y la negra surgen a través de las Coplas, entre el siglo XV y XVI, fue en la literatura española del Siglo de Oro donde encontramos en un gran número de publicaciones la presencia de la representación sexualizada de las mujeres negroafricanas a través de dos personajes femeninos: Comba y Dominga. Se popularizó ya que se difundieron entre la población española a través de la literatura de $\operatorname{cordel}^{235} \mathrm{de}$ carácter popular y con textos coloquiales. El personaje de la Dominga aparece en un entremés del siglo XVII, Los negros (1602) del dramaturgo Simón Aguado que versa en torno de la cuestión del matrimonio de dos esclavos negros. Se describe a Dominga de manera burlesca, de gran belleza, joven virgen y dispuesta a tener hijos (Martín Casares 2011 174,183).

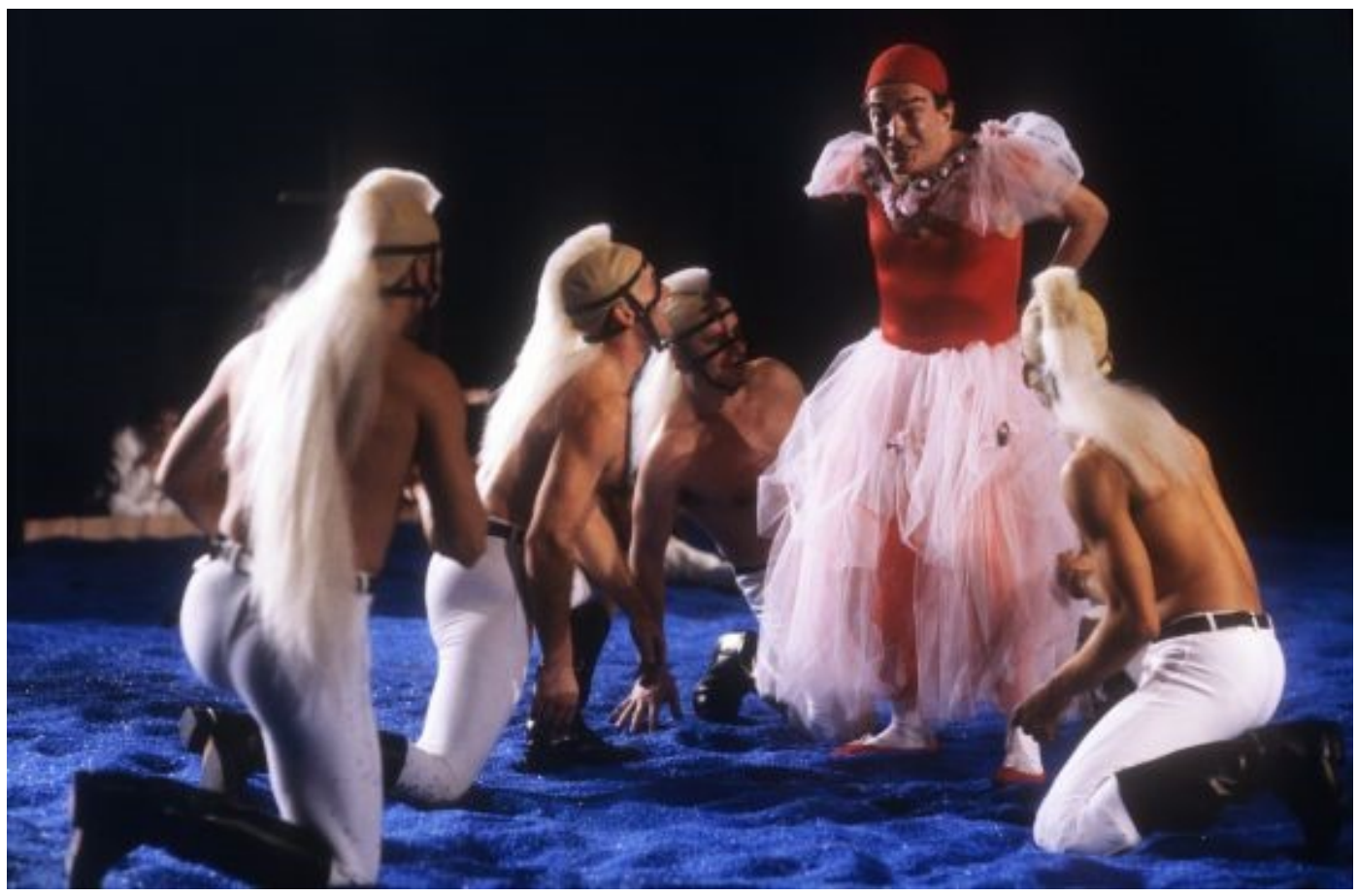

Fig. 91: Los caballos rodean al Director, quien se quitará la vestimenta para dejar de ser Guillermina, metamorfosearse y llamarse la Dominga de los negritos.

235 Consistía en cuadernillos de poesías que los libreros vendían colgados por cuerdas, y sus ventas se realizaban por numerosas ciudades españolas. 


\subsubsection{4.- EI Traje de Bailarina}

De nuevo, junto al Traje de Arlequín, un personaje hueco y vacío. Esta alusión a los pequeños cascabeles puede ayudarnos a relacionar el personaje del Director y la Figura de Cascabeles, siendo una personalidad similar y una relación con las máscaras y la verdad común en ambos.

En definitiva, el Director (Enrique) se muda en Arlequín, durante la escena de «Ruina romana» en Figura de Cascabeles, luego en Bailarina (Guillermina) para finalizar afirmando ser la Dominga de los negritos. Todas estas metamorfosis, que experimenta el Director, tienen una función de búsqueda. Hay que quitar máscara tras máscara, una encima de otra que oculta al verdadero yo, buscando la verdad. Lo que se quiere es eliminar lo postizo (las máscaras) que tiene el personaje, hasta descubrir la esencia verdadera.

\subsubsection{5.- Desnudo Rojo}

Diversos personajes reúnen características similares que significan la sensibilidad del Hombre 1, como son la Figura de Pámpanos y el Desnudo Rojo (Jesucristo). Desnudo Rojo, coronado de espinas azules, en el centro de la escena, en alusión al papel histórico y central del cristianismo. En el siguiente capítulo ampliaremos el valor simbólico de este personaje. El color rojo de la sangre y el azul de la esperanza.

Un equivalente al Desnudo Rojo lo encontramos en el Viaje a la luna con el hombre de las venas, personaje que de despoja de todos los disfraces y muestra su personalidad verdadera y su parte más íntima:

Aparece en la calle el hombre de las venas y queda en cruz. Avanza en saltos de pantalla (Viaje a la luna, 47, 71).

Termina la representación del Desnudo Rojo y entonces «la cama gira sobre su eje y el DESNUDO desaparece. Sobre el reverso del lecho aparece tendido el HOMBRE 1, siempre con frac y barba». El Hombre 1 sustituye, en una última y trágica configuración, al Desnudo Rojo con todo su supuesto simbolismo y, al cerrar los ojos, exclama: «¡Agonía!»: 
DESNUDO. — ¿Cuánto falta para Jerusalén?

ENFERMERO.- - Tres estaciones, si queda bastante carbón.

DESNUDO.- - Padre mío, aparta de mí este cáliz de amargura (Cuadro IV, 171).

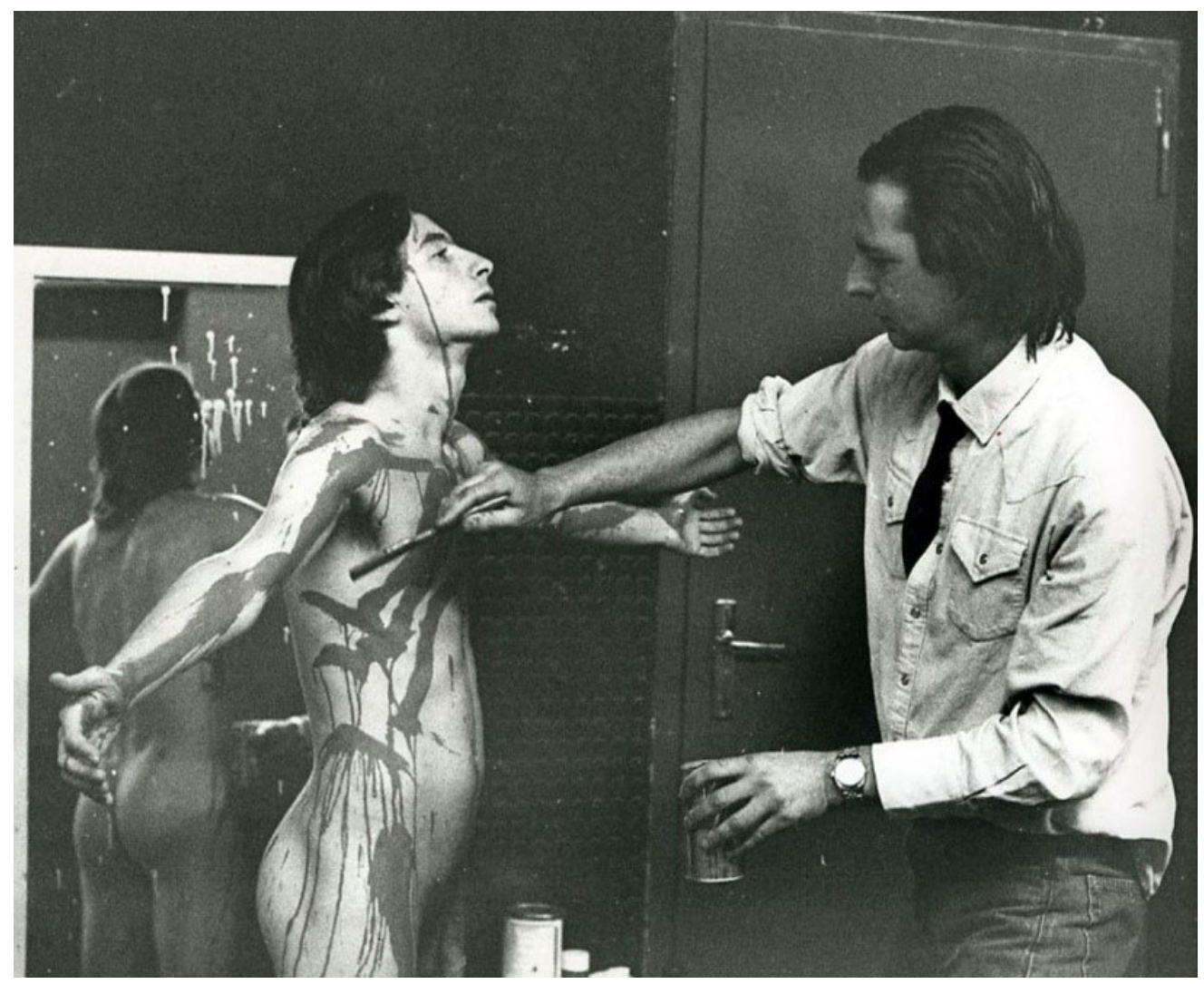

Fig. 92: Frederic Amat maquillando al actor que representa al Desnudo Rojo en la adaptación del 1987 de Lluís Pasqual. Encontramos una semejanza con el hombre con las venas y arterias dibujadas del cortometraje Viaje a la luna realizado por Amat.

\subsubsection{6.- Enfermero}

El enfermero es un personaje que aparece por primera vez en el Cuadro Cuarto, manteniendo una conversación con el personaje del DESNUDO. Al encontrar similitudes de este personaje con Jesucristo, podríamos afirmar que el ENFERMERO corresponde al soldado romano de la crucifixión:

DESNUDO.- - Yo quiero morir. ¿Cuántos vasos de sangre me habéis sacado?

ENFERMERO.- Cincuenta. Ahora te daré la hiel, y luego, a las ocho, vendré con el bisturí para ahondarte la herida del costado (Cuadro IV, 170). 
Es un personaje que, como afirma Martínez Nadal, «se encuentra en una zona fronteriza entre realidad y sueño» ([1970]1974, 70).

\subsubsection{7.- Los estudiantes: Estudiante 1, 2, 3 y 4}

El grupo de estudiantes que aparecen en el Cuadro Cuarto son personajes pertenecientes al mundo real, nos describen lo ocurrido tras la revolución y los estallidos. Como todos los personajes del cuadro anterior, pertenecientes al mundo de los sueños, se convierten en seres reales. El grupo de caballos, que podían expresar sus sentimientos y deseos, son meros animales:

ESTUDIANTE 2.- ¿Y los caballos?

ESTUDIANTE 1.- Los caballos lograron escapar rompiendo el techo de la escena.

ESTUDIENTE 4. - [...] Los vi agrupados por la colina. Iban con el Director de escena (Cuadro IV, 171).

El primer caído por las bombas de la revolución es el profesor de Retórica, disciplina clásica, que representa el declive de una enseñanza caduca:

ESTUDIANTE 4.- - La primera bomba de la revolución barrió la cabeza del profesor de Retórica (Cuadro IV, 172).

Los Estudiantes intentarán encontrar el motivo del estallido de la revolución y, como el público ante el descubrimiento de la verdad detrás de la representación, se sienten engañados. Pero los estudiantes creen que sobre el escenario todo es posible, sin la necesidad de tener su referencia en la realidad. Pero el teatro burgués necesita tener sus referentes en una sociedad y asemejarse a ésta, un teatro decadente en el que su público no acepta ningún cambio:

ESTUDIANTE 4.- La gente se olvida de los trajes en las representaciones, y la revolución estalló cuando se encontraron a la verdadera Julieta amordazada debajo de las sillas y cubierta de algodones para que no gritase.

ESTUDIANTE 1.- Ahí está la gran equivocación de todos y por eso el teatro agoniza. El público no debe atravesar las sedas y los cartones que el poeta levanta en su 
dormitorio. Romeo puede ser un ave y Julieta puede ser una piedra ${ }^{236}$. Romeo puede ser un grano de sal y Julieta puede ser un mapa. ¿Qué le importa esto al público?

ESTUDIANTE 4.- - Nada, pero un ave no puede ser un gato, ni una piedra puedes ser un golpe de mar.

ESTUDIANTE 2.- Es cuestión de forma, de máscara. [...] El público se ha de dormir en la palabra y no ha de ver a través de la columna.

ESTUDIANTE 4.- Por eso ha estallado la revolución. El Director de escena abrió los escotillones, y la gente pudo ver cómo el veneno de las venas falsas había causado la muerte verdadera de muchos niños (Cuadro IV, 175-176).

La referencia a los escotillones de un teatro y cómo hay que abrirlos para dejar ver la verdad que se oculta detrás de la máscara, la encontramos en los versos finales del poema «Ciudad sin sueño»:

Pero si alguien tiene por la noche exceso de musgo en las sienes,

abrid los escotillones para que vea bajo la luna

las copas falsas, el veneno y la calavera de los teatros.

(Poeta en Nueva York, [1929] 2013, 145)

En el que compara a la ciudad con un teatro en el que la humanidad no puede soñar, ya que se encuentra en desesperación y en la soledad individual.

\subsubsection{8.- El Muchacho 1 y las damas: Dama 1, 2, 3 y 4}

También pertenecientes al mundo real, en el Cuadro Cuarto, aparecen junto al Muchacho 1, las cuatro damas que representan al público burgués, escandalizadas ante la revolución teatral. Habían asistido al teatro para contemplar un drama y la revolución lo ha desmontado mostrando la realidad de sus actores:

DAMA 1.- Pero ¿por qué? Era un drama delicioso y la revolución no tiene derecho para profanar las tumbas.

\footnotetext{
${ }^{236}$ Estas palabras ya las pronunciaba el Hombre 1 en el primer Acto.

HOMBRE 1.- Romeo puede ser un ave y Julieta puede ser una piedra. Romeo puede ser un grano de sal y Julieta puede ser un mapa (Cuadro I, 107),

cuando los Hombres van a felicitar al Director de la obra teatral que se estaba representando Romeo y Julieta.
} 
DAMA 2.- Las voces estaban vivas y sus apariencias también. ¿Qué necesidad teníamos de lamer los esqueletos?

MUCHACHO 1.— [...] Yo descubrí la mentira cuando vi los pies de Julieta [...] eran demasiado pequeños para ser pies de mujer. Eran demasiados perfectos y demasiado femeninos. Eran pies de hombre, pies inventados por un hombre.

DAMA 2.- ¡Qué horror! (Cuadro IV, 173-174).

\subsubsection{9.- El Prestidigitador}

El personaje del Prestidigitador aparece por primera vez, en la obra, en el último cuadro. En la acotación nos indica cuál es su vestuario «viste de frac, capa blanca de raso que le llega a los pies y lleva sobrero de copa». Cumple una doble función, el mago del gran teatro del mundo y, a su vez, la imagen de la muerte del Director:

PRESTIDIGITADOR.- - [...] No recuerda que nosotros usamos la cortina oscura.

$[\ldots]$

PRESTIDIGITADOR.- Naturalmente, la cortina del prestidigitador presupone un orden en la oscuridad del truco [...].

$[\ldots]$

PRESTIDIGITADOR.- Yo puedo convertir un navegante en una aguja de coser (Cuadro V, 188-192).

El Director, en el último diálogo, se encuentra agonizante. Él pero quería impulsar una nueva expresión dramática, mostrando el teatro bajo la arena, muere de frío cuando el Prestidigitador, que encarna la muerte, cierra la obra abanicándose:

DIRECTOR.- Tengo frío

PRESTIDIGITADOR.- ¿Cómo?

DIRECTOR.- - Le digo que tengo frío.

PRESTIDIGITADOR.- (Abanicándose.) Es una bonita palabra: frío.

[...]

PRESTIDIGITADOR: (Abanicándose.) ¿Pero es que el frío es cosa mala?

DIRECTOR: (Con voz débil.) El frío es un elemento dramático como otro cualquiera (Cuadro V, 196-197). 


\subsubsection{0.- La Señora}

Este personaje representa a todas aquellas madres que han perdido un hijo, sacrificado por defender la verdad y su identidad. Ella cubre su rostro con un velo negro, en luto, para esconder su dolor y sentimiento por la muerte de su hijo Gonzalo:

$$
\begin{aligned}
& \text { SEÑORA.— ¿Dónde está mi hijo? } \\
& \text { DIRECTOR.— ¿Qué hijo? } \\
& \text { SEÑORA.— Mi hijo Gonzalo (Cuadro V, 194). }
\end{aligned}
$$

Aparece «vestida de negro con la cara cubierta por un espeso tul que impide ver sus rostro» esta descripción nos recuerda al personaje de la Sombra $^{237}$ representado por el propio Federico García Lorca en la escenificación del Auto sacramental La vida es sueño, de Calderón de la Barca, puesto en escena en el Paraninfo Histórico de la Universidad Central de Madrid, en octubre de 1932, por el grupo teatral universitario La Barraca.

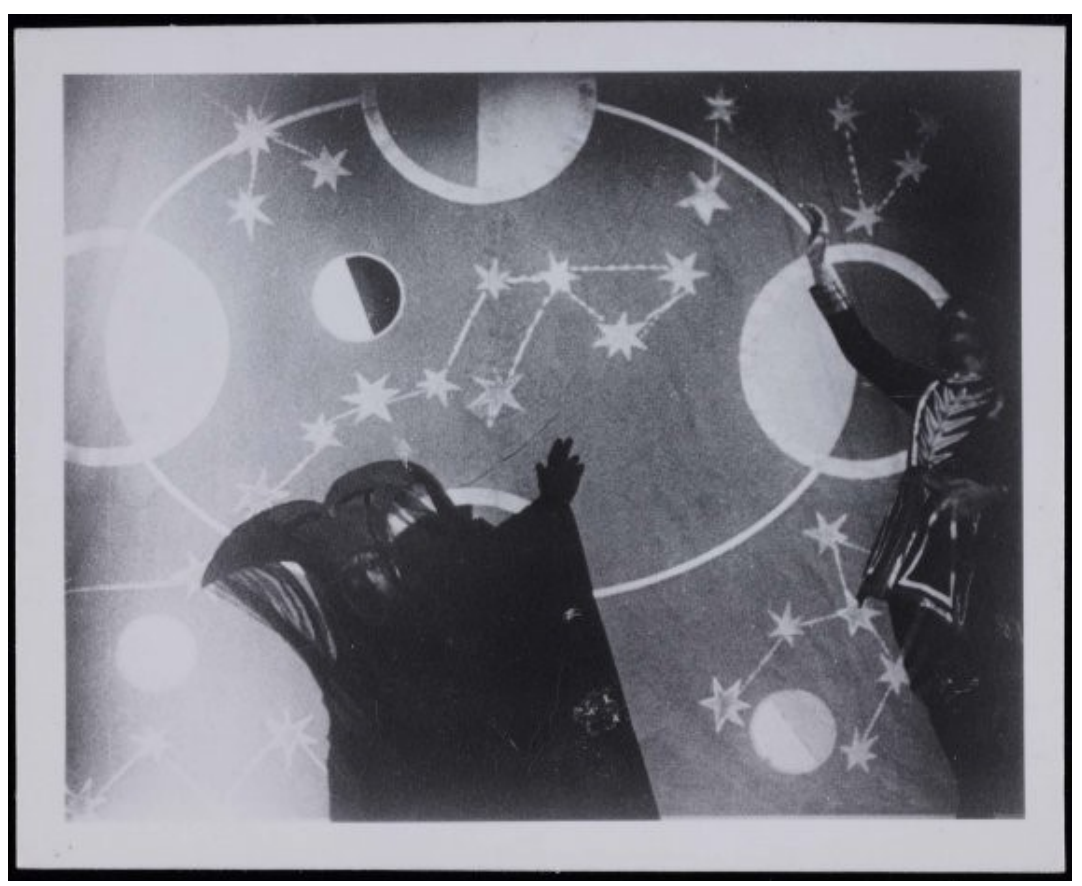

Fig. 93: Fotografía ${ }^{238}$ de Federico García Lorca en el papel de «Sombra» (1932 / Copia posterior).

Gelatinobromuro de plata sobre papel, $12,5 \times 16,9 \mathrm{~cm}$.

\footnotetext{
${ }^{237}$ Sombra es un personaje medular en la obra y lo encarnaba el propio Federico: iba envuelto en amplios tules negros con un tocado bicorne del que pendían también oscurísimos velos (cf. Luis Saénz de la Calzada. La Barraca. Teatro universitario. Madrid: Revista de Occidente, 1976, 53).

${ }^{238}$ La copia se encuentra en el Museo Nacional Centro de Arte Reina Sofía, en depósito temporal, cedido por la Fundación Federico García Lorca desde 2012.
} 


\subsubsection{1.- Los ladrones: Ladrón 1 y 2}

Los personajes de los ladrones los analizaremos, en lo referente a su simbología, en el apartado siguiente. Son dos personajes sin referencias en cuanto a sus descripciones y cuya función casi es, exclusivamente, para situar la acción en un espacio y un tiempo, encontrando gran similitud con la crucifixión de Jesucristo.

\subsubsection{2.- Traspunte}

Es un personaje apenas descrito pero su papel es fundamental para no olvidar que nos encontramos ante una representación, el teatro dentro del teatro. El traspunte es un miembro indispensable para que el actor consiga continuar el texto ante un posible descuido de la memoria, tratándose de un teatro al aire libre, basado en una memorización de un texto sin posibilidad de la improvisación.

\section{2.- Códigos no verbales}

Este tipo de códigos pueden presentarse de diferentes maneras dentro del texto. En las acotaciones encontramos referencias a objetos, movimientos, gestos, etc. que ayudan al director a llevar a escena la obra teatral, indicando cuáles han de ser las gesticulaciones del actor, la vestimenta y maquillaje de los personajes, o ayudarnos a situarnos en un espacio gracias a sus decorados, iluminaciones o la fuerza de su música y sonidos en el avance de la acción.

Estos códigos no están presentes únicamente en las acotaciones, también los podemos localizar dentro del propio diálogo. En las propias palabras de los personajes entrevemos sus sentimientos individuales $\mathrm{y}$, en la relación entre algunos de los personajes, descubrimos las tensiones que surgen en una situación concreta.

Con la información que nos proporcionan las acotaciones y el propio diálogo, podemos presuponer cuál es la intención del dramaturgo para su puesta en escena y para que el público entienda la relación entre los personajes, su papel en el drama y hacia dónde nos lleva el avance de la acción. 
A continuación, vamos a realizar un estudio del extenso número de acotaciones que aparecen en el texto, las dividiremos en diferentes tablas según su categoría. También anotaremos la información que nos proporciona el diálogo para introducir acciones en los personajes, o que anuncian cambios en la trama:

\subsection{1- Expresión corporal}

La expresión corporal de los actores, la distancia a la que se sitúen entre ellos, los gestos, el tono de voz..., todo debe orientarse mediante las indicaciones que nos proporciona el dramaturgo, adquiriendo sentido con relación al texto hablado.

\subsubsection{1.- Mímica-Gesto}

Los elementos gestuales van muy unidos a los tonales aunque, en muchas ocasiones, un gesto no necesita del sonido para expresar un sentimiento. Cierto es que algunos elementos gestuales no se diferencian claramente de los tonales, ya que el gesto va asociado al tono de la voz del personaje.

Según los diferentes gestos que vienen anotados, es el Director el que más expresa sus sentimientos, que van desde la furia, al miedo y al llanto; es comprensible ya que él es quien más forzado está a tomar diferentes decisiones y abandonar su estado de confort. Ya que ha de reconocer su verdadera identidad sexual, su intención de cambiar a un teatro innovador y desprenderse de la máscara de la falsedad social.

Muchos de los personajes lloran, debido a las situaciones a las que los enfrenta el autor: el Hombre 1 que quiere abrir los ojos al Director, Julieta y su soledad ante un amor, o los diferentes trajes huecos, a diferencia del Prestidigitador, que se siente alegre por cumplirse sus propósitos.

\begin{tabular}{|c|c|}
\hline Director & $\begin{array}{l}\text { «Furioso. [...] Llorando» (Cuadro I, 104). } \\
\text { «Temblando» (Cuadro I, 108). } \\
\text { «Llorando» (Cuadro I, 114). } \\
\text { «Frío» siendo el Arlequín Blanco (Cuadro I, 115). } \\
\text { Elena, los tres Hombres y los Caballos, al finalizar }\end{array}$ \\
\hline
\end{tabular}




\begin{tabular}{|c|c|}
\hline & $\begin{array}{l}\text { el cuadro, se quedan «rígidos en sus puestos» } \\
\text { (Cuadro I, 119). } \\
\text { «Llora» (Cuadro III, 140) } \\
\text { «Temblando» de miedo (Cuadro III, 141). } \\
\text { «Displicente» (Cuadro V, 192). } \\
\text { «Llora» (Cuadro V, 194). } \\
\text { «Lleno de temblor» de frío (Cuadro V, 197). }\end{array}$ \\
\hline $\begin{array}{l}\text { Los cuatro } \\
\text { Caballos Blancos: } \\
1,2.3 \text { y } 4\end{array}$ & $\begin{array}{l}\text { «Llorando» (Cuadro I, 104). } \\
\text { Elena, los tres Hombres y el director, al finalizar el } \\
\text { cuadro se quedan «rígidos en sus puestos» (Cuadro } \\
\text { I, 119). }\end{array}$ \\
\hline $\begin{array}{l}\text { Los tres Caballos } \\
\text { Blancos: } 2,3 \text { y } 4\end{array}$ & «Furiosos» (Cuadro III, 154). \\
\hline Hombre 1 & $\begin{array}{l}\text { «Se cubre la cara con las manos» (Cuadro I, 115). } \\
\text { «Llorando» (Cuadro I, 116). } \\
\text { Elena, el Hombre 2, el Hombre 3, el Director y los } \\
\text { caballos, al finalizar el cuadro se quedan «rígidos } \\
\text { en sus puestos» (Cuadro I, 119). } \\
\text { «Entornando los ojos» (Cuadro III, 142). } \\
\text { «Cerrando los ojos» (Cuadro IV, 181). }\end{array}$ \\
\hline Hombre 2 & $\begin{array}{l}\text { «Tímido» (Cuadro I, 116). } \\
\text { Elena, el Hombre 1, el Hombre 3, el Director y los } \\
\text { caballos, al finalizar el cuadro se quedan «rígidos } \\
\text { en sus puestos» (Cuadro I, 119). }\end{array}$ \\
\hline Hombre 3 & $\begin{array}{l}\text { Elena, el Hombre 1, el Hombre 2, el Director y los } \\
\text { caballos, al finalizar el cuadro se quedan «rígidos } \\
\text { en sus puestos» (Cuadro I, 119). } \\
\text { «Se tapa la cara con las manos» (Cuadro III, 140). } \\
\text { «Galante» (Cuadro III, 163). }\end{array}$ \\
\hline Elena & $\begin{array}{l}\text { El Director, los tres Hombres y los caballos, al } \\
\text { finalizar el cuadro se quedan «rígidos en sus } \\
\text { puestos» (Cuadro I, 119). }\end{array}$ \\
\hline $\begin{array}{l}\text { Figura de } \\
\text { Cascabeles }\end{array}$ & $\begin{array}{l}\text { «Tímidamente» (Cuadro II, 126) } \\
\text { «Tembloroso» (Cuadro II, 127). }\end{array}$ \\
\hline
\end{tabular}




\begin{tabular}{|c|l|}
\hline $\begin{array}{c}\text { Figura de } \\
\text { Pámpanos }\end{array}$ & «Angustiado» (Cuadro II, 128). \\
\hline Caballo Negro & «Persuasivo» (Cuadro III, 154). \\
\hline Julieta & $\begin{array}{l}\text { «Llorando» (Cuadro III, 148). } \\
\text { «Llorando» (Cuadro III, 158). } \\
\text { «Temblando» (Cuadro III, 165). }\end{array}$ \\
\hline Traspunte & «Displicente» (Cuadro IV, 185). \\
\hline Traje Arlequín & «Llorando» (Cuadro V, 194). \\
\hline Traje de Bailarina & «Llora» (Cuadro III, 166). \\
\hline Prestidigitador & $\begin{array}{l}\text { «Displicente» (Cuadro V, 192). } \\
\text { «Con gran alegria» (Cuadro V, 198). }\end{array}$ \\
\hline
\end{tabular}

\subsubsection{2.- Tono}

El tono indica la entonación, ritmo, velocidad e intensidad en la voz de los actores y actrices durante la representación. Lorca, en estas acotaciones, muestra el carácter de los personajes y la fuerza en el diálogo que mantienen. El poder que ejerce unos sobre otros, o cómo la acción se precipita a un tono más elevado según sea la tensión de algunos personajes - como encontramos en los diálogos entre el Director y el Hombre 1, la Figura de Cascabeles y la Figura de Pámpanos, los tres Caballos Blancos con Julieta-. Sus conversaciones son tensas y, en ocasiones, violentas, al expresar posiciones enfrentadas. Por eso, sus tonos, aunque empiezan en la misma altura, varían según uno de los miembros de la pareja domina sobre el otro, siendo estas tonalidades opuestas.

\begin{tabular}{|l|l|}
\hline Director & «A voces» (Cuadro I, 113). \\
& «En alta voz» (Cuadro III, 139). \\
& «Fuerte y mirando al HOMBRE 3» (Cuadro III, \\
$140)$. \\
& «Irritado» (Cuadro V, 191). \\
& «Irritado» (Cuadro V, 194). \\
\hline
\end{tabular}




\begin{tabular}{|c|c|}
\hline & «Con voz débil» (Cuadro V, 197). \\
\hline Caballos 1 y 2 & «Furiosos. [...] Reproche» (Cuadro I, 106). \\
\hline $\begin{array}{l}\text { Los tres Caballos } \\
\text { Blancos: } 2.3 \text { y } 4\end{array}$ & «Furiosos» (Cuadro III, 155). \\
\hline Caballo Blanco 1 & $\begin{array}{l}\text { «Burlón» (Cuadro III, 158). } \\
\text { «Riendo» (Cuadro III, 158). }\end{array}$ \\
\hline Hombre 1 & $\begin{array}{l}\text { «Interrumpiendo. [...] Lentamente» (Cuadro I, } \\
\text { 109). } \\
\text { «Fuerte» (Cuadro I, 117). } \\
\text { «Enérgico» (Cuadro III, 139). } \\
\text { «En voz baja» (Cuadro III, 142). } \\
\text { «Inicia el mutis» (Cuadro III, 142). } \\
\text { «Irritado» (Cuadro III, 158). } \\
\text { «Gritando» (Cuadro III, 162). } \\
\text { «Entrando» (Cuadro III, 166). } \\
\text { «Con voz débil» (Cuadro IV, 185). }\end{array}$ \\
\hline Hombre 2 & $\begin{array}{l}\text { «Tímido» (Cuadro I, 116). } \\
\text { «Secamente» (Cuadro I, 117). }\end{array}$ \\
\hline Hombre 3 & $\begin{array}{l}\text { «Suave» (Cuadro III, 144). } \\
\text { «Furioso» (Cuadro III, 163). }\end{array}$ \\
\hline Voz & «Sarcástica» (Cuadro II, 124). \\
\hline $\begin{array}{l}\text { Figura de } \\
\text { Cascabeles }\end{array}$ & $\begin{array}{l}\text { «Tímidamente [...]. Más fuerte [...]. Vibrante» } \\
\text { (Cuadro II, 126). } \\
\text { «Tembloroso» (Cuadro II, 127). } \\
\text { «En voz baja» (Cuadro II, 129). }\end{array}$ \\
\hline $\begin{array}{l}\text { Figura de } \\
\text { Pámpanos }\end{array}$ & $\begin{array}{l}\text { «Enérgico }[\ldots] . \text { Más débil }[\ldots] \text {. Desfallecido» } \\
\text { (Cuadro II, 126). } \\
\text { «Angustiado [...]. Con voz débil» (Cuadro II, 128). } \\
\text { FIGURA DE CASCABELES.— ¿Otra } \\
\text { vez?¿Otra vez estás llorando? (Cuadro II, } \\
\text { 130). }\end{array}$ \\
\hline
\end{tabular}




\begin{tabular}{|c|c|}
\hline Emperador & $\begin{array}{l}\text { «Displicente» (134). } \\
\text { «Suspirando» (Cuadro II, 136). }\end{array}$ \\
\hline Julieta & $\begin{array}{l}\text { «Temblando» (Cuadro III, 147). } \\
\text { «Furiosa» (Cuadro III, 148). } \\
\text { «Enérgica» (Cuadro III, 156). }\end{array}$ \\
\hline Traje de Arlequín & $\begin{array}{l}\text { «Con voz débil» (Cuadro III, 167). } \\
\text { «Con voz cada vez más débil» (Cuadro III, 167). } \\
\text { «Con voz tenue» (Cuadro III, 167). }\end{array}$ \\
\hline Traje de Bailarina & $\begin{array}{l}\text { «lora» (Cuadro III, 166). } \\
\text { «Con voz tenue» (Cuadro III, 167). }\end{array}$ \\
\hline Caballo Negro & «Inquieto» (Cuadro III, 148). \\
\hline Enfermero & $\begin{array}{l}\text { «En alta voz» (Cuadro IV, 180). } \\
\text { «En voz alta» (Cuadro IV, 180). }\end{array}$ \\
\hline Estudiante 4 & $\begin{array}{l}\text { «Irritado» (Cuadro IV, 177). } \\
\text { «Serio» (Cuadro IV, 183). } \\
\text { «Con asombro» (Cuadro IV, 183). }\end{array}$ \\
\hline Estudiante 5 & $\begin{array}{l}\text { «Alegrísimo» (Cuadro IV, 183). } \\
\text { «Rompiendo a reír» (Cuadro IV, 183). }\end{array}$ \\
\hline Señora & «Inicia el mutis» (Cuadro V, 195). \\
\hline
\end{tabular}

\subsubsection{3.- Movimiento (Cinética)}

El movimiento queda encomendado al argumento, los personajes, al espacio y al tiempo. El público es una obra con un elevado número de entradas y salidas de personajes en el escenario, y durante el momento que se encuentran en escena, suelen estar realizando algún tipo de acción. La intención de Lorca es provocar el desconcierto al espectador y romper con las normas clásicas de la línea temporal continua y el espacio fijo por actos. 


\begin{tabular}{|c|c|}
\hline Pastor Bobo & $\begin{array}{l}\text { «Viene por la derecha» (Loa del Pastor bobo, } 99 \text { ). } \\
\text { «Danza con ritmo lento» (Loa del Pastor bobo, } \\
100) \text {. } \\
\text { «Empuja el armario, que va montado sobre ruedas, } \\
\text { y desaparece» (Loa del Pastor bobo, 102). }\end{array}$ \\
\hline Director & $\begin{array}{l}\text { «Sentado» (Cuadro I, 103). } \\
\text { «Golpeando» [al criado] (Cuadro I, 105). } \\
\text { «Se sienta detrás de la mesa» (Cuadro I, 106). } \\
\text { «Pausa [...]. Reaccionado» (Cuadro I, 110). } \\
\text { «Levantándose» (Cuadro I, 112). } \\
\text { «Corre a la puerta» (Cuadro I, 113). } \\
\text { «Los HOMBRES } 2 \text { y } 3 \text { empujan al DIRECTOR. } \\
\text { Éste pasa por detrás del biombo, y aparece por la } \\
\text { otra esquina un muchacho vestido de raso blanco» } \\
\text { (Cuadro I, 114). } \\
\text { «Empuja bruscamente al HOMBRE 2» (Cuadro I, } \\
\text { 116) } \\
\text { «Por detrás [del biombo] sale» junto a los tres } \\
\text { Hombres (Cuadro II, 136). } \\
\text { «Abrazando al HOMBRE 1» (Cuadro III, 142). } \\
\text { El Director y el Hombre 1«Luchan. [...] Luchan } \\
\text { sordamente. [...] Desaparecen luchando por la } \\
\text { derecha» (Cuadro III, 142-143). } \\
\text { «Aparece por la derecha [con el Hombre 1]. [...] } \\
\text { Viene, como en el primer acto, transformado en un } \\
\text { Arlequin blanco» (Cuadro III, 156). } \\
\text { El Director y el Hombre } 1 \text { «luchan» (Cuadro III, } \\
\text { 158). } \\
\text { «Luchando» con el Hombre } 1 \text { (Cuadro III, 159). } \\
\text { «Se arranca las gasas y aparece vestido con un } \\
\text { maillot todo lleno de pequeños cascabeles. Las } \\
\text { arroja detrás de la columna y desaparece seguido } \\
\text { de los CABALLOS» (Cuadro III, 161). } \\
\text { «Fuera» del escenario (Cuadro III, 162). } \\
\text { «Por las escaleras» (Cuadro IV, 185). } \\
\text { «Entra [junto al Prestidigitador]» (Cuadro V, 187). }\end{array}$ \\
\hline
\end{tabular}




\begin{tabular}{|c|c|}
\hline & $\begin{array}{l}\text { «Sentándose en la mesa» (Cuadro V, 192). } \\
\text { «Cayendo de bruces sobre la mesa» (Cuadro V, } \\
\text { 198). }\end{array}$ \\
\hline $\begin{array}{l}\text { Cuatro Caballos } \\
\text { blancos }\end{array}$ & $\begin{array}{l}\text { «Entran» (Cuadro I, 104). } \\
\text { «Danzan lentamente al son de su canto» (Cuadro I, } \\
\text { 105). } \\
\text { «Salen» (Cuadro I, 106). } \\
\quad \text { HOMBRE3.- (A los CABALLOS.) } \\
\quad \text { Tomad asiento donde queráis (CUADRO I, } \\
\quad 116) . \\
\text { «Detrás [del Emperador y el Centurión] vienen [...] } \\
\text { con sus trompetas» (Cuadro II, 133). }\end{array}$ \\
\hline Caballo Blanco 1 & $\begin{array}{l}\text { «Apareciendo» (Cuadro III, 146). } \\
\text { «Acercándose» a Julieta (Cuadro III, 147). } \\
\text { «Baila» (Cuadro III, 151). } \\
\text { «Abrazándolo» al Director (Cuadro III, 160). }\end{array}$ \\
\hline $\begin{array}{c}\text { Tres Caballos } \\
\text { Blancos }\end{array}$ & 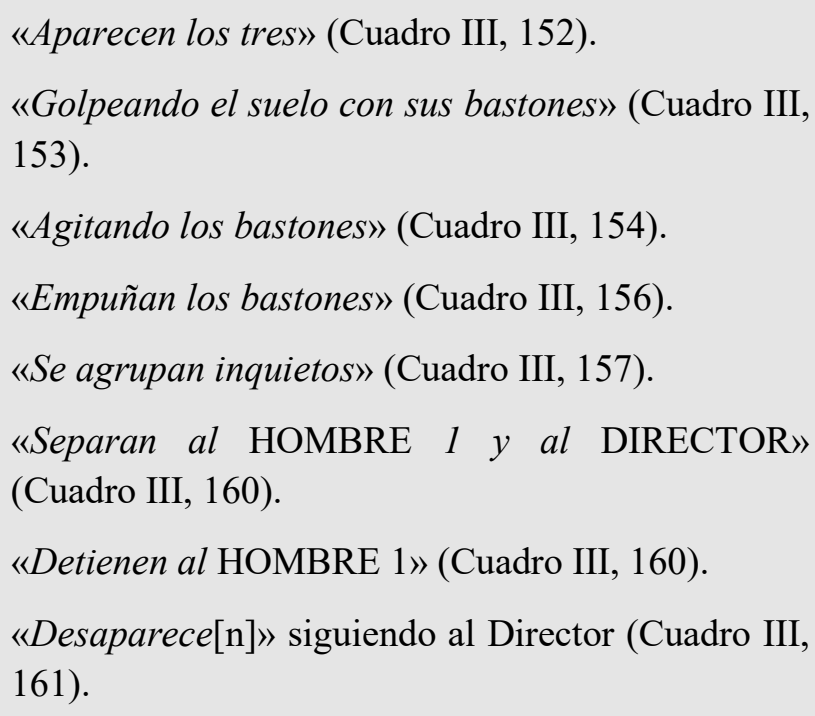 \\
\hline El criado & $\begin{array}{l}\text { «Entra» (Cuadro I, 104). } \\
\text { DIRECTOR.— (Al CRIADO.) ¡Abre las } \\
\text { puertas! (Cuadro I, 105). } \\
\text { «Abre la puerta» (Cuadro I, 106). } \\
\text { «Aparece. [...] Pasa por detrás del biombo y sale } \\
\text { de la misma manera» (Cuadro I, 119). } \\
\text { «Toma en brazos [a Elena]» (Cuadro I, 119). }\end{array}$ \\
\hline
\end{tabular}




\begin{tabular}{|c|c|}
\hline & $\begin{array}{l}\text { «Entrando precipitadamente» (Cuadro V, 194). } \\
\text { «Empuja al TRAJE DE ARLEQUÍN» (Cuadro V, } \\
\text { 196). } \\
\text { «Entrando de haberse llevado el ARLEQUíN» } \\
\text { (Cuadro V, 196). } \\
\text { «Sale [...] por la puerta central» (Cuadro V, 196). } \\
\text { «Desaparece» (Cuadro V, 197). } \\
\text { «Asoma por la puerta temblando, con las manos } \\
\text { sobre el pecho» (Cuadro V, 197). } \\
\text { «Cayendo de rodillas» (Cuadro V, 197). }\end{array}$ \\
\hline Tres hombres & $\begin{array}{l}\text { «Entran» (Cuadro I, 106). } \\
\text { «Por detrás [del biombo] salen los tres HOMBRES } \\
\text { barbados y el DIRECTOR de escena» (Cuadro II, } \\
\text { 136). }\end{array}$ \\
\hline Hombre 1 & $\begin{array}{l}\text { «Se levanta» (Cuadro I, 111). } \\
\text { «Se dirige al fondo y abre la puerta» (Cuadro I, } \\
\text { 114). } \\
\text { «Mirando al DIRECTOR» (Cuadro I, 112). } \\
\quad \text { DIRECTOR._ [...] ¿Cuánto dinero tienes } \\
\quad \text { en el bolsillo? iQuémalo! (Cuadro I, 116). } \\
\text { «Enciende un fósforo y quema los billetes» (Cuadro } \\
\text { II, 116). } \\
\text { «Entrando» (Cuadro III, 138). } \\
\text { El Director y el Hombre 1 «luchan. [...] Luchan } \\
\text { sordamente. [...] Desaparecen luchando por la } \\
\text { derecha» (Cuadro III, 142-143). } \\
\text { «Aparece por la derecha con el DIRECTOR de } \\
\text { Escena» (Cuadro III, 156). } \\
\text { «Abraza» al Director (Cuadro III, 158). } \\
\text { El Director y el Hombre 1 «luchan» (Cuadro III, } \\
\text { 158). } \\
\text { «Luchando» con el Director (Cuadro III, 159). } \\
\text { «Se quieta rápidamente el traje y lo tira detrás de } \\
\text { una columna» (Cuadro III, 160). } \\
\text { «Sale detrás violentamente» (Cuadro III, 162). } \\
\text { «Entrando» (Cuadro III, 166). }\end{array}$ \\
\hline
\end{tabular}




\begin{tabular}{|c|c|}
\hline & $\begin{array}{l}\text { «Abrazando al TRAJE [de Arlequín]» (Cuadro III, } \\
\text { 166). } \\
\text { «Abrazándolo con violencia» al Traje de Arlequín } \\
\text { (Cuadro III. 167). } \\
\text { «Arrojando el TRAJE al suelo y subiendo por las } \\
\text { escaleras» (Cuadro III, 167). } \\
\text { «Sobre el reverso del lecho aparece tendido [...] } \\
\text { siempre de frac y barba negra» (Cuadro IV, 181) }\end{array}$ \\
\hline Hombre 2 & $\begin{array}{l}\text { Y el Hombre } 3 \text { «empujan al DIRECTOR» (Cuadro } \\
\text { I, 114). } \\
\text { «Se saca el lápiz por debajo de la barba y lo } \\
\text { ofrece» al Director (Cuadro I, 116). } \\
\text { «El DIRECTOR empuja bruscamente al HOMBRE } \\
2, \text { y aparece por el otro extremo del biombo una } \\
\text { MUJER vestida con pantalones de pijama negro» } \\
\text { (Cuadro I, 116). } \\
\text { «Abrazando al HOMBRE 1» (Cuadro III, 141). } \\
\text { «Luchan. [...] empuja al HOMBRE } 3 \text { y } \\
\text { desaparecen por el lado opuesto» (Cuadro III, 144). } \\
\text { Junto al Hombre } 3 \text { «Aparece por la izquierda [...] } \\
\text { es la MUJER DE PIJAMA» (Cuadro III, 162). } \\
\text { El TRAJE DE PIJAMA «lo hace desaparecer por } \\
\text { la derecha» (Cuadro III, 164). }\end{array}$ \\
\hline Hombre 3 & $\begin{array}{l}\text { «Se dirige a ELENA y le aprieta las muñecas» } \\
\text { (Cuadro I, 119). } \\
\qquad \text { HOMBRE } 1 .-\quad \text { [...] ¡Pronto! ¡El } \\
\text { biombo! ¡El biombo! (Cuadro I, 133). } \\
\text { «Saca un biombo y lo coloca en medio de la } \\
\text { escena» (Cuadro I, 134). } \\
\text { Y el Hombre } 2 \text { «Empujan al DIRECTOR» (Cuadro } \\
\text { I, 114). } \\
\text { «Pasa rápidamente por detrás del biombo y } \\
\text { aparece sin barba con la cara palidísima y un } \\
\text { látigo en la mano. [...] Azotando al DIRECTOR» } \\
\text { (Cuadro I, 119). } \\
\text { «Se dirige a ELENA y le aprieta las muñecas» } \\
\text { (Cuadro I, 119). } \\
\text { «Entrando» (Cuadro III, 138). }\end{array}$ \\
\hline
\end{tabular}




\begin{tabular}{|c|c|}
\hline & $\begin{array}{l}\text { «Se tapa la cara con las manos. [...] Se sienta en } \\
\text { una silla» (Cuadro III, 140). } \\
\text { «Luchan. [...] [el Hombre } 3 \text { le] empuja [...] y } \\
\text { desaparecen por el lado opuesto» (Cuadro III, 144). } \\
\text { Junto al Hombre } 2 \text { «Aparecen por la izquierda [...] } \\
\text { sin transformar» (Cuadro III, 162). } \\
\text { «Desnuda violetamente» al Hombre } 2 \text { (Cuadro III, } \\
\text { 163). } \\
\text { «Saca del bolsillo una gran capa roja que pone } \\
\text { sobre sus hombros enlazando a JULIETA» (Cuadro } \\
\text { III, 164). } \\
\text { «Junto al sepulcro» (Cuadro III, 166). } \\
\text { «Abraza [a Julieta]» (Cuadro III, 166). } \\
\text { «Abre un paraguas y sale en silencio sobre las } \\
\text { puntas de los pies» (Cuadro III, 166). }\end{array}$ \\
\hline Arlequín blanco & $\begin{array}{l}\text { El Director «pasa por detrás del biombo, y aparece } \\
\text { por la otra esquina un muchacho [...] Debe ser una } \\
\text { actriz» (Cuadro II, 114-115). }\end{array}$ \\
\hline Traje de Arlequín & $\begin{array}{l}\text { «Queda rígido» (Cuadro III, 160). } \\
\text { «Por detrás de la columna aparece el TRAJE de } \\
\text { Enrique. Este personaje es el mismo que el } \\
\text { ARLEQUÍN blanco» (Cuadro III, 162). } \\
\text { «En el suelo» (Cuadro III, 167). } \\
\text { «Entra» (Cuadro V, 194). } \\
\text { «Desaparece por la izquierda [empujado por el } \\
\text { Criado]» (Cuadro V, 196) }\end{array}$ \\
\hline $\begin{array}{l}\text { Mujer vestida con } \\
\text { pantalones de } \\
\text { pijama negro y una } \\
\text { corona de amapolas }\end{array}$ & $\begin{array}{l}\text { «Aparece por el otro extremo del biombo» después } \\
\text { de que el Director empujara al Hombre } 2 \text { (Cuadro I, } \\
\text { 116). }\end{array}$ \\
\hline Elena & «Sale de la izquierda» (Cuadro I, 117). \\
\hline $\begin{array}{l}\text { Los Caballos, el } \\
\text { Director, ELENA y } \\
\text { los tres Hombres }\end{array}$ & $\begin{array}{l}\text { «Los personajes están rígidos en sus puestos» } \\
\text { (Cuadro I, 119) TELÓN LENTO }\end{array}$ \\
\hline Figura de & «Sentado sobre un capitel» (Cuadro II, 122). \\
\hline
\end{tabular}




\begin{tabular}{|c|c|}
\hline Pámpanos & $\begin{array}{l}\text { «Levantándose» (Cuadro II, 127). } \\
\text { «Cayendo al suelo» (129). } \\
\text { FIGURA DE CASCABELES.— [...] } \\
\text { Levántate del suelo, cobarde (Cuadro II, } \\
\text { 130). } \\
\text { «Levantándose» (Cuadro II, 131). } \\
\text { EMPERADOR.- (Al CENTURIÓN) } \\
\text { ¡Desnúdalos! (Cuadro II, 135). } \\
\text { «Se despoja de los pámpanos y aparece un desnudo } \\
\text { de blanco yeso» (Cuadro II, 135). }\end{array}$ \\
\hline $\begin{array}{c}\text { Figura de } \\
\text { Cascabeles }\end{array}$ & $\begin{array}{l}\text { «Danza en el centro de la escena» (Cuadro II, 122). } \\
\text { «Dejando de danzar (125). Acercándose [a } \\
\text { Pámpanos]» (Cuadro II, 129) } \\
\text { «Tira de una columna y ésta se desdobla en el } \\
\text { biombo blanco de la primera escena» (Cuadro II, } \\
\text { 136). }\end{array}$ \\
\hline Niño & $\begin{array}{l}\text { «el techo cae» (Cuadro II, 131). } \\
\text { «En el suelo. [...] Se dirige al EMPERADOR » } \\
\text { (Cuadro II, 133). }\end{array}$ \\
\hline Emperador & $\begin{array}{l}\text { «Aparece. [...] Toma en sus brazos [Al niño][...] y } \\
\text { se pierden en los capiteles» (Cuadro II, 133). } \\
\text { «Aparece [...] limpiándose la frente» (Cuadro II, } \\
\text { 134). } \\
\text { «Abrazándolo» [a la Figura de Pámpanos (desnudo } \\
\text { blanco de yeso)] (Cuadro II, 135). } \\
\text { «Está abrazando a la FIGURA DE PÁMPANOS» } \\
\text { (Cuadro II, 136). TELÓN } \\
\quad \text { DIRECTOR._ [...] ¡El Emperador está en } \\
\quad \text { la ruina! (Cuadro III, 139). }\end{array}$ \\
\hline Centurión & $\begin{array}{l}\text { «Aparece» con el Emperador (Cuadro II, 133). } \\
\text { «Escupe» (Cuadro II, 134). } \\
\text { «Escupiendo» (Cuadro II, 135). }\end{array}$ \\
\hline Julieta & $\begin{array}{l}\text { «Está tendida en el sepulcro» (Cuadro III, 144). } \\
\text { «Saltando del sepulcro» (Cuadro III, 145). } \\
\text { «Retorciéndose las manos» (Cuadro III, 153). }\end{array}$ \\
\hline
\end{tabular}




\begin{tabular}{|c|c|}
\hline & $\begin{array}{l}\text { Tiene miedo a las tres Caballos blancos y «se } \\
\text { refugia con el CABALLO NEGRO. [...] } \\
\text { Rehaciéndose» (Cuadro III, 155). } \\
\text { EL Hombre } 3 \text { la «enlaza» bajo su capa (Cuadro III, } \\
\text { 164). } \\
\text { El Caballo Negro la tiende en el sepulcro, } \\
\text { «Durmiéndose» (Cuadro III, 165). }\end{array}$ \\
\hline Caballo Negro & $\begin{array}{l}\text { «Aparece» (Cuadro III, 151). } \\
\text { «Agitando la rueda» (Cuadro III, 165) } \\
\text { «Coge rápidamente [a Julieta] y la tiende en el } \\
\text { sepulcro» (Cuadro III, 165). } \\
\text { «Saliendo» (Cuadro III, 165). }\end{array}$ \\
\hline Traje de Bailarina & $\begin{array}{l}\text { El Directo «Se arranca las gasas y aparece vestido } \\
\text { con un maillot todo lleno de pequeños cascabeles. } \\
\text { Las arroja detrás de la columna y desaparece } \\
\text { seguido de los CABALLOS. Entonces aparece» } \\
\text { (Cuadro III, 161). } \\
\text { «Cae al suelo dormida»(Cuadro III, 162). }\end{array}$ \\
\hline Traje de Pijama & $\begin{array}{l}\text { «Aparece. [...] Empuja al HOMBRE } 2 \text { y lo hace } \\
\text { desaparecer por la derecha» (Cuadro III, 164). } \\
\text { «Se sienta en las escaleras y golpea su cara lisa } \\
\text { con las manos, hasta el final» (Cuadro III, 164). }\end{array}$ \\
\hline Desnudo Rojo & $\begin{array}{l}\text { «La cama gira sobre un eje y }[\ldots] \text { desaparece» } \\
\text { (Cuadro IV, 181). }\end{array}$ \\
\hline Enfermero & $\begin{array}{l}\text { «Entrando rápidamente» (Cuadro IV, 170). } \\
\text { «Incorpora al DESNUDO y le arregla las } \\
\text { almohadas» (Cuadro IV, 172). } \\
\text { «Mirando el reloj» (Cuadro IV, 180). } \\
\text { Y los ladrones «desaparecen con paso de baile sin } \\
\text { dar la espalda» (Cuadro IV, 181). }\end{array}$ \\
\hline Los Ladrones & $\begin{array}{l}\text { «Por las escaleras bajan» (Cuadro IV, 173). } \\
\text { «Se sientan a los pies de la cama con unos cirios } \\
\text { encendidos» (Cuadro IV, 178). } \\
\text { «Levantando los cirios» (Cuadro IV, 180). } \\
\text { Y el Enfermero «desaparecen con paso de baile sin }\end{array}$ \\
\hline
\end{tabular}




\begin{tabular}{|c|c|}
\hline & dar la espalda» (Cuadro IV, 181). \\
\hline Los Estudiantes & $\begin{array}{l}\text { «Aparecen» (Cuadro IV, 171). } \\
\text { «Discuten» entre ellos (Cuadro IV, 173). } \\
\text { «Salen rápidamente» (Cuadro IV, 177). } \\
\text { «Salen por debajo de uno de los arcos» (Cuadro } \\
\mathrm{IV}, 181) \text {. } \\
\text { «Entran en la Universidad» (Cuadro IV, 185). }\end{array}$ \\
\hline Estudiante 1 & $\begin{array}{l}\text { «Aparte» del Estudiante } 2 \text { y Estudiante } 3 \text { (Cuadro } \\
\text { IV, 173). } \\
\text { «Huyendo por los arcos» con el Estudiante } 5 \\
\text { (Cuadro IV, 185) }\end{array}$ \\
\hline Estudiante 5 & $\begin{array}{l}\text { «Saliendo de los palcos» (Cuadro IV, 177). } \\
\text { «Arrojándole el zapato» al Estudiante } 1 \text { (Cuadro } \\
\text { IV, 184). } \\
\text { «Huyendo por los arcos» con el Estudiante } 1 \\
\text { (Cuadro IV, 185) }\end{array}$ \\
\hline Las Damas & $\begin{array}{l}\text { «Salen precipitadamente de los palcos» (Cuadro } \\
\mathrm{IV}, 173 \text { ). }\end{array}$ \\
\hline Dama 1 & «Por las escaleras» (Cuadro IV, 185). \\
\hline Dama 4 & «Asomándose a los arcos» (Cuadro IV, 179). \\
\hline $\begin{array}{l}\text { Las Damas y el } \\
\text { Muchacho } 1\end{array}$ & $\begin{array}{l}\text { «Salen» (Cuadro IV, 174). } \\
\text { «Aparece[n]» (Cuadro IV, 179). }\end{array}$ \\
\hline Traspunte & $\begin{array}{l}\text { «Aparece» (Cuadro IV, 178). } \\
\text { «Se va» (Cuadro IV, 178). } \\
\text { «Apareciendo» (Cuadro IV, 184). }\end{array}$ \\
\hline Prestidigitador & $\begin{array}{l}\text { «Entra [junto al Director de escena]» (Cuadro V, } \\
\text { 187). } \\
\text { «Golpeando la cabeza de caballo con las yemas de } \\
\text { los dedos» (Cuadro V, 192). } \\
\text { «Mirándolo fijamente» al Director (Cuadro V, 193). } \\
\text { «Pausa» (Cuadro V, 193). } \\
\text { «Se quita la capa y cubre con ella a la SEÑORA. }\end{array}$ \\
\hline
\end{tabular}




\begin{tabular}{|c|c|}
\hline & $\begin{array}{l}\text { Da dos o tres pases con las manos, tira de la capa y } \\
\text { la SEÑORA desaparece. [...] saca un gran } \\
\text { abanico blanco y empieza abanicarse mientras } \\
\text { canta suavemente» (Cuadro V, 196). } \\
\text { «Abanicándose» (Cuadro V, 196). } \\
\text { «Abanicándose» (Cuadro V, 197). } \\
\text { «Sentado cerca de la cabeza de caballo, silba y se } \\
\text { abanica con gran alegría» (Cuadro V, 198). } \\
\text { «Agita con viveza el abanico por el aire» (Cuadro } \\
\mathrm{V}, 198 \text { ). }\end{array}$ \\
\hline Señora & $\begin{array}{l}\text { «Entra» (Cuadro V, 194). } \\
\text { «Va a salir por la puerta de la derecha» (Cuadro } \\
\text { V, 195). } \\
\text { «Desaparece» (Cuadro V, 196). }\end{array}$ \\
\hline
\end{tabular}

La adecuada dosificación de entradas y salidas de los personajes rompen la monotonía y crea un gran contraste. El movimiento de estos dentro del escenario crea situaciones contrarias, los personajes demuestran sentimientos opuestos, tanto individuales contradictorios, como en sus relaciones con el otro. Destacamos el gran movimiento de entradas y salidas de personajes, no únicamente dentro y fuera del escenario, sino que, mediante el biombo, los personajes se mutan en otros seres, al traspasarlo.

A continuación, nombraremos los personajes que aparecen en los diferentes actos:

La Estampa Inicial la forma un único personaje que no volverá a salir en toda la representación, el Pastor bobo.

En el Cuadro Primero, aparecen once personajes: Criado, Director, Caballo Blanco 1, los Caballos; Caballo Blanco 2, Caballo Blanco 3 y Caballo Blanco 4, Hombre 1, Hombre 2, Hombre 3, Elena y Julieta.

En el Cuadro Segundo intervienen siete personajes: Figura de Cascabeles, Figura de Pámpanos, Niño, Centurión, Emperador, Hombre 1 y Director; añádase a ellos una Voz de fuera del escenario. Antes de finalizar el cuadro, también participan con su presencia, pero sin diálogo, los tres Caballos Blancos. 
En el Cuadro Tercero intervienen doce personajes: Hombre 1, Hombre 2, Hombre 3, Director, Julieta, Caballo Blanco 1, Caballo Negro, los 3 caballos blancos 2, 3 y 4, Traje de Arlequín, Traje de Bailarina y Voz Fuera.

En el Cuadro Cuarto intervienen quince personajes: Desnudo, Enfermero, Estudiante 1, Estudiante 2, Estudiante 3, Estudiante 4, Dama 1, Dama 2, Dana 3, Dama 4, Muchacho 1, los Ladrones: Ladrón 1 y Ladrón 2, Traspunte y Hombre 1.

En el Cuadro Quinto aparecen cinco personajes: Director, Prestidigitador, Criado, Señora y Traje de Arlequín. Desde fuera del escenario se puede oír una Voz.

\begin{tabular}{|c|c|c|c|c|c|}
\hline \multicolumn{6}{|c|}{ Tabla de aparición de personajes ${ }^{239}$} \\
\hline LOA & $\begin{array}{l}\text { CUADRO } \\
\text { PRIMERO }\end{array}$ & $\begin{array}{l}\text { CUADRO } \\
\text { SEGUNDO }\end{array}$ & $\begin{array}{l}\text { CUADRO } \\
\text { TERCERO }\end{array}$ & $\begin{array}{l}\text { CUADRO } \\
\text { CUARTO }\end{array}$ & $\begin{array}{l}\text { CUADRO } \\
\text { QUINTO }\end{array}$ \\
\hline \multirow[t]{15}{*}{$\begin{array}{l}\text { Pastor } \\
\text { Bobo }\end{array}$} & Criado & $\begin{array}{l}\text { Figura de } \\
\text { Pámpanos }\end{array}$ & Hombre 1 & $\begin{array}{l}\text { Desnudo } \\
\text { Rojo }\end{array}$ & Director \\
\hline & Director & $\begin{array}{c}\text { Figura de } \\
\text { Cascabeles }\end{array}$ & Hombre 2 & Enfermero & Prestidigitador \\
\hline & Caballo Blanco 1 & Niño & Director & Estudiante 1 & Criado \\
\hline & $\begin{array}{c}\text { Los Caballos } \\
\text { Blancos } 2,3 \text { y } 4\end{array}$ & Centurión & Hombre 3 & Estudiante 2 & Señora \\
\hline & Hombre 1 & Emperador & Julieta & Estudiante 3 & $\begin{array}{l}\text { Traje de } \\
\text { Arlequín }\end{array}$ \\
\hline & Hombre 3 & Hombre 1 & $\begin{array}{c}\text { Caballo Blanco } \\
1\end{array}$ & Estudiante 4 & \\
\hline & Hombre 2 & Director & Caballo Negro & Dama 1 & \\
\hline & Elena & & $\begin{array}{c}\text { Los Caballos } \\
\text { Blancos: } 2,3 \text { y } \\
4\end{array}$ & Dama 2 & \\
\hline & & & $\begin{array}{l}\text { El Traje de } \\
\text { Arlequín }\end{array}$ & Dama 3 & \\
\hline & & & $\begin{array}{l}\text { El Traje de } \\
\text { Bailarina }\end{array}$ & Dama 4 & \\
\hline & & & & Muchacho 1 & \\
\hline & & & & Estudiante 5 & \\
\hline & & & & $\begin{array}{c}\text { Los } \\
\text { Ladrones: } \\
\text { Ladrón } 1 \text { y } 2\end{array}$ & \\
\hline & & & & Traspunte & \\
\hline & & & & Hombre 1 & \\
\hline
\end{tabular}

${ }^{239}$ Con color rojo se indica la aparición de los personajes por primera vez en la obra. 
Lorca se ayuda del efecto de las metamorfosis de sus personajes para encontrar la verdad, al ser la búsqueda de esta uno de los temas principales de la obra. Esta verdad viene escondida detrás de las máscaras, que provocan una falsificación de la realidad inmediata, por eso los personajes van desprendiéndose de las mismas, con la ayuda de las diferentes transformaciones que van sucediendo durante la obra. Todas ellas se revelan cuando atraviesan el biombo, o la columna de la Ruina romana que aparece al final del primer cuadro, en que esta, arrastrada por la Figura de Cascabeles, «se desdobla en el biombo blanco de la primera escena»(Cuadro II, 136). Atravesar el biombo, capaz de descubrir la personalidad oculta de quien lo traspase por detrás, es una acción producida por voluntad propia o mediante la fuerza de otros personajes hacia los seres metamorfoseados.

La primera metamorfosis la encontramos hacia el final del Cuadro Primero. El Director se transforma en «un muchacho vestido de raso blanco con una gola blanca al cuello» tratándose del Arlequín Blanco que aparecerá más tarde en el texto. El Hombre 1 le llama Enrique al dirigirse al Director; el Hombre 2, empujado bruscamente por el Director, aparece transfigurado en una «mujer vestida con pantalones de pijama negro y una corona de amapolas en la cabeza» llamada Maximiliana por el Director y el Hombre 3 no sufre cambios notables al pasar rápidamente por detrás del biombo, «aparece sin barba con la cara palidísima y un látigo en la mano. Lleva muñequeras con clavos dorados». Los Hombres 2 y 3 encarnan algunos rasgos negativos del arquetipo homosexual. También en el Cuadro Primero, el criado «pasa por detrás del biombo y sale de la misma manera», pero este personaje no sufre cambios al atravesarlo.

En el Cuadro segundo los personajes no sufren metamorfosis, aunque, hasta el final del cuadro, no aparece el biombo, tan sólo cuando la Figura de Cascabeles «tira la columna y ésta se desdobla en el biombo blanco»y y por detrás aparecen los tres Hombres barbados y el Director. Existe una similitud entre la pareja de la Figura de Cascabeles y la Figura de Pámpanos, y la del Director con el Hombre 1.

Al inicio del Cuadro tercero, aunque no se indica ningún tipo de metamorfosis, se puede observar cómo el personaje del Hombre 1 se dirige al Director con el nombre de Enrique y cómo el Hombre 2 se dirige al Hombre 1 con el de Gonzalo. Ya al final del cuadro, ocurre una segunda transformación del Director al desprenderse del traje de 
Enrique y «debajo lleva un sutilísimo traje de bailarina». Lanza este detrás de la columna y aparece el de Enrique, que es el personaje del Traje de Arlequín «con una careta amarillo pálido». El atuendo de Arlequín carece de cuerpo aunque se mueva y hable. El propio Director, vestido de bailarina, se dirige a ella como Guillermina, que dará paso a su última metamorfosis. Se arranca el Traje de bailarina y muestra el cuerpo lleno de pequeños cascabeles dorados y se dice llamar la Dominga de los negritos.

\begin{tabular}{|c|c|c|c|}
\hline \multicolumn{4}{|c|}{ Metamorfosis de los personajes } \\
\hline & CUADRO & CUADRO & RCERO \\
\hline \multirow[t]{2}{*}{$\begin{array}{l}\text { Director } \\
\text { (Enrique) }\end{array}$} & \multirow[t]{2}{*}{$\begin{array}{c}\text { Muchacho vestido } \\
\text { de blanco }\end{array}$} & $\begin{array}{c}\text { Bailarina } \\
\text { (Guillermina) }\end{array}$ & $\begin{array}{l}\text { La Dominga de } \\
\text { los negritos }\end{array}$ \\
\hline & & $\begin{array}{c}\text { Traje de Arlequín } \\
\text { blanco }\end{array}$ & $\begin{array}{l}\text { Traje de } \\
\text { Bailarina }\end{array}$ \\
\hline \multicolumn{4}{|l|}{$\begin{array}{l}\text { Hombre } 1 \\
\text { (Gonzalo) }\end{array}$} \\
\hline Hombre 2 & $\begin{array}{l}\text { Mujer vestida con } \\
\text { pantalones de } \\
\text { pijama negro } \\
\text { (Maximiliana) }\end{array}$ & & \\
\hline Hombre 3 & Mínimos cambios & & \\
\hline Criado & Sin cambios & & \\
\hline
\end{tabular}

Los dos personajes principales del drama son el Director y el Hombre 1, desdoblados en Enrique y Gonzalo y en la Figura de Cascabeles y la Figura de Pámpanos, respectivamente. Aun siendo importante el resto de personajes, la acción de la obra se centra, principalmente, alrededor de esta pareja. 


\subsection{2.- Apariencia exterior del actor}

En este punto agrupamos la información que nos proporciona el texto sobre el peinado y el maquillaje de los actores y actrices y acerca del vestuario para representar los diferentes personajes. Estos elementos paraverbales ayudan, tanto al director de escena como a los propios actores, para dar forma y personalidad a sus personajes. El aspecto exterior es lo primero que observa el espectador. Crea una primera impresión que puede variar según cambie la actitud del personaje durante el transcurso de la obra. Y, precisamente, El público es una obra con grandes cambios en los personajes, los cuales se van desprendiendo de varias capas en el aspecto exterior, hasta alcanzar la más radical identidad.

\subsubsection{1.- Maquillaje-Peinado}

Las acotaciones del maquillaje o peinado del actor son mínimas, pero las que encontramos son claras simbologías de lo masculino y lo femenino. Cabe destacar, cómo Lorca utiliza referencias no reales para definir los rasgos femeninos de Elena.

\begin{tabular}{|c|c|}
\hline El Director & $\begin{array}{l}\text { «Cambia su peluca rubia por una morena» (Cuadro I, } \\
106 \text { ). }\end{array}$ \\
\hline $\begin{array}{l}\text { Hombre } 1,2 \\
\text { y } 3\end{array}$ & $\begin{array}{l}\text { «Llevan barbas oscuras» (Cuadro I, 106). } \\
\text { «Barbados» (Cuadro II, 136). }\end{array}$ \\
\hline Hombre 2 & $\begin{array}{l}\text { «Poniéndose el bigote sobre los labios» (Cuadro I, 117). } \\
\text { «Se lleva el bigote a los labios» (Cuadro I, 118). }\end{array}$ \\
\hline Elena & $\begin{array}{l}\text { «Lleva cejas azules, el cabello blanco y los pies de yeso» } \\
\text { (Cuadro I, 117). }\end{array}$ \\
\hline $\begin{array}{l}\text { Hombre } 3 \\
\text { (Al pasar por } \\
\text { el biombo) }\end{array}$ & $\begin{array}{l}\text { «Sin barba con cara palidísima» (Cuadro I, 119). } \\
\text { «Saca del bolsillo una careta de ardiente expresión y se } \\
\text { cubre el rostro» (Cuadro III, 163). }\end{array}$ \\
\hline Centurión & «Carne gris» (Cuadro II, 133). \\
\hline $\begin{array}{l}\text { Traje de } \\
\text { Pijama }\end{array}$ & $\begin{array}{l}\text { «La cara de este personaje es blanca, lisa y comba como } \\
\text { un huevo de avestruz» (Cuadro III, 164). }\end{array}$ \\
\hline
\end{tabular}




\subsubsection{2.- Traje}

La gran variedad de vestuario y de cambios en los personajes es debido a que Lorca se apoya en ellos para transformar su apariencia externa y desarrollar el tema de la casualidad del amor y la de mostrar la verdadera identidad oculta tras la máscara.

El color azul está muy presente en toda la obra, para dar una sensación de sueño. Pero no sólo lo encontramos en el vestuario, también en el decorado, con las cortinas azules del inicio del Solo del Pastor bobo, el decorado azul del primer cuadro; en la iluminación con los arcos y las escaleras teñidas de azul; en el peinado con las cejas azules de Elena y las espinas azules del Desnudo Rojo, entre otros.

Junto al azul, otro color principal en la obra es el blanco, el desnudo blanco de yeso, el biombo blanco, el traje blanco de ópera, la capa blanca del Prestidigitador, etc.

\begin{tabular}{|c|c|}
\hline Pastor Bobo & $\begin{array}{l}\text { «iste de pieles bárbaras y lleva en la cabeza un embudo } \\
\text { lleno de plumas y ruedecillas» (Loa del Pastor Bobo, 99). }\end{array}$ \\
\hline Director & $\begin{array}{l}\text { «Viste de chaqué» (Cuadro I, 103). } \\
\text { «Viene, como en el primer acto, transformado en un } \\
\text { Arlequín blanco» (Cuadro III, 156). } \\
\text { «Se quita rápidamente el traje y lo tira detrás de una } \\
\text { columna. Debajo lleva un sutilísimo TRAJE de bailarina. } \\
\text { Por detrás de la columna aparece el TRAJE de Enrique. } \\
\text { Este personaje es el mismo ARLEQUÍN blanco con una } \\
\text { careta [de] amarillo pálido» (Cuadro III, 160). } \\
\text { «Se arranca las gasas y aparece vestido con un maillot } \\
\text { todo lleno de pequeños cascabeles. Las arroja detrás de } \\
\text { la columna y desaparece [...]. Entonces aparece el } \\
\text { personaje de TRAJE DE BAILARINA» (Cuadro III, } \\
\text { 161). } \\
\text { «Tiene el traje del primer cuadro» (Cuadro V, 187) } \\
\text { «Se pone unos guantes y se sube el cuello del frac» } \\
\text { (Cuadro V, 197) }\end{array}$ \\
\hline $\begin{array}{l}\text { Caballos } \\
\text { Blancos }\end{array}$ & «Traen largos bastones de laca negra» (Cuadro III, 152). \\
\hline $\begin{array}{l}\text { Hombre } 1,2 \text { y } \\
3\end{array}$ & «Vestidos de frac exactamente iguales» (Cuadro I, 106). \\
\hline
\end{tabular}




\begin{tabular}{|c|c|}
\hline $\begin{array}{l}\text { Arlequín } \\
\text { (Al pasar el } \\
\text { Director por } \\
\text { detrás del } \\
\text { biombo) }\end{array}$ & $\begin{array}{l}\text { «Muchacho vestido de raso blanco con una gola blanca al } \\
\text { cuello. [...] Lleva una pequeña guitarra negra» (Cuadro I, } \\
\text { 115). }\end{array}$ \\
\hline Hombre 1 & «Siempre con frac y barba negra» (Cuadro IV, 181). \\
\hline $\begin{array}{l}\text { (Al pasar el } \\
\text { Hombre } 2 \text { por } \\
\text { detrás del } \\
\text { biombo) }\end{array}$ & $\begin{array}{l}\text { «Mujer vestida con pantalones de pijama negro y una } \\
\text { corona de amapolas en la cabeza» (Cuadro I, 116). } \\
\text { «El HOMBRE } 2 \text { es la MUJER DEL PIJAMA negro y las } \\
\text { amapolas del Cuadro I» (Cuadro III, 162). } \\
\text { El Hombre } 3 \text { «Furioso [...] Lo desnuda violentamente, le } \\
\text { quita el pijama, la peluca, y aparece el HOMBRE 2, sin } \\
\text { barba, con el traje del primer cuadro)» (Cuadro III, 163). }\end{array}$ \\
\hline Elena & $\begin{array}{l}\text { «iste de griega }[. . .] \text { el vestido, abierto totalmente por } \\
\text { delante, deja ver sus muslos cubiertos por apretada malla } \\
\text { rosada» (Cuadro I, 117-118). }\end{array}$ \\
\hline $\begin{array}{c}\text { Hombre } 3 \\
\text { (Al pasar el } \\
\text { Hombre } 3 \text { por } \\
\text { detrás del } \\
\text { biombo) }\end{array}$ & $\begin{array}{l}\text { Con «un látigo en la mano. Lleva muñequeras de cuero } \\
\text { con clavos dorados» (Cuadro I, 119). } \\
\text { «El HOMBRE } 3 \text {, sin transformar [...] saca del bolsillo } \\
\text { una careta de ardiente expresión y se cubre el rostro» } \\
\text { (Cuadro III, 162-163). } \\
\text { «Saca del bolsillo una gran capa roja que pone sobre sus } \\
\text { hombres enlazando a JULIETA» (Cuadro III, 164). }\end{array}$ \\
\hline $\begin{array}{l}\text { Figura de } \\
\text { Pámpanos }\end{array}$ & $\begin{array}{l}\text { «Una figura, cubierta totalmente DE PÁMPANOS rojos» } \\
\text { (Cuadro II, 121). } \\
\text { «Se despoja de los pámpanos y aparece un desnudo } \\
\text { blanco de yeso» (Cuadro II, 135). }\end{array}$ \\
\hline $\begin{array}{l}\text { Figura de } \\
\text { Cascabeles }\end{array}$ & $\begin{array}{l}\text { «tra FIGURA, cubierta DE CASCABELES dorados» } \\
\text { (Cuadro II, 121). }\end{array}$ \\
\hline Niño & «Vestido con una malla roja» (Cuadro II, 131). \\
\hline Centurión & «De túnica amarilla» (Cuadro II, 133). \\
\hline Emperador & $\begin{array}{l}\text { «Se quita unos guantes negros, después unos guantes } \\
\text { rojos, y aparecen sus manos de una blancura clásica» } \\
\text { (Cuadro II, 134). }\end{array}$ \\
\hline
\end{tabular}




\begin{tabular}{|c|c|}
\hline Julieta & $\begin{array}{l}\text { «Viste un traje blanco de ópera. Lleva al aire sus dos } \\
\text { senos de celuloide rosado» (Cuadro III, 144). } \\
\text { «El HOMBRE } 3 \text { deja la careta sobre el rostro de } \\
\text { JULIETA y cubre el cuerpo de ésta con la capa roja» } \\
\text { (Cuadro III, 166). }\end{array}$ \\
\hline Caballo Negro & $\begin{array}{l}\text { «leva un penacho de plumas del mismo color y una } \\
\text { rueda en la mano» (Cuadro III, 151). }\end{array}$ \\
\hline $\begin{array}{l}\text { Traje de } \\
\text { Pijama }\end{array}$ & $\begin{array}{l}\text { «MUJER vestida con pantalones de pijama negro y una } \\
\text { corona de amapolas en la cabeza. Lleva en las manos } \\
\text { unos impertinentes cubiertos por un bigote rubio, que } \\
\text { usará sobre su boca en algunos momentos del drama» } \\
\text { (Cuadro I, 116-117). } \\
\text { «Con las amapolas» (Cuadro III, 164). }\end{array}$ \\
\hline $\begin{array}{l}\text { Desnudo } \\
\text { Rojo }\end{array}$ & «Coronado de espinas azules» (Cuadro IV, 169). \\
\hline Estudiantes & «Visten mantos negros y becas rojas» (Cuadro IV, 171). \\
\hline Damas & «Vestidas de noche» (Cuadro IV, 173). \\
\hline $\begin{array}{l}\text { El } \\
\text { Prestidigitador }\end{array}$ & $\begin{array}{l}\text { «Viste de frac, capa blanca de raso que le llega a los pies, } \\
\text { lleva sobrero de copa»(Cuadro V, 187). } \\
\text { «Se quita la capa y cubre con ella a la SEÑORA» } \\
\text { (Cuadro V, 196) }\end{array}$ \\
\hline Señora & $\begin{array}{l}\text { «Vestida de negro con la cara cubierta por un espeso tul } \\
\text { que impide ver el rostro» (Cuadro V, 194). }\end{array}$ \\
\hline
\end{tabular}

\subsection{3.- Aspecto del espacio escénico}

El escenario es un espacio físico por el que, mediante el decorado, los objetos que lo componen y el juego de luces, el dramaturgo crea un ambiente para que la obra tome cuerpo en un lugar específico. En la actualidad, el director de escena toma un gran papel a la hora de llevar a cabo una representación. El dramaturgo escribe un texto, con unas acotaciones, pero es el director de escena quien le imprime personalidad propia a esas indicaciones, llegando a acompañar el nombre del director al título de la obra, dejando, en ocasiones, en un segundo lugar, el nombre del dramaturgo. 


\subsubsection{1.- Iluminación}

La luz teatral es un elemento que puede delimitar el espacio escénico, incluso focalizar la acción, dando más importancia a unos personajes y situaciones determinados. La iluminación no tiene un valor meramente funcional, sino que, en ocasiones, adquiere un significado simbólico: La luz o su falta se manifiesta en las acotaciones. Es un elemento indispensable en la evolución y el progreso del teatro de principios de siglo XX. La utilización de la iluminación en las representaciones es relativamente reciente, su aparición la encontramos a finales del siglo XVII. Los avances eléctricos del siglo XX y la introducción de estos en el uso de la iluminación en el teatro constituyen una renovación general en la escenografía.

En este apartado vendrán expuestos todos aquellos efectos que impliquen un cambio en la iluminación como es el caso de la lluvia, que aunque no es precisamente un efecto lumínico sí produce un cambio de luz en el ambiente, porque la lluvia la relacionamos con una disminución lumínica.

\begin{tabular}{|c|}
\hline $\begin{array}{l}\text { «ada careta tiene su lucecita delante» (Loa del Pastor Bobo, } \\
100)\end{array}$ \\
\hline «Una luna transparente casi de gelatina» (Cuadro III, 137). \\
\hline «Luna» (Cuadro III, 144). \\
\hline «Empieza a llover» (Cuadro III, 163). \\
\hline HOMBRE 3.- $[\ldots]$ Llueve demasiado (Cuadro II, 166). \\
\hline «La escena queda en penumbra» (Cuadro IV, 178). \\
\hline «Levantando los cirios» (Cuadro IV, 180). \\
\hline $\begin{array}{c}\text { «La luz toma un fuerte tinte plateado de pantalla cinematográfica. } \\
\text { Los arcos y escaleras del fondo aparecen teñidos de una } \\
\text { granulada luz azul [...] Los ESTUDIANTES [...] llevan } \\
\text { pequeñas linternas eléctricas» (Cuadro IV, 181). }\end{array}$ \\
\hline $\begin{array}{l}\text { «La escena va quedando en penumbra. Los ESTUDIANTES } \\
\text { enciende sus linternas» (Cuadro IV, 185). TELÓN }\end{array}$ \\
\hline $\begin{array}{l}\text { «La escena está a oscuras. La linterna del MUCHACHO } 1 \\
\text { ilumina la cara muerta del HOMBRE } 1 »(\text { Cuadro IV, 185). }\end{array}$ \\
\hline
\end{tabular}


«Aparece un cielo de nubes largas, vivamente iluminado»

(Cuadro V, 198).

\subsubsection{2.- Accesorios}

En una obra teatral, los accesorios pueden tener una función teatral para identificar un lugar o una situación o pueden cobrar un valor simbólico dentro de la representación.

«Cortina azul. En el centro, un gran armario lleno de caretas blancas de diversas expresiones. Cada careta tiene su lucecita delante» (Loa del Pastor Bobo, 99).

« [el armario] va montado sobre ruedas» (Loa del Pastor bobo, 102)

El HOMBRE 3 «saca un biombo y lo coloca en medio de la escena» 114

El HOMBRE 3 «se saca el lápiz [para los labios]» (Cuadro I, 116).

La FIGURA DE CASCABELES «tira de una columna y ésta se desdobla en el biombo blanco de la primera escena» (Cuadro II, 136).

CABALLO BLANCO 1 «trae una espada en la mano» (Cuadro III, 146)

Los tres CABALLOS BLANCOS «traen largos bastones de laca negra» (Cuadro III, 152).

Los tres CABALLOS BLANCOS «empuñan los bastones y por las conteras de éstos saltan tres chorros de agua» (Cuadro III, 156).

«En el centro de la escena, una cama frente y perpendicular, como pintada por un primitivo» (Cuadro IV, 169) 


\subsubsection{3.- Decorado}

La finalidad del decorado es representar un lugar y un momento. Nos describe el espacio en el que transcurre la acción y a su vez, nos permite situarnos en el tiempo. Aunque no es un elemento indispensable, en esta obra nos permite ubicarnos, según su decorado, en una realidad o representación, en la vigilia o el sueño. Y según sus cambios, nos facilita el avance de la historia, cada vez más profunda.

\begin{tabular}{|c|c|}
\hline $\begin{array}{l}\text { Loa del Pastor } \\
\text { Bobo }\end{array}$ & $\begin{array}{l}\text { «Cortina azul. En el centro, un gran armario lleno } \\
\text { de caretas blancas de diversas expresiones. Cada } \\
\text { careta tiene su lucecita delante }[. . .] \text { montado sobre } \\
\text { ruedas» (99-102). }\end{array}$ \\
\hline Cuadro I & $\begin{array}{l}\text { «Cuarto del DIRECTOR [...] Decorado azul. Una } \\
\text { gran mano impresa en la pared. Las ventanas son } \\
\text { radiografias» (101). }\end{array}$ \\
\hline Cuadro II & $\begin{array}{l}\text { «El HOMBRE } 3 \text { saca un biombo y lo coloca en } \\
\text { medio de la escena» (114). } \\
\text { «La FIGURA DE CASCABELES tira de una } \\
\text { columna y ésta se desdobla en el biombo blanco de } \\
\text { la primera escena» (136). }\end{array}$ \\
\hline Cuadro III & $\begin{array}{l}\text { «Mro de arena. A la izquierda, y pintada sobre el } \\
\text { muro, una luna transparente casi de gelatina. En el } \\
\text { centro, una inmensa hoja verde lanceolada» (137). } \\
\text { «El muro se abre y aparece el sepulcro de } \\
\text { JULIETA en Verona. Decoración realista. Rosales } \\
\text { y yedras. Luna» (144). }\end{array}$ \\
\hline Cuadro IV & $\begin{array}{l}\text { «En el centro de la escena, una cama de frente y } \\
\text { perpendicular, como pintada por un primitivo, } \\
\text { donde hay un DESNUDO ROJO [...]. Al fondo, } \\
\text { unos arcos y escaleras que conducen a los palcos } \\
\text { de un gran teatro. A la derecha, la portada de una } \\
\text { universidad» (169). }\end{array}$ \\
\hline Cuadro V & $\begin{array}{l}\text { «a misma decoración que en el primer cuadro. A } \\
\text { la izquierda una gran cabeza de caballo colocada } \\
\text { en el suelo. A la derecha un ojo enorme y un grupo } \\
\text { de árboles con nubes apoyados en la pared» (187). } \\
\text { «Todo el ángulo izquierdo de la decoración se } \\
\text { parte y aparece un cielo de nubes largas, vivamente } \\
\text { iluminado, y una lluvia lenta de guantes blancos, }\end{array}$ \\
\hline
\end{tabular}


rígidos y espaciados» (198).

«En la escena empiezan a caer copos de nieve» (198). TELÓN LENTO

\subsection{4.- Efectos sonoros}

En este punto se engloba tanto la música como el sonido. El sonido es todo aquello que artificialmente se introduce en una representación, imitando la naturaleza, por ejemplo el sonido de la lluvia; el ruido de objetos, como el tumulto de espadas; o de acciones, los aplausos. Todo ello para proporcionar o colaborar en el sentido de la obra y en el significado a la acción. La música son aquellas composiciones con instrumentos, acompañadas en ocasiones con voces, o sólo estas asociadas a los cantos.

\subsubsection{1.- Música}

Para Lorca, la música es un elemento indispensable en la representación de un espectáculo. Así como hay autores que consideraban que la música era un acompañante innecesario en una historia, y un aditamento antinatural, observamos que, en la mayoría de las obras teatrales de Lorca, la música es un elemento imprescindible ya que su papel es ampliar o subrayar el significado de las palabras, incluso, en ocasiones, contradecirlas.

$\mathrm{Su}$ importancia nos la muestra Lorca tanto en la utilización de instrumentos como también por la introducción de canciones por diferentes personajes. Esto se da en gran parte de sus obras teatrales.

El acompañamiento musical de El público nos viene dado por trompetas ${ }^{240}$, flautas, cascabeles dorados, las cuerdas de una guitarra perdida, etc. No cabe duda alguna de la importancia del sonido musical por la numerosa cantidad de instrumentos que aparecen en el texto. También el canto, ya que los personajes entonan canciones, como personajes tan importantes como Julieta o el Prestidigitador.

\footnotetext{
240 «Instrumento de música utilizado para determinar los principales momentos del día o anunciar los grandes acontecimientos históricos y cósmicos» (Chevalier y Gheerbrant 1993, 1027)
} 


\begin{tabular}{|c|c|}
\hline Pastor Bobo & «Toca un aristón» (Loa del Pastor Bobo, 100) \\
\hline $\begin{array}{l}\text { Los cuatro caballos } \\
\text { blancos }\end{array}$ & $\begin{array}{l}\text { «Tocan sus trompetas. (104) [...] Sacan largas } \\
\text { trompetas doradas y danzan lentamente al son de } \\
\text { su canto. [...] Danzan lentamente al son de canto. } \\
\text { (105) [...] Suenan las trompetas» (114). [...] } \\
\text { Suenan sus largas trompetas» (Cuadro I, 119). } \\
\text { TELÓN LENTO }\end{array}$ \\
\hline El Director & $\begin{array}{l}\text { Trasformado en Arlequín Blanco «Pulsando las } \\
\text { cuerdas [de una pequeñita guitarra negra]» (Cuadro } \\
\text { I, 115). }\end{array}$ \\
\hline $\begin{array}{l}\text { Figura de } \\
\text { Pámpanos }\end{array}$ & «Toca una flauta» (Cuadro II, 121). \\
\hline \multirow[t]{2}{*}{$\begin{array}{l}\text { Figura de } \\
\text { Cascabeles }\end{array}$} & «Danza en el centro de la escena» (Cuadro II, 121). \\
\hline & «Suena una trompa» (Cuadro II, 133). \\
\hline El centurión & «Canta» (Cuadro II, 134). \\
\hline \multirow[t]{2}{*}{ Julieta } & «Canta» (Cuadro III, 145). \\
\hline & «Canta el verdadero ruiseñor» (Cuadro III, 167). \\
\hline El Prestidigitador & $\begin{array}{l}\text { «Canta suavemente» (Cuadro V, 196). } \\
\text { «Silba» (Cuadro V, 198). }\end{array}$ \\
\hline
\end{tabular}

\subsubsection{2.- Sonido}

Si eliminamos la palabra y la música, el ruido que nos queda en escena es el componente que incluiremos en este punto. El sonido que nos interesa describir es el producido con intencionalidad, son ruidos naturales o artificiales, pero reproducidos artificialmente para formar parte de los efectos sonoros de la representación.

«Las careta balan imitando las ovejas y alguna tose» (Loa del Pastor Bobo, 101).

«Las caretas balan» (Loa del Pastor Bobo, 102) FINAL DE LA

LOA DEL PASTOR BOBO 


\begin{tabular}{|c|}
\hline El Director «toca un timbre» (Cuadro I, 104). \\
\hline $\begin{array}{l}\text { La Figura de Pámpanos «Toca un silbato de plata [...] Suena el } \\
\text { silbato otra vez. [...] Suena el silbato» (Cuadro II, 131). }\end{array}$ \\
\hline $\begin{array}{c}\text { «Un grito largo y sostenido se oye detrás de las columnas» } \\
\text { (Cuadro II, 134). }\end{array}$ \\
\hline $\begin{array}{c}\text { «Tumulto de espadas y voces surge al fondo de la escena» } \\
\text { (Cuadro III, 146). }\end{array}$ \\
\hline $\begin{array}{l}\text { «El tumulto de voces y espadas vuelve a surgir en el fondo de la } \\
\text { escena» (Cuadro III, 149). }\end{array}$ \\
\hline $\begin{array}{l}\text { Los tres caballos blanco golpean «el suelo con sus bastones» } \\
\text { (Cuadro III, 153). }\end{array}$ \\
\hline «Se oye la bocina [de un barco]» (Cuadro III, 166). \\
\hline $\begin{array}{l}\text { «Sobre el ruido de la lluvia canta el verdadero ruiseñor» (Cuadro } \\
\text { III, 167). TELÓN }\end{array}$ \\
\hline $\begin{array}{l}\text { «Al levantarse el telón se oye una salva de aplausos» (Cuadro IV, } \\
169) .\end{array}$ \\
\hline «Se oye una salva de aplausos» (Cuadro IV, 172). \\
\hline $\begin{array}{l}\text { «Del teatro llegan murmullos y ruido de espadas» (Cuadro IV, } \\
174) .\end{array}$ \\
\hline «Se oye una campana» (Cuadro V, 180). \\
\hline
\end{tabular}




\section{0.- Análisis semiótico teatral: Nivel semántico}

A continuación, en este punto analizaremos el espacio y el tiempo en el que transcurre la acción. Un espacio en ocasiones compartido por diferentes actuaciones entrecruzadas pero independientes entre ellas, y un tiempo muy poco definido: mostrarnos una acción sin tiempo ni espacio delimitados y concretos. Ello nos produce una sensación de ensueño, dudando si lo vivido es real, sueño del autor, o cercano a la muerte. La historia avanza sin ser lineal, en varias ocasiones regresamos a situaciones ya vividas, y sus escenarios están difuminados, de ahí la simultaneidad de las acciones. Existe una ruptura de la cronología mediante flash-backs o analepsis y adelantamientos o prolepsis.

En este punto, junto al espacio y al tiempo teatrales, analizaremos el significado y la simbología de los personajes, y cómo estos comparten características con otros personajes y situaciones que Lorca utiliza tanto en su obra poética como dramática.

\section{1.- El espacio teatral}

El texto de El público se caracteriza principalmente por la fragmentariedad de escenas. La historia se divide en dos secuencias principales: el teatro al aire libre y el teatro bajo la arena. Estas dos secuencias, a su vez, se dividen en secuencias menores: el cuarto del Director, la Ruina romana, el muro de arena, el sepulcro de Julieta, la cama del Desnudo Rojo, los arcos y escaleras de un gran teatro, la portada de una universidad y la vuelta al cuarto del Director. En la obra se nos presentan referencias a la realidad exterior y también al subconsciente del autor.

Podemos diferenciar dos espacios mayores que son opuestos entre sí: el teatro al aire libre y el teatro bajo la arena. Lorca introduce un elemento para poder comunicar estos dos espacios: el biombo. Su utilización facilita las diferentes transformaciones y metamorfosis que tienen lugar durante toda la obra. Como ya lo hizo anteriormente Luigi Pirandello en Seis personajes en busca de autor $(1921)^{241}$, el biombo permite revelar la verdadera relación que existen entre los personajes de El Padre y La Hijastra:

\footnotetext{
${ }^{241}$ Escrito en 1921, publicado en 1925.
} 
LA HIJASTRA. - ¡Pero es la verdad!

EL DIRECTOR.- ¡ Y qué tiene que ver la verdad! ¡Estamos en el teatro! ¡La verdad sólo sirve hasta cierto punto!

LA HIJASTRA. - ¿Y, entonces, qué quiere hacer ahora?

EL DIRECTOR.- ¡ YYa lo verá, ya lo verá! ¡Déjalo en mis manos!

LA HIJASTRA.- ¡Eso sí que no, señor! De mi asco, de todos los motivos, a cuál más cruel e infame, por los que soy «ésta» y «así», ¿quiere hacer usted un pastiche romántico y sentimentaloide, en el que él me pregunta por las razones de mi luto y yo le respondo llorando que mi parte había muerto dos meses atrás? ¡Eso no, señor! Es necesario que él me diga lo que dijo: «QQuitémoslo, quitémoslo de inmediato, ahora mismo, ese vestidito!». Y yo, con mi corazón enlutado, apenas dos meses atrás, me dirigí allá. ¿Lo ve? Allá, detrás del biombo, y con estas manos que se estremecen por la deshonra, por la repugnancia, me quité el vestido... (La escena, 75).

El propio director exclama que se encuentran en el teatro y, por tanto, la verdad es relativa. Existe una relación entre la literatura y la realidad. El autor nos muestra una historia con unos personajes, que en realidad están representando un papel determinado, sin necesidad de ser la verdadera identidad de cada cual.

También Miguel de Unamuno, en su obra teatral El otro (1926), recurre al biombo para ampliar el desdoblamiento de la personalidad que vertebra todo el texto.

(En el fondo de la escena, un espejo de luna y de cuerpo entero, tapado por un biombo. El OTRO se pasea cabizbajo y gesticulando, como quien habla para sí, hasta que al fin se decide, separa el biombo y se detiene ante el espejo, crúzase de brazos y se queda un momento contemplándose. Se cubre la cara con las manos, se las mira, luego se las tiende a la imagen espejada, como para cogerla de la garganta; mas al ver otras manos que se vienen a él, se las vuelve a sí, a su propio cuello, como para ahogarse. Luego, presa de grandísima congoja, cae de rodillas al pie del espejo, y apoyando la cabeza contra el cristal, mirando al suelo, rompe a sollozar) (Unamuno 1969, 400).

En El público, como afirma Fernando de Diego, la función utilitaria del biombo es la de separar espacios, como signo que crea el efecto de realidad en el espacio escénico, se transforma simbólica en la frontera que separa el "teatro al aire libre" del "teatro bajo la arena". A partir de este momento, la obra se subdivide en los dos espacios principales en el que se confrontarán las dos formas de teatralidad. El cambio de vestuario de los 
personajes, que ocupan el nuevo espacio creado, y su punto de vista que se refleja en el cambio de registros discursivos, tienen una referencia común: el "el teatro bajo la arena" $(1995,234-235)$.

La verdadera naturaleza de los personajes se encuentra oculta tras la máscara en un mundo de apariencias. Al atravesar el biombo, quien lo cruza es capaz de descubrir la personalidad que oculta, consigue desprenderse de la máscara y se despoja de los trajes de falsedad y ocultamiento. Esta serie de transformaciones facilitará el descenso hacia el interior de cada uno. Cuanto más profundo sea este descendimiento, más cerca del subconsciente del autor nos encontramos. Como afirma Ricardo Doménech, el biombo es como «si se tratara de un aparato de rayos $\mathrm{X}$, destinado a revelar el interior de las mentes, los personajes que pasan tras él aparecen enormemente cambiados, mostrándose como son en realidad sin tapujos» $(2008,202)$.

El Director atravesará el biombo y, en cada cruce, sufrirá una metamorfosis, acercándose a su verdadera identidad. Y cuanto más se libere de las normas establecidas por la sociedad, más libre se sentirá y más cerca de la autenticidad. Sentimiento que ya buscaban los surrealistas, liberarse de las normas y lógica que nos atan para dejar rienda suelta al mundo interior de los sueños y del subconsciente. Según avance el drama, el Director se sentirá menos atado y más próximo a las ideas renovadoras que el teatro bajo la arena defenderá.

La obra comienza con el anuncio de la llegada del público al despacho del director. En el Cuadro I, en la acotación inicial, se indica el decorado, «Cuarto del DIRECTOR. [...] Decorado azul. Una gran mano impresa en la pared. Las ventanas son radiografías» (Cuadro I, 101). El color azul ${ }^{242}$ es el color del Modernismo ${ }^{243}$ y la fantasía. A finales del siglo XIX y comienzos del XX, los poetas describen su estado de ánimo y su relación con la naturaleza mediante la utilización del color azul, con nuevos matices, tonalidades y sus connotaciones. En su plurisimbolismo significa la pasividad,

\footnotetext{
${ }^{242}$ En 1888, Rubén Darío escribió su libro Azul, que iniciará el Modernismo en España. Años más tarde, en Historia de mis libros (1916) describió el color azul como «el color de ensueño, el color del arte, un color helénico y homérico, color oceánico y del firmamento» (1988, 38-39).

243 Del 3 de mayo al 25 de agosto de 2019 tuvo lugar la exposición Azul. El color del Modernismo en el Caixa Forum de Sevilla y la importancia del color en el arte a finales del siglo XIX y su inspiración en los poetas modernistas.

https://caixaforum.es/es/sevilla/p/azul-el-color-del-modernismo_a932320
} 
el de la infinitud celeste y el del pensamiento. La mano, «expresa la idea de actividad al mismo tiempo que la de potencia y dominio» (Chevalier y Gheerbrant 1993, 682). Esta mano abierta significa el comienzo de algo, o «el desarrollo de la experiencia interior, en un microcosmos que escapa al condicionamiento espaciotemporal» (Chevalier y Gheerbrant 1993, 682). Y aunque no se especifica, cabe suponer que esta mano abierta tendrá las rayas que permiten leer, según la quiromancia, ese mundo interior del hombre y el destino que le está asignado. Las radiografías, elementos técnicos y científicos característicos del teatro de vanguardia, revelan de manera gráfica lo que permanece invisible por debajo de la piel (Rubia Barcia 1986, 391), aquello que no se puede ver a simple vista.

Aunque no forme parte del decorado, es importante la idea de la acción dialogada, en la que el director duda ante el peligro de quitar las barandas del puente:

DIRECTOR.- (Reaccionando.) Pero no puedo. Se hundiría todo. Sería dejar ciegos a mis hijos, y luego ¿qué hago con el público si quito las barandas al puente? Vendría la máscara a devorarme. Yo vi una vez a un hombre devorado por la máscara (Cuadro I, 110).

El puente nos permite pasar de una ribera a otra del río o cruzar dos espacios distanciados. Al atravesarlo, advertimos dos factores: el pasaje y el peligro, el trayecto de una posición a otra, recorrer un camino que nos lleva a lo desconocido o al menos a algo diferente, y con la añadidura del peligro que supone atravesar un puente. Lorca quita las barandas del puente, que tienen como función la de proteger a aquel que lo transita del abismo, y aumenta el peligro a la acción. Como afirma Carlos Feal Deibe, «la unión de las dos orillas que él lleva a cabo encierra una significación sexual. Cruzar un puente, puede, entonces, representarse como algo peligroso $(1973,33)$. Lorca recurre al concepto de baranda en diferentes composiciones poéticas. Por ejemplo, en el «Romance sonámbulo»:

Con la sombra en la cintura

ella sueña en su baranda,

[...]

Ella sigue en su baranda, verde carne, pelo verde, soñando en la mar amarga. 
$[\ldots]$

Dejadme subir al menos

hasta las altas barandas,

dejadme subir, dejadme,

hasta las verdes barandas.

Barandas de la luna

por donde retumba el agua

(Romancero gitano [1981] 2012, 67-71).

El espacio del Cuadro II, "Ruina romana" es el más simbólico de toda la obra, en el que nos presenta el teatro clásico enfrentado a su teatro transgresor. En su primera acotación nos presenta dos personajes y dónde se encuentra una de las dos figuras, «sentada sobre un capitel» (Cuadro II, 121). En el manuscrito de El público debajo del título aparece tachada en una línea aparte «Una estatua de Venus» como sugerencia escénica. Con alusiones a columnas y capiteles derrumbados, nos trae el recuerdo de las ruinas de las antiguas civilizaciones clásicas grecorromanas y del teatro del pasado, el modelo a seguir y a interpretar.

Las acotaciones descriptivas del escenario son mínimas y debemos buscar, en los diálogos o en el vestuario de los personajes, los signos para configurar el espacio escénico, en el que hay una participación activa del espectador. Es un espacio lúdico por los movimientos y gestos de la Figura de Pámpanos y la Figura de Cascabeles «una figura, cubierta totalmente de pámpanos rojos, toca una flauta sentada sobre un capitel. Otra figura, cubierta de cascabeles dorados, danza en el centro de la escena» (Cuadro II, 121):

FIGURA DE CASCABELES._- [...] Si voy bajando por la ruina iré encontrando amor y cada vez más amor.

$[\ldots]$

FIGURA DE PÁMPANOS.- Estoy esperando la noche, angustiado por el blancor de la ruina (Cuadro II, 128-129).

En la conversación entre las dos figuras observamos cómo descienden por la ruina, un descenso al interior del personaje, y, de este modo, al encuentro del auténtico amor. 
En posteriores acotaciones se indica de nuevo cuál es el espacio escénico en el que nos encontramos, «El NIÑO se dirige al EMPERADOR. Éste lo toma en sus brazos, y se pierden en los capiteles» (Cuadro II, 133). Según Chevalier y Gheerbrant, las columnas en ciertos casos simbolizan «la piedra sacrificial. [...] Las leyes están inscritas sobre la columna y sobre ella se pronuncian los juramentos» $(1993,327)$.

En suma, el capitel en el que se encuentra sentado la Figura de Cascabeles, la blancura de la ruina y los capiteles entre los que se pierde el Emperador son elementos claros de las construcciones y civilizaciones clásicas, símbolos del conocimiento y de la cultura grecorromana ante la que aparece el teatro de Lorca, de insomnio y libertad.

En el Cuadro III hallamos dos espacios diferentes claramente delimitados y separados por un muro de arena que comparten escenario: en el primer espacio, los personajes presentes son los Hombres 1, 2 y 3 y el Director; y en el segundo, comparten escena Julieta y el Caballo Blanco y, posteriormente, se unirá el Caballo Negro.

En la primera acotación de este Cuadro, Lorca nos describe un «Muro de arena. A la izquierda y pintada sobre el muro, una luna transparente casi de gelatina. En el centro, una inmensa hoja verde lanceolada» (Cuadro III, 137). La arena está formada por multitud de granos, «fácil de penetrar y plástica, adopta las formas que la moldean: a este respecto, es un símbolo de matriz» (Chevalier y Gheerbrant 1993, 137). Según Rubia Barcia, la luna de gelatina «sugiere una luna que, pese a su artificialidad o a causa de ella, conlleva y arrastra aún, entre sus muy variados simbolismos, el de madre de la feminidad, guía del lado oculto de la naturaleza en oposición al sol y patrona de irracionalidades» $(1986,392)$. La hoja lanceolada puede ser símbolo fálico, ya que entre las acotaciones tachadas del manuscrito encontramos «tronco del árbol». En este cuadro son diversas las acotaciones tachadas, que pueden deberse a que inicialmente Lorca tuviera la idea de una escenografía diferente. No debemos olvidar el rigor y las correcciones del autor en la mayoría de sus obras, ya que acostumbraba a ir modificando el texto según iban avanzando los ensayos de las obras para estrenar.

Como hemos dicho, mediante un muro de arena consigue separar los espacios. El segundo espacio viene descrito por «El muro se abre y aparece el sepulcro de JULIETA en Verona. Decoración realista. Rosales y yedras. Luna» (Cuadro III, 144). El muro de arena no sólo separa espacios físicos sino que, al abrirse, nos da acceso al 
«teatro bajo la arena»; ya hemos dejado atrás el «teatro al aire libre» y nos encontramos en el teatro dentro del teatro, con la aparición de Julieta. El metateatro está muy presente cuando surgen los personajes de la obra Romeo y Julieta de Shakespeare, aunque nos encontramos ante una decoración realista, como si de obra teatral tradicional se tratara, dirigida a un público burgués y conservador.

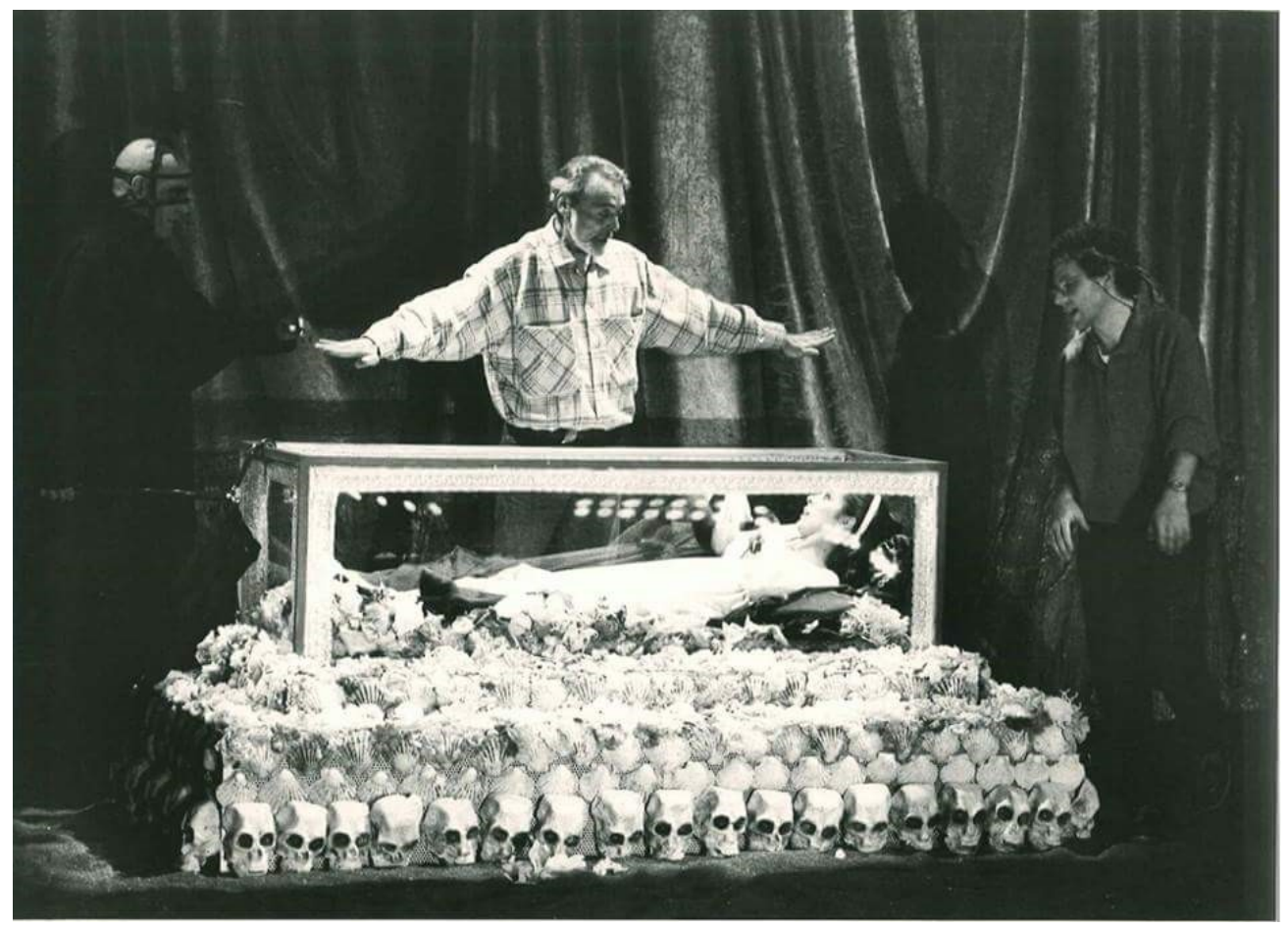

Fig. 94: En la imagen, Julieta está en el sepulcro junto al Caballo Negro escuchando las indicaciones de Fabià Puigserver, ante la mirada de Lluís Pasqual.

Sigue presente la luna, — símbolo plurisignificacional en la obra de Lorca — no sólo el astro que ilumina el espectáculo, sino una luna observadora de toda acción ocurrida sobre el escenario, símbolo de transformación y cambios. También connota el paso del tiempo, a través de sus fases sucesivas y regulares, de ahí que la relacionemos como un incesante nacer y morir, como los ciclos vitales e inevitables.

En el Cuadro IV, suceden tres acciones distintas, aunque simultáneas, que coexisten en tres espacios diferentes y diferenciados: en el centro de la escena, una cama de frente y en perpendicular; al fondo, unos arcos y escaleras de un gran teatro y, a la derecha, la portada de una universidad. Al inicio del Cuadro IV, la primera acotación nos describe cómo serán estos tres ambientes distintos. «En el centro de la escena, una cama de frente y perpendicular, como pintada por un primitivo [...]. Al fondo, unos arcos y 
escaleras que conducen a los palcos de un gran teatro. A la derecha, la portada de una universidad» (Cuadro IV, 169).

Estas tres zonas que coexisten en el escenario representan el fracaso del experimento del teatro bajo la arena. En este espacio único convergen tres grupos de personajes: en el centro de la escena, sobre la cama, se encuentra coronado de espinas el Desnudo; al fondo, un grupo de estudiantes universitarios dialogan y discuten sobre la obra que acaban de ver representada y, a la derecha del escenario, encontramos el grupo de damas escandalizadas por la situación vivida dentro del teatro, ya que el público ha asaltado el teatro. Estos tres puntos de vista se entrecruzan simultáneamente.

El simultaneísmo ${ }^{244}$ es una técnica narrativa en la que la historia de dos hechos se entrelaza para dar la impresión de simultaneidad. Su origen proviene de una técnica pictórica de principios del siglo XX que consiste en la unión de dos imágenes del mismo objeto a través de perspectivas diferentes.

Como analizaremos más adelante, la muerte del personaje el DESNUDO (semejante al Hombre 1) es una iconización de la muerte de Cristo que transforma este espacio para trasladarnos al del "teatro al aire libre". Jesús murió por salvar a la humanidad y el Desnudo (Hombre 1) también muere por unos ideales de verdad en un mundo desnudo de máscaras y ocultamientos.

Lorca quiere unir este Cuadro IV con el II, mediante la asociación de Pilato con el Emperador al enlazar, en su sentido más profundo, este cuadro casi sacramental y el que trascurría en la ruina romana:

DESNUDO.- ¿Falta mucho?

ENFERMERO.- Poco. Ya han dado la tercera campanada. Cuando el Emperador se disfrace de Poncio Pilato (Cuadro IV, 179).

\footnotetext{
${ }^{244}$ El matrimonio de artistas Robert y Sonia Delaunay fueron quienes acuñaron el término para definir la pintura en la que se emplea el color como medio de crear espacio y formas en un cuadro, dando la sensación de movimiento. El termino proviene del escrito De la loi du contraste simultané des couleurs (1839) del químico Eugène Chevreul sobre las características de la percepción humana del color que sentó las bases de estudio para impresionistas y neoimpresionistas.

Guillaume Apollinaire adaptó el término para utilizarlo en poesía como principio artístico según el cual dos elementos sin relación se unen de un modo arbitrario, y creando un conflicto y contraste entre ellas. Buscaba el movimiento entre dos momentos separados pero con un tiempo compartido.
} 
Una nueva asociación de imágenes, que vinculan los dos cuadros, se muestra cuando la Dama 3 menciona la subida al monte que nos remite al Gólgota de la ruina romana:

DAMA 3.- Cuando subíamos por el monte de la ruina [...] (Cuadro IV, 179).

Las cuatro Damas se encuentran en un teatro, cabe suponer un teatro a la italiana en el que el público está alejado del escenario y de los actores y existe una clara diferenciación en los espacios, donde, después de finalizar la representación de la obra Romeo y Julieta, ha dado comienzo la revolución.

La tercera acción tiene lugar delante de la portada de la Universidad con la presencia y la participación de los Estudiantes, cuya conversación girará en torno al análisis de lo ocurrido durante y después de la representación. La universidad representa una entidad opresora y limitadora de la libertad por su doctrina y sentido de lo establecido.

En el último cuadro, con el que se finaliza la obra, el Cuadro V, volvemos al decorado del primero, aunque añadiendo objetos inconexos sobre el escenario. Según nos indica la acotación inicial, «La misma decoración que en el primer cuadro. A la izquierda una gran cabeza de caballo colocada en el suelo. A la derecha un ojo enorme y un grupo de árboles con nubes apoyados en la pared» (Cuadro V, 188).

Con el mismo decorado descrito en la primera acotación del texto, los cambios que se producen son referentes al vestuario de los personajes, y con unos objetos aportados del subconsciente del autor. En este cuadro, la muerte está presente en diferentes elementos y acciones. La cabeza «simboliza la fuerza y el valor guerrero del adversario, [...] y la decapitación garantizaba la muerte» (Chevalier y Gheerbrant 1993, 221). Ha llegado el momento de la muerte del caballo fuerte y vigoroso, y para asegurarlo no sólo muere, sino que es decapitado. La decapitación implicaba la destrucción de aquello perteneciente al mundo interior y mental. Ese enorme ojo es símbolo de conocimiento, un ojo que percibe el mundo intelectual y de percepción sobrenatural, como testigo de todo lo ocurrido y sabedor de la verdad. El ojo, como la luz, «es símbolo de inteligencia, la acción de ver, que no mirar, representa un acto espiritual que simboliza entendimiento, $\mathrm{y}$, desde luego, conocimiento. [...] Son iluminadores, alumbradores y lúcidos (Plaza Chillón 2014, 235). 
En la penúltima acotación leemos «una lluvia lenta de guantes blancos, rígidos y espaciados» (Cuadro V, 198). El significado simbólico que adquiere la mano que aparece en el primer cuadro y los guantes, en este último cuadro, es muy similar. La pureza de una mano abierta y de unos guantes blancos tan presentes en algunos ritos religiosos o actos de galas significando la paz o nobleza del acto (Chevalier y Gheerbrant 1993, 544-545). Así, los guantes blancos en las ceremonias de los doctorados honoris causa en la universidad.

No sólo coincide el espacio del primer y del quinto cuadro, el cuarto del Director, sino que el breve diálogo del inicio de la pieza se repite al final, indicando el carácter circular de la obra:

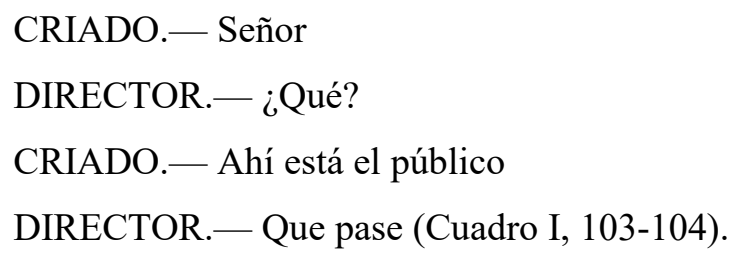

Con este regreso se cierra definitivamente al teatro bajo la arena. Mediante el diálogo, que mantienen del Director y el Prestidigitador, se clausurará ese espacio circular y, aunque parece que completa el espacio del teatro bajo la arena, en el último diálogo nos abre la posibilidad de reinicio:

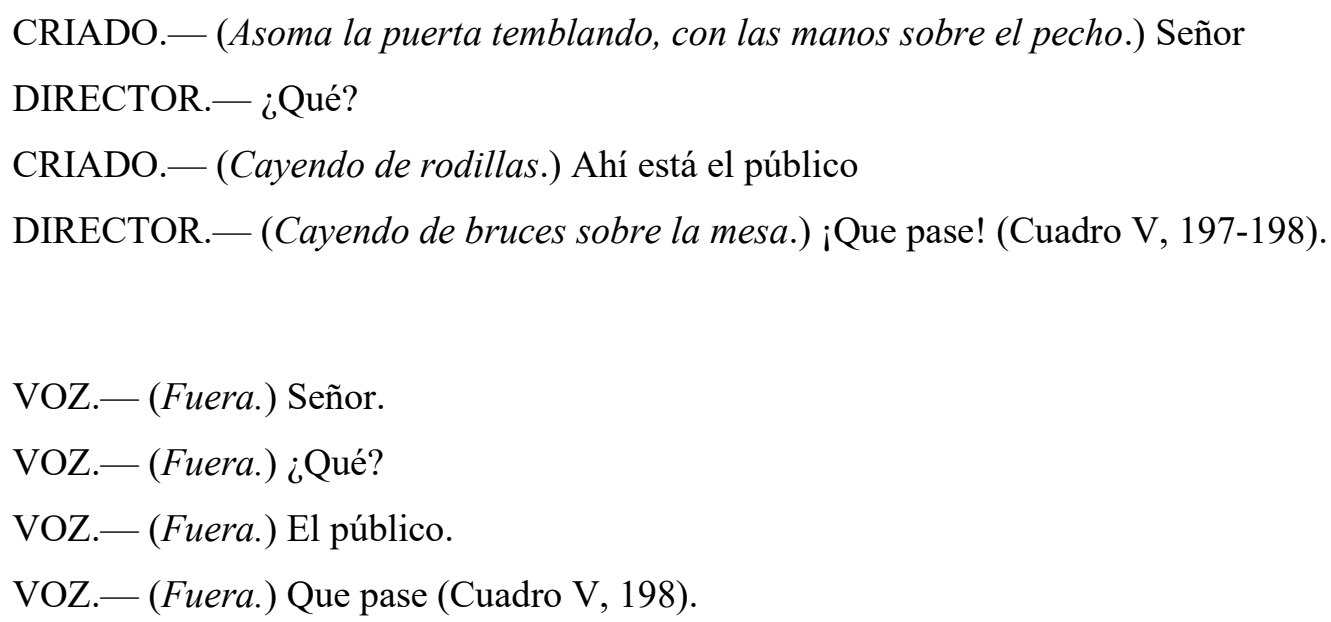

La obra termina con «el PRESTIDIGITADOR agita con viveza el abanico por el aire. En la escena empieza a caer copos de nieve» (Cuadro V, 198). Ese frío que sienten los personajes y esa nieve que empieza a caer simbolizan la muerte que ha estado presente en todo el último cuadro, que acaba con la del Director del teatro. 
Antes de finalizar este punto, debemos recalcar que sólo en tres de los cinco cuadros, en el I, IV y V, encontramos breves referencias del mundo real y objetivo, «Primero, planteamiento en el despacho del Director de si es o no posible representar un "teatro bajo la arena" [...]. Segundo, cambio durante la representación de la obra de Shakespeare, Romeo y Julieta [...]. Y por último, vuelta al despacho del Director» (Millán 1986a, 402). El resto de la trama transcurre en el teatro bajo la arena.

\section{2.- El tiempo teatral}

En la obra El público existe una atemporalidad o ucronía y se pierde el sentido durativo del tiempo. Federico García Lorca efectúa un tratamiento especial del tiempo, sustituye la linealidad de un argumento tradicional por la simultaneidad de acciones.

Distintos ambientes y acciones coexisten en el escenario durante el transcurso de la obra. El ejemplo más claro, como ya hemos citado en el apartado anterior, es en el Cuadro IV donde el Desnudo Rojo, los Estudiantes y las Damas coinciden sobre el escenario en un mismo tiempo pero con diálogos paralelos, sin conversar ni relacionarse entre ellos. Como afirma Millán, esta técnica es

característica del cine, que puede manejar con mucha mayor libertad los distintos tiempos y niveles en que transcurre una obra [...].

García Lorca conocía bien esta terminología, como así lo demuestra su guión cinematográfico, Viaje a la luna, coetáneo a El público $(1986,405)$.

Así Lorca utiliza una particularidad cinematográfica para ignorar la continuidad, eliminar la coordinación y poder manejar con mucha más libertad los distintos tiempos y niveles en los que transcurre la obra:

Sólo el simultaneísmo que proporciona la cámara cinematográfica permite expresar en todas sus posibilidades la coexistencia de acciones, el desdoblamiento de los personajes, o la identidad entre imágenes distintas. Para conseguir este arte utilizará recursos como la “sobreimpresión”, o la “doble exposición” de imágenes (Millán 1986, 405). 
En esta obra apenas hallamos referencias al tiempo exterior, sólo en el Cuadro V en el que indica un tiempo concreto de duración: los días que estuvo luchando para destruir el teatro y las horas en el que la representación ha terminado:

DIRECTOR. (Irritado.) Pero eso es mentira, ¡eso es teatro! Si yo pasé tres días luchando con las raíces y los golpes de agua fue para destruir el teatro (Cuadro V, 191).

DIRECTOR.- La representación ha terminado hace horas y yo no tengo responsabilidad de lo que ha ocurrido (Cuadro V, 195).

En el resto de la obra no hay límites cronológicos, todo instante se da sin duración y sin sucesión inmediata. Con la desaparición del valor durativo del tiempo, se permite la simultaneidad de acciones y el desdoblamiento de personajes, y así proporciona un carácter a la acción de mundo interior del autor.

A esta desorientación, a la que se encuentra sometido el espectador durante toda la obra, Lorca busca una solución añadiendo un gran carácter visual y plástico de sus imágenes, con la utilización de una amplia gama cromática y un elevado número de transformaciones continuas.

Encontramos una referencia simbólica, el canto del ruiseñor. En la lírica tradicional, el ruiseñor siempre se ha considerado como la unión entre el amor y la muerte. Es un ave que tiene el hábito poco común de cantar hasta bien entrada la noche. La belleza de su canto hace olvidar los peligros del día.

Encontramos en el Acto XIX de la Tragicomedia de Calisto y Melibea (1499) de Fernando de Rojas la referencia de este canto que hechiza a los enamorados:

\footnotetext{
MELIBEA.- $-[\ldots]$

Papagayos, ruiseñores, que cantáis al alborada, llevad nueva a mis amores, cómo espero aquí asentada. La media noche es pasada, y no viene; sabedme si hay otra amada
} 
que lo tiene.

(La celestina, Acto XIX, 320).

También en el Romancero viejo encontramos el «Romance de Fontefrida» de autor anónimo escrito en el siglo XVI. El ruiseñor representa la traición amorosa en contraposición a la fidelidad en el amor por parte de la tórtola:

Por ahí fuera pasar — el traidor del ruiseñor,

las palabras que él decía - llenas son de traición:

- Si tú quisieras, señora, - yo sería tu servidor.

- Vete de ahí, enemigo, — malo, falso, engañador,

$[\ldots]$

Déjame, triste enemigo, — malo, falso, mal traidor,

que no quiero ser tu amiga - ni casar contigo, no.

(Romancero Viejo, 99, 233).

El elemento del ruiseñor en El público es una clara referencia al canto del ruiseñor que encontramos en la obra de Romeo y Julieta de Shakespeare, en la que el canto del ruiseñor se opone al de la alondra: esta como representante del amor en la noche, y el ruiseñor, como el mensajero del anuncio del alba y la separación de los amantes:

JULIETA. - ¿Te vas a marchar? Todavía no se acerca el día: era el ruiseñor, y no la alondra, lo que traspasó el temeroso hueco de tu oído; de noche, canta en ese granado: créeme, amor, era el ruiseñor.

ROMEO.- Era la alondra, heraldo de la mañana, y no el ruiseñor: mira, amor, qué envidiosas franjas ciñen las nubes dispersas allá a oriente: las candelas de la noche se han extinguido, y el jovial día se pone de puntillas en las neblinosas cimas de las montañas: tengo que irme y vivir, o quedarme y morir.

JULIETA.- Aquella luz no es luz del día, lo sé muy bien; es algún meteoro que emana del sol para que te sea esta noche tu portador de antorcha, alumbrándote en el camino de Mantua. Así que espérate todavía. No tienes que marcharte.

ROMEO.- Que me detengan, que me den la muerte; lo consentiré si así lo deseas. Diré que aquella luz gris no es el alba, sino el pálido reflejo del rostro de Cintia, y que no es el canto de la alondra lo que llega hasta la bóveda del cielo. En lugar de irme, quedarme quisiera. ¿Que venga la muerte! Lo quiere Julieta. ¿Hablamos, mi alma? Aún no amanece. 
JULIETA.- Sí es, sí es: ¡Vete, márchate de aquí! Es la alondra la que canta tan destemplada, forzando ásperas disonancias y agudos desagradables. Dicen algunos que la alondra hace dulce armonía: no así ésta, pues nos separa. Algunos dicen que la alondra y el odioso sapo se han cambiado los ojos: ¡ah, ahora querría yo que hubieran cambiado también las voces, puesto que esa voz nos arranca de los brazos, acosándote para que te vayas de aquí al tocar diana al día! Ah, vete ahora, cada vez está más y más claro.

ROMEO.- ¿Más y más claridad? Más y más negro es nuestro infortunio.

(Romeo y Julieta, Acto III, Escena V, 64).

La figura del ruiseñor como nuncio del alba se puede recoger ya en el Cancionero tradicional con la canción del alba y la despedida de los amantes, en el que el alba interrumpe a los enamorados, obligándoles a separarse. Estas canciones tenían connotaciones dolorosas en la que dos amantes se encuentran durante la noche y deben separarse al romper el alba para no ser descubiertos:

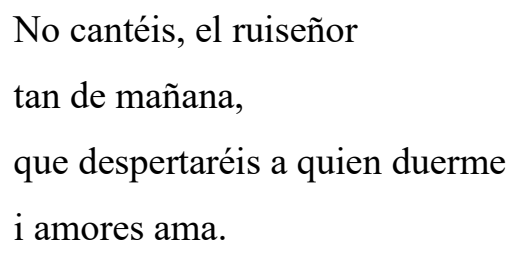

(Frenk [s.XVII] 1987 Corpus, 2303).

El canto del ruiseñor anuncia, en tres momentos diferentes del drama, la muerte de tres personajes: Julieta, el Traje de Arlequín (Enrique) y el Desnudo Rojo. La muerte del amor en los tres casos: el amor del Desnudo a la humanidad, el amor de Enrique por Gonzalo y el amor de Julieta por Romeo. Aunque las acciones son independientes entre ellas, existe la conexión del canto del ruiseñor en las tres, como anunciador de la llegada de la muerte.

Julieta, con la ayuda del Caballo Negro vuelve al sepulcro. Ella cierra los ojos oyendo el canto del ruiseñor, muere de nuevo por amor:

HOMBRE 3.- Espera, espera. Ahora canta el ruiseñor.

JULIETA.— (Temblando.) ¡El ruiseñor, Dios mío! ¡El ruiseñor...!

CABALLO NEGRO.- ¿Que no te sorprenda! (La coge rápidamente y la tiende en el sepulcro.)

JULIETA.— (Durmiéndose.) ¡El ruiseñor...! (Cuadro III, 165). 
Y el Estudiante 4, como espectador del drama, comentará la actuación y la emoción que le produjo contemplar la muerte de Julieta.

ESTUDIANTE 4.- La repetición del acto ha sido maravillosa, porque indudablemente se amaban con una amor incalculable, aunque yo no lo justifique. Cuando cantó el ruiseñor yo no pude contener mis lágrimas (Cuadro IV, 182).

También el Hombre 3 anuncia el canto del ruiseñor, poco antes la muerte del Hombre 1:

HOMBRE 3.- Espera, espera, ahora canta el ruiseñor [...].

$[\ldots]$

EL TRAJE DE ARLEQUÍN.- (Con voz débil.) Tengo frío. Luz eléctrica. Pan. Estaban quemando goma.

HOMBRE 1.- (Abrazándolo con violencia.) ¡Enrique!

EL TRAJE DE ARLEQUÍN.- (Cada vez más débil.) Enrique...

$[\ldots]$

([...] Sobre el ruido de la lluvia canta el verdadero ruiseñor.) (Cuadro III, 166-167).

En el espacio, donde transcurre la acción del Desnudo Rojo, el canto del ruiseñor es el aviso de los últimos minutos del sacrificio de Jesucristo por la Humanidad y su entrega a Dios Padre:

DESNUDO.- Padre, en tus manos encomiendo mi espíritu.

ENFERMERO.- - Te has adelantado dos minutos ${ }^{245}$.

DESNUDO.- Es que el ruiseñor ha cantado ya (Cuadro IV, 180).

Las referencias al ruiseñor son abundantes en la obra de Lorca, aunque en un principio le daba un valor más positivo como el anunciador del amor y de la vida. A partir del periodo neoyorquino, este significado amoroso va unido a la tragedia y a la muerte (García-Posada 1981, 278). Por ejemplo, el ruiseñor, que anuncia la llegada de la muerte, lo encontramos en la voz del Niño muerto de Así que pasen cinco años:

Ayer se me paró muy despacito

ruiseñor de mi cama.

(Así que pasen cinco años, Acto I, 218).

${ }^{245}$ Con esta afirmación, el Enfermero provoca una ruptura del sistema y la expectativa con la escena evocada. 
En el texto de El público también aparece otra referencia temporal, cuando el Enfermero anuncia que ya han dado la tercera campanada. En el cristianismo, la hora tercia ${ }^{246}$ equivale a las nueve de la mañana.

DESNUDO.- ¿FFalta mucho?

ENFERMERO.- Poco. Ya han dado la tercera campanada. Cuando el Emperador se disfrace de Poncio Pilato (Cuadro IV, 179).

\section{3.- Los personajes y su simbología}

En todo el texto, Lorca utiliza referencias de diferentes textos clásicos, como Romeo y Julieta, o Sueño de una noche de verano de William Shakespeare, cuyo argumento tiene gran importancia para Lorca, por referirse al elemento del azar en el amor; la clara alusión de pasajes bíblicos (Antiguo y Nuevo Testamento) y el sacrificio; los personajes propios de la tradición, como es el Pastor Bobo, de la mitología clásica grecolatina, o de las Metamorfosis $(8$ d. C.) de Ovidio. En este punto analizamos esas diferentes simbologías de los personajes o situaciones:

\subsection{1.- EI Pastor Bobo}

La función del Pastor Bobo en El público es la de informante y su parlamento va dirigido al público que se encuentra sentado en la sala, mediante un monólogo o canción. Al dirigirse al espectador, se rompe la barrera que separa la escena del público e integra a los espectadores en el drama que, a continuación, va a dar comienzo para formar parte de él, resultando un elemento principal.

Como pastor de animales, su principal función es apacentar al rebaño y dirigir al público al destino elegido. De un modo cómico y grotesco quiere liberar, provisionalmente, al público con el espíritu lúdico de la carnavalización, dentro de los márgenes aceptados por el discurso oficial del «teatro al aire libre». El mensaje del

\footnotetext{
${ }^{246}$ Las horas canónicas son una división del tiempo surgida en la Edad Media. Cada hora indicaba una parte de la Liturgia de las Horas (conjunto de las oraciones oficiales). La división tiene su origen en el Libro de los Salmos de la Biblia. La hora tercia equivale a las tercera hora después del amanecer, sobre las nueve.
} 
Pastor Bobo, con un lenguaje infantil, irracional y lúdico, anticipa, brevemente, el argumento de la obra que se va a representar, Romeo y Julieta, «en el asesinato de Julieta» (Loa del Pastor Bobo, 102). La canción continúa y, casi al final, el Pastor realiza una apología del teatro liberado de la máscara, a favor de una modernización de la escena teatral:

Europa se arranca las tetas

Asia se queda sin lunetas

y América es un cocodrilo 247

que no necesita careta (Loa del Pastor Bobo, 102).

El rebaño simboliza el instinto gregario. Cuanto más capaz es un ser humano de vivir en solitario, fuera del grupo, más cerca estará de convertirse en persona, en individuo. El grupo o el rebaño tiene la necesidad de sentir a otros seres a su alrededor. Entendemos que el rebaño «se presenta como una masa, una totalidad de la cual no emerge ningún animal o ningún hombre. [...] El rebaño simboliza entonces una perversión de la vocación social del hombre, así como una perversión de la vocación humana de la sociedad»(Chevalier y Gheerbrant 1993, 874). Recordemos el término egregio (exgregem) de La rebelión de las masas (1930) de Ortega y Gasset, en el que «la masa arrolla todo lo diferente, egregio, individual, calificado y selecto. Quien no sea como todo el mundo, quien no piense como todo el mundo, corre el riesgo de ser eliminado» (Ortega y Gasset [1937] 2012, 52).

\subsection{2.- El Director}

El Director es el protagonista de El público, quien en un principio está muy satisfecho de la representación en su teatro del montaje convencional de Romeo y Julieta, y cómo los espectadores reaccionan con aplausos, pero tres amigos (el Hombre 1, 2 y 3) increpan porque su teatro al aire libre es falso y engañoso. El Director se justifica, ya que hay temas que son tabúes en la sociedad actual, y al eliminar las máscaras podría hacer peligrarlo todo. Influido por la crítica de sus amigos, el Director cambia de

\footnotetext{
${ }^{247}$ El cocodrilo es el símbolo de la duplicidad y la hipocresía. «Su posición de intermediario entre los elementos tierra y agua hace del cocodrilo el símbolo de las contradicciones fundamentales [...]. Es el amo de los misterios de la vida y de la muerte» (Chevalier y Gheerbrant 1993, 314).
} 
opinión y abandona el teatro al aire libre y, aunque no se compromete a representar el teatro bajo la arena, sí asume la necesidad de variar su discurso dramático (Doménech 201, 195). Durante el transcurso de la obra, el Director se debate con sus fantasmas interiores: la importancia de encontrar y vivir el verdadero amor.

\subsection{3.- Los Caballos: los cuatro caballos blancos y el caballo negro}

El caballo constituye uno de los arquetipos fundamentales de la humanidad. Tiene múltiples acepciones simbólicas, entre ellas la del psiquismo inconsciente o de la psique humana y la de la impetuosidad del deseo. Símbolo de la fuerza y de la potencia sexual de la juventud (Chevalier y Gheerbrant 1993, 208).

Entre el gran bestiario que forma la obra de Lorca, es el caballo el que destaca sobre cualquier otro animal. La presencia del caballo en la poesía y en el teatro de Lorca es constante. El Caballo puede ser un símbolo de la vida, del amor y la pasión, y también, de la muerte (García-Posada 1981, 274). En Bodas de Sangre se convierte en una imagen obsesiva. El caballo sudoroso de fatiga es el símbolo de la fuga deshonrosa, preludio de la muerte y la venganza inevitables (Babín 1976, 463). El ruido de los cascos del caballo delata el amor prohibido. Cuando Leonardo rapta a la novia y la sube al caballo, es el símbolo de la pasión descontrolada. En La casa de Bernarda Alba, un tremendo garañón, nunca visible, representa el amor y la muerte, símbolo de la pasión que ahoga a unas mujeres que viven sin amor, dando un dramatismo a las escenas en las que aparece. En el drama de Mariana Pineda, ella siente la angustia de la muerte que la acecha y espera el galope del caballo anunciador de su amado:

\footnotetext{
Don Pedro vendrá a caballo

como loco cuando sepa

que yo estoy encarcelada

por bordarle su bandera.
}

(Mariana Pineda, Estampa III, Escena III, 83).

Pedro, coge tu caballo

$\mathrm{O}$ ven montado en el día.

¡Pero pronto! ¡Que ya vienen 
Para quitarme la vida!

Clava las duras espuelas.

(Ibidem, Estampa III, Escena VI, 91).

En El público, tanto los Hombres como los Caballos representan niveles diferentes del mundo no consciente, como afirma Julio Huélamo Kosma, «los Caballos son el mundo plenamente inconsciente y reprimido, totalmente inaceptable para la consciencia del Director» $(1996,28)$. Compartimos la misma opinión de María Clemanta Millán al afirmar que los caballos «representan la intromisión del teatro bajo la arena en el teatro al aire libre, por lo que son rechazados en un primer momento por el Director» ([1987] 2012, 59).

Debemos observar la presencia de la numeración de los personajes, tanto en el grupo de caballos como el de hombres, como derivación de lo colectivo y la expresión, en un sentido negativo, del tumulto en contra de la corriente individual.

Los caballos en grupo aparecen al comienzo de la obra siendo expresión de los impulsos y los instintos desbocados de la pasión amorosa. En un principio, Lorca los presenta sin la cualidad del habla, ya que sólo utilizan sonidos carentes de significado ${ }^{248}$, como la parte animal de la psique humana. Los Caballos quieren que el Director deje de autocensurarse y permita aflorar sus pasiones ocultas, secretas e inconfesables. Pero el yo racional del Director se impone usando el látigo sobre los Caballos:

DIRECTOR.- ¡ ¡Fuera!¡Fuera! ¡Fuera

$[\ldots]$

DIRECTOR.- ¡ ¿Dame un látigo ${ }^{249}$ ! (Cuadro I, 104-105).

Los caballos utilizan un lenguaje cercano a la naturaleza salvaje de ser humano, proporciona un lenguaje carnavalesco sin intención de buscar la burla, el malestar del público burgués de la época, acomodado en la tradición teatral:

LOS TRES CABALLOS BLANCO.- (Empuñan los bastones y por las conteras de éstos saltan tres chorros de agua.) Te orinamos, te orinamos. Te orinamos como

\footnotetext{
${ }^{248}$ Como la jitanjáfora, donde lo importante era el valor eufónico y sorprendente de las palabras, con el menor contenido de sentido lógico.

${ }^{249}$ El látigo es símbolo de castigo y de poder sobre el otro. «Del poder judicial y de su derecho a infligir castigos» (Chevalier y Gheerbrant 1993, 629).
} 
orinamos a las yeguas, como la cabra orina el hocico del macho y el cielo orina a las magnolias para ponerlas de cuero (Cuadro III, 156).

Como afirma Mijail Bajtin,

los gestos e imágenes populares carnavalescas, tales como arrojar excrementos o el rociar con orina, etc., hay que tomar en cuenta lo siguiente: las imágenes verbales y demás gestos de ese tipo formaban parte del conjunto carnavalesco estructurado en base a una lógica unitaria. Este conjunto es el drama cómico, que abarca a la vez la muerte del viejo mundo y el nacimiento del nuevo ([1987] 1995, 135).

Los cuatro Caballos Blancos representan la fuerza viril, el vigor vital y sexual, en una relación que quiere ser heterosexual. El Caballo Blanco 1, independizado del grupo es el opuesto al Caballo Negro, son alegorías de Eros y Tánatos, el amor frente a la muerte. Como afirma Eich, «la fecundación y la muerte son, al mismo tiempo, los momentos de máxima intensidad que la vida puede ofrecer. En la fecundación y en la muerte culmina y se agota la vida. Muerte y fecundación forman los dos aspectos, destructor y creador de la vida y del tiempo» $(1970,136)$. En ambos se da el delirium tremens.

El Caballo Negro «lleva un penacho de plumas del mismo color y una rueda en la mano» (Cuadro III, 151). El penacho de plumas negras como los caballos de las carrozas fúnebres, y la rueda como símbolo del paso del tiempo. El caballo negro tiene una valoración negativa como mensajero de la muerte ${ }^{250}$, tiene un sentido trágico.

En la obra de Federico García Lorca podemos encontrar el caballo negro como algo fúnebre, así la «Canción del jinete»:

Caballito negro.

¿Dónde llevas tu jinete muerto?

(Obras completas II [1996] 2006, 339).

En esta canción la muerte es negra, como el caballo, incluso la luna testigo de los acontecimientos es negra. Y la suerte de este jinete, herido y moribundo, está a lomos de

\footnotetext{
${ }^{250}$ Los caballos como presagio de la muerte ya existen desde la antigüedad griega y se extiende hasta todo el folklore europeo. La mayor parte de los caballos de la muerte son negros. (Chevalier y Gheerbrant 1993, 211).
} 
un caballo negro, y a la pregunta «¿Dónde llevas tu jinete muerto?», Lorca la deja sin respuesta.

\subsection{4.- Los tres hombres: Hombre 1, Hombre 2 y Hombre 3}

Los Hombres también pertenecen al mismo mundo inconsciente de los Caballos, pero en un plano menos latente, menos profundo. Aunque, en un principio, el diálogo entre los Hombres y el Director es más racional, luego se vuelve más violento e irónico. Al final, los Hombres terminan triunfando sobre el Director.

Así, el Hombre 1 se dirige al Director para que reconozca su secreta homosexualidad. De nada sirve seguir autocensurándose y convocar a Elena, para seguir oculto tras la máscara y el teatro convencional. El juego de la verdad ya no tiene vuelta atrás y se impone, objeto leitmotiv de la obra. Las máscaras y los trajes esconden la identidad de los personajes, pero también el teatro al aire libre oculta el verdadero teatro bajo la arena:

HOMBRE 1.- [...] Pero usted lo que quiere es engañarnos. Engañarnos para que todo siga igual y nos sea imposible ayudar a los muertos. [...]

DIRECTOR.- (Levantándose.) Yo no discuto, señor. ¿Pero qué es lo que quiere de mí? ¿Trae usted una obra nueva?

HOMBRE 1.- ¿Le parece a usted obra más nueva que nosotros con nuestras barbas... y usted?

DIRECTOR.- - ¿Y yo...?

HOMBRE 1.- - Sí..., usted.

HOMBRE 2.- ¡Gonzalo!

HOMBRE 1.- (Mirando al DIRECTOR.) Lo reconozco todavía [...] Y tú, ¿me reconoces?

DIRECTOR. - No es éste el argumento. ¡Por Dios! ( $A$ voces) ¡Elena! ¡Elena! (Corre a la puerta.)

HOMBRE 1.- Pero te he de llevar al escenario quieras o no quieras. Me has hecho sufrir demasiado. ¡Pronto! ¡El biombo! ¡El biombo! (Cuadro I, 111-113). 
A partir de ahora, el biombo será el elemento fundamental para que todo aquel que lo traspase muestre su verdadera identidad oculta tras las máscaras. Y es por eso que el Hombre 1 obliga al Director a cruzarlo y, de este modo, sincerarse.

Poeta en Nueva York, Viaje a la luna y El público no sólo comparten estética, sino que en ocasiones, algunos personajes de las tres obras guardan relación entre ellos. Es el caso de los tres tipos del guión:

Ya en la calle nocturna hay tres tipos con gabanes que dan muestras de frío. Llevan los cuellos subidos. Uno mira la luna hacia arriba levantando la cabeza y aparece la luna en la pantalla, otro mira la luna y aparece una cabeza de pájaro en gran plano a la cual se estruja el cuello hasta que muera ante el objetivo, el tercero mira la luna y aparece en la pantalla una luna dibujada sobre fondo blanco que se disuelve sobre un sexo y el sexo en la boca que grita (Viaje a la luna 45,70 ).

Cada uno de ellos obtiene una visión diferente de lo que está observando, la luna.La luna misma, la cabeza de un pájaro que muere lo relacionamos con la represión sexual masculina y la luna dibujada como un sexo que se transforma en boca, recordándonos al sexo femenino. En El público los tres Hombres también muestran posturas y visiones diferentes.

También los personajes de «Fábula y rueda de los tres amigos» en Poeta en Nueva York nos sugieren la relación entre ellos. En el poema aparece el nombre de Enrique, el tema del disfraz y la numeración para definir la identidad de cada personaje:
Enrique,
Emilio
Lorenzo.
$[\ldots]$
Uno
$\mathrm{y}$ uno
y uno.
[...]
Tres
y dos
y uno.
[...] 
Enrique,

Emilio,

Lorenzo

(Poeta en Nueva York [1929] 2013, 109-112).

\subsection{5.- Elena}

La figura de Elena personifica todo aquello característico de lo femenino que va tras el hombre sin clara identidad. Temida por el Emperador, Elena aparece en el Cuadro I, se dirige al Hombre 3 y, señalando al Director del teatro, le dice:

ELENA.- (Al HOMBRE 3.) ¡Vete con él! Y confiésame ya la verdad que me ocultas. No me importa que estuvieras borracho y que te quieras justificar, pero tú lo has besado y has dormido en la misma cama (Cuadro I, 119).

Elena se enfrenta con el Hombre 3 y delata ante los demás los placeres prohibidos que trataba de ocultar socialmente. Es el símbolo del escarnio público al que será víctima el Hombre 3, al poner en evidencia su sexualidad.

En la acotación de su indumentaria, la describe vestida de griega, para hacer referencia a la Elena de Troya, sus pies están calzados de yeso, unos pies desnudos cubiertos de yeso que le dificultan el movimiento libremente. El calzado es símbolo de afirmación social y de autoridad. Para los antiguos era un signo de libertad - en Roma los esclavos iban descalzos - , símbolo de afirmación social y autoridad. Chevalier y Gheerbrant afirman que «según los psicoanalistas (Freud, Jung, etc.), el pie también tiene significación fálica y el calzado sería símbolo femenino; al pie corresponde adaptarse a él. El pie sería el símbolo infantil del falo» $(1993,827)$.

\subsection{6.- La Figura de Cascabeles y la Figura de Pámpanos}

La Figura de Cascabeles representa lo masculino, personaje que coincide en el ámbito del Director. La Figura de Pámpanos representa lo femenino, relacionado con el personaje del Hombre 1. Son arquetipos de lo opuesto: de lo masculino y de lo femenino. Entre ellas se libra una lucha dialogada, en forma de danza, cuyo tema principal es el amor imposible y cómo alcanzarlo mediante la metamorfosis. 
En la tradición popular, los cascabeles eran utilizados como un símbolo de los genitales masculinos. En los refranes españoles, los cascabeles suelen tener también claras connotaciones eróticas. «Esta identificación de los cascabeles con los testículos masculinos se halla también documentada en chistes y cuentecillos del Renacimiento y del Siglo de Oro. [...] También en la poesía erótica del Siglo de Oro, las alusiones a cascabeles suelen implicar el referente oculto de los testículos» (Pedrosa 1998, 382383). La identificación de los cascabeles con los testículos está presente en gran parte de la zona hispanohablante. En sus diversas fiestas carnavalescas y «en bailes de distintas regiones de España, [...] también hay danzas, exclusivamente masculinas, en que los cascabeles tienen un papel fundamental de representación de la virilidad» (Pedrosa 1998, 384).

De nuevo, la utilización de un lenguaje escatológico está presente en la obra en diferentes personajes, su intención no es buscar la vulgaridad de las palabras sino que son expresiones comunes al lenguaje familiar de todos los pueblos:

FIGURA DE CASCABELES.- - Si me convirtiera en caca...

FIGURA DE PÁMPANOS.- . ..Yo me convertiría en mosca. (Cuadro II, 123).

En simbología, los pámpanos, es decir la viña y la parra, son metáforas de la mujer y de lo femenino. Abundan los refranes españoles que identifican la viña y las parras con el sexo femenino. Como afirma José Manuel Pedrosa «en el Renacimiento y en el Siglo de Oro españoles abundaron los poemas en que la viña y la parra aparecían como correlatos eróticos de la mujer. [...] En la tradición oral más reciente, también se han recogido canciones» $(1998,374-375)$ con la misma simbología. La identificación de este elemento con la mujer sigue perdurando en muchas tradiciones poéticas. En los pueblos antiguos de Oriente, la vid fue identificada como la hierba de la vida; en el ideograma sumerio, una hoja de parra era el signo para la vida; para los antiguos griegos, la cepa simbolizaba a la mujer-madre; entre los antiguos judíos se identifica a la esposa con una vid fecunda; en los textos islámicos a la mujer es llamada campo, viña de uvas, etc. Esta visión es común en muchos pueblos, que «consideran la vid como signo de inmortalidad. Asimismo pasó a Israel y por éste al cristianismo. El propio Jesús, como dador de vida, se compara con la vid» (Revilla [1990] 2009, 697). 
La Figura de Pámpanos nos remite al dios $\mathrm{Baco}^{251}$ representado en el arte bajo «la figura de un joven imberbe, fresco, mofletudo, coronado de hiedra o pámpanos, llevando un tirso en la mano, o bien un racimo de uvas o una copa; una piel de leopardo le sirve de vestido» (Humbert 2012, 73), símbolo del entusiasmo y de los deseos amorosos. El Baco mitológico, que hallamos detrás de la Figura de Pámpanos, «se hace más evidente cuando conocemos que los motivos de la danza y las metamorfosis que incluye Lorca en su drama escénico también se hallan presentes en la leyenda pagana» (Pedrosa 1998, 380).

Existe una clara analogía entre el diálogo de las figuras de Pámpanos y Cascabeles y el mito clásico de Baco y Ciso, el cual se metamorfosea en vid para poder seguir disfrutando de la presencia de su amado. Una vez más, Lorca utiliza el mito en sus obras. En la conferencia «La imagen poética de don Luis de Góngora», acudía a los versos de una Soledad de Góngora, en los que menciona estas transformaciones:

Seis chopos, de seis yedras abrazados,

Tirso eran del griego dios, nacido

Segunda vez, que en pámpanos desmiente

Los cuernos de su frente.

(citado en Obras completas III [1996] 2006, 47).

Estos versos Lorca los introduce con la aclaración del mito y sus metamorfosis siguiente: «por amor a su bailarín Ciso, que muere y se convierte en yedra, Baco, con el ansia de abrazarlo eternamente, se convierte en vid» (Obras completas III [1996] 2006, 47). La figura cubierta de pámpanos es, pues, una derivación del dios Baco, y la Figura de Cascabeles está inspirada en Ciso.

La flauta que toca al comienzo del cuadro, mientras la Figura Cascabeles danza, es un instrumento que su sonido se relaciona simbólicamente con lo femenino. En la entrada del Emperador a escena en busca de Uno, la Figura de Pámpanos «se despoja de los pámpanos y aparece un desnudo blanco de yeso» (Cuadro II, 135). Se libera de sus

\footnotetext{
${ }^{251}$ En la antigüedad clásica el dios Baco, nombre romano de Dionisos, y las personas a él consagradas aparecen coronados de pámpanos. Baco, es el dios «del arrebato, el frenesí y el entusiasmo. También dios del vino, originariamente representativo de las fuerzas desatadas de la naturaleza salvaje. Se acompaña de una ropa de sátiros y bacantes, representado por lo general coronado de pámpanos y con alguna frecuencia ebrio». (Revilla [1990] 2009, 78).
} 
atributos masculinos para entregarse en todo su carácter femenino, mostrando una ambigüedad sexual, característica muy lorquiana.

Como hemos expuesto con anterioridad, la simbología erótica y cultural, subyacente en los pámpanos y en los cascabeles, constituye motivos cruciales en el Cuadro segundo y en toda la obra de El público de Lorca:

asimilaba y recreaba de modo original las influencias más diversas: de la tragedia griega y el cine mudo, del folclore infantil y la vanguardia americana, del mundo gitano y el surrealismo, de la música cultura europea y el arte japonés... A El público concretamente, además de influencias de Shakespeare, Pirandello, Cocteau, Goethe o Calderón [...] Las Mil y una Noches [...] El Bosco [...]. Lorca captaba y fundía en su obra todo el mundo, el físico, el artístico y el soñado o imaginado, que le rodeaba. (Pedrosa 1998, 385).

Son múltiples las concomitancias de Lorca que encontramos en la obra El público: la abundancia de imágenes plásticas poéticas tan cinematográficas, la importancia de la infancia y su inocencia, libre de máscaras y ataduras sociales, la ambigüedad erótica y amorosa de Shakespeare, la obra pictórica de El Bosco, en concreto con El jardín de las delicias, el dramaturgo Pirandello con fusión de la realidad y la ficción, la vida como representación de Calderón de la Barca, etc.

\subsection{7.- El Emperador, Centurión y Niño}

El Emperador y el Centurión son personajes que pertenecen al teatro bajo la arena que mantienen su apariencia sin cambios. El Emperador representa la sexualidad impuesta desde el poder pero, en cambio, el Centurión nos ofrece una perspectiva grotesca de la potencia masculina:

CENTURIÓN.- - [...] Yo tengo doscientos hijos y tendré muchos más (Cuadro II, 134).

No quiere que se dude de su virilidad y de su potencia de engendrar hijos.

La figura del Emperador podemos identificarla con el poder, incluso, en un sentido negativo, con la dominación y la tiranía. Ordena pues ya tiene voluntad de poder y posee la supremacía de la inteligencia. También es un personaje complejo, ya que en el 
juego, al quitarse los guantes, «Se quita unos guantes negros, después unos guantes rojos, y aparecen sus manos de una blancura clásica» (Cuadro II, 134), puede mostrarnos sus diferentes personalidades, lo masculino, lo pasional y lo femenino. Los guantes evitan el contacto directo con lo material y la realidad.

El niño o el hijo es una figura muy presente en toda la obra de Lorca, la inocencia de la infancia, libre aún de normas, restricciones e hipocresía. Es el estado natural que ansía el autor alcanzar, lo mismo que los surrealistas creían que, durante la infancia, es cuando más libertad alcanzaba el ser humano. En El público, aún siendo un personaje muy secundario, tiene un gran valor simbólico, ya que el niño es engañado por el Emperador y este acaba con su vida utilizando la fuerza de sus manos. El Emperador con su poder destruye la inocencia del niño, convirtiéndose en la víctima del mundo.

\subsection{8.- Julieta}

La salida de Julieta del sepulcro, donde yace, guarda relación con la canción del Arlequín en el comienzo del Cuadro I del Acto III de Así que pasen cinco años, en el que se entrecruzan los conceptos del sueño y el tiempo. En ambos poemas el conflicto y la unión del sueño y el tiempo están tratados de manera muy similar, los dos cantan: Julieta desde la muerte y el Arlequín, posible mensajero de la muerte, fuera del tiempo (Martínez Nadal [1970] 1974, 73):

Julieta.-

(Canta)

Un mar de sueño.

Un mar de tierra blanca

Y los arcos vacíos por el cielo.

Mi cola por las naves, por las algas.

Mi cola por el tiempo.

Un mar de tiempo.

Playa de los gusanos leñadores

Y delfín de cristal por los cerezos.

$¡$ Oh puro amianto fe final! $¡$ Oh ruina!

¡Oh soledad sin arco! ¡Mar de sueño! (Cuadro III, 145). 


\author{
Arlequín.- \\ El Sueño va sobre el Tiempo \\ flotando como un velero. \\ Nadie puede abrir semillas \\ en el corazón del Sueño. \\ $[\ldots]$ \\ El Tiempo va sobre el Sueño \\ Hundido hasta los cabellos \\ Ayer y mañana comen \\ Oscuras flores de duelo.
}

(Así que pasen cinco años, Acto III, Cuadro I, 292-293)

En las dos canciones la fugacidad de la vida y el sueño forman parte del tema principal.

También, nos muestran la soledad de la humanidad.

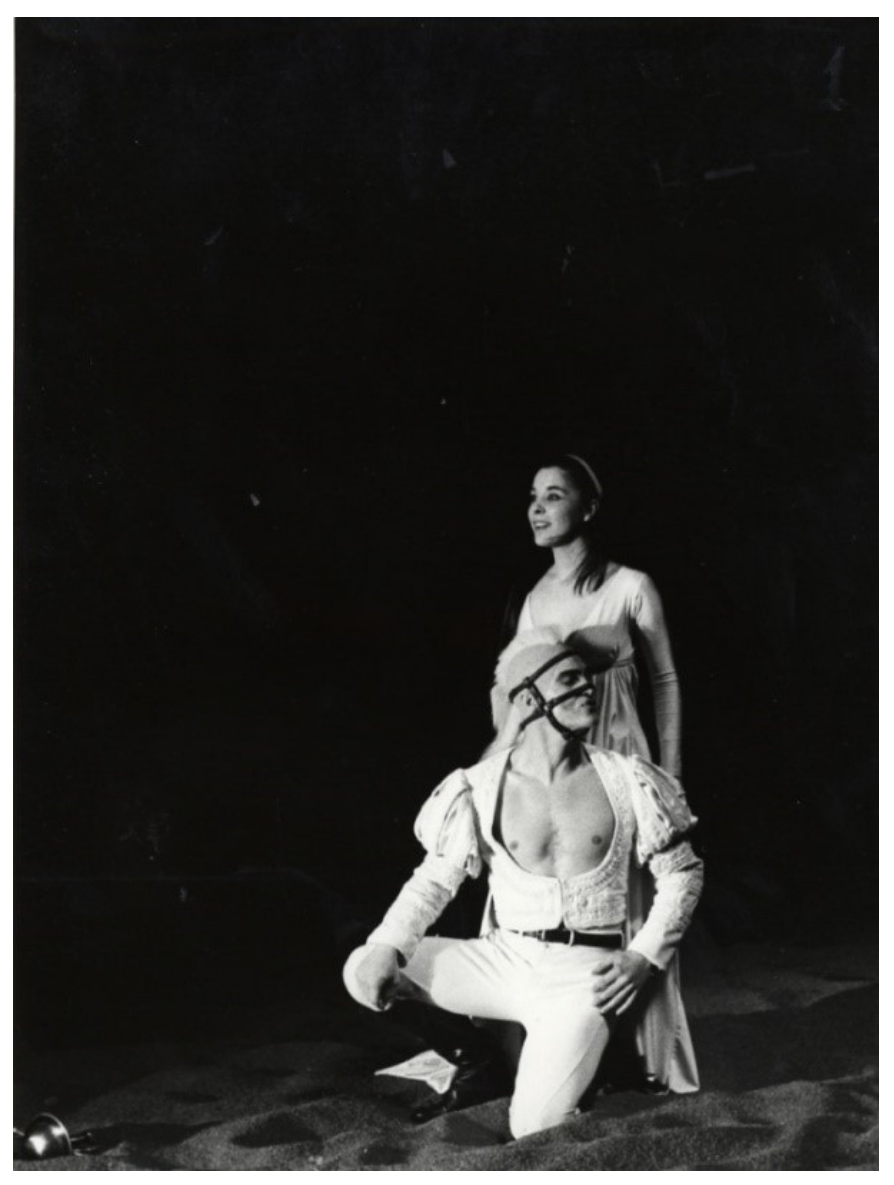

Fig. 95: Julieta y el Caballo Blanco 1 durante la representación de El público de Lluís Pasqual en el Teatro María Guerrero Madrid, 1987.

Fotografía de Manuel Martínez Muñoz. 
Así como los Caballos blancos le ofrecían el falso deseo, el Caballo Negro conduce a Julieta, de nuevo, al sepulcro antes de que escuche el canto del ruiseñor. El simbolismo de los caballos, blancos y negro, expresa una finalidad en contraposición, un oxímoron.

\subsection{9.- Los trajes}

El tema de las máscaras y el traje tiene una gran significación en El público. Diferentes trajes vacíos hablan, se mueven e intervienen en determinadas ocasiones. El símbolo del traje, como aquello hueco y vacío, se aplica a todo lo que no logra encontrar su propia identidad. Según afirma Gustavo Correa, «el hueco como la expresión más exacta de la pérdida del ser, subraya en forma angustiosa el sentimiento de soledad que constituye el subsuelo emocional de donde se nutre esta poesía» $(1975,179)$. El concepto de vestido significa lo pasivo y lo negativo, al estar huecos, están vacíos de vida y de existencia. Trajes que han perdido la vida y son sólo apariencia.

En el poema «La voz a ti debida» de Pedro Salinas, otro miembro del 27, el poeta exige a la amada que se desprenda de los trajes y disfraces de la falsedad, y que se muestre como es ella, pura y libre:

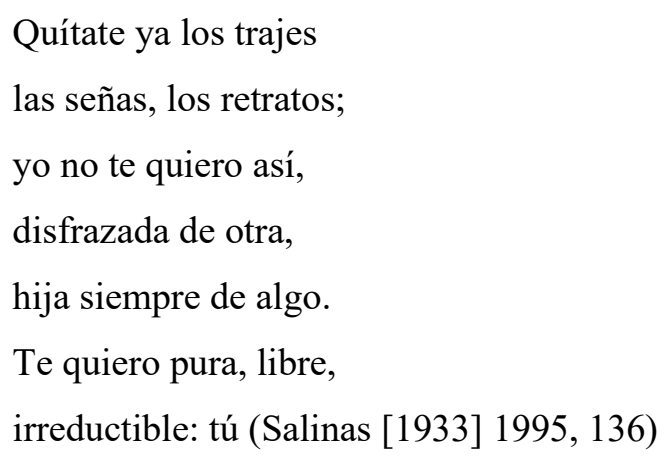

En el Cuadro I, el Traje de Arlequín es la primera metamorfosis que experimenta el Director, un muchacho vestido de blanco. En el Cuadro III es un personaje autónomo al del Director. En el Cuadro II, el Traje de Bailarina es la segunda metamorfosis del Director. En un inicio, son unos atuendos dependientes del Director que se convertirán en personaje en el Cuadro III.

En el Cuadro I, el Traje de Pijama es la indumentaria del Hombre 2, tras pasar por el biombo. En el Cuadro III, aparece ya como traje convertido en personaje independiente 
del Hombre 2. Su acción es mímica ya que no habla nunca. Es como un personaje inanimado, vacío, que ya no vuelve a aparecer.

El Traje de Bailarina, el Traje de Pijama negro y el Traje de Arlequín habitan en una dimensión diferente a la de los demás personajes, vagando en una especie de limbo, sin personalidad ni recuerdo del personaje que los habitó.

Existe un paralelismo entre el personaje del Maniquí de Así que pase cinco años con estos trajes-personajes. Identificamos a la figura del maniquí del vestido de novia con una falta de amor o frustración amorosa tras una espera infructuosa:

MANIQUÍ.-

¿Quién se pondrá mi traje? ¿Quién se lo pondrá?

Se lo pondrá la ría grande para casarse con el mar.

$[\ldots]$

¿Quién usará la ropa buena

De la novia chiquita y morena?

$[\ldots]$

¿Quién se pondrá mi traje? ¿Quién se lo pondrá?

(Así que pasen cinco años, Acto II, 277-284).

La importancia de esos trajes y el dominio sobre ellos los expone el Director del teatro cuando admite que

Cuando los trajes hablen, las personas vivas son ya botones de hueso en las paredes del calvario. Yo hice el túnel para apoderarme de los trajes y, a través de ellos, haber enseñado el perfil de una fuerza oculta cuando ya el público no tuviera más remedio que atender, lleno de espíritu y subyugado a la acción (Cuadro V, 190).

El concepto del traje como configuración de la vida mediante la sucesión de los mismos, la encontramos ya en su obra más temprana. Así, en el poema «Confusión», perteneciente a sus Suites:

¿Por qué cambia mi traje

de colores?

(Obras Completas I [1996] 2005, 169). 
Aunque su presencia más continua la encontramos en su periodo neoyorquino. El traje como algo negativo está muy presente en diversos poemas de Poeta en Nueva York. La idea de la pérdida de identidad y la búsqueda por mostrar los sentimientos las reitera en el poema «El niño Stanton» quien, a sus diez años, acaba de morir de cáncer y cuyo recuerdo es evocado por el poeta, al buscar un traje para manifestar su dolor:

Mi agonía buscaba su traje,

polvorienta, mordida por los perros,

y tú la acompañaste sin temblar

hasta la puerta del agua oscura.

(Poeta en Nueva York [1929] 2013, 162).

Asimismo, en el poema neoyorquino «El rey de Harlem» muestra el traje como un símbolo negativo, para expresar la inexistencia de las personas, la ausencia total del ser:

¡Ay, Harlem disfrazada!

¡Ay, Harlem, amenazada por un gentío de trajes sin cabezas!

(Poeta en Nueva York [1929] 2013, 123).

También en Poeta en Nueva York, encontramos el poema «1910 (Intermedio)», en el que Lorca recurre a los elementos del vacío, el hueco, los trajes y el desnudo, para describir el abandono de la pureza y la pérdida de la inocencia. Cuando abandonamos atrás la infancia, nos socializamos y nos vestimos, dejando atrás la desnudez de la autenticidad, y entonces aparecen esos trajes vacíos y huecos:

[...] He visto que las cosas

Cuando buscan su curso encuentran su vacío.

Hay un dolor de huecos por el aire sin gente

$\mathrm{Y}$ en mis ojos criaturas vestidas $¡$ sin desnudos!

(Poeta en Nueva York [1929] 2013, 106).

En el guion cinematográfico Viaje a la luna nos describe un traje de arlequín sobre un desnudo que deja al descubierto el sistema de circulación venosa:

En lo alto aparece un desnudo de muchacho. Tiene la cabeza como los muñecos anatómicos con los músculos y las venas y los tendones. Luego sobre el desnudo lleva dibujado el sistema de circulación de la sangre y arrastra un traje de arlequín. (Viaje a la luna 43,69$)$. 
El traje del arlequín es el disfraz, la hipocresía, en contraposición a la sinceridad del hombre de las venas.

\subsubsection{1.- El traje de Arlequín}

La primera intervención del Traje del Arlequín se da al atravesar el Director, el biombo, revelándosenos como alguien totalmente distinto, un arlequín, prototipo de la ambigüedad sexual. Las intervenciones del Traje de Arlequín son siempre repetitivas: volviendo a decir lo que él ha dicho o el eco de las palabras de Gonzalo (Hombre 1).

El Traje de Arlequín aparece, por su parte, como personaje cuando el Director se desprende de él al huir con los Caballos. Julio Huélamo Kosma lo define como

puro recuerdo de la existencia abandonada, esto es, resto deshabitado de la conciencia que lo animaba, se convierte en un ente vacío, carente de personalidad, [...] condenado a vagar, ausente el calor que proporcionaba la vida, en un mundo de sombras con la más absoluta sensación de desamparo y frialdad (1996, 238).

Según Morales y Marín, el arlequín «simboliza la inconsciencia, sin ideas, sin principios, sin carácter» $(1984,55)$.

\subsubsection{0.- Desnudo Rojo, Enfermero y Ladrones}

En el Cuadro IV, comparten escena y diálogo una serie de personajes que son equivalentes a los personajes que surgen en los pasajes evangélicos de la pasión y muerte de Jesús. El texto deja evidencias claras (en ocasiones con citas prácticamente textuales sacadas de los evangelios del Nuevo Testamento), de la relación que existe entre el Desnudo Rojo y Jesucristo, el Enfermero con el soldado romano y los Ladrones (Ladrón 1 y 2) con los dos hombres que son crucificados junto a Jesús: Dimas, el buen ladrón y Gestas, el mal ladrón. El texto relata la crucifixión y muerte de Jesús, que se narra de una forma sencilla. Describe la agonía y la muerte del Desnudo Rojo como claro reflejo de la que sufrió Jesucristo en el Calvario. Historia que Lorca entrelaza con otras historias simultáneas, como ya hemos dicho, representando la crucifixión un sacrificio en aras de un teatro de la verdad. 
Ya desde la primera acotación, «DESNUDO ROJO coronado de espinas azules», encontramos la evidente representación de Jesús crucificado.

A continuación, analizaremos los diálogos entre los personajes y compararemos sus referentes con el texto de la Biblia ${ }^{252}$ :

DESNUDO.- - Yo deseo morir. ¿Cuántos vasos de sangre me habéis sacado?

ENFERMERO.- Cincuenta. Ahora te daré la hiel y luego, a las ocho, vendré con el bisturí para ahondarte la herida del costado (Cuadro IV, 170).

El Desnudo rojo está agonizando desde el inicio del cuadro cuarto y el Enfermero le ofrece hiel. La mención de hiel en el Evangelio, según San Mateo, la situamos «cuando llegaron al lugar llamado Gólgota ${ }^{253}[. .$.$] , le dieron a beber vino mezclado con hiel; él lo$ probó, pero no quiso beberlo» (Mt 27, 33-34). A los ajusticiados se les daba un brebaje anestesiante, a base de vino mezclado con mirra, para paliar el dolor del moribundo. La mención de hiel evoca el dolor, la queja y la angustia del justo que sufre, descrito en el Salmo 22:

En mi comida me echaron hiel,

Para mi sed me dieron vinagre (Sal 69, 22).

En la expresión de la herida del costado, de nuevo el drama sigue de cerca la narración evangélica, según la cual los judíos rogaron a Pilato acelerar la muerte de Cristo con los dos ladrones quebrándoles las piernas, como se lee en el Evangelio según Juan:

Los judíos entonces, como era el día de la Preparación, para que no se quedaran los cuerpos en la cruz el sábado, porque aquel sábado era un día grande, pidieron a Pilato que les quebraran las piernas y que los quitaran. Fueron los soldados, le quebraron las piernas al primero y luego al otro que habían crucificado con él; pero al llegar a Jesús viendo que ya había muerto, no le quebraron las piernas, sino que uno de los soldados, con la lanza, le traspasó el costado, y al punto salió sangre y agua (Jn 19, 31-34).

\footnotetext{
${ }^{252}$ Las citas están tomadas de la versión oficial de la Sagrada Biblia (2011), publicada por la Conferencia Episcopal Española, en Madrid por Biblioteca de Autores Cristianos. También se ha consultado el Nuevo comentario Bíblico San Jerónimo. Nuevo Testamento y artículos temáticos (2004), editado por Raymond E. Brown, Joseph A. Fitzmyer y Roland E. Murphy, en Estella (Navarra) por Editorial Verbo Divino.

${ }^{253} \mathrm{El}$ nombre griego del lugar es la transliteración del término arameo gulgultā, «calavera» que se refiere a la forma y uso al que estaba destinado el lugar. En la tradición, el nombre de Calvario procede de la palabra latina «calavera» (calvaria). Gólgota era una pequeña colina rocosa fuera de los muros de la ciudad (Jerusalén).
} 
En el cuadro cuarto intervienen más personajes que comparten escena pero son historias paralelas. Después del diálogo entre los cuatro estudiantes, vuelve el protagonismo a la escena del Desnudo rojo y el Enfermero:

DESNUDO.——Cuánto falta para Jerusalén?

ENFERMERO.- Tres estaciones si queda bastante carbón

DESNUDO.- Padre mío, aparta de mí este cáliz de amargura (Cuadro IV, 171).

Si volvemos a la Biblia encontramos que, durante la oración en el huerto de los Olivos, Jesús se apartó de sus discípulos y se arrodilló, adoptando una postura de humildad, para orar, diciendo: «Padre, si quieres, aparta de mí este cáliz; pero que no se haga mi voluntad, sino la tuya» (Lc 22,42). La versión de Lorca es casi literal a la del Evangelio, según Lucas:

DESNUDO.- - Tengo sed.

$[\ldots]$

DESNUDO.- Padre mío, perdónalos, que no saben lo que se hacen (Cuadro IV, 172,177).

En diferentes momentos de la intervención del Desnudo rojo, volvemos a encontrar referencias literales de los Evangelios. En el momento final de la muerte de Jesús y también del Desnudo Rojo, este expresa que tiene sed, frase que encontramos en el Evangelio según Juan:

Después de esto, sabiendo Jesús que ya todo estaba cumplido, para que se cumpliera la Escritura, dijo: «Tengo sed».

Había allí un jarro lleno de vinagre. Y, sujetando una esponja empapada en vinagre a una caña de hisopo, se le acercaron a la boca. Jesús, cuando tomó el vinagre, dijo «Está cumplido». E, inclinando la cabeza, entregó el espíritu (Jn 19, 28-29).

La siguiente intervención del Desnudo Rojo pide el perdón de los pecados de quienes están acabando con su vida por la ignorancia de la verdad. La frase es una variante de la oración evangélica de Lucas, «Y cuando llegaron al lugar llamado «La Calavera», lo crucificaron allí a él y a los malhechores, uno a la derecha y otro a la izquierda. Jesús decía: "Padre, perdónalos, porque no saben lo que hacen"» $(\operatorname{Lc} 23,34)$ :

LOS LADRONES.- (Levantando los cirios.) Santo. Santo. Santo. 
DESNUDO.- Padre, en tus manos encomiendo mi espíritu.

$[\ldots]$

ENFERMERO.- (Mirando el reloj y en voz alta.) Traed la sábana [...]

LOS LADRONES.- Santo. Santo. Santo.

DESNUDO.- Todo se ha consumado.

(La cama gira sobre un eje y el DESNUDO desaparece [...]) (Cuadro IV, 180-181).

De nuevo, en la intervención del Desnudo Rojo, encontramos otra frase literal del Evangelio según Lucas:

Era ya como la hora de sexta, y vinieron las tinieblas sobre toda la tierra, hasta la hora nona, porque se oscureció el sol. El velo del templo se rasgó de medio. Y Jesús, clamando con voz potente, dijo: «Padre, a tus manos encomiendo mi espíritu». Y, dicho esto, expiró (Lc 23, 44-46).

La oración de Jesús se basa en el Salmo 31 que describe al justo que sufre inocentemente:

Sácame de la red que me han tendido,

Porque tú eres mi amparo (Sal 31,5).

Una vez descienden el cuerpo de Jesús, lo cubren con una sábana para llevarlo al sepulcro, la misma que exige el Enfermero que le traigan. Hay referencias a la crucifixión de Jesucristo en el diálogo que mantienen el Desnudo Rojo y el Enfermero y también entre otros personajes que aparecen durante el cuadro cuarto. Así, en la intervención del Traspunte, personaje enlace entre la realidad y la teatralidad, comenta que ha perdido la barba de José de Arimatea, considerando que es un atrezo de un actor pero, a su vez, es una referencia evangélica:

TRASPUNTE.- Le ruego me perdone, pero se había perdido la barba de José de Arimatea (Cuadro IV, 178).

El paralelismo evangélico culmina con esta referencia, a José de Arimatea, propietario del sepulcro, a quien Pilato concedió el permiso para retirar el cuerpo de Jesús y darle sepultura. En el Evangelio de Lucas le otorga un gran relieve a esta escena:

Había un hombre, llamado José, que era miembro del Sanedrín, hombre bueno y justo, (este no había dado su asentamiento a la decisión ni a la actuación de ellos); era natural 
de Arimatea, ciudad de los judíos, y aguardaba el reino de Dios. Este acudió a Pilato y le pidió el cuerpo de Jesús. Y, bajándolo, lo envolvió en una sábana y lo colocó en un sepulcro excavado en la roca, donde ninguno había sido puesto todavía (Lc 23 50-53).

Mediante estas alusiones bíblicas, Lorca imprime a sus escenas y, por tanto, obra una significación mítica.

En el diálogo entre el Desnudo Rojo y el Enfermero, la utilización de términos como bisturí, termómetro, quirófano, vitaminas, inyecciones, farmacias y el propio personaje de un enfermero nos remite a una operación quirúrgica, anacrónico con respecto a las escenas de la Biblia.

Aunque podamos relacionar la personalidad del Desnudo Rojo con otros personajes de la obra, en el siguiente diálogo comprobamos que no es Gonzalo ni el Director:

\author{
DESNUDO.- ¿Qué piden? \\ ENFERMERO.- Piden la muerte del Director de escena. \\ DESNUDO.- ¿Y qué dicen de mí? \\ ENFERMERO.- - Nada. \\ DESNUDO.- Y de Gonzalo, ¿se sabe algo? \\ ENFERMERO.- Lo están buscando en la ruina (Cuadro IV, 170).
}

Aún así, Lorca enlaza al Desnudo Rojo con el Hombre 1 (Gonzalo) en su agonía, como símbolo de todas las víctimas de la máscara y, mediante la desnudez de su cuerpo, nos muestra quién es en realidad, sin máscaras ni trajes que ocultan el estado natural del personaje, motivo de unión entre el Desnudo Rojo y el Hombre 1. En la última acotación de la intervención final del Desnudo Rojo, «la cama gira sobre un eje y el DESNUDO desaparece. Sobre el reverso del lecho aparece tendido el HOMBRE 1» (Cuadro IV, 181). Entre los múltiples significados, la cama es el lugar de la muerte. Después de la muerte del Desnudo, vendrá la muerte del Hombre 1.

Son múltiples las referencias de tema de la crucifixión en la obra de Lorca, pero consideramos apropiado nombrar su dibujo Soledad Montoya, sacado del «Romance de la pena negra» en la que una mujer vestida de rojo, de cabello negro y largo, con las brazos cruzados, en la que podemos ver en el fondo un paisaje andaluz y sobre una cruz la palabra «HOMBRE», conecta directamente con el DESNUDO ROJO. 


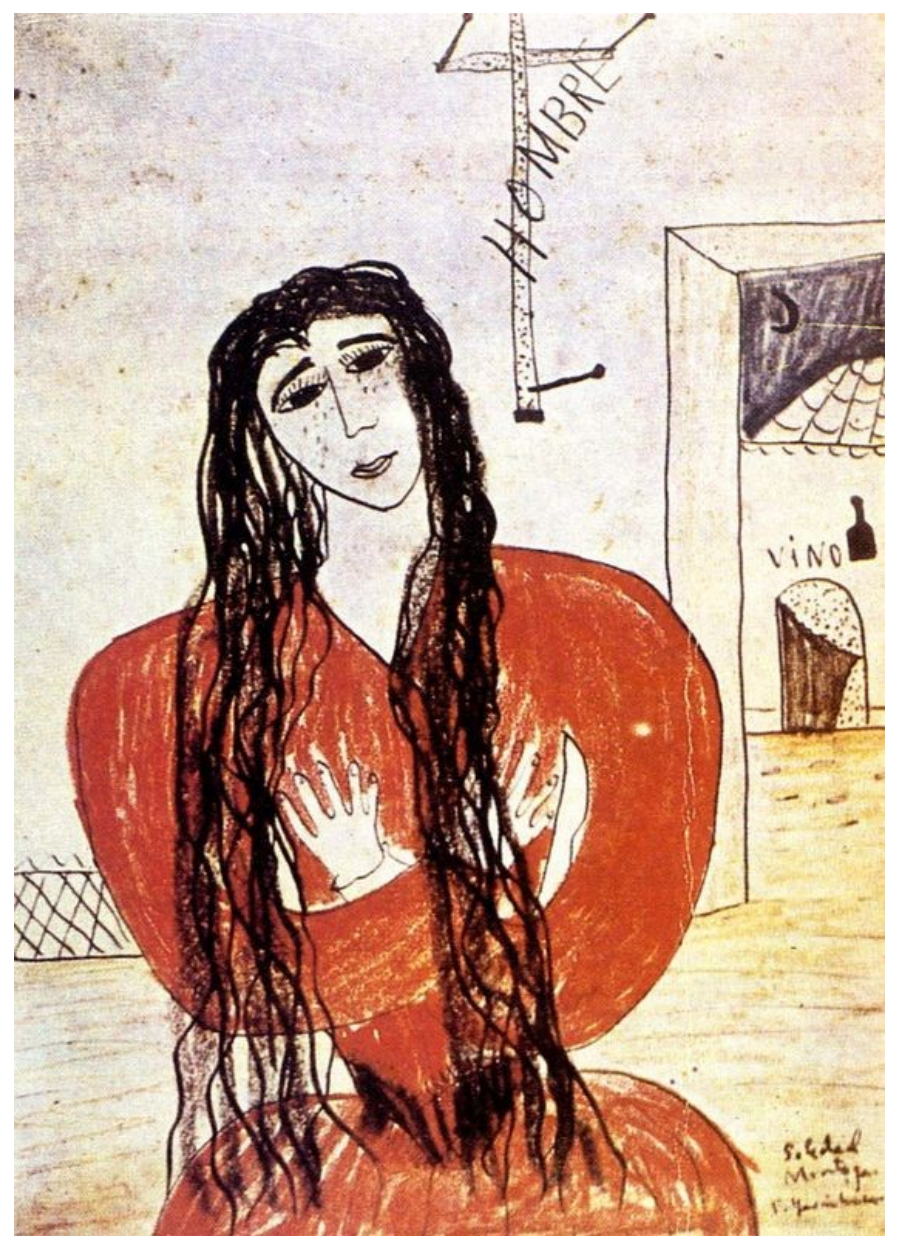

Fig. 96: Soledad Montoya (1930).

Tinta y lápices de color frente a «Romance de la pena negra».

\subsubsection{1.- Los Estudiantes, Las Damas y el Muchacho}

El componente originario de la tragedia griega es el coro. Era un personaje colectivo que tomaba decisiones en la acción. Su función principal era la presentación en el contexto o la explicación de las situaciones paras ayudar al público a seguir los sucesos ocurridos en la obra, y era un intermediario entre la acción y el espectador. En Federico García Lorca la utilización del coro es indispensable en el teatro y aparece en varias de sus obras, como en Bodas de Sangre y Yerma. En la entrevista ${ }^{254}$, que ofrecía en diciembre de 1924, el autor afirmaba:

\footnotetext{
254 J.L.. 1930. «La vida escénica. Ecos, noticias y comentarios del día. Antes del estreno. Hablando con Federico García Lorca». En La Libertad, Madrid, 24 de diciembre: 9
} 
El coro..., intervención directa; es la voz de la conciencia, de la religión, del remordimiento.

El coro es algo insustituible, algo tan profundamente teatral, que su exclusión no la concibo.

[...] De lo clásico, el corte amplio, magnífico, teatral, concepción gigante..., eso sí...; pero con libertad, sin tendencias minúsculas de ideas; teatro que respira con fuerza titánica, buscando en lo popular, en el pueblo, el nervio, el alma, la acción.

Figuras, ambiente... imaginativos. Pero una vez buscados, verlos abajo, junto a la tierra, en su vida..., en su medio pasional..., procurando coger esos momentos sublimes de exposición lírica, epílogo de los seres torturados (citado en Inglada 2017, 44).

En El público, encontramos varios coros: el de los Caballos, el de los Estudiantes y el de las Damas. El coro de los Estudiantes representa al grupo progresista y renovador de la sociedad. En su debate, analizan la representación de Romeo y Julieta y examinan la situación vivida durante el levantamiento. Entre ellos existen divergencias y puntos enfrentados.

Las Damas asumen el pensamiento conservador y tradicional de un público burgués que asiste a ver una representación realista, y su gusto se aleja de toda experimentación vanguardista.

A diferencia del coro clásico, que reflexionaba sobre el comportamiento y las acciones de los personajes, aquí el coro es más subjetivo ya que opina, comenta y juzga llevado por los sentimientos.

En cualquier obra literaria y artística existen diversas interpretaciones y recepciones, en el arte de vanguardia no sólo existe un punto de vista y una interpretación única, ya que la obra se distancia de los cánones clásicos. En El público, observamos el reflejo de la plurirrecepción de la obra teatral, con la presentación de ambos grupos, los estudiantes y las damas, en el que cada receptor percibe el texto según su perspectiva personal. Como afirma Gómez Torres, «el texto, desde luego, es único e invariable; pero cada receptor lo experimenta de un modo» $(1992,308)$.

La única esperanza de una revolución teatral está en manos de los estudiantes. Esa revolución teatral es la que Lorca describe en el único acto conservado de Comedia sin título. 
Entre los jóvenes estudiantes, cabe destacar la postura del Estudiante 5 que plantea la oposición entre la realidad y la representación, entre el actor y el personaje. No le importa la verdad de la representación, incluso afirma el rechazo que le produce esa realidad y la reacción que tendría al enfrentarse a esa verdad:

ESTUDIANTE 5.- (Alegrísimo.) Mirad: he conseguido un zapato de Julieta. La estaban amortajando las monjas y lo he robado.

ESTUDIANTE 4.- (Serio.) ¿Qué Julieta?

ESTUDIANTE 5.- ¿Qué Julieta iba a ser? La que estaba en el escenario, la que tenía los pies más bellos del mundo.

ESTUDIANTE 4.- (Con asombro.) ¿Pero no te has dado cuenta de que la Julieta que estaba en el sepulcro era un joven disfrazado, un truco del Director de escena, y que la verdadera Julita estaba amordazada debajo de los asientos?

ESTUDIANTE 5.- (Rompiendo a reír.) ¡Pues me gusta! Parecía muy hermosa, y si era un joven disfrazado no me importa nada; en cambio, no hubiese recogido el zapato de aquella muchacha llena de polvo que gemía como una gata debajo de las sillas (Cuadro IV, 183).

\subsubsection{2.- El Prestidigitador}

El prestidigitador es quien inicia el juego y anima el espectáculo, en simbología «por una extraña paradoja es un histrión, un escamoteador, el creador de un mundo ilusorio por sus gestos y por su palabra quien abre el juego» (Chevalier y Gheerbrant 1993, 614).

No sólo con este personaje relacionamos el teatro como magia, también en el juego del ilusionismo del biombo o con la capa del Prestidigitador que hace desaparecer a la Señora. Además, en diferentes acotaciones se pueden observar cambios producidos por la ilusión óptica de mutaciones de lugares o personajes. En la última acotación de $E l$ público «todo el ángulo izquierdo de la decoración se parte y aparece un cielo de nubes largas» (Cuadro V, 198) como una apertura más profunda a lo que estamos presenciando, un nuevo territorio que descubrir. 


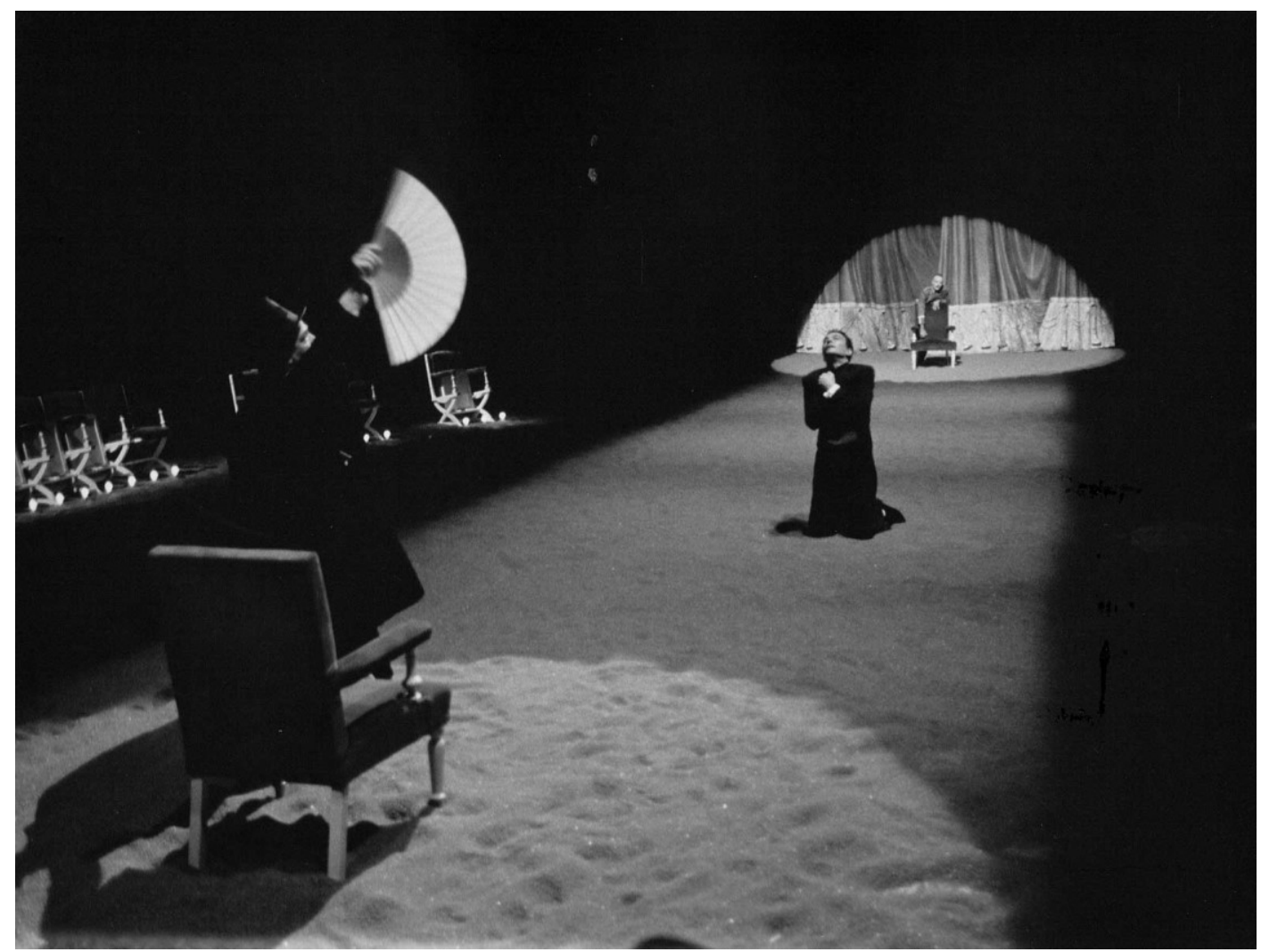

Fig. 97: Representación del último cuadro de El público en el que el Prestidigitador «empieza a abanicarse», durante la representación dirigida por Lluís Pasqual, en 1986 en el Teatro de la Comedia.

Fotografía de Bielva.

En el inicio del último cuadro, el Prestidigitador «saca un gran abanico blanco y empieza a abanicarse mientras canta suavemente» (Cuadro V, 196). Así efectúa su primera entrada. En la iconografía hindú, el abanico es un símbolo de sacrificio (Chevalier y Gheerbrant 1993,39) y debemos observar cómo al final del cuadro el Director muere. Con anterioridad, el Desnudo rojo también ha muerto, sacrificado, ya que en la obra el sacrificio y la muerte son dos elementos fundamentales para alcanzar el destino establecido desde el inicio de la obra. En ocasiones, querer mostrar la verdad, oculta tras la máscara, tiene como consecuencia la muerte. Como afirma Gómez Torres, Lorca identifica

la máscara con el público, que busca con furor quienes han osado mostrar verdades subterráneas. El espectador rechaza el enfrentamiento con lo real: si un autor dice la verdad e implica en ella al público — quita "las barandas al puente"—, corre el riesgo de que la máscara lo devore, de que la sociedad lo destruya por presentarse desnudo, violentando las reglas sociales, enemigas de toda autenticidad $(1992,305)$. 
Durante todo su intervención, el Prestidigitador abanica con alegría en un ambiente frío, donde el Director y el Criado lo sienten y también el miedo ante la posible muerte que está por llegar. Al final de la obra, «empiezan a caer copos de nieve» (Cuadro V, 198). Para Lorca la nieve posee un significado positivo y negativo. Entre los valores positivos, encontramos la pureza y la inocencia, pero, en este caso, la nieve, junto al frío que sienten los personajes que se hallan en escena, son un anuncio de la muerte, del final de algo y el principio de lo nuevo (García-Posada 1981, 140).

Todo el texto está repleto de referencias surrealistas, con diálogos absurdos, asociación de objetos inconexos, límites no definidos entre el sueño y la vigilia, entre el teatro al aire libre o bajo la arena. En el personaje del Prestidigitador se concentran mejor todas estas ideas surrealistas, ya que podemos considerarlo como más próximo al subconsciente. Ejemplo de ello, la conversación que mantiene con el Director:

PRESTIDIGITADOR.- Yo convierto sin ningún esfuerzo un frasco de tinta en una mano cortada llena de anillos antiguos.

[...]

PRESTIDIGITADOR. - Yo puedo convertir un navegante en una aguja de coser (Cuadro V, 191-192).

En los dibujos de Federico García Lorca encontramos numerosas manos cortadas y guantes. La mano cortada es una imagen utilizada por los surrealistas, forma parte en la pintura de La miel es más dulce que la sangre (1927) de Salvador Dalí, y también en la película Un perro andaluz (1929) de Luis Buñuel y Salvador Dalí.

Lorca repetirá este motivo de la mano cortada, típicamente surrealista, en diferentes ilustraciones. Por citar alguna, las manos cortadas sangrantes aparecen en el dibujo «Animal fabuloso dirigiéndose a una casa» (h. 1929-1930), o en la poema en prosa «Santa Lucía y san Lázaro», en donde se nombra una mano sangrante, «la inmensa mano cortada de la guantería, poema en el aire, que suena, sangra y borbotea como la cabeza de Bautista» (Obras completas II [1996] 2006, 463). 


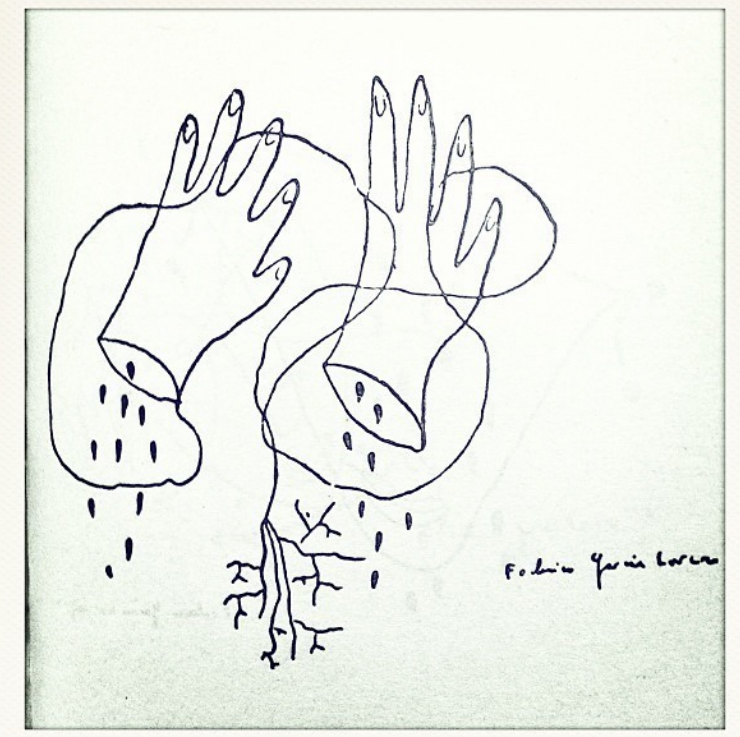

Fig. 98: Manos cortadas (h. 1935-1936).

Tinta china sobre papel tela, $23,1 \times 16,5 \mathrm{~cm}$.

Colección: Fundación Federico García Lorca (Legado Jean Gebser).

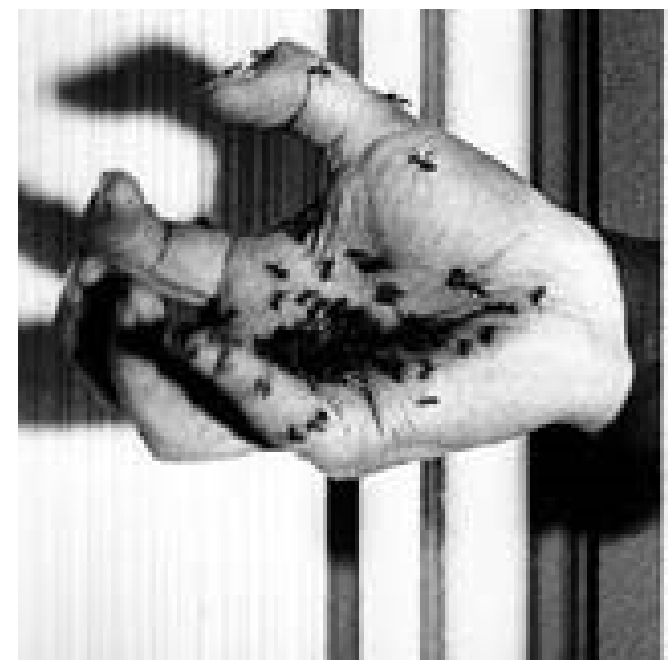

Fig. 99: Secuencia de la mano llena de hormigas atrapada en una puerta de la película Un perro andaluz.

La aguja de coser, a la que se refiere el Prestidigitador, nos recuerda la cámara de disección de Lautréamont en la que, de forma fortuita, se encuentran dos objetos dispares para crear una imagen artística. La búsqueda constante entre los miembros del grupo surrealista fue encontrar objetos nuevos producidos por el enlace de realidades inconexas, incluso contradictorias. 


\subsubsection{3.- La Señora}

La Señora se asemeja a un personaje del mundo real que entra en el ámbito de la imaginación. Representa la maternidad que asegura la supervivencia de la especie y que, como abstracción o símbolo, es inmortal y, por tanto, no perecedera. La Señora es la madre anónima, y Gonzalo representa a todos los hijos de madre, nacido sin máscara.

La Señora presiente la muerte trágica de su hijo y entra en escena, acompañada por el Traje de Arlequín, en busca de Gonzalo:

$$
\text { SEÑORA.— ¿Dónde está mi hijo? }
$$

$$
\text { SEÑORA.- Mi hijo Gonzalo. }
$$

\section{$[\ldots]$}

SEÑORA.- ¿Dónde está mi hijo? Los pescadores me llevaron esta mañana un enorme pez luna, pálido, descompuesto, y me gritaron: ¡aquí tienes a tu hijo! Como el pez manaba sin cesar un hilito de sangre por la boca, los niños reían y pintaban de rojo las suelas de sus botas. Cuando yo cerré mi puerta, sentí cómo la gente de los mercados lo arrastraba hacia el mar (Cuadro V, 195).

Como afirma Eich, «el mar [...] oscuro manantial de toda fuerza viva, también tiene que morir. Todo ha de doblegarse a la muerte» $(1970,188)$. Y es por eso que la madre, ante la búsqueda de su hijo, encuentra un «pez luna» muerto sacado de ese mar de muerte. La madre llora sobre su cadáver, demanda justicia delante de todos por la muerte de su hijo e intenta salir de la habitación del Director pero no puede:

PRESTIDIGITADOR.- Señora, por ahí no puede salir.

SEÑORA.- Tiene razón. El vestíbulo está completamente a oscuras. (Va a salir por la puerta de la derecha.)

DIRECTOR.- Por ahí tampoco. Se caería por las claraboyas.

PRESTIDIGITADOR.- - Señora, tenga la bondad, yo la conduciré.

(Se quita la capa y cubre con ella a la SEÑORA. Da dos o tres pases con las manos, tira de la capa y la SEÑORA desaparece.) (Cuadro V, 195-196).

De nuevo, un elemento muy presente en el conjunto dramático de Lorca es el mar. Entre las cantigas de amigo, de origen tradicional en la lírica galaico-portuguesa de la Edad Media, encontramos composiciones dedicadas al mar en las que la enamorada dialoga 
con él en un estado melancólico. Lorca compuso Seis poemas gallegos como un homenaje a la cultura y al paisaje gallegos. Junto a los diferentes viajes que realizó a tierras gallegas, también en Madrid, Lorca tenía varios amigos gallegos que pudieron influir en él.

El mar $^{255}$ es el símbolo materno. El agua se relacionaba con el retorno al seno materno, en sentido positivo como un refugio del mundo exterior. Negativamente, es introducirse a lo desconocido, abandonando el mundo vivido (era conocido el miedo que tenía Lorca a introducirse en el mar, un simple baño o viajar en barco) (Feal Deibe 1973, 27).

En el conjunto de la obra dramática de Lorca, la fórmula bipolar de Madre-Hijo está muy presente. En Bodas de Sangre el miedo de la madre a perder al hijo, como muestra Gustavo Correa, «la Madre habla por la voz de la especie y de ahí la angustia que la oprime al presentir que va a perder a su hijo» $(1975,91)$.

${ }^{255}$ En simbología, la madre se relaciona con el mar y con la tierra. «El mar y la tierra son símbolos del cuerpo maternal» (Chevalier y Gheerbrant 1993, 674). 


\section{1.- Análisis semiótico teatral: Nivel pragmático}

En este punto analizaremos las diferentes representaciones teatrales de la obra $E l$ público de Federico García Lorca. Escrita en agosto de 1930, según consta en el manuscrito ${ }^{256}$ fechado por el autor, se mantuvo inédita hasta 1978. Después de que la obra se hubiera escenificado, de la mano de diversos grupos teatrales y diferentes directores profesionales, tuvo que esperar casi sesenta años para que el texto completo fuera llevado a escena bajo la dirección de Lluís Pasqual e interpretado en diferentes países. La última representación en español, hasta el momento, se llevó a cabo en octubre de 2015, cuando Àlex Rigola nos presenta un nuevo montaje en el Teatro de La Abadía de Madrid. En el año 2018, la compañía teatral japonesa Ksec Act presentó una nueva puesta en escena al japonés, donde la parte visual y plástica adquiría gran importancia.

\section{1.- Las primeras representaciones}

En 1972 se representó, por primera vez, una escena de El público, todavía inédita entonces, donde se combinaron música, ballet y teatro entre las figuras de Pámpanos y Cascabel:

En 1972, en un workshop de The Place de Londres, teatro-escuela de danza moderna, Jacinta Castillejo presentó una coreografía de la primera parte del cuadro Ruina romana. Dos bailarines en maillot danzaron el diálogo del amor imposible al sincopado ritmo de flauta e instrumentos de percusión. A veces, el diálogo, entrecortado, grabado previamente, provenía de altavoces; otras, lo decían los anhelantes bailarines acercándose amorosamente, sin jamás tocarse, separándose con violencia, deslizándose por el suelo en súplica humillante o enfrentándose con ira y odio, dentro del cuadro espacial en que se movían, réplica visual al ritornello que una y otra vez interrumpía la danza de las posibles metamorfosis amorosas (Martínez Nadal 1978b, 269).

\footnotetext{
${ }^{256}$ Autógrafo, a tinta y lápiz, con correcciones. Al final viene fechado «Sabado [sic] 22 de Agosto 1930». El manuscrito se encuentra digitalizado en la Biblioteca Nacional de España. La consulta del original, al tratarse de un fondo reservado sólo puede autorizarse si la reproducción no resuelve aspectos imprescindibles para la investigación.
} 
El segundo montaje, también fragmentario, se realizó en 1973, en la Universidad de Austin, Texas, cuando Rafael Martínez Nadal fue invitado para pronunciar una conferencia sobre la obra El público:

El segundo experimento tuvo lugar en 1973, en la Universidad de Austin, Texas. El profesor Rodolfo Cardona, jefe del Departamento de Estudios Hispánicos, en colaboración con el Departamento de Artes Dramáticas de aquella universidad, me había invitado a dar una conferencia en inglés sobre el inédito lorquiano. Quise que las numerosas citas que ilustrarían la conferencia, así como Ruina romana, el cuadro quinto y casi todo el cuadro final, que cerraría la velada, tomaran forma de lectura escenificada a cargo de los jóvenes actores bajo la dirección de sus maestros. La atención y el silencio del público que llenaba la amplia sala fueron mucho más elocuentes que la ovación que premió la labor de estudiantes y profesores (Martínez Nadal 1978b, 269).

Los estudiantes del Departamento de Arte Dramático y los alumnos de Drama y Ballet representaron las extensas y numerosas citas de la conferencia, el cuadro de la Ruina romana, el cuadro quinto y casi el cuadro final. Una representación efectuada en un escenario circular y, según afirma Ricardo Gullón ${ }^{257}$, «desde un punto de la circunferencia leía su texto el conferenciante mientras los actores ilustraban en el escenario lo traducido o descrito por él» $(1987,74)$.

Hasta 1977 no se produjo un estreno de El público en su versión íntegra. Tuvo lugar una única representación, en un ámbito no profesional, en la Facultad de Letras de Universidad de Murcia, a cargo del grupo «La Bella Aurelia», bajo la dirección de Antonio Morales. «En España sólo existía el precedente de un espectáculo basado en los cuadros publicados en obras poéticas del granadino, dirigido por Juan Antonio de Hormigón, en 1962, con el Teatro Universitario de Zaragoza» (Gómez Torres 1997, 507).

El 15 de febrero de 1978 se estrenó en Puerto Rico, en la Sala del Teatro de la Universidad un montaje del texto completo, realizado por una compañía de la Universidad de Río Piedras:

\footnotetext{
${ }^{257}$ Como anécdota, el profesror Ricardo Gullón (1908-1991), en 1973 se encontraba en Austin, Texas y tuvo la ocasión de poder asistir a la representación como espectador (Gullón 1987, 73).
} 
En el mes de febrero de este año, la Universidad de Río Piedras, Puerto Rico, me invitó a asistir a la primera representación mundial de El público, montado por el departamento de drama de aquella universidad bajo la excelente dirección de la doctora Victoria Espinosa. Durante diez días con el teatro abarrotado, estudiantes y público en general acogieron la obra con sorprendente emoción y entusiasmo (Martínez Nadal 1978b, 269).

Según afirma José Monleón en su crítica del estreno, «la acogida fue decididamente favorable, representándose casi dos meses, plazo largo en una ciudad como San Juan, máximo si consideramos el carácter insólito de la obra y la entidad estudiantil de los intérpretes» $(1979,47)$.

La directora, Victoria Espinosa, alteró el orden del texto, «fraccionando el cuadro final e incorporando las escenas al desarrollo de la obra. Introdujo movimientos de marionetas y el recurso cinematográfico de la cámara lenta» (Gómez Torres 1997, 515). El vestuario estuvo a cargo de Gloria Sáez. En la iluminación, Alfonso Raos utilizó el uso de apagones para el cambio de escenario y, en la composición musical, Francis Schwartz modificó, en ocasiones, el ritmo de velocidad lenta y rápida del sonido o de los diálogos. Por lo que respecta a la escenografía, Fernando Rivero incluyó el uso de diapositivas y, de gran importancia, fue el empleo de máscaras desde el inicio de la obra. Escenificada sin intermedios ni entreactos, «el trabajo de Victoria Espinosa pone de manifiesto [...] que el rechazo por parte del espectador tradicional de obras como $E l$ público no procede de su carácter revelador, sino de la dificultad de entenderlas» (Monleón 1979, 47).

Con carácter profesional fue representado - junto a Comedia sin título - en Polonia, en 1984, en el Teatr Studyjny de la ciudad de Lodz, bajo la dirección de Pawel Nowicki, cuyo estreno tuvo lugar el 19 de mayo de 1984 (Martín 1985, 59). Utilizó la versión al polaco traducida por Zofia Szleyen y, publicada en 1982, en un libro, Comedia sin título y El público editado por Wydawnictowo Literackie en Cracovia. En su montaje invierte la cronología de las piezas, utilizó Comedia sin título en primer lugar, seguido de $\mathrm{El}$ público. Aunque las piezas fueran escritas con una distancia de seis años, «en ambas el tema central gira en torno al teatro, protagonista y tema» (Aszyk 1984, 24). La escenografía, en el sentido tradicional, no existía. «El escenario vacío cambia su aspecto 
con la aparición de los actores que constituyen el centro de este universo teatral, y se convierten en los elementos plásticos más importantes en el espacio escénico» (Aszyk 1986, 279). Los únicos elementos plásticos fueron los actores, bajo las directrices coreográficas de Marta Bocheneck. Como recurso escenográfico utilizó las luces y empleó la oscuridad y la música sustituyendo la utilización del telón para separar los cuadros. En la música, a cargo de Zbigniew Preismer, destaca el sonido del contrabajo que marca «los momentos de melancolía y reflexión separando así los sucesos escénicos» (Aszyk 1986, 279). El doble programa volvió a representarse los días 23-31 de octubre y 4-9 de diciembre de 1984. Mientras, el público español aún tendrá que esperar hasta 1986 para verla representada, «los telespectadores polacos tuvieron ocasión de presenciar [...] el espectáculo en la primera quincena de diciembre» (Martín $1985,56)$.

Por primera vez, en 1986, una compañía profesional monta la obra en una versión danzada. Del 14 de enero al 1 de febrero, en Ginebra, una coproducción de la Comédie de Genève-Grand Théâtre de Genève hizo posible una puesta en escena coreográfica, sin texto, realizada por el Group Théâtre-Danse du Grand Théâtre de Ginebra, bajo la dirección de Óscar Araiz, con decorados y vestuario de Carlos Cytrynowski (Gómez Torres 1997, 509).

La interpretación de Araiz fue demasiado literal, tan sólo transportó las acciones a la danza. Al no recurrir al texto, eliminó todo el mundo metafórico de Lorca. Según la crítica de José Ramón Díaz Sande, en el montaje hubo «aciertos plásticos, elementos de representatividad de gran intuición, así como la construcción escenográfica ambiental de ese surrealismo que anida en la obra» $(1986,19)$. La destreza de los bailarines que se movían entre la danza y la expresión corporal, junto a la banda sonora en la que se integraron fragmentos del diálogo, a cargo de Bark-Rate, Philip Glass y la original de Hugues Le Bars, crearon un clima favorable para visualizar el texto (Díaz Sande 1986, 19).

El montaje sería ofrecido posteriormente en el Teatro Español de Madrid los días 21, 22 y 23 de octubre de 1986, coincidiendo con el Festival de Otoño de la Comunidad de Madrid. Tanto en Suiza como en España, la recreación de Óscar Araiz fue recibida en 
un teatro lleno, aunque fuera más por la investigación arriesgada, la belleza escénica y la habilidad de los bailarines (Díaz Sande 1986, 18).

\section{2.- Lluís Pasqual: estreno mundial. Visión crítica}

La consagración escénica de El público no tuvo lugar hasta el 12 de diciembre de 1986, cincuenta años después de la muerte del poeta. Lluís Pasqual sería el responsable de dirigir el estreno internacional de la obra. El Centro Dramático Nacional, el Piccolo Teatro di Milano ${ }^{258}$ y el Odéon-Théâtre de l'Europe de París coproducían el espectáculo. El estreno se celebró en Milán ante unos 500 espectadores, en el Teatro Studio, la recién estrenada sala experimental del Piccolo Teatro de Milán, antes Teatro Fossati:

Del viejo edificio se conservan en el exterior dos de sus fachadas de época, y por dentro, ha sido restaurado conservando su estructura arquitectónica al desnudo, convertidos sus palcos en balcones, donde los espectadores se asoman con los codos sobre las barandas, sentados sobre banquetas altas de barra de bar. Arriba, el techo, deja al descubierto las vigas y cubiertas de manera, mientras el escenario ha ocupado también la platea (Pérez 1987, 5).

Aún así, la restauración no había resuelto los problemas acústicos y de iluminación, la compañía tuvo que reducir la embocadura del escenario y acolchar las paredes de ladrillo del Teatro Studio. Sin embargo, sí se encontraron con algo parecido a un esqueleto de un teatro que, según Moisés Pérez Coterillo, Fabià Puigserver supo aprovechar para instalar «una esencial escenografía, porque el desnudamiento, la búsqueda de lo esencial, la huida del artificio y del truco han sido propósitos deliberados de este montaje» $(1987,5)$.

\footnotetext{
${ }^{258}$ En septiembre de 2020, el programa de la 2 de RTVE Imprescindibles estuvo dedicado a la figura de Lluís Pasqual, con el título «Reus, París, Londres. El teatro libre de Lluís Pasqual». Entre las muchas declaraciones, encontramos su opinión sobre el Piccolo Teatro di Milano: «Lo que me sirve del Piccolo es ponerte el listón aquí [alto] [...]. De repente te ponen el listón más alto y tú lo que haces es profundizar más. Intentar saltar más alto. Los teatros que han hecho revoluciones teatrales nunca son grandes teatros. Todos son teatros de medidas humanas» (Pomés y Mas de Xaxàs 2020).
} 
Aunque los actores de la compañía recitaban en español, el idioma no era el principal obstáculo para la comprensión de la obra por los espectadores italianos (Escala 1986, 45) ya que la dificultad se encuentra más en las imágenes del texto. Como afirmaba Alejandro Pistolesi «resulta difícil entender el significado del drama, entre otros aspectos por la abundancia y atrevimiento de las metáforas» $(1986,91)$.

El hecho de que El público se estrenase en Milán (según lo estipulado en el convenio de coproducción) provocó un comprensible descontento en los medios teatrales españoles. Las representaciones continuaron hasta el 21 de diciembre (Gómez Torres 1997, 510).

Finalmente, tras su representación milanesa, el 16 de enero de 1987 se estrenaba El público en el Teatro María Guerrero de Madrid. En contra de lo establecido legalmente, era obligatorio vender un mínimo de un $10 \%$ de las entradas, ninguna se puso a la venta en la primera representación: «El aforo está [...] reducido por el aprovechamiento de todo el espacio, para el escenario, y el par de cientos de localidades disponibles estaba repartido de antemano entre espectadores de calidad, de forma que el verdadero público -el que da título y carne metafísica a la obra- tuvo que estar ausente» (Haro 1987, 25). Al igual que en Milán, el patio de butacas del teatro María Guerrero quedó convertido en un enorme espacio de arena azul y, por tanto, el número de espectadores por representación quedó limitado.

Las butacas de la platea, el escenario y el foso de orquesta fueron eliminados para dejar un enorme espacio casi circular en el centro del teatro para convertirse en un espacio cambiante del que Puigserver transformó en un desierto lunar, en una playa de arena azul o en una pista de circo, en cuyos límites se situaron los espectadores junto a los actores. De este modo, la tradicional relación del actor y el público desaparecía y así resultaba «una inversión del modelo teatral en el que el público observaba a los actores mirando a otros actores, por lo tanto negando la estabilidad de un único punto de vista» (Delgado 1998, 395). Al fondo, cuatro telones rígidos: azul, rojo, blanco y dorado, enmarcaban alternativamente los cuadros del drama. Como afirma Pérez Coterillo:

Una playa o un desierto azul, como un paisaje lunar, sobre el que quedan, como arrojadas tras un naufragio, perdida su razón de ser y su función, unas filas de butacas y unos telones fosilizados (azul, rojo, blanco y dorado) que se levantan como autómatas 
en el vano del que fuera su escenario. Eso es todo el aparato. Y la luz, una luz surreal que remite a la sinrazón de los sueños $(1987,5)$.

Sobre una tonelada de arena plástica de color azul, desde cuatro telones-biombo, desfilaron los cuarenta actores. La crítica hizo notar que la interpretación fue el factor más débil del espectáculo, mientras las expresiones corporales y verbales brillaban en algunos actores en otros se apagan, produciendo discontinuidad en la percepción del drama por el espectador. Como afirmó Eduardo Haro Tegglen «Hay una buena interpretación de conjunto, rota por algunas intervenciones pésimas, pero elevada por otras: por el ímpetu desgarrado de Alfredo Alcón, por la cantidad de matices de voz y colocación de Pedro María Sánchez, [...]» $(1987,25)$. La actuación del actor principal, Alfredo Alcón, consiguió sobresalir del resto de actores y, transmitir

la angustia del Director de Escena, con un admirable grado de lucidez, de fiebre, de alucinación, mientras los demás actores, seguramente por la breve intervención de sus personajes, difícilmente alcanzan ese registro, por más que individualmente y con independencia del conjunto, su trabajo sea siempre correcto (Pérez Coterillo 1987, 5).

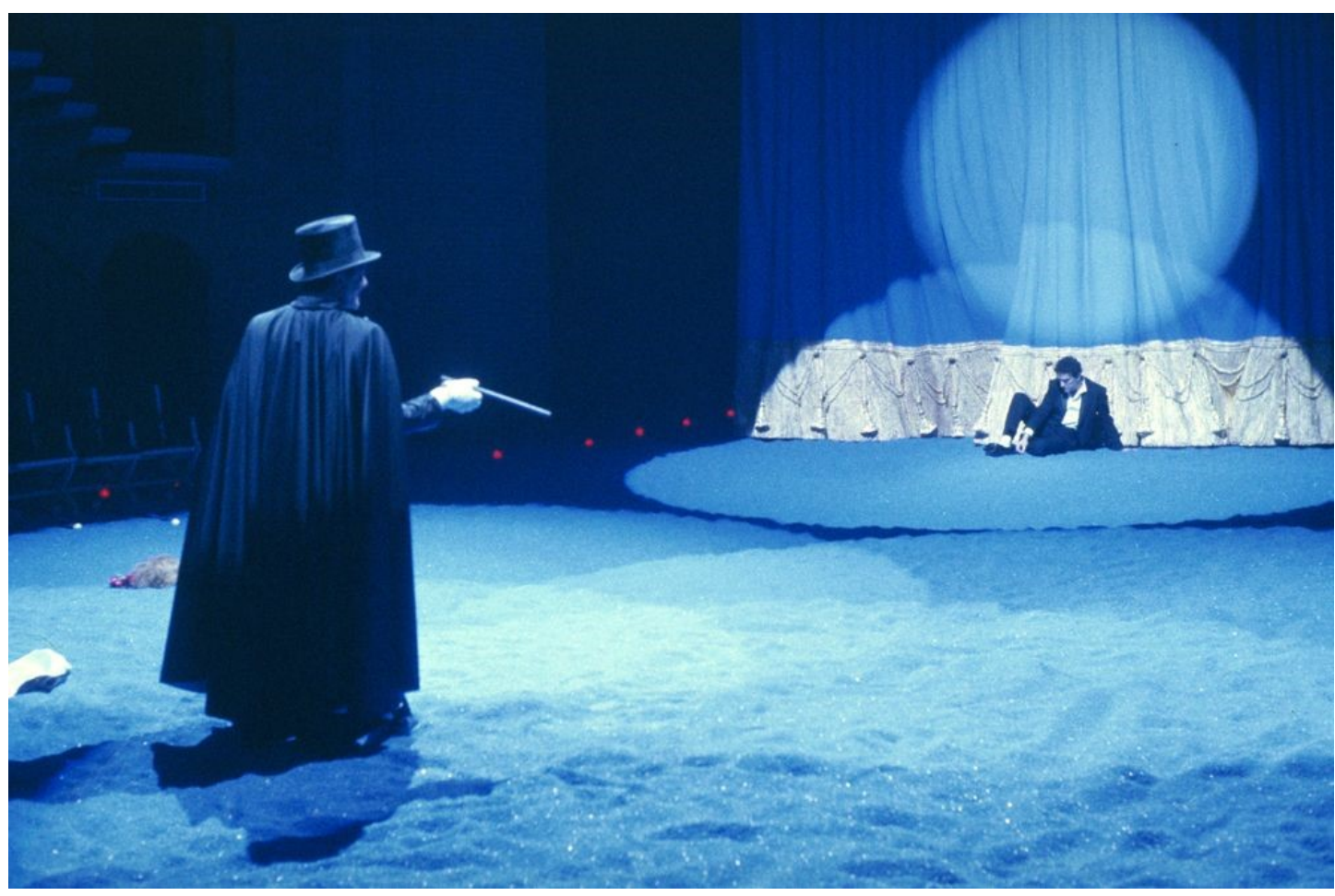

Fig. 100: En el último cuadro aparece el Prestidigitador, ante un Director moribundo sobre un escenario cubierto de arena azul.

Fotografía de Luigi Ciminaghi. 
La crítica elogió la labor del director, como afirmaba Joan-Anton Benach en su crítica del estreno en Milán: «Lluís Pasqual ha conseguido visualizar el misterio. [...] Su trabajo, que tiene ya valor "histórico", será ineludiblemente el punto de referencia para cualquier lectura que quiera hacerse en el futuro sobre este material "imposible de representar"》 $(1986,28)$. Si bien la escenografía y el vestuario de Fabià Puigserver no se ajustaron a las acotaciones del texto, la crítica alabó la belleza plástica del montaje. Según explicaba Puigserver,

El texto está ahí [...]. En cambio, las propuestas dramáticas de Federico han sufrido más deterioro [...]. Por el contrario, ese deterioro no le ha alcanzado al texto literario.

[...] Lorca utiliza el lenguaje plástico como un revulsivo, como una forma de romper, hace cincuenta años, con un teatro profundamente tradicional, pero su eficacia en el terreno plástico es mucha más circunstancial que en el de la poseía. [...] Pero romper moldes en el terreno de la plástica es hoy día prácticamente imposible $(1987,10)$.

La obra permaneció en cartel desde el 6 de enero hasta el 15 de abril de 1987, con tal acogida de público que todos los días se agotaron las localidades; un año más tarde el montaje volvería a representarse en el teatro María Guerrero. El éxito se repitió durante la gira por diversas ciudades españolas, que comenzó el 26 de marzo de 1988, en Gerona, y finalizó, el 4 de junio de 1988, en Barcelona. En su gira internacional cabe destacar las nueve representaciones que pusieron en escena en París. Estuvo en cartel del 6 al 12 de abril de 1988 en el Teatro Odeón, dentro de la programación del Théâtre de l'Europe. El montaje obtuvo, en la figura de Lluís Pasqual, el Premio de la Asociación de Críticos Teatrales Franceses al mejor espectáculo en lengua extranjera en junio de 1988 (Galindo 1988, 101).

Los dos temas fundamentales de El público según Lluís Pasqual son

el amor y el teatro, una realidad frente a otra realidad, un ser frente a otro, una búsqueda interna de uno mismo y de los demás. Nuestra necesidad de amor y el teatro como refugio y mentira, como lugar de transformación de la realidad en lucha diaria contra la muerte $(2016,80)$.

Supo rodearse de un buen equipo para llevar a cabo esta puesta en escena. Para Pasqual, «El público es antes que nada, un viaje, una aventura personal que transcurre en la más absoluta soledad del individuo. Y había dos opciones o hacerla una sola persona, o 
encontrar una forma más teatral para contar lo que en el texto ocurre» $(1987,6)$. Y también, en ese mismo año, afirmaría que

El público es un acto de valentía, de un autor, de un creador que se mete los dedos en la garganta para vomitar, para poner al ser humano encima de un escenario y para mostrarse a él y mostrar todas las angustias y las contradicciones y el dolor y la cobardía de un ser humano al desnudo. No en vano la primera acotación dice "Las ventanas son radiografías". Es un ser humano visto como con rayos X (Pomés y Mas de Xaxàs 2020).

Lluís Pasqual, junto a Fabià Puigserver como encargado de la escenografía y del vestuario, se acercaron a la obra sin utilizar lecturas convencionales que pudiesen reducir a la obra a un único tema. En vez de reproducir miméticamente las acotaciones y direcciones presentes en el texto, reinterpretan el texto y eliminan el proscenio del escenario para crear un espacio escénico fluido (Delgado 1998, 391). De esta manera, demuestran la necesidad de transformar el espacio escénico en las obras de teatro. Lluís Pasqual afirmaba, en la entrevista realizada por Julio Bravo, que

no hubiera hecho El público sin Fabià Puigserver, como tampoco lo hubiera hecho sin Alfredo Alcón. El escenógrafo en el teatro no es que sea importante; es que es fundamental. Un espectáculo como éste tiene una parte plástica, que emana del propio texto y de la interpretación. Poner los caminos por los que puede evolucionar eso, tener las primeras intuiciones de colores y formas, adecuarse a compartir ese trabajo con las propuestas de un director... y hacerlo bien, requiere mucho talento, y [...] Fabià lo tiene (Bravo 1987, 10).

Ambos mantuvieron la referencia constante del creador plástico, Frederic Amat, y de este modo poder confrontar el trabajo realizado con la interpretación y la crítica que hacía el artista de lo elaborado hasta el momento. Pasqual expresaba «Hemos contado con la colaboración de Frederic Amat, un extraordinario pintor, que ha puesto su visión en una obra en que la pintura es muy importante» (Bravo 1987, 10). El propio Amat opina que El público es

una obra de teatro donde es una reflexión sobre el teatro. El teatro bajo la arena, el de la verdad de las sepulturas, no el teatro de la máscara, al aire libre, el teatro del engaño. Buscar el pulso. El pulso de las cosas. Y esto, con una gran capacidad poética, ese es el teatro que a Lluís le gusta más (Pomés y Mas de Xaxàs 2020). 
Lluís Pasqual recalcaba la necesidad de documentarse para representar una obra, consultar la correspondencia, ensayos científicos, incluso en el caso de El público consultar el propio manuscrito ya que

hay muy pocos tachones y si una línea le quedaba cursi la corregía en la línea posterior, como si fuera una ininterrumpida convesación consimo mismo. Está escrito en la urgencia, como un vómito. Eso te da una información sobre la vitalidad de la obra, sobe el lugar anímico desde el que Lorca pudo escribirla (Pasqual 2020, 3).

El texto de Lorca implicaba un experimento en el terreno de la plástica y del color, y Puigserver conocía muy bien el mundo de Lorca. El discurso del amor y del teatro ocurría en un lugar muy especial y la idea que concebía Puigserver de la relación del espectador con el teatro era que «cuando la gente penetra en un teatro se encuentra con un foco de atención prefijado, mientras en este otro teatro, los espectadores debieran encontrar algo así como su caricatura» (Pasqual 1987, 6). En la primera acotación, que encontramos en el texto, se puede leer «las ventanas son radiografías», en esencia quiere decir que vemos el interior, y para ello querían crear un teatro nuevo.

La intención de Pasqual y de Puigserver fue estrenar la obra en Granada, en un teatro móvil construido a propósito diseñado por Puigserver y Amat. Puigserver, «no solo se inventó un lugar para que eso ocurriera, sino un teatro único, extraordinario, desmontable, un teatro soñado que, como La Barraca paseara de pueblo en pueblo, y que está en el origen del espacio que creó después para El público» (Pasqual 2016, 69). Se propuso un teatro imaginario, el Teatro Federico García Lorca, un teatro inventado, «que era a la vez la caricatura y la síntesis de los elementos fundamentales que componen un teatro. [...] esa era la idea: un teatro lunar». (Pasqual 1987, 6). Aunque, en un principio, el Ministerio de Cultura apoyó la idea, surgieron problemas económicos relacionados con el coste del proyecto y su mantenimiento y el edificio no se pudo construir. Como afirma Pasqual,

Fabià no pudo construir su teatro, pero pudo hacer su extraordinario espacio y sus maravillosos trajes. Y, sin el teatro, que se iba a llamar Federico García Lorca, Frederic Amat no pudo ver a tamaño natural el manto protector, la lona con dibujos color tierra que había preparado en la maqueta, pero estuvo en el espectáculo hasta el final, con sus manos, modelando, pintando [...] Pero los trazos de Frederic Amat son la memoria más 
viva y el testimonio auténtico de ese doloroso y -aunque a alguien le suene a paradojaalegre viaje, de esa obsesión $(2016,70)$.

En el libro El teatro de Federico García Lorca, publicado en 1988, se pueden comprobar todos los trabajos realizados por Puigserver y Amat para el interior y el exterior de esa propuesta de proyecto de teatro inventado.

La idea principal de la puesta en escena era una viaje hacia el interior y hubieran querido que el escenario y la platea «se fueran convirtiendo en una especie de embudo, a medida que transcurre la obra, que progresivamente se fueran hundiendo, pero era imposible de realizar» (Pasqual 1987, 6). Al final, con el juego de luces y colores y el escenario creado por Puigserver, se consiguió que los actores deambularan con un dinamismo fluido y variado. La distribución en el montaje, en palabras de Pasqual, fue

en el fondo del teatro hay una sucesión de telones, que se van levantando como capas, pero son telones exentos, no esconden nada, son rígidos y potentes como cajas fuertes. Son como fósiles de un teatro del siglo XIX depositados sobre la arena de otro siglo. Son un resto de lo que Lorca llama "teatro al aire libre" y que en nuestra interpretación, concebimos como las viejas arquitecturas teatrales que han perdido toda su esencia, su perfume, y de las que su parte más forma, su aspecto externo. Este juego de telones permitía además de los personajes aparecieran y desaparecieran como en los sueños. Porque en ese viaje mental no hay puertas, ni entradas, el paso entre el aparecer y el existir es imperceptible (1987, 6-7).

Después de más de seis meses de selección y de pruebas, el reparto estuvo formado por cuarenta actores: algunos profesionales, como Alfredo Alcón, Walter Widarte, Joan Miralles, Maruja Boldoba y Pedro Mari Sánchez, y otros debutantes, Paola Dominguín y José Coronado. En un principio, el papel de Julieta recaía en la actriz Ángela Molina pero, al no conseguir aplazar un rodaje, fue Maruchi León quien interpretaría la Julieta de Federico. (Pasqual 2016, 76).

El músico José María Arrizabalaga fue quien realizó la composición musical y también la canción del Pastor Bobo. Para la elección de actor realizó una prueba de canto a Juan Echanove y fue escogido para interpretarlo. En la representación, Pasqual ubicó el monólogo del Pastor Bobo antes del cuadro quinto para llenar el hueco del supuesto «cuadro cuarto» perdido. Por lo que respecta a la intervención de Juan Echanove en el 
papel de Pastor Bobo, el juego del actor provocó que parte de los espectadores de la sala se rieran, desapareciendo el instante dramático que sí tiene el texto. También faltó «en el centro, un gran armario lleno de caretas blancas de diversas expresiones» que aparece en la acotación del texto (Gómez Torres 1997, 514).

En resumen, debemos compartir las palabras de Pasqual sobre su opinión respecto al manuscrito de El público:

Es probable que El público sea una obra incompleta, pero no inacabada [...] Todos los temas y los caminos están ahí. Hay que intentar rastrearlos. En cualquier caso, lo que me parece equivocado es adjudicarle el término de irrepresentable. Lo era en aquel momento, cuando rompía todas las paredes del teatro $(2016,74)$.

\section{3.- El público después de Lluís Pasqual. La ópera. Siguientes críticas}

Lluís Pasqual marcó un antes y un después en la puesta en escena del texto de Lorca, aunque fueron muchos los que también se atrevieron con la complejidad de la obra y en proponer traducciones del texto a otros idiomas.

El 7 de enero de 1988, Jorge Lavelli, director teatral argentino, nacionalizado francés, dirigió y preparó la obra El público para inaugurar un nuevo teatro nacional francés: el Théâtre National de la Colline (TNC) (Bassets, 1988). Lavelli había intentado ya estrenar El público en 1986, dentro del Festival de Aviñón, pero al ser una producción tan costosa imposibilitó encontrar un teatro que se hiciera cargo. El público de París pudo asistir a la representación del 7 de enero hasta el 25 de febrero de 1988.

Lavelli optó por subrayar los aspectos más polémicos y espinosos del texto. Esta versión se caracterizó por otorgar un especial protagonismo a la idea de la teatralidad en la obra,

el viaje a través de un laberinto de teatro, para conducir la pasión de los personajes y su búsqueda o rechazo de la verdad. Ha utilizado un escenario de enormes dimensiones y ha situado al fondo de él, sobre el montacargas que permite que aparezca o desaparezca de la visión de los espectadores, el simulacro de otro teatro, del que sólo se perciben las puertas de entrada de sus palcos. De él salen y entran los personajes del drama [...]. 
Entre el teatro del fondo, donde se asiste a una representación de la que sólo nos llegan los comentarios de los personajes, y el teatro de verdad que presencian los espectadores, se sitúa un espacio cambiante (Pérez Coterillo 1988, 4).

El texto traducido al francés por Armando Llamas se publicó, en 1988, bajo el título Le Public. Drame en cinq temps et un interlude, «traducido meticulosamente, para que las expresiones mantengan todas sus aristas y las imágenes conserven su valor subversivo» (Pérez Coterillo 1988, 4). Según Moisés Pérez Coterillo, «la versión de Llamas es menos literaria, menos erudita, no ha maquillado la violencia de las imágenes, ni la crudeza de las expresiones, ha intentado que sirva como dramaturgia del espectáculo y ha aceptado la corrección y a interferencia de los ensayos» (1988a, 9). Louis Dercout, arquitecto y escenógrafo, ideó el ambiente de El público, tomando un distanciamiento respecto a la estética surrealista indicada por Lorca. Francesco Zito, pintor y dibujante, fue el encargado del vestuario, y de las máscaras el pintor y escultor Rodolfo Natale. Contó con siete músicos en directo,

con partitura original y dirección de Zygmunt Kraze, pianista y compositor polaco que contribuyó al escándalo del estreno con su música para trombón, violín, percusión, clarinete, guitarra, contrabajo y trompeta, en la que -según explicó- "quise mezclar estilos; por eso lo mismo me refiero con toda libertad a los años treinta que creó una música contemporánea" (Caballero 1988, 24).

Los músicos pertenecientes al Taller Musical de Varsovia interpretaban en directo, durante toda la representación, la partitura para crear un clima y subrayar una estética del jazz y del universo urbano de Nueva York.

Los treinta y cinco personajes del drama, más sus desdoblamientos, se reparten entre veintidós actores. Lavelli se permitió diversas libertades escénicas, como la presencia de una alfombra roja, donde suceden algunas de las acciones más importantes del drama (Pérez Coterillo 1988, 9). Mantuvo la utilización del biombo que sí aparece en las acotaciones del texto y para

imprimir drama a la atmósfera litúrgica, recurrió al empleo de un micrófono inalámbrico que amplificaba las palabras del Desnudo Rojo con un eco de nave de iglesia. Durante la agonía del Desnudo, Lavelli ideó introducir al personaje de una Elena perdida en el teatro tras un amor imposible, mientras recitaba el parlamento de 
Titania del Sueño de una noche de verano al que más tarde alude el Prestidigitador (Gómez Torres 1997, 517).

Cuatro meses después del estreno en París del montaje de Lavelli, llega El público de Lluís Pasqual al Theatre de l'Europe (L'Odéon). Son dos visiones distintas, en las que subrayan con distinto énfasis aspectos formales y textuales, Así como Lavelli propuso una lectura formalmente "tradicional" [...], Pasqual propone una lectura formalmente más "rupturista"» (Quiñonero 1988, 91). Los montajes se complementan e iluminan.

El público llegó a Londres el 3 de octubre de 1988, en el Teatre Royal, Stratford East, bajo la dirección de David Ultz. El dramaturgo británico Henry Livings realizó la traducción del texto al inglés. Veinticuatro actores trabajaron a las órdenes de Ultz, con Gerald Murphy como protagonista. Según expone Ana María Gómez Torres:

La escenografía trató de respetar, en general, las indicaciones del autor; tal fidelidad sólo se vio quebrada en lo que respecta a la figura del Pastor Bobo, encarnada por el Director en la producción londinense. [...] El vestuario, diseñado por el director, ostentaba un aire cómico que lo hacía más adecuado para la pantomima que para el drama. La respuesta negativa de la prensa no se hizo esperar $(1997,517)$.

La reacción de la prensa conservadora londinense ante la homosexualidad que ilustra, a modo de parábola, amenazó con posibles acciones legales — la opinión pública británica consideró que «la obra vulneraba la sección 28 de la Local Government Act» (Gómez Torres 1997, 518; Doménech 2008, 189) — y con la prohibición de mantener la obra en cartel.

El portugués Luis Miguel Cintra fue el siguiente director en montar El público. El estreno se produjo en Lisboa el 11 de mayo de 1989, a cargo del grupo Teatro da Cornucopia. La traducción del texto estuvo a cargo de los mismos miembros del grupo, como explica Luis Miguel Cintra en una entrevista: «al traducir nosotros mismos el texto, el trabajo de dramaturgia comienza en la traducción misma; entonces, tratándose de un texto con todas las dificultades de interpretación que tenía, pensé que habría ventaja en comenzar, a partir de la traducción, por el análisis del texto» $(1989,63)$. Según Carlos Porto, la visión del director se muestra mediante «los elementos circenses, el proceso del teatro dentro del teatro, la presencia de la figura de los caballos, [...] Luis 
Miguel Cintra no se limitó a una lectura de sus códigos literarios, más bien intentó su reinvención» $(1989,62)$.

La escenografía y el vestuario de Cristina Reis, junto a la música de Paulo Brandao, fueron elementos fundamentales en la creatividad del trabajo. La austeridad de los medios técnicos y del elenco hizo posible que el presupuesto del montaje no fuera elevado (Porto 1989, 62). Consiguieron, mediante la duplicidad de papeles entre los actores, e incluso en la escena de Pámpanos y Cascabel, «evocarla con muñecos que no pueden tener expresión, sugiriendo con la voz las diferentes actitudes de los dos personajes» (Cintra 1989, 65). Ante la reacción negativa del público a la recepción del espectáculo, Cintra respondió:

las personas no aceptan un espectáculo que no pueden prender en términos lógicos: se sienten perdidas porque andaban a la búsqueda de una historia, de situaciones, de una continuidad de tiempo, cosas, por lo demás, que no exigen a otras artes. [...] hay espectadores que se irritan y protestan y hay otras que se quedan fascinados, a pesar de no conseguir entrar en el texto, y que dicen que tienen que ver la obra otra vez (1989, $66)$.

Hubo numerosas representaciones tanto a nivel nacional como internacional, en ámbitos minoritarios, por teatros universitarios e independientes. Por nombrar algunas: en agosto de 1991, la compañía de teatro Cuarta Pared, de Madrid, bajo dirección de Luis Garbán, representó a España en el VII Festival Nacional Juvenil de Teatro y Danza de Caracas, Venezuela, con la obra El público. A continuación del Festival, la compañía representó el montaje en otras ciudades venezolanas. En 1995, Teatro del Sur, bajo la dirección de Francisco Ortuño, estrenó el 3 de julio en Palma del Río de Córdoba, dentro del VI Feria de Teatro en el Sur. La compañía teatral sevillana Atalaya eligió el texto de Lorca para celebrar el vigésimo aniversario de la compañía el 23 de octubre del 2002 en el Teatro Lope de Vega. Ricardo Iniesta fue su director y escenógrafo, quien contó con once actores que formaban parte de su equipo artístico habitual.

Cabe destacar la idea de Gerard Mortier, en 2010, de convertir en ópera la obra de Lorca, encargo realizado por el compositor Mauricio Sotelo, del que Andrés Ibáñez fue el autor del libreto, quien se planteó: 
extraer del texto original un libreto de ópera que respetara la estructura original y en el que estuvieran claramente recogidos todos los elementos de esta obra perpetuamente oscura. En cuanto a la estructura, [...] El público tiene cinco cuadros, divididos cada uno en tres escenas (a excepción del cuadro cuarto, imposible de dividir en tres, que convertí en una especie de rondó en siete partes). Finalmente, la ópera ha quedado dividida en dos actos, de tres y dos cuadros, respectivamente $(2015,5)$.

El compositor Mauricio Sotelo tenía la intención que el texto «debía llegar limpio e inteligible a los espectadores. [...] Si se entiende el texto con claridad, entonces será posible que éste proyecte toda su luz al espectador» $(2015,5)$. El 24 de febrero de 2015 se estrenó la ópera de El público en el Teatro Real de Madrid que contó con ocho únicas representaciones. El responsable de la escenografía fue Alexander Polzin que incluyó «nueve telones de más de doce metros de altura que evocan los icónicos biombos lorquianos y los rascacielos de Nueva York» (Calzado 2015, 7), el vestuario de Wojciech Dziedzic, la iluminación de Urs Schönebaum y la coreografía de Darrell Grand Moultrie. Andrés Ibáñez prescindió de muchos personajes ya que su intención era «reducir muchísimo el esqueleto original y luego intentar que tuviera sentido» (Gaviña 2014, 55). El número de personajes quedó reducido a ocho voces principales, junto a artistas del flamenco con los cantaores Arcángel y Jesús Méndez que representan el papel de Caballo blanco primero y Caballo blanco segundo, respectivamente; por su parte, el bailaor Rubén Olmo para el Caballo blanco tercero (Bravo 2015, 58).

Se formó una orquesta por treinta y cuatro músicos solistas del Klangforum de Viena que se encontraban en el foso, además de un percusionista, Agustín Diassera, y, un guitarrista solista, Juan Manuel Cañizares, procedentes del mundo del flamenco. La intención era que la música de estos intérpretes se proyectara en el espacio, a través de la electrónica, para repartir el sonido en la sala a través de veinticuatro altavoces para lograr una dimensión musical y espectral. Según Sotelo,

Al principio de la ópera el público tiene la sensación de estar ante un teatro mozartiano o shakesperiano, un teatrito de madera con una pequeña, pero muy delicada, acústica. Sin embargo, a lo largo de la ópera la fuente sonora se va repartiendo y se expande o se romper en infinitos universos. 
A partir del segundo acto, donde aparece el coro, ese universo se traslada a otra dimensión sonora. [...] Intentamos transformar el espacio acústico, creando una multiplicidad de atmósferas musicales que se metamorfosean en simbiosis con el insondable texto de Lorca $(2015,6)$.

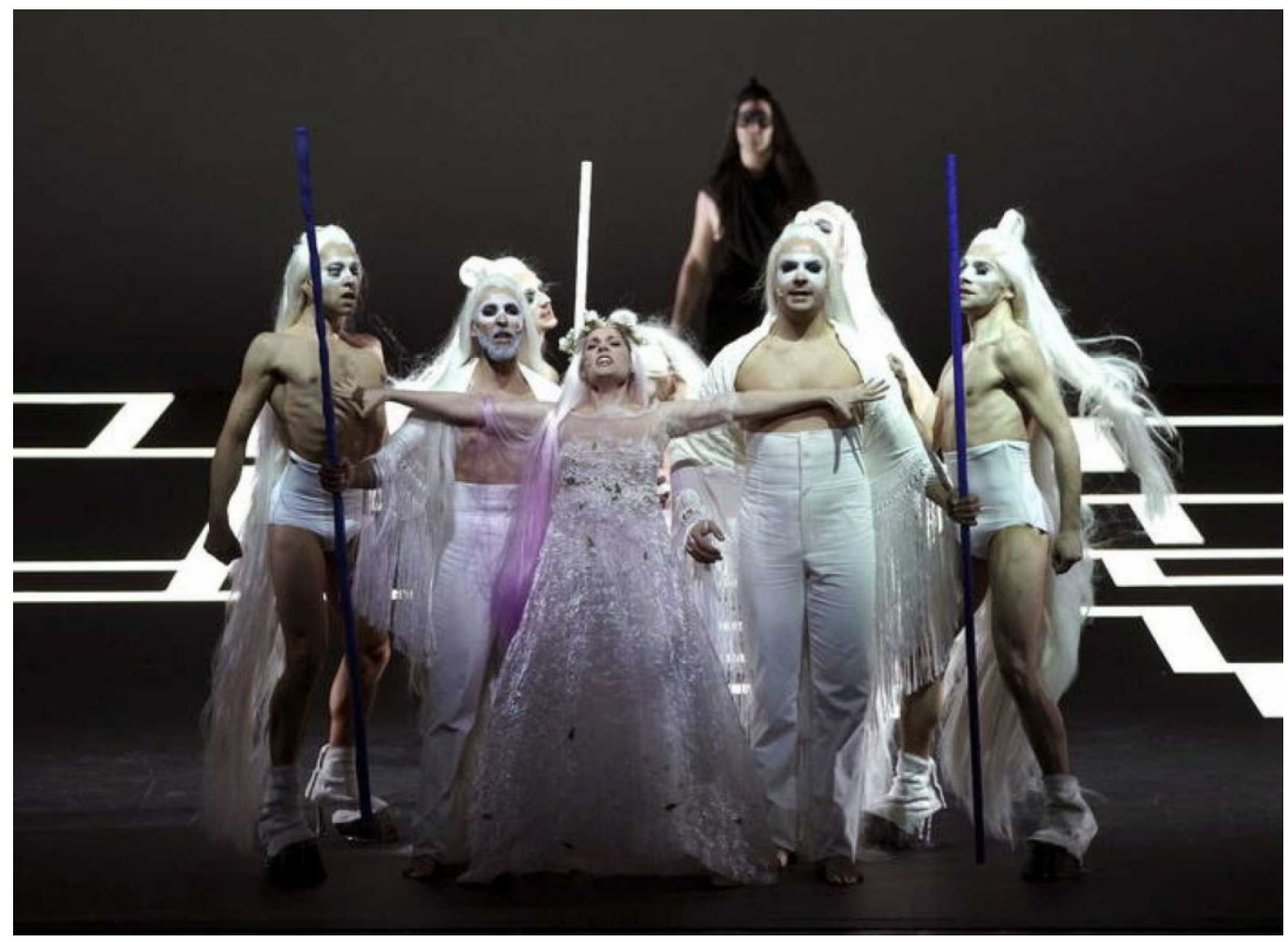

Fig. 101: Momento del Acto III, en el que Julieta se encuentra rodeada por los cuatro Caballos Blancos y en el fondo se encuentre al Caballo Negro.

\section{4.- Llegamos a Àlex Rigola}

En 2015, Àlex Rigola nos presenta una nueva interpretación del texto, la última versión hasta el momento. El montaje estuvo coproducido por el Teatro de La Abadía (antigua iglesia de la Sagrada Familia) y el Teatre Nacional de Catalunya. Àlex Rigola ya había presentado en La Abadía siete montajes anteriores, pero nunca antes se había acercado a un texto de Lorca. El público para Rigola era una obra con

un espacio infinito donde uno se convierte en un aventurero con el deseo de avanzar entre gigantes freudianos e inmensas olas poéticas. Donde uno pasa a ser un caminante con capacidad para deslizarse en un agujero de gusano por el tiempo y ver cómo nuestros propios yos intentan engullirnos y acariciarnos a la vez $(2015,28)$. 
Su estreno tuvo lugar en Madrid, el 28 de octubre de 2015, en la Sala Juan de la Cruz del Teatro de La Abadía. El peculiar recinto, la antigua iglesia de la Sagrada Familia, permitió la proximidad del escenario y el público. En Madrid se mantuvo en cartel hasta el 29 de noviembre para después trasladarse a Barcelona. El estreno tuvo lugar el 17 de diciembre, en la Sala Gran del Teatre Nacional de Catalunya ${ }^{259}$. Las representaciones se realizaron hasta el 3 de enero. Después de una gira por diferentes ciudades de España, regresó al teatro de La Abadía del 25 de noviembre al 18 de diciembre de 2016.

En las representaciones que tuvieron lugar en el Teatro de la Abadía y el Teatre Nacional de Catalunya, el reparto estuvo compuesto por catorce intérpretes: Nao Albet, Jesús Barranco, David Boceta, Juan Codina, Laia Duran, Irene Escolar, María Herranz, Jaime Lorente, David Luque, Pau Roca, Pep Tosar, Jorge Varandela, Nacho Vera y Guillermo Weickert. Posteriormente, en la gira por España y, de nuevo, un año más tarde en la Abadía, Pau Roca, Jorge Varandela y Pep Tosar fueron sustituidos por Rubén de Eguía, Óscar de la Fuente y Alejandro Jato.

La crítica no fue unánime respecto a la actuación de los intérpretes. Así como JoanAnton Benach destacó «un conjunto homogéneo donde nada chirría» $(2015,62)$, Marcos Ordónez reflejó en su crítica la falta de técnica en los actores Jorge Varandela y Jaime Lorente, en la escena de Cascabeles y de Pámpanos, con voces impostadas. Y la de María Herranz como Elena. En cambio, sí alabó la actuación de Juan Cotina quien encarnaba a los que representan la muerte, el Caballo negro y el Prestidigitador, y la de Irene Escolar como Julieta:

\begin{abstract}
impresionante de principio a fin. La gama y los matices de su Julieta son una lección de teatro, voz y gesto de auténtica tragedia, aterrada, sonámbula, suplicante, apasionada, amazona [...] y víctima, y luego la Estudiante 3 en una escena dificilísima, óptimamente montada y servida. [...] y como madre de Gonzalo, quebrada por el dolor, casi escapada de los seis personajes pirandellianos (Ordóñez 2015, 17).
\end{abstract}

\footnotetext{
${ }^{259}$ El inconveniente que tiene la Sala Gran del Teatre Nacional de Catalunya es la sonoridad que en algunas zonas es deficiente; para remediar el defecto amplificaron las voces de los actores por toda la sala $\mathrm{y}$, con ello, hicieron que muchos finales de frases fueran ininteligibles, según Benach $(2015,62)$.
} 
El escenógrafo Max Glaenzel transformó el espacio en todo un cosmos, con las paredes recubiertas por una cortina de cientos de tiras plateadas que llenaban de reflejos móviles todo el recinto. El suelo del escenario estaba oculto bajo un corcho que imitaba la tierra «que no sólo crea túmulos en el escenario sino que avanza hacia las butacas para integrarlas en un universo» (Barranco 2015b, 30), «unas dunas oscuras y orgánicas, un espacio vivo, difícil para los actores» (Barranco 2015, 50). Todo envuelto bajo una luz azul de Carlos Marquerie, encargado de la iluminación.

Antes del inicio de la obra, en un lateral, un grupo de músicos, formado por los actores Nao Albet, David Boceta, Nacho Vera y David Luque, y la voz de Pep Tosar forman un orquesta que interpretan las canciones de El bayón de Ana, Autumn leaves (Les fuilles nortes) y These foolish things, engarzándolas y así crear un efecto de inmersión del espectador en ese mundo onírico de Lorca. La música durante la representación está a cargo del actor Nao Albet, quien también compuso y cantó la canción del Pastor bobo.

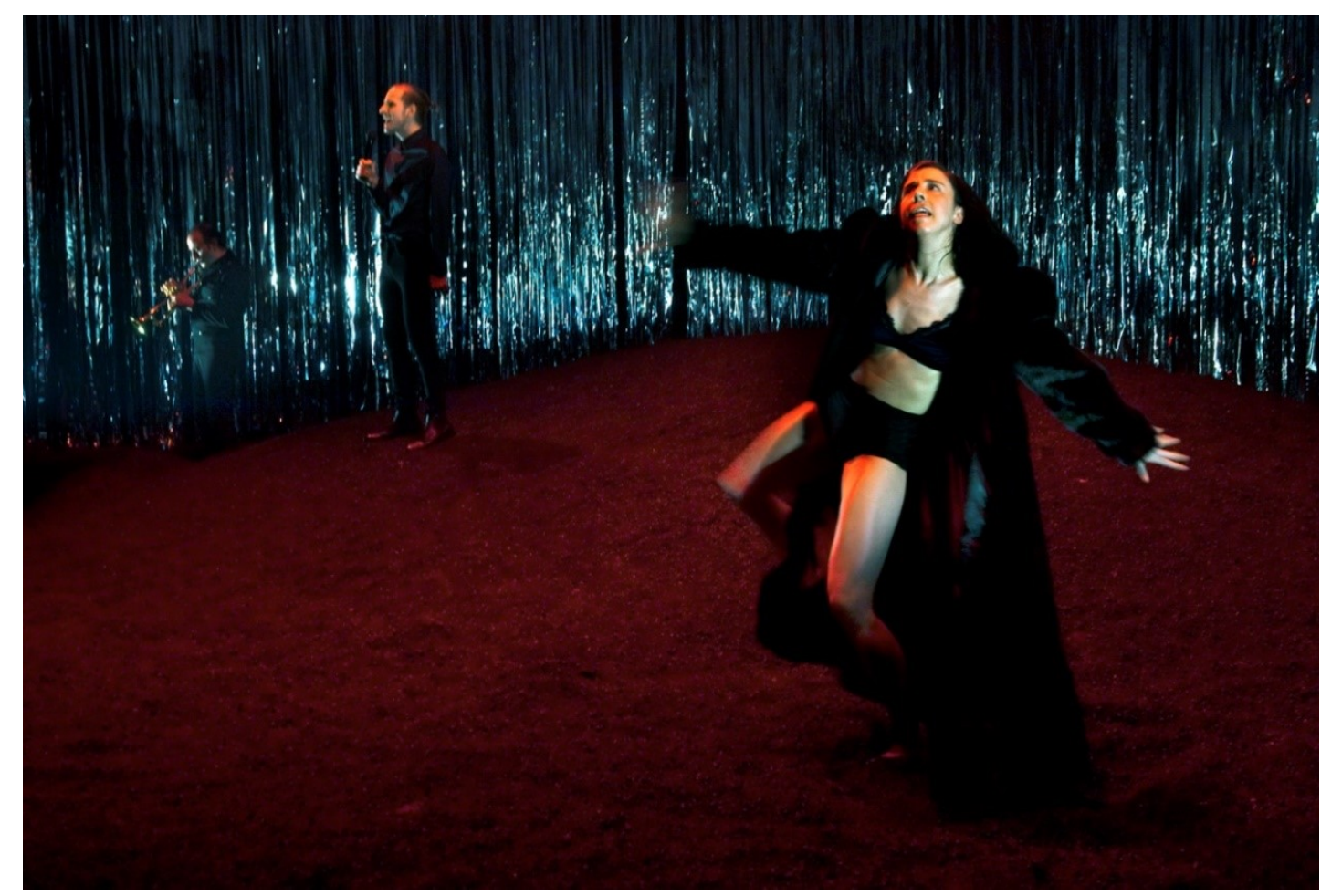

Fig. 102: Nao Albert interpreta la canción del Pastor Bobo, mientras Laia Druán danza y representa mediante muecas todos las posibles máscaras del armario del Pastor.

En opinión de Àlex Rigola, en el teatro, como en el arte, existe una tensión entre el público y el creador. El artista cada vez que empieza una nueva obra se enfrenta a una 
lucha interna para alcanzar el éxito sin perder su espíritu. Y es la búsqueda de ese equilibrio la que se ha de conseguir para Rigola el texto de Lorca:

Hablaba de pureza. Todos la vamos a perder. Forma parte del juego de vivir, Y a pesar de errar con todos los disfraces que la vida nos ha ido vistiendo hay que despojarse de ellos y seguir teniendo esa ilusión del primer día. Cuando mirábamos al infinito y todo era posible y todas las direcciones alcanzables. Hay que seguir amando. Ante la vida, ante la sociedad. AMAR. Cuando dice amor yo veo que cada grano de arena se convierte en una hormiga vivísima ${ }^{260}$. Seguir siendo un NAVEGANTE. Un artista NAVEGANTE. Un espectador NAVEGANTE. Un ser NAVEGANTE (Rigola 2015, 29).

\section{5.- Análisis de la obra El público a través de Lluís Pasqual y Àlex Rigola}

El público es una obra abierta, y esto garantiza que existan y existirán diversas interpretaciones. A continuación, analizaremos los montajes realizados por Lluís Pasqual en 1986 y Àlex Rigola en 2015.

\subsection{1.- A través de Lluís Pasqual}

Lluís Pasqual pretendía que el público no fuera un mero espectador pasivo, quería que se sintiera participe del espectáculo por eso al crear ese espacio ovalado involucraba al público «en una relación que renegociaba las esferas de lo público y lo privado» (Delgado 1998, 397). Por ejemplo, en el cuadro tercero, mientras sucede la actuación, el Hombre 1 y los caballos blancos esperan sentados en primera fila compartiendo espacio entre el público. El público no tenía un foco centralizado de la acción ya que ésta sucedía en diferentes lugares del escenario.

\footnotetext{
${ }^{260}$ En alusión al diálogo entre el Prestidigitador y el Director, en el último cuadro:

Prestidigitador: Si avanzas un escalón más, el hombre te parecerá una brizna de hierba. Director: No una brizna de hierba, pero sí un navegante.

$[\ldots]$

Director: Cuando dice usted amor yo me asombro.

Prestidigitador: Se asombra, ¿de qué?

Director: Veo que cada grano de arena se convierte en una hormiga vivísima (Cuadro V, 184185)
} 


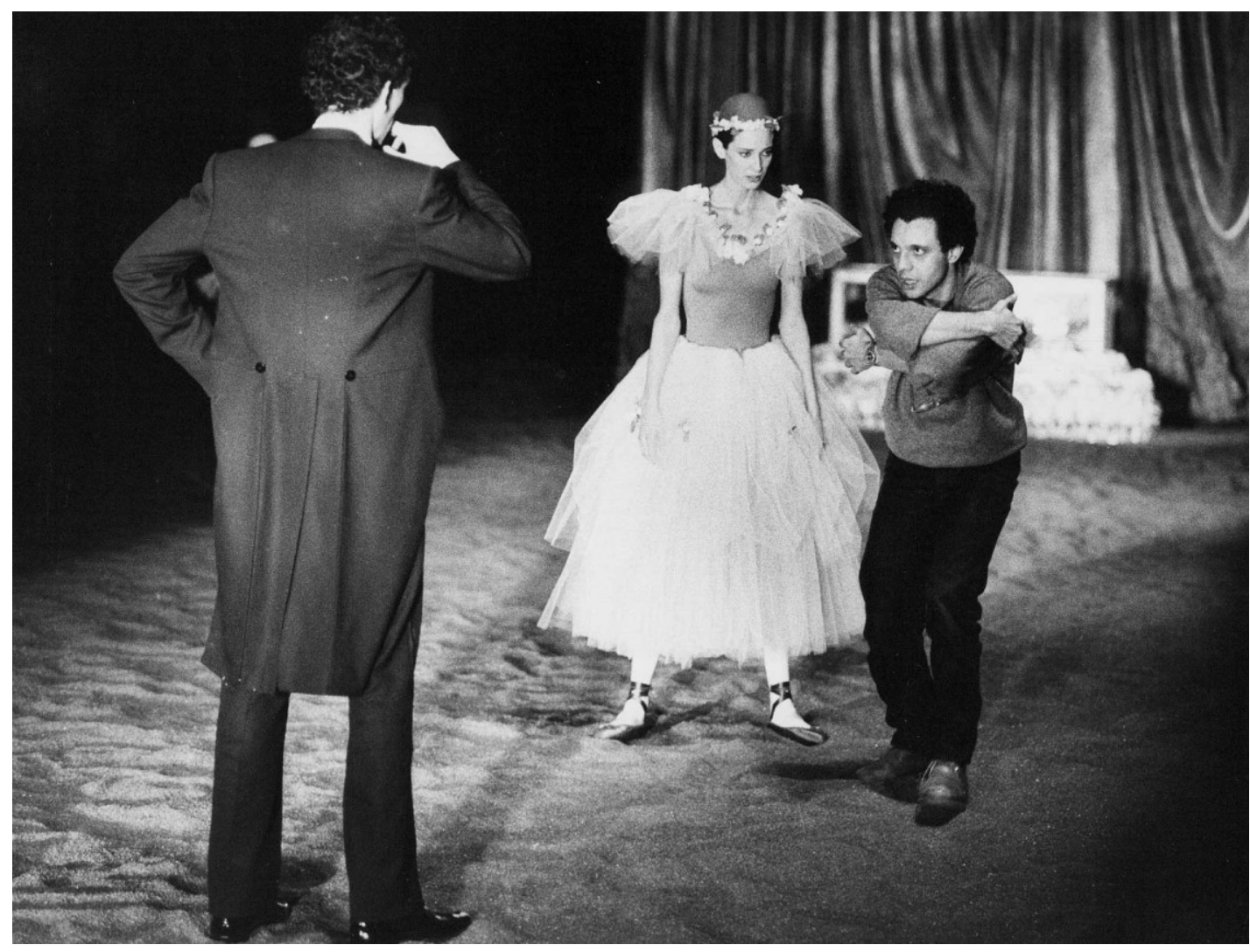

Fig. 103: Lluís Pasqual da instrucciones al actor Alfredo Alcón durante el ensayo de El público (1986).

Para finalizar los cuadros, utilizaron el juego de luces (de la completa oscuridad las escenas se iluminaban tenuemente), el cambio de los telones rígidos de colores y el uso de aplausos grabados. Con el juego de los desdoblamientos y de metamorfosis que tanto aparecen en el texto, Pasqual opta por la solución de que varios actores representaran diferentes personalidades de un mismo personaje. Según el actor Alfredo Alcón,

casi podría decirse que todo sucede en la cabeza del Director de Escena, que todos son partes o sueños de él. Ese juego de desdoblamientos era sumamente difícil. Pasar de un estado a otro, de un color a otro, sin buscar razones, un poco como sucede en los sueños y como a veces también ocurre en la vida, cuando uno vive sin tramoya exterior, como en un deslumbramiento. Esa dificulta no es sólo para nosotros, es también para el público que se va a encontrar con algo distinto a lo habitual, a lo que conoce $(1987,12)$.

En el cuadro tercero de la obra, cuando el Hombre 1 dice que no tiene máscara, el Director nos revela que no hay nada más que máscaras, en El público, como dice Pasqual: 
el Hombre I representa muy bien dibujado por Lorca, el hombre "sin máscara", el que afronta la verdad, en ese juego de reflejos entre Federico, el Director, y los tres hombres que invaden su espacio. A ese hombre que representa una actitud limpia ante la vida le da un nombre: Gonzalo. [...] Gonzalo/Hombre I es quien durante toda la obra empuja al Director hacia el camino de la verdad $(2016,72)$.

El juego de luces estaba muy presente en toda la representación, pero, en especial, en este cuadro tercero que se inicia con un iluminado recto sobre la arena desde la butaca del director hasta el sepulcro de Julieta. Y, más tarde, cuando Julieta dialoga con el caballo negro y el resto de personaje, todo el espacio es iluminado con focos circulares con una clara referencia a las pistas de circo.

En el cuadro cuarto con telón dorado, el foco de luz va dirigido constantemente durante todo el cuadro a El Desnudo Rojo que ha sufrido un castigo, se pueden ver las marcas en el cuerpo desnudo crucificado en una cama de hierro en posición vertical. En la oscuridad acontece la conversación entre los estudiantes que llevan linternas con poca luminosidad. De mismo modo, ocurren entre sombras el diálogo de las mujeres de negro que representan la burguesía. «Todo funciona como metáfora en una producción que funciona alrededor de la praxis de revelación: la revelación de la obra 'desconocida' de Lorca, la revelación de un Lorca 'desconocido’» (Delgado 1998, 398).

En sustitución al cuadro quinto, Lluís Pasqual introduce el solo del Pastor Bobo. El Pastor Bobo sale tímidamente, desde detrás del telón rígido de color azul, y empieza a cantar mientras juguetea con los espectadores $\mathrm{y}$, de este modo, provoca que el público se ría rompiendo la tensión que ha habido hasta el momento.

En el cuadro sexto y último, el Director vuelve de ese viaje. Aterrorizado por eso, reniega de Gonzalo ante su madre «casi al final, a la madre le traerán a su hijo muerto, Gonzalo, en forma de pez luna» (Pasqual 2016, 72). La escena final del enfrentamiento entre el Director (Alfredo Alcón) y el Prestidigitador (Walter Vidarte) es magistral, «en el terrible momento que empieza el asesinato por congelación del Director (el instante en que el prestigiador empieza a abanicarse), este dice: "Tengo frío." (Pasqual 2016, 72). La función del personaje del Prestidigitador es la de crear ilusiones, el engaño teatral ocurre «cuando ambos son vistos, abanico en mano, como siluetas en un telón a cierta distancia, creando una manifestación seductora de lo efímero e intangible de la 
representación teatral, que sólo se convierte en sí misma cuando desaparece» (Delgado 1998, 395-396).

\subsection{2.- A través de Àlex Rigola}

Ante la noticia de un nuevo montaje, a cargo de Àlex Rigola, en 2015, Pasqual opinará:

Han transcurrido casi treinta años desde su estreno. [...] Àlex Rigola, que ha decidido emprender el mismo viaje que nosotros hicimos en 1986, nos ha invitado a hablar con su compañía, para poder acompañarles con algún recuerdo de lo que para nosotros era cada figura, cada metáfora en ese intrincado bosque de palabras e imágenes. [...] $E l$ público es ese río oscuro y violento que cada uno debe cruzar a nado con su propio cuerpo, según sus propias emociones y sentimientos más íntimos (Pasqual 2016, 71).

Rigola se enfrenta al texto como si se tratara de un sueño, en el que el espectador debe sumergirse, con «la voluntad de ir penetrando en el interior y que dando paso a un viaje en el que realidad y sueño se confunden» (Barranco 2015b, 31). El crítico Javier Vallejo diferenciará entre la puesta de escena de Pasqual y la de Rigola:

el montaje dirigido por Àlex Rigola, elegante, estático y formal amortigua el vigor de la obra, hace de ella el recuerdo de un sueño, nos lleva de la mano afablemente allí donde la tan celebrada puesta en escena de Lluís Pasqual, de 1987, nos llevaba de sorpresa en sorpresa (2015).

Antes del inicio de la obra, los espectadores, cuando entran en el patio de butacas, se encuentran con el decorado (el escenario cubierto por arena y colgando dos elegantes lámparas de cristal de roca estilo imperio), con actores en escena y por la sala, vestidos con trajes azules y los rostros cubiertos por máscaras negras (creadas por Ricardo Vergne) y con una pequeña orquesta en un lateral que toca y canta en directo creando un ambiente íntimo. Los actores que se encuentran en la sala harán la función de los acomodadores, encargados de ir aposentando a los espectadores en sus butacas.

En la primera acotación de El público, se puede leer «Una gran mano impresa en la pared». Esa gran mano impresa en la pared, Rigola la sustituye por el rostro de Federico proyectado sobre la cortina plateada. También antes de que empiece la obra, quiere 
hacer partícipe al autor situándolo también en unas proyecciones de la película de pocos minutos que se rodó cuando formaba parte de La Barraca y, por último uno, de entre todos los actores destaca, vestido de traje negro, al cruzar el escenario hasta situarse en la parte más elevada del montículo de arena observando la entrada del público. Su papel es importante ya que será el encargado de dar inicio al espectáculo que, a su vez, será tratado como un sueño del autor.

Al simplificar y eliminar imágenes, personajes y mutaciones, el montaje de Rigola provoca indeterminación en las interpretaciones. En palabras de Javier Vallejo:

La multiplicación de los actores en personajes diversos sin que queden del todo definidos siempre los cambios de identidad [...] el cambio de sexo de uno de los Caballos blancos (símbolos de la libido), interpretado por Laia Durán [...], producen un desplazamiento perceptible del contenido simbólico de la obra y dificultan más que aclaran su lectura (2015).

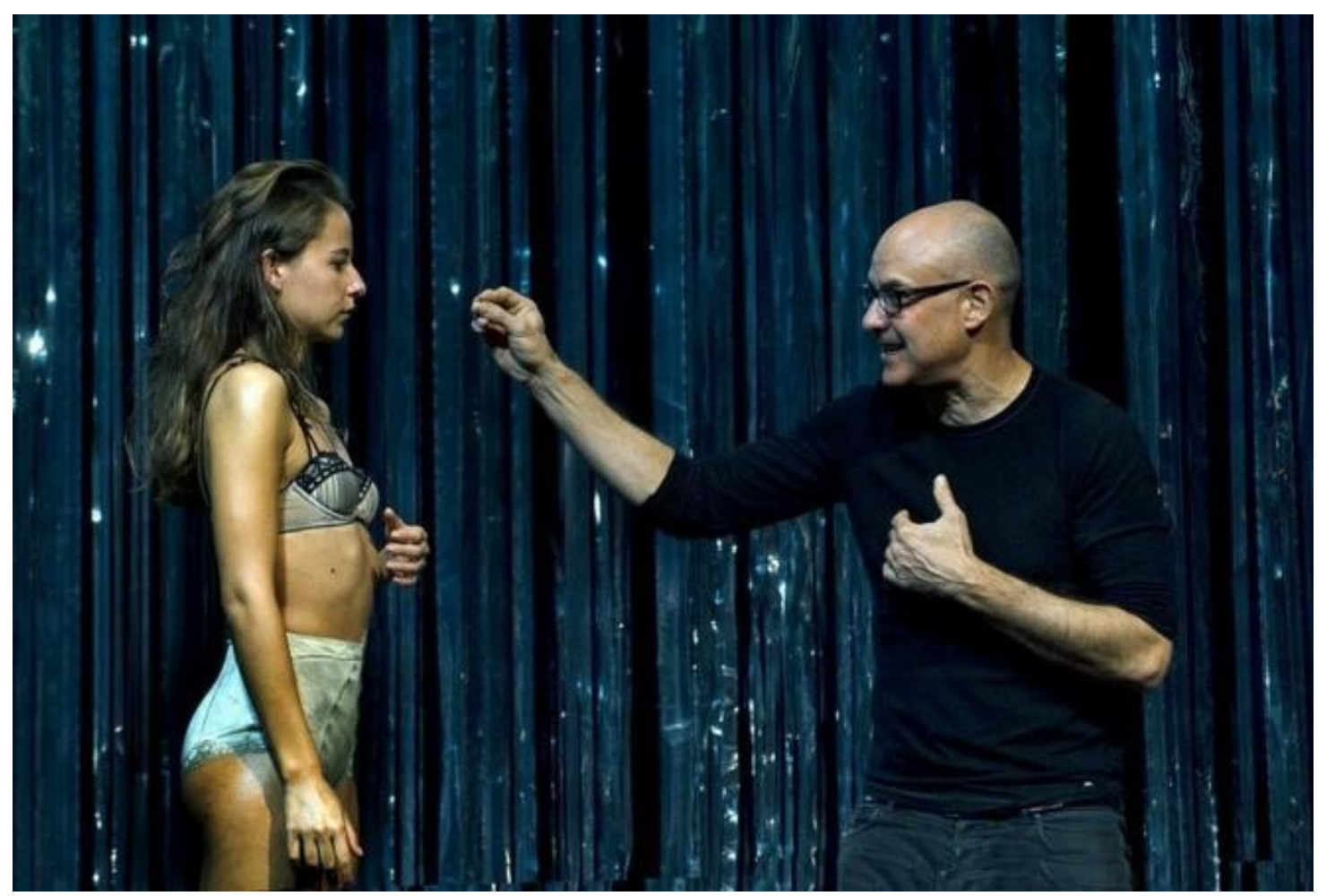

Fig. 104: Àlex Rigola da instrucciones a la actriz Irene Escolar, quien interpreta a Julieta.

El montaje respeta la misma estructura del drama en cinco cuadros, incluyendo el solo del Pastor Bobo entre el quinto y sexto cuadro. Para los cambios de cuadros sólo utiliza un juego de variaciones en la altura de las lámparas de cristal. Hacia el final del cuadro 
quinto, empieza a sonar una trompeta, que dará paso al solo del Pastor Bobo. Una estremecedora canción, interpretada y creada por Nao Albet, acompañado en el escenario por Laia Duran, que danzará y cambiará el rostro como si se tratara de las máscaras del «gran armario lleno de caretas blancas de diversas expresiones» de la acotación del inicio del texto.

\section{6.- La última puesta en escena: Ksec Act}

La compañía teatral japonesa Ksec Act con su sede en Nagoya, Japón, fue fundada en 1986. La compañía, junto a su traductor y adaptador Yoichi Tajiri, se dedica a la promoción y divulgación del teatro clásico español. Han llegado a estrenar más de 15 obras de autores españoles, el autor más repetido en su repertorio es Federico García Lorca (CDN 2018).

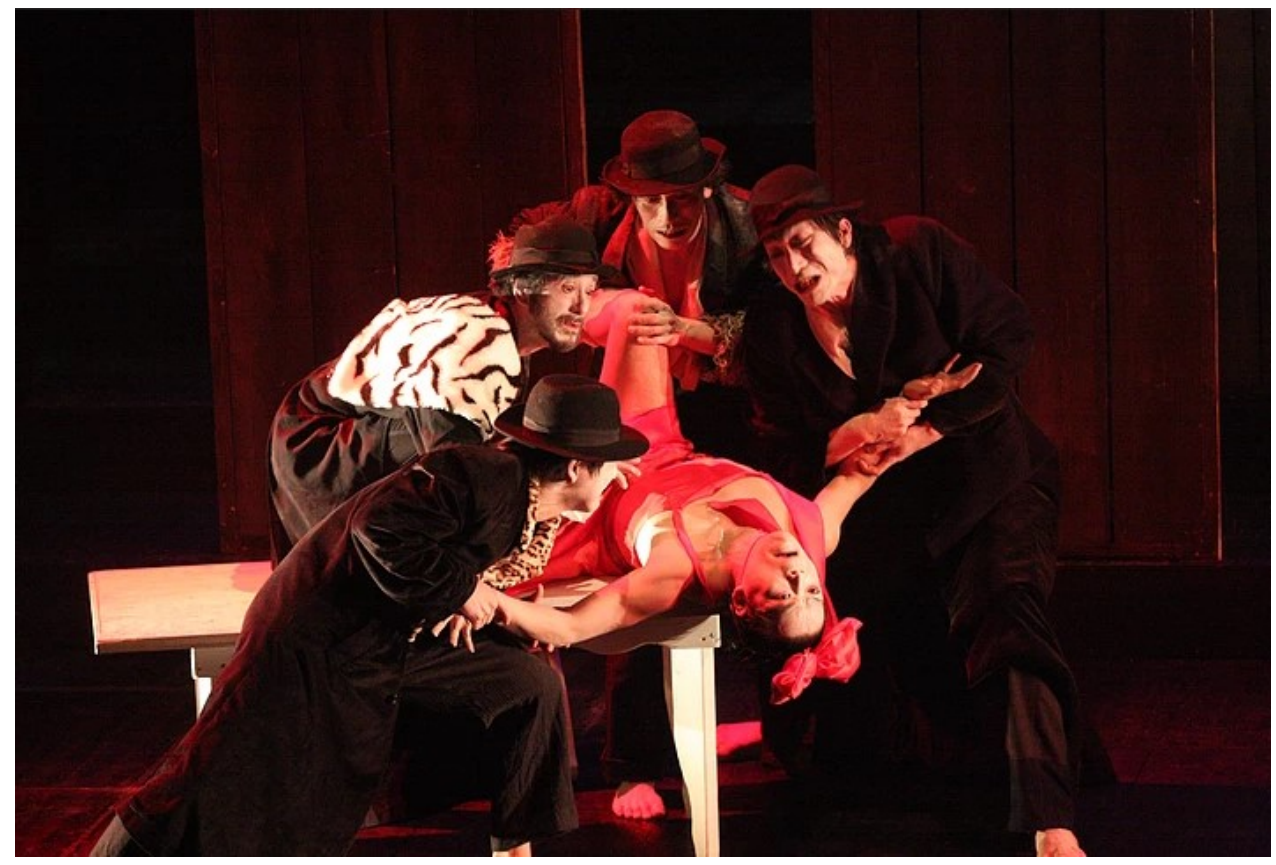

Fig. 105: La escena en la que Julieta es tentada por los caballos blancos, todos los personajes están interpretados por hombres, incluso Julieta quien ,según diálogo entre los Estudiantes, se trataba de un joven disfrazado de Julieta.

En 2018, en colaboración con el Centro Dramático Nacional, presentó un nuevo proyecto, la puesta en escena de El público, la séptima obra teatral que representan de Federico García Lorca. La dirección estuvo a cargo de Kei Jinguji que consigue crear una dimensión onírica del texto, junto a la música, a cargo de Tooru Tanaka y de 
Hitomi Ozaki, con bases electrónicas que sugieren un ambiente onírico en el que el espectador se sumerge fascinado.

La obra, bajo el título El público (Una mirada al mundo), se estrenó el 15 de febrero, en el Teatro Valle Inclán de Madrid y en gira sólo se pudo ver el día 21 de febrero, en el Teatro Circo de Murcia (TCM). La obra se presentaba en japonés pero acompañada de sobretítulos en español para que el espectador tuviera una comprensión total.

La versión de la ópera de Mauricio Sotelo, en la que hay más libertad, es en la que Tajari encuentra más próxima a su montaje. Como afirma Hernández Garrido, Tajiri «logra una dramaturgia esclarecedora, en la que individualiza los personajes personales creando un coro de voces que representa un público, narrativo y coercitivo, del proceso (dicho esto en plan kafkiano) que representa esta obra» (2018). 


\section{ANÁLISIS SEMIÓTICO TEATRAL DE COMEDIA SIN TÍTULO}




\section{2.- El origen de Comedia sin título}

En su viaje a Nueva York, en 1929, Lorca puede observar cómo el modelo, el teatral neoyorquino, era muy diferente al predominante en España. Hacía falta un teatro nuevo que escapara de las limitaciones del teatro realista y burgués representado mediante la cuarta pared $^{261}$. Lorca quiere eliminarla $y$, de este modo, conseguir que la representación entrara en contacto con el público y así traer la realidad a la escena (Harretche 1998, 182). En este tipo de escenificación, el público se siente como si fuera parte de la representación, como si el autor hubiera contado con él desde el principio y, por ello, el autor está presente en todas las representaciones para que el público pueda formar parte de la acción en todas estas.

Como explica Harretche, «en el escenario de este teatro de cambio al que Federico García Lorca quiere llegar está la luz, porque es el teatro de la verdad. La oscuridad persiste entre los que prefieren el cómodo mundo emboscado de la mentira» (1998, 184). Lorca quiere mostrar la verdad sobre el escenario, no solamente la verdad en la identidad personal como ocurre en El público, sino también busca un cambio revolucionario en el teatro y sus textos.

En esta obra inacabada, que Federico García Lorca compuso durante los últimos años de su vida, aparece el concepto teatral en toda su dimensión, con una gran conexión con El público. En ella se puede observar cómo Lorca nos muestra un teatro diferente en oposición al teatro convencional de la década de los años treinta en España. Como afirma Jordi Julià, en «Comedia sin título el prólogo no es una parte desgajada de la obra, sino que provoca el verdadero conflicto de la acción [...]. Lorca reclamaba en 1936 un concepto de autor comprometido con la realidad de su sociedad» $(2001,276)$. El Autor, que prologa la obra, es el propio Lorca que «proyecta su desdén contra el teatro caduco y romo mediante los airados parlamentos de este personaje. Lorca alcanzó aquí el cénit de su ruptura formal, que tenía como precedentes explícitos El público y Así que pasen cinco años» (Ojeda 2019, 38).

\footnotetext{
261 La invención de la cuarta pared, a finales del siglo XIX, fue una manera de dar realismo a la representación. Como afirma Harretche, «los actores, rodeados de un decorado, se encerraban en el escenario separados del público por una cuarta pared para, de ese modo, aislados, comportarse 'como si' estuvieran viviendo una realidad en el aquí y el ahora del escenario» (1998, 181-182).
} 
En el momento en que se concibe Comedia sin título, en España se vive una gran tensión y violencia en las calles y las fábricas. Con la proclamación de la República y las propuestas de una serie de reformas muy ambiciosas en diferentes sectores, los sindicatos de la CNT vieron peligrar su posición ante el gobierno socialista e inician una política de oposición basada en la acción directa. Y se convocan unas huelgas generales que se sucedieron en Sevilla, Barcelona, Vizcaya, Asturias Madrid y Zaragoza. También, entre 1932 y 1933, ocurren las insurrecciones de los mineros en Cataluña y Valencia. Junto a estas movilizaciones, crecerán las protestas patronales de la industria y del comercio. Estos conflictos obreros urbanos ocurrían al mismo tiempo que surgían los conflictos en el campo de Sevilla, Córdoba, Toledo y Salamanca, por causa de la frustración de los jornaleros por la tardanza en la reforma agraria y la oposición de los propietarios en cumplir la nueva legislación (Valdeón, Pérez y Juliá 2003, 462-463). Lorca intenta reflejar esos momentos convulsos en su obra, acercando su posición a los sentimientos y a los problemas del proletariado.

\section{1.- Las ideas anteriores de Comedia sin título}

Federico García Lorca nunca quiso inscribirse a unas siglas políticas, por más que insistieran diferentes partidos. A los diversos homenajes, actos y conferencias que asistía, siempre lo hacía de una manera personal sin representar a ningún partido político. Aún así, no quiere decir que Lorca no se implicara políticamente en los problemas sociales de España y sobre todo entre las clases más desfavorecidas. Por eso, encontramos opiniones en diferentes entrevistas o conferencias, en las que plantea sus preocupaciones sobre los problemas sociales y humanos que se están viviendo y que incorpora posteriormente en la pieza Comedia sin título.

Ejemplo claro son las ideas que muestra en su conferencia «Charla sobre el teatro», dictada el 1 de febrero de 1935, tras el segundo acto de una representación especial de Yerma y que entrega a Miguel Pérez Ferrero para que se publique al día siguiente, en el Heraldo de Madrid, en la que exponía:

Los teatros están llenos de engañosas sirenas coronadas con rosas de invernadero, y el público está satisfecho y aplaude viendo corazones de serrín y diálogos a flor de dientes: 
pero el poeta dramático no debe olvidar, si quiere salvarse del olvido, los campos de rocas mojados por el amanecer donde sufren los labradores y ese palomo herido por un cazador misterioso, que agoniza entre los juncos sin que nadie escuche su gemido (García Lorca 1935, 6).

En la entrevista, del 27 de septiembre de 1935, «Federico García Lorca parla per als obrers catalans» publicada en L'Hora de Palma de Mallorca, expondrá:

Me parece absurdo imaginar que el arte pueda desligarse de la vida social, cuando no es otra cosa que la interpretación de una fase de la vida por un temperamento sensible [...]. El artista, como observador de la vida, no puede permanecer insensible a la cuestión social (citado en Inglada 2017, 408,412).

O en La Humanitat, en Barcelona, el 6 de octubre de 1935, en «La poesía vista per un poeta. Parlant amb Federico García Lorca» de Jordi Jou:

Ante el hecho social, el poeta se debe apasionar. No puede de ninguna manera permanecer impasible. ¿Cómo pretenden que el poeta pueda cerrar los ojos ante los hombres que sufren, ante la tragedia espantosa del hombre oprimido? El poeta debe sentirlo y comprenderlo, y ayudar en sus posibilidades a la conquista de un mundo más justa y más humano (citado en Inglada 2017, 425).

También encontramos ideas similares en el diálogo-entrevista con el caricaturista Luis Bagaría, el 10 de junio de 1936, publicado en El Sol, en el que añade:

En este momento dramático del mundo, el artista debe llorar y reír con su pueblo. Hay que dejar el ramo de azucenas y meterse en el fango hasta la cintura para ayudar a los que buscan las azucenas. Particularmente, yo tengo una ansia verdadera por comunicarme con los demás. Por eso llamé a las puertas del teatro y al teatro consagro toda mi sensibilidad (García Lorca 1936, 5).

Como podemos comprobar, son múltiples las referencias de Lorca sobre su implicación con los problemas sociales y su preocupación ante los más desfavorecidos, y la necesidad de no olvidarlos y ayudarlos. También estaba preocupado ante la posibilidad de una guerra, y cómo esta sería el fracaso de la civilización. 


\section{2- La historia del manuscrito}

El texto se supone que fue redactada entre el otoño de 1935 y el invierno de 1936. Sólo se conserva un manuscrito ${ }^{262}$, consistente en único acto, no fechado, aunque según testimonios de Margarita Xirgu y Pablo Suero, por las lecturas que realizó, la situamos entre 1935 y 1936, y asimismo por las diferentes entrevistas y noticias que aparecen en la prensa de esos años.

En el autógrafo, que se conserva, aparece sin título (encabeza, la primera página del manuscrito, la frase Casa de maternidad ${ }^{263}$, pero nada tiene que ver con el argumento), pero en diferentes entrevistas realizadas durante el año 1936, nombra su existencia y la posibilidad de un título.

En una entrevista ${ }^{264}$ de principios de 1936 pero publicada el 24 de febrero de 1937 en Mundo Gráfico, realizada por Antonio Otero Seco, Federico García Lorca indicaba que se encontraba trabajando en «un drama social, aún sin título, con intervención del público de la sala y de la calle, donde estalla una revolución y asaltan el teatro» (1937, 10).

En varios momentos, Comedia sin título es nombrada con el título La vida es sueño, en la sección de rumores teatrales del Heraldo de Madrid, como fue en el ejemplar del 12 de febrero de 1936:

Se dice $[\ldots]$

Que el gran poeta Federico García Lorca, uno de los grandes prestigiosos de España, trabaja febrilmente.

Que está terminando el segundo acto de una obra ultramoderna en la que maneja los más audaces procedimientos y sistemas teatrales.

Que el espectador no irá a ver lo que pasa, sino a sentir lo que les pasa.

\footnotetext{
${ }^{262}$ Consta de un total de 24 hojas: Veintidós de 17,5 x $25 \mathrm{~cm}$. escritas en lápiz y tinta por una sola cara y numeradas del 1 al 22; una hoja de 21,5 x 27,5 cm. dobladas por la mitad y escrita por dos de las cuatro caras y numeradas las caras escritas 22 y 23 , y una hoja de 17,4 x 21,5 cm. numerada 24 .

Con modificaciones y correcciones hechas a lápiz y tinta, según la página escrita.

263 Según afirma Marie Laffanque, corresponde a «un título y a unos breves apuntes también conservados en el archivo familiar. Representa a otro proyecto, otro intento, momentánea o definitivamente abandonado» $(1978,277)$.

${ }^{264}$ Está publicada en el número 1321 de Mundo Gráfico con fecha del 24 de febrero de 1937. Pero por los datos que se exponen en dicha entrevista, entre ellos el estreno teatral de Doña Rosita la soltera, se puede suponer que se realizó, un año antes de su publicación, entre enero y febrero de 1936.
} 
Que el escenario y la sala están unidos en el desarrollo de la obra.

Que la obra es sumamente fuerte; y en previsión de no poderla estrenar en España ha entablado relaciones con una compañía argentina, que la estrenará en Buenos Aires.

Que la obra no tiene título aún, pero que el que más le cuadraría hubiese sido La vida es sueño.

Que ese título ya lo utilizó Calderón...

Que, de todas formas, el título será parecido a éste.

Que la intensidad emocional de la obra va en aumento y que los espectadores que no puedan mantener el control de sus nervios harán bien en abandonar la sala.

Que la obra trata de un problema social agudo y latente.

Que la obra está resuelta de un modo sorprendente (Heraldo de Madrid 1936, 9).

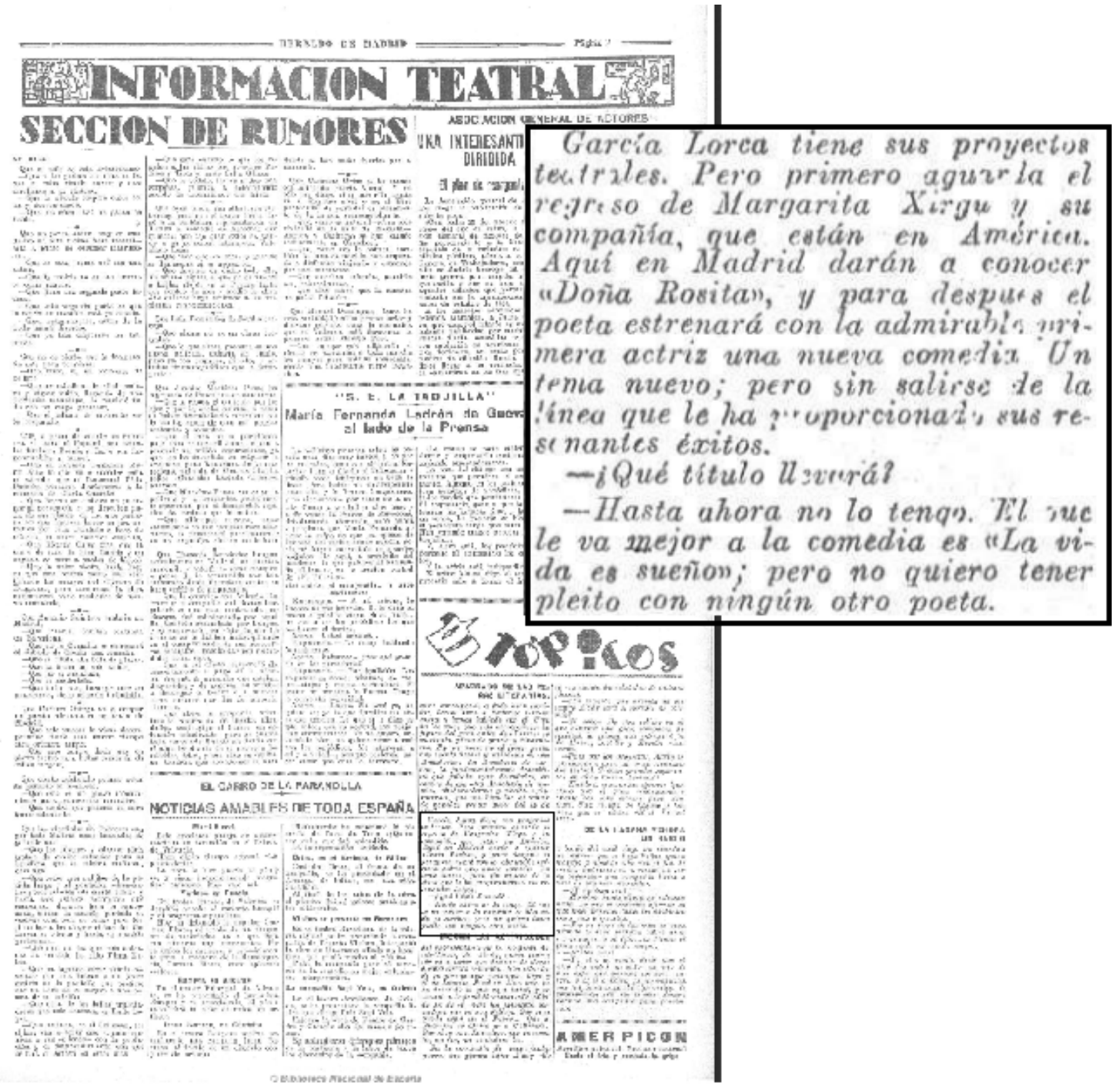

Fig. 106: Recorte de «Tópicos» publicado en la página 13 de la información teatral del periódico Heraldo de Madrid, el 29 de febrero de 1936. 
También, el 29 de febrero de 1936, en el Heraldo de Madrid, en la información teatral, sección «Tópicos», aparece el próximo proyecto después del estreno de Doña Rosita:

Para después el poeta estrenará con la admirable primera actriz una nueva comedia. Un nuevo tema; pero sin salirse de la línea que le ha proporcionado sus resonantes éxitos.

- ¿Qué título llevará?

- Hasta ahora no lo tengo. El que le va mejor a la comedia es «La vida es sueño»; pero no quiero tener pleito con ningún otro poeta (Heraldo de Madrid 1936, 13).

En la entrevista ${ }^{265}$, realizada por Felipe Morales en La Voz de Madrid el 7 de abril de 1936, hace referencia a una nueva comedia, una comedia sin título:

Ahora estoy trabajando en una nueva comedia. Ya no será como las anteriores. Ahora es una obra en la que no puedo escribir nada, ni una línea, porque se han desatado y andan por los aires la verdad y la mentira, el hambre y la poesía. Se me han escapado de las páginas. La verdad de la comedia es un problema religioso y económico-social. El mundo está detenido ante el hambre que asola a los pueblos. Mientras haya desequilibrio económico, el mundo no piensa. Yo lo tengo visto. [...].

El día que el hambre desaparezca, va a producirse en el mundo la explosión espiritual más grande que jamás conoció la Humanidad. Nunca jamás se podrán figurar los hombres la alegría que estallará el día de la Gran Revolución (citado en Suero 1937 [2015], 337; en Monegal 2017, 198; en Laffranque 1978, 280).

Y el 29 de mayo del mismo año, en la sección «Rumores» del Heraldo de Madrid aparece que, entre los proyectos que lleva Lorca en marcha, se encuentra «muy adelantada la labor en su drama social El sueño de la vida» (citado en Monegal 2017, 201). En ambos, se abandona la idea provisional de Comedia sin título para presentarla bajo el título El sueño de la vida.

\section{3.- Los primeros testimonios de Comedia sin título}

Entre los oyentes de las lecturas que realizó Federico García Lorca de Comedia sin título, destacan los testimonios de Margarita Xirgu y Pablo Suero.

265 «Conversaciones literarias. Al habla con Federico García Lorca». 
En el caso testimonial de Margarita Xirgu, hasta en tres ocasiones, en 1937, 1949 y 1956, declara haber escuchado parte de este drama. En Buenos Aires, Margarita Xirgu comparte recuerdos con los de Pablo Suero, quien reconoce dicho acto:

— [...] Me había leído el primer acto de una obra formidable, sin título aún.

- Conozco este acto; me lo leyó a mí en una taberna en la calle de la Luna, una noche inolvidable (citado en Suero 1937 [2015], 381).

Puede tratarse de dos lecturas diferentes, la de Xirgu, a finales de enero de 1936, y en la misma calle o barrio, a mitad de ese mismo mes o en el siguiente, la de Pablo Suero (Laffranque 1978, 283; 1987, 88).

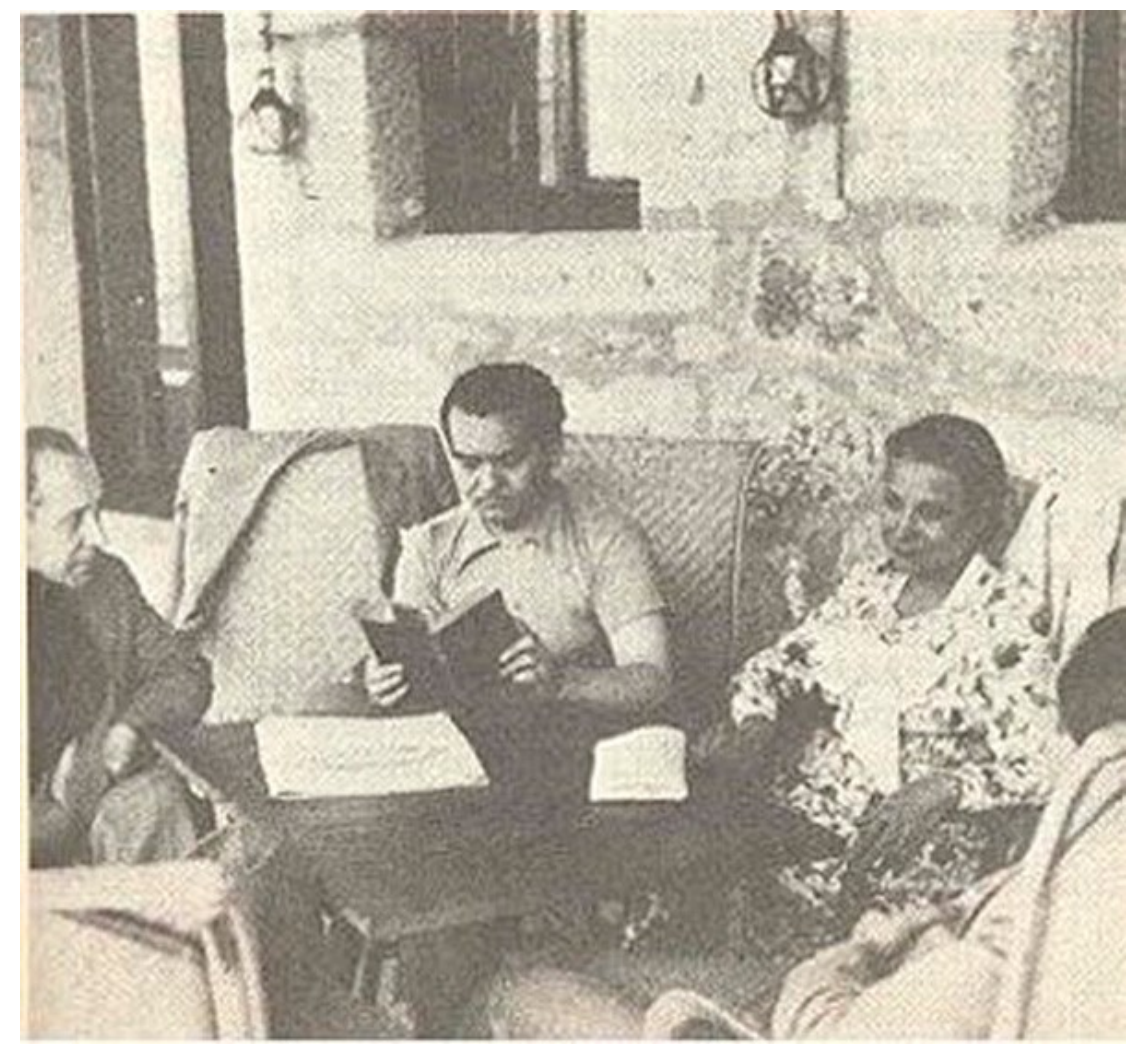

Fig. 107: Federico García Lorca, Margarita Xirgu, Miguel Ortín, Rivas Cherif y José Arnall, en la terraza del parador de Gredos, frente a los picos nevados de la Sierra.

Pero esta lectura es posterior a la que tuvo lugar en el parador de Gredos, en el verano de 1935. Estuvieron presentes, junto a Margarita Xirgu, su marido Miguel Ortín, Cipriano Rivas y José Arnall. En la entrevista, realizada por Valentín de Pedro, en 1949, Xirgu confesaba sin demasiados detalles la sensación de «sorpresa, sobre todo, por el tono, tan distinto al de la comedia que me había leído el día anterior: una obra de 
carácter social, al menos lo que me leyó de ella» (citado en Laffranque 1978, 284). El día anterior tuvo lugar la lectura, entre los mismos presentes, de Doña Rosita la soltera o el lenguaje de las flores, en la que Lorca había pensado que Margarita Xirgu interpretara a Rosita. Las escenas de esta nueva obra apenas las tenía abocetadas, las cuales se desarrollaban en un depósito de cadáveres al que iban Titania y el Autor (Laffranque 1987, 88).

En cambio, catorce años después de esa lectura, la recuerda ${ }^{266}$ más detalladamente. En la entrevista ${ }^{267}$ realizada por María Teresa León, en 1956, concretaba:

La representación de pronto se interrumpía, pero sin que cayera el telón. Sorpresa en el público, murmullos. ¿Qué ocurría? ¿Por qué se retiraban los actores de la escena? De entre bastidores, se adelantaba entonces hasta las candilejas el poeta, un poeta que podía ser el director artístico de la compañía, y comunicaba al público que había estallado una revolución. Los espectadores, en un movimiento instintivo, se levantaban, como para echar a correr; pero el poeta les advertía que era conveniente que nadie se moviera: resulta muy peligroso salir. Dentro del teatro podían estar tranquilos: las puertas habían sido fuertemente cerradas. Los espectadores optaban por no moverse de su sitio, aunque, permanecieran en sus asientos como sobre ascuas; y desde ese instante se convertían en actores. Una señora, en el patio de butacas, comenzaba a gritar:

— ¡Mis hijos! ¡Mis hijos! ¿Qué va a ser de mis hijos, solos en casa, si no podemos salir...? [...]

El segundo acto, que tenía apenas abocetado y del que sólo leyó algunas escenas, se desarrollaba en el depósito de cadáveres, adonde iban Titania y el poeta. Del Tercero no tenía nada escrito, pero explicó que pasaría en el cielo: un cielo con ángeles andaluces, que vestirían con faralaes... (citado en Rodrigo 1975, 359-361; en Laffranque 1978, 286).

El testimonio de Margarita Xirgu coincide con el de Pablo Suero, publicado por primera vez en las Noticias Gráficas de Buenos Aires, en las que declaraba:

\footnotetext{
${ }^{266}$ Durante la entrevista, junto a Margarita Xirgu y María Teresa León, estaba presente Miguel Ortín, quien confirmaba sus recuerdos.

267 «Federico y Margarita». En El Nacional de Caracas, 11 de octubre de 1956.
} 
Federico me llevaba diariamente a dos tabernas típicas madrileñas. Una en la calle del Pozo y otra en la calle de la Luna. En una de ellas, nos reunimos una noche para leerme, después de comer, sus últimas cosas. Me leyó primero un acto de una pieza grande. Es un drama social de extraordinaria fuerza. [...] Le dije a Federico que nos situaba con esa obra frente a un teatro nuevo, que confundía escenario, público y calle. La obra se anticipaba de manera sorprendente a lo que está ocurriendo en España. Los revolucionarios aprovechaban una procesión para pasar en la custodia un contrabando de un poderoso explosivo que iba a asegurar el triunfo de la reacción. Hay un cuadro de las madres en una Morgue que alcanza verdadera grandeza. La obra es una fuerza de sensación brutal y al mismo tiempo está encendida de extraña poesía (citado en 1937 [2015], 336-337).

Entre otros testimonios, también encontramos una carta del escritor gallego, Eduardo Blanco Amor dirigida a Marie Laffranque, del 27 de septiembre de 1960, en la que recordaba cómo Lorca le había contado: «varias escenas de una tragedia: El Estado, de las que jamás he visto una línea» (citado en Laffranque 1978, 278).

\section{4.- La publicación y posteriores ediciones}

Entre todas las ediciones de la obra teatral Comedia sin título, destacaremos las publicadas: en 1978, junto a El público, a cargo de Rafael Martínez Nadal; en 1987, Marie Laffranque presenta todo el teatro inconcluso de Lorca en una edición facsímil; en el año 2000, bajo el título El público. El sueño de la vida, Antonio Monegal y Mario Hernández realizan un estudio introductorio de la relación entre sí de las dos obras y sus posibles diferencias y, para finalizar, en el año 2018, Emilio Peral Vega edita el acto primero de Lorca junto a los dos actos que propone Alberto Conejero como continuación a partir de la edición de Antonio Monegal.

En 1978, Comedia sin título aparece, junto a El público, en la edición presentada por Rafael Martínez Nadal titulada, Federico García Lorca. El público y Comedia sin título. Dos obras póstumas, en la editorial Seix Barral de Barcelona., cuya presentación y estudio estuvieron a cargo de Marie Laffranque y Rafael Martínez Nadal. Según relata este, hasta 1972 no conocía de la existencia del único acto de Comedia sin título: 
[fue] en un almuerzo en casa de nuestro común amigo Víctor Hurtado. Isabel [García Lorca] nos descubrió allí que entre los papeles de su hermano había aparecido un acto inédito, sin título, de una obra de tipo social no acabada. Pensé, ¿no sería acaso el desaparecido cuadro, o “acto" IV que faltaba en el autógrafo en mi poder? $(1978,267)$.

Y aunque en un principio pensó que podía tratarse del cuadro que faltaba en El público, enseguida reconoció que no se trataba de este, ya que el único acto de Comedia sin título «parece oscilar entre temeroso surrealismo y un neorrealismo político-social [...]. En algunos momentos, el prólogo, por ejemplo, nos recuerda, más que a El público, a la ingenua exposición de generosos sentimientos que caracterizan las páginas del juvenil libro Impresiones y paisajes» (Martínez Nadal 1978, 268).

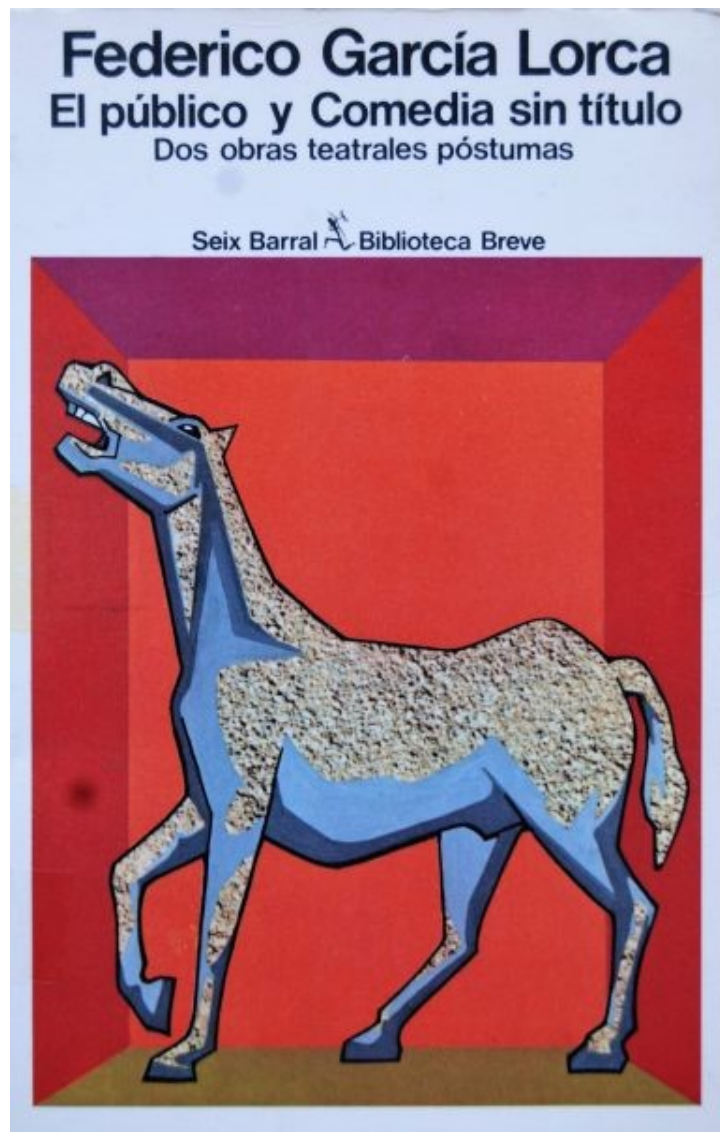

Fig. 108: Portada de la edición de Seix Barral publicada en 1978.

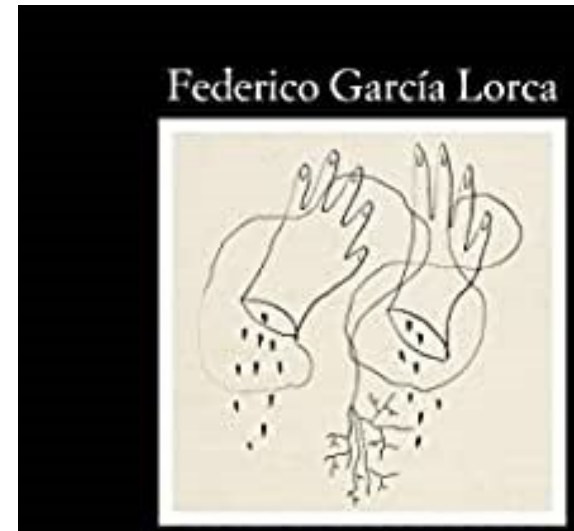

Comedia sin título

(seguida de El sueño de la vida de Alberto Conejero)

Edición de Emilio Peral Vega

\section{CATEDRA}

Letras Hispánicas

Fig.109: Portada de la edición de Cátedra de 2018, seguida de El sueño de la vida de Alberto

Conejero. Con la ilustración del mismo autor Manos cortadas (h. 1935-36).

La transcripción de Comedia sin título de Marie Laffranque en edición facsímil aparece en Federico García Lorca, Teatro inconcluso publicado en 1987, por la Universidad de 
Granada y la Fundación Federico García Lorca. Es la primera edición en España donde se recoge todo el teatro inacabado, posterior a 1925.

En el año 2000, en Alianza editorial (Madrid), Antonio Monegal, bajo la coordinación de Mario Hernández, editó El público. El sueño de la vida, junto a diferentes entrevistas, notas de prensa y una aclaratoria introducción a las dos obras. Aunque se ha llegado a considerar la hipótesis de que este acto aislado sea el cuadro cuarto que falta a El público, según se presentan hoy en día los dos textos, es remota esa posibilidad, ya que faltaría una reestructuración y una reescritura. Más que lo que une a las dos obras, encontramos lo que las separa. Según afirma Antonio Monegal, «El público y El sueño de la vida representan posturas antagónicas, la primera trágica, la segunda utópica. El modo inconcluyente en El público se intenta resolver en El sueño de la vida abriendo las puertas del teatro» $(2017,40)$. El público es una obra de múltiples voces y de una gran ambigüedad, Comedia sin título, por su parte, es más un monólogo como discurso, impulsado por el Autor que inicia la obra.

En el año 2018, Emilio Peral Vega publicó Comedia sin título (seguida de El sueño de la vida, de Alberto Conejero), en la editorial Cátedra. Peral parte de la edición de Antonio Monegal, con mínimas modificaciones de puntuación. Y sigue con los dos actos de Alberto Conejero de El sueño de la vida. En la introducción, realiza un estudio del contexto histórico social del momento en el que Lorca redacta la obra, junto a la revolución estética que surge en el teatro de principios del siglo XX. En los dos actos de Conejero, aparecen numerosas notas a pie de página, en las que Peral nos indica las referencias lorquianas que se inspiran a Conejero para continuar el único acto de la obra. 


\section{3.- Análisis semiótico teatral: Nivel sintáctico}

Siguiendo el mismo sistema de análisis semiótico realizado para el texto de El público, analizaremos el único acto conservado de la obra Comedia sin título. En el texto, Lorca utiliza la presentación por parte del Autor de lo que se encontrará el espectador una vez se levanta el telón. Sus palabras son críticas hacia el teatro conservador y hacia el público burgués acomodado. Esta postura ya la encontramos en diferentes prólogos y presentaciones o en alguna intervención de algún personaje en otras obras teatrales de Lorca, como hemos apuntado:

Como es el caso de Mosquito, en Tragicomedia de don Cristóbal y la señá Rosita, que, según la acotación, es «un personaje misterioso, mitad duende, mitad martinico, mitad insecto» (Obras Completas II [1996] 2006, 12), propio del teatro épico y clásico y que es el encargado de presentar la obra que a continuación van a representar. En sus palabras, muestra la hipocresía del público burgués frente a la pureza del pueblo:

Yo y mi compañía venimos del teatro de los burgueses, del teatro de los condeses y de los marqueses, un teatro de oro y de cristales, donde los hombres van a dormirse y las señoras... a dormirse también. Yo y mi compañía estábamos encerrados. No podéis imaginar qué pena teníamos. Pero un día vi por el agujerito de la puerta una estrella que temblaba con una fresca violeta de luz [...]. Entonces yo avisé a mis amigos, y huimos por esos campos en busca de la gente sencilla, para mostrarles las cosas, las cosillas y las cositillas del mundo (Obras Completas II [1996] 2006, 12).

La crítica directa al público conservador del momento es clara y directa, pero al estar dirigida por un animalillo indefinido y no real, el público se incomoda como si el personaje fuera un autor o director.

Diferente es en La zapatera prodigiosa en la que, mediante un prólogo clásico, en el que no sólo anticipa el argumento de la obra sino que realiza una declaración de intenciones, el Autor se dirige de tú a tú al público presente y solicita la implicación ante el espectáculo que van a presenciar, y para que no esperen un teatro al estilo tradicional:

Respetable público... (Pausa.) No, respetable público no, público solamente, y no es que el autor no considere al público respetable, todo lo contrario, sino que 
detrás de esta palabra hay como un delicado temblor de miedo y una especie de súplica para que el auditorio sea generoso con la mímica de los actores y el artificio del ingenio. El poeta no pide benevolencia, sino atención, una vez que ha saltado hace mucho tiempo la barra espinosa de miedo que los autores tienen a la sala. Por este miedo absurdo y por ser el teatro en muchas ocasiones una finanza, la poesía se retira de la escena en busca de otros ambientes donde la gente no se asuste (La zapatera prodigiosa, Prólogo, 53).

Como ocurre en Comedia sin título, es el Autor de la obra, y no el Director de escena, quien se dirige al público para mostrar su descontento ante la situación teatral y las reacciones del público ante posibles cambios en los temas y obras dramáticas propuestos por los dramaturgos y poetas. Y solicita, seguramente, al público que se involucre en esos cambios.

\section{1.- Códigos verbales}

Comedia sin título es una obra breve y, al mismo tiempo, la falta de complejidad de acción y de caracteres humanos. En el único acto que forma la obra, son mínimas las acotaciones, así que expondremos con más profundidad el argumento tratado en el acto y su conexión con El público.

\subsection{1.- Estudio de la acción (argumento) y de las acotaciones}

El prólogo que encabeza la obra se refiere a la intención del Autor de eliminar el miedo al público y mostrarle temas que provoquen incomodidad y necesidad de pensar, aunque sea de una manera violenta. Quiere provocar una revolución y un cambio radical tanto en el teatro como en las mentes de ese público medio que asistía al teatro durante el primer tercio del siglo XX. Federico García Lorca, como había afirmada en diversas ocasiones, quería que el pueblo puediera tener acceso al teatro, deseaba abrir las puertas al gran parte de ese público que hasta entonces se quedaba fuera, afirmando ${ }^{268}$ :

\footnotetext{
${ }^{268}$ Entrevista publicada el 10 de septiembre de 1935, en Renovación. Diario de la noche., Barcelona.
} 
El triunfo del teatro será cuando el pueblo tenga libre asiento en toda representación.

¡Entonces, sí que no habrá una sola obra mal en cartel! (citado en Inglada 2017, 388).

La violencia del conflicto se manifiesta en los elementos paraverbales del texto, como son el bombardeo y el fuego con los que acaban el acto, en el que no deja dudas que nos encontramos en una situación conflictiva y anunciadora de una posible guerra. Cabe suponer que la obra debería continuar sobre un escenario incendiado, con todas las dificultades que comporta en su puesta en escena.

La introducción violenta del Autor es interrumpida por un espectador que se siente indignado y estafado, ya que él ha abonado su entrada y considera tener el derecho de ver un espectáculo de su agrado.

El primer acto de Comedia sin título es una denuncia de la ideología burguesa y conservadora y un presagio de la guerra que estaba a punto de estallar. Esto queda claro, sobre todo, en dos papeles, el Espectador $2^{\circ}$ y el Obrero, como representantes del fascismo y el comunismo.

Este acto no sólo es una denuncia social, es también una exigencia de un teatro verdadero junto a la búsqueda del amor. La relación que existe entre la Actriz y el Autor así lo demuestra. Ella enamorada de él, le demuestra que siente un amor verdadero a las acusaciones por parte de este de que todo lo que siente es falso y una simple farsa, al declararle que el sentido de su vida y de su implicación en el teatro es por estar junto a él. El Autor no la cree, al dudar que todo en ella es artificio, y le responderá:

AUTOR.- (Agrio.) ¿Dónde has aprendido esa frase? ¿En qué obra la dices?

ACTRIZ.- - En ninguna. La digo por primera vez.

AUTOR.- Mentira. Si el cuerpo que tienes fuera tuyo, te azotaría para ver si hablabas de verdad (Comedia sin título, Acto I, 84).

Uno de los temas principales de Comedia sin título, que comparte con El público, es la casualidad del amor, como acaece el azar, por ser una fuerza poderosa superior a la voluntad humana, muy presente en Sueño de una noche de verano de Shakespeare. 


\subsection{2.- Coincidencias con $E l$ público}

Encontramos la actitud revolucionaria, destructora y violenta contra el teatro y el propio dramaturgo y, así, topamos con un teatro nuevo, incluso en las dos obras Lorca recurre al sacrificio del Director en El público y del Autor en Comedia sin título, como posible solución para ese teatro futuro que buscaba. En declaraciones del propio Lorca afirmaba:

Nosotros [...] estamos llamados al sacrificio. [...]. A mí me ponen en una balanza el resultado de esta lucha: aquí, tu dolor y tu sacrificio, y aquí, la justicia para todos, aun con la angustia del tránsito hacia una futuro que se presiente, pero que se desconoce, y descargo el puño con toda mí fuerza en este útlimo platillo (García Lorca 1934, 8).

Toda la obra de Comedia sin título es una revolución y una lucha hacia el público, el teatro y la sociedad. En El público, ya aparecían en diversas ocasiones la palabra revolución, y surgían acciones violentas para conseguir esos cambios que se busca en este nuevo teatro:

HOMBRE $1-[\ldots .$.$] Tendremos necesidad de enterrar el teatro por la cobardía de todos,$ $\mathrm{y}$ tendré que darme un tiro.

$[\ldots]$

Tendré que darme un tiro para inaugurar el verdadero teatro, el teatro bajo la arena (Cuadro I, 109).

DAMA1.- - [...] la revolución no tiene derecho

$[\ldots]$

ESTUDIANTE 4.- Por eso ha estallado la revolución. El Director de escena abrió los escotillones, y la gente pudo ver cómo el veneno de las venas falsas había causado la muerte verdadera de muchos niños (Cuadro IV, 173,176)

DIRECTOR.- Pero algún día, cuando se quemen todos los teatros, [...] ¡Hay que destruir el teatro o vivir en el teatro! (Cuadro V, 191).

En el excepcional poema de Pere Gimferrer «Oda a Venecia ante el mar de los teatros», recrea la ciudad de Venecia, la ciudad de las máscaras, y la convierte en una especie de escenario teatral de la Cultura que se va descomponiendo y pudriendo: 
Tiene el mar su mecánica como el amor sus símbolos.

Con qué trajín se alza una cortina roja

o en esta embocadura de escenario vacío

suena un rumor de estatuas, hojas de lirio, alfanjes,

palomas que descienden y suavemente pósanse

(Arde el mar, [1966] 2009, 107).

Federico García Lorca ya mostró la ciudad de Nueva York como un espacio teatral en el poema «Ciudad sin sueño» del poemario Poeta en Nueva York:

No duerme nadie por el mundo. Nadie, nadie.

Ya lo he dicho.

No duerme nadie.

Pero si alguien tiene por la noche exceso de musgo en las sienes,

abrid los escotillones para que vea bajo la luna

las copas falsas, el veneno y la calavera de los teatros.

(Poeta en Nueva York, [1929] 2013, 145)

Volviendo a las similitudes entre Comedia sin título y El público, también existen numerosos rasgos en común al recurrir a Shakespeare: a Romeo y Julieta en El público $\mathrm{y}$ al Sueño de una noche de verano en Comedia sin título, dos obras en las que se muestra el azar en el amor y el sacrificio por conseguir el verdadero amor.

Entre los personajes que aparecen en las dos obras, existen conexión entre el responsable de la sala, el dueño del teatro, el Hombre de Comedia sin título que representa a los empresarios teatrales y la postura del Director de El público que tiene miedo al fracaso, en la importancia del público y el éxito comercial:

HOMBRE. - ¡Mano dura! ¡Mano dura! ¡Hagamos una gran rosa de cabezas rebeldes! Adornemos las fachadas, las farolas, los pórticos de la arquitectura milenaria con guirnaldas de las lenguas que quieren destruir lo instituido.

$[\ldots]$

AUTOR.- ¿Quién es usted?

DIRECTOR.- Yo. El propietario del teatro. ¡Mano dura! El bien, la verdad y la belleza han de tener en esta época un fusil entre las manos (Comedia sin título, Acto I, 88-89). 
En el inicio de El público, ante la exigencia de los tres Hombres de un cambio en su teatro, el Director defenderá su postura conservadora, cuya búsqueda es el éxito, ante el miedo al fracaso, y argumentará:

DIRECTOR.- (Reaccionando.) Pero no puedo. Se hundiría todo. Sería dejar ciegos a mis hijos, y luego ¿qué hago con el público? ¿Qué hago con el público si quito las barandas al puente? Vendría la máscara a devorarme.

$[\ldots]$

DIRECTOR.- (Llorando.) Me ha de ver el público. Se hundirá mi teatro... Yo había hecho los dramas mejores de la temporada, ipero ahora...! (El público, Acto I, $110,114)$.

También encontramos un paralelismo entre el Autor y ese Director que quiere atreverse a presentar ante el público un «teatro bajo la arena», revolucionario, vanguardista, arriesgado e innovador. Al comienzo de Comedia sin título, la presentación del Autor expone esa postura:

AUTOR.- - Señoras y señores:

No voy a levantar el telón para alegrar al público con un juego de palabras, ni con un panorama donde se vea una casa en la que nada ocurre y adonde dirige el teatro sus luces para entretener y haceros creer que la vida es eso. [...]

Venís al teatro con el afán único de divertiros y tenéis autores a los que pagáis, y es muy justo, pero hoy el poeta os hacer una encerrona porque quiere y aspira convencer vuestros corazones enseñándoos las cosas que no queréis ver, gritando las simplísimas verdades que no queréis oír (Comedia sin título, Acto I, 75-76).

El Autor de Comedia sin título deja clara su actitud, quiere un teatro que se aleje del teatro como diversión y evasión, exigiendo un teatro que obligara al público a que distinguiera la verdad de la propia realidad, que viera reflejada sobre el escenario los problemas sociales y la situación actual de la sociedad. También el Director de El público coincide con la misma opinión, pero Lorca utiliza un lenguaje más surrealista. El Director busca en las profundidades del teatro el verdadero teatro, «el teatro bajo la arena». Quiere desprenderse de los trajes y las máscaras para mostrar la realidad, exigiendo al público a presenciarlo y vivir la acción sobre el escenario: 
DIRECTOR.- Todo el teatro sale de las humedades confinadas. Todo el teatro verdadero tiene un profundo hedor de luna pasada. Cuando los trajes hablan, las personas vivas son ya botones de hueso en las paredes del calvario. Yo hice el túnel para apoderarme de los trajes y, a través de ellos, haber enseñado el perfil de una fuerza oculta cuando ya el público no tuviera más remedio que atender, lleno de espíritu y subyugado por la acción (El público, Acto V, 190).

Si en El público los espectadores forman parte del drama, ya que Lorca cuenta con él desde el inicio, en Comedia sin título, el público toma parte activa ya que incluso interviene en la obra.

\subsection{2.- Estudio y caracterización funcional de los personajes}

En esta obra, al igual que en El público, el número de personajes es considerable, siendo, según el orden de aparición, el siguiente: Autor, Espectador $1^{\circ}$, Voz, Criado, Espectadora 1 $1^{\mathrm{a}}$, Joven, Apuntador, Actriz 1 ${ }^{\mathrm{a}}$, Nick Bottom, Espectadora 2a, Espectador $3^{\mathrm{o}}$, Hombre, Leñador, Espectador $2^{\mathrm{o}}$, Tramoyista, Obrero, Mujer $1^{\mathrm{a}}$, Mujer $2^{\mathrm{a}}$, Hada y Silfo.

Podemos dividir los personajes en dos grupos: los que forman parte del teatro, la representación y la ficción (el autor y los actores), y los que se encuentran en la sala, en el teatro físico y real, los espectadores que van a ver esa representación y que intervienen en la revolución exterior. Todos constituyen parte de la obra.

Una división general entre los que componen parte de la realidad y los de la ficción, pero los límites no se encuentran definidos, y esto provoca al resto de espectadores que desconozcan dónde empieza y acaba la representación de un texto fijo o improvisado (performance). Como en un sueño en el que la ilusión y la realidad se encuentran comunicadas, sin saberlas diferenciar.

En el grupo de los personajes del teatro encontramos: Autor, Criado, Apuntador, Actriz $1^{\text {a }}$, Nick Bottom, Leñador, Tramoyista, Hada y Silfo. Entre ellos, destacamos el Autor y la Actriz que son los dos personajes con más peso en la obra. Dentro de este grupo encontramos los propios personajes que pertenecen al grupo teatral que está 
simultaneamente representando la obra de Shakespeare: el Leñador, Nick Bottom, la Hada y Silfo.

$\mathrm{Y}$ en el segundo grupo, los personajes de la sala lo forman: Espectador $1^{\circ}$, Espectadora $1^{\mathrm{a}}$, Joven, Espectadora $2^{\mathrm{o}}$, Espectador $3^{\circ}$, Hombre, Espectador $2^{\mathrm{o}}$, Obrero, Mujer $1^{\mathrm{a}} \mathrm{y}$ Mujer $2^{\mathrm{a}}$.

\subsubsection{1.- Autor}

Aunque a este personaje no le vienen anejos su vestimenta, maquillaje o peinado, sí son numerosas las acotaciones en las que describe sus gestos, tono y sus movimientos. Todos coinciden en que es una actitud enfadada y violenta y, durante su intervención, son continuas sus entradas y salidas en escena.

Lorca se siente reflejado con este personaje, porque, como hemos dicho, en diferentes entrevistas se posiciona con las mismas ideas que el Autor. Entre las diferentes ideas que encontramos en su conocida conferencia «Charla sobre el teatro», Lorca afirmaba:

Yo no hablo esta noche como autor ni como poeta, ni como estudiante sencillo del rico panorama de la vida del hombre, sino como ardiente apasionado del teatro de acción social. El teatro es uno de los más expresivos y útiles instrumentos para la edificación de un país y el barómetro que marca su grandeza o su descenso. Un teatro sensible y bien orientado [...] puede cambiar en pocos años la sensibilidad del pueblo; y un teatro destrozado, donde las pezuñas sustituyen a las alas, puede achabacanar y adormecer a una nación entera ([1935] 1989, 5).

Tanto Lorca como el Autor quieren despertar al público para que se involucre en los acontecimientos sociales que están ocurriendo en la calle, anuncio del inicio de la guerra civil.

\subsubsection{2.- Actriz}

La Actriz primeramente aparece «vestida de Titania» (84) y después «se quita la peluca blanca y enseña al viento una cabellera negra. Se despoja de una gran capa blanca y aparece con un traje rojo fuego» (85-86) en el papel de Lady Macbeth. 
En las dos acotaciones observamos que se refieren a una actriz caracterizada por sus diferentes papeles, en los que se mezcla la personalidad de sus personajes con la propia, según la situación en la que se encuentre. La acción recurre a uno de sus papeles para no tener que acudir a su verdadera identidad.

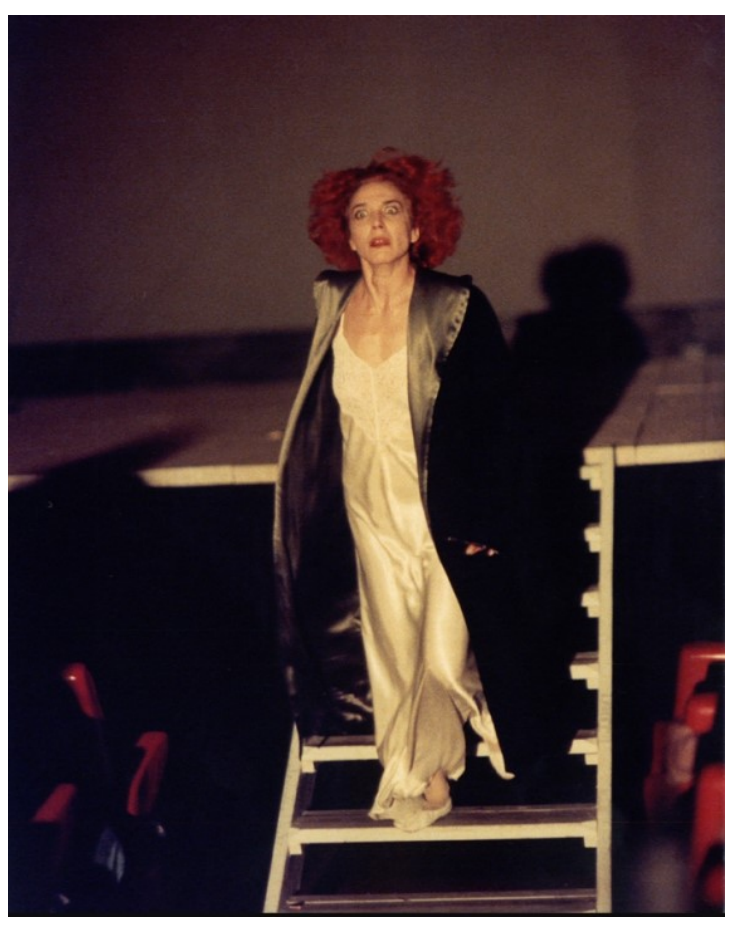

Fig. 110:.Marisa Paredes vestida de Titania durante la representación de 1989.

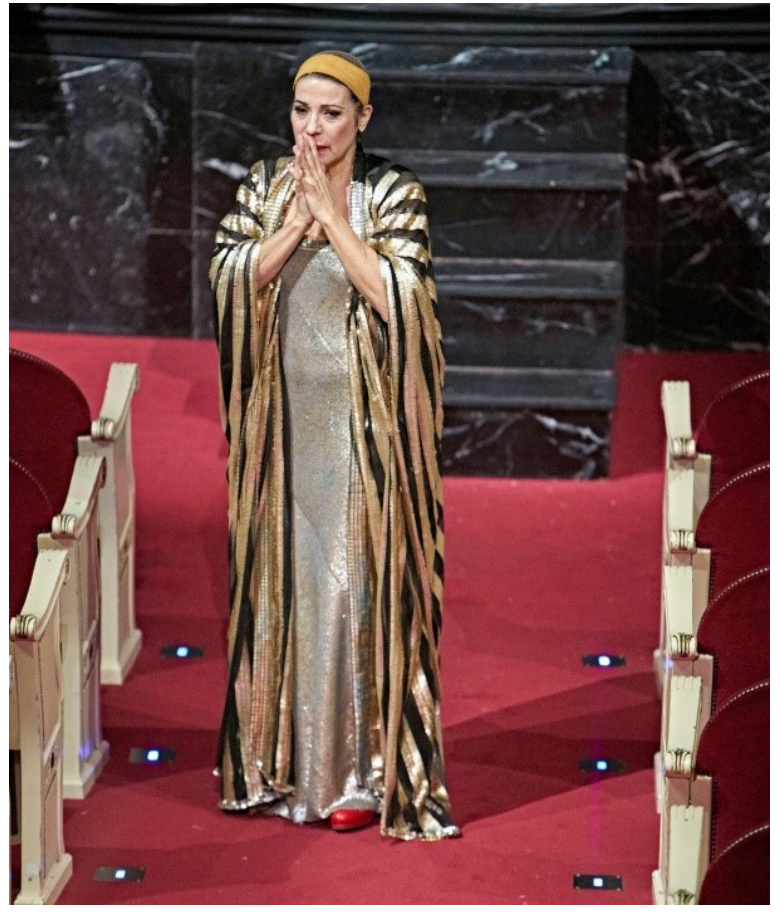

Fig. 111: Emma Vilarasau, en su representación de Titania de 2019.

\subsubsection{3.- Los espectadores de la Sala: Espectador $1^{\circ}$, Espectadora $1^{\circ}$, Espectador $2^{\circ}$, Espectadora $2^{\mathrm{a}}$ y Espectador $3^{\mathrm{a}}$}

La apariencia externa y la funcionalidad del grupo de espectadores no vienen descritas en el texto. También, son mínimas las acotaciones de movimiento, de entradas o salidas. Las que encontramos son para situarlos entre el público de platea.

En general, representan al típico público burgués de la época de la década de los años treinta del siglo XX, que exigen que el espectáculo sea de su agrado, sin sentirse agredidos. Cada espectador, según sus diálogos, representa un grupo determinado de público, diferencias que expondremos en la parte simbólica de los personajes. 


\subsubsection{4.- Joven}

El joven «de frac» (80) sentado desde un palco de platea, observa el espectáculo. Es uno de los personajes más complejos del texto, ya que García Lorca nos lo muestra intencionadamente con cierta ambigüedad a través del avance de la acción.

\subsubsection{5.- Hombre}

El Hombre aparece en escena «vestido de negro» (88). Es el dueño del teatro y representa a los empresarios teatrales en su conjunto, solo preocupados por sus propios intereses.

\subsubsection{6.- Obrero}

El Obrero «vestido de mono» (92) nos recuerda a la indumentaria de los miembros de la formación teatral, La Barraca.

Son mínimas sus intervenciones. En la primera, irrumpe en el recinto «levantado los brazos» (92) bajo el grito de

$$
\text { OBRERO.- }-[\ldots] \text { ¡Camaradas! }
$$

En la segunda, casi al final del acto, pocos minutos antes de morir, ya agonizante:

$$
\text { OBRERO.- - [...] Viva la revolución (Comedia sin título, Acto I, 94, 95). }
$$

Por sus palabras, no deja dudas que se trata de un proletario a favor del cambio revolucionario.

\subsubsection{7.- Leñador y el resto de personajes de la obra de Shakespeare}

El Leñador «con la cara completamente blanca, un haz de leña al hombro y un farolito en la mano» (88) es el personaje que destaca entre el resto de personajes shakesperiano, sólo interesado en interpretar su papel. Como afirma Emilio Peral Vega, «de forma tan acomodaticia y caduca que no se sonroja al asegurar que en ese teatro las balas de la revolución son impermeables» $(2019,27)$. 
Nick Bottom «con la cabeza de asno en la mano» (87), un hombre vestido con mallas rojas «lleva una cabeza de lobo» (77) y el resto de personajes que interpretan Sueño de una noche de verano no participan directamente en el conflicto que se plantea entre el Autor y el resto de espectadores.

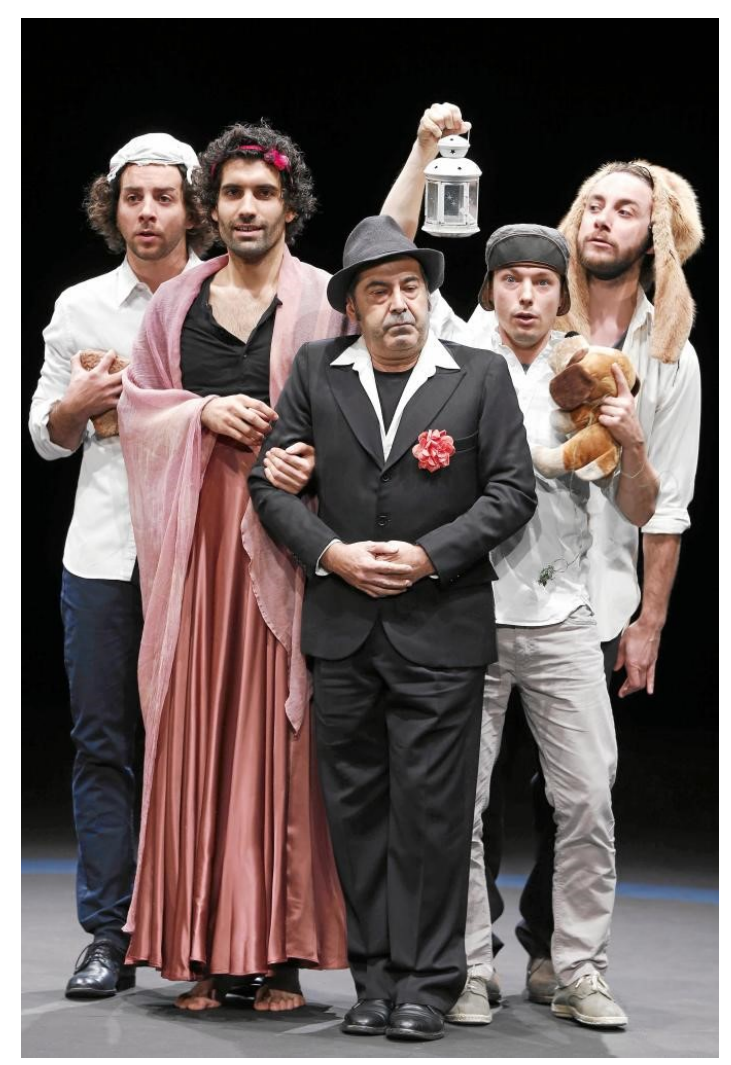

Fig. 112. El grupo de personajes shakesperianos se esconde detrás de la figura del Hombre (propietario del teatro) de la propuesta de Corazza, en 2013.

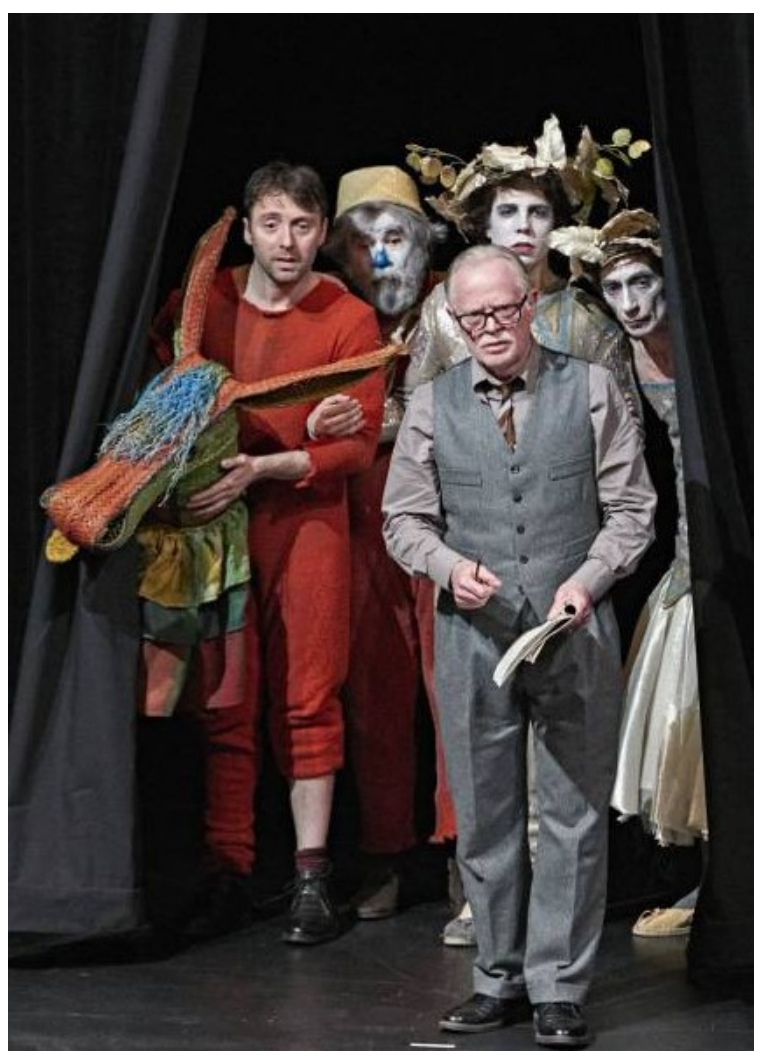

Fig. 113: La misma idea en la puesta en escena de Pasqual, en 2019.

\section{2.- Códigos no verbales}

Al tratarse de un único acto y ser limitado el número de acotaciones, uniremos diferentes códigos, ya que son más difíciles de mantener las oposiciones entre ellos. En cuanto a la expresión corporal, unificaremos en una tabla los gestos y el tono de los personajes; en la apariencia exterior del actor agruparemos el maquillaje y el vestuario (traje); en el espacio escénico diferenciaremos la iluminación de los accesorios y el 
decorado y, para finalizar, presentaremos en una única tabla la música y el sonido en los efectos sonoros.

\subsection{1- Expresión corporal}

Mediante las acotaciones que describen de los gestos y el tono utilizado por los actores, podemos descubrir la personalidad de ellos o las reacciones ante las situaciones cambiantes. Ya afirmábamos que en El público son numerosas las entradas y salidas de escena de los personajes, incluso con la ayuda de un biombo, los movimientos y los cambios de los personajes se dan sin salir del escenario. En Comedia sin título estos numerosos movimientos también se repiten, añadiendo cambios fuera del propio escenario con el consiguiente desconcierto del espectador, al utilizar Lorca el espacio no escénico, como son los palcos y la platea, para que la representación continúe y romper, de este modo, los límites entre la realidad y la ficción teatral.

\subsubsection{1.- Mímica-Gesto y Tono}

El personaje que más importancia tiene en el texto es el Autor y, como podemos comprobar, es quien más acotaciones suma. En todas ellas, muestra una actitud violenta y enfadada ante la situación que se está viviendo, tanto en la representación y la reacción de los espectadores como en el desencadenamiento de la revolución y destrucción del teatro. El resto de acotaciones son mínimas, siendo los Espectadores y el Joven del palco quienes reaccionan ante lo que están viendo durante la representación e la interrumpen, enfadados y con miedo, ante el estallido de la revolución que se escucha desde el exterior del teatro.

\begin{tabular}{|l|l|}
\hline Autor & «Violento» $(78)$. \\
& «Agrio» $(84)$. \\
& «Furioso» $(85)$. \\
& «A voces» (86). \\
& «Furioso» (88). \\
& «Sarcástico» (88). \\
\hline
\end{tabular}




\begin{tabular}{|c|c|}
\hline Criado & «Ríe» (81), \\
\hline Apuntador & «Temblando» (88). \\
\hline Leñador & «Llorando» $(90)$. \\
\hline Espectadora $2^{\mathrm{a}}$ & «Asustada» (90). \\
\hline Joven & $\begin{array}{l}\text { «e la platea, lanzando una carcajada» (93). } \\
\text { «Bajando la voz» (93). }\end{array}$ \\
\hline Espectador $2^{\circ}$ & «Frio» $(92)$. \\
\hline OBRERO & $\begin{array}{l}\text { «Da un grito» }(92) . \\
\text { «Agonizante» }(95) .\end{array}$ \\
\hline Actriz & $\begin{array}{l}« E n \text { voz alta }(95) \\
« E n \text { voz baja y temblando» }(95) .\end{array}$ \\
\hline
\end{tabular}

\subsubsection{2.- Movimiento}

El movimiento de los actores y actrices no se limita al espacio del escenario, puesto que el espacio escénico se amplía y extiende sus límites a toda la arquitectura del teatro. Los actores no sólo entran y salen del escenario, sino que se encuentran en la platea, sentados en sus butacas, desde un principio, también antes de empezar la representación. Los actores son parte del público que, al dejar de ser simples espectadores para representar su papel, causan confusión al resto del público que no sabe si realmente la reacción de estos espectadores es realidad o ficción.

La confusión que provocan el diálogo y los movimientos del Autor y los espectadores también se ve reflejada en reacciones de los actores que forman parte de la representación dentro de la misma, dejando de lado su papel shakesperiano para asumir el papel de espectador.

Entre las numerosas entradas y salidas, también se encuentra las del grupo que forma parte de la revolución, como son el Obrero y el Tramoyista, al entenderse que su movimiento no sólo se limita al espacio teatral, sino que acceden a este desde exterior del teatro. 


\begin{tabular}{|c|c|}
\hline Autor & $\begin{array}{l}\text { «Se sienta» (77). } \\
\text { «Se dirige al CRIADO que tiene la taza de café» } \\
(80) . \\
\text { «Ha subido por una escalera y no se lo ve» }(92) . \\
\text { «Saliendo» }(95) . \\
\text { «Saliendo» }(95) .\end{array}$ \\
\hline Espectador $1^{\circ}$ & $\begin{array}{l}\text { «En butacas» }(77) . \\
\text { «Saliendo, al ACOMODADOR» }(80) . \\
\text { «Salen» junto a la Espectador } 1^{\mathrm{a}}(80) \text {. }\end{array}$ \\
\hline $\begin{array}{l}\text { Un hombre vestido } \\
\text { de mallas rojas }\end{array}$ & $\begin{array}{l}\text { «Aparece corriendo por la escena [...] Da dos } \\
\text { saltos y cae en medio de la escena» (77). }\end{array}$ \\
\hline El lobo & «Sale [...], iluminado y seguido por un foco» (78). \\
\hline $\begin{array}{l}\text { ESPECTADORA } \\
1^{\mathrm{a}}\end{array}$ & «Salen» junto a la ESPECTADOR $1^{\circ}(80)$ \\
\hline Joven & «En una platea» $(80)$. \\
\hline Voz & $\begin{array}{l}\text { «Dentro» }(80) . \\
\text { «En la delantera del paraíso» }(90) . \\
\text { «Del paraíso» }(92) . \\
\text { «Más lejana» }(95) .\end{array}$ \\
\hline CRIADO & $\begin{array}{l}\text { AUTOR._- [...] Puede usted marcharse (83). } \\
\text { «Se va [...]. Dirigiéndose a la izquierda» (83) } \\
\text { «Entrando. [...] Se va» (83). }\end{array}$ \\
\hline Apuntador & $\begin{array}{l}\text { «Entrando» }(83) . \\
\text { «En la escena» }(87) . \\
\text { «Entrando }[. . .] \text { Sale» }(89) . \\
\text { «Entrando» }(90) . \\
\text { «Entrando» }(95) .\end{array}$ \\
\hline Actriz & $\begin{array}{l}\text { «Saliendo vestida de Titania» (84). } \\
\text { «Abraza» al AUTOR (85). } \\
\text { «Se quita la peluca» (85). }\end{array}$ \\
\hline
\end{tabular}




\begin{tabular}{|c|c|}
\hline Nick Bottom & $\begin{array}{l}\text { «Cruza la escena }[. . .] \text { con la cabeza de asno en la } \\
\text { mano» }(87) . \\
\text { «Entrando» }(90) \text {. }\end{array}$ \\
\hline Espectadora $2^{\mathrm{a}}$ & $\begin{array}{l}\text { «Sentada en el centro del patio» }(87) \text {. } \\
\mathrm{Y} \text { el ESPECTADOR } 1^{\circ} \text { «Entran [...] que antes } \\
\text { estaban en las butacas» }(89) . \\
\text { «Agarrando a su marido» }(90) .\end{array}$ \\
\hline Hombre & $\begin{array}{l}\text { «Entrando» }(88) . \\
\text { «Saliendo» }(88) .\end{array}$ \\
\hline Leñador & «Entra en escena» (88). \\
\hline Espectador $2^{\circ}$ & $\begin{array}{l}\text { Y la ESPECTADORA } 2^{\mathrm{a}} \text { «Entran [...] que antes } \\
\text { estaban en las butacas» (89). } \\
\text { «Aparte [...]. Escribe en una libretita» (92). } \\
\text { «Saca un pequeño reflector y lo dirige hacia el } \\
\text { paraíso» (92). } \\
\text { «Saca una pistola y dispara» (92). } \\
\text { «Mirando a un lado y a otro para hablar» (93). } \\
\text { «Se va con su mujer» (93). } \\
\text { «Hace ademán de sacar su pistola; su mujer lo } \\
\text { contiene» (95). }\end{array}$ \\
\hline Tramoyista & $\begin{array}{l}\text { «Saliendo de la sombra» }(91) . \\
\text { «Se va» }(91) . \\
\text { «Se va con su mujer» (94). } \\
\text { «Saliendo» }(94) . \\
\text { «Entrando» }(95) .\end{array}$ \\
\hline OBRERO & $\begin{array}{l}\text { «Levanta los brazos» (92). } \\
\text { «Cae» }(92) .\end{array}$ \\
\hline $\begin{array}{l}\text { Grupo de } \\
\text { personajes }\end{array}$ & $\begin{array}{l}\text { «Al fondo cruza }[\mathrm{n}][\ldots] \text { con trajes de HADAS y } \\
\text { SILFOS que llevan a un herido» (94). } \\
\text { «Cruza la escena [...] que lleva un OBRERO } \\
\text { herido» }(94) . \\
\text { «Salen» }(95) .\end{array}$ \\
\hline
\end{tabular}


La aparición de los personajes en la obra es la siguiente: Autor, Espectador $1^{\circ}$, Criado, Espectadora 1 a , Joven, Apuntador, Actriz 1 ${ }^{\mathrm{a}}$, Nick Bottom, Espectadora 2a, Espectador $3^{\mathrm{o}}$, Hombre, Leñador, Espectador $2^{\mathrm{o}}$, Tramoyista, Obrero, Mujer $1^{\mathrm{a}}$, Mujer $2^{\mathrm{a}}$, Hada y Silfo.

\subsection{2.- Apariencia exterior del actor: Maquillaje-Peinado y Traje}

En el punto del estudio de personajes y de su caracterización funcional hemos expuesto que existen dos tipos de personajes. División que queda muy clara con la descripción de la apariencia exterior de los actores y las actrices. Según su vestuario y maquillaje, también encontramos tres tipos diferentes de personajes: los que visten para realizar una representación (Sueño de una noche de verano), los que, de gala, van al teatro a ver representada esa obra y el grupo de revolucionarios que se alzan en la revolución.

También podríamos divisir entre el grupo que va vestido y caracterizado para la representación y el grupo que forma parte la vida real, la ficción frente a la realidad.

\begin{tabular}{|c|l|}
\hline $\begin{array}{c}\text { Un hombre } \\
\text { vestido con } \\
\text { mallas rojas }\end{array}$ & «Lleva una cabeza de lobo» (77). \\
\hline Joven & «De frac» (80). \\
\hline Actriz & $\begin{array}{l}\text { «estida de Titania» (84). } \\
\text { «Se quita la peluca blanca y enseña al viento una } \\
\text { cabellera negra. Se despoja de una gran capa blanca y } \\
\text { aparece con un traje rojo fuego» (85-86). } \\
\text { «Se ha puesto un impermeable rápidamente y ha ocultado } \\
\text { su cabellera bajo un sombrero de fieltro gris» (87). }\end{array}$ \\
\hline Nick Bottom & «Con la cabeza de asno en la mano» (87). \\
\hline Leñador & $\begin{array}{l}\text { «Con la cara completamente blanca, un haz de leña al } \\
\text { hombro y un farolito en la mano» (88). }\end{array}$ \\
\hline Hombre & «Vestido de negro» (88). \\
\hline OBRERO & «Vestido de mono» (92). \\
\hline
\end{tabular}




\subsection{3.- Aspecto del espacio escénico}

En Comedia sin título, Lorca propone romper los límites del espacio escénico. La iluminación no sólo está dirigida al escenario, sino que, según la acción avanza y los espectadores se convierten en actores, la luz es redirigida hacia espacios dedicados a los espectadores pasivos. Tomando como decorado el propio teatro, precisan los cambios la platea y los palcos del teatro para que la acción transcurra en ellos y se entremezclen, en contraste, la pasividad del público y la actividad de los actores y actrices.

\subsubsection{1.- Iluminación}

Junto al sonido, la iluminación es uno de los elementos más importantes para situarnos en un ambiente de miedo y violencia. La iluminación no sólo va dirigida al escenario, sino también todo el teatro es parte de ella. El teatro se ilumina por completo para, posteriormente, quedarse a oscuras.

Al final del acto, el escenario es iluminado en todos los tonos, para finalizar con luz roja todo el teatro. La iluminación ayuda a situarnos ante un posible cambio de realidad, ya que la destrucción del teatro iluminada de rojo, debe proponernos un encuentro con un teatro nuevo.

\begin{tabular}{|c|}
\hline «Sale el lobo, iluminado y seguido por un foco» (78). \\
\hline «La luz se cambia lentamente por una luz azul de luna» (86). \\
\hline «Luz roja» (86). \\
\hline $\begin{array}{c}\text { «El ESPECTADOR } 2^{\circ} \text { saca un pequeño reflector y lo dirige hacia } \\
\text { el paraíso, que queda iluminado» (92). }\end{array}$ \\
\hline «Todo el teatro se ilumina» (92). \\
\hline qEl ESPECTADOR $2^{\circ}$ apaga el reflector y todo el teatro vuelve a \\
quecuras» (92). \\
\hline «Luces de todos los tonos iluminan la escena» (94). \\
\hline «El teatro se ilumina de rojo» (95). \\
\hline
\end{tabular}




\subsubsection{2.- Accesorios y Decorado}

Todos los accesorios y decorados que son descritos en las acotaciones no dejan duda que nos encontramos dentro de un teatro, en el que este es parte del escenario. Los personajes se encuentran entre las butacas, en platea, sobre el escenario, etc. Con el juego de caídas de telones, Lorca nos hace partícipes del cambio de espacios: varias casas, un palacio, el claustro de un monasterio o iglesia y un muro. $\mathrm{Y}$ así el espectador reconoce el juego de la realidad y la fantasía en el teatro, en espacios dibujados sobre telas.

\begin{tabular}{|c|}
\hline «Telón gris» (75). \\
\hline «Cae un telón pintado con casas y basuras» (77). \\
\hline «En butacas» (77). \\
\hline «n una platea» (80). \\
\hline «Cae un telón en el que hay pintado un palacio inverosímil» (83). \\
\hline $\begin{array}{c}\text { «El telón del fondo se levanta y aparece otro telón en el que hay } \\
\text { pintado un sombrio claustro de piedra con cipreses y árboles } \\
\text { fantásticos» (86). }\end{array}$ \\
\hline «En la delantera del paraíso» (90). \\
\hline «Cae un telón que es un muro de grandes piedras» (94). \\
\hline
\end{tabular}

\subsection{4.- Efectos sonoros: Música y Sonido}

Los efectos sonoros que aparecen durante el primer acto nos remiten, por un lado, al sonido de una representación teatral con los aplausos del público y, por otro, la gran mayoría, al de una guerra o una revolución que acaba de estallar: golpes, disparos, cañonazos y bombardeos...

«Hacen palmas» (77).

«Se oyen violines» (77). 


\begin{tabular}{|c|}
\hline «Se oyen tres grandes golpes» (83). \\
\hline «Se oyen unos disparos» (87). \\
\hline «Se oyen más cerca los disparos» (87). \\
\hline «Se oyen dos cañonazos» (89). \\
\hline «Se oye el comienzo del bombardeo» (92). \\
\hline «Todos están silenciosos, arrimados a los muros» (92). \\
\hline «Un gran ruido de bombardeo invade la escena» (93). \\
\hline «El bombardeo crece» (94). \\
\hline «Rompe un bombardeo furioso» (94). \\
\hline
\end{tabular}




\section{4.- Análisis semiótico teatral: Nivel semántico}

\section{1.- El espacio teatral}

La obra se inicia con un prólogo del Autor, que ante un «telón gris» (75), se dirige, desde el escenario, al público que se encuentra en platea. En un principio, podemos pensar que se trata del inicio de una obra con prólogo, como en otras obras de Lorca. El Autor, al formular una pregunta al público, es interrumpido por un Espectador que se encuentra sentado en platea. Y el espacio dramático que, en un inicio es mínimo, de repente, se amplía y los límites clásicos de un teatro a la italiana se infringen, ya que toda la sala forma parte del espacio teatral en el que transcurrirá la acción. Como afirma Fernando de Diego, Lorca desdobla el espacio escénico,

—mediante el artificio de situar algunos de los personajes entre el público espectador-, y logra con ello convertir la sala en parte integrante de la obra. Nos encontramos, de esta manera, frente a un metateatro en que los personajes adoptan una postura de autonomía con respecto al Autor-director de la obra (1995, 237).

Existen dos espacios en Comedia sin título, «el espacio abierto y el espacio cerrado» (Diego 1995, 237), todo lo que ocurre dentro del espacio, enmarcado por los límites del edificio del teatro, se encuentra supeditado a las señales precedentes del mundo exterior: los sonidos de disparos y de los bombardeos, que provocan el miedo entre los personajes del espacio interior. La aparición de un herido es el único elemento que une los dos espacios.

Esta división de espacios ya la encontramos en La casa de Bernarda Alba, obra coetánea de Comedia sin título, en la que transcurre toda la acción en el interior de la casa pero no dejan de oírse efectos sonoros del exterior que influyen en las decisiones de los personajes.

Mediante una técnica tradicional, Lorca modifica el decorado escénico, con un subir y bajar diferentes telones para situarnos en diversos espacios teatrales. Todos los telones están relacionados con paisajes fantásticos como son «un palacio inverosímil» (83) o «un sombrio claustro de piedra con cipreses y árboles fantásticos» (86). Con estos dibujos, consigue un clima fantasmagórico, incluso onírico (efecto que utilizará Alberto Conejero para crear el segundo y tercer actos). 
El último telón es «un muro de grandes piedras» (94) que podríamos relacionarlo con las paredes desnudas del teatro. Y, junto al sonido de la revolución y el bombardeo, nos mostrará la destrucción del teatro; lo que nos lleva a suponer que, si Lorca hubiera podido concluir la obra, su intención hubiera sido crear un nuevo teatro a partir de los cimientos del tradicional.

\section{2.- El tiempo teatral}

El único acto que se conserva de Comedia sin título transcurre en un tiempo lineal y continuo. El inicio se lleva a cabo con un prólogo del autor, como era costumbre en Lorca, para dar paso a la obra que se verá representada, Sueño de una noche de verano, pero este se verá interrumpido por un espectador.

La acción avanza hacia adelante linealmente, con una duración temporal real, ya que la revolución estalla a los pocos minutos de que se inicie la discusión entre el Autor y el Espectador $1^{\circ}$, sobre cómo conseguir un teatro verdadero y cuáles han de ser estos cambios. El acto termina con la destrucción del teatro y el tiempo se detiene bruscamente.

\section{3.- Los personajes y su simbología}

Algunos personajes tienen un significado simbólico en la obra, más destacados e importantes que otros, como son el Autor, que podría ser el alter ego del propio Lorca, la Actriz que llega a un punto que no distingue entre la realidad y la ficción, el grupo de Espectadores, reflejo de la sociedad burguesa del momento, el Obrero, representante de la clase baja trabajadora y el Hombre como empresario teatral preocupado de su negocio.

Otro grupo de personajes lo englobamos en los actores que forman parte de la representación de la obra Sueño de una noche de verano. Su única función y preocupación es que su actuación, en el ensayo y la representación, se lleven a cabo. El 
caso más destacado es el del Leñador que, aunque haya estallado la revolución, su interés estriba en que le dejen representar, sin obstáculo alguno, su papel.

\subsection{1.- Autor}

Lorca, quien en 1936, invitaba a los autores a que estuvieran comprometidos con la realidad social, construye un Autor que toma consciencia de la convulsión política y social que vive España en ese período y utiliza el teatro para exponer el problema, dar su opinión y posicionarse al lado de los menos favorecidos.

El Autor pide constantemente que se ilumine la escena y el patio de butacas para que se pueda ver claramente la realidad. Incluso quiere abrir las puertas del teatro para que la revolución penetre. Sólo intenta mostrar la situación real y forzar al público a que vea la verdad, aunque esta sea dolorosa:

AUTOR.- Hay que despertarlos y abrirles los ojos aunque no quieran (Comedia sin título, Acto I, 82).

El factor del azar en el amor es un tema recurrente en la obra de Lorca. Así como en El público, encontramos el diálogo entre la Figura de Pámpanos y de Cascabeles, en el que proponen diferentes opciones para que surja el amor, sin cerrarse a nada, en Comedia sin título el Autor nos explica el hechizo del duendecillo Puck de Sueño de una noche de verano, quien queda encantado por su hechizo y se enamora de la primera persona que ve. Demuestra, así, que el amor puede surgir sin ser nosotros responsables de nuestras acciones:

AUTOR.- - [...] El amor, sea de la clase que sea, es una casualidad y no dependen de nosotros en absoluto. La gente queda dormida, viene Puk el duendecillo, les hace oler una flor y, al despertar, se enamoran de la primera persona que pasa, aunque estén preparados de otro ser antes del sueño. Así la reina de las hadas Titania, se enamora de un campesino con cabeza de asno. Es una verdad terrible, pero una verdad destructora puede llevar al suicidio y el mundo necesita ahora más que nunca verdades consoladoras, verdades que construyan. Se necesita no pensar en uno sino pensar en los demás (Comedia sin título, Acto I, 84). 


\subsection{2.- Actriz $1^{\mathrm{a}}$}

La Actriz oculta su identidad y utiliza expresiones y actitudes extraídas de textos dramáticos y, como afirma Emilio Peral Vega, «ha incorporado a su existencia rutinaria la impostura del teatro que pretende desterrarse, hasta el punto de hablar por boca de los papeles que ha interpretado. De esta forma, su único contacto directo con la vida se cifra en el efectivismo provocado en el espectador» $(2019,54)$.

Es un personaje que rehúye la verdad y se refugia en la vida de sus personajes para hacer frente a situaciones reales. Afirmando que un poco de verdad sí le gusta. Incluso, si tuviera valor, se dirigiría a ese público conservador y gritaría las verdades que le acucian, pero tiene miedo de ser rechazada y perder el favor del público y su estatus social. Así lo afirma ante la posible la pérdida de sus joyas:

AUTOR.- - Tú no me dirías nunca la verdad.

ACTRIZ.- - [...] te cantaría la mentira más hermosa. A mí me gusta también la verdad, un momento nada más. La verdad es fea, pero si la digo, me arrojan del teatro. Me dan ganas de dirigirme al público y en la escena más lírica gritarles de pronto una palabrota la más soez, ja, ja, ja. Pero yo quiero mis esmeraldas y me las quitarían.

La Actriz, al tener una vida oculta siempre tras una máscara, no consigue empatizar con los demás. Muestra de ello es, al final del acto, cuando ha estallado la revolución y la Espectadora $2^{\text {a }}$ llora por el destino de sus hijos. En ese momento la actriz se burla porque está representando mal el sufrimiento:

ESPECTADORA $2^{\mathrm{a}}$.- ¡Mis hijos! ¡mis hijos!

ACTRIZ.- Estoy harta de oírla gritar mal. No lo puedo sufrir. Su voz tiene un aire falso que no logrará conmocionar nunca. No, así, es así: ¡mis hijos, mis hijos, mis niños pequeños! ¿Lo ha oído? ¡Mis niños pequeños! Y las manos hacia adelante, imprimiéndoles un temblor, como si fueran dos hojas en una fiebre de viento (Comedia sin titulo, Acto I, 95). 


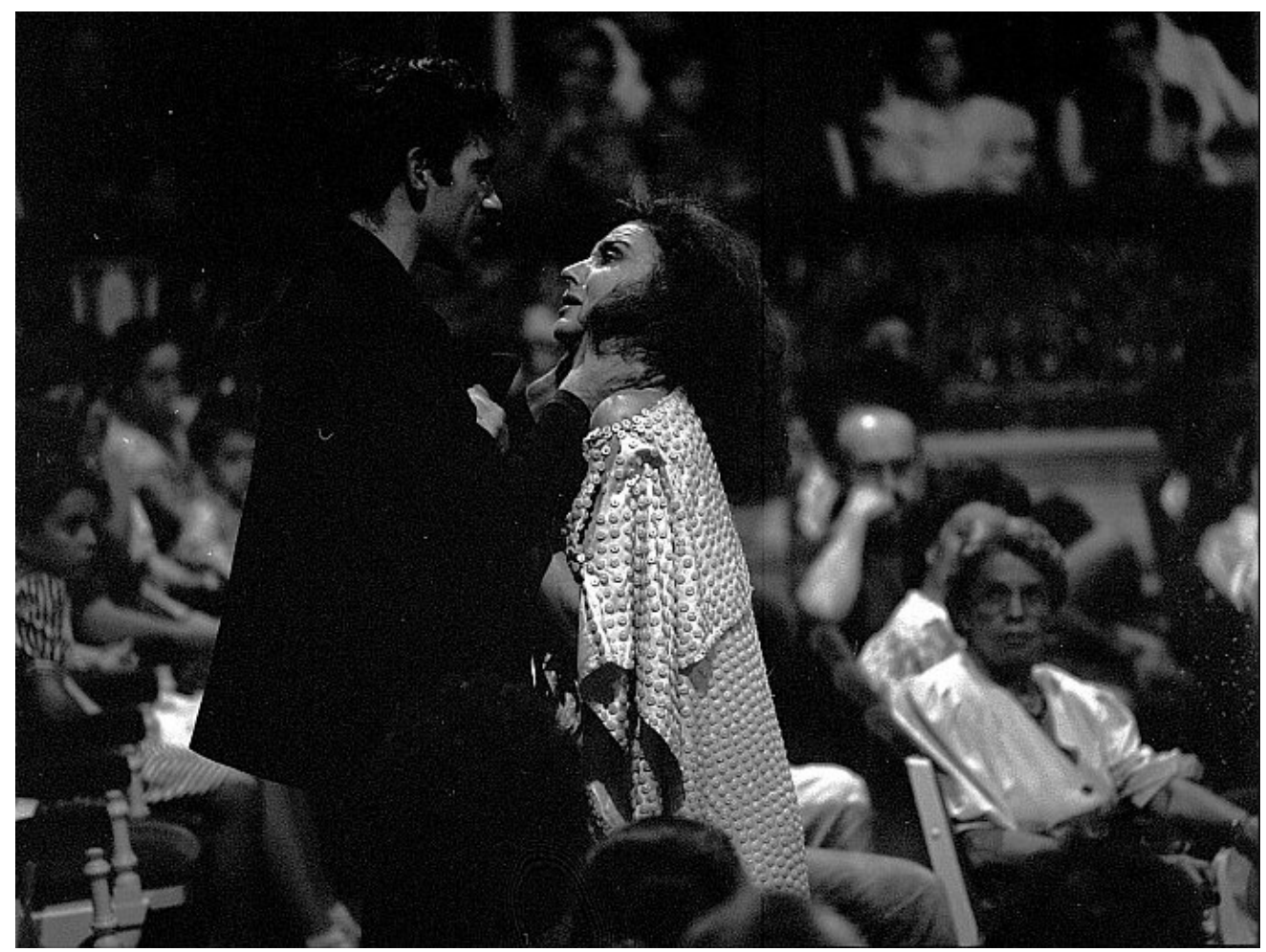

Fig. 114: Representación de Comedia sin título en el Teatro María Guerrero de Madrid el 26 de junio de 1989. En la imagen Imanol Arias y Marisa Paredes en los papeles de Autor y Actriz.

Negativo sintético en blanco y negro. Fotografía de Chicho.

\subsection{3- Espectador $1^{\circ}$ y Espectadora $1^{a}$}

El Espectador $1^{\mathrm{o}}$ es el primero en enfrentarse al Autor por su intención de desenmascarar la representación y mostrar la verdad del teatro. A partir de una posición social acomodada, se cree con el poder de exigir. En la conversación, que mantiene con el Autor, queda clara la posición de creer tener derecho ya que ha pagado su entrada. Federico García Lorca criticaba que el público tuviera la fuerza y el poder en la programación teatral y que sólo el teatro burgués conservador tuviera cabida en el panorama comercial, ya que, si tienen derecho a juzgar y exigir, el dramaturgo pierde poder a la hora de representar sus nuevas propuestas rupturistas:

ESPECTADOR $1^{\circ}$.- Tengo derecho. ¡He pagado mi butaca!

AUTOR.- Pagar la butaca no implica derecho de interrumpir al que he habla, ni mucho menos juzgar la obra.

ESPECTADOR $1^{\circ}$.- - Absolutamente.

AUTOR.- A usted le gusta o no le gusta, aplaude o rechaza, pero ¡nunca juzga! 
ESPECTADOR $1^{\circ}$.- La única ley del teatro es el juicio del espectador (Comedia sin título, Acto I, ).

Esta postura ya la había defendido García Lorca en su conferencia «Charla sobre teatro» en la que afirmaba que «el teatro se debe imponer al público y no el público al teatro» ([1935] 1989, 7).

La Espectadora $1^{\mathrm{a}}$, esposa del Espectador $1^{\mathrm{o}}$, mantiene la creencia de que es una apariencia lo que está viendo, y que el Autor sigue interpretando un papel, por eso muestra interés en el drama y se enfada con su marido porque no le deja verlo. Aunque una vez que descubre que todo es realidad, se siente escandalizada y ya no quiere presenciar más ese horror:

ESPECTADORA $1^{\text {a }}$.- No me quisiera ir. Me interesa el argumento.

$[\ldots]$

ESPECTADORA $1^{\text {a }}$-- Pero no te pongas así. En el teatro todo es mentira.

ESPECTADORA 1 $1^{\text {a }}$ - - Pues si es verdad ¡vámonos! ¡Qué horror! ¡Ay, qué desagradable!

$[\ldots]$

ESPECTADORA 1 $1^{\text {a }}$ - ¿Cómo has permitido que delante de mí digan estas cosas? ¡Era verdad! ¿Y cómo no los prendieron inmediatamente? (Comedia sin título, Acto I, 79$80)$.

La actuación de la pareja de espectadores es una acción dentro de la acción del drama y, como afirma Peral Vega,

bajo la apariencia del inmovilismo del varón —incapaz de abrir su mente a la vía poética que le ofrece el Autor - y la supuesta apertura de su esposa, las cosas siguen en el mismo estado, porque ella adolece de una falta de sensibilidad mayúscula ante el dolor ajeno. Al descubrir que la muerte de la madre es cierta, su supuesto interés por el argumento de la obra $(2018,55)$. 


\subsection{4.- Espectador $2^{\circ}$ y Espectadora $2^{a}$}

Así como la pareja primera de espectadores representa la actitud del público burgués ante las nuevas propuestas vanguardistas teatrales, la pareja segunda de espectadores representa al grupo en contra de la revolución.

La Espectadora 2a, al enterarse de que ha estallado la revolución en las calles, siente miedo por las posibles consecuencias y por lo que les puede ocurrir a sus hijos, que han dejado, en casa, a cargo de la institutriz y los criados, y, por el temor de que, al pertenecer a la clase obrera, cabe la posibilidad de que los maten:

ESPECTADORA 2 ${ }^{\mathrm{a}}$.- ¡Ay! ¡Mis hijos! ¡mis hijos! Estoy segura que asaltarán la casa y como están solos con la institutriz y los criados ¡los matarán! (Comedia sin título, Acto I, 90).

El Espectador $2^{\circ}$, el más reaccionario entre todos los espectadores, es uno de los pocos personajes con nombre propio y Lorca escoge el nombre de Enrique, nombre que ya lo utiliza en el drama El público. Asegura que en las revoluciones siempre cometieron barbaridades y masacres y, para argumentar que tiene la razón, afirma contar entre sus amistades con un gran periodista que las presenció:

ESPECTADOR $2^{\circ}$.- - Lo sé muy bien. Un periodista mío presenció el hecho, ¡un gran periodista!, y para prueba, se trajo dos ojos azules, vivos, que enseñaba a todo el mundo, dentro de una cajita de laca (Comedia sin titulo, Acto I, 91).

Ante el miedo de la Espectadora 2 ${ }^{\mathrm{a}}$, el tramoyista del teatro se ofrece a ir su casa, que sorteará las balas y les dirá que sus padres están seguros. Pero la actitud desconfiada del Espectador $2^{\circ}$ ante la revolución y sus agentes provoca que pregunte su nombre para denunciarlo con posterioridad:

ESPECTADOR $2^{\circ}$.- ¿ ¿Quién es este hombre?

LEÑADOR.- ¡Un tramoyista!

ESPECTADOR $2^{\circ}$. - ¿Cómo se llama?

LEÑADOR.- Bakunin ${ }^{269}$ el loco le dicen sus compañeros.

ESPECTADORA $2^{\mathrm{a}}$.- $-[. .$.$] ¿Para qué preguntas su nombre?$

\footnotetext{
${ }^{269}$ Mijail Alexandrovich Bakunin (Priamujino [Rusia], 1814- Berna [Suiza], 1876) fue un revolucionario anarquista ruso. La referencia de Bakunin como el nombre del tramoyista de Comedia sin título lo relaciona directamente con un miembro de la revolución del proletariado.
} 
ESPECTADOR $2^{\circ}$.- [...] Para denunciarlo después (Comedia sin título, Acto I, 9192).

El Espectador $2^{\circ}$ tiene una actitud militar y llega a la violencia en nombre de un único Dios católico que cuenta con su ayuda, cuando afirma:

ESPECTADOR $2^{\circ}$.- $[\ldots]$ ¡No hay más que un solo Dios!

$[\ldots]$

ESPECTADOR $2^{\circ}$.- Con los judíos y demás tenebrosa gente hay que andar con cuidado (Comedia sin título, Acto I, 92-93).

\subsection{5.- Obrero}

El Espectador $2^{\circ}$ y el Obrero son dos personajes antagónicos. El primero es conservador y no admite ningún cambio, estando a favor de la mano fuerte, de la coacción para mantener el orden, del autoritarismo; el segundo, por su parte, busca esos cambios, incluso si es necesario, con el estallido de una revolución para conseguirlos.

Con la entrada del Obrero a escena, «todo el teatro se ilumina.» (92). Podemos relacionar esa irradiación de luz con la importancia que tuvo La Barraca en la vida de Lorca y su proyecto de llegar a todas las clases sociales, más, en concreto, a la gente de los pueblos, siendo en este periodo, junto a las Misiones Pedagógicas, dos de las actividades más brillantes de la hechos culturales de la época. El Obrero representa la revolución de las clases sociales más desprotegidas, a las que quiere dirigir todo ese teatro nuevo de la verdad.

El Espectador $2^{\circ}$ disparará sobre el Obrero a los pocos segundos de su entrada, hiriéndole de muerte. Como años más tarde, serán los fascistas sublevados quienes lo harán contra los soldados de la República, hiriéndoles de muerte y ganando la guerra.

\subsection{6.- Joven}

Como hemos dicho en su estudio y caracterización, es uno de los personajes más complejos. La ambigüedad en su actuación es constante. Tiene una postura de hombre cultivado y que tiene interés por las nuevas experiencias que propone el Autor: 
JOVEN.- Sí, me interesa mucho su experiencia (Comedia sin título, Acto I, 80).

Sin embargo, a continuación, muestra sus reticencias y defiende el teatro de las apariencias.

JOVEN.- $[\ldots]_{i}$ Es tan hermoso el teatro! ¿Qué va a hacer usted de las copas de plata, de los trajes de armiño?... Esa voz que ha sonado dos veces me conmueve a mí mucho más que una verdadera voz de agonía

$[\ldots]$

JOVEN.- ¿Lo ve usted? Ese muchacho lloraría con una historia de amor bien narrada.

$¡$ Hace falta la escena! ¡Va usted a fracasar! (Comedia sin título, Acto I, 80)

Ante las diversas situaciones en las que se encuentra ante los espectadores, sus reacciones también son ambiguas. Frente a la postura del Espectador $2^{\circ}$, que defiende la religión católica, él bromeará afirmando que es mahometano y que en el cielo le esperan un millón de concubinas. Prefiere callar a descubrir quién ha disparado contra el obrero.

Ante esta situación, asume una posición distante y hasta cínica. Y, aunque comparte la misma opinión, prefiere mantenerse callado:

JOVEN.- ¡Tiempos felices! ¡Por cierto que le felicito porque veo que es usted un magnífico tirador!

$[\ldots]$

JOVEN.- En voz baja tengo su mima opinión, pero yo prefiero estar al margen (Acto I, 93-94).

\subsection{7.- Hombre}

El Hombre, dueño del teatro, interviene poco en el primer acto. Está a favor de la necesidad de la fuerza y la violencia para imponerse a cualquier revolución:

HOMBRE.— ¡Mano dura! ¡Mano dura!

$[\ldots]$

HOMBRE.- - [...] ¡Hay que vencerlos! (Comedia sin título, Acto I, 88-89).

Pero a su vez, afirma que la belleza de la poética en tiempo de revolución consistirá en estar armado e implicarse en la situación, de ahí esta proclama de la violencia: 
HOMBRE.- [...] El bien, la verdad y la belleza han de tener en esta época un fusil entre las manos (Comedia sin título, Acto I, 89). 


\section{5.- Análisis semiótico teatral: Nivel pragmático}

Pese a considerarse una pieza inacabada y, por lo tanto, de corta duración, por su carácter surrealista han sido diversas sus puestas en escena, tanto por agrupaciones profesionales como por compañías de teatro universitario. Al haber sido numerosas sus representaciones teatrales, al igual que hemos hecho con el análisis de las representaciones de El público, a continuación, realizaremos un recorrido por las diferentes representaciones que consideramos más relevantes, o que han aportado propuestas nuevas.

En 1989, la familia de Lorca ofreció el texto de Comedia sin título para poderla estrenar, tarea que llevó a cabo Lluís Pasqual. Junto a la media hora que dura el primer acto, Pasqual antepuso dos escenas de El sueño de una noche de verano. Tenía sentido, ya que Lorca presenta una compañía que va a escenificar dicha obra de Shakespeare, en la que aparece un autor que se niega a presentar una obra clásica y sin ningún cambio en la sociedad. Se estrenó el 23 de junio de 1989, en el Teatro María Guerrero bajo la dirección del director catalán. La escenografía y el vestuario estuvieron a cargo de Fabià Puigserver y la música de Josep María Arrizabalaga. El día de su estreno, al finalizar la representación, ni Lluís Pasqual ni la compañía salieron a saludar, ya que «hubieran roto el clima creado en los últimos minutos de la representación, cuando los espectadores, casi acongojados, terminan presenciando cómo se derrumba, literalmente, el escenario» (Torres 1989). El público se quedaba «inmerso en la gran polvareda surgida de los escombros de lo que parece un teatro derruido» (Torres 1989). «El teatro (como edificio $\mathrm{y}$ arte) queda destruido físicamente por la fuerza de lo inmediato» (Medina Vicario 1989, 17). El propio Lluís Pasqual afirmaba que «aunque en una primera lectura pueda verse que abogo por la destrucción del teatro, y de hecho lo destruyo, detrás de todo eso no hay más que un profundo amor por esta profesión y por el teatro» (citado en Torres 1989).

La propuesta de Pasqual se inicia con el ensayo de El sueño de una noche de verano de Shakespeare, con las discusiones entre los actores, las posibles correcciones del texto y los cambios en los efectos luminosos y sonoros de la escenografía. Todo transcurre con la sala a oscuras y el foco de atención se encuentra sobre el escenario. A continuación, 
se interrumpe el ensayo y se escucha una grabación del prólogo del Autor pronunciado con un claro acento andaluz, con la intención de que el público crea que es la propia voz de Lorca $^{270}$. La grabación se detiene y la continúa el actor Imanol Arias desde platea, ahora totalmente iluminada, en el papel del Autor. La obra prosigue con el texto de Lorca, ocupando todo el espacio teatral, tanto el propio escenario como la platea. De repente, la sala se queda a oscuras, cuando se oyen unos disparos y da inicio la revolución. La obra finaliza con la destrucción del teatro cayendo las claraboyas sobre el escenario y levantando una gran polvareda que cubre parte de los espectadores situados en la platea.

El 10 de noviembre de 2005, se estrenó en la Sala Juan de la Cruz del Teatro de la Abadía de Madrid. La puesta en escena estuvo a cargo del director portugués Luis Miguel Cintra, con su habitual colaboradora Cristina Reis en la escenografía y el vestuario. En esta nueva versión, se añadieron otros textos lorquianos, principalmente de El público, entrevistas, textos teóricos y, casi al final de la obra, algunos versos de $E l$ gran teatro del mundo de Calderón de la Barca, con lo que conectaba la obra de Lorca con el auto sacramental. La introducción de algunos personajes de El público, como es el caso del Prestidigitador que recita la introducción del Autor (repetido minutos más adelante por el personaje del Autor), y que luego representa al Joven y, casi al final de la obra, recita las palabras del Mundo de la obra de Calderón de la Barca, o la mezcla de partes de diferentes obras, provocan una visión poco clara de Comedia sin título, creando una propuesta muy alejada del texto original del Lorca y de la idea de revolución y destrucción del teatro.

Se trata de una lectura muy personal, en la que Cintra «ha elegido un camino menos accidentado que conduce al auto sacramental. [...] Lo que ofrece es un espectáculo frío, que logra no entusiasmar. La emoción es sustituida por la reflexión» (López Mozo

\footnotetext{
${ }^{270}$ No existe, hasta el momento, ningún registro sonoro de la voz de Lorca.

Tomás Navarro Tomás, ensayista y director de la Biblioteca Nacional de España, entre 1936 a 1939, dirigió el proyecto El archivo de la Palabra del Centro de Estudios Históricos que se trataba de grabaciones con las voces de eminentes españoles de la primera mitad del siglo XX, que fueron grabadas entre 1931 y 1933, aunque quedó inconcluso. Entre las voces que faltan encontramos la de Federico García Lorca que aceptó la invitación de Tomás Navarro para incluir su voz a la colección, concretaron un día y una hora, pero Lorca no acudió porque se quedó dormido (González Luna 2018).

En el artículo «La voz perdida de Lorca» de Alejandro González Luna se realiza un exhaustivo recorrido de la búsqueda de su voz en archivos sonoros en diferentes países americanos.
} 
2005). De marzo a mayo del 2006, realizó una gira por Logroño, Barakaldo, Budapest, Málaga, Granada, Gijón, Avilés, Sevilla y Valladolid.

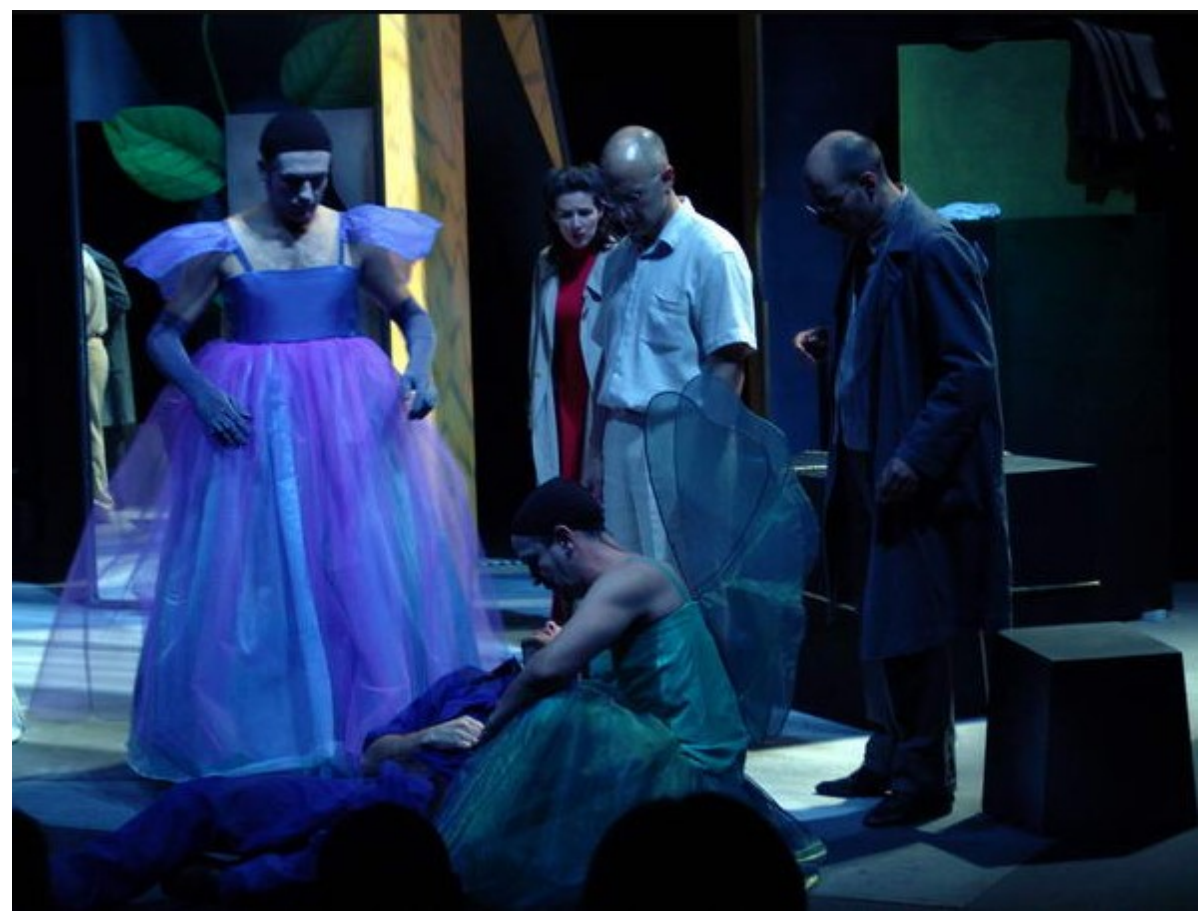

Fig. 115: Escena de la propuesta de Luis Miguel Cintra, en 2005. Fotografía: Manuel Martínez Muñoz.

Al existir una estética común entre El público y Comedia sin título, se plantean montajes en los que pueden convivir los dos textos, como es el caso del director polaco Pawel Nowicki, quien, en 1984, la entrenó en Polonia, como hemos expuesto, anteriormente, en el apartado de las representaciones de El público. El mismo director afirmaba que «estos dos dramas [...] brillan con un especial, atemporal y universal belleza. Son una maravillosa reflexión sobre la creación y el artista» (Nowicki 2012, 3). Según Urszula Aszyk, Pawel Nowicki aprovecha la presencia común de «representaciones de metáforas e imágenes, de frases y preguntas, de situaciones y personajes» $(1986,279)$ entre Comedia sin título y El público, para crear un espectáculo fusionado.

En 2011, se repuso en el teatro Estudio del centro Julio Mario Santo Domingo de Bogotá, Colombia. Llegó a España en el 2012, estuvo en cartel del 26 al 29 de enero, en la Sala Verde de los Teatros del Canal. La producción del Teatro Mayor Julio Mario Santo Domingo de Bogotá tuvo el apoyo de la embajada de Colombia en España. La 
obra se inicia con Comedia sin título y continúa con El público alterando la cronología de la obra que provocaba dejarla inacabada. Es una propuesta más clásica, porque los personajes de la sala se encuentran en primera fila de la sala, en el caso de los Espectadores, y el Joven del palco dialoga ya desde el escenario, quedando los límites de la representación y del espectador más claros y definidos. También el Autor, durante su prólogo y su actuación, no recorre la sala, toda su representación transcurre sobre el escenario.

En 2013, Juan Carlos Corazza presenta la obra Comedia y Sueño, en la que adapta Comedia sin título junto a Sueño de una noche de verano de William Shakespeare. Los dos textos están unidos con otros textos que dan coherencia a otro nuevo para representar. Esta iniciativa fue la primera producción teatral de la Fundación Federico García Lorca, propuesta a la Compañía Teatro del Estudio. La idea del teatro dentro del teatro es clara, y la elección de las dos obras muestra las ideas en común que tienen, como son el amor, la revolución y el humor. Según Corazza, «en Shakespeare o en Lorca podemos aprender que el teatro es una vía para la compasión, la humanización y el conocimiento. [...] El teatro es ahora más que nunca un acto de fe y compasión, urgente y necesario» $(2013,5)$.

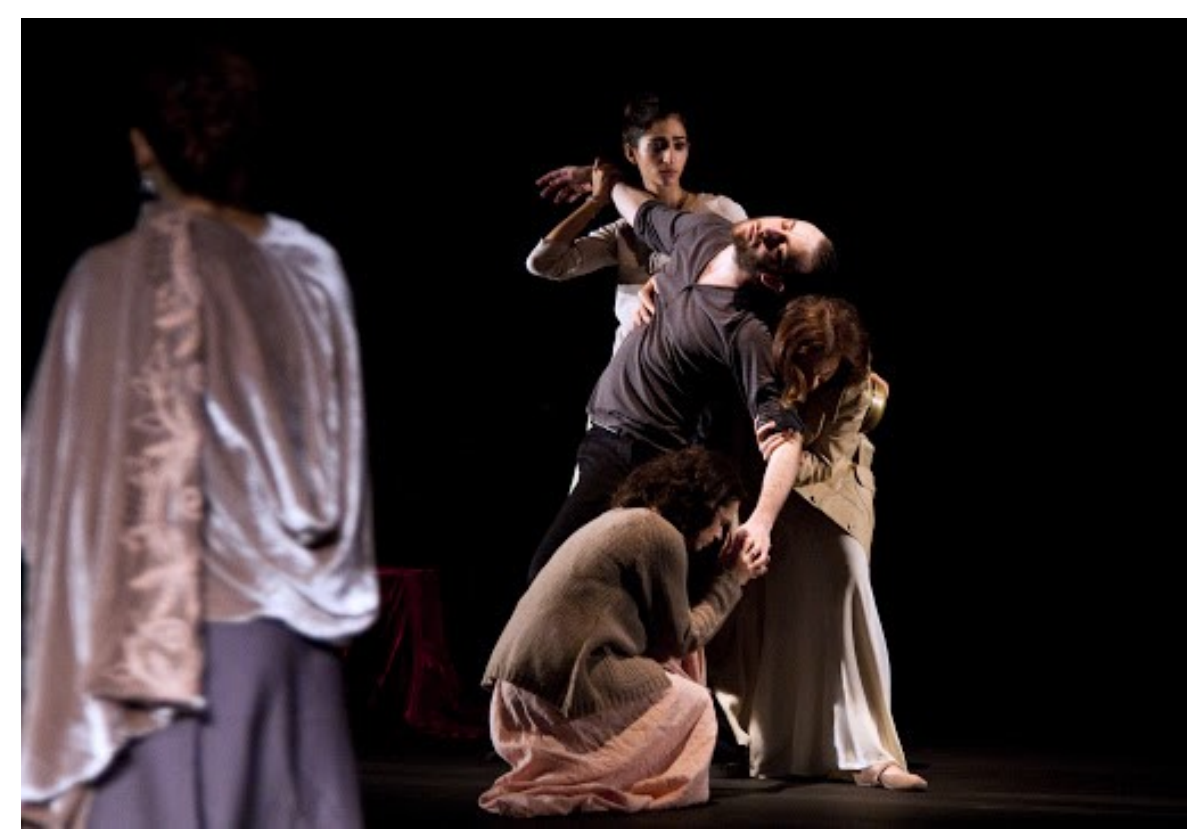

Fig. 116: La propuesta de Juan Carlos Corazza estuvo representada por actores y actrices conocidos del cine y la televisión como Jan Cornet, Alba Flores, Ana Gracia y Manuel Morón, entre otros. 
Como con anterioridad sucedió con Nowicki, en esta propuesta Corazza apostó por una escenografía vacía, ya que no existe montaje. En un escenario desnudo de elementos decorativos, da protagonismo al elenco de doce actores y actrices que con su actuación se convierten en los elementos plásticos en el espacio escénico y son quienes proporcionan sentido a la representación. Acerca de esta importancia y protagonismo, el director de escena opinaba: «el teatro de actores es una oportunidad para hacer un trabajo artesanal, una invitación a reconocernos» (Corazza 2013, 5).

También son varias las propuestas universitarias. Entre las últimas, encontramos la propuesta del grupo del Aula de Teatro de la Universidad de Alicante, bajo la dirección de Iván Jiménez. Aunque el estreno, en 2017, llevada a cabo en castellano por primera vez, se ha traducido el texto al valenciano para posteriores representaciones. En marzo del 2018, se presentó en la decimosexta edición del Encuentro Internacional de Teatro Universitario de Granada (EITUG).

En la programación del Año Lorca 2019, Sara Molina Doblas presentó una nueva propuesta de Comedia sin título. En 1995, la dramaturga, actriz y directora presentaba por primera vez la pieza. Sin embargo, en 2019, se atrevía de nuevo a llevarla a escena. Pero, esta vez, de una manera diferente, ya que la propia Sara Molina también ha cambiado con el paso del tiempo. Ella misma afirmaba que pretende «comparecer de nuevo para dar testimonio. Testimonio del encuentro, del esfuerzo, del error. [...]. De lo que falta, lo que no está, lo inconcluso, las palabras otro» (Molina Doblas, 2019). Estrenada en el $37^{\circ}$ Festival de Otoño de Madrid, en la sala Negra de los teatros del Canal, la escenografía estuvo a cargo de José Luis Lucas, y el escenario estaba prácticamente vacío. Joaquín Cutillas en la iluminación crea contrastes con luces intimistas y, en oposición, una gran luminosidad.

El texto de Lorca mantiene un diálogo con las palabras de la dramaturga, incluyendo vivencias personales de los intérpretes, oyéndose el español acompañado de otras lenguas como son el wolof, francés, inglés, persa y alemán. Sara Molina se vale de un 
nutrido grupo de intérpretes, de los cuales un gran número no son actores profesionales $^{271}$. Sara Molina opina sobre su nueva propuesta:

Comedia sin título es una pieza inacabada, interrumpida, premonitoria en lo que se refiere a los hechos que relata. Está dividida en tres actos, de los que solo tenemos el primero, un fragmento que usamos como dispositivo. Ningún intérprete es un personaje en concreto, entre los más de diecisiete que propone la pieza. Nuestra propuesta fragmenta el texto, repite escenas, es tragicómica. Es un continuo diálogo con lo que quedó escrito y lo que falta, que se hace palabra viva, elocuente, equivocada, misteriosa, necesaria o superflua. Nuestra. Contemporánea. El segundo y tercer acto van a ser escritos sobre la página en blanco de la escena, en una ahora elaborado y reflexivo, pero, al mismo tiempo, lleno de aventura, asumiendo riesgos. Serán escritos de tal manera que puedan después ser borrados y permitan al pensamiento mantener su compromiso con la pieza (Molina Doblas 2019).

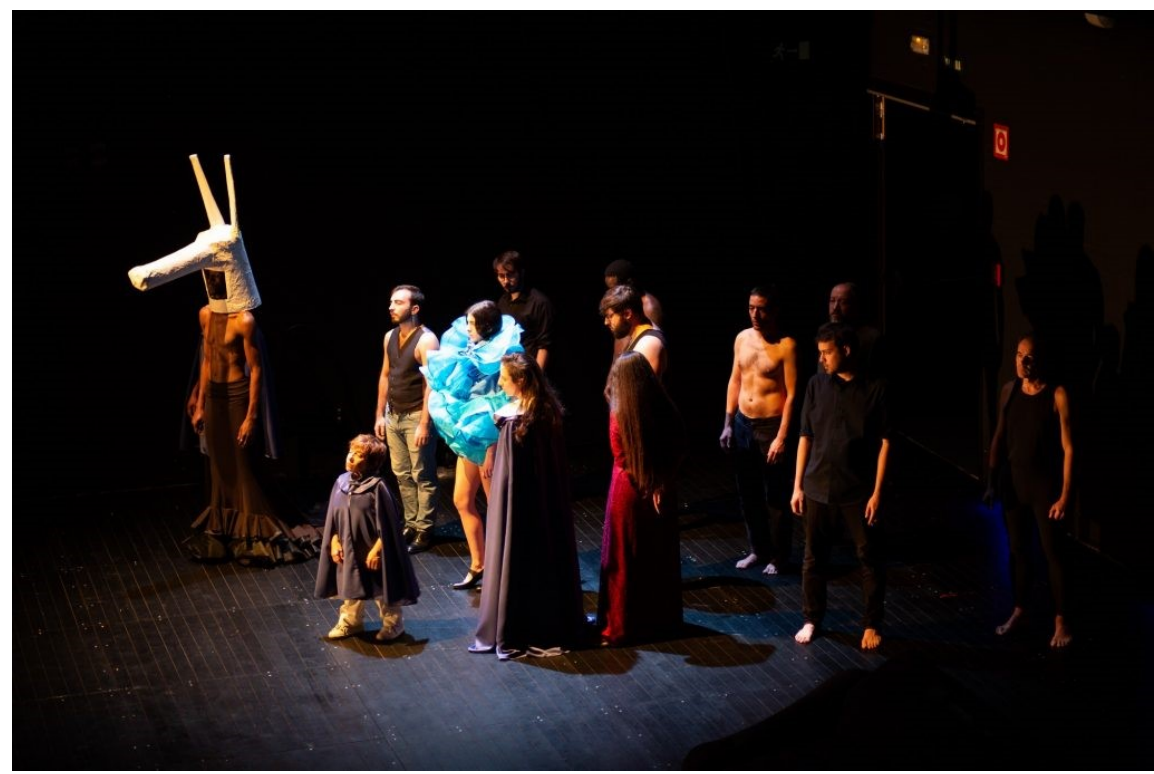

Fig. 117: Momento de la representación en los teatros del Canal, en 2019.

\section{1.- La propuesta de Alberto Conejero: El sueño de la vida}

En diciembre de 2016, se anuncia que el dramaturgo Alberto Conejero pondrá fin a Comedia sin título de Lorca, por encargo de la Comunidad de Madrid. El proyecto se

${ }^{271}$ El 5, 6 y 7 de marzo de 2020 se presentó en el Centro Federico García Lorca de Granada. En este montaje, la escritora Cristina Morales fue una de las actrices no profesionales que formaba el elenco. 
envuelve en una gran polémica. En las redes sociales son innumerables los insultos y amenazas recibidos por el autor. Pero pronto aparecen defensores del proyecto, como son los dramaturgos Miguel del Arco y el propio Lluís Pasqual, encargado de la puesta en escena dos años más tarde. Incluso, la sobrina nieta del poeta, Laura García Lorca, se encontraba entre los defensores del proyecto de Conejero, ya que le inspiraba confianza y sabía que sería respetuoso con el texto de Lorca (Bravo 2016, 50-51).

Alberto Conejero no pretendía dar un final a Comedia sin título, ni reescribirla. Para el dramaturgo, El sueño de la vida era «un nuevo texto escrito en un vacío infinito, un diálogo entre lo que fue y lo que no pudo ser. [...] La Comedia sin título siempre será la de García Lorca, una obra sin terminar. Hubiera sido una soberbia pretender terminar esa obra» (Conejero 2019b). En otra entrevista, también afirmó que «es una obra que estará siempre por clausurar. Yo sólo he pretendido ocupar con otro material el espacio que dejó aquel jarrón roto por la guerra» (Conejero 2019a, 36).

Según afirma Conejero:

Lorca se pregunta ¿Qué hacer con el teatro? El teatro no puede estar de espaldas a la realidad. Ha de abrir sus puertas al dolor del mundo, pero también ha de protegerse de la oscuridad del mundo. Esa tensión que quizá no tiene una respuesta fácil, [...], esa pregunta me la hago como dramaturgo, para escribir los dos actos después de la Comedia sin titulo, $[\ldots]$, la he hecho, porque no vengo al teatro a esperar el aplauso fácil y esperar el beneplácito de todos (2019b).

Como hemos dicho, según testimonio de Margarita Xirgu, el segundo acto transcurre en una morgue y el tercero en el cielo. A partir de aquí, Conejero ha seguido «esta invitación que ocurre en el foso del teatro que se ha convertido en una morgue, que la ha de reconstruir el espectador [...]. El tercer acto transcurre en un cielo, un poco más oscuro, con ángeles flamencos y querubines» (2019b).

Conejero mantiene un diálogo con Lorca y propone un final para Comedia sin título. A partir del primer acto conservado de Lorca, recurre a Poeta en Nueva York, también a El Diván del Tamarit, e incluso a la obra Amor de don Perlimplín con Belisa en su jardín y a entrevistas realizadas por el propio Lorca, para extraer frases de Lorca y formar parte del texto de la obra teatral El sueño de la vida. El propio Conejero afirma: 
No he ocultado esa intertextualidad; al revés, es un texto formado con muchas voces, entre ellas la de Federico. [...] Siento una hermandad con estos autores [Angélica Liddell, Wajdi Mouawad o Antonin Artaud] por su concepción de la tragedia contemporánea. Al igual que en sus obras, éste no es un teatro realista sino que entiende lo poético como una forma revolucionaria $(2018 b, 21)$.

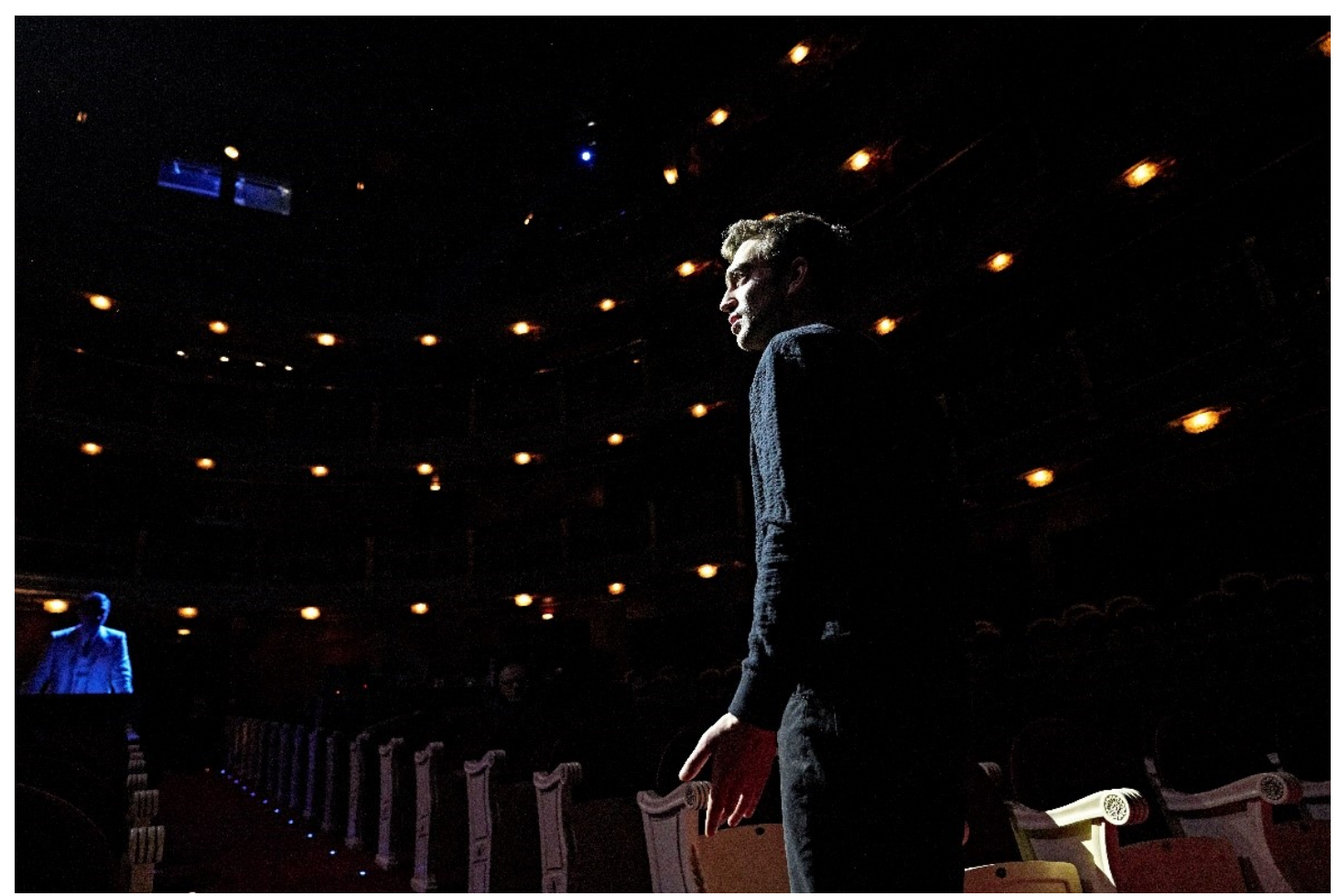

Fig. 118: El actor Nacho Sánchez en el papel del Autor actuando entre la platea.

Conejero completa los personajes presentados en el primer acto por Lorca. El Autor, que agoniza durante el segundo acto, lo revive en el tercero. La Actriz es el personaje que más evoluciona durante el drama. En un comienzo, incapaz de sentir empatía por el prójimo, consigue tomar conciencia de lo que propone el Autor y finaliza el segundo acto con un exaltado discurso revolucionario.

Otro personaje que evoluciona y toma una gran importancia es el Joven. Así como en el primer acto, Lorca nos lo presenta distante y apático ante la situación teatral, Conejero consigue que crezca acercándose a la postura del Autor, con un espléndido diálogo en el tercer acto, entre el Autor, el Estudiante y el Joven. Como afirma Peral,

la única posibilidad de regeneración ética del teatro, y de la sociedad en su conjunto, se centra en las nuevas generaciones, de ahí la importancia que tiene el Joven y el 
Estudiante como interlocutores naturales del Autor en el último tranco de la pieza $(2018,61)$.

Como hemos dicho, en la edición de Emilio Peral Vega hay un extenso estudio sobre las referencias lorquianas del texto. De entre todas ellas, citaremos a aquellas con la que Conejero finaliza el segundo acto, poniendo en boca de la actriz, ante un Autor agonizante, los versos del propio Lorca. La última estrofa que cierra el Acto II, es íntegra a la última estrofa del poema «Grito en Roma» de Poeta en Nueva York:

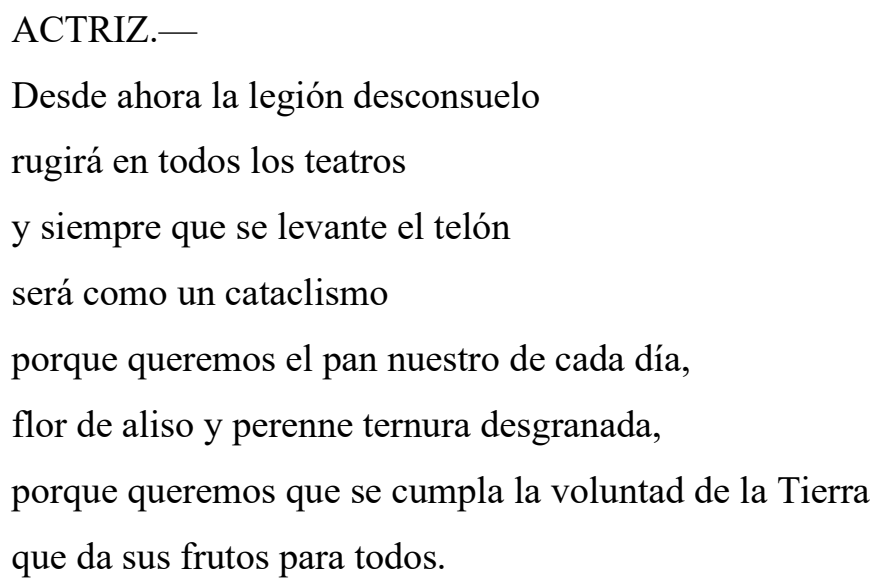

Alberto Conejero aprovecha la conexión de Comedia sin título con El público, y la recalcará utilizando referencias de El público en su propuesta El sueño de la vida:

ESTUDIANTE. - Los estudiantes vamos a tomar al teatro moribundo y lo vamos a esconder en un bosque [...]. Será un teatro fuera de los muros. Un teatro bajo la arena. Como lo fue en este país hasta que lo envenenaron los banqueros, los notarios y los sepultureros de la taquilla. Es mejor cerrar los teatros que dejarlos más tiempo en su prostitución. Hay que pensar en el teatro del porvenir.

(El sueño de la vida, Acto II, 114).

La idea del teatro del porvenir la encontramos en la correspondencia mantenida con su familia mientras se encontraba en Nueva York, en 1929. Y también, posteriormente, en una entrevista realizada por Pablo Suero, en 1933, en el que mantiene conciencia del problema de la recepción en los siguientes términos:

La sensibilidad de las masas necesita lógicamente mayor tiempo para afirmarse que la de los grupos selectos. Para meter algo en la comprensión del público hay que atacarlo 
primero. Obras como Así que pasen cinco años lo indignan, lo desconciertan, aunque capte algunas de sus bellezas, pero las rechaza. Pero yo me atrevo a afirmar que este es el teatro del porvenir. El teatro agoniza, porque está detenido en su desarrollo por las fuertes ataduras de la realidad. El teatro se muere [...] y necesita volver a las manos de los poetas, morar en el reino de la fantasía, que no tiene limitaciones (citado en Gómez Torres 1992, 307).

En El público, Lorca nos muestra, asimismo, en oposición dos tipos de teatro: el teatro al aire libre, y el teatro bajo la arena. El Estudiante de El sueño de la vida exige un teatro bajo la arena, que no se vende por dinero. Aquel que representa el teatro alejado de las normas establecidas y del gusto del consumidor:

AUTOR.- $[\ldots]$ Yo no he venido aquí a esconderme de un biombo.

(El sueño de la vida, Acto II, 118).

El biombo es un elemento fundamental en El público. Todos los que lo atraviesan van desprendiéndose de todas esas máscaras que ocultan la verdadera identidad del ser. En El sueño de la vida, y en la obra La vida es sueño de Calderón de la Barca sus personajes sufren una alteración de la vida y el sueño. Será el verdadero teatro el que no ha de esconderse, ha de enseñar la verdadera revolución teatral a un público aún no preparado para los cambios:

JOVEN.- [...] Si levantas el telón con la verdad original, las butacas se llenarán de sangre (El sueño de la vida, Acto III, 136).

DIRECTOR.- [...] En cambio, si hubiera levantado el telón con la verdad original, se hubieran manchado de sangre las butacas desde las primeras escenas (Cuadro V, 188).

Como podemos comprobar, las palabras del Joven son una variante de las palabras del Director. Ambos personajes, las pronunciarán en la conclusión de las dos obras, cuando el final está cerca y su mensaje en evidencia.

\subsection{2.- La nueva puesta en escena de Lluís Pasqual}

Antes del proyecto, Pasqual y Conejero no se conocían. Tan pronto, aquel se enteró de que Conejero estaba escribiendo los dos actos ausentes, se ofreció para realizar la puesta 
en escena, «esto lo has escrito para mí. No lo sabes, pero lo has escrito para mí. Necesito hacer esto» (Pasqual 2019a).

En un principio, la idea era ensayar en el Teatre Lliure, donde se presentaría luego del estreno en Madrid, pero debido a las presentes acusaciones de trato machista a sus actrices, tuvo que renunciar a la dirección del Teatre Lliure y la consecuente cancelación de la participación con el teatro (Ojeda 2019, 38).

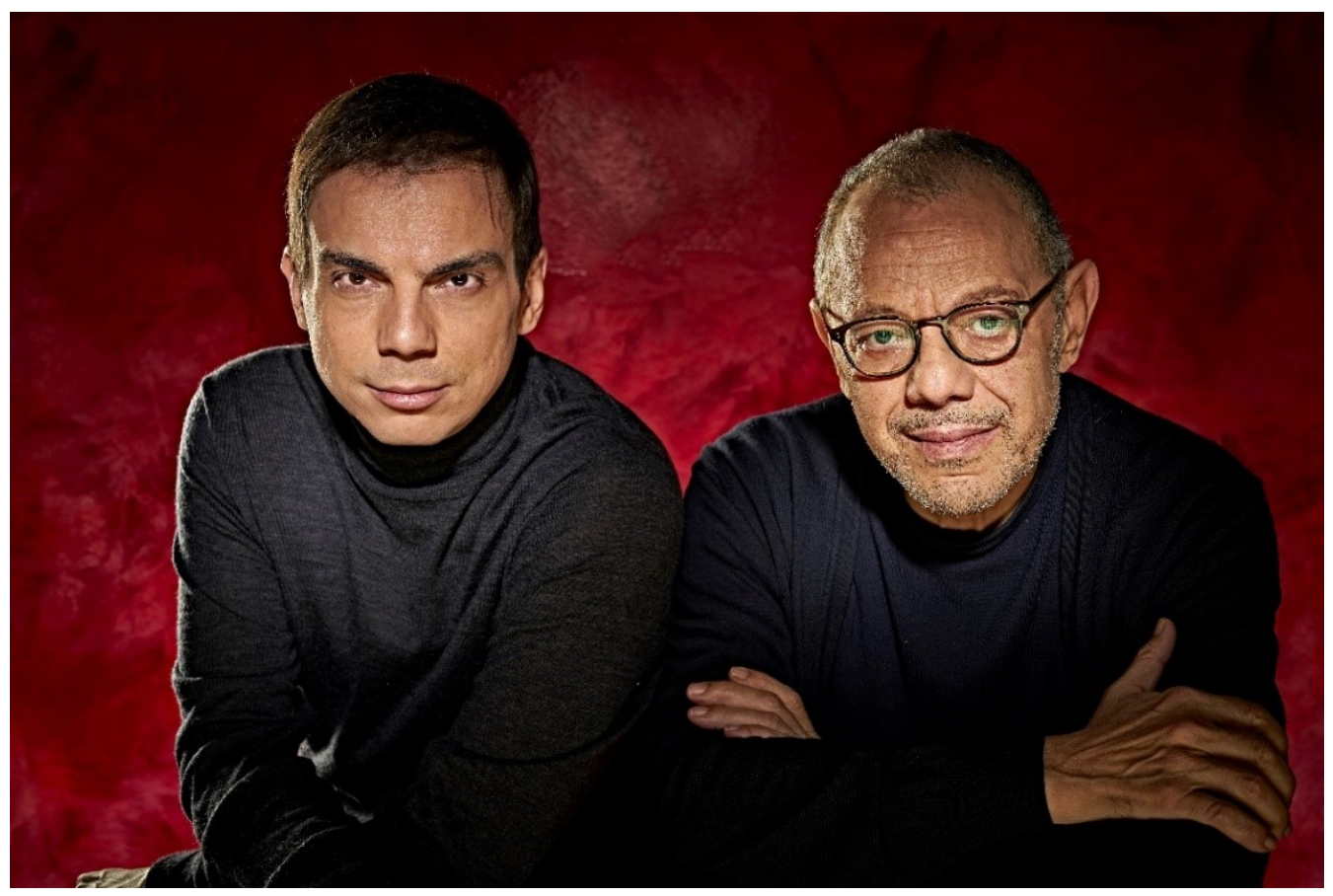

Fig. 119: Alberto Conejero junto a Lluís Pasqual en la serie de fotografías promocionales de $E l$ sueño de la vida (2018).

En la representación de 1989, el primer acto era más violento, incluso la función finalizaba con una explosión en la que se caía el teatro María Guerrero. Pasqual afirmaba «toda la gente quedaba manchada y teníamos que repartir vales para ir al tinte, todos los días. Era más violenta, pero hace 30 años» (2019). Pero Pasqual, con cada representación, empieza de nuevo «el espectáculo que hice hace 15 años lo hizo otra persona no yo, el yo que ahora soy» (Pasqual 2019b, 15)

El segundo acto es el punto de encuentro entre los dos autores, Lorca y Conejero. Encontramos textos, poemas y frases extraídas de entrevistas de García Lorca. Para Pasqual «es un texto por una parte surrealista, por otro cubista» (2019a).

Lluís Pasqual añade un elemento al segundo acto que no encontramos en el texto: 
no ocurre lo que ocurre. Lo que ocurre es un ensayo en el cual ocurre lo que ocurre. Eso por dos motivos. De la misma manera que Alberto no ha pretendido suplantar, yo tampoco puedo hacer creer que eso es una obra de Lorca. Es una prueba, un ensayo, una posibilidad, la cual es cambiante, como en un ensayo. En una etapa de un ensayo, casi final, en el que la gente aún está alguno con el ejemplar en la mano, alguno está sentado, y otros ya están haciendo la escena. Es una manera de contar que eso no es. Lo mismo que Alberto, eso es una acción de que podría ser de alguna manera. [...]

Esta forma de ensayo permite ver el amor por el teatro, visto que en el primer acto lo que hace [Lorca] es desear que se hunda, que se queme, que se destruyan esas formas anquilosadas donde hasta el espectador tiene forma de espectador (Pasqual 2019a).

El tercer acto ya es Alberto Conejero. Tiene una duración de nueve minutos, Pasqual lo clasifica como un «haikú [...] pequeño poema japonés donde se encuentran dos personajes. Tiene una brevedad y es lo que Lorca pone en el Paraíso» (2019a).

El jueves 17 de enero de 2019, en el Teatro Español de Madrid, Lluís Pasqual estrenó El sueño de la vida. Pudimos ver cómo Pasqual consiguió escuchar y mostrar el diálogo mantenido entre Federico García Lorca y Alberto Conejero. Según crítica de Marcos Ordóñez, «los tres han convocado el temblor del miedo como la cercanía de un bombardeo, el caos prebélico creciendo como un cáncer, el hedor de la muerte desatada: eso es El sueño de la vida [...]. La fiera belleza de El sueño de la vida es un regalo para todos los amantes de Lorca» $(2019,12)$.

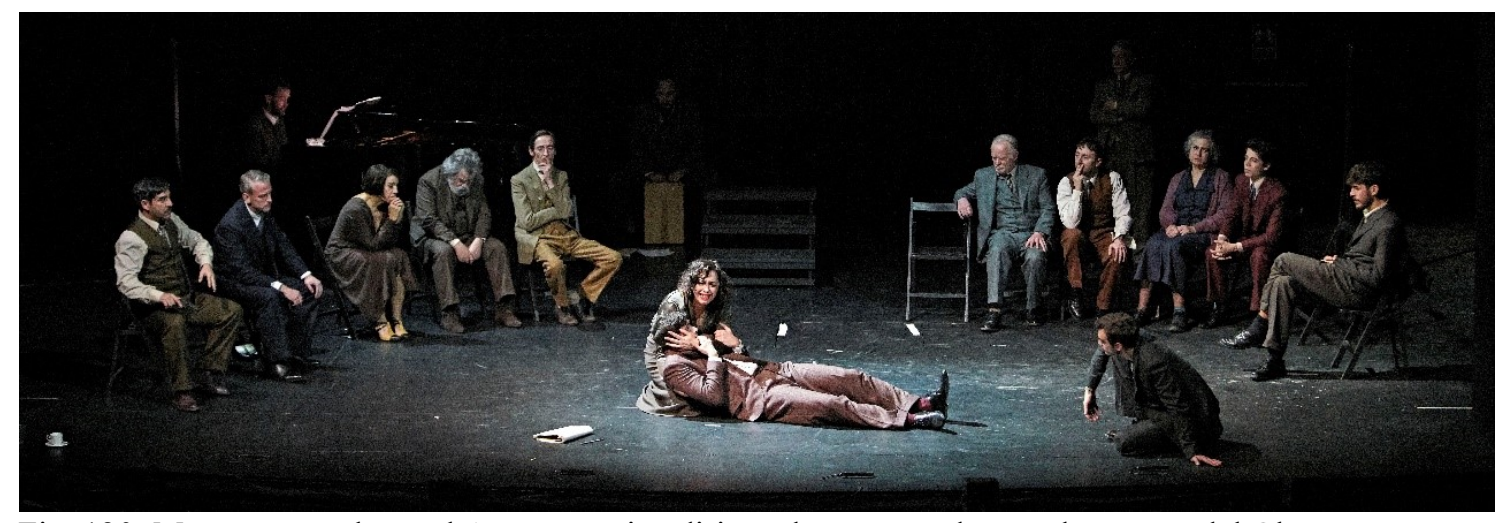

Fig. 120: Momento en el que el Autor es quien dirige a los actores durante la muerte del Obrero.

El reparto está formado por Nacho Sánchez como Lorenzo, la voz protagonista, autor de El sueño de la vida. El actor ya coincidió con Conejero como el joven soldado que 
custodiaba a Rafael Rapún en La piedra oscura ${ }^{272}$; Emma Vilarasau, Elena, la primera actriz; Daniel Jumillas, vestido de blanco, es el amante de Lorenzo, hasta un total de dieciséis actores y actrices. Hemos de destacar, en el tercer acto, a modo de epílogo, el mano a mano entre los dos actores, Nacho Sánchez y Daniel Jumillas.

La dirección musical estuvo a cargo de Dani Espasa. Durante la obra se pudieron escuchar varias canciones. En la primera parte, dos canciones con letra de Federico García Lorca, cantadas por Luis Perezagua sin acompañamiento (un tango y un bolero, esa fue la intención de Pasqual) y, en la segunda parte, una canción, con letra de Alberto Conejero, inspirada en canciones de Manuel de Falla y canciones españolas antiguas. En escena hay dos músicos, Miguel Huerta en el piano e Iván Mellén en la percusión. Alejandro Andújar fue el encargado de la escenografía y el vestuario. Un escenario casi desnudo, con unas sillas que nos recuerdan el tablado flamenco.

${ }^{272}$ Pieza teatral en la que Conejero recrea los últimos instantes de la vida de Rafael Rodríguez Rapún encarcelado (cuya personalidad ya la hemos tratado con anterioridad) y que recuerda los momentos vividos con Federico García Lorca. 


\section{CONCLUSIONES}


A finales de siglo XIX, nos encontramos ante un cambio de cosmovisión frente a los avances científicos y tecnológicos, hechos que se verán reflejados en las nuevas propuestas teatrales europeas. Estos cambios tardarán a darse a conocer en el teatro español, ya que el teatro naturalista/realista era el que triunfaba en la época, al gusto de un público burgués, conservador y acomodado, que principalmente buscaba la diversión y el esparcimiento a la hora de asistir a las representaciones teatrales.

El teatro es un género literario que ofreció diversos alicientes para los escritores. La escenificación de la obra permitía alcanzar a un número de oyentes mayor que la lectura individual. Y, de este modo, alcanzaba beneficios económicos de una manera más rápida $\mathrm{y}$, al mismo tiempo, la consecución de la fama. La mayoría de autores no quería experimentar en las propuestas teatrales, sino se acomodaba al estilo de épocas anteriores realistas para continuar agradando al gran público.

A principios de siglo XX, en Europa empiezan a aparecer nuevas propuestas dramáticas, mientras que, en España, gran parte del teatro estaba en manos privadas que, sobre todo, buscaban el beneficio económico. El empresario teatral trataba las propuestas como mercancía a la que debía rentabilizar y, por esa razón, su teatro iba dirigido al gusto de un público burgués acomodado, ya que este era habitualmente el que asistía y aplaudía el espectáculo. No quería arriesgar y lo que perseguía era un teatro fácil, de diversión y evasión, sin querer involucrar al espectador ni hacerlo partícipe del mismo. El sistema teatral presentaba una estructura casi exclusivamente comercial, cuya mera finalidad era el entretenimiento del público. Entre los autores más representados, encontramos en España los hermanos Álvarez Quintero, Jacinto Benavente, Pedro Muñoz Seca, Eduardo Marquina, entre otros.

A pesar de que el repertorio teatral español no se diferenciaba del bien situado en las demás ciudades europeas, será en las primeras décadas del siglo, con la aparición de las vanguardias europeas, la nueva reforma teatral, la renovación de nuevos textos y los avances tecnológicos (mediante la iluminación, por ejemplo, - los teatros empiezan a utilizar electricidad - se consigue el juego de luces y sombras para crear volúmenes en la escenografía y así proporcionar nuevas visiones en las representaciones) cuando España se distanció de Europa. En el resto del continente empieza a florecer un teatro vanguardista que también llega a España, pero, debido a la programación teatral de los 
escenarios españoles, dominada por uno comercial y conservador, no dejará espacio para este tipo de teatro.

Es un periodo en el que los críticos teatrales se posicionan en contra o a favor de este teatro, con numerosos artículos y publicaciones. La decadencia teatral es un tema recurrente en la mayoría de escritores, intelectuales y críticos. Todos ellos reflejan, en los diarios, la crisis teatral existente y pretenden esclarecer los motivos que la propiciaron. Los autores españoles — tanto jóvenes como maestros- quieren renovar el teatro, proponiendo textos más filosóficos, en los que obligaban a que el público se viera representado sobre el escenario y comprobara la realidad (cotidiana) de la calle en escena. Tarea harto difícil, puesto que el público conservador estaba acostumbrado a una determinada clase de teatro y, al ser este propiedad de los empresarios teatrales quienes sólo pensaban en los beneficios, no querían cambiar lo que sí era exitoso. Aun así, autores como Miguel de Unamuno, Ramón María de Valle-Inclán, Azorín, Ramón Gómez de la Serna, entre otros, no renunciaron a escribir este tipo de teatro, más rupturista $\mathrm{y}$, por tanto, difícil de representar. Aunque finalmente se quedará simplemente en un teatro para leer o para ser representado en privado con muy poco público, normalmente amigos del autor.

Entre los jóvenes escritores y dramaturgos de la época, encontramos a Rafael Alberti, María Teresa León, Max Aub, Miguel Hernández, Adrià Gual, etc. También irrumpe una gran renovación en la comedia teatral y en el lenguaje del humor con Miguel Mihura y Enrique Jardiel Poncela. Surgen numerosos grupos teatrales experimentales en la línea de los teatros de arte como son El Mirlo Blanco, el Cántaro Roto, El Caracol, El Teatro Íntimo Fantasio y, asimismo, clubs teatrales como el Teatral Anfistora, dirigido por el mismo Federico García Lorca.

Especial mención merece el matrimonio Gregorio Martínez Sierra y María de la O Lejárraga que fueron dos figuras claves en la renovación teatral española, no sólo por los obras dramáticas escritas por ambos sino por las propuestas arriesgadas de llevar a escena textos de jóvenes dramaturgos desconocidos, como es el caso de Federico García Lorca y su El maleficio de la mariposa en 1920, obra vanguardista que ocasionó un escándalo para el público y la crítica. 
Federico García Lorca desarrolló dos vertientes relacionadas con el teatro. Por una parte, como dramaturgo y, por otra, como director de escena, con propuestas como La Barraca o el Club Teatral Anfistora, debido a la importancia que empiezan a cobrar la figura del director de escena y su punto de vista en la representación del texto.

A este respecto, la producción dramática de Federico García Lorca la podemos contextualizar en este periodo, que abarca entre finales de los años veinte y los años treinta y aunque, en un principio, fue rechazado su teatro vanguardista, con los años consigue el éxito teatral tanto de público como de la crítica sin renunciar a sus principios. Por otra parte, en 1932 se funda el Teatro Universitario de La Barraca, en cuya dirección encontramos a Lorca. Sus objetivos eran llegar a los lugares más recónditos de España para mostrar las propuestas más populares del teatro clásico español. Debemos añadir que, junto al teatro universitario de La Barraca, en estos años, aparece el Teatro del Pueblo de las Misiones Pedagógicas, dirigido por Alejandro Casona, cuya mayor diferencia entre ambos consistía en que este poseía una intención educativa, mientras que el primero, acercar la cultura española, el teatro, sobre todo al pueblo.

Otro aspecto que exponemos en nuestra investigación es que, a principios del siglo XX, surgen numerosos movimientos vanguardistas. Entre ellos, destacamos la aparición del surrealismo, con la publicación, en 1924, de Le Manifeste du surréalisme de André Breton y Une vague des rêves de Louis Aragon. Las principales teorías del surrealismo son la superación de las barreras de la lógica, la razón y la moral establecidas por la sociedad burguesa de la época. Eran numerosos los miembros que consideraban que en el estado del sueño era donde el ser humano podía liberarse de ellas y, mediante el surrealismo, cómo conseguir tal libertad. Los surrealistas reivindicaban la continuidad entre el estado del sueño y el de la vigilia que no tenían por qué ser opuestos. Para Breton, debíamos volver a la infancia donde la imaginación era más libre que la razón, el progreso y la civilización. La síntesis surrealista era la liberación del individuo, la incorporación de lo onírico en nuestra vida cotidiana y la importancia de la síntesis de los estados contrarios para crear una nueva realidad.

El surrealismo se extendió por diferentes países de Occidente, aunque, más que un movimiento grupal, fue una influencia en autores aislados y, sobre todo, en España 
donde hubo una gran oposición a reconocer la influencia surrealista francesa. A excepción del grupo Gaceta de Arte de Tenerife, en el que el carácter de grupo surrealista fue patente, la distancia física con la Península facilitó la creación y el desarrollo del grupo.

La existencia o no del surrealismo español constituyó una problemática que alcanzó, incluso, a la hora de denominar el movimiento, ya que se creyó que era un movimiento autóctono respecto al surrealismo francés. Son diversos los autores, Juan Larrea, Rafael Alberti, Josep Vicenç Foix, José María Hinojosa, entre otros, que se dejaron influenciar por las ideas del surrealismo y de otras vanguardias europeas, pero pocos los que lo reconocen, por el miedo de ser rechazados o no bien valorados. De entre todos los autores, uno de los pocos que reconoce su vinculación con el surrealismo fue Luis Cernuda, con el riesgo que suponía reconocerlo ya que se exponía a ser marginado por sus contemporáneos, como se produjo con José María Hinojosa. Incluso Vicente Aleixandre y Federico García Lorca negaron esta etiqueta por la implicación a aceptar la escritura automática y la misma conciencia de grupo.

Entre las grandes diferencias existentes entre los surrealistas españoles y los franceses encontramos su voluntad literaria y artística. Los autores españoles tenían conciencia de estar haciendo literatura, por rupturista y revolucionaria que fuera. También debemos añadir que en España no hubo espíritu de grupo, de ahí que hubiera tanta polémica acerca de un supuesto surrealismo español. Otra diferencia entre ambos fue el rechazo a la escritura automática, en el que no existía la intervención de la razón en el pensamiento, clave en el surrealismo francés y muy presente en el citado Manifiesto del surrealismo de André Breton. Aun así, posteriormente, el propio Breton rectificó, respecto a la escritura automática, afirmando que había que seleccionar entre toda esa producción lo que realmente era digno de ser considerado a destacar.

Durante las primeras décadas del siglo XX, son numerosas la aparición de diferentes revistas por todo el territorio español en las que tratan las nuevas propuestas vanguardistas, con la publicación de manifiestos, artículos teóricos y de textos literarios de diferentes autores, tanto nacionales como extranjeros, en lengua original o también en traducciones. Los jóvenes autores españoles, durante estos años, buscaban ideas y 
conceptos nuevos, siendo habituales las influencias de los movimientos vanguardistas, entre ellas, la surrealista tanto por su actitud como por sus ideas.

Pero Federico García Lorca, como hemos observado en nuestro análisis, nunca aceptó el principio surrealista, debido a su concepción acerca del escritor, ya que no creía que la liberación de la escritura estuviera fuera del control del autor, pues él quería ser dueño de sus palabras y su obra. Aunque no hay duda de que sí podemos observar cómo se acercó al surrealismo en algunos de sus textos, ya que son varios los vínculos entre su obra y el Surrealismo pues la presencia de la unión de objetos relacionados entre sí, sin ningún enlace racional, son múltiples y sus imágenes están cargadas de conexiones de objetos opuestos.

Aunque existe la tendencia de centrar su ciclo surrealista después de su viaje a Nueva York, no debemos olvidar que sus teorías, muy semejantes a las surrealistas, ya las muestra en sus conferencias «Imaginación, inspiración, evasión» impartidas a finales de 1928 y principio de 1929. Más tarde, en 1935, encontramos un nexo entre esta y la de «Juego y Teoría del duende». En ambas conferencias teoriza sobre el artista y la creación, y cómo esta la encontramos en el interior de uno mismo y pocos la consiguen liberar. También su correspondencia personal y sus dibujos explican y muestran esa liberación por medio de la creación artística, concepción muy próxima a la producción artística automática.

García Lorca en sus Diálogos (1925) y en sus Poemas en prosa (1927-1928), anteriores a su viaje a Nueva York, ya manifiesta un primer contacto con ese nuevo estilo que desarrollará en su ciclo neoyorquino, formado por su poemario Poeta en Nueva York (1929-1930), el guión cinematográfico Viaje a la luna (1929), las comedias imposibles El público (1929) y Así que pasen cinco años (1931) y la obra inconclusa Comedia sin título (1935-1936).

Habiendo contextualizado el teatro del primer tercio del siglo XX en España, con un breve recorrido entre sus principales dramaturgos y los diferentes géneros, y presentado la influencia de las vanguardias entre los jóvenes autores de las vanguardias, centrándonos en concreto en el movimiento surrealista, consideramos la parte principal de nuestra investigación en el análisis de dos manuscritos de las obras dramáticas de Federico García Loca, El público (1930) y Comedia sin título (1935-1936) y su 
relevancia en esta nueva concepción en el teatro, tanto en el espacio, el tiempo, la acción como en el texto mismo.

Su primer viaje a América, a finales de junio de 1929, marcó un antes y un después en la estética de la producción dramática de Lorca. La experiencia neoyorquina le proporcionó el contacto con una sociedad cosmopolita muy diferente a la sociedad española que había dejado atrás. Aunque tuvo problemas en el aprendizaje del idioma, no consiguió superar la barrera del inglés pese a que su círculo de amistades fue muy amplio. Descubrió la noche en Nueva York, con sus clubs nocturnos, el teatro chino, la revista negra, el jazz, los espectáculos de Broadway, quedando impresionado por la gran variedad y propuestas nuevas en el mundo teatral. Todo ello cambiará sus ideas sobre el teatro, en cuanto la organización del teatro mismo como empresa y como espectáculo.

Conoce la dureza del Wall Street, centro de negocios financieros, la grandeza de los rascacielos y la velocidad con que se alzaban. Durante los meses, en los que vivió en Nueva York, pudo observar la construcción del edificio Chrysler, llegando a ser la ciudad de Nueva York la más moderna del mundo en cuanto a arquitectura y economía. Fue un gran observador social y, en sus visitas al barrio de Harlem, pudo comprobar las diferencias sociales entre clases, denuncia que mostró en varios de sus poemas que recopiló en Poeta en Nueva York. Incluso durante la visita a Coney Island observa el comportamiento de los norteamericanos durante su tiempo de ocio, y allí descubrirá el ciclorama «Viaje a la luna» que inspirará su único guión cinematográfico homónimo.

Durante su estancia neoyorquina consiguió superar su crisis personal y, antes de su regreso a España, visitó La Habana invitado por Fernando Ortiz, presidente de la Institución Hispanocubana, para impartir una serie de conferencias por varias de sus sedes urbanas. Consigue, pues, romper completamente sus ataduras (convenciones sociales y culturales), dejándose llevar de la libertad, de los colores, de la luz y de los sonidos que descubrió en Cuba. Lorca encontró en las ciudades cubanas la cercanía de la tierra andaluza y en su ambiente y en su naturaleza la presencia de lo surreal. Tres fueron los círculos en los que transcurrió su vida privada: el entorno del matrimonio español Antonio Quevedo y María Muñoz; los cuatro hermanos Loynaz del Castillo y su círculo más privado, formado por su amigos Luis Cardoza y Aragón, Adolfo Salazar y Gabriel García Maroto con quienes descubrió la noche y sociedad habaneras. Lorca 
conoció el ambiente teatral en el que el género de variedades estaba floreciendo, visitó los bares nocturnos del puerto, llegando a frecuentar el Teatro Alhambra, que constituye una base de inspiración. También se sintió hipnotizado por el son cubano, desconocido aún en España.

Durante los días que pasó en La Habana empezó a escribir El público. Prueba de ello son las cuartillas utilizadas del Hotel La Unión de La Habana para los primeros actos y los mismos testimonios de los hermanos Loynaz sobre las lecturas que realizó en su casa, conocida como «la casa encantada». El manuscrito lo finalizó ya en su regreso a España, fecha que viene indicada al final del manuscrito, «22 de Agosto 1930». Aunque Lorca tuvo un primer de intento de representación en verano de 1932, finalmente no se llevó a cabo, pero sí poseemos datos que acreditan su lectura primeramente ante unos amigos y la versión definitiva el 12 de julio de 1936. El texto se trata del borrador, el único manuscrito que se conserva, que Lorca entregó a Rafael Martínez Nadal, dividido en actos en dos publicados en vida del autor y también por el papel utilizado para escribirlo y sus diferentes formatos: cuartillas, hojas de libreta, etc.

En Nueva York, en 1929, Lorca pudo observar cómo el modelo, el teatral neoyorquino, era muy diferente al modelo predominante en España. Hacía falta un teatro nuevo que escapara de las limitaciones del realista y burgués representado mediante la cuarta pared. Lorca quiere eliminarla, y de este modo conseguir que la representación entrara en contacto con el público y así traer la realidad a la escena. En este tipo de escenificación, el público se siente como si fuera parte de la representación, como si el autor hubiera contado con él desde el principio y, por ello, el autor está presente en todas las representaciones para que el público pueda formar parte de la acción en todas estas. Lorca quiere mostrar la verdad sobre el escenario, no solamente la verdad en la identidad personal como ocurre en El público, sino también busca un cambio revolucionario en el teatro y sus textos.

En esta obra inacabada, que Federico García Lorca compuso durante los últimos años de su vida, aparece el concepto teatral en toda su dimensión, con una gran conexión con $E l$ público. En ella se puede observar cómo Lorca nos muestra un teatro diferente en oposición al teatro convencional de la década de los años treinta en España. El Autor 
que prologa la obra, es el propio Lorca que se posiciona contra ese teatro caduco, putrefacto es el vocablo lorquiano.

En el momento en que se concibe Comedia sin título, en España se vive una gran tensión y violencia en las calles y las fábricas. Suceden las diferentes huelgas generales en las españolas, los conflictos obreros, las insurrecciones entre los mineros y, también, en el campo surgen los conflictos entre los jornaleros y la oposición de los propietarios. Lorca intenta reflejar esos momentos convulsos en su obra, acercando su posición a los sentimientos y los problemas del proletariado.

Sólo se conserva un único acto de la Comedia sin título, escrito años más tarde que El público y, también, leído ante sus amigos. En un principio, hubo testimonios, como el de Cipriano Rivas Cherif y el de José Luis Cano, que lo consideraron como el posible acto perdido de $E l$ público, pero pronto se rechazó tal opción ya que, aun teniendo mucho en común y gran conexión entre personajes, son dos obras diferentes en cuanto a que El público tiene una estructura cíclica, mientras que Comedia sin título, aun conservando un único acto, este finaliza con un espacio destruido y en ruinas, por tanto es difícil recuperar el primer momento de la obra. Y además, consideramos que $E l$ público es una obra acabada.

El tema común de ambas es la importancia de reformar el teatro y el papel que tiene el dramaturgo en ese cambio. Así como en El público, el Director, en el último acto, proclamará que «hay que destruir el teatro o vivir en el teatro», en Comedia sin título será, mediante la revolución, cómo el Autor conseguirá estos cambios, incluso destruyendo el propio espacio del teatro físico. En ambas obras, el espacio teatral no está limitado exclusivamente al escenario, facilitando así que la realidad forme parte de la representación, ya que Lorca quiere que la falsedad y la mentira desaparezcan de la escena. Busca que la sociedad se vea reflejada en la representación e, incluso, que el propio espectador forme parte de ella, dándole peso en la trama de las obras, porque no se limita sólo a unos cambios teatrales, quiere que esas transformaciones se vean reflejadas en la sociedad.

Otro de los temas, que comparten las dos obras, es la concepción de realidad y ficción que se vive en el teatro y su línea divisoria no definida. Así como en El público, las metamorfosis son las que nos ayudan a ir mostrando la realidad oculta en el traje y la 
máscara del papel que se nos ha sido asignado en la sociedad, en Comedia sin título es el propio Espectador quien asume su rol en la obra.

El público es una obra mucho más compleja ya que la relación del público con el teatro está presente desde el comienzo de esta exponiendo cómo el dramaturgo ha de mostrar el verdadero teatro al espectador y dejar de tener miedo al fracaso y al rechazo del público, ya que la función del autor es conseguir que el gusto teatral cambie. En El público son numerosos los personajes, y gran parte de ellos sufren metamorfosis al atravesar un biombo, presente en parte de la obra. Este elemento facilitará a desprenderse del traje y la máscara que nos oculta la verdadera identidad del sujeto. Estas transformaciones, cada vez más profundas, ayudarán a mostrar la realidad tanto del hombre como del teatro, por eso «el teatro bajo la arena» es el más profundo y verdadero, el que no se oculta tras la mentira ni la falsedad.

El texto de El público se caracteriza por la fragmentariedad de escenas. La historia se divide en dos secuencias principales: el teatro al aire libre y el teatro bajo la arena. Y estas, a su vez, en secuencias menores: el cuarto del Director, la Ruina romana, el muro de arena, el sepulcro de Julieta, la cama del Desnudo Rojo, los arcos y escaleras de un gran teatro, la portada de una universidad y la vuelta al cuarto del Director. El teatro al aire libre y el teatro bajo la arena son dos espacios opuestos entre sí, en los que Lorca introduce el biombo para comunicarlos. Este elemento también facilitará las diferentes transformaciones y metamorfosis de los diversos personajes.

El espacio de Comedia sin título viene relacionado con un teatro clásico a la italiana, en el que la acción transcurre tanto sobre el escenario como en el propio teatro. Aunque existen dos espacios diferenciados, uno en el interior del teatro, donde transcurre una representación, un ensayo y unas protestas por parte de los espectadores $\mathrm{y}$, otro exterior, que nos da información de lo que está ocurriendo en la realidad del momento.

Así como en El público existe una atemporalidad y se pierde el sentido durativo del tiempo, en el que Lorca elimina la linealidad del argumento por la simultaneidad de acciones, característica típica del cine en el que existe más libertad para el manejo de distintos niveles y tiempos, en Comedia sin título el único acto ocurre de manera lineal durante el tiempo que transcurre el estallido de la revolución. 
El público se ha representado en numerosas ocasiones. A principios de los años setenta, grupos universitarios y no profesionales lo llevaron a los escenarios. Al principio, de manera fragmentaria y, posteriormente, el texto total. Pero no fue hasta 1986, cuando Lluís Pasqual la estrena a nivel mundial. Una versión completa, en la que Pasqual, junto a Puigserver, transformaban el Teatro María Guerrero, eliminando las butacas de platea e integrando ese espacio al escenario. Más tarde, son numerosas las adaptaciones, traduciendo el texto al francés, al inglés, al portugués, etc. Incluso, en 2010, Mauricio Sotelo lo convirtió en ópera, estrenándose en el Teatro Real de Madrid. En 2015, Àlex Rigola nos presenta una nueva interpretación, en la que cubre todo el escenario de una arena roja, cuyos granos también rojos producían una inestabilidad, cuya simbología nos llevaba a la eliminación de los límites entre el teatro al aire libre y el teatro bajo la arena. La última puesta en escena, en 2018, estuvo a cargo de la compañía teatral japonesa Ksec Act, en la que todos sus personajes estaban interpretados por hombres, cuya inspiración se aproximaba a la propuesta de Mauricio Sotelo.

Respecto a Comedia sin título, al tratarse de un único acto y, por lo tanto, de corta duración, siempre ha sido representada acompañada de otros textos. En 1989, la familia de Lorca ofreció el texto para poderla estrenar a Lluís Pasqual, quien junto a la media hora que dura el primer acto, antepuso dos escenas de El sueño de una noche de verano de William Shakespeare, obra que la compañía de Comedia sin título iba a escenificar. Encontramos diferentes propuestas, como la del portugués Luis Miguel Cintra, en la que añadía otros textos lorquianos, principalmente de El público. Al existir una estética común entre El público y Comedia sin título se plantean montajes en los que pueden convivir los dos textos, como es el caso del polaco Pawel Nowicki.

En diciembre de 2016, la Comunidad de Madrid anunciaba que el dramaturgo Alberto Conejero finalizaría Comedia sin título. Bajo el título de El sueño de la vida, Conejero mantiene un diálogo con Lorca y propone un final, recurriendo a Poeta en Nueva York, El Diván del Tamarit, Amor de don Perlimplín con Belisa en su jardín y a entrevistas realizadas por el propio Lorca. El dramaturgo aprovecha la conexión de Comedia sin título con El público y utiliza referencias del mismo. El sueño de la vida fue llevada a escena por Lluís Pasqual. 
Para concluir, afirmamos que Lorca innovó teatralmente la escena española. Quería explorar una estética nueva con los temas vigentes en la sociedad y pedía que el teatro llegara a todo el público, que no fuera sólo exclusivo de una sociedad acomodada, solicitaba que el pueblo tomara asiento en platea y que la inocencia de una mirada limpia pudiera valorar más los textos clásicos, proyecto que llevó a cabo con $L a$ Barraca. Con obras innovadoras, como las dos que hemos estudiado y que representan un teatro nuevo en todos los ámbitos, quiso actualizar la temática y la visión del teatro, que exigía una revolución teatral y, para ello, exploró nuevos y atrevidos caminos llevando a escena esos cambios innovadores, tanto en el tratamiento del tema del amor como en el teatro en sí. Su intención era, en definitiva, mostrar el auténtico rostro de cada individuo, al desprenderse de la máscara social. Con la ayuda de una reforma teatral lo conseguiría. 


\section{6.- Bibliografía}

\section{1.- Fuentes primarias}

García Lorca, Federico (1929) 1985. Federico García Lorca. Escribe a su familia desde Nueva York y La Habana [1929-1930], editado por Christopher Maurer. Madrid: Poesía, Revista Ilustrada de Información Poética, 23-24.

- (1930) 1986. Obras completas. Tomo II, editado por Arturo del Hoyo. Madrid: Aguilar.

- (1930) 1987. El público. Madrid: Centro Dramático Nacional.

- (1935) 1989. Charla sobre Teatro. Fuente Vaqueros (Granada): Casa-Museo Federico García Lorca; Diputación Provincial de Granada.

- 1990. Bodas de sangre. Madrid: Ediciones Cátedra.

- 1993. Romancero gitano. Poeta en Nueva York. El público, editado por Derek Harris. Madrid: Taurus Ediciones.

- (1930) 1996. El público. Granada: Fundación Federico García Lorca; Editorial Comares.

- (1930) 2006. El público. Madrid: Editorial Espasa Calpe.

- (1996) 2006. Obras completas I. Teatro, editado por Miguel García-Posada. Barcelona: Círculo de Lectores.

- (1996) 2006. Obras completas II. Prosas, editado por Miguel García-Posada. Barcelona: Galaxia Gutenberg; Círculo de Lectores.

- (1996) 2006. Obras completas III. Prosas I, editado por Miguel García-Posada. Barcelona: Círculo de Lectores.

- (1996) 2006. Obras completas IV. Prosas II, editado por Miguel García-Posada. Barcelona: Círculo de Lectores.

- (1981) 2012. Romancero gitano, editado por Mario Hernández. Madrid: Alianza Editorial.

- (1929) 2013. Federico García Lorca en Nueva York y La Habana. Cartas y recuerdos, editado por Christopher Maurer y Andrew A. Anderson. Barcelona: Galaxia Gutenberg; Círculo de Lectores.

- (1930) 2015. El público: drama en cinco cuadros. Tarragona: Arola Editors. 
- (1930) 2016. Teatro completo. Barcelona: Galaxia Gutenberg.

- 2017. Treinta y una entrevistas a Federico García Lorca, editado por Andrés Soria Olmedo. Granada: Etnográfico ediciones.

- (1928) 2020. Las nanas. Canciones de cuna españolas. Logroño (La Rioja): Pepitas de Calabaza.

\section{2.- Entrevistas}

García Lorca, Federico. 1930. «Voces de desembarque. Veinte minutos de paseo con Federico García Lorca. Al gran poeta de la moderna estética se le antoja que Nueva York se parece mucho a Madrid. Tres libros, un drama...; especulaciones críticas y evocaciones musicales». Por Miguel Pérez Ferrero. Heraldo de Madrid, 9 de octubre de 1930: 8 .

- 1931. «Bajo la sonrisa de la zapatera prodigiosa. Margarita, Federico y Cipriano». Por César González Ruano. Crónica. Madrid, 11 de enero de 1931: 5.

- 1933a. "“Iré a Santiago...”: Poema de Nueva York en el cerebro de García Lorca». Por Luis Méndez Domínguez. Blanco y negro, $\mathrm{n}^{\circ} 2177,5$ de marzo de 1933: s/p.

- 1933b. «Charla amable con Federico García Lorca». Por José Salustiano Serna. Heraldo de Madrid, 11 de julio de 1933: 5.

- 1934. «Federico García Lorca y la tragedia». Por Juan Chabás. Luz, Madrid, 3 de julio de 1934: 7.

- 1934. «Los artistas en el ambiente de nuestro tiempo. El poeta Federico García Lorca espera para el teatro la llegada de la luz, de arriba, del paraíso». Por Alardo Prats. El Sol, Madrid, 15 de diciembre de 1934: 8.

- 1935. «Galería. Federico García Lorca, el poeta que no se quiere encadenar. Infancia de campo. El paisaje y el hombre. El teatro seudointelectual. América. Obra en proyecto. Una sana risa para todo». Por Ángel Lázaro Proel. La Voz, Madrid, 18 de febrero de 1935: 3.

— 1935. «Interviús de ESCENA. Federico García Lorca y el Teatro de hoy. La poesía dramática como obra perdurable. - Romanticismo, naturalismo, 
modernismo... - El autor de "Yerma" y el teatro romántico. - Un día siempre nuevo en una vida de renovación». Por Nicolás González-Deleito. Escena, 1. Madrid, mayo: 3,17.

- 1937. «Una conversación inédita con Federico García Lorca. Índice de las obras inéditas que ha dejado el gran poeta». Por Antonio Otero Seco. Mundo Gráfico, $n^{\circ} 1321,24$ de febrero de 1937: 10.

\section{3.- Fuentes secundarias}

Abad Nebot, Francisco. 1996. «El teatro del 27 (Lorca, Alberti, Salinas)». En Actas del X Congreso de Literatura Española Contemporánea (El universo creador del 27: literatura, pintura, música y cine), celebrado en Universidad de Málaga, del 11 al 15 de noviembre de 1996 coordinado por Enrique Baena Peña, 113-130.

Abella, Carlos. 2010. Dalí, Lorca y la Residencia de Estudiantes. Barcelona: Obra Social Fundación "la Caixa".

Adelantado Mateu, Eulalia. 1990. La Revolución Surrealista. Valencia: Servicio de Publicaciones Facultad de Bellas Artes; Universidad Politécnica de Valencia.

Ades, Dawn. 2013. «Una ola de sueños». En El surrealismo y el sueño, V.V.A.A. (eds.). [Congreso internacional celebrado en Madrid, 8 y 9 de octubre del 2013], 35-47. Madrid: Departamento de Publicaciones del Museo Thyssen.

Aguilera Sastre, Juan. 1992. «El debate sobre el Teatro Nacional durante la dictadura y la República». En El teatro en España. Entre la tradición y la vanguardia (1918-1939), editado por Dru Dougherty y $\mathrm{M}^{\mathrm{a}}$ Francisca Vilches de Frutos, 175-187. Madrid: Consejo Superior de Investigaciones Científicas; Fundación Federico García Lorca; Tabacalera, S.A.

Alberti, Rafael. (1959) 1976. La arboleda perdida. Libro I y II de Memorias. Barcelona: Editorial Seix Barral.

- 1984. Federico García Lorca (Poeta y Amigo). Granada: Biblioteca de la Cultura Andaluza. 
Alcón, Alfredo. 1987. «Crecer para merecer este texto». El público. Periódico mensual del Centro de Documentación Teatral: 11-12.

Aleixandre, Vicente. 1971. Poesía surrealista: Antología. Barcelona: Seix Barral Editores.

- (1944) 1978. Obras completas. Volumen II. Madrid: Aguilar.

- (1956) 1978. Mis poemas mejores. Madrid: Editorial Gredos.

- 2001. Correspondencia a la generación del 27 (1928-1984). Madrid: Editorial Castalia.

Alfaro, José María. 1978. «Hombres, aconteceres y nostalgias. Federico y "El público"». $A B C, 18$ de junio, 28.

Álvarez Barrientos, Joaquín. 2000. «Acreditar el costumbrismo». Ínsula, 637: 3-4.

Alonso, Dámaso. (1952) 1999. «Una generación poética (1920-1936)». En Las vanguardias literarias en España: bibliografía y antología crítica, editado por Harold Wentzlaff-Eggebert, 387-401. Madrid: Iberoamericana; Frankfurt am Main: Vervuert.

Amat, Frederic. 1998. «Notes de Viaje a la luna». Nexus. Revista semestral de cultura. Arts plàstiques, lletres, música, ciencia, 20: 22-29.

Anderson, Andrew A., ed. 1998. Diálogos de Federico García Lorca. Granada: Editorial Comares; Fundación Federico García Lorca.

— 2005. «“Corazón bleu y coeur azul”: Dalí y Lorca en diálogo». Scriptura, 18: $13-23$.

- 2018. La recepción de las vanguardias extranjeras en España. Cubismo, Futurismo, Dadá. Estudio y ensayo de bibliografia. Valencina de la Concepción (Sevilla): Editorial Renacimiento.

Aragon, Louis. 1968. «L'homme coupé en deux: un commentarie en marge des Champs magnétiques». Les lettres françaices, $\mathrm{n}^{\circ} 1233$ (9-15 May): 3-9. París.

— 2004. Una ola de sueños. Buenos Aires: Editorial Biblos.

Araquistáin, Luis. 1928. «Muchedumbres y minorías». El Sol, 10 de octubre, 8. 
Aranda Torres, Cayetano. 2001. «El duende: una aportación de Lorca a la estética contemporánea». En Almería hacia el 2005: Lengua, Historia, Arte, Economía y Turismo, editado por Rafael del Moral. Actas del XXXV Congreso Internacional de la Asociación Europea de Profesores de Español, celebrado en Almería, del 24 al 29 de junio de 2000: 101-112. Almería: Excmo. Ayuntamiento de Roqueta de Mar; AEPE.

Aszyk, Urszula. 1984. «El último Lorca, privilegio polaco». El público. Periódico mensual del Centro de Documentación Teatral: 24-25.

- (1983) 1986. «El teatro español frente a las vanguardias del siglo XX». En Actas del VIII Congreso de la Asociación Internacional de Hispanistas, celebrado en Brown University, Providence Rhode Island, del 22 al 27 de agosto de 1983. Volumen I: 175-83. Madrid: Ediciones Istmo.

- 1986. «Federico García Lorca y su teatro en Polonia». Cuadernos hispanoamericanos, Volumen I: Homenaje a García Lorca. Con Federico, en memoria, 433-434: 270-280.

Aub, Max. (1956) 1993. El teatro español sacado a la luz de las tinieblas de nuestro tiempo. Segorbe (Castellón): Archivo Biblioteca "Max Aub".

Aznar Soler, Manuel. 1993. Max Aub y la Vanguardia Teatral. (Escritos sobre teatro, 1928-1939). Valencia: Universitat de Valencia.

Aznar Soler, Manuel y Francesc Foguet i Boreu (eds.). 2018. Margarita Xirgu. Epistolario. Sevilla: Editorial Renacimiento.

Babín, María Teresa. 1976. Estudios lorquianos. Barcelona: Editorial Universitaria de la Universidad de Puerto Rico.

Baeza, Ricardo. 1926. «El trascendental problema del Teatro». El Sol, 19 de octubre, 1.

— 1927. «En torno al problema del teatro. Necesidad de una acción pública». El Sol, 22 de enero, 1.

Bajtin, Mijail. (1987) 1995. La cultura popular en la Edad Media y en el Renacimiento. El contexto François Rabelais. Madrid: Alianza Editorial. 
Balló, Tània. 2016. Las Sinsombrero. Sin ellas, la historia no está completa. Barcelona: Espasa.

Barranco, Justo. 2015a. «El Lorca irrepresentable». La Vanguardia, 12 de diciembre, 50 .

— 2015b. «En el cerebro de Lorca». Cultura|s La Vanguardia, 12 de diciembre, 30-31.

Bassets, Lluís. 1988. «El público de Lavelli». El País, 8 de enero.

Béhar, Henri. 1987. «Sueño y sonrisas, el teatro surrealista». En Surrealismo. El ojo soluble, editado por Jesús García Gallego, 353-358. Málaga: Revista Litoral.

Benach, Joan-Anton. 1986. «"El público” y el atractivo de un drama “imposible”». La Vanguardia, 14 de diciembre, 28.

— 2015. «El universo más íntimo de Lorca». La Vanguardia, Barcelona, 20 de diciembre, 62 .

Benítez Vega, Yolanda. 2013. «Pedro Salinas y el teatro desde dentro». Revista de Humanidades, núm. 20, acceso 3 de noviembre de 2018, http://www.revistadehumanidades.com/articulos/36-pedro-salinas-y-el-teatro-desdedentro

Benjamin, Walter. 2013. El surrealismo. Madrid: Casimiro libros.

Bianchi Ross, Ciro. 1997. García Lorca. Pasaje a La Habana. Barcelona: Puvill Libros, S.A.; Pablo de la Torriente Editorial.

Bilbatúa, Miguel. 1976. Teatro de agitación política 1933-1939. Rafael Alberti. Germán Bleiberg. Rafael Dieste. Miguel Hernández. María Teresa León. Madrid: Cuadernos para el diálogo, Edicusa.

Blecua, José Manuel. 1977. Sobre el rigor poético en España y otros ensayos. Barcelona: Editorial Ariel. 
Bodini, Vittorio. 1971. Los poetas surrealistas españoles, Barcelona: Cuadernos Ínfimos 26, Tusquets Editor.

Bozal, Valeriano. 1978. La construcción de la vanguardia (1850-1939). Madrid: Editorial Cuadernos para el Diálogo.

Bravo, Julio. 1987. «Lluís Pasqual, con Lorca en el telón y en la cabeza». ABC literario, 10 de enero, 8-9.

— 2015. «El Teatro Real lleva a la ópera el oscuro surrealismo de Lorca». $A B C, 23$ de febrero, 58 .

- 2016. «Comedia sin título. Acabar la obra de Lorca, un reto envuelto en polémica». $A B C, 21$ de diciembre de 2016: 50-51.

Breton, André. 1935. «Entrevista». Índice. Revista de cultura, acceso el 5 de mayo de 2020, https://kaosenlared.net/andr-breton-y-benjam-n-p-ret-en-tenerife-con-textossobre-la-visita/

- 1972. El surrealismo: Puntos de vista y manifestaciones. Barcelona: Barral Editores.

- 2001. Manifiestos del surrealismo. Buenos Aires (Argentina): Editorial Argonauta.

- 2005. Los vasos comunicantes. Madrid: Editorial Siruela.

- 2009. Manifiestos del surrealismo. Madrid: Visor Libros.

Breton, André et al. (1935) 1983. «Boletín Internacional del surrealismo». En El manifiesto surrealista escrito en Tenerife, editado por C.B. Morris, 17-31. La Laguna: Universidad de La Laguna Instituto de Estudios Canarios.

Brihuega, Jaime. 1983. «Fuentes literarias del surrealismo español 1924-1936». En El surrealismo, editado por Antonio Bonet Correa, 205-220. Madrid: Ediciones Cátedra.

Buñuel, Luis (1982) 2015. Mi último suspiro. Barcelona: Penguin Random House.

Caballero, Óscar. 1988. «Jorge Lavelli escandaliza a los espectadores parisinos con su puesta en escena de "El público"». La Vanguardia, 7 de enero de 1988, 24. 
Caballero, Ernesto. 2019. «Nuestro teatro. Capítulo 9: María Lejárraga». En CDN, 15 de mayo de 2019, https:/www.youtube.com/watch?v=eI-2LluTZB0

Calvo Serraller, Francisco. 1983. «La teoría artística del surrealismo». En El surrealismo, editado por Antonio Bonet Correa, 27-56. Madrid: Ediciones Cátedra.

Calzado, David. 2015. «Soleá angustiosa y contemporánea». ABC Cultural, 7 de febrero, 6-7.

Campoamor González, Antonio. 1986. «La Barraca y su primera salida por los caminos de España». Cuadernos Hispanoamericanos. Volumen II: Homenaje a García Lorca. Con Federico, en memoria, 435-436: 779-790.

Cano, José Luis. (1962) 1974. García Lorca. Barcelona: Ediciones Destino.

Cao, Antonio F. 1984. Federico García Lorca y las vanguardias; hacia el teatro. Londres: Tamesis Books Limited.

Cardona, Rodolfo y Anthony N. Zahares. 1989. «La función histórica del espectáculo: el arte de Valle-Inclán. Quimera, Cántico. Busca y rebusca de Valle-Inclán, editado por Juan Antonio Hormigón, 123-131. Madrid: Instituto Nacional de las Artes Escénicas y de la Música.

Carreira, Antonio. 2003. «Ojeada al teatro breve de Max Aub». En Colloque Internacional.Max Aub (1903-1972): Enracinements et deracinements, celebrado en París, del 27 al 28 de marzo de 2003, coordinado por Bernad Sicot, Luís Llorens y Joan Oleza, acceso el 12 de febrero de 2017, https://www.uv.es/entresiglos/max/index.htm

Carreño, Antonio. 1998. «Del lenguaje del humor al humor del lenguaje: el teatro de Miguel Mihura. Una poética de la parodia». En Vanguardia y Humorismo. La otra generación del 27, editado por Burguera Nadal, María Luisa y Santiago Fortuño Llorens, 11-35. Castelló de la Plana: Publicacions de la Universitat Jaume I.

Carrero Eras, Pedro. 2010. «Rubén Darío y el tema de la mujer mulata: "La negra dominga"». En Actas del XVI Congreso de la Asociación Internacional de Hispanistas. 
Nuevos caminos del hispanismo...Vol.2, celebrado en París, del 9 al 13 de julio de 2007, coordinado por Civil, Pierre y Françoise Crémoux, 217-224.

Castillo, David y Marc Sardà. 2007. Conversaciones con José «Pepín» Bello. Barcelona: Anagrama.

Cataslán García, Pedro. 2008. «Ak y la humanidad: Una obra bajo sospecha». Teatro: Revista de Estudios Culturales / A Journal of Cultural Studies, 22: 167-195.

Caudet, Francisco. 2017. «Introducción». En Luces de bohemia de Ramón del ValleInclán, 9-295. Madrid: Cátedra.

CDAEM. 2017. Recuerdos de un siglo de teatro. Colección teatral de prensa madrileña escogida (1851-1955), acceso el 14 de febrero de 2018, http://teatro.es/es/publicaciones/recuerdos-de-un-siglo-de-teatro-1851-1955

CDN. 2018. «El público (Una mirada al mundo)», acceso el 25 de marzo de 2018 https://cdn.mcu.es/espectaculo/publico-una-mirada-al-mundo/

Cernuda, Luis (1958) 1991. «Historial de un libro (La Realidad y el Deseo)». En La Realidad y el Deseo (1924-1962), 381-420. Madrid: Alianza Editorial.

Chabás, Juan. 1933. «El teatro en 1933». Luz, 25 de diciembre, 6.

- 1934a. «Una función del Club Anfistora». Luz, 14 de junio, 6.

- 1934b. «Vacaciones de La Barraca». Luz, Madrid, 3 de septiembre, 6.

Checa Puerta, Julio Enrique. 1992. «Los teatros de Gregorio Martínez Sierra». En El teatro en España. Entre la tradición y la vanguardia (1918-1939) editado por Dru Dougherty y $\mathrm{M}^{\mathrm{a}}$ Francisca Vilches de Frutos, 121-126. Madrid: Consejo Superior de Investigaciones Científicas; Fundación Federico García Lorca; Tabacalera, S.A.

Chevalier, Jean y Alain Gheerbrant. 1993. Diccionario de los símbolos. Barcelona: Editorial Herder.

Cintra, Luis Miguel. 1989. «La prueba de "El público”». El público. Periódico mensual del Centro de Documentación Teatral: 63-67. 
Conde Guerri, María José. 1998. «El teatro de humor de Enrique Jardiel Ponce». En Vanguardia y Humorismo. La otra generación del 27, editado por Burguera Nadal, María Luisa y Santiago Fortuño Llorens, 83-93. Castelló de la Plana: Publicacions de la Universitat Jaume I.

Conejero, Alberto. 2018a. El sueño de la vida. Madrid: Ediciones Cátedra.

— 2018b. «Alberto Conejero completa 'Comedia sin título' de Lorca». Por José Luis Romo. Papel. El Mundo, 13 de febrero: 21.

— 2019a. «El sueño de la vida, la comedia con título». El Cultural, 36-38.

— 2019b. «El sueño de la vida. Conejero y Lorca mano a mano». Por José R. Díaz Sande. Madrid Teatro, 30 de enero, acceso el 12 de febrero 2019 http://www.madridteatro.net/index.php?option=com_content\&view=article\&id= 5178:el-sueno-de-la-vida-conero-y-lorca-mano-amano\&catid $=314$ :entrevistas $\&$ Itemid $=286$

Correa, Gustavo. 1975. La poesía mítica de Federico García Lorca. Madrid: Editorial Gredos.

Correa Ramón, Amelina. 2019. «Geografías urbanas para un poeta surrealista». En Federico García Lorca: 100 años en Madrid (1919-2019), dirigido por Emilio Peral Vega, 111-138. Madrid: Consejería de Educación y Cultura de la Comunidad Autónoma de Madrid.

Cuadernos Pedagógicos. 1999. Fedra de Miguel de Unamuno. Cuadernos Pedagógicos 11. Centro Dramático Nacional. Temporada Teatral 98-99. https://cdn.mcu.es/escueladel-espectador/cuadernos-pedagogicos/

Darío, Rubén (1916) 1988. Historia de mis libros. Managua (Nicaragua): Editorial Nueva Nicaragua.

Delgado, María. 1998. «Los lorcas desconocidos de Lluís Pasqual». Teatro: Revista de Estudios Teatrales, 13-14: 387-406. 
Díaz, Elías. 1974. Notas para una historia del pensamiento español actual (1939-1973). Madrid: Edicusa; Editorial Cuadernos para el Diálogo.

Díaz Fernández, José. (1930) 1988. «La juventud y la política de El nuevo romanticismo». En Los novelistas sociales españoles (1928-1936). Antología, editado por José Esteban y Gonzalo Santonja, 25-27. Barcelona: Editorial Anthropos.

Díaz Roig, Mercedes (ed.). 1984. El Romancero viejo. Madrid: Ediciones Cátedra.

Díaz Sande, José Ramón. 1986. «El público. Lorca según Aráiz». Reseña de Literatura, Arte y Espectáculos, 168: 18-19.

Díaz Valera, Cristina. 2004. «El surrealismo visto y oído: el cine de Luis Buñuel». En Buñuel, siglo XXI, coordinado por Isabel Santaolalla et al., 79-88. Zaragoza: Prensas Universitarias de Zaragoza e Institución "Fernando el Católico".

Díaz-Plaja, Guillermo. (1931) 1975. «Superrealismo» En Vanguardismo y protesta en la España de hace medio siglo, editado por José-Carlos Mainer, 69-71. Barcelona: Ediciones Asenet.

Diego, Fernando de. 1995. «La fragmentación del espacio dramático en Comedia sin título y El público de Federico García Lorca». En El teatro de Lorca. Tragedia, drama y farsa, editado por Enrique Baena, 231-240. Málaga: Publicaciones del Congreso de Literatura Española Contemporánea; Universidad de Málaga.

Díez Canedo, Enrique. 1938. «Panorama del Teatro Español desde 1914 hasta 1936». Hora de España. Revista Mensual XVI: 13-52.

Díez de Revenga, Francisco Javier. 1974. «Dos poetas, dos ciudades (Lorca-Alberti: Nueva York-Roma)». En Estudios literarios dedicados al Prof. Mariano Baquero Goyanes, 55-68. Murcia: Universidad de Murcia.

Díez Taboada, Juan María. 1992. «Alejandro Casona en su primera época». En El teatro en España. Entre la tradición y la vanguardia (1918-1939) editado por Dru Dougherty y $\mathrm{M}^{\mathrm{a}}$ Francisca Vilches de Frutos, 111-119. Madrid: Consejo Superior de Investigaciones Científicas; Fundación Federico García Lorca; Tabacalera, S.A. 
Doménech, Ricardo. 2008. García Lorca y la tragedia española. Madrid: Editorial Fundamentos.

Dougherty, Dru. 1984. «Talía Convulsa: la crisis teatral de los años 20». En 2 ensayos sobre teatro español de los 20, editado por César Oliva, 85-157. Murcia: Cuadernos de Cátedra de Teatro de la Universidad de Murcia.

Eich, Christoph. 1970. Federico García Lorca poeta de la intensidad. Madrid: Editorial Gredos.

Einstein, Albert. 1999. Sobre la teoría de la relatividad especial y general. Barcelona: Ediciones Altaya.

Escala, Albert. 1988. "Lluís Pasqual dirige hoy el estreno mundial en Milán de "El público", de Federico García Lorca». La Vanguardia, 12 de diciembre, 45.

Escobar, José. 2000. «La crítica del costumbrismo en el XIX». Ínsula, 637: 5-7.

Espina, Antonio. 1934a. «Representaciones de la T.E.A.». Diablo Mundo, 5 de mayo, 9.

- 1934b. «Las tendencias exclusivistas en el teatro». Diablo Mundo, 26 de mayo, 10.

Eureka [seud.]. 2019. «Girls to the front! El primer ateneo feminista solo para mujeres». Agente Provocador, acceso el 30 de septiembre de 2019, http://www.agenteprovocador.es/publicaciones/girls-to-the-front

Feal Deibe, Carlos. 1973. Eros y Lorca. Barcelona: Edhasa.

— 1979. «Un caballo de batalla: el surrealismo español». Bulletin Hispanique, 81 (3-4): 265-279.

Felten, Uta. 1998. «El discurso onírico e intermedial en la obra de Federico García Lorca». En Nuevos caminos en la investigación de los años 20 en España, coordinado por Harald Wentzlaff-Eggebert. Tübingen (Alemania): Max Niemeyer Verlag, 77-81.

Fernández Cifuentes, Luis. 1986. García Lorca en el teatro: la norma y la diferencia. Zaragoza: Prensas Universitarias. 
Fernández Guerra, Jorge. 2019. «'Doña Francisquita’, otra vez será». El País, 16 de mayo, acceso el 10 de septiembre de 2019, https://elpais.com/cultura/2019/05/16/actualidad/1557998877_035758.html

Fernández Urtasun, Rosa. 1999. «La crítica ante el reto surrealista». RILCE, Revista de Filología Hispánica de la Universidad de Navarra, 15 (1): 357-368.

Ferrater Mora, José. 1991. Diccionario de Filosofía. E-J. Vol. 2. Barcelona: Círculo de Lectores.

Ferreyra, Marta Magdalena. 2004. Federico García Lorca: Un Poeta en Nueva York. Entre los laberintos de la modernidad y las huellas surrealistas. Mar de Plata (Argentina): Editorial Martin, colección La Pecera.

Floeck, Wildfried. 1996. «García Lorca y la vanguardia. Observaciones sobre el drama de García Lorca El público». Revista de Filología y Lingüística de la Universidad de Costa Rica, XXII (2): 27-44.

Fortuño Llorens, Santiago. 1995. «El neopopularismo de la generación del veintisiete (Federico García Lorca y Rafael Alberti)». Cuadernos para Investigación de la Literatura Hispánica, 20: 63-88.

- (ed.). 2003. Poesías asiáticas puestas en verso castellano por el Conde de Noroña. Madrid: Hiperión.

- 2008. «Jacinto Benavente (1866-1954) y el teatro modernista». EPOS, Revista de Filología U.N.E.D., Vol. XXIV: 85-101.

Fortuny, Carlos. 1930. «Vida, esplendor y muerte del llamado género chico». Heraldo de Madrid, 26 de septiembre, 8-9.

Frenk, Margit. 1987. Nuevo corpus de la antigua lírca popular hispánica, siglos XV a XVII, vol.2. Madrid: Editorial Castalia.

Fuente, Ricardo de la. (1992) 1999. «El imposible vanguardismo en el teatro español». En Las vanguardias literarias en España: bibliografia y antología crítica, editado por Harald Wentzlaff-Eggebert, 507-520. Madrid: Iberoamericana Editorial Vervuert. 
Fuentes, Ivette. 2004. «El surrealismo en Federico García Lorca: las voces de un duende». Moenia. Revista Lucense de Lingüistica y Literatura, vol. 10: 213-224.

Fuentes, Víctor. 2006. La marcha al pueblo en las letras españolas 1917-1936. Madrid: Ediciones de la Torre.

Galindo, Carlos. 1988. «"El Público”, premiado por la crítica especializada de París». $A B C, 8$ de junio, 101.

Gallego Morell, Antonio. 1955. «Un poeta reunido». ABC Madrid, 20 de enero, 13.

Gallén, Enric. 1992. «La reanudación del "Teatre Intim” de Adrià Gual, en los años veinte». En El teatro en España. Entre la tradición y la vanguardia (1918-1939) editado por Dru Dougherty y $\mathrm{M}^{\mathrm{a}}$ Francisca Vilches de Frutos, 165-173. Madrid: Consejo Superior de Investigaciones Científicas; Fundación Federico García Lorca; Tabacalera, S.A.

García, Carlos ed. 2009. Federico García Lorca/Guillermo de Torre. Correspondencia y amistad. Madrid: Iberoamericana Editorial Vervuert.

García, José. 2020. «El Público de Lorca: 40 años de la representación de un deseo irrepresentable». En El tercer puente, acceso el 8 de septiembre de 2020, https://eltercerpuente.com/publico-lorca-40-anos-la-representacion-deseoirrepresentable/

García, Josep Miquel. 2001. «Lleida, del surrealisme al logicofobisme». En Surrealismo y Literatura en España, editado por Jaume Pont. Actas del Congreso Internacional "Surrealismo y Literatura", celebrado en la Universitat de Lleida, del 17 al 19 de octubre de 2000, 221-230.

García, Obdulia A. 1930a. «La Conferencia de García Lorca». Diario de la Marina: periódico oficial del apostadero de La Habana, núm. 98, 9 de abril, 5.

- 1930b. «Sobre la Mecánica de la Poesía, habló García Lorca en Cienfuegos». Diario de la Marina: periódico oficial del apostadero de La Habana, núm. 155, 6 de junio, 20. 
García Gallego, Jesús. 1984. La recepción del surrealismo en España (1924-1931). (La crítica de las revistas literarias en castellano y catalán). Granada: Antonio Ubago.

- 1987. «Introducción». En Surrealismo. El ojo soluble, editado por Jesús García Gallego, 11-23. Málaga: Revista Litoral.

García Lorca, Francisco. 1981. Federico y su mundo. Madrid: Alianza Editorial.

García Martín, José Luis. 2004. Poetas del Novecientos: entre el Modernismo y la vanguardia: (Antología). Tomo II: De Guillermo de Torre a Ramón Gaya, acceso el 12 de enero de 2019, http://www.cervantesvirtual.com/nd/ark:/59851/mc64015.

García Montero, Luis. 1984. «Poeta y amigo: un caso extraño». En Federico García Lorca (Poeta y Amigo) de Rafael Alberti. Granada: Biblioteca de la Cultura Andaluza, $9-43$.

García Templado, José. 1980. El teatro anterior a 1939. Madrid: Editorial Cincel.

García-Posada, Miguel. 1981. Lorca: interpretación de Poeta en Nueva York. Madrid: Akal Universitaria.

— 1997. «Lorca y el surrealismo: una relación conflictiva». Barcarola. Revista de Creación Literaria. Dosier Generación del 27, 159-174. Albacete.

Gaviña, Susana. 2014. «García Lorca. "El público”, una ópera surrealista con aires mozartianos». $A B C, 11$ de agosto, 54-55.

Geist, Anthony Leo. 1987. «Los ángeles del infierno: una lectura de sobre los ángeles, de Rafael Alberti». En Surrealismo. El ojo soluble, editado por Jesús García Gallego, 224-241. Málaga: Revista Litoral.

— 1993. «El 27 y la vanguardia: una aproximación ideológica». Cuadernos Hispanoamericanos, 514-515: 53-64.

Di Gesù, Floriana. 2006. Vanguardia teatral española. Madrid: Editorial Biblioteca Nueva. 
Gibson, Ian. 1998. Vida, pasión y muerte de Federico García Lorca. Vol. 2. Barcelona: Plaza \& Janes.

Gimferrer, Pere. (1966). 2009. Arde el mar. Madrid: Cátedra.

Gómez de la Serna, Ramón. 1930. «En, por, sin, sobre el sin sombrerismo». El Sol, 24 de agosto, 1 .

Gómez-Navarro, Alicia. 2018. «Introducción». En Una habitación propia. Federico García Lorca en la Residencia de Estudiantes, 1919-1936, de Andrés Soria Olmedo. Madrid: Publicaciones de la Residencia de Estudiantes.

Gómez Torres, Ana María. 1992. «La resistencia a una teoría experimental del teatro concepto de recepción y lecturas de "El Público" de Federico García Lorca». Analecta malacitana: Revista de la Sección de Filología de la Facultad de Filosofía y Letras, Volumen 15, 1-2: 303-318

— 1997. «Historia de una recepción teatral: Los estrenos de El público, de Federico García Lorca». Revista de Literatura, Tomo 59, Número 118: 505-520.

- 1999. «El cine imposible de Federico García Lorca». En América en un poeta. Los viajes de Federico García Lorca al nuevo mundo y la repercusión de su obra en la literatura americana. Actas del Simposio Internacional LORCAAMÉRICA: CONTACTOS Y REPERCUSIÓN, celebrado en Sevilla, del 26 al 30 de octubre de 1998, editado por Andrew A. Anderson, 43-68. Sevilla: Universidad Internacional de Andalucía; Fundación Focus-Abenga.

Gómez Trueba, Teresa. 2003. «El libro de los sueños de Juan Ramón Jiménez y su problemática aproximación al surrealismo». Hispanic Review, Volumen 71, 3: 393-413.

González Luna, Alejandro. 2018. «La voz perdida de Lorca». Revista Global 81. Acceso 15 de febrero de 2020, http://revista.global/la-voz-perdida-de-lorca/

Goutier, Jean-Michel. 2005. «El surrealismo y los infortunios de la política». En París $i$ els surrealistes, 312-316. Barcelona: Centre de Cultura Contemporània de Barcelona; Institut d'Edicions de la Diputació de Barcelona. 
Gracia, Jordi. 2006. Estado y cultura. El despertar de una conciencia crítica bajo el franquismo, 1940-1962. Barcelona: Editorial Anagrama. Colección Argumentos.

Gracia, Jordi y Miguel Ángel Ruiz Carnicer. 2004. La España de Franco (1939-1975). Cultura y vida cotidiana. Madrid: Editorial Síntesis.

Greene, Brian Randolph. 2012. El universo elegante. Supercuerdas, dimensiones ocultas y la búsqueda de una teoría final. Barcelona: Crítica.

Gullón, Ricardo. (1975) 1982. «¿Hubo un surrealismo español?». En El Surrealismo, editado por Víctor García de la Concha, 77- 89. Madrid: Taurus Ediciones.

— 1987. «Radiografía de El público». En Surrealismo. El ojo soluble, editado por Jesús García Gallego, 72-87. Málaga: Revista Litoral.

Gutiérrez Flórez, Fabián. 1989. «Aspectos del análisis semiótico teatral». Estudios de literatura, 14: 75-92.

Haro Tegglen, Eduardo. 1987. «La tragedia del amor imposible». El País, 18 de enero, 25 .

Harretche, Estela. 1987. «Una cuestión debatida: el surrealismo de Lorca». En Surrealismo. El ojo soluble, editado por Jesús García Gallego, 259-267. Málaga: Revista Litoral.

— 1998. «Comedia sin título: análisis de una revolución teatral». En Actas del XII Congreso de la Asociación Internacional de Hispanistas vol. 4 (Del Romanticismo a la Guerra Civil), celebrado en University of Birmingham, Departmenf of Hispanic Studies, del 21 al 26 de agosto de 1995, coordinado por Derek Flitter, 180-185.

Hermenegildo, Alfredo. 1995. Juegos dramáticos de la locura festiva. Pastores, simples, bobos y graciosos del Teatro Clásico español. Palma de Mallorca: Oro Viejo.

Hernández, Luis Rafael. 2009. «Lorca en Cuba, Cuba en Lorca». Revista de Occidente, núm. 337: 69-83. 
Hernández, Mario. 1981. «Prólogo: Francisco y Federico García Lorca». En Federico y su mundo, de Francisco García Lorca, I-XXXVII. Madrid: Alianza Editorial.

— 1986. «Proyecto y catalogación». En Dibujos de Federico García Lorca. Barcelona: Ministerio de Cultura; Fundación para el apoyo de la Cultura, Fundaicón Federico García Lorca, Fundacio Caixa de Barcelona.

- 1992. «Falla, Lorca y Lanz en una sesión granadina de títeres (1923)». En El teatro en España. Entre la tradición y la vanguardia (1918-1939) editado por Dru Dougherty y $\mathrm{M}^{\mathrm{a}}$ Francisca Vilches de Frutos, 227-239. Madrid: Consejo Superior de Investigaciones Científicas; Fundación Federico García Lorca; Tabacalera, S.A.

Hernández Garrido, Raúl. 2018. «La dualidad de Lorca en la inmanencia del teatro japonés: El Público según Ksec Act». En Ovejas muertas, acceso el 25 de marzo de 2018, https://ovejasmuertas.wordpress.com/2018/02/17/la-dualidad-de-lorca-en-lainmanencia-del-teatro-japones-el-publico-segun-ksec-act/

Herrera Cepero, Daniel. 2017. «1925-1929: La gran ciudad en la probeta preneoyorquina de Lorca». Poéticas. Revista de Estudios Literarios, 5: 17-41.

Hevia, Elena. 2018. «La fotografía perdida de Lorca en Barcelona». El Periódico, acceso el 15 de enero de 2020, https://www.elperiodico.com/es/ocio-ycultura/20180820/fotografia-garcia-lorca-margarita-xirgu-6995706

Hormigón, Juan Antonio. 1972. «Del «Mirlo Blanco» a los Teatros Independientes». Cuadernos Hispanoamericanos, 260: 349-355.

- 1985a. «Escenificaciones en vida de Valle-Inclán». ADE Teatro. Revista de la Asociación de Directores de Escena de España. Núm. 137, octubre: 20-86.

— 1985b. «Consideraciones sobre las escenificaciones en vida de Valle-Inclán». ADE Teatro. Revista de la Asociación de Directores de Escena de España. Núm. 137, octubre: 88-93.

- 1997. Autoras en la Historia del Teatro Español (1500-1994). Volumen II. Madrid: Publicaciones de la Asociación de Directores de Escena de España. Serie: Teoría y Práctica del Teatro $n^{\circ} 11$. 
Hoyo, Arturo del. 1986. «Un poeta reunido». ABC Madrid, 17 de agosto, 133.

Huélamo Kosma, Julio. 1996. El teatro imposible de García Lorca (Estudio sobre El público). Granada: Cátedra Federico García Lorca, Universidad de Granada.

— 2003. «El arte escénico en la edad de plata». En Historia del teatro español. Tomo II. Del siglo XVIII a la época actual dirigido por Javier Huerta Calvo, 2528-2574. Madrid: Editorial Gredos.

Huerta Calvo, Javier. 2011. La Barraca: Teatro y Universidad. Ayer y hoy de una utopía. Madrid: Acción Cultural Española; Universidad Complutense de Madrid; ITEM: Instituto del Teatro de Madrid.

Huidobro, Vicente. (1917) 2002. Horizon Carré. Horizonte Cuadrado. París: Indigo \& côte-lemmes éditions, acceso el 25 de mayo de 2020, http://liseuse.harmattan.fr/978-2914378-27-7

Humbert, Juan. 2012. Mitología griega y romana. Barcelona: Editorial Gustavo Gili.

Hurtado Hernández, Mónica. 2019. Los cristobitas de Lorca. Tradición y vanguardia en los «puntales del teatro». Vigo (Pontevedra): Editorial Academia del Hispanismo, Biblioteca Theatralia, 33.

Ibáñez, Andrés. 2015. «Letra y música para Lorca». ABC cultural, 7 de febrero, 4-5.

Ibarlucía, Ricardo. 2004. «Estudio preliminar: Louis Aragon y el otro manifiesto del surrealismo». En Una ola de sueños, de Louis Aragon, 9-48. Buenos Aires (Argentina): Editorial Biblos.

Inglada, Rafael ed. 2017. Palabra de Lorca. Declaraciones y entrevistas completas. Barcelona: Malpaso Ediciones.

Ionesco, Eugène. 1975. «Ni un Dios, ni un demonio...». En ¿Quién conoce a Antonin Artaud? editado por Rodolfo Alonso. Buenos Aires (Argentina): Rodolfo Alonso Editor. 
Jaén Urban, Gaspar. 2014. El paisaje urbano de Nueva York e la obra escrita de Federico García Lorca. San Vicente del Raspaig (Alicante): Publicaciones Universidad de Alicante.

Jerez-Farrán, Carlos. (1991) 1999. «Decadencia y revitalización en el teatro español de los años 20». En Las vanguardias literarias en España: bibliografía y antología crítica, editado por Harald Wentzlaff-Eggebert, 521-541. Madrid: Iberoamericana Editorial Vervuert.

Jiménez, Juan Ramón. 1967. Estética y ética estética: crítica y complemento. Madrid: Aguilar.

Jiménez Gómez, Hilario. 2005. «García Lorca, Gallo. Dos gallos y un pavo. Historia de una doble revista (que no una granja)». En Revistas literarias españolas del siglo XX (1919-1975). Volumen I (1919-1975), editado por Manuel J. Ramos Ortega, 281-298. Madrid: Ediciones Ollero y Ramos.

Julià, Jordi. 2001. «Comedia sin título de Federico García Lorca: un "drama social” de crítica teatral». En Literatura y sociedad, el papel de la literatura en el siglo XX: [I Congreso Nacional Literatura y Sociedad], 265-280. A Coruña: Universidade da Coruña.

Katona, Eszter. 2015. «Nueva York en un poeta». Colindancias: Revista de la Red de Hispanistas de Europa Central, núm. 6: 117-135.

Kronik, John W. 1992. «Vanguardia y traición en el teatro de Jacinto Grau». En El teatro en España. Entre la tradición y la vanguardia (1918-1939) editado por Dru Dougherty y $\mathrm{M}^{\mathrm{a}}$ Francisca Vilches de Frutos, 79-87. Madrid: Consejo Superior de Investigaciones Científicas; Fundación Federico García Lorca; Tabacalera, S.A.

Lautréamont. 2012. Los Cantos de Maldoror. Madrid: Ediciones Cátedra.

Laffranque, Marie. 1987. «Estudio preliminar y notas». En Teatro inconcluso de Federico García Lorca, 7-99. Granada: Universidad de Granada; Fundación Federico García Lorca. 
Leante, César. 1986. «Federico en Cuba». Cuadernos Hispanoamericanos. Volumen I: Homenaje a García Lorca. Con Federico, en memoria, 433-434: 235-240.

León, José Javier. 2018a. El duende. Hallazgo y cliché. Sevilla: Athenaica Ediciones Universitarias.

— 2018b. Juego y Teoría del duende de Federico García Lorca. Estudio y edición critica anotada. Sevilla: Athenaica Ediciones Universitarias.

- 2020. «Una conferencia en clave dulce. Nota a esta edición». En Las nanas. Canciones de cuna españolas de Federico García Lorca, 9-32. Logroño (La Rioja): Pepitas de Calabaza.

López Mozo, Jerónimo. 2005. «Comedia sin título. Las entrañas del teatro». Madrid Teatro, el Portal de Arte Escénico, acceso el 16 de septiembre de 2019, http://www.madridteatro.net/index.php?option=com_content\&view=article\&id=1783:c omedia-sin-titulo-critica\&catid $=61$ :critica $\&$ Itemid $=16$

López Ojeda. Leandro. 2000. «Hacia el fin del teatro y del arte». En La estética de la transgresión. Revisiones críticas del teatro de vanguardia, coordinado por Antonio Ballesteros Gonzáles y Cécile Vilvandre de Sousa, 87-95. Cuenca: Ediciones de la Universidad de Castilla-La Mancha.

Loynaz, Dulce María. 1987. «Yo no destruí el manuscrito de "El público”». $A B C, 30$ de mayo, 42.

— 1989. «El manuscrito». $A B C, 8$ de octubre, 24.

Lunatxarski, Anatol V. (1921-24) 1972. Teatre i acció popular. Valencia: Tres i Quatre. Machado, Antonio. (1935) 2001. Juan de Mairena. Madrid: Bibliotex.

Mahieu, José Agustín. 1986. «García Lorca y su relación con el cine». Cuadernos Hispanoamericanos. Volumen I: Homenaje a García Lorca. Con Federico, en memoria, 433-434: 119-128.

Mainer, José Carlos. 2013. Historia de la literatura española. Vol.6. Modernidad y nacionalismo 1900-1939. Barcelona: Editorial Crítica. 
Mañero Rodicio, Javier. 2012. "Acción surrealista y medios de intervención. El surrealismo en las revistas, 1919-1929». De Arte: Revista de Historia del Arte, núm. 11: $185-222$.

- 2013. «Acción surrealista y medios de intervención. El surrealismo en las revistas, 1930-1939». Anales de la Historia del Arte, Vol. 23: 209-258.

Marinello, Juan. 1964. Contemporáneos. Noticia y memoria. Las Villas (Cuba): Universidad Central de las Villas, Editora del Consejo Nacional de Universidades.

- 1975. Contemporáneos. Noticia y memoria II. La Habana (Cuba): Ediciones UNEAC.

Martín, Eutimio. 1985. «El teatro imposible de Federico García Lorca en escena en Polonia». Quimera. Revista de literatura. Núm. 44: 56-59.

Martín Casares, Aurelia. 2011. «Comba y Dominga: La imagen sexualizada de las negroafricanas en la literatura de cordel en la España Moderna». En La esclavitud negroafricana en la historia de España, 173-188. Albolote (Granada): Comares.

Martínez Carmenate, Urbano. 2002. García Lorca y Cuba: todas las aguas. La Habana (Cuba): Centro de Investigación y Desarrollo de la Cultura Cubana Juan Marinello.

Martínez Nadal, Rafael. (1970) 1974. El público. Amor y muerte en la obra de Federico García Lorca. México D. F.: Editorial Joaquín Mortiz.

- 1975. «Introducción». En Autógrafos I. Poemas y prosas, de Federico García Lorca, XI-XXXVI. Oxford: The Dolphin Book Co. Ltd.

- 1976. «Introducción». En Autógrafos II. El público, de Federico García Lorca, VII-X. Oxford: The Dolphin Book Co. Ltd.

- 1978a. «Introducción». En El público y Comedia sin título. Dos obras teatrales póstumas, de Federico García Lorca, 11-29. Barcelona: Seix Barral.

— 1978b. «Guía al lector de "El público"». En El público y Comedia sin título. Dos obras teatrales póstumas, de Federico García Lorca, 169-269. Barcelona: Seix Barral. 
- 1979. «Estudio». En Autógrafos III. Así que pasen cinco años, de Federico García Lorca, 229-248. Oxford: The Dolphin Book Co. Ltd.

Maurer, Christopher. 1985. «Nueva York, 1930» En Escribe a su familia desde Nueva York y La Habana [1929-1930], de Federico García Lorca, 131-142. Madrid: Poesía, Revista Ilustrada de Información Poética, número 23-24.

- 2018. «Biografía, una vida en breve». En Fundación Federico García Lorca, acceso el 26 de junio de 2018, http://www.garcia-lorca.org/Federico/Biografia.aspx.

Maurer Christopher y Andrew A. Anderson. 2013. Federico García Lorca en Nueva York y La Habana. Cartas y recuerdos. Barcelona: Galaxia Gutenberg; Círculo de Lectores.

Medina, Pablo L. 2017. «Los títeres de Federico García Lorca en el Teatro Avenida de Buenos Aires. 25 de marzo de 1934». En Titeresante. Revista de títeres, sombras y marionetas, acceso 14 de junio de 2019, http://www.titeresante.es/2017/05/los-titeresde-federico-garcia-lorca-en-el-teatro-avenida-de-buenos-aires-25-de-marzo-de-1934por-pablo-l-medina/.

Medina Vicario, Miguel. 1989. «Comedia sin título. Lo último y lo primero de Lluís Pasqual». Reseña, núm 198, 17.

Merino, Ángela. 1978. «Historia de una desilusión: 1927, los surrealistas y el P.C. francés». Tiempo de Historia, Num. 42, Año IV: 94-97.

Miguel Martínez, Emilio de. 1998. «El humor de Miguel Mihura y el teatro del absurdo». En Vanguardia y Humorismo. La otra generación del 27, editado por Burguera Nadal, María Luisa y Santiago Fortuño Llorens, 121-141. Castelló de la Plana: Publicacions de la Universitat Jaume I.

Mignon, Paul-Louis. (1969) 1973. Historia del teatro contemporáneo. Madrid: Ediciones Guadarrama.

Millán, María Clementa. 1986a. «El público, de García Lorca: obra de hoy». En Cuadernos Hispanoamericanos. Volumen I: Homenaje a García Lorca. Con Federico, en memoria, 433-434: 399-407. 
- 1986b. «Líneas de una biografía». En Dibujos de Federico García Lorca, catalogado por Mario Hernández, 55-62. Barcelona: Ministerio de Cultura; Fundación para el apoyo de la Cultura; Fundación Federico García Lorca; Fundació Caixa de Barcelona.

- (1987) 2012. «Introducción». En El público, de Federico García Lorca, 9-115. Madrid: Ediciones Cátedra.

Miquis. Alejandro. 1998. «El Teatro Nacional». En La renovación teatral española de 1900: Manifiestos y otros ensayos, editado por Jesús Rubio Jiménez, 228-231. Madrid: Publicaciones de la Asociación de Directores de Escena de España, Serie: «Debate» ${ }^{\circ}$ 8.

Molina Barea, María del Carmen. 2012. «Buster Keaton y el surrealismo en la Residencia de Estudiantes. Razones de una confluencia». En Archivo Español de Arte, LXXXVI, 341: 29-48.

Molina, Doblas, Sara. 2019. «Comedia sin título». En 37 Festival de Otoño. 2019, $\begin{array}{lllll}\text { acceso } & \text { el de diembre }\end{array}$ http://www.madrid.org/fo/2019/comediasintitulo.html

Molina Fajardo, Eduardo. 1990. Manuel de Falla y el «Cante Jondo». Granada: Servicio de Publicaciones de la Universidad de Granada; Campus Universitario de Cartuja.

Monegal, Antonio. 1987. «Entre el papel y la pantalla: Viaje a la luna de Federico García Lorca». En Surrealismo. El ojo soluble, editado por Jesús García Gallego, 242258. Málaga: Revista Litoral.

- 1994. «Introducción». En Viaje a la luna (guión cinematográfico) de Federico García Lorca, 7-55. Valencia: Pre-Textos.

- (2000) 2017. «Una revolución teatral inacabada». En El público. El sueño de la vida, de Federico García Lorca, 9-49 Madrid: Alianza editorial.

Monleón, José. 1975. El teatro del 98 frente a la sociedad española. Madrid: Ediciones Cátedra. 
- 1976. «El teatro de los Machado». Cuadernos Hispanoamericanos, 304-307: 1064-1087.

— 1979. «Estreno de "El público”, de García Lorca». Triunfo, n 867: 47.

Morales y Marín, José Luis. 1984. Diccionario de iconografía y simbología. Madrid: Taurus Ediciones.

Morelli, Gabriele. 2007. La generación del 27 y su modernidad. Málaga: Centro Cultural Generación del 27.

Morris, C.B. (1972) 2000. El surrealismo y España. 1920-1936. Madrid: Editorial Espasa Calpe.

- 1983. El manifiesto surrealista escrito en Tenerife. La Laguna: Universidad de La Laguna Instituto de Estudios Canarios.

- 2000. Lorca entre la muchedumbre de Nueva York. Santander: Sociedad Menéndez Pelayo.

Muñoz, Matilde. 1946. Historia de la zarzuela y el género chico. Madrid: Editorial Tesoro.

Nadeau, Maurice. 1972. Historia del surrealismo. Barcelona: Ediciones Ariel.

Navas Ocaña, Isabel. 2009. «La crítica al surrealismo en España». Bulletin Hispanique: $551-580$.

Neira, Julio. 2005. «Litoral, la revista emblemática del 27». Revistas literarias españolas del siglo XX (1919-1975). Volumen I (1919-1975), editado por Manuel J. Ramos Ortega, 211-240. Madrid: Ediciones Ollero y Ramos.

Nicoll, Allardyce. 1977. El mundo de Arlequín. Estudio crítico de la Commedia dell'arte. Barcelona: Barral Editores.

Nieva de la Paz, Pilar. 1992. «Tradición y Vanguardia en las autoras teatrales de preguerra: Pilar Millan Astray y Halma Angelico». En El teatro en España. Entre la tradición y la vanguardia (1918-1939), editado por Dru Dougherty y Ma Francisca 
Vilches de Frutos, 429-448. Madrid: Consejo Superior de Investigaciones Científicas; Fundación Federico García Lorca; Tabacalera, S.A.

- 1993. Autoras dramáticas españolase entre 1918 y 1936. Madrid: Consejo Superior de Investigaciones Científicas.

- 1997. «Las autoras teatrales españolas frente al público y la crítica (19181936)». En Actas del XI Congreso de la Asociación Internacional de Hispanistas, Vol. 2 (La mujer y su representación en las literaturas hispánicas), coordinado por Juan Villegas, 129-139. Irvine (Estados Unidos): Asociación Internacional, de Hispanistas.

- 2018. «María Francisca Clar Margarit». En Real Academia de la Historia, acceso el 1 de septiembre de 2018, http://dbe.rah.es/biografias/63222/mariafrancisca-clar-margarit.

Nowicki, Pawel. 2012. Comedia sin título y El público. Acceso el 16 de septiembre de 2019, https://www.cancilleria.gov.co/sites/default/files/Programa\%20de\%20mano.pdf

Nuez, Sebastián, de la. 1988. «La poesía de la revista «Caballo verde» de Neruda (1935-1936)». En Anales de Literatura Hispanoamericana, vol. 7: 206-257.

O’Connor, Patricia W. 2000. «María Martínez Sierra: Verdad y Literatura». En Autoras y Actrices en la historia del teatro español, editado por Luciano García Lorenzo, 201215. Murcia: Festival de Almagro; Universidad de Murcia.

Ojeda, Alberto. 2019. «El sueño de la vida, la comedia con título». El Cultural, 36-38.

Oliva, César y Francisco Torres Monreal. 1994. Historia básica del arte escénico. Madrid: Ediciones Cátedra.

Onís, Carlos Marcial, de. 1974. El surrealismo y cuatro poetas de la generación del 27 (Ensayo sobre extensión y límites del surrealismo en la generación del 27). Madrid: Ediciones José Porrúa Turanzas, S.A.

Ordóñez, Marcos. 2015. «Tiritando bajo el polvo». El País, Babelia, Madrid, 14 de noviembre, 17.

— 2019. «Una fiera belleza». Babelia, El País, 26 de enero, 12. 
Ortega, José. «El gitano y el negro e la poesía de García Lorca». En Cuadernos Hispanoamericanos, Volumen I: Homenaje a García Lorca. Con Federico, en memoria, 433-434: 145-168.

Ortega y Gasset, José. 1915. Vieja y nueva política.San José (Costa Rica): Colección Ariel.

— (1937) 2012. La rebelión de las masas. Madrid: Espasa Libros.

Osuna, Rafael. 1978. «Las revistas españolas durante la República (1931-1936). Idiologies and Literature, 5: 47-54.

Otero Urtaza, Eugenio. 2008. «Misiones y misioneros en la cultura rural republicana. Aportaciones al estudio de las Misiones Pedagógicas». En La República de les Lletres. Les Lletres de la República, editado por Colón Domènech, Germà y Santiago Fortuño Llorens, 209-226. Castelló de la Plana: Fundació Germà Colón i Domènech; Publicacions de la Universitat Jaume I.

Pasqual, Lluís. 1987. «La verdad del amor y del teatro». El público. Periódico mensual del Centro de Documentación Teatral: 6-9.

- 2016. De la mano de Federico. Barcelona: Arpa Editores.

- 2019a. «El sueño de la vida. Conejero y Lorca mano a mano». Por José R. Díaz Sande. En Madrid Teatro, 30 de enero, acceso el 12 de febrero 2019 http://www.madridteatro.net/index.php?option=com_content\&view=article\&id= 5178:el-sueno-de-la-vida-conero-y-lorca-mano-amano\&catid $=314$ :entrevistas $\&$ Itemid $=286$

— 2019b. «La puesta en escena. El director Lluís Pasqual». La Diabla. Revista pedagógica del teatro español, núm. 47: 14-16, acceso el 20 de junio de 2019 https://www.teatroespanol.es/sites/default/files/201901/La\%20Diabla\%2047\%20OK.pdf

— 2020. «Entrevista a Lluís Pasqual: "En política hay que tener capacidad para el engaño"». Por Salvador Sostres. ABC Cultural, 4 de julio de 2020: 3-5. 
Pedrosa, José Manuel. 1998. «Pámpanos, Cascabeles, y las simbología erótica en El público de Lorca». Teatro: Revista de Estudios Teatrales, 13-14: 371-386.

Peláez Martín, Andrés. 2000. «Escenografía teatral española: entre la tradición y la vanguardia». En La estética de la transgresión. Revisiones críticas del teatro de vanguardia, coordinado por Antonio Ballesteros Gonzáles y Cécile Vilvandre de Sousa, 99-111. Cuenca: Ediciones de la Universidad de Castilla-La Mancha.

- 2003. «El arte escénico en la Edad de Plata». En Historia del teatro español. Tomo II. Del siglo XVIII a la época actual dirigido por Javier Huerta Calvo, 2201-2238. Madrid: Editorial Gredos.

Pellón, Gustavo. 1999. «Góngora, Lorca, Lezama y la imagen poética». En América en un poeta. Los viajes de Federico García Lorca al Nuevo Mundo y la repercusión de su obra en la literatura americana, editado por Andrew A. Anderson, 131-140. Sevilla: Universidad Internacional de Andalucía; Fundación Focus-Abengoa.

Peral Vega, Emilio. 2018. «Introducción». En Comedia sin título (seguida de El sueño de la vida de Alberto Conejero) de Federico García Lorca, 9-71. Madrid: Ediciones Cátedra.

Perales, Liz. 2019. «Doña Francisquita ante la cólera del español sentado». El Cultural, acceso el 31 de mayo de 2019, https://elcultural.com/dona-francisquita-ante-la-coleradel-espanol-sentado

Pérez Bazo, Javier. 1993. «Introducción en tres actos». En El teatro español sacado a la luz de las tinieblas de nuestro tiempo de Max Aub, 7-39. Segorbe (Castellón): Archivo Biblioteca "Max Aub".

Pérez Coterillo, Moisés. 1987. «El público: amor, teatro y caballos». El público. Periódico mensual del Centro de Documentación Teatral: 4-5.

- 1988a. «Lorca en La Colina de Lavelli». El público. Periódico mensual del Centro de Documentación Teatral: 3-6.

— 1988b. «Jorge Lavelli: “El teatro es el desorden». El público. Periódico mensual del Centro de Documentación Teatral: 6-11. 
Pérez Galdós, Benito. 1998. «Viejos y nuevos moldes». En La renovación teatral española de 1900: Manifiestos y otros ensayos, editado por Jesús Rubio Jiménez, 84-90. Madrid: Publicaciones de la Asociación de Directores de Escena de España, Serie: «Debate» $n^{\circ} 8$.

Pérez Minik, Domingo. 1974. «La conquista surrealista de Tenerife». Ínsula, núm. 137: 8.

- 1975. Facción española surrealista de Tenerife. Barcelona: Tusquets Editor.

Pérez-Rasilla, Eduardo. 1997. Antología del teatro breve español (1879-1940). Madrid: Editorial Biblioteca Nueva.

Pérez-Villanueva Tovar, Isabel. 1990. «El liberalismo institucionalista en la Residencia de Estudiantes: una ética, una estética». Studia histórica. Historia contemporánea, 8: 77-88.

Personneaux Conesa, Lucie. 1986. «El surrealismo en España: espejismos y escamoteo». En Actas del VIII Congreso de la Asociación Internacional de Hispanistas: celebrado en Brown University, Providence Rhode Island, del 22 al 27 de agosto de 1983. Volumen II: 447-454. Madrid: Ediciones Istmo.

Pirandello, Luigi. 1999. Seis personajes en busca de autor. Madrid. Unidad Editorial.

Pistolesi, Alejandro. 1986. «Calurosa cosecha de aplausos y elogios en el estreno mundial de "El público" en Milán». $A B C$, Madrid, 12 de diciembre, 91.

Plaza Chillón, José Luis. 2001. Clasicismo y vanguardia en La Barraca de F. García Lorca, 1932-1937 (De pintura y teatro). Granada: Comares.

— 2014. «Una proyección gráfica de la palabra: Los dibujos "abstractos" y vibracionistas de Federico García Lorca». De Arte, 13: 216-239.

— 2019. «La dimensión simbólica de los dibujos lorquianos». En Federico García Lorca: 100 años en Madrid (1919-2019), dirigido por Emilio Peral Vega, 263284. Madrid: Consejería de Educación y Cultura de la Comunidad Autónoma de Madrid. 
Pomés, Poldo y Mas de Xaxàs, Xavier (dirs.). 2020. «Reus, París, Londres. El teatro libre de Lluís Pasqual». En Imprescindibles, acceso el 28 de septiembre de 2020 https://www.rtve.es/alacarta/videos/imprescindibles/imprescindibles-reus-paris-londresteatro-libre-1luis-pasqual/5671845/

Porto, Carlos. 1989. «"El público”, de García Lorca, por el Teatro da Cornucopia». El público. Periódico mensual del Centro de Documentación Teatral: 62-63.

Prats, Alardo. 1934. «Los artistas en el ambiente de nuestro tiempo. El poeta Federico García Lorca espera para el teatro la llegada de la luz, de arriba, del paraíso. En cuanto los de arriba bajen al patio de butacas todo estará resuelto». El Sol, 15 de diciembre, 8 .

Puigserver, Fabià. 1987. «Lo importante es el viaje». El público. Periódico mensual del Centro de Documentación Teatral: 9-11.

Quiles Faz, Amparo. 2018. «Dolores Ramos de la Vega». En Real Academia de la Historia, acceso el 29 de agosto de 2018, http://dbe.rah.es/biografias/63122/doloresramos-de-la-vega.

Quiñonero, Juan Pedro. 1988. «Lluís Pasqual pisa el área de Jorge Lavelli: "El Público vuelve a la escena de París"». $A B C$, Madrid, 8 de abril, 91.

Rabassó, Carlos A. 1995. «Federico García Lorca entre el jazz, el flamenco y el afrocubanismo». En Actas del XII Congreso de la Asociación Internacional de Hispanistas, Vol. IV. Del romanticismo a la Guerra Civil, editadas por Ward, Aengus M., Jules Whicker y Derek W. Flitter, 208-218.

Rabassó, Carlos A. y Francisco Javier Rabassó. 1998. Granada - Nueva York - La Habana. Federico García Lorca entre el flamenco, el jazz y el afrocubanismo. Madrid: Ediciones Libertarias-Prodhufi, S.A.

Rabourdin, Dominique. 2005. «Las revistas del surrealismo». En París $i$ els surrealistes, 317-321. Barcelona: Centre de Cultura Contemporània de Barcelona; Institut d'Edicions de la Diputació de Barcelona.

Ramos Ortega, Manuel J. 2005. «La revista Caballo Verde para la Poesía (19351936)». En Revistas literarias españolas del siglo XX (1919-1975). Volumen I (1919- 
1975), editado por Manuel J. Ramos Ortega, 377-394. Madrid: Ediciones Ollero y Ramos.

Rebollo Calzada, Mar. 2004. «La crisis teatral de los años veinte en España». Teatro. Revista de Estudios Culturales: 55-68.

Revilla, Federico. (1990) 2009. Diccionario de Iconografia y Simbología. Madrid: Ediciones Cátedra.

Residencia de Estudiantes. 2010a. 100\% Residencia. La Residencia de Estudiantes compleix 100 anys 1910-2010. Barcelona: Generalitat de Catalunya; Madrid: Residencia de Estudiantes.

— 2010b. «100\% Residencia. Una tradición recuperada». En Residencia de Estudiantes, acceso el 20 de marzo de 2018, http://www.residencia.csic.es/100residenciam/citas/index.htm.

Rey Faraldos, Gloria. 1992. «El teatro de las misiones pedagógicas». En El teatro en España. Entre la tradición y la vanguardia (1918-1939), editado por Dru Dougherty y M Francisca Vilches de Frutos, 153-164. Madrid: Consejo Superior de Investigaciones Científicas; Fundación Federico García Lorca; Tabacalera, S.A.

Rigola, Àlex. 2015. «Vómito a propósito de EL PÚBLICO». Cultura|s La Vanguardia, 12 de diciembre, $28-29$.

Ríos, Fernando, de los. 1932. «Discurso de D. Fernando de los Ríos». Luz, 24 de marzo, $10-11$.

Ríos Carratalá, Juan Antonio. 1992. «Arniches, los límites de un autor de éxito». En El teatro en España. Entre la tradición y la vanguardia (1918-1939) editado por Dru Dougherty y $\mathrm{M}^{\mathrm{a}}$ Francisca Vilches de Frutos, 103-109. Madrid: Consejo Superior de Investigaciones Científicas; Fundación Federico García Lorca; Tabacalera, S.A.

— 2003. «Arniches y el teatro cómico». En Historia del teatro español. Tomo II. Del siglo XVIII a la época actual, dirigido por Javier Huerta Calvo, 2393-2418. Madrid: Editorial Gredos. 
Rivas Cherif, Cipriano. 1931. «Bajo la sonrisa de la zapatera prodigiosa. Margarita, Federico y Cipriano». Por César González Ruano. Crónica. Madrid, 11 de enero de 1931: 5.

Rodrigo, Antonina. 1975. García Lorca en Cataluña. Barcelona: Editorial Planeta.

- 1980. Margarita Xirgu. Barcelona: Plaza y Janés.

— 1985. «"Doña Rosita” cumple 50 años de soltería». El País, 12 de diciembre: 34.

Rodríguez Lafora, Gonzalo. 1932. «Misiones Pedagógicas. Los titiriteros de Esquivias». Luz, Madrid, 16 de mayo, 3.

Rodríguez Rapún, Rafael. 1935. «El teatro universitario. La Barraca». Almanaque Literario: 275-277.

Rojas, Fernando, de. 1986. La Celestina, editado por Francisca Domingo del Campo. Madrid: Biblioteca Didáctica Anaya.

Romero Ferrer. Alberto. 2004. «De Araquistáin a Ricardo Baeza: la batalla teatral en la España de los locos años veinte». Assaig de teatre. Revista de l'associació d'investigació i experimentació teatral, 42: 181-189.

Rojas Yedra, Rubén. 2014. «Lorca en imágenes. El paseo de Buster Keaton». Castilla. Estudios de Literatura, 5: 168-199.

Roger, Juan. 1956. El surrealismo francés. Madrid: Editorial Escelicer.

Rojas, Waldo. 2012. Cronología del movimiento surrealista: síntesis comentada. Santiago (Chile): Ediciones Universidad Católica de Chile.

Romero Ferrer, Alberto. 2003. «El género chico». En Historia del teatro español. Tomo II. Del siglo XVIII a la época actual dirigido por Javier Huerta Calvo, 2031-2050. Madrid: Editorial Gredos.

Rubia Barcia, José. 1986. «Ropaje y desnudez de El público». Cuadernos Hispanoamericanos. Volumen I: Homenaje a García Lorca. Con Federico, en memoria, 433-434: 385-397. 
Rubio Jiménez, Jesús. 1982. Ideología y teatro en España: 1890-1900. Zaragoza: Departamento de Literatura española Universidad de Zaragoza; Libros Pórtico.

- 1998. «La renovación teatral española de 1900». En La renovación teatral española de 1900: Manifiestos y otros ensayos, editado por Jesús Rubio Jiménez, 21-55. Madrid: Publicaciones de la Asociación de Directores de Escena de España, Serie: «Debate» $n^{\circ} 8$.

Ruiz-Copete, Juan de Dios. 2002. La otra Generación del 27. Los narradores. Málaga: Centro Cultural de la Generación del 27.

Ruiz Ramón, Francisco. 1986. Historia del teatro español. Siglo XX. Madrid: Ediciones Cátedra.

Ruiz Ramón, Francisco. 1977. «Dramaturgias mayores: las tres primeras décadas», En Conferencias de la Fundación Juan March, 19 de octubre, archivo en MP3, acceso el 15 de septiembre 2017, https://www.march.es/conferencias/anteriores/voz.aspx?p1=2963\&l=1.

Salaün, Serge. 1998. «Vanguardias estéticas en España». En Nuevos caminos en la investigación de los años 20 en España, coordinado por Harald Wentzlaff-Eggebert. Tübingen (Alemania): Max Niemeyer Verlag, 37-46.

- 1999. «Introducción». En Teatro de ensueño. La intrusa (de Maurice Maeterlinck) de Gregorio Martínez Sierra, 7-100. Madrid: Biblioteca Nueva.

Salinas, Pedro. (1933) 1970. «Del «género chico» a la tragedia grotesca: Carlos Arniches». En Pedro Salinas: Literatura española siglo XX, 126-131. Madrid. Alianza Editorial.

- (1933) 1995. La voz a ti debida. Razón de Amor. Largo Lamento. Escartín, Monserrat (ed.). Madrid: Ediciones Cátedra.

Salvat, Ricard, Enric Ciurans y Núria Salvat. 1997. «Federico García Lorca, un genio en el teatro español». Assaig de teatre: revista de l'Associació d'Investigació $i$ Experimentació Teatral, 5-6: 61-82. 
Sánchez, José A. (ed.). 1999. La escena moderna. Manifiestos y textos sobre teatro de la época de vanguardias. Madrid: Ediciones Akal.

Sánchez García, Remedios. 2012. «Teatro para el pueblo o despertar al dormido. A propósito del compromiso lorquiano con "La Barraca"». Anuario de Estudios Filológicos de la Universidad de Extremadura, XXXV: 201-213.

Sánchez Rodríguez, Alfonso. 1987. «José María Hinojosa: 1925-1936. Apuntes sobre la trayectoria de un surrealista». En Surrealismo. El ojo soluble, editado por Jesús García Gallego, 134-144. Málaga: Revista Litoral.

Sánchez Vidal, Agustín. 1988. Buñuel, Lorca, Dalí: El enigma sin fin. Barcelona: Editorial Planeta.

- 1999. «La cultura española de vanguardia». En Las vanguardias literarias en España: bibliografía y antología crítica, editado por Harald WentzlaffEggebert, 341-354. Madrid: Iberoamericana Editorial Vervuert.

Sanmartín Bastida, Rebeca. 2004. «De Dalí a Lorca: El poema en prosa surrealista». Forma Breve: O poema em prosa, 2: 81-103.

Santos Torroella, Rafael. 1948. «Genio y figura del Surrealismo. Anécdota y balance de una subversión». Cobalto. Arte Antiguo y Moderno, Cuaderno Especial Surrealismo: 516.

Saradia, Nydia. 2007. Días cubanos de Lorca. La Habana (Cuba): Editorial Cultura Popular.

Sassone, Felipe. 1928. «Superrealismo y ultrarrealismo: opiniones sin fundamento». $A B C, 26$ de abril, 10-11.

Sebbag, Georges. 2013. «Filosofía surrealista del sueño». En El surrealismo y el sueño, V.V.A.A. (eds.). [Congreso internacional celebrado en Madrid, 8 y 9 de octubre del 2013], 25-34. Madrid: Departamento de Publicaciones del Museo Thyssen-Bornemisza.

Scholz-Hänsel, Michael. 1998. «El surrealismo español (1924-51) y la necesidad de una perspectiva intercultural en la historia del arte». En Nuevos caminos en la investigación 
de los años 20 en España, coordinado por Harald Wentzlaff-Eggebert. Tübingen (Alemania): Max Niemeyer Verlag, 55-65.

Serrano, Pío E. 2012. «Lorca en La Habana». Revista Hispano Cubana, núm. 42: 69-75.

Shakespeare. William. 2000. Romeo y Julieta. Barcelona: Planeta DeAgostini.

Sito Alba, Manuel. 1987. Análisis de la Semiótica Teatral. Madrid: Universidad Nacional de Educación a Distancia

Solà Solé, Pere. 2014. Louis Aragon y España. Lleida: Edicions de la Universitat de Lleida.

Soldevila-Durante, Ignacio. 1992. «Ramón Gómez de la Serna entre la tradición y la vanguardia». En El teatro en España. Entre la tradición y la vanguardia (1918-1939) editado por Dru Dougherty y $\mathrm{M}^{\mathrm{a}}$ Francisca Vilches de Frutos, 69-78. Madrid: Consejo Superior de Investigaciones Científicas; Fundación Federico García Lorca; Tabacalera, S.A.

Soria Olmedo, Andrés (ed.). 1992. Pedro Salinas/Jorge Guillén. Correspondencia (1923-1951). Barcelona: Tusquets Editores.

— 2007. «El estudiante Federico García Lorca». El fingidor. Revista de cultura, 3334: 14-19, acceso el 19 de febrero de 2020, https://editorial.ugr.es/pages/publicacionesenabierto/elfingidor/numero3334

— 2016. «Introducción a la obra de Federico García Lorca. En Instituto Cervantes Virtual, acceso el 15 de noviembre de 2016, http://cervantesvirtual.com/portales/federico_garcia_lorca/introduccion_a_la_ob ra/\#teatro

- (ed.). 2017. Treinta y una entrevistas a Federico García Lorca. Atarfe (Granada): Entorno Gráfico Ediciones. Colección Itineraria.

- 2018. Una habitación propia. Federico García Lorca en la Residencia de Estudiantes, 1919-1936. Madrid: Publicaciones de la Residencia de Estudiantes. 
Sotelo, Mauricio. 2015. El Público. Ópera bajo la arena, acceso el 1 de septiembre de 2017 , http://teatroreal.com/assets/uplads/files/documentos/9aaf2304adea49399abbb5dc8abb5669.pdf.

Suero, Pablo. (1937) 2015. España levanta el puño. Valencina de la Concepción (Sevilla): Ediciones Espuela de Plana; Editorial Renacimiento.

Temes, José Luis. 2014. El Siglo de la Zarzuela 1850-1950. Madrid: Ediciones Siruela.

Tordera Sáez, Antonio. 1978. «Teoría y técnica del análisis teatral». En Elementos para una semiótica del texto artístico, 157-199. Madrid: Ediciones Cátedra.

Torre, Guillermo de. 1965. Historia de las literaturas de vanguardia. Madrid: Ediciones Guadarrama.

- 1967. Qué es el superrealismo. Buenos Aires (Argentina): Editorial Columba, Colección Esquemas, núm.18. (1955).

Torres, Rosana. 1989. «Lluís Pasqual destroza el escenario en 'Comedia sin título'». El País, 24 de junio, acceso el 16 de septiembre de 2019, htpps://elpais.com/diario/1989/06/24/cultura/614642404_850215.html

Turel, Sarah. 1986. «La "quimera” de García Lorca: expresión surrealista de un mito». Cuadernos hispanoamericanos, Volumen I: Homenaje a García Lorca. Con Federico, en memoria, 433-434: 351-358.

Ucelay, Margarita. 1992. «El club teatral Anfistora». En El teatro en España. Entre la tradición y la vanguardia (1918-1939) editado por Dru Dougherty y $\mathrm{M}^{\mathrm{a}}$ Francisca Vilches de Frutos, 453-467. Madrid: Consejo Superior de Investigaciones Científicas; Fundación Federico García Lorca; Tabacalera, S.A.

- (1995) 2008. «Introducción». En Así que pasen cinco años. Leyenda del Tiempo de Federico García Lorca, 9-145. Madrid: Ediciones Cátedra.

Unamuno, Miguel. 1970. Ensayos. Novela. Teatro. Poesía. Barcelona: Círculo de Lectores. 
Urrutia, Jorge. 1989. «Los espacios textuales en el teatro de Valle-Inclán». En Quimera, Cántico. Busca y rebusca de Valle-Inclán, editado por Juan Antonio Hormigón, 77-83. Madrid: Instituto Nacional de las Artes Escénicas y de la Música.

Valdeón, Julio, Joseph Pérez y Santos Juliá. 2003. Historia de España. Madrid: Espasa Calpe.

Valender, James. 1987. «Luís Cernuda y el surrealismo: algunos comentarios generales». En Surrealismo. El ojo soluble, editado por Jesús García Gallego, 145-159. Málaga: Revista Litoral.

Vallejo, Javier. 2015. «Cuando la doctrina desata su cabellera». El País, Madrid, 2 de noviembre, acceso el 12 de febrero de 2016, https://elpais.com/cultura/2015/10/30/actualidad/1446201273_095939.html

Vega, Matías. 1930. «Habla por radio Manuel Salazar». Diario de la Marina: periódico oficial del apostadero de La Habana, núm. 152, 3 de junio, 12.

Vicente Hernando, César de. 2009. «Literatura y teatro proletarios». En La República y la cultura: Paz, guerra y exilio, coordinado por Julio Rodríguez Puértolas. Madrid: Ediciones Istmo, 31-38.

Videla, Gloria. 1971. El ultraísmo. Estudios sobre movimientos poéticos de vanguardia en España. Madrid: Editorial Gredos.

Vilches de Frutos, María Francisca y Dru Dougherty. 1992a. Los estrenos teatrales de Federico García Lorca [1920-1945]. Madrid: Tabapress; Grupo Tabacalera; Fundación Federico García Lorca.

- 1992b. «Federico García Lorca como director de escena». En El teatro en España. Entre la tradición y la vanguardia (1918-1939) editado por Dru Dougherty y $\mathrm{M}^{\mathrm{a}}$ Francisca Vilches de Frutos, 241-251. Madrid: Consejo Superior de Investigaciones Científicas; Fundación Federico García Lorca; Tabacalera, S.A

- 1997. La escena madrileña entre 1926 y 1936. Un lustro de transición. Madrid: Editorial Fundamentos. 
Villanueva, Darío. 2015. Imágenes de la ciudad. Poesía y cine, de Whitman a Lorca. Madrid: Ediciones Cátedra.

Villena, Luis Antonio de. 1997. «Los placeres prohibidos de Luis Cernuda: el surrealismo en pie de guerra». Barcarola. Revista de Creación Literaria. Dosier Generación del 27, 153-157. Albacete.

Zamora Vicente, Alonso. 2010. «Introducción». En Luces de bohemia. Esperpento de Ramón del Valle-Inclan, 9-32. Madrid: Austral. 


\section{7.- Créditos de las imágenes}

Fig. 1: Cortesía de la familia Mata-Nieto. Granada.

Fig. 2: Archivo Universitario de Granada. 2020. «Expediente académico de Federico García Lorca. Universidad de Granada. Facultad de Filosofía y Letras», acceso el 19 de febrero de 2020, https://archi.ugr.es:8443/jopac/registro?id=00090365

Fig. 3: Archivo Universitario de Granada. 2020. «Expediente académico de Federico García Lorca. Universidad de Granada. Facultad de Derecho», acceso el 19 de febrero de 2020, https://archi.ugr.es:8443/jopac/registro?id=00051078

Fig. 4: Palomo, Quique y Ian Gibson. 2018. Vida y muerte de Federico García Lorca. Barcelona: Ediciones B, 36.

Fig. 5: Universo Lorca. 2019. «Lugares lorquianos. Plaza de los aljibes», acceso el 15 de julio de 2019, https://www.universolorca.com/lugar/plaza-de-los-aljibes/

Fig. 6: Ajuntament de Girona. 2019. «Galeries Dalmau. Foco de arte de vanguardia en Catalunya», acceso el 30 de octubre de 2019, https://www.girona.cat/sgdap/movio11/es/presentacion

Fig. 7: Armero, Gonzalo. 1996. Álbum fotográfico de Federico García Lorca. Granada: Editorial Comares; Fundación Federico García Lorca (fotografía 44).

Fig. 8 y 9: Medina, Pablo L. 2017. «Los títeres de Federico García Lorca en el teatro Avenida de Buenos Aires. 25 de marzo de 1934». Titeresante. Revista de títeres, sombras y marionetas, acceso el 12 de septiembre de 2019, http://www.titeresante.es/2017/05/los-titeres-de-federico-garcia-lorca-en-el-teatroavenida-de-buenos-aires-25-de-marzo-de-1934-por-pablo-1-medina/

Fig. 10: Bonet, Enrique. 2018. La araña del olvido. Bilbao: Astiberri Ediciones, 4.

Fig. 11: Carroll, Lewis. 2013. El hombre que amaba a las niñas. Correspondencia y relatos. Madrid: La Felguera, 119.

Fig. 12: Armero, Gonzalo. 1996. Álbum fotográfico de Federico García Lorca. Granada: Editorial Comares; Fundación Federico García Lorca (fotografía 75). 
Fig. 13: $A B C$, Madrid, 16 de enero de 1924, 17.

Fig. 14: CDAEM. 2017. Vol 1907-1909, 221, acceso el 14 de marzo de 2019, http://teatro.es/es/publicaciones/recuerdos-de-un-siglo-de-teatro-1851-1955

Fig.15: CDAEM. 2017. Vol 1925-1926 (I), 158, acceso el 14 de marzo de 2019, http://teatro.es/es/publicaciones/recuerdos-de-un-siglo-de-teatro-1851-1955

Fig. 16: Blanco y Negro, Madrid, el 14 de diciembre de 1907, 15.

Fig. 17: Gibson, Ian. 1998. Vida, pasión y muerte de Federico García Lorca. Vol. 2. Barcelona: Plaza \& Janes, 193.

Fig. 18: $A B C$, Madrid, el 22 de julio de 1924, 19.

Fig. 19: El Sol, el 19 de octubre de 1926, 1.

Fig. 20: Universo Lorca. 2019. «Quién fue quién. Rivas (de) Cherif, Cipriano», acceso el 15 de julio de 2019, https://www.universolorca.com/personaje/rivas-de-cherifcipriano/

Fig. 21: Eméritos. 2014. «Medea 1933», acceso el 10 de marzo de 2019, http://emeritosdelpatrimonio.blogspot.com/2014/06/medea-1933.html

Fig. 22: Solana, José. 1920. La tertulia del Café del Pombo, acceso el 10 de marzo de 2019, https://www.museoreinasofia.es/coleccion/obra/tertulia-cafe-pombo

Fig. 23: RTVE. 2019. «Lyceum Club: la primavera de las mujeres», acceso el 9 de abril de 2019, http://www.rtve.es/alacarta/videos/todxs-por-igual/lyceum-club-primaveramujeres/5111178/

Fig. 24: García Lorca, Francisco. 1981. Federico y su mundo. Madrid: Alianza tres. También disponible, acceso 19 de marzo de 2019, en la página electrónica: http://www.residencia.csic.es/es/pres/galeria/pages/001.htm

Fig. 25: BNE. 2016. «Donan a la BNE diez fotografías del teatro de los años 20», $\begin{array}{lllll}\text { acceso } & 19 & \text { de } & \text { marzo }\end{array}$ http://www.bne.es/es/Inicio/Perfiles/Bibliotecarios/NoticiasBibliotecarias/1108-DonanBNE-10-fotografias-teatro-anos-20.html 
Fig. 26: García Lorca, Francisco. 1981. Federico y su mundo. Madrid: Alianza tres.

Fig. 27: Hernández, Mario. 1986. «Proyecto y catalogación». En Dibujos de Federico García Lorca. Barcelona: Ministerio de Cultura; Fundación para el apoyo de la Cultura; Fundación Federico García Lorca; Fundació Caixa de Barcelona, 233.

Fig. 28: Universo Lorca. 2019. «Obras literarias. La zapatera prodigiosa», acceso el 15 de julio de 2019, https://www.universolorca.com/obra-literaria/la-zapatera-prodigiosafarsa-violenta-en-dos-actos/

Fig. 29: Hernández, Mario. 1986. «Proyecto y catalogación». En Dibujos de Federico García Lorca. Barcelona: Ministerio de Cultura; Fundación para el apoyo de la Cultura; Fundación Federico García Lorca; Fundació Caixa de Barcelona, 235.

Fig. 30 Armero, Gonzalo. 1996. Álbum fotográfico de Federico García Lorca. Granada: Editorial Comares; Fundación Federico García Lorca (fotografía 61). También disponible, acceso 19 de marzo de 20109, en la página: https://www.universolorca.com/personaje/membrives-fernandez-lola/

Fig. 31: Crónica de Madrid, el 6 de enero de 1935, 29.

Fig. 32: Anónimo. 1934. Montaje de escenario. Misiones Pedagógicas, acceso 10 de marzo de 2019, https://www.museoreinasofia.es/coleccion/obra/montaje-escenariomisiones-pedagogicas

Fig. 33: Val del Omar, José. 1932-1936. Misiones pedagógicas, acceso 10 de marzo de 2019, http://catalogo.bne.es/uhtbin/cgisirsi/0/x/0/05?searchdata1=a4717996

Fig. 34: Inglada, Rafael (ed.). 2017. Palabra de Lorca. Declaraciones y entrevistas completas de Federico García Lorca. Barcelona: Malpaso, 77.

Fig. 35: Palencia, Benjamín. 1931. Insignia de La Barraca, acceso el 10 de marzo de 2019, https://www.museoreinasofia.es/coleccion/obra/insignia-barraca

Fig. 36: Benjamín Palencia. 1932. Máscara. Cartel de «La Barraca», acceso el 10 de marzo de 2019, https://www.museoreinasofia.es/coleccion/obra/mascara-cartel-barraca 
Fig. 37: Anónimo. 1932. Montaje del escenario por los componentes de La Barraca para la representación de «La guarda cuidadosa», de Miguel de Cervantes (Almazán,

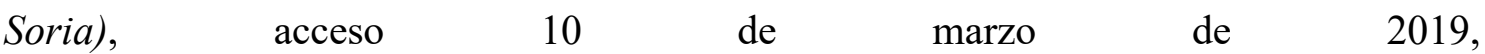
https://www.museoreinasofia.es/coleccion/obra/montaje-escenario-componentesbarraca-representacion-guarda-cuidadosa-miguel-0

Fig. 38: Anónimo. 1932. Federico García Lorca leyendo un texto antes de la representación por La Barraca de «La guarda cuidadosa», de Miguel de Cervantes (Almazán, Soria), acceso 10 de marzo de 2019, https://www.museoreinasofia.es/coleccion/obra/federico-garcia-lorca-leyendo-textoantes-representacion-barraca-guarda-cuidadosa

Fig. 39: Residencia de Estudiantes. 2018. «Una habitación propia. Federico García Lorca en la Residencia de Estudiantes 1919-1936», acceso el 17 de septiembre de 2019, http://www.residencia.csic.es/expolorca/residencia.htm

Fig. 40: Residencia de Estudiantes. 2018. «Una habitación propia. Federico García Lorca en la Residencia de Estudiantes 1919-1936», acceso el 17 de septiembre de 2019, http://www.residencia.csic.es/expolorca/fonda.htm

Fig. 41: Residencia de Estudiantes. 2018. «Una habitación propia. Federico García Lorca en la Residencia de Estudiantes 1919-1936», acceso el 17 de septiembre de 2019, http://www.residencia.csic.es/expolorca/fonda.htm

Fig. 42: Armero, Gonzalo. 1996. Álbum fotográfico de Federico García Lorca. Granada: Editorial Comares; Fundación Federico García Lorca (fotografía 27).

Fig. 43: Hernández, Mario. 1986. «Proyecto y catalogación». En Dibujos de Federico García Lorca. Barcelona: Ministerio de Cultura; Fundación para el apoyo de la Cultura; Fundación Federico García Lorca; Fundació Caixa de Barcelona, 193.

Fig. 44: Ahora de Madrid, 29 de enero de 1935, 21.

Fig. 45: Archivo La Fuente. 2017. «Dadá Zúrich», acceso el 17 de septiembre de 2019, https://www.archivolafuente.com/exposicion/dada-zurich-46/ 
Fig. 46: V.V.A.A. (eds.). 2013. El surrealismo y el sueño. [Catálogo de la exposición que tuvo lugar en el museo Thyssen-Bornemisza de Madrid, del 8 de octubre de 2013 al 12 de enero de 2014]. Madrid: Departamento de Publicaciones del Museo Thyssen, 18.

Fig. 47: Ernst, Max. 1922. La reunión de amigos, acceso el 17 de septiembre de 2019, https://museum-ludwig.kulturelles-erbe-koeln.de/documents/obj/05010296

Fig. 48: V.V.A.A. (eds.). 2013. El surrealismo y el sueño. [Catálogo de la exposición que tuvo lugar en el museo Thyssen-Bornemisza de Madrid, del 8 de octubre de 2013 al 12 de enero de 2014]. Madrid: Departamento de Publicaciones del Museo Thyssen, 36.

Fig. 49: Mañero Rodicio, Javier. 2009. París 1919-1939: escultura, crítica y revistas de arte. Madrid: Universidad Complutense de Madrid, acceso el 17 de septiembre de 2019, https://www.researchgate.net/figure/Primera-pagina-del-panfleto-anti-bretonianoUn-cadaver-enero-1930_fig26_39697389

Fig. 50: Mañero Rodicio, Javier 2013. «Acción surrealista y medios de intervención. El surrealismo en las revistas, 1930-1939». Anales de la Historia del Arte, Vol. 23: 209258.

Fig. 51: Ajuntament de Girona. 2018. «Galeries Dalmau. Foco del arte de vanguardia en Catalunya», acceso 10 de marzo de 2019, https://www.girona.cat/sgdap/movio11/es/presentacion

Fig. 52: UOC. 2019. «DALÍ, Salvador; MONTANYÀ, Lluís; GASCH, Sebastià (1928). El Manifest Groc», acceso 10 de marzo de 2019, http://biblioteca.uoc.edu/es/recursos/recurso/dali-salvador-montanya-lluis-gaschsebastia-1928-el-manifest-groc

Fig. 53: Rodrigo, Antonina. 1975. García Lorca en Cataluña. Barcelona: Editorial Planeta, 221.

Fig. 54: Residencia de Estudiantes. 2018. «Una habitación propia. Federico García Lorca en la Residencia de Estudiantes 1919-1936», acceso el 17 de septiembre de 2019, http://www.residencia.csic.es/expolorca/jardines.htm 
Fig. 55: Universidad de Las Palmas de Gran Canaria. 2019. «Gaceta de arte», acceso 10 de marzo de 2019, https://jable.ulpgc.es/jable/cgi-bin/Pandora.exe

Fig. 56: André Breton. 2013. «The Colecction. André et Jaqueline Breton aux Canarias», acceso 10 de marzo 2019, https://www.andrebreton.fr/en/work/56600100916290

Fig. 57: Dipòsit Digital de Documents de la UAB. 2019. «Cobalto: Arte antiguo y modern», acceso 10 de marzo de 2019, https://ddd.uab.cat/record/27497

Fig. 58. Centro Federico García Lorca. 2016. «Teoría del duende», acceso el 9 de marzo de 2019, http://www.centrofedericogarcialorca.es/es/actividades/exposiciones/17/teoriadel-duende-en-el-centro-federico-garcia-lorca

Fig. 59 y 60: Hernández, Mario. 1986. «Proyecto y catalogación». En Dibujos de Federico García Lorca. Barcelona: Ministerio de Cultura; Fundación para el apoyo de la Cultura; Fundación Federico García Lorca; Fundació Caixa de Barcelona, 157.

Fig. 61: Hernández, Mario. 1986. «Proyecto y catalogación». En Dibujos de Federico García Lorca. Barcelona: Ministerio de Cultura; Fundación para el apoyo de la Cultura; Fundación Federico García Lorca; Fundació Caixa de Barcelona, 164.

Fig. 62: La Gaceta Literaria, el 15 de enero de 1929, 1.

Fig. 63 y 64: Hernández, Mario. 1986. «Proyecto y catalogación». En Dibujos de Federico García Lorca. Barcelona: Ministerio de Cultura; Fundación para el apoyo de la Cultura; Fundación Federico García Lorca; Fundació Caixa de Barcelona, 176.

Fig. 65: BNE. 2019. «Viaje a la luna [guión cinematográfico]», acceso el 10 de marzo de 2019, http://datos.bne.es/edicion/a4990872.html

Fig. 66: Hernández, Mario. 1986. «Proyecto y catalogación». En Dibujos de Federico García Lorca. Barcelona: Ministerio de Cultura; Fundación para el apoyo de la Cultura; Fundación Federico García Lorca; Fundació Caixa de Barcelona, 167.

Fig. 67: El País. 2016. «La película que escribió Lorca», acceso 10 de marzo de 2019, https://elpais.com/ccaa/2016/11/28/madrid/1480351619_753317.html 
Fig. 68: Esquembre, Carles. 2016. Lorca. Un poeta en Nueva York. Torroella De Montgrí (Girona): Panini Cómics España, 25.

Fig. 69: Maurer, Christopher y Andrew A. Anderson (eds.). 20 . Federico García Lorca en Nueva York y La Habana. Barcelona: Galaxia Gutenberg; Círculo de Lectores, 20 .

Fig. 70: Palomo, Quique y Ian Gibson. 2018. Vida y muerte de Federico García Lorca. Barcelona: Ediciones B, 61 .

Fig. 71: Palomo, Quique y Ian Gibson. 2018. Vida y muerte de Federico García Lorca. Barcelona: Ediciones B, 62.

Fig. 72: Historias de Nueva York. 2013. «Edificio Chrysler en construcción (1929)», acceso 19 de marzo de 2019, https://historiasdenuevayork.es/2013/11/23/edificiochrysler-en-construccion-1929/

Fig. 73: Esquembre, Carles. 2018. Lorca. Un poeta en Nueva York. Torroella de Montgrí (Girona): Evolution Comics Panini, 81

Fig. 74: Diario de la Marina: periódico oficial del apostadero de La Habana, 14 de marzo de 1930, 1.

Fig. 75: Diario de la Marina: periódico oficial del apostadero de La Habana, 7 de abril de 1930, 13.

Fig. 76: García Lorca, Francisco. 1981. Federico y su mundo. Madrid: Editorial Alianza tres.

Fig. 77: Habaneando. 2015. «La casa encantada de Federico García Lorca», acceso 24 de junio de 2019, http://dosencuba.blogspot.com/2015/10/la-casa-encantada-defederico-garcia.html

Fig. 78: Maurer, Christopher y Andrew A. Anderson (eds.). 20 . Federico García Lorca en Nueva York y La Habana. Barcelona: Galaxia Gutenberg; Círculo de Lectores, 314. 
Fig. 79: Libraries Digital Collections. 2019 «Federico García Lorca with a friend at Marianao Beach in Havana, Cuba», acceso 15 de diciembre de 2019, https://merrick.library.miami.edu/cdm/ref/collection/chc5324/id/64/rec/16

Fig. 80: Libraries Digital Collections. 2019 «Lydia and Orlando, two children photographed by Federico García Lorca», acceso 15 de diciembre de 2019, https://merrick.library.miami.edu/cdm/singleitem/collection/chc5324/id/56/rec/35

Fig. 81 y 82: Biblioteca Digital Hispánica. 2019. «El público: drama en veinte cuadros y un asesinato», acceso el 10 de marzo de 2019, http://bdh.bne.es/bnesearch/detalle/bdh0000206841

Fig. 83: Heraldo de Madrid, 4 de mayo de 1932, 6.

Fig. 84: Gibson, Ian. 1979. Granada en 1936 y el asesinato de Federico Garcia Lorca. Barcelona: Editorial Crítica Grijalbo (fotografía 31).

Fig. 85: El Bosco, Jheronimus van Aken. 1501-1505. La extracción de la piedra de la locura. [Óleo], Museo Nacional del Prado, Madrid, acceso el 19 de octubre de 2019, https://www.museodelprado.es/coleccion/obra-de-arte/la-extraccion-de-la-piedra-de-lalocura/313db7a0-f9bf-49ad-a242-67e95b14c5a2

Fig. 86: Fundación Juan March. 2019. «Poética y Teatro. Recopilación. Lluís Pasqual. Recursos en la Biblioteca, acceso 19 de octubre de 2019, https://www.march.es/conferencias/poetica-teatro/detalle.aspx?p0=4\&p1=8

Fig. 87: Hitchcock, Alfred. 1940. Spellbound

Fig. 88: Picasso, Pablo. 1923. Arlequín con espejo. [Óleo sobre lienzo], Museo Nacional Thyssen-Bornemisza, Madrid, acceso el 19 de octubre de 2019, https://www.museothyssen.org/coleccion/artistas/picasso-pablo/arlequin-espejo

Fig. 89: Dalí, Salvador. 1925. Pierrot tocant la guitarra (Pintura cubista). [Óleo sobre lienzo], Museo Nacional Centro de Arte Reina Sofía, acceso el 19 de octubre de 2019, https://www.museoreinasofia.es/coleccion/obra/pierrot-tocant-guitarra-pintura-cubistapierrot-tocando-guitarra-pintura-cubista

Fig. 90: García Lorca, Federico. 1932-1936. Pierrot priápico [Tinta china y lápices de color sobre cartulina]. En Dibujos de Federico García Lorca, 187. Barcelona: Ministerio 
de Cultura; Fundación para el apoyo de la Cultura; Fundación Federico García Lorca; Fundació Caixa de Barcelona.

Fig. 91: El País. 2015. «Aquella aventura pública», acceso 15 de septiembre de 2018, https://elpais.com/cultura/2015/02/18/babelia/1424284432_698821.html

Fig. 92: Frederic Amat. 2019. «El público. 1986», acceso 24 de marzo de 2019, http://www.fredericamat.net/es/escena/el-pblico-1986

Fig. 93: Museo Nacional Centro de Arte Reina Sofia. 2019. «Federico García Lorca en el papel de "Sombra" para la representación por La Barraca del auto sacramental «La vida es sueño», de Calderón de la Barca, con decorados de Benjamín Palencia», acceso el 20 de septiembre de 2019, https://www.museoreinasofia.es/coleccion/obra/federicogarcia-lorca-papel-sombra-representacion-barraca-auto-sacramental-vida-es

Fig. 94: Desde el patio. 2013. «”El público” y Lluís Pasqual», acceso 15 de septiembre de 2018, http://daviddesdeelpatio.blogspot.com/2013/10/lluis-pasqual.html

Fig. 95: Fundación Juan March. 2019. «Poética y Teatro. Recopilación. Lluís Pasqual. Recursos en la Biblioteca, acceso 19 de octubre de 2019, https://www.march.es/conferencias/poetica-teatro/detalle.aspx?p0 $=4 \& \mathrm{p} 1=8$

Fig. 96: García Lorca, Federico. Soledad Montoya: Hernández, Mario. 1986. «Proyecto y catalogación». En Dibujos de Federico García Lorca. Barcelona: Ministerio de Cultura; Fundación para el apoyo de la Cultura; Fundación Federico García Lorca; Fundació Caixa de Barcelona, 208.

Fig. 97: Don Galán. 2014. «Una visión incompleta de la escenografía en España desde 1975, acceso el 15 de septiembre de 2018, http://teatro.es/contenidos/donGalan/donGalanNum4/imagenesCitadas.php?vol=4\&doc $=1 \_2$

Fig. 98: García Lorca, Federico. Manos cortadas: Hernández, Mario. 1986. «Proyecto y catalogación». En Dibujos de Federico García Lorca. Barcelona: Ministerio de Cultura; Fundación para el apoyo de la Cultura; Fundación Federico García Lorca; Fundació Caixa de Barcelona, 191. 
Fig. 99: Buñuel, Luis y Salvador Dalí. 1929. Un perro andaluz

Fig. 100: Pinterest. 2019. «Piccolo Teatro di Milano», acceso el 19 de octubre de 2019, https://nl.pinterest.com/pin/405394403955185688/?amp_client_id=CLIENT_ID(_)\&m web_unauth_id $=\{\{$ default.session $\}\} \&$ simplified $=$ true

Fig. 102: Teatro de La Abadía. 2016. « Archivo - Temporada 2016-2017 “El público”», $\begin{array}{llllll}\text { acceso } & \text { el } & 15 & \text { de } & \text { septiembre }\end{array}$ https://www.teatroabadia.com/es/imagenes/contenido/obras/5[1].jpg

Fig. 103: Don Galán. 2014. «Una visión incompleta de la escenografía en España desde 1975, acceso el 15 de septiembre de 2018, http://teatro.es/contenidos/donGalan/donGalanNum4/imagenesCitadas.php?vol=4\&doc $=1 \_2$

Fig. 104: El Mundo. 2016. «Àlex Rigola, a punto de firmar por los Teatros del Canal de Madrid», acceso el 15 de septiembre de 2018, https://www.elmundo.es/cultura/2016/07/14/57878c69468aeb5b558b4618.html

Fig. 105: K+S+E+C ACT. 2016. 《2016 年公演 観客》, acceso 9 de enero de 2020， https://www.ksec-act.com/kankyaku?lightbox=dataltem-iouujdsb4

Fig. 106: Heraldo de Madrid, 29 de febrero de 1936, 13.

Fig. 107: Rodrigo, Antonina. 1975. García Lorca en Cataluña. Barcelona: Editorial Planeta, 353.

Fig. 108: García Lorca, Federico. 1978. El público y Comedia sin título. Dos obras teatrales póstumas, edición Rafael Martínez Nadal y Marie Laffranque. Barcelona: Seix Barral, portada.

Fig. 109: García Lorca, Federico. 2018. Comedia sin título (seguida de El sueño de la vida de Alberto Conejero), edición Emilio Peral Vega. Madrid: Catedra, portada.

Fig. 110: CDAEM. 2019. "Comedia sin título», acceso 15 de octubre de 2019, http://teatro.es/catalogo-integrado/comedia-sin-titulo-609733-4

Fig. 111: Teatro Español. 2018. «El sueño de la vida», acceso el 15 de octubre de 2019, https://www.teatroespanol.es/prensa/el-sueno-de-la-vida 
Fig. 112: La Razón. 2013. «Un juego de matrioskas con Lorca y Shakespeare», acceso el 15 de octubre de 2019, https://www.larazon.es/cultura/teatro/un-juego-de-matrioskascon-lorca-y-shakespeare-XH3687725/

Fig. 113: Teatro Español. 2018. «El sueño de la vida», acceso el 15 de octubre de 2019, https://www.teatroespanol.es/prensa/el-sueno-de-la-vida

Fig. 114: CDAEM. 2019. "Comedia sin título», acceso 15 de octubre de 2019, http://teatro.es/catalogo-integrado/comedia-sin-titulo-618757-4

Fig. 115: CDAEM. 2019. «Comedia sin título», acceso 15 de octubre de 2019, http://teatro.es/catalogo-integrado/comedia-sin-titulo-618757-4

Fig. 116: Estudio Corazza para el actor. 2020. «Comedia y Sueño, la mentira más hermosa», acceso el 9 de enero de 2020, http://estudiocorazza.com/compania/comediay-sueno/

Fig. 117: Mambo. 2019. «Sara Molina: «Todavía hay que responderse qué sucede», acceso 9 de enero de 2020, http://www.tea-tron.com/mambo/blog/2019/12/10/saramolina-todavia-hay-que-responderse-que-sucede/

Fig. 118: Teatro Español. 2018. «El sueño de la vida», acceso el 15 de octubre de 2019, https://www.teatroespanol.es/prensa/el-sueno-de-la-vida

Fig. 119: Teatro Español. 2018. «El sueño de la vida», acceso el 15 de octubre de 2019, https://www.teatroespanol.es/prensa/el-sueno-de-la-vida

Fig. 120: Teatro Español. 2018. «El sueño de la vida», acceso el 15 de octubre de 2019, https://www.teatroespanol.es/prensa/el-sueno-de-la-vida 